\title{
0
}

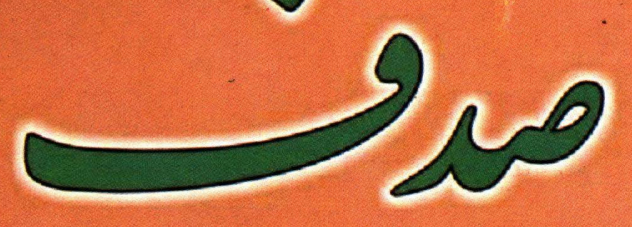

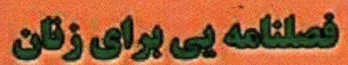

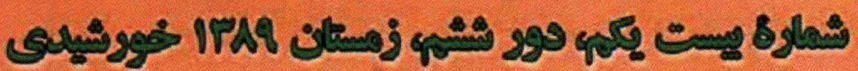

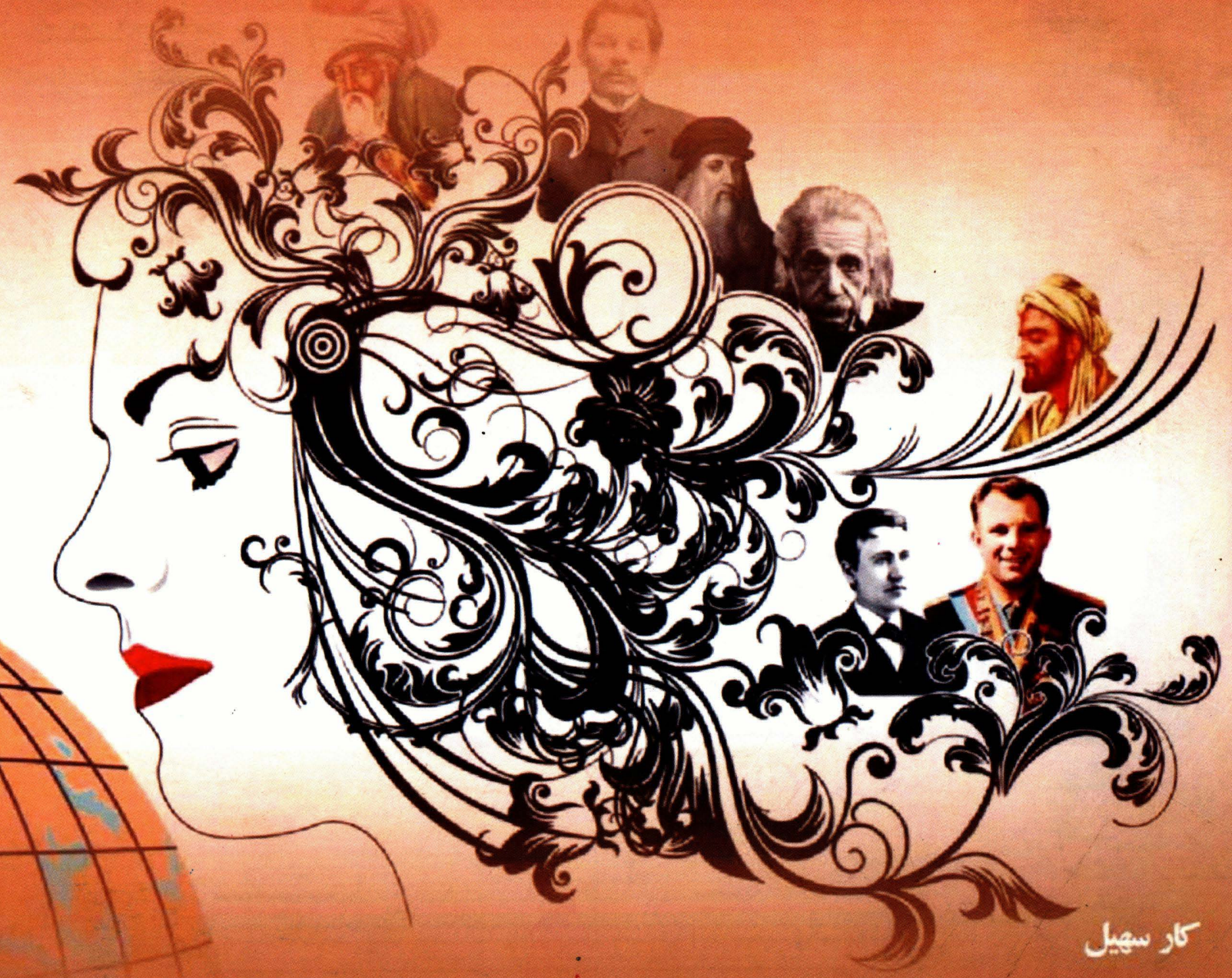




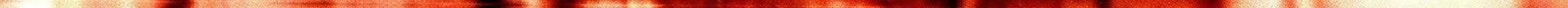




\section{دوين شماره}

- در اجتماع كنونى بوخى اورسنت ها ...

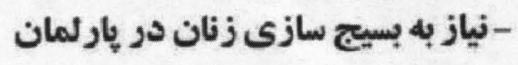
- د بندئو سياسي حقوق بازي

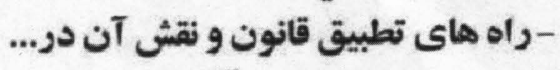
- سياسي او اقتصادي آزادي

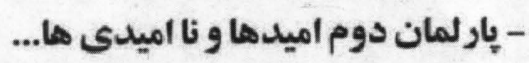

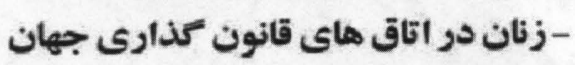

ri

tr

re

rา

ri

$r \varepsilon$

ra

\&7

ir

$\circ$.

or

71

79

vr

vr

ro

rา

no

94

- مسووليت انسان ته زور او...

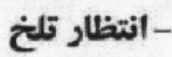
- تجلى ارزش و حقوق انسان دو سياست...

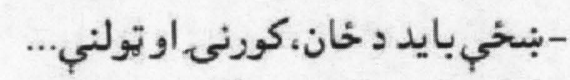

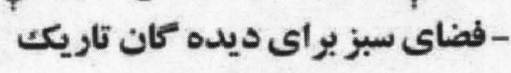

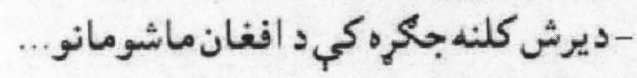
- اين دفتر خالى... - -

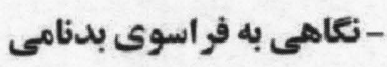

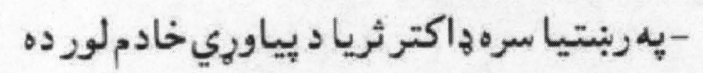
- من بانوى با نجابت خورشيدم...

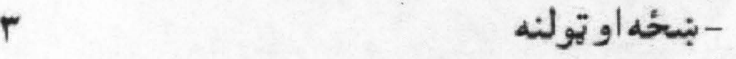
-بيانيه مشتر ك كميته مشار كت سياسى زنان...

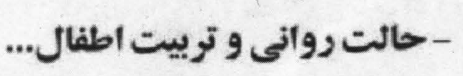

- باز شناسى نقش زنان افنانستان...

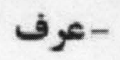

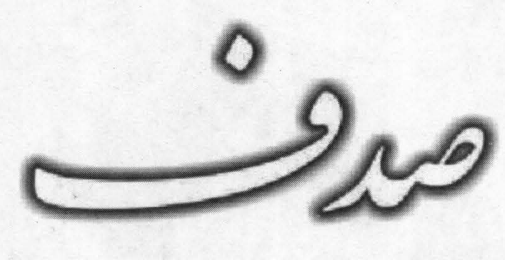

فصلنامه يیى براى زنان
صاحب امثياز: موكز تعاون افغانستان (متا) مديو مسوول: ع ع. آذرشين طراح و صفحه آرا: فويد احمد (يوسفزى)

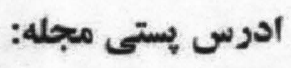
افغنانستان - كايل

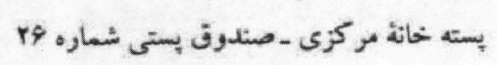

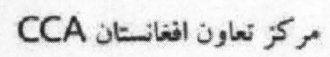
Email: sadafcca@yahoo.com Mobil: 0702151573

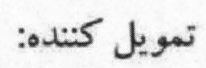
National Endowment for Democracy عقايد و آراء نويسنده كان الزامأ بازتاب ديدكاه صدف نيستند

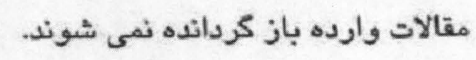
صدف در ويراستارى نبشته ها آزادى دارد.

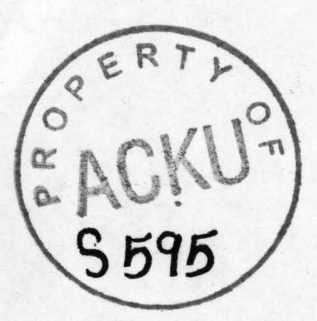

\section{CCA}

$$
\text { حاب: بنكاه انتشارات ميوند }
$$

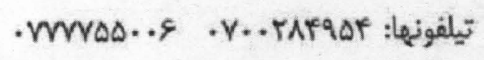





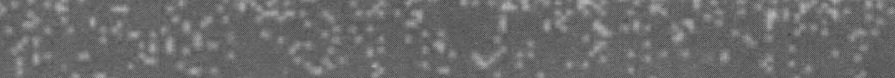

مانس

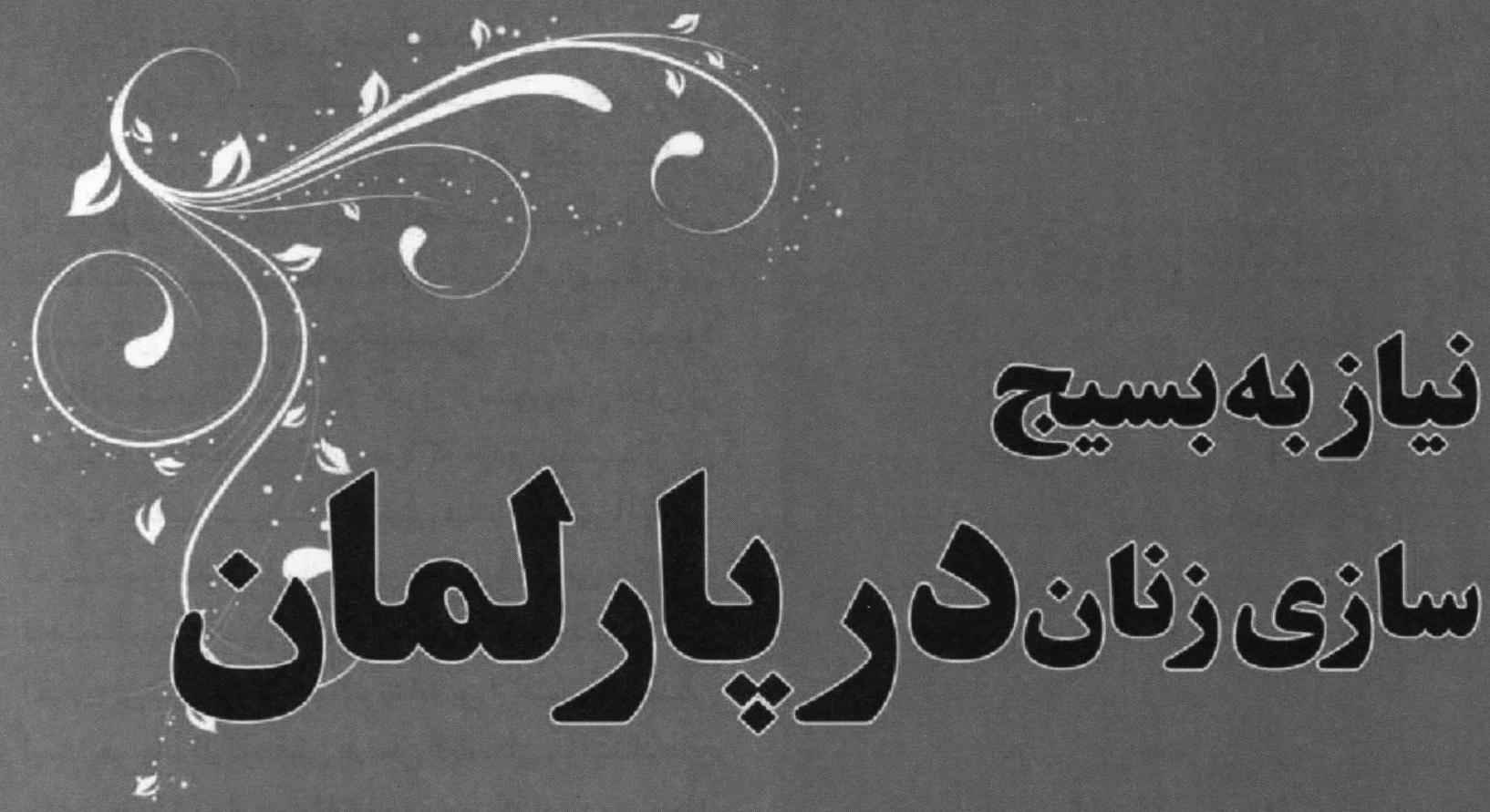

حضورشان به سياست رنك و بو مى دهند و قدذرت رابـراى عامل و تعارض همزمان كه جغر افيايى بـه نام افقانسـتان در

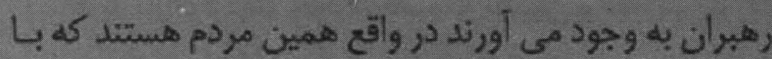

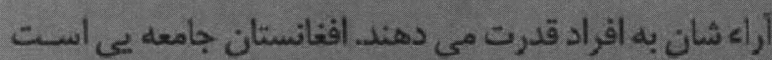

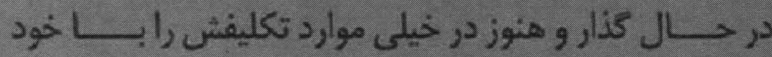

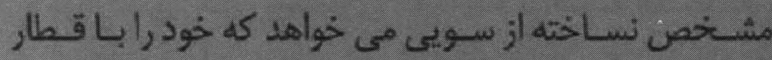
جامعه جهانى همسو و هم مسير بسازد و أز سويى ديكر سنت

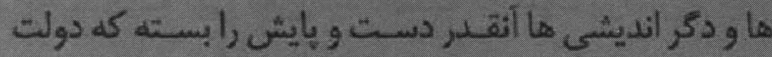

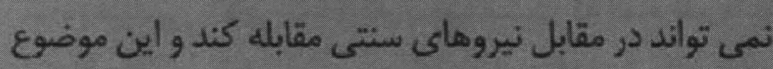
تناوم يك جنت فرسايشى بين دو جاح كثته است.

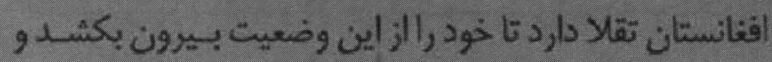
به سوى ترقي و ييشرفت حركت كند البـته دولت افغانسـتان

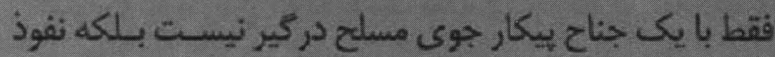

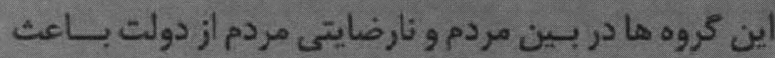
شده تا اين جناح از ميان كروهمباى مردمى سربـاز كيرى كند

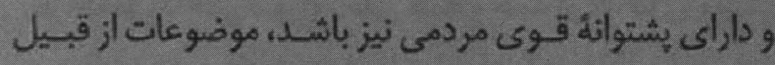
مشكالاتى" جون: فساد ادارى و مصلحت انديشى هاى دي داخل دولت و عدم قاطعيت در اجراى طرح ها و بلان ها نيز بـاعث شده است كه دولت افغانستان در مسير دولت سازى، تقـويت يووسه صلح، نظام قضايى عادلانه و طرح و اجراى قوانين به

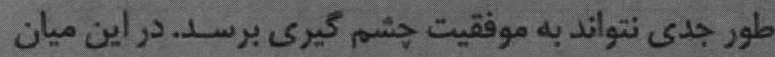

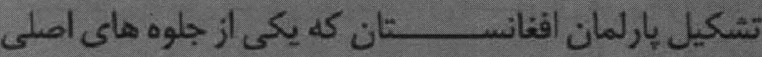

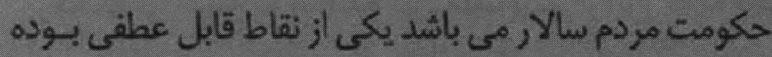
است كه مردم افغانستان به أن حشم اميد داشته اند و با وجيود

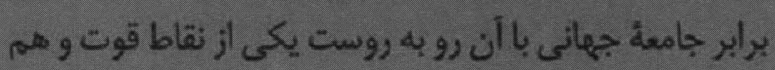

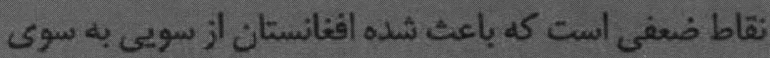

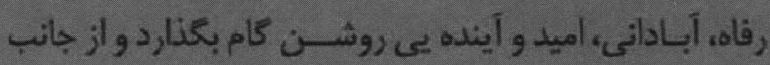
ديكر با حفظ سنت هائ خرد ستيز و غير عقانانى در مقايلـ هر نوع بيشرفت و توسعه يع بازدارنده كى ايجاد كند.

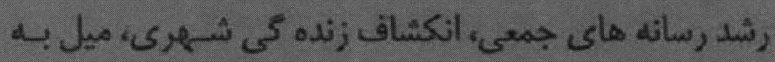

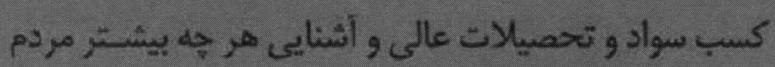

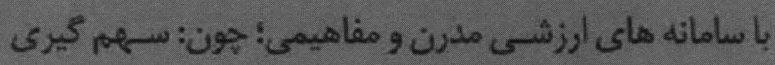

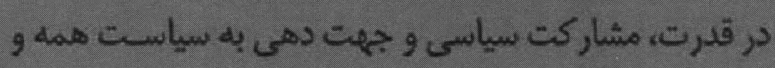

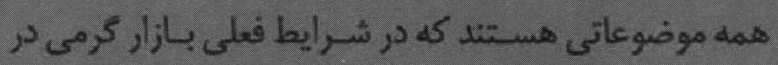

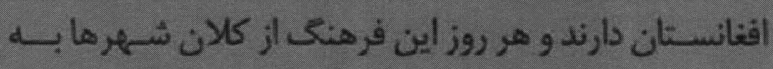
روستاهاى افغانستان تسرى مى يابد كويا با تمام سنتى بودن

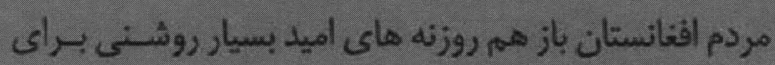
تسريع تشكيل فرهنك ش-هروندى در اقغائسـتان وجود دارد

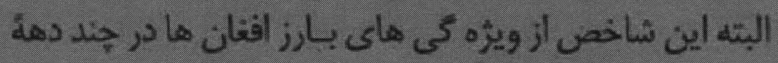

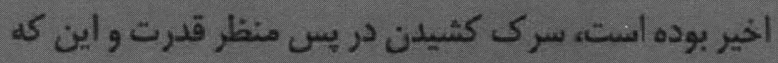

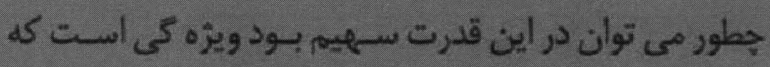

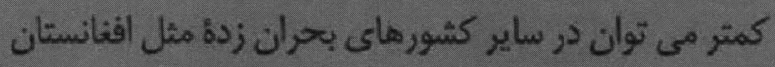

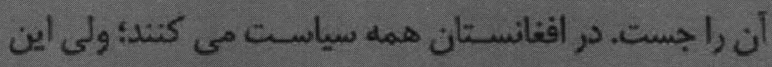
مشـاركت سياسـى متاسـفانه هيج كاه از يك أكاهي و هدف سياسى كه در يشت خود اهداف متعالى داشته باشد برخوردار نيوده است ولى بـا تمام اين اوصاف اين مردم هسـتند كه بـا بـا 
بيشتر به دنبال منفعت جويى هاى شخصى بودند.

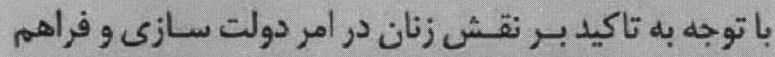

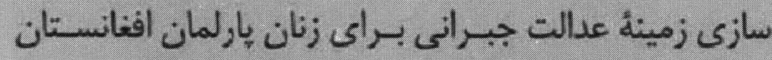

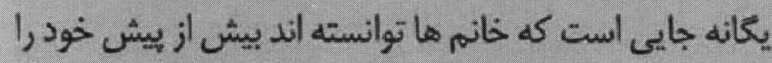

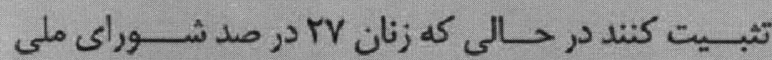

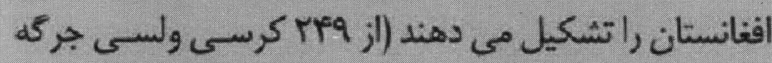

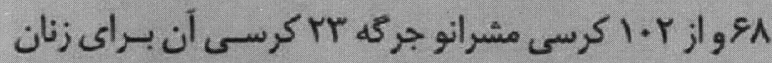

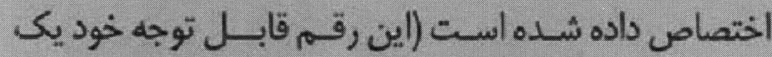

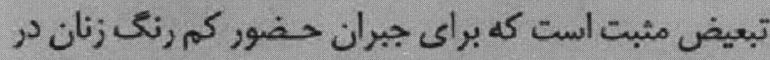

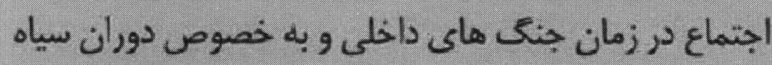

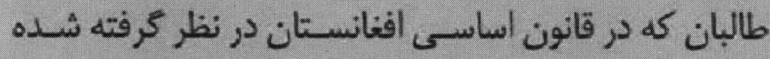

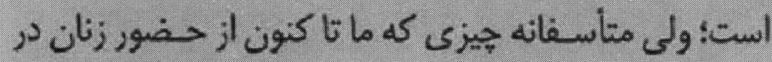

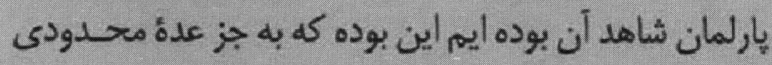

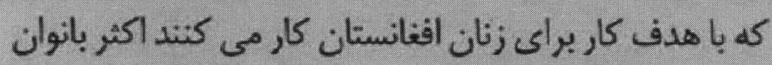

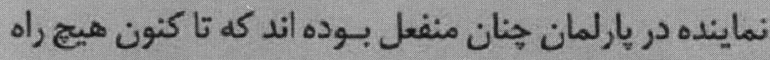
كار و يا طرح قابل توجهى از سـوى آنان نه تنهها در زمينه كار

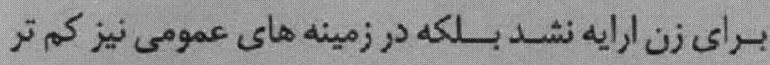

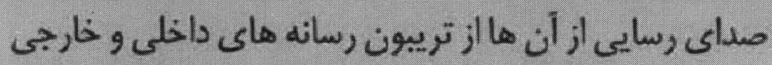

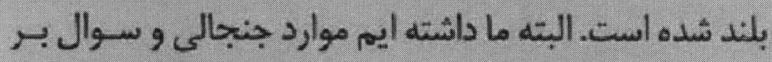

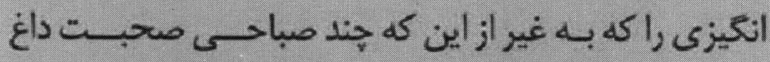

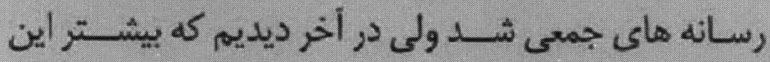

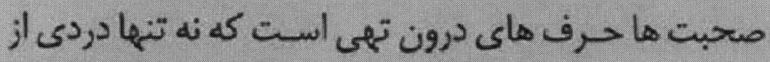

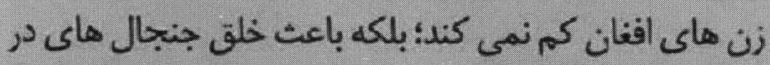

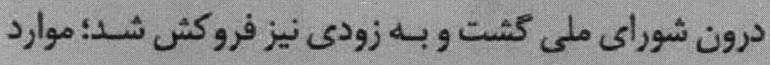

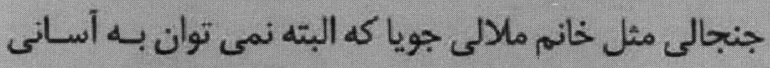

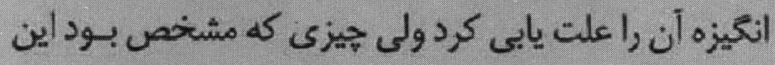

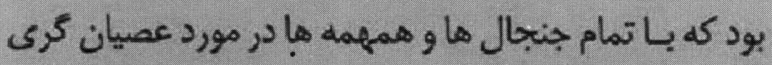

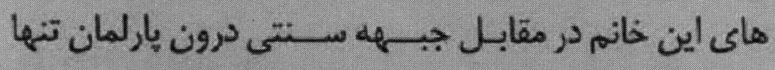

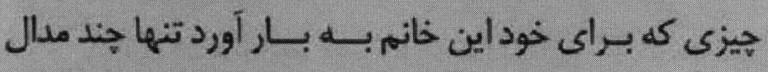

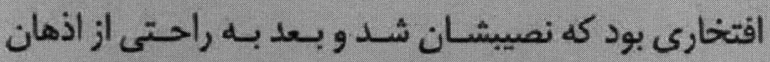

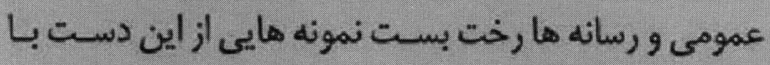

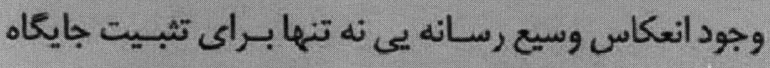
نماينده كان زن كمكى نكرد بلكه با وجود ستتى بودن و توده

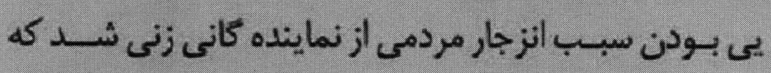

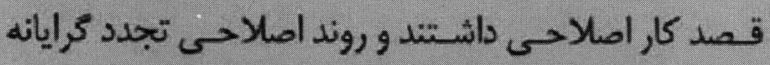
درون يارلمانى رانيز بطى ساخت.

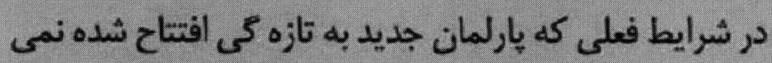

مشكلات بسيار با شركت در انتخابات نشان داده اند كه هنوز به هارلمان و تتايج كارى آن خشم اميد دارند.

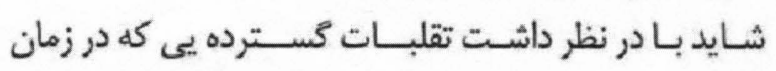

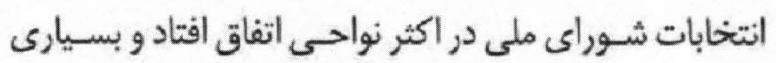

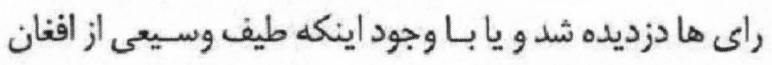

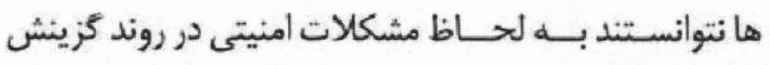

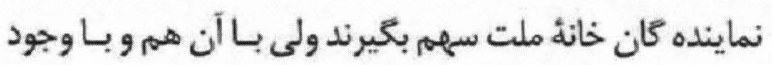
مشكلات متعدد شركت تعداد كثيرى از شهبروندان افغان در

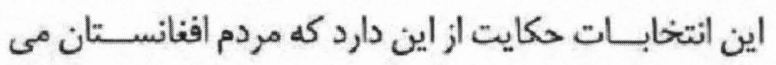
خواهند در تغيير سرنوشت خود نقش داشته باشند و با انتخاب نمايندة مورد نظرشــان از طريق مجرايى قـــانونى از كاركرد

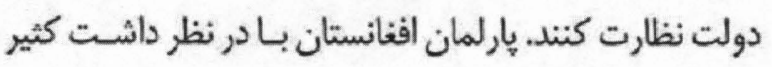
القوم بودن اين سرزمين نماد و نشانه يـى از اقـوام افغانسـتان بـان

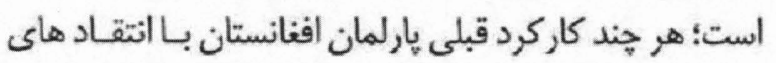
جدى مواجه شده است اما انتظار مى رود كه اين دور يارلمان

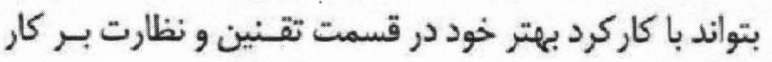

دولت خلاهاى قبلى خود را ير بسازد.

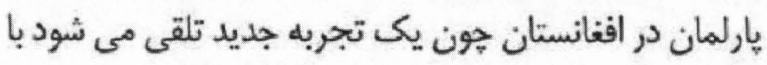

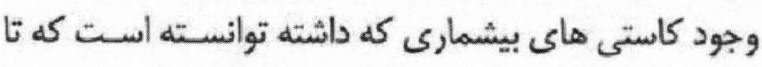

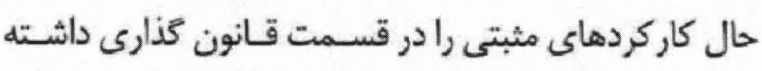

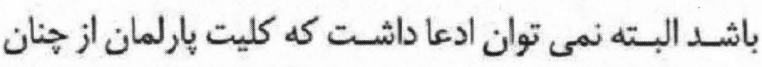

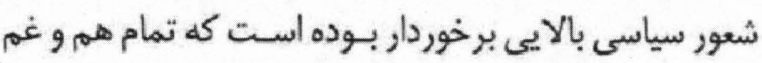

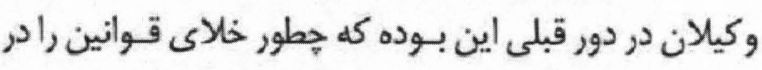

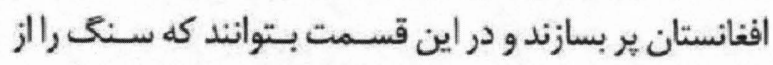

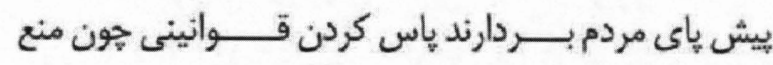

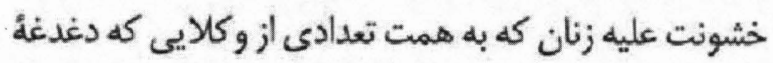
كار براى زنان افغان را داشتند، به تصويب شوراى ملى ملى رسئ تعديد

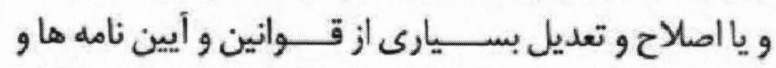

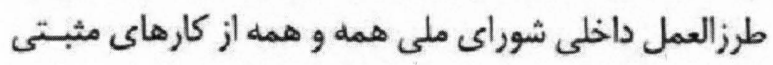
بوده كه در دوره كذشـته انجام يذيرفته است ولى ولى الى اين رانيز

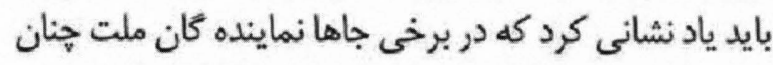

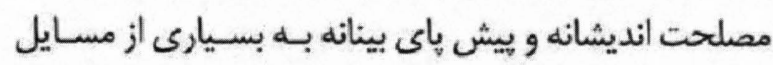

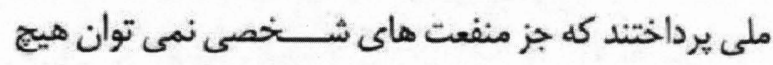

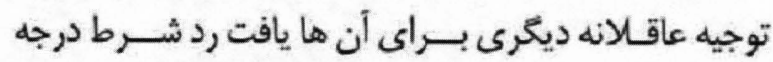

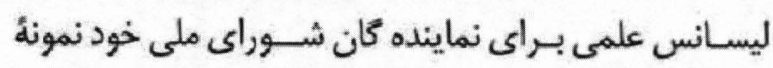

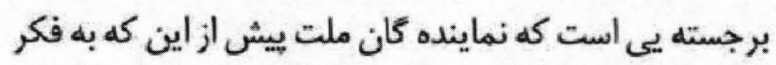

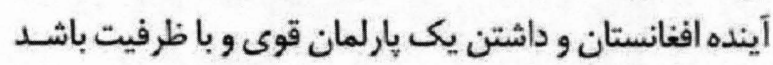


تصميمات يارلمانى تاثير بخذارند.

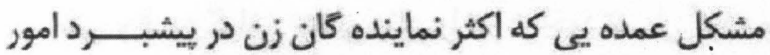

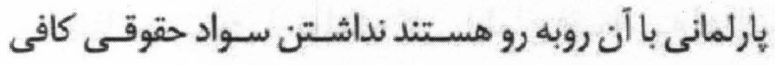
است با توجه به اين كه يكى از وظايف عمده قوه مقنته قانون

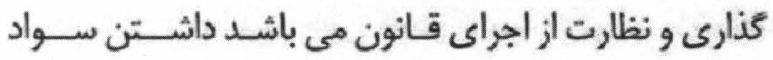
حقوقى يكى از موارد الزامى است كه اشراف بر آن براى تمام

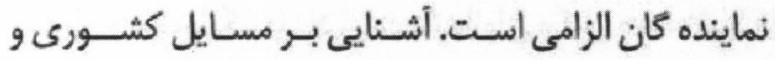

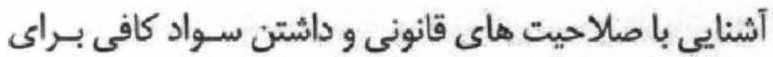

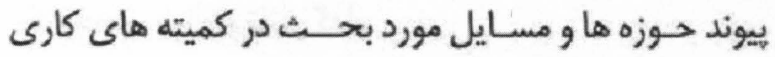
درون يارلمانى بـا قـوانين نافذهُ كشـور يكى از نقـاط ضعفى مانى

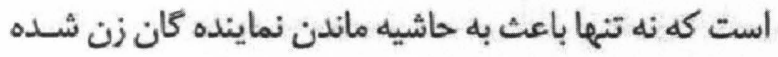

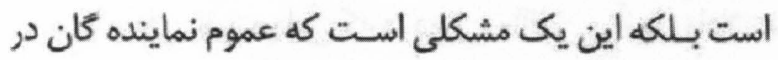
شوراى ملى با آن روبه رو هسـتند ولى زنان مى توانتد در اين اين

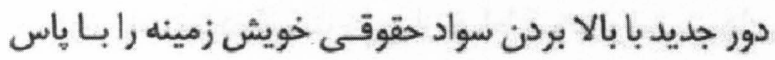

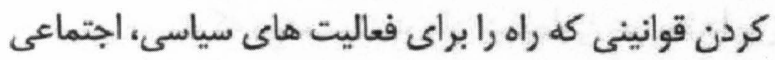
و اقتصادى زنان هموار مى سازد بيش از ييش فر اهم سازند.

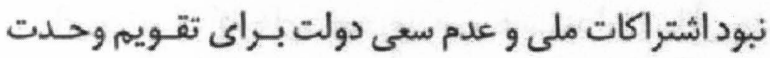

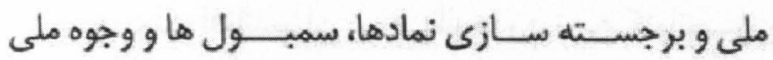
متاسفانه باعث شده افغانسـتان هميشــــ از اين ناحـيه لطمه

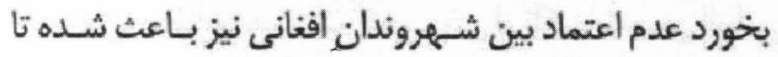

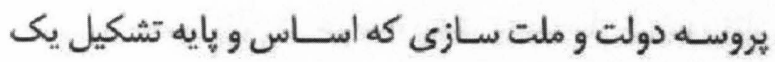

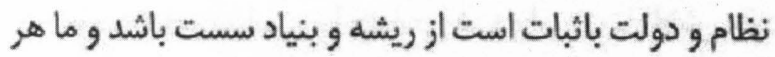
روز بيشتر از ديروز در بديينى هاى خودمان دركير باشيمه و اما

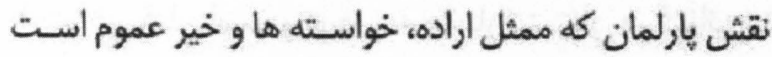

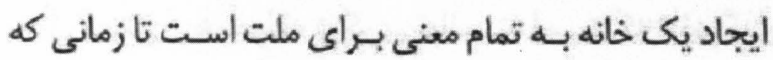

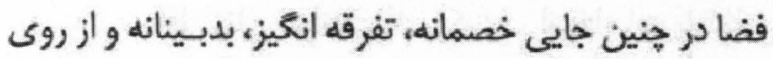

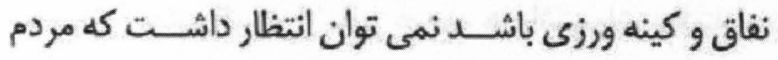

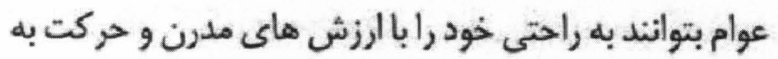
سوى جامعه ايى روشن و مرفه همسو بسازند لازمى است كه اين حـركت از داخل تشكل هاي درون هار لمانى آغاز شـود و

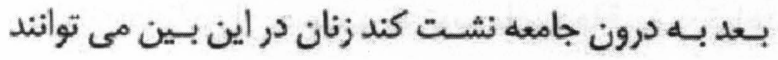

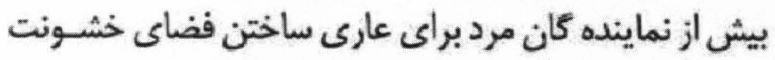

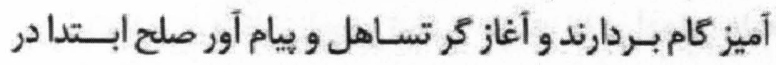
خانه ملت شوند آغاز روند تساهل و تسامح مطمتنا آثار سريع

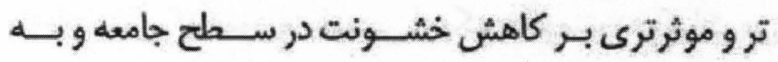
خصوص بر روى زنان راخواهد داشت. اما جيزى كه تا حـال بـــه صورت عينى از عمل كرد نماينده

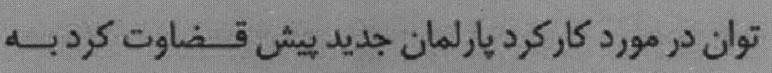
همين دليل آنجه كه در محوريت اين بحث و مقال مي كن كنجد

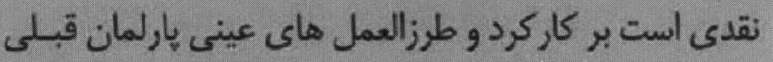

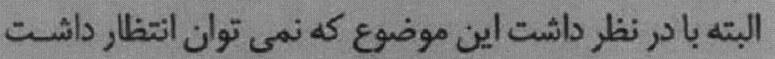

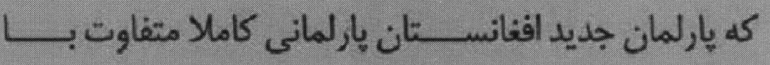

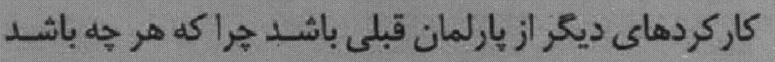

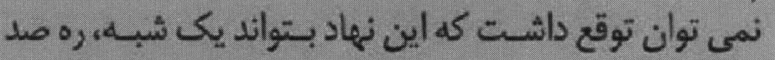

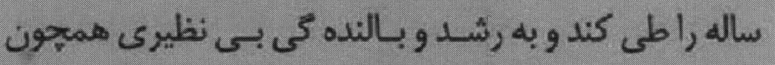
يارلمان كشور هاى توسعه يافته بر بسد.

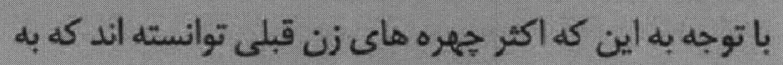

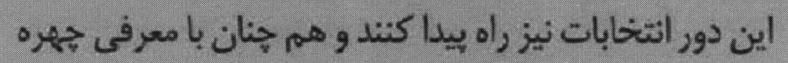

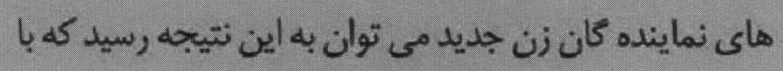

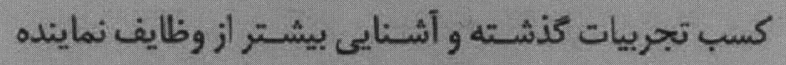

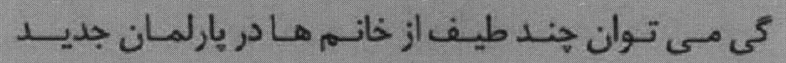
افغانستان ييش بين بودان

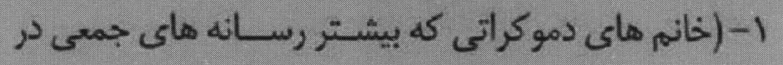

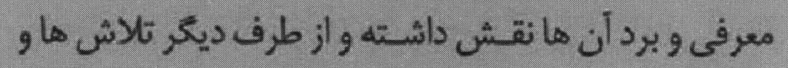

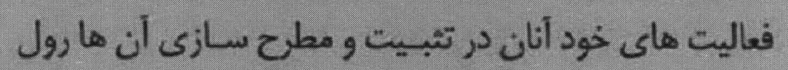

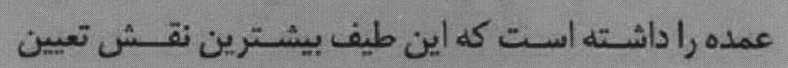

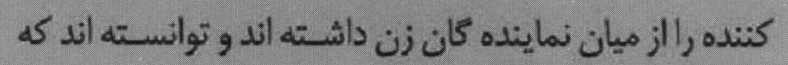

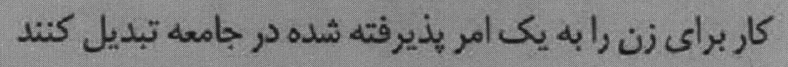

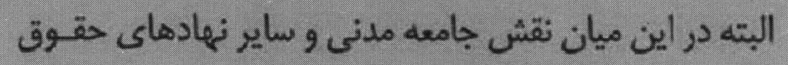

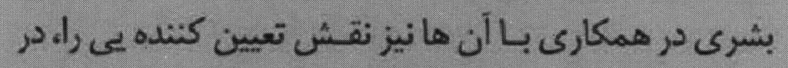

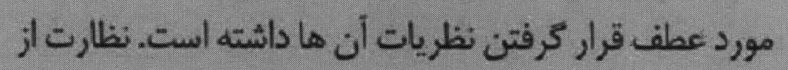
زندان زنان و تلاش تعدادى از نماينده كان زن در در اين زمينها

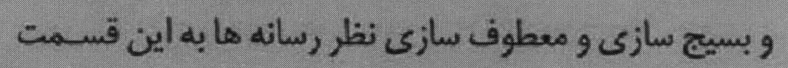
از كاركردهاى نظارتى مثبت اين طيف بوده است.

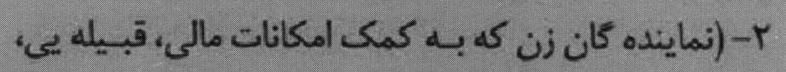

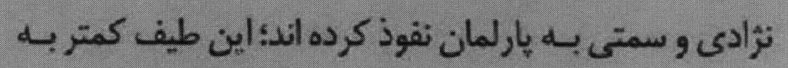
دنبال دغدغة كار براي زن و مصلحت عموم است؛ اكثر اينان

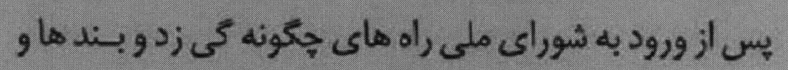

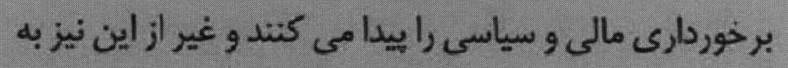

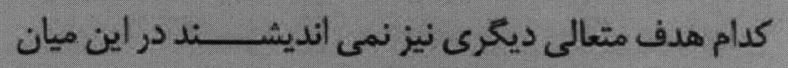

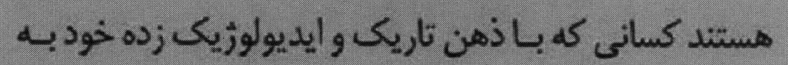

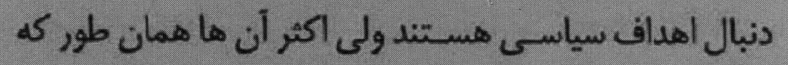

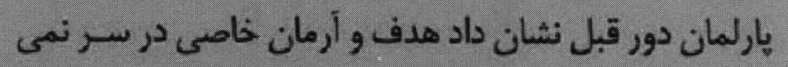

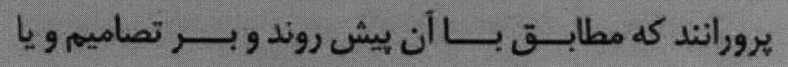


بيشتر محصول تصميهم وار اده دولتها بوده اسـت، تالينكه ثمره

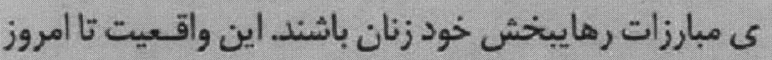

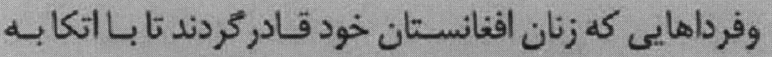

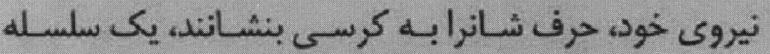
نوسانها رادر داد وكرفت حقوقى زنان و جامعه ترسيهم خواهد

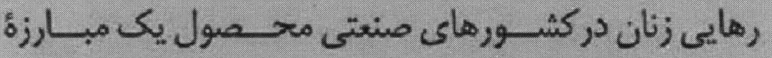

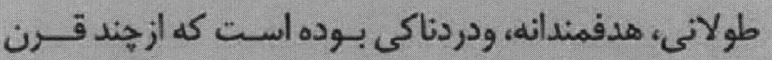

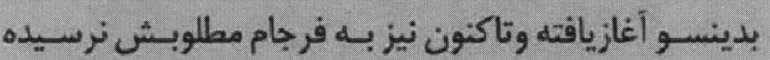

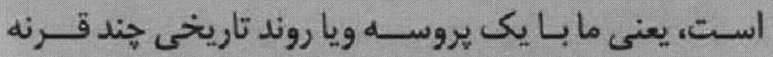

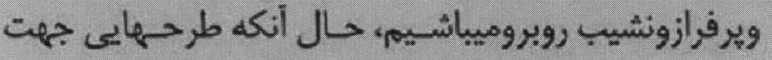

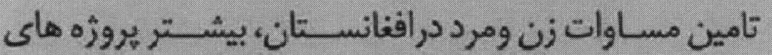
دولتهاى افغانستان يا آنجه جامعهء بين المللى خوانده ميشود

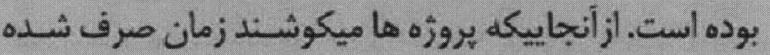

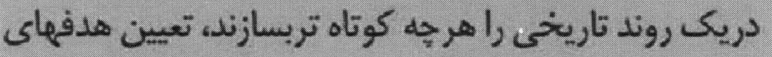

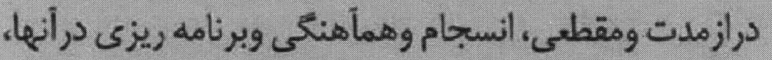

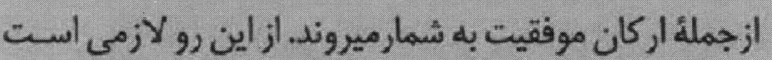

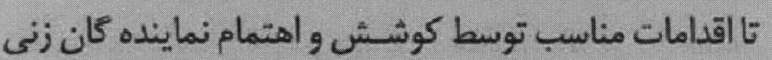

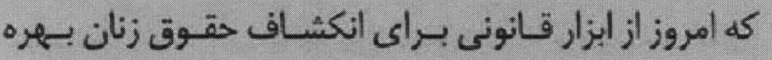

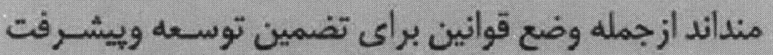

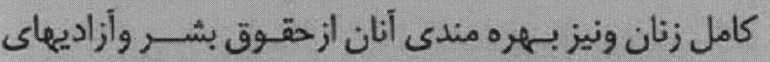

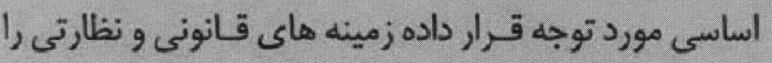
براى دفاع از حقوق زنان فراهم آورند.

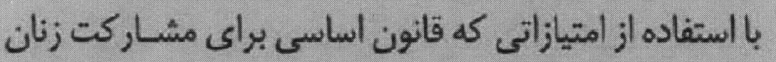

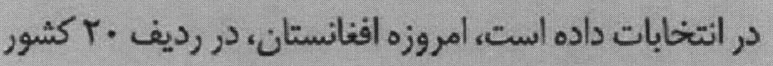

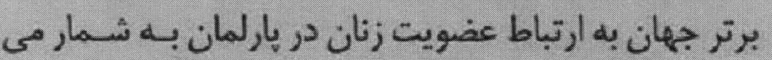
رود. تعداد وكلاى زن در شوراى ملى افغانستان بيش از تمام

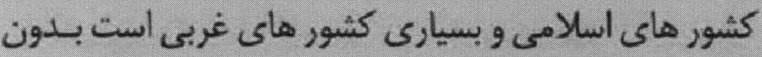

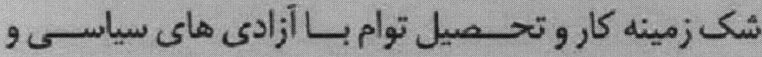

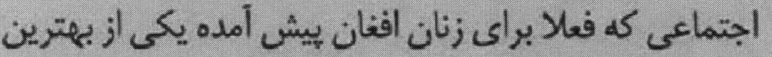

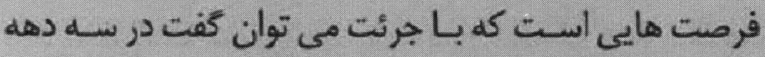

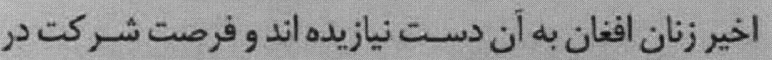

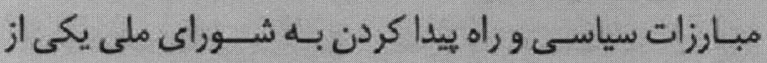

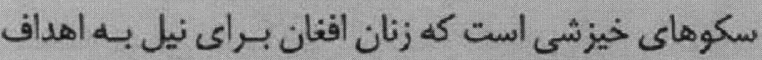

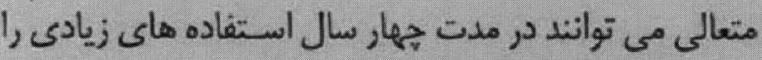

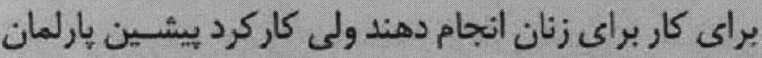

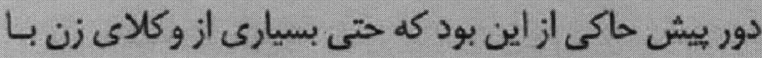

كان در پارلمان ديده شــده اسـت كه متاسـفانه سليقـه هاى

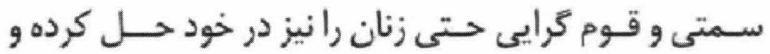

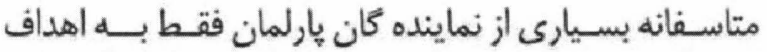

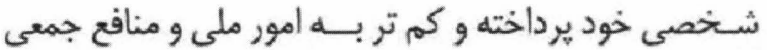

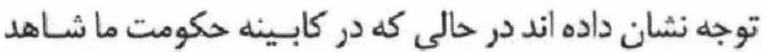

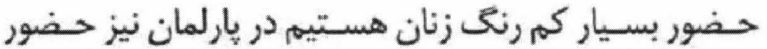
منفعل و سمبوليك تعداد زيادى از بانوان وكيل باعث شــــان

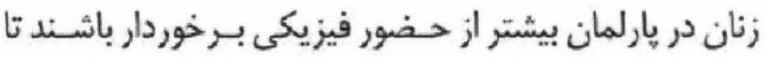

$$
\text { يك حضور فعال و تاثير كذار. }
$$

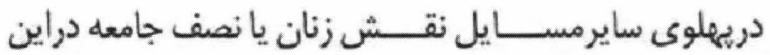

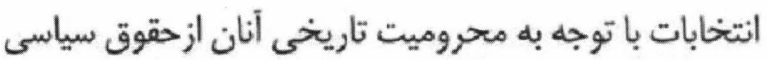

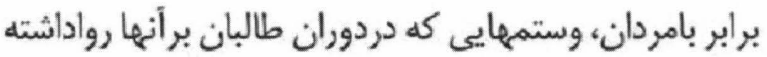

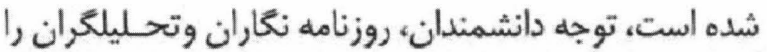

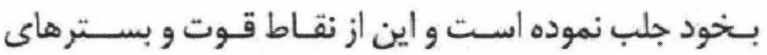

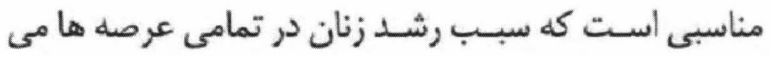
شود يعنى در كنار اينكه زنان با بسيارى از موانع سنتى جامعه سيه

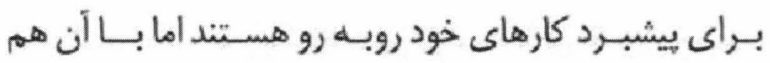
بيوستن دولت افغانسـتان بـهـ قـطار مدرن ترين كنوانسـيون هاى جهانى جهون كنوانسيون رفع تبعيض و يا منع خشـونت عليه زن، ما شاهد هسـتيم كه بــرخى از تاكيدات بـين المللى

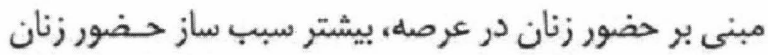

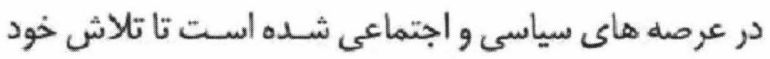

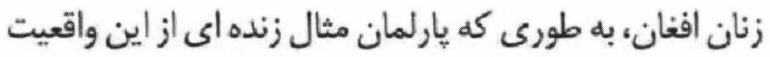

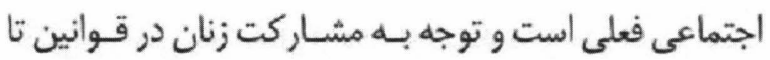

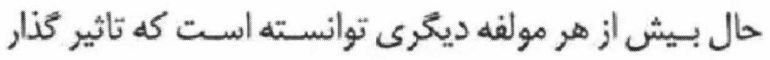

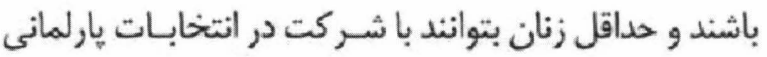
حضورى جشمه كير تر از ساير عرصه ها داشته باشند البته اين بن باين

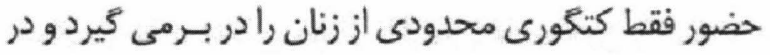
ساير عرصه ها حتى در كابينه حكومت جنانهِ كه فشارهاي خارجى براى حضور زنان وجود نداشته باشد يكى يا دو وزارتى دئ دائه

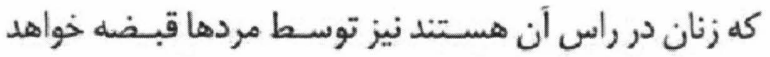

شد.

بى اعتمادى بــه كار زنان در تمامى عرصه ها در اذهان عامه

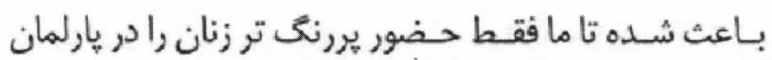

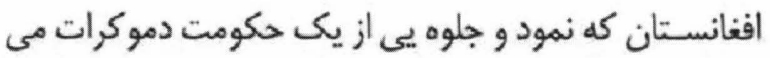

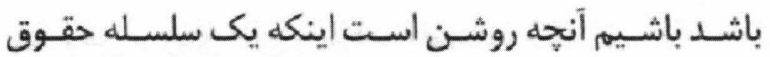

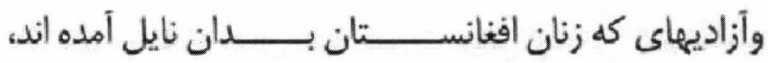


روى طرح هاى كلان و بستر سازى هاى قانونى براى بهبود

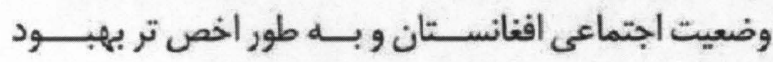

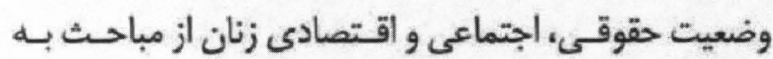

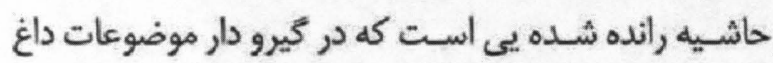

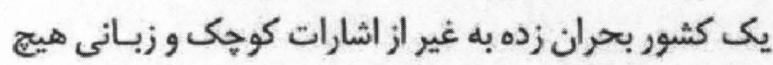
راهكار جدى براى آن سنجيده نشده است.

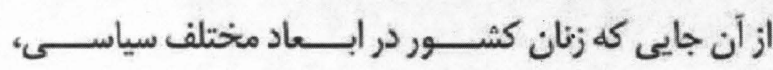
اجتماعىى، اقتصادى و فرهنكى دجار مشكلات زيادى بونى بوده و

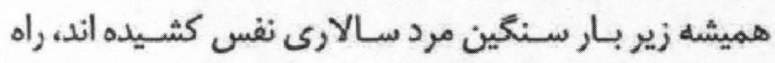

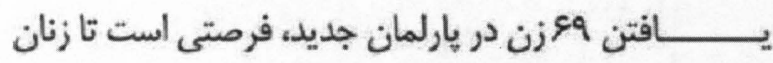

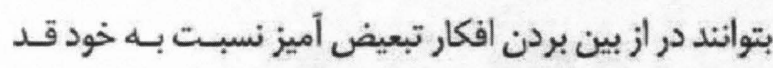

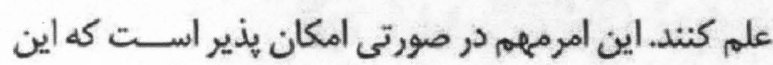

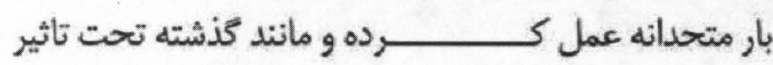

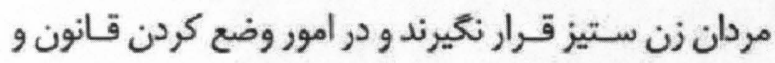
نظارت بر آن، فعالانه عمل كنتئد

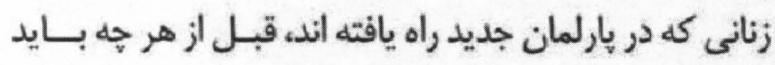

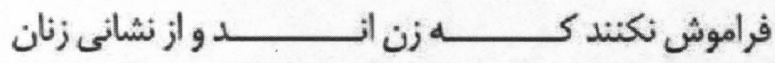
افغانستان نماينده كى مى كنند. آنان بايد با تشكلات منسجم

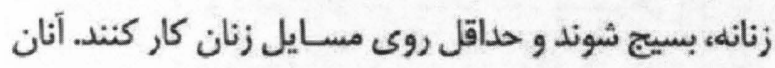

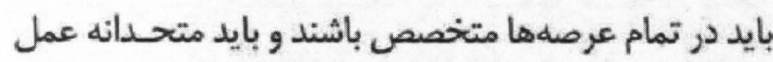

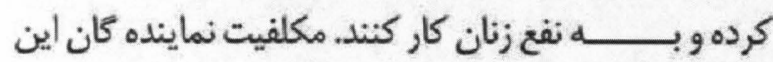

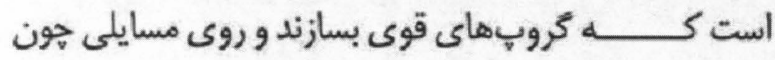

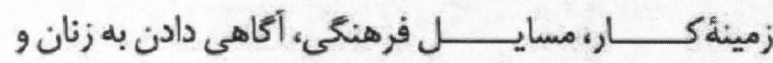
رسيده كى به زنان قربانى و محو خشونتها بير دازند.

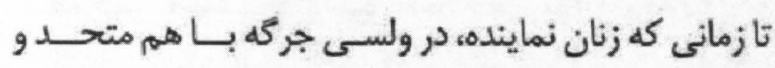

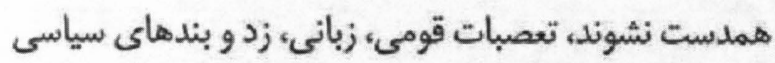

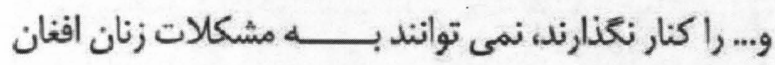

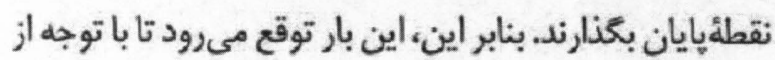

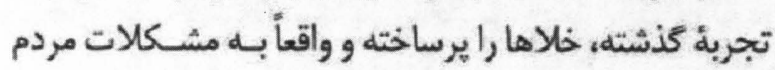

$$
\text { رسيده كى كنتد. }
$$

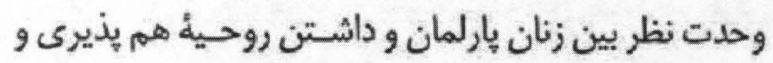

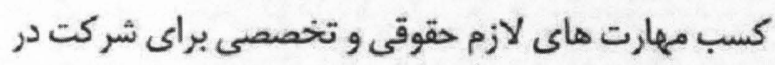

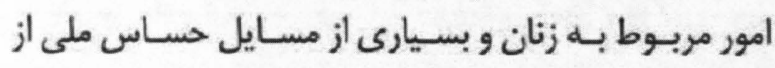
موضوعاتى است كه وكلاى زن با توجه بـه آن قـادر خواهند

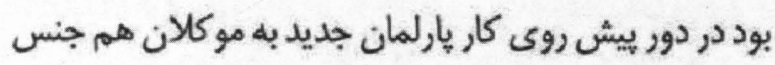
خود كمك كنند و مسير را براى رشد و انكشـاف سـ مطح زنده كى زنان فراهم آورند.
هدف سيرى كردن دوزمركى هاو در كنار آن دست يافتن به

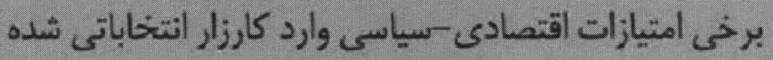
اند و بيشتر در صدد اين بـوده اند كه بـا دنبـاله كيرى بـ بـرخي

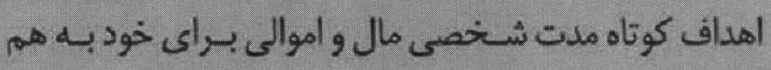

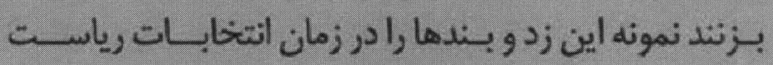

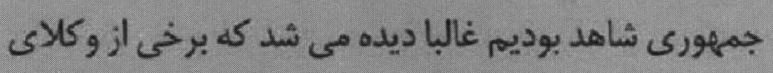

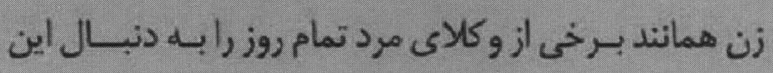

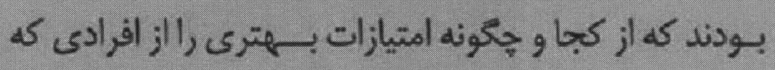

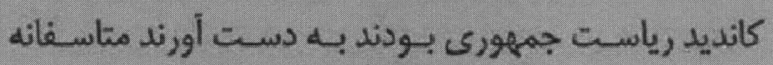
داشتن وجه مردمى براى تعدادى أز وكلاى زن نيز بـ به وسيـيله

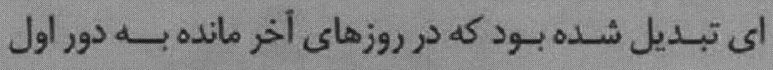

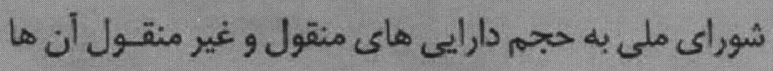

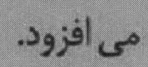
دور كارى جهار ساله اول يارلمان اين رانشان داد كه در كنار

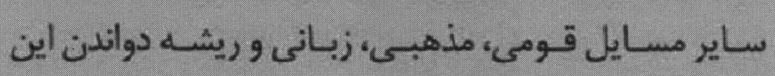

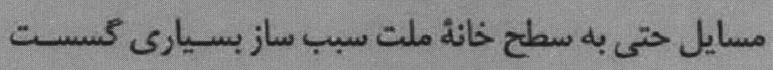

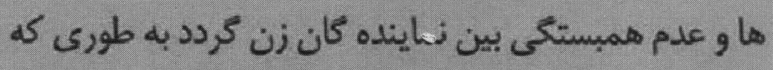

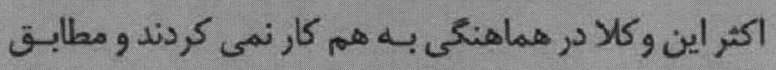

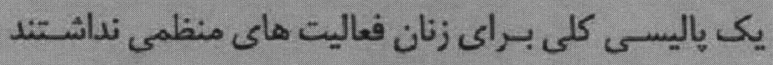

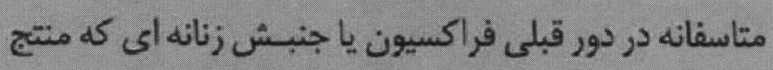
به قوام بخشى و نظم به كار براى زنان باشد از اقتدار و جلديت

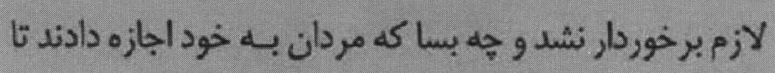

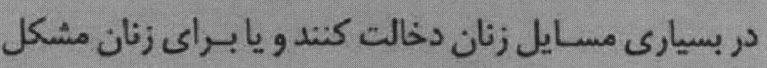
ايجاد كنند. يار لمان افغانسـتان تافته جدا بـافته ائ از جامعه افغانســان

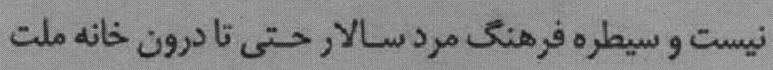

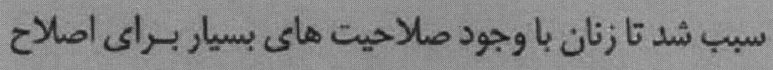

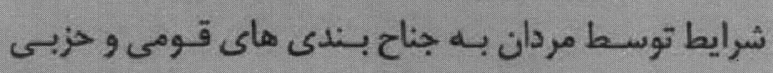

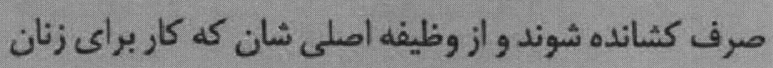

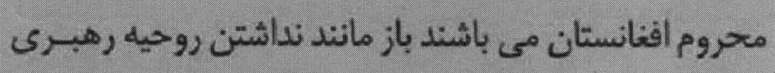

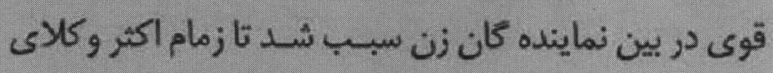

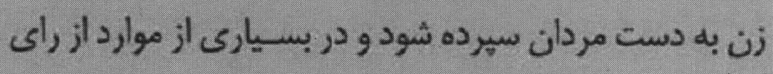

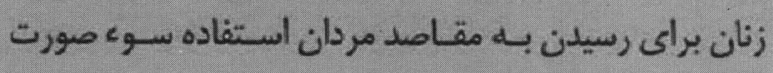
بكيرد. ابتكارات بديع براى تشكيل جنبش هاى زنانه درون يارلمانى

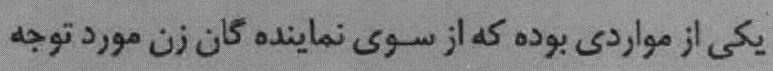

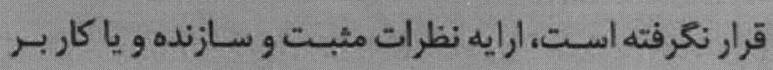




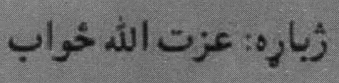
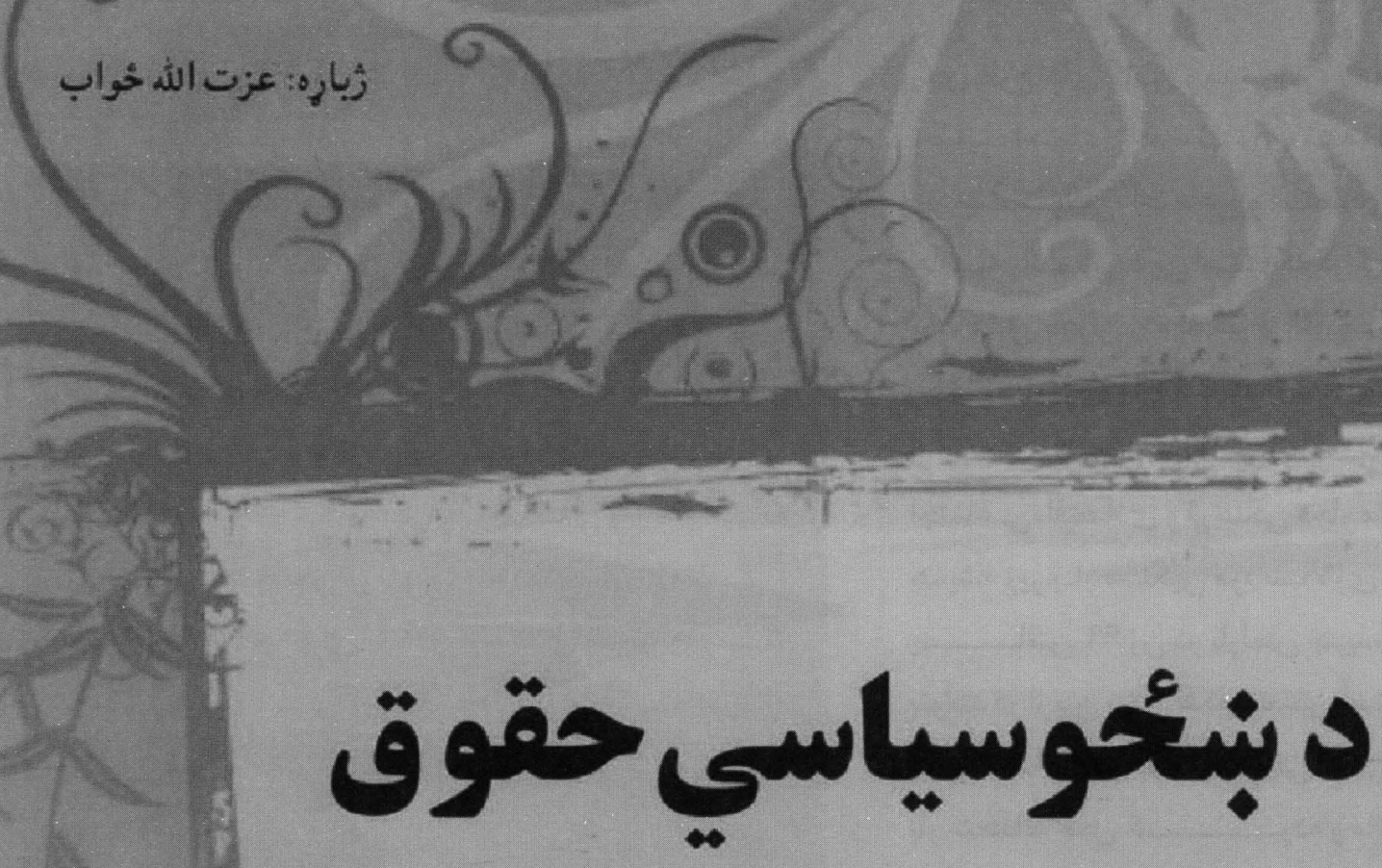

نارينه وو مثـري وكري. خو امام ابـن خلدون اورة اكتر

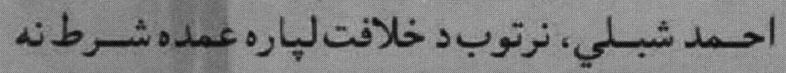

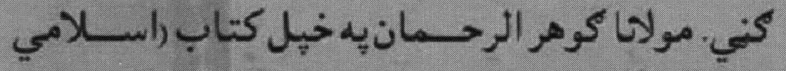

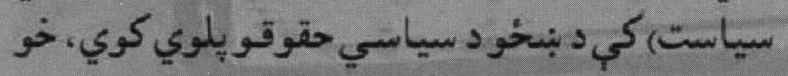

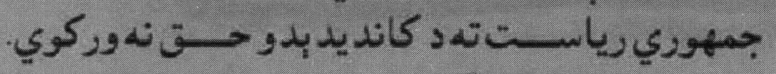

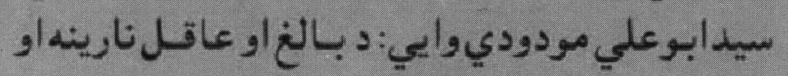

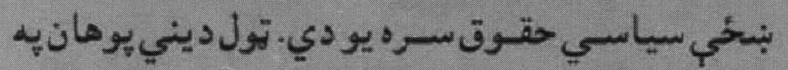

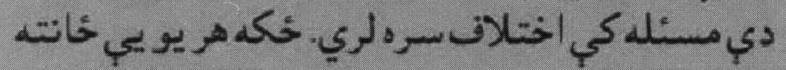

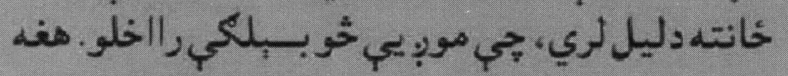

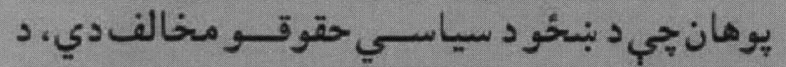

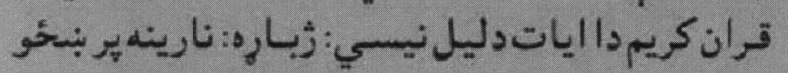

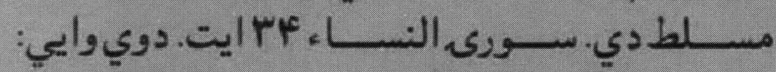

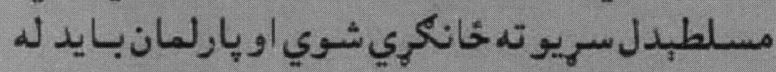

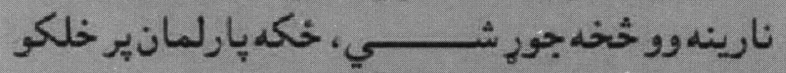

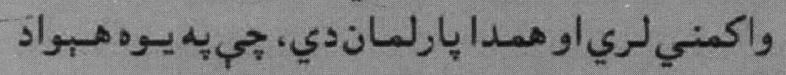

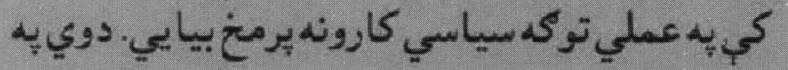

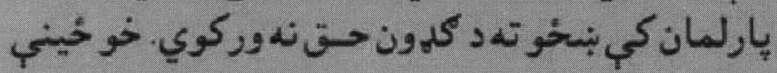

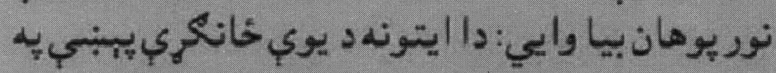

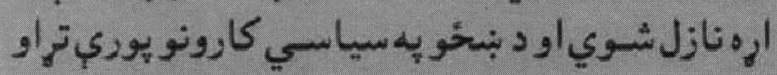

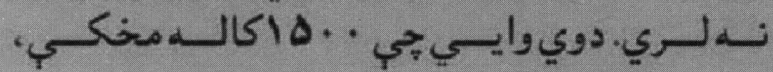

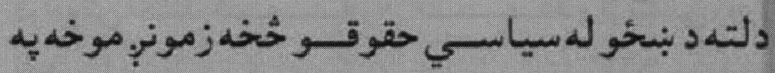

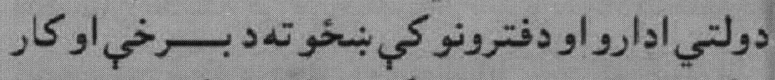

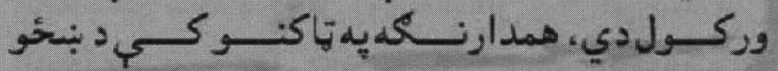

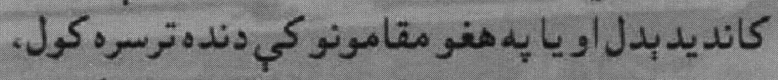

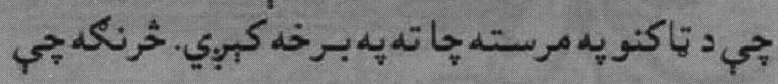

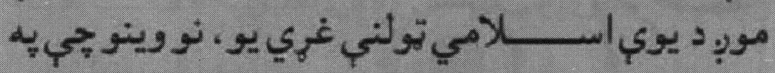

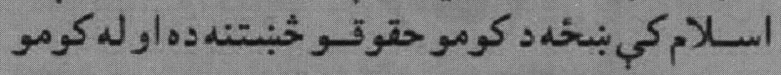

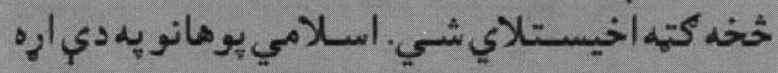

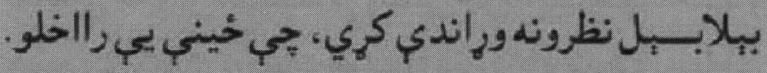

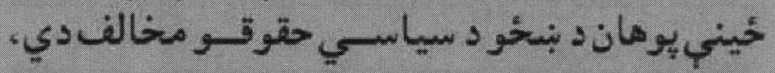

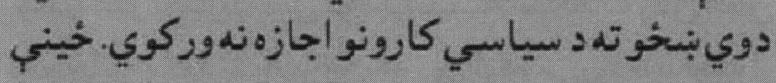

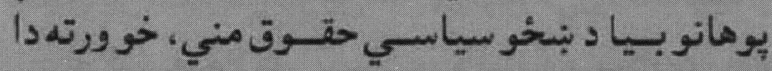

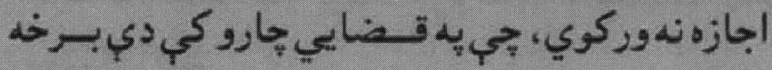

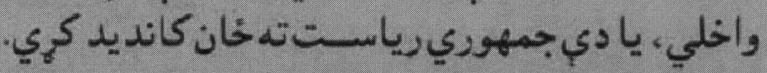

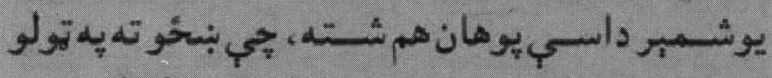

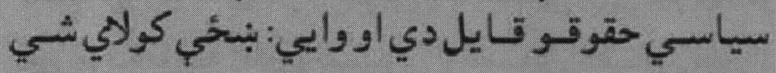

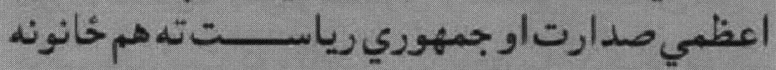

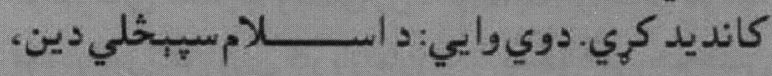

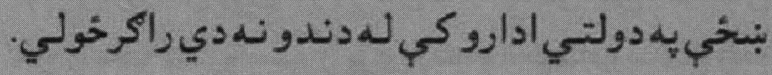
خو

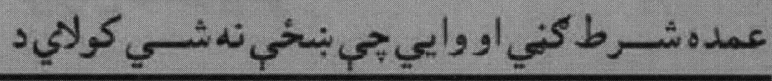


الازض". دويوايسي: يهمومنانسوكي نارينسهاو بندخي

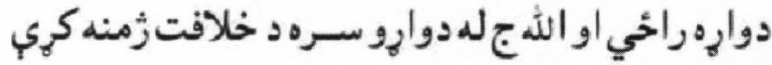

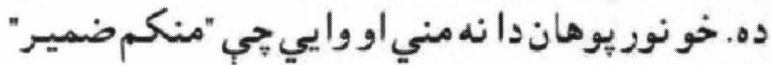

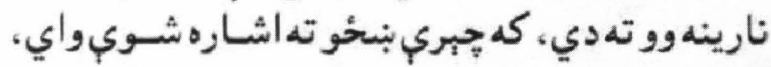

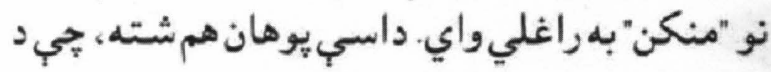

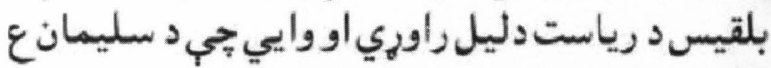

حكومتونو سـاده بـنهنه درلوده او د ببلابـبـلو لاملونو له

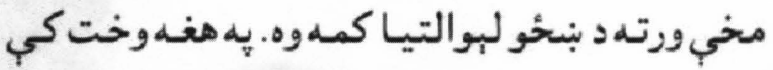

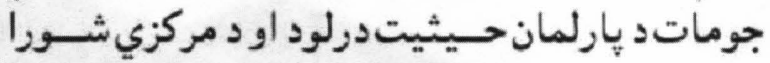

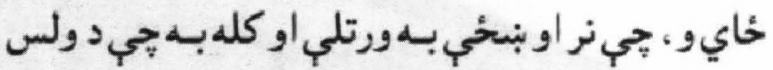

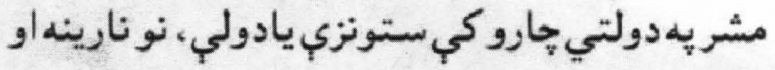

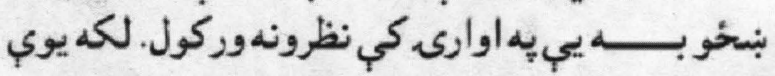

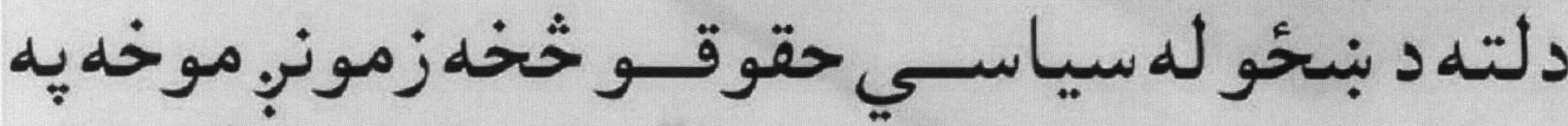

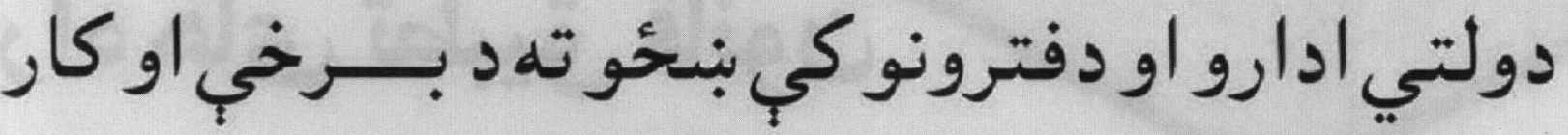

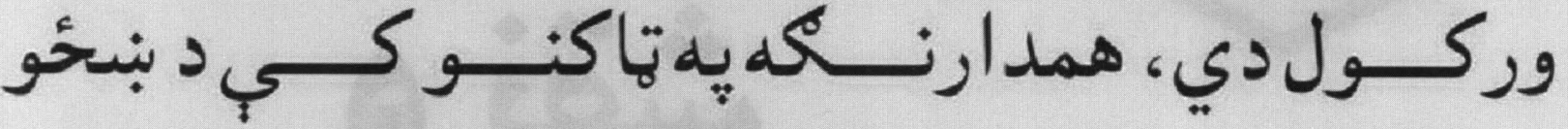
كانل يل بـل

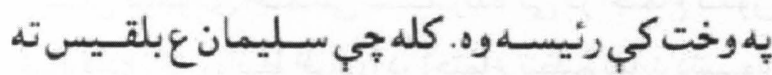

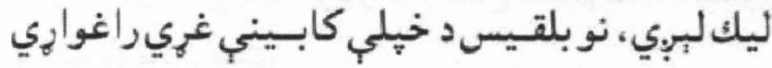

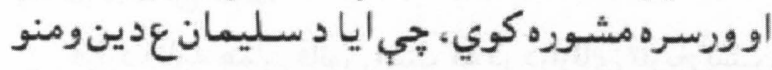

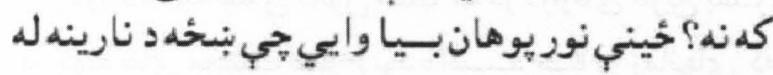

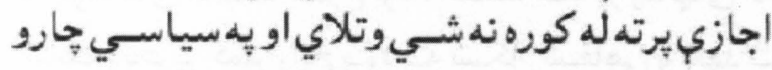

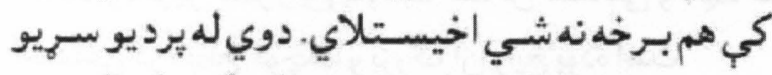

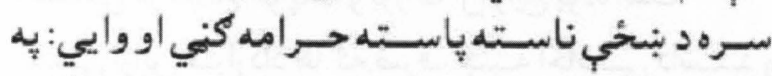

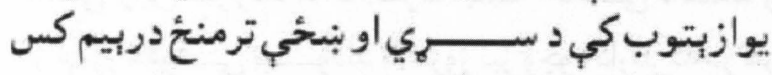

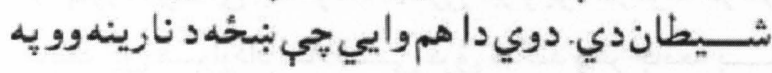

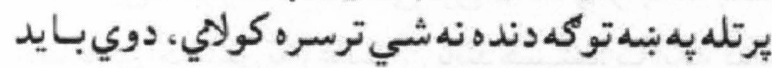

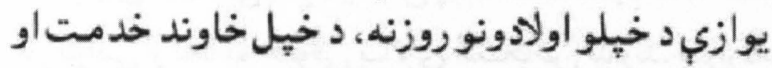

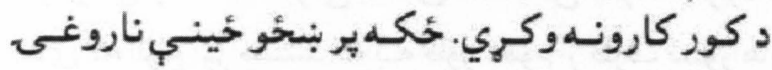

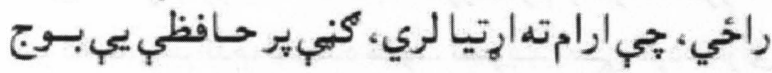

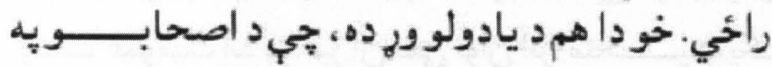

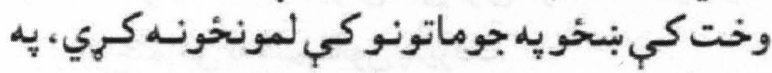

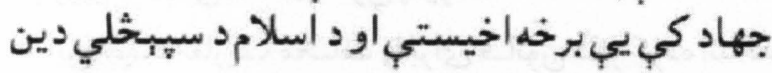

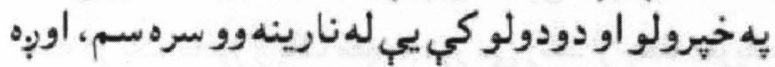

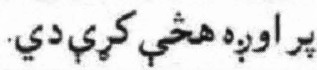

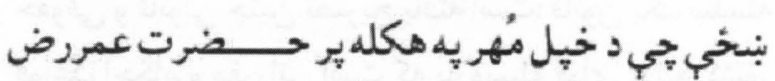

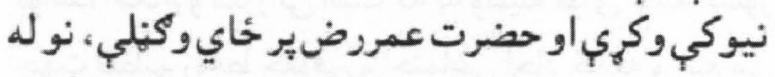

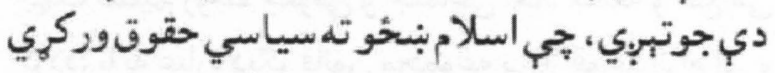

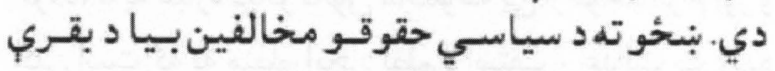

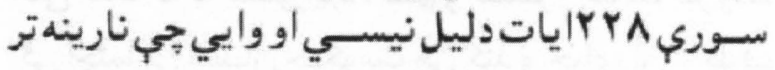

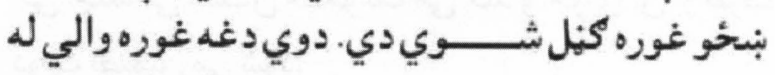

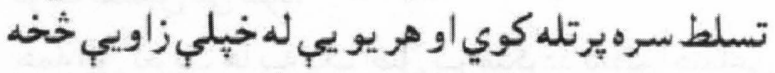

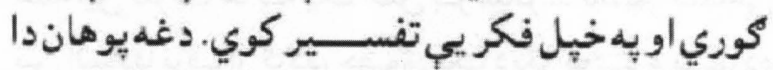

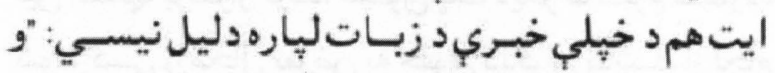
قرن في بيوتكن ولاتبرجن تبرجيت الجاهليه الاولي". دوي

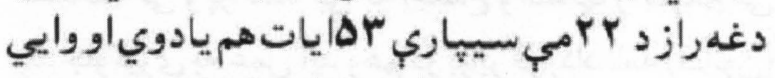

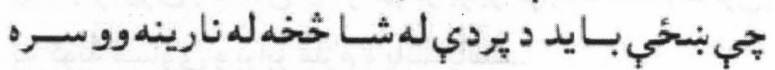

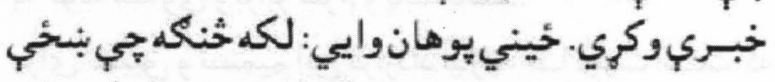

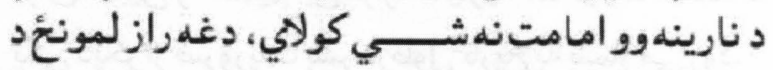

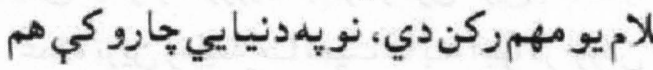

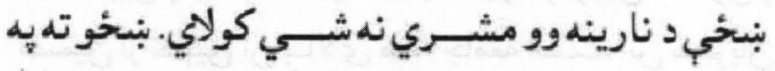

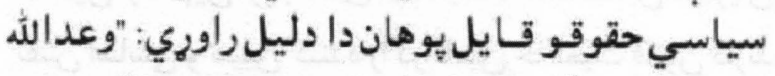

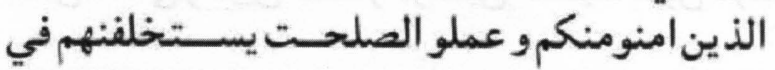


عبدالمنير كوهستانى

\section{راه هاى تطبيق قانون

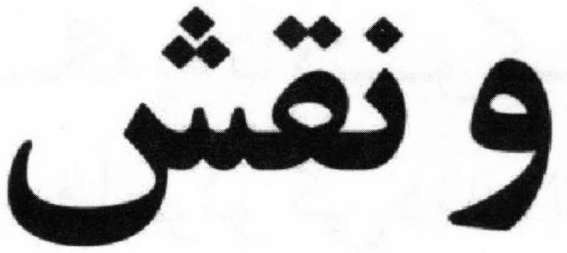 \\ آن درحمايت از زنان}

حقوقى وقانونى هنين تصريح يافته است: قانون يك سلسله قواعد، احكام و مقر راتى است كه به وسيله قواى عاليه كشور جهت تنظيم روابط حقوقى و اجتماعى آحاد جامعه و ضع مى ودى

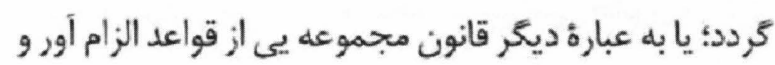

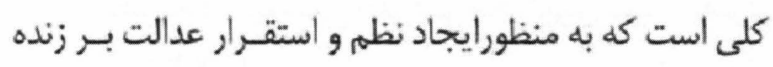

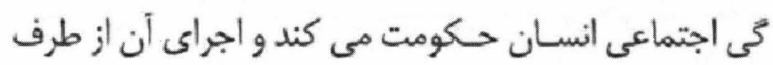

$$
\text { دولت تضمين مى شود. }
$$

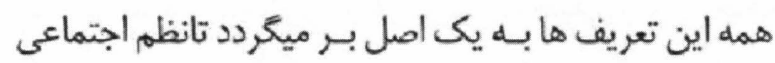

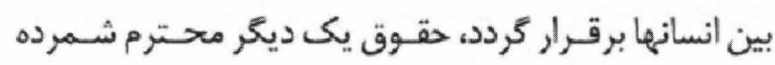
شود، كسى را مجال تعرض به حقوق ديخران نباشــ، از لجام

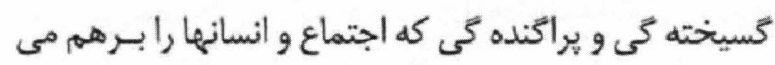

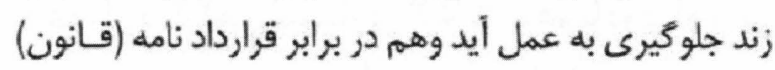
به كونهُ مساوى و برابر ملزم و هابئد باشند.

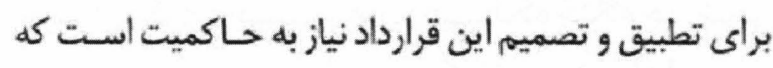
يكى ديكر از ضروريات بشر درطول تاريخ به شمار مى رود.

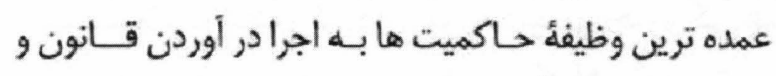

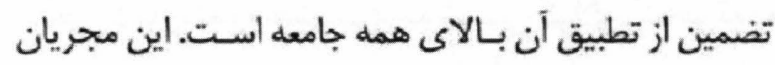
نقش اساسى و تعيين كنتده رادر تامين حاكميت قانون دارند الدمان
انسـان موجودى اجتماعى سـت؛ زنده كى در اجتماع بـدون

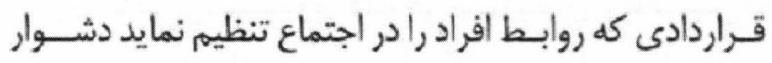
وياهم ناممكن است. اين قراردادنامه همان قانون است كه در درازناى تاريخ بشـر،

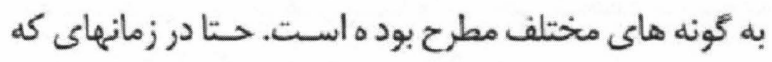

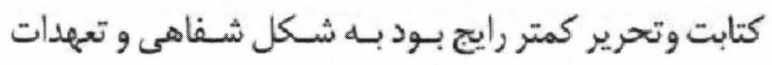
اجتماعى در سطح كوحى و بزرى آن رايج بوده است.

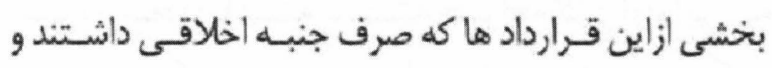

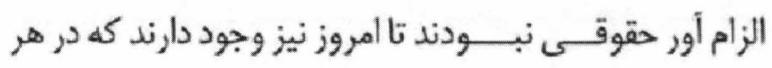

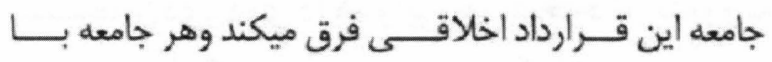

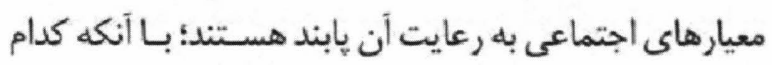

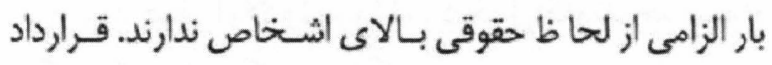

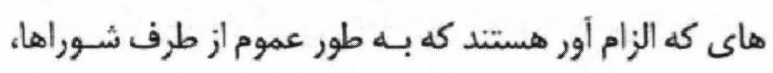

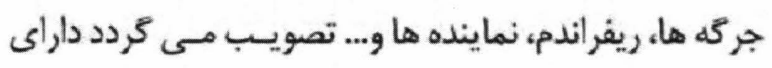

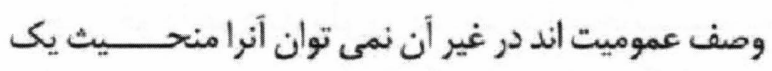
قرارداد اجتماعى به اسم قانون يذيرفت. از اين جهت تعاريف مختلف را براى قـانون ذكر كرده اند كه همه در يك محور و يك مفهوم دور مى زنند.از جمله تعريف 
انجام مى دهد متعلق به خود آنها است"

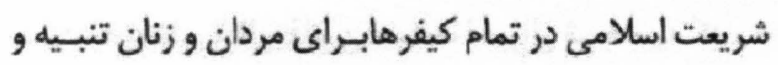

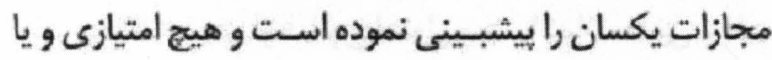

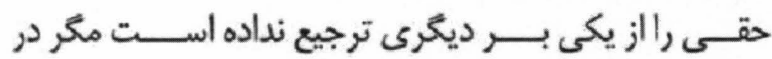
مواردخاص كه نسبت به زنان بر مبناى جايكا هاء اجتماعى أنها

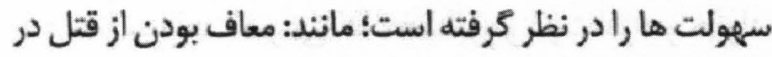

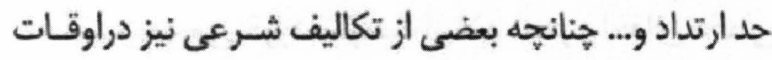

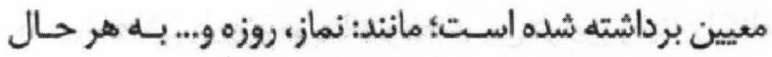

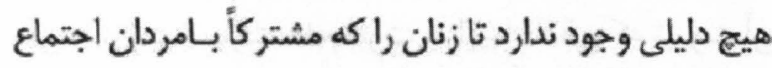
را تشـكيل ميدهند ونقـش اساسـى رادر سـاختار و وييشبـرد اجتماع دارند در انعقاد و تطبيق قرارداد ها (قوانين (از نظر دور

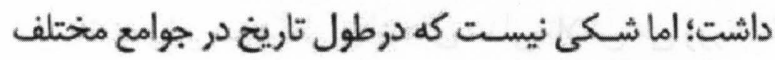
روى انكيزه هاى متفاوت نقش زنان راهم در قانسانون كذارى وهم در تطبيق يكسان قـانون يا كاملا از نظر انداخته اند و يا نائ هم نقش ثانوى وياضمنى براى زنان قايل بوده اند. با تاسف كه تا هنوز هم در جوامع فقير و عقب ماضن مانده اين روند

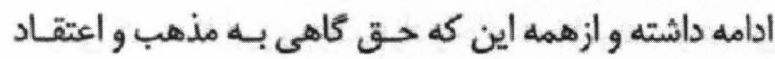
رابطه داده مى شود و كاهى هم تحت نام ارزش ها يا يا فرهنى

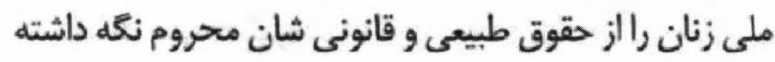

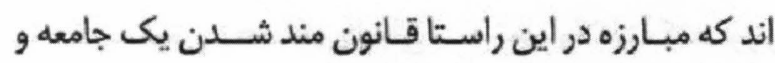
مسئووليت و مكلفيت همه افراد جامعه در برابر قانون و وظيفة فئل نهاد ها و شخصيت هاى آكاه در كشور است.

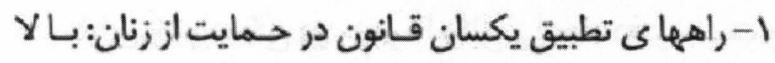

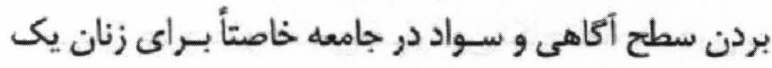

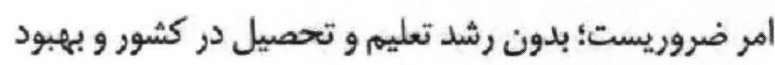
يافتن و ضع فرهنكى نمى توان تنها با حمايت و مصارف بــــ اين مامول دست يافت. r- قراعت واحد ودرست از دين و تعليمات دينى و جلوكيرى

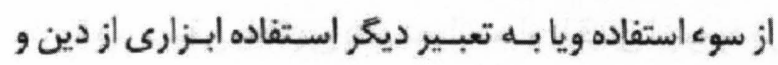

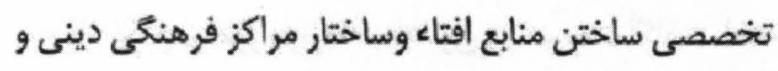

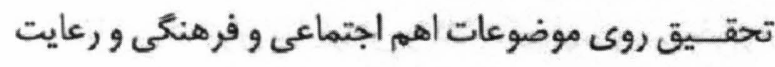

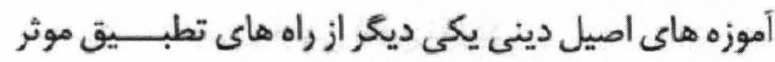

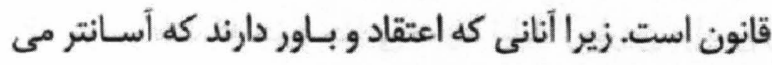

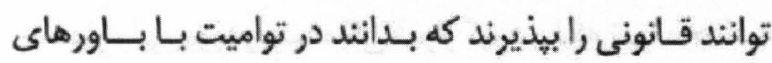

$$
\text { مذهبى شان دارد. }
$$

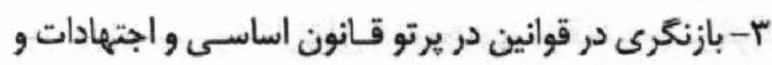

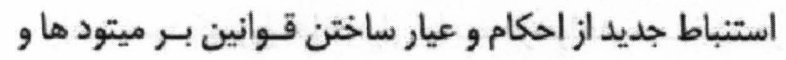

كه از اين طريق عدالت اجتماعى را تامين وزنده كى انسان را

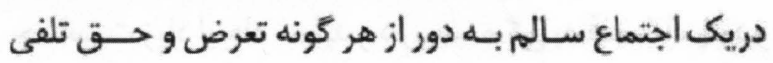

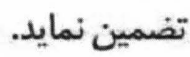
قـانون هر قـــر خوب باشــــد درصورتى كه مجريان قــانون

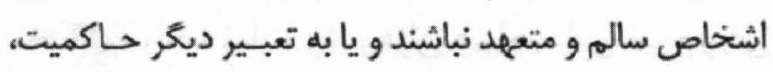

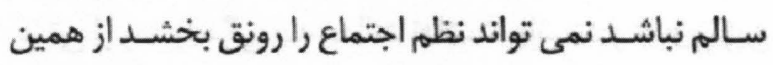

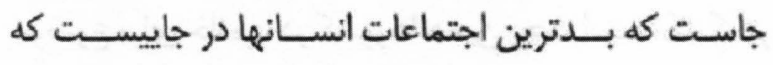

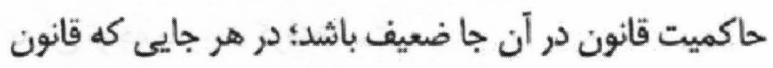

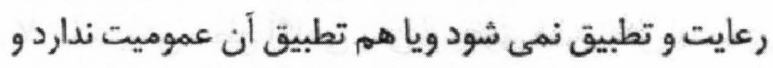

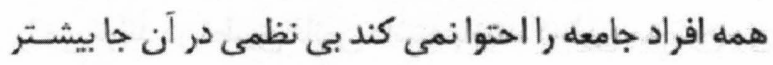

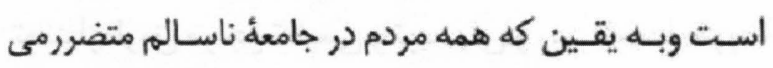

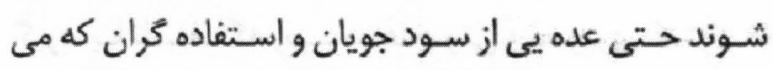

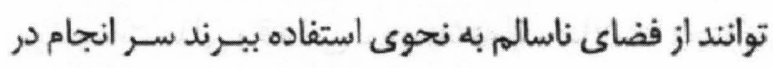

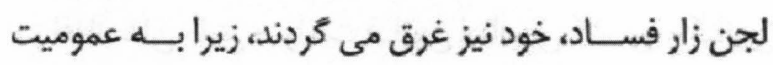

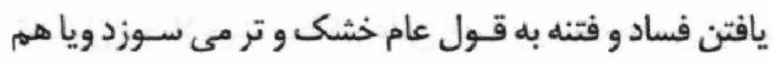

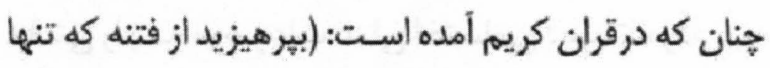

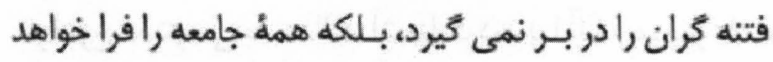

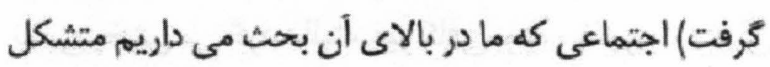

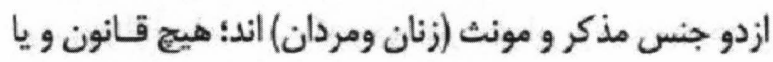

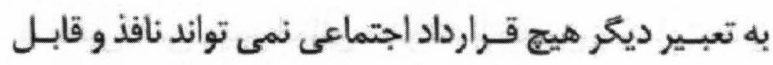

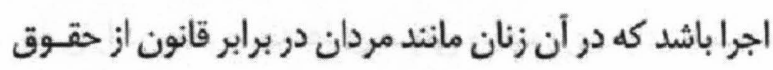
و وجايب يكسان برخوردار نباشند. قانون همان طوريكه در بـالا تعريف شـــ از همه جامعه نظمه

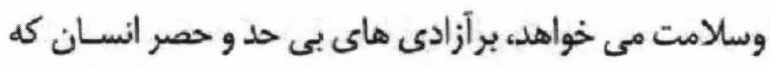

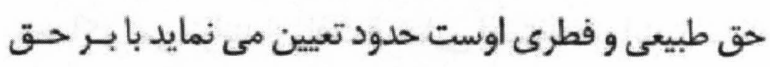

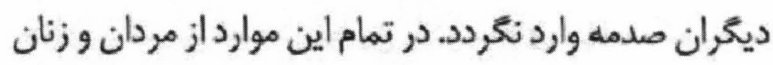

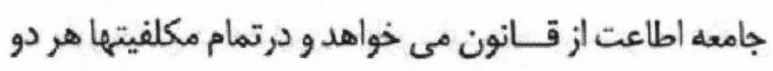

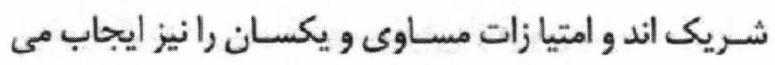

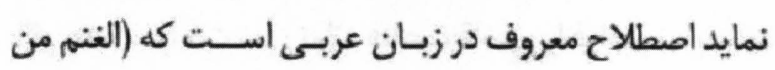

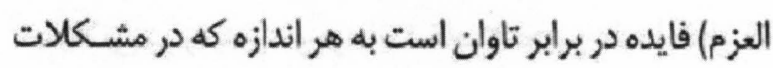

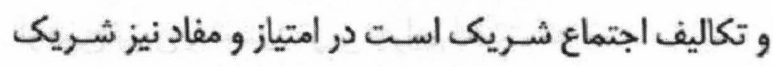

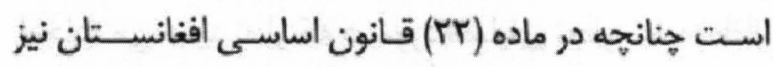

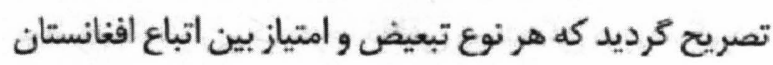

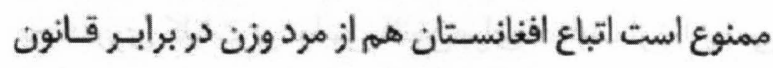
داراى حقوق و وجايب مساوى هستند.

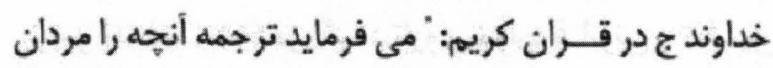

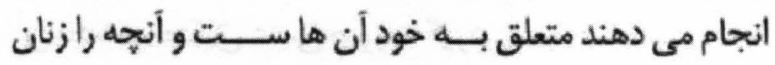


هوضوعات مربوط به خانم ها به نحوى رسـيده كَى كردد كه

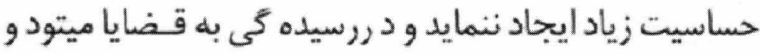
شيوه ها ى خاص صورت كيرد تا همه متتظرين و متقاضيان

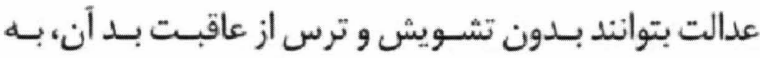

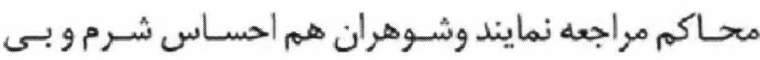

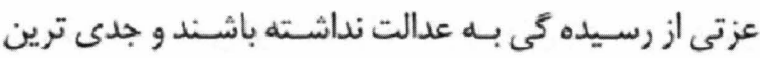

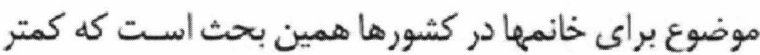
به آن توجه صورت كرفته است. V- بلند بردن سطح آكاهى زنان از حقوق إنه شان نقش اساسى

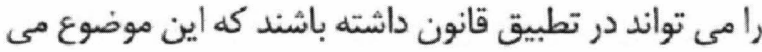
تواند ازطريق مراجع تعليمى و تربــيتى و رســانه ها صورت

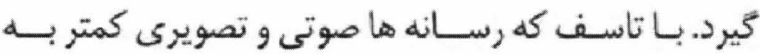
موضوعات عدلى و قضايى توجه داشته اند حـالانكه محـاكم در افغانستان طبق صراحت قـانون اساسـى كشــور و قـانون تشكيل و صلاحيت محاكم علنى است و رسانه ها مى توانند وقتى را بـــه موضوعات عدلى اختصاص دهند تا مردم بــــه

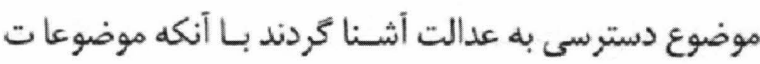

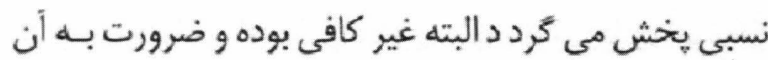

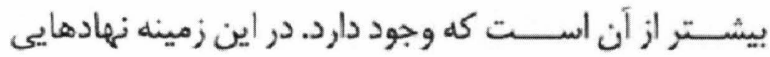
شخصى، ملى و بين المللى ميتوانند با تشويق و حمايت مالى جايى رادر تمام رسانه ها ي صوتى و تصويرى براى رسئ رسيده كَى به عدالت ايجاد نمايند.

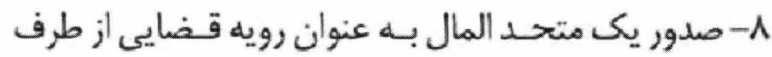

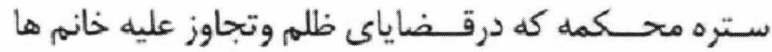
محـاكم نمى توانند إز رافت قـضايى اسـتفاده نمايند؛ بـــلكه جزاى ييشبينى شده در قوانين رادر بـالاي آنهبا حـكم نمايند

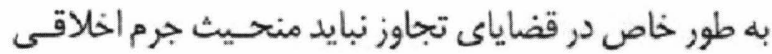

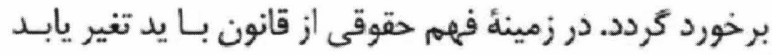
اكر عدم صراحت نمى تواند قناعت قاضى را فراهم نمايد بايد تعديلاتى در زمينه به وجود آيد؛ خاصتا تجاوز عليه اطفال كه

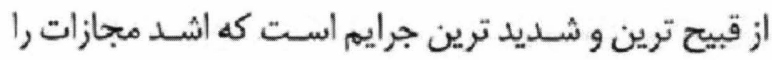
ايجاب مى نمايد نه اينكه در مورد قضاياى تجاوز عليه اطفال معصوم به عنوان يك جرم اخلاقى رسيده گیى صورت كيرد. بحث روى كليات در تطبيق قانون براى حمايت از زنان نمى

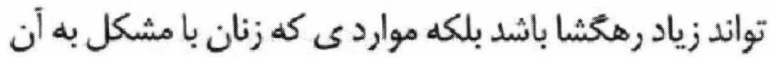

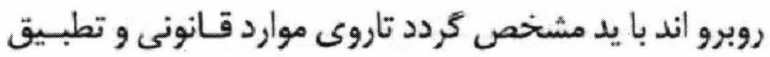
آن بحث و تحقيق علمى صورت كيرد.
روشهاى نو خاصتا قـوانينى كه طرز اجراآت را مشـخص مى إنى

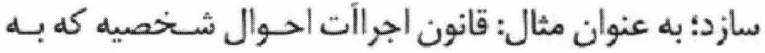

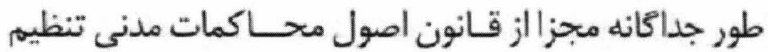
كردد. f- مجازات اخلاقى كه بر خلاف موازن شرعى مطرح اسـت و عمدتاً مصلحت شرعى كه حفظ آبرو و عزت افراد و خانواده

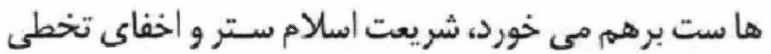
ها ي اخلاقى را بهتر مى داند و تجسـس در اين زمينه را كُناه

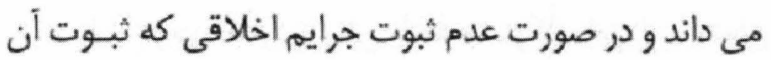

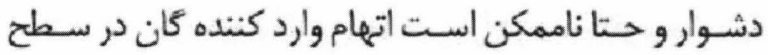
افر ادو اشخاص با شد و يا هم در سطح نهاد ها قابل مجازات

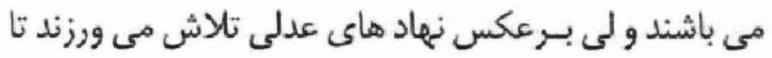
قضايا را كشف و در تحقيق آن مواردى ديده مى شود كه بـ بـه هيج وجه توجه شـرعى وحقوقى ندارد مبــادرت مى ورزندا؛

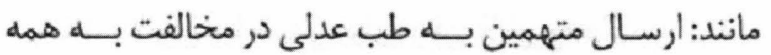
موازين حقوقى و شرعى اسـت و مصلحست وافعى حقوقى و

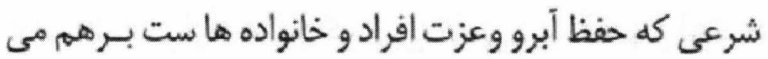

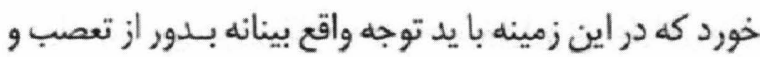
احساسات صورت كيرد.

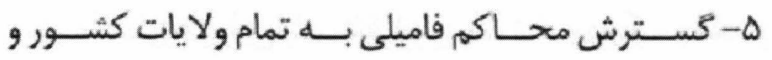

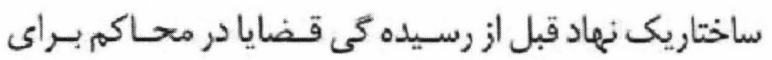

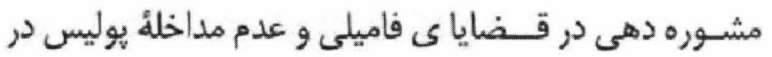

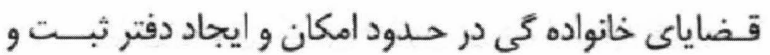

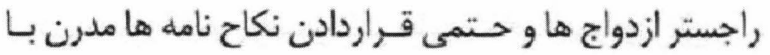

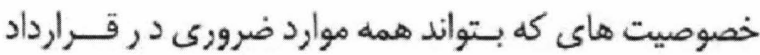

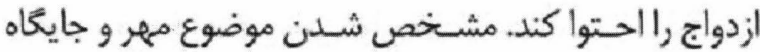

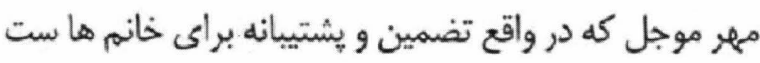

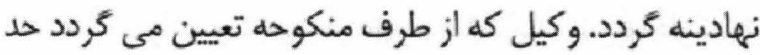

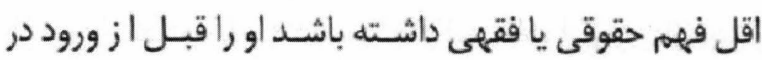
محفل نكاح از امور مربوطه به قانون و شـر يعت آتاه سـاخته

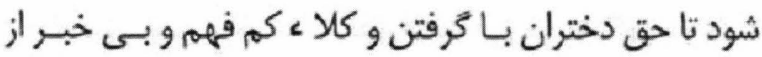
موضوعات قانونى و فقهى ضايع نكر دد. و- موضوعات كه جنبه جزايى ندارند نبايد از طريق يوليس و وصنو

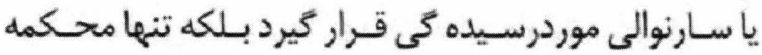

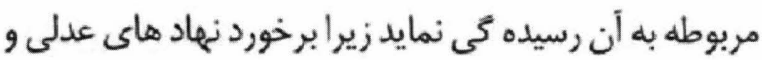

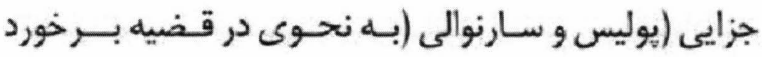

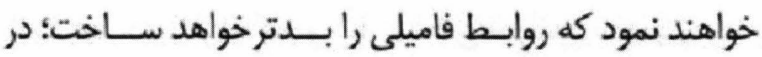




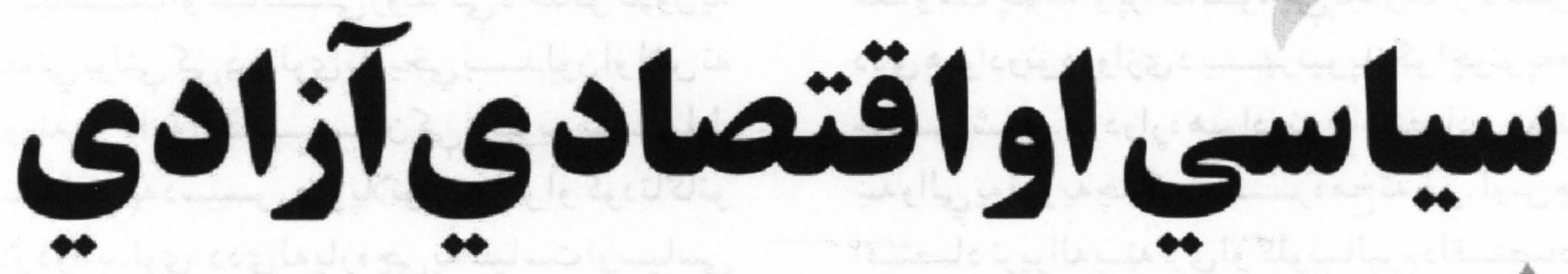

اميرالمومنين. .. لقبـونو وركول وو. كله خي بـه رهبـر!

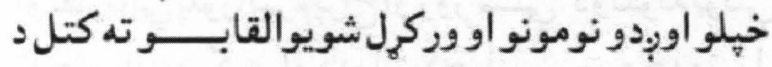

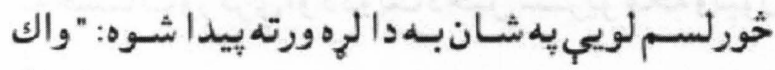

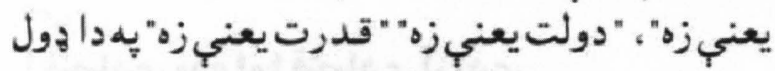

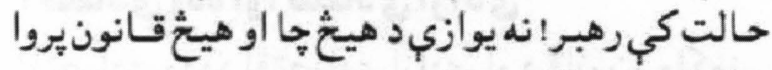

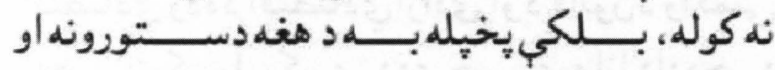
رهنمودونه يه قانون بـدليدل. داسي هم كيدل حيجي دا او هغه مشر به يي اسمان ته يورته كاوه او بيا بـه يـي يخيله يه عمودي توكه קه خمكه راغورخاوه.

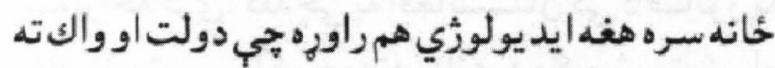

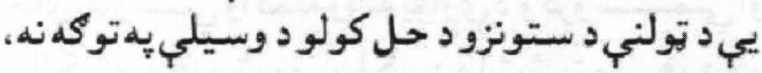

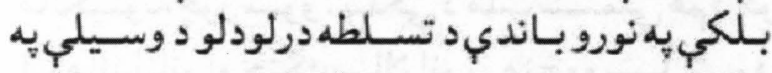
توكه قانونيت وركاوه. همدارنكه وروستيو درولسيزو

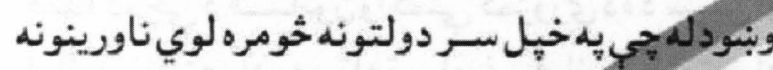

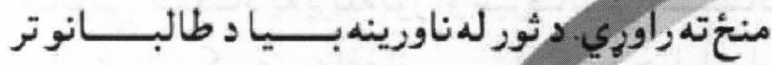

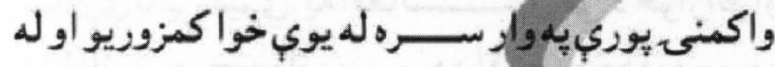

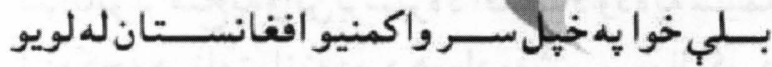

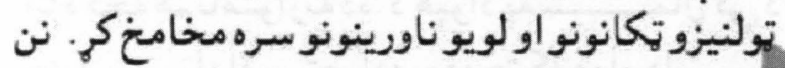

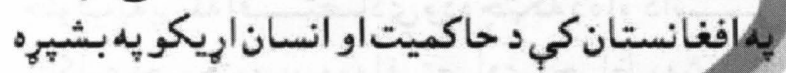

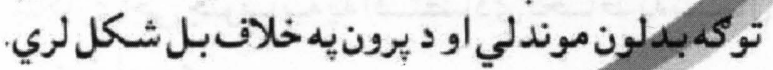
اوس اصل يهوالكي دي تولو له كلدون خخه عبارت دوي. اوس اصل له كوزهدوراكمنيو بدلوندي. اوس اصل له كوزي خوا واكمنى ته مشــــــــــروعيت او

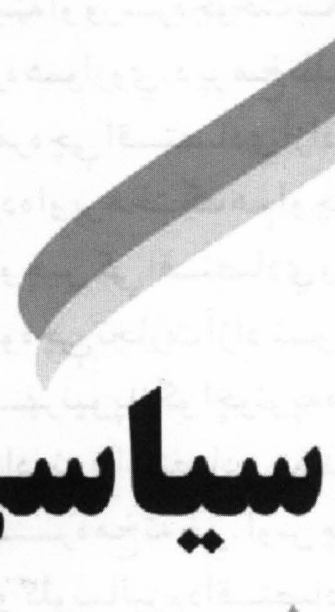

r
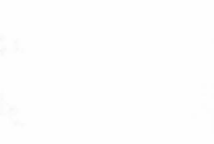


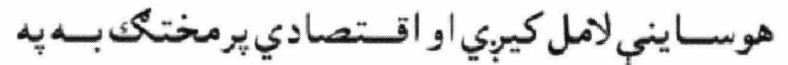

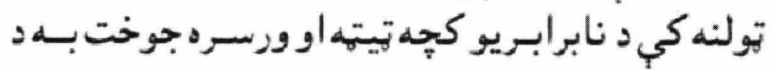

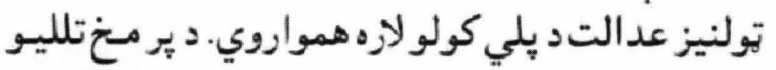

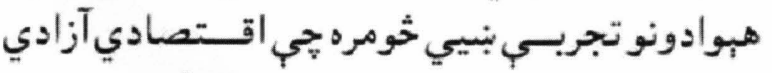

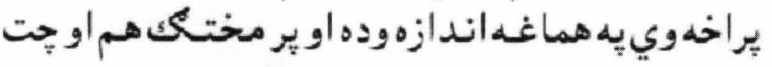

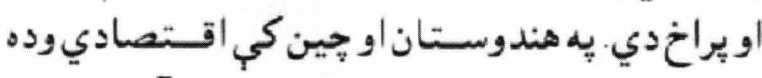

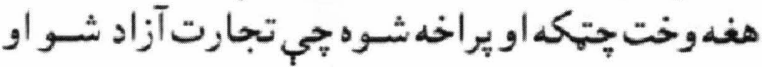

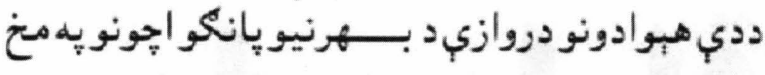

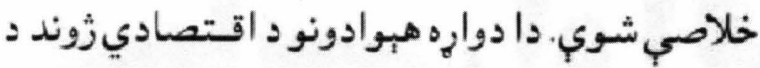

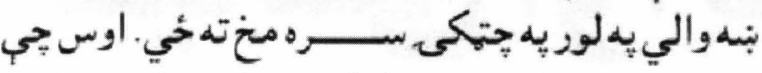

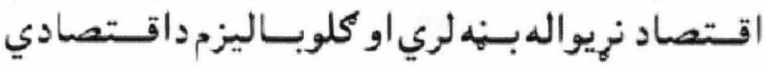

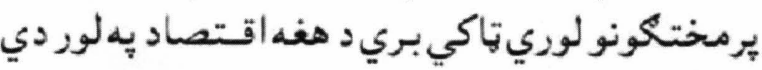

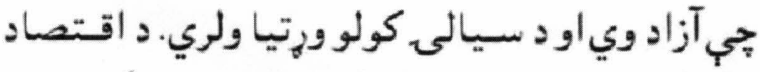

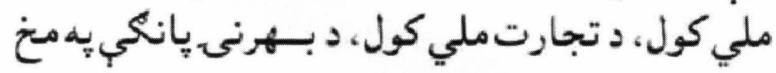

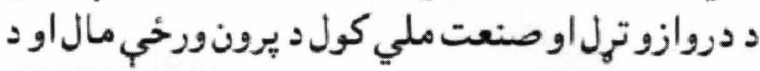

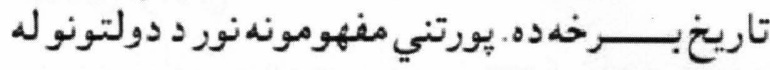
اجند او ثخد وتلب خبري شمبرل كيربِي.

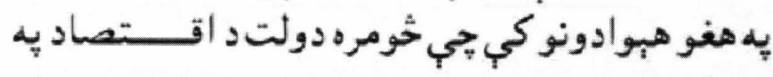

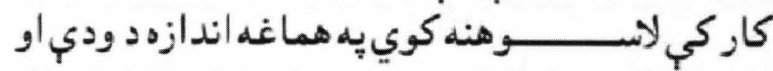

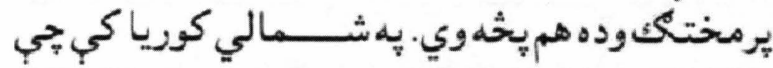

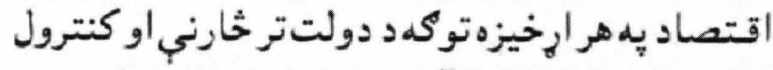

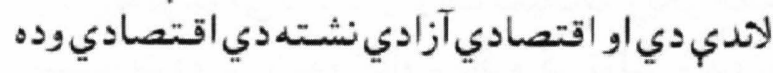

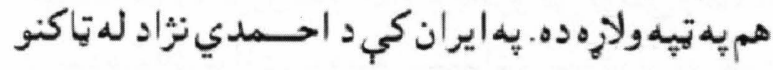

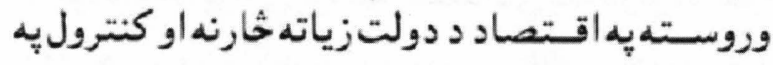

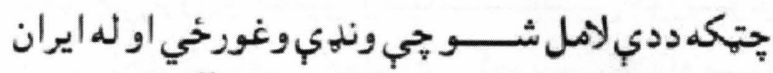

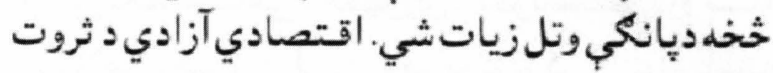

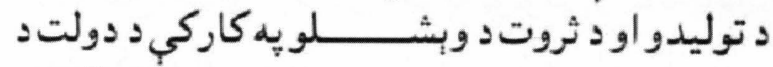

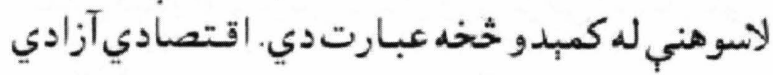

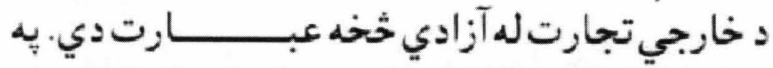

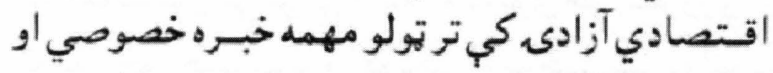
شخصي مالكيت تهدرناوي اود قانونيه وسيله دو هغه

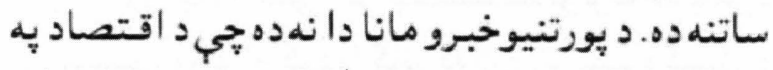

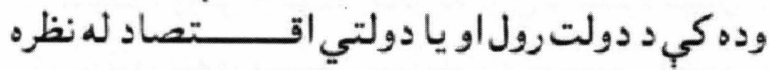

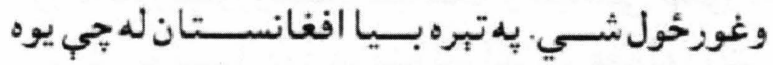

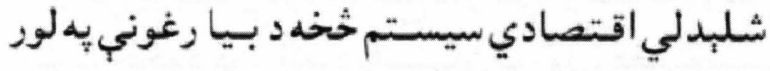

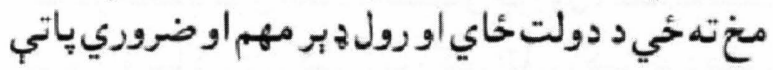
كيبِي.
قــــانونيت وركولدي. د يوه نظام اود يوه سياســــي

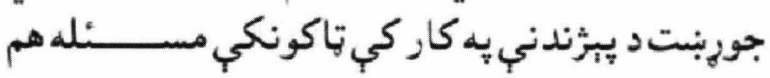

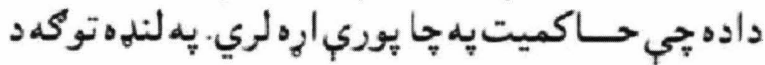

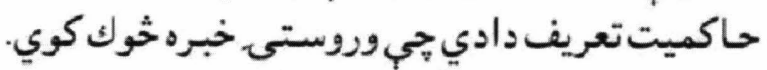

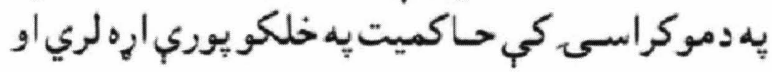
همدا خلك دي جيب وروستى خبره كوي.

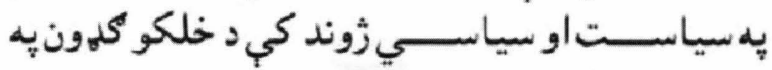

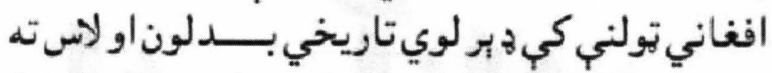

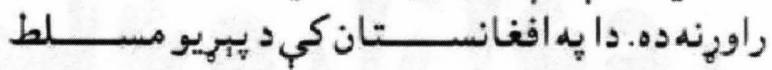

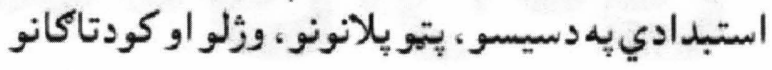

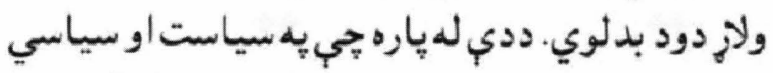

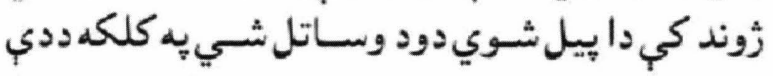

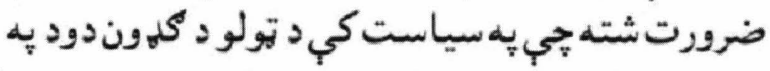

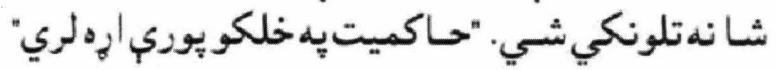

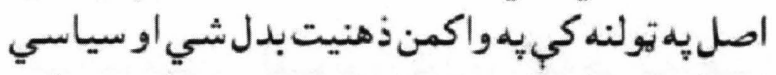

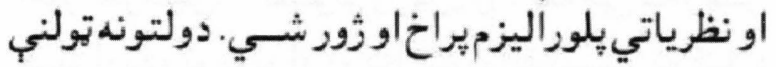

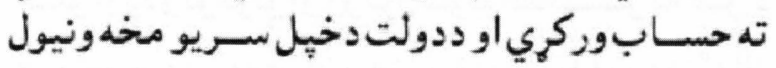

\section{اقتصادي وده اوا قتصادي آزادي}

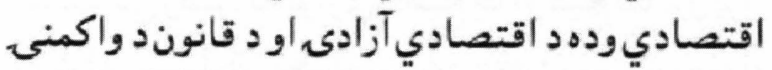

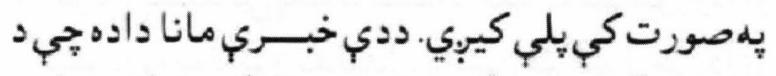

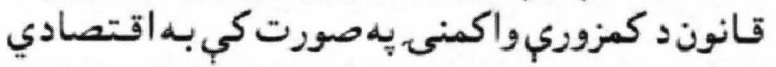
وده د تولني د يوي وري برخي يه كته تمامه او نابرابري

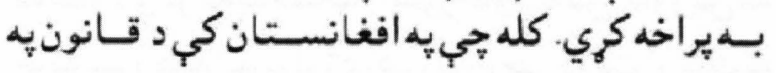

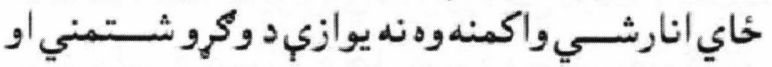

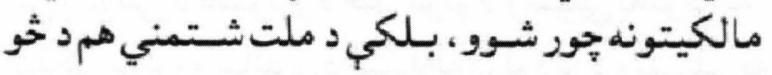

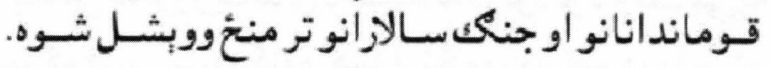

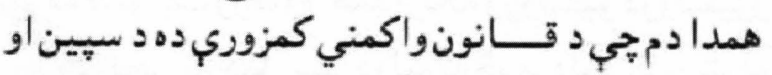

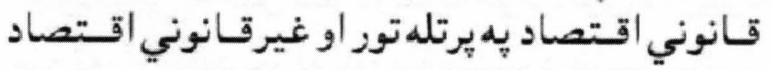

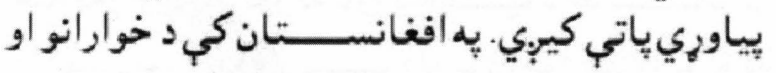

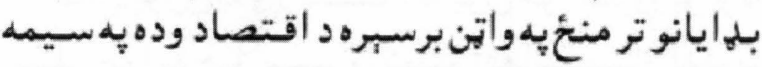

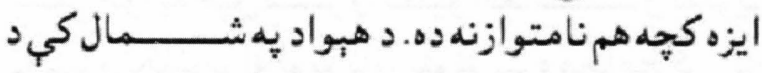

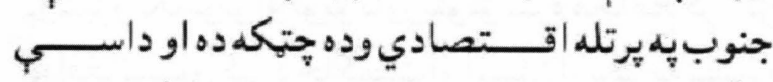

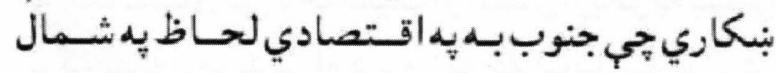
يوري تولي وي.

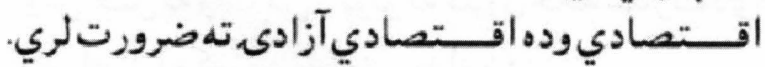

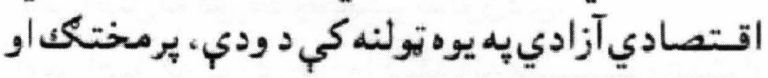




\section{بار لمان دوم اميد ها

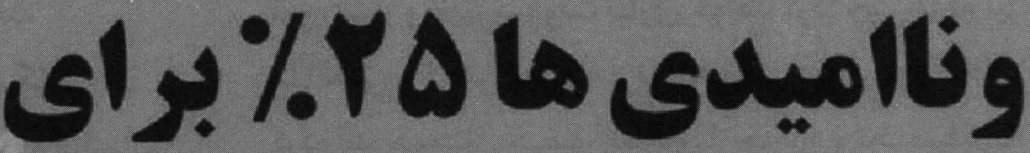

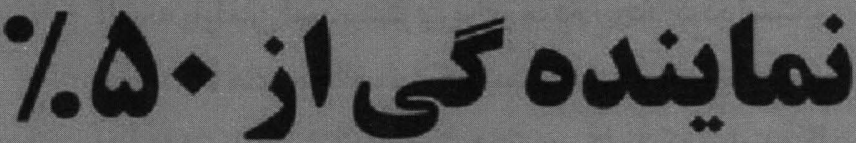

زنان سراسر جهان در يارلمان آخرين كزارش اتحاديه بين المجالس جهان هـ -. r (IPU)

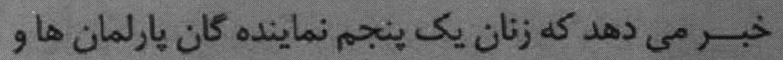
مجالس قانون كذارى رادر سراسر جهان تشكل مى دهد. به به

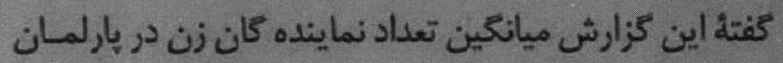

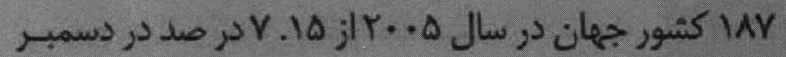

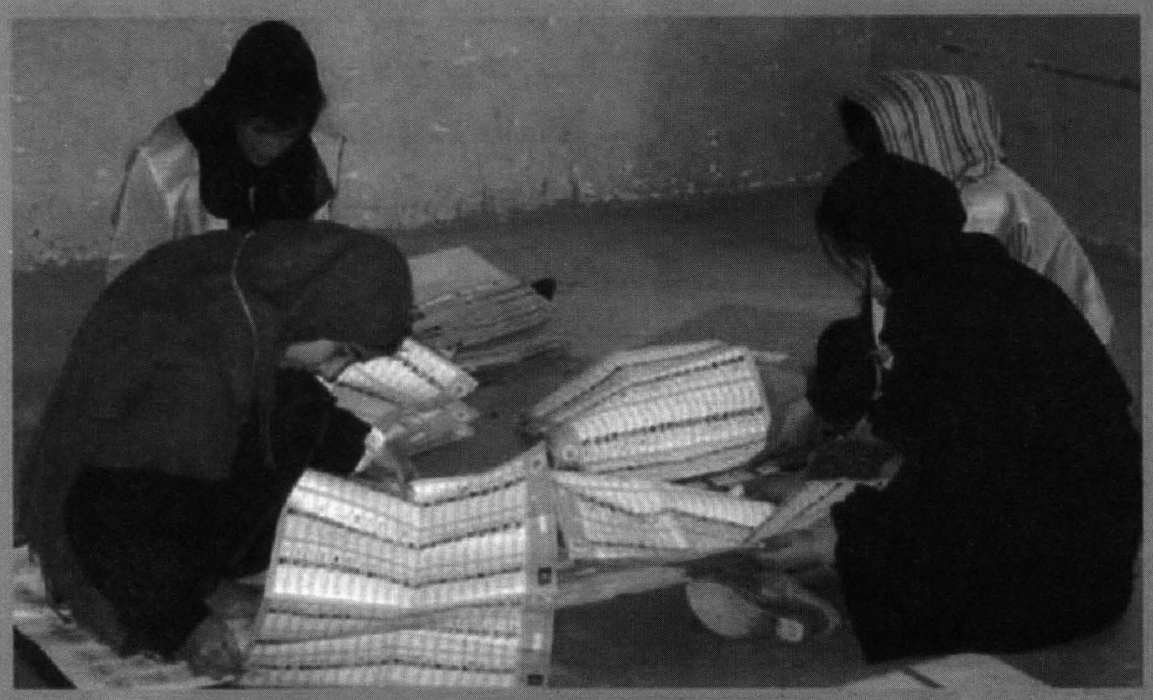

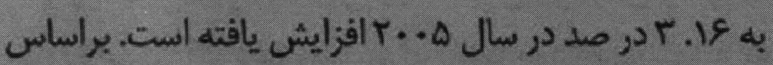

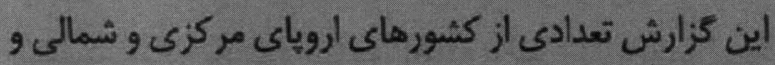

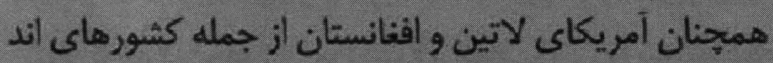

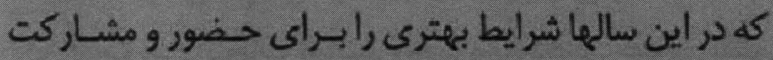

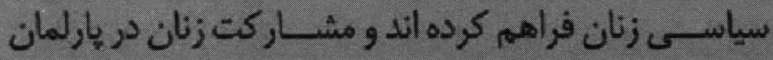

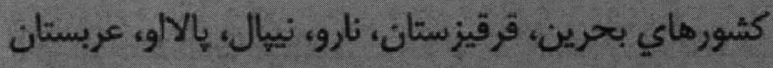

مريم روى صفحة كمييوتر اسكرول مى كند و ليست بـرنده ها را يكى يكى بررسى مى نمايد، مى خواهد بداند كانديداى مورد نظرش در جمع برنده كان حضور دارد يا نه؟ او صفحسله

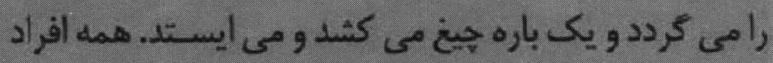
حاضر در اتاق با حيرت به او مى بينند: به دخترى كئ كه أز برنده

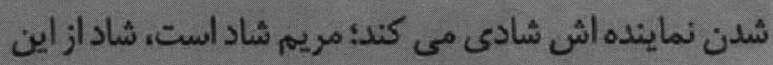

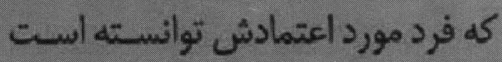
نماينده كى او رابه عهبده بكيرد. شـايد

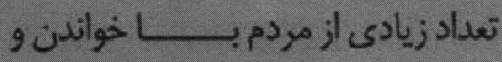
أكاهى يافتن از نتايج انتخابات فريادى

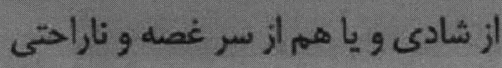

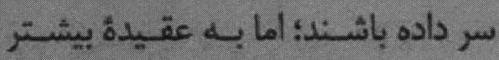
مردم، دور دوم انتخابات با وجود تقلبلب

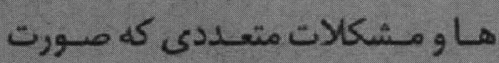

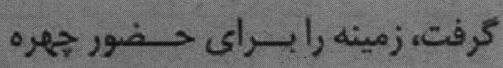
هاي جديد بـه ويثره جوانان ايجاد كرد.

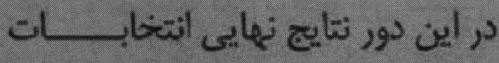

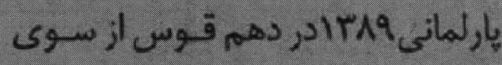

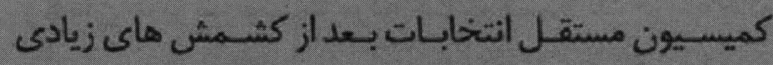
اعلام كرديد. نتايج نشان مى دهد كه بيش از نيمى از بـرنده

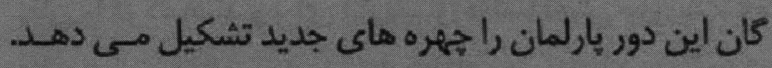

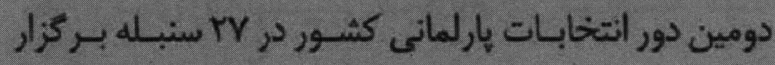

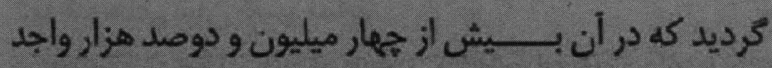

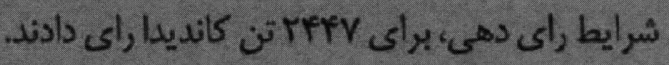


تصادف باشد و مردم قلبـاً اين را نخواهند كه اين حـرف بـه حقيقت نزديكتر است".

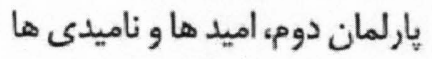
ميرويس نجم كارمند يكى از موسسات خارجى معتقد اسـت داميل

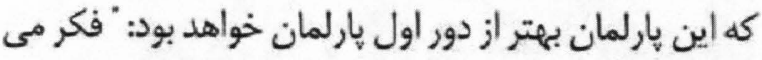

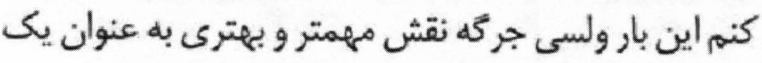

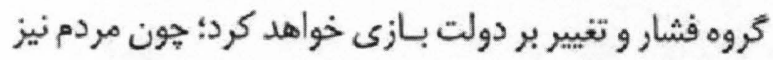

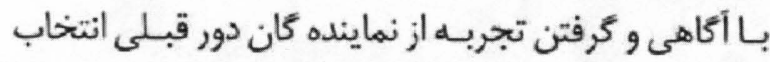

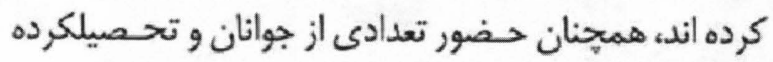

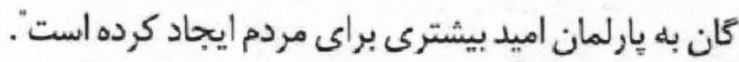

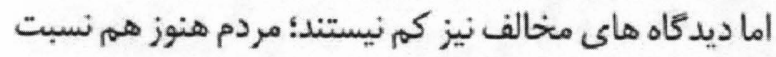

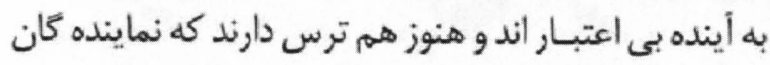

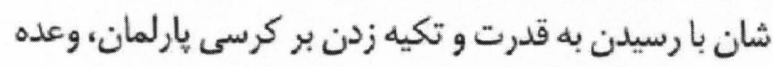

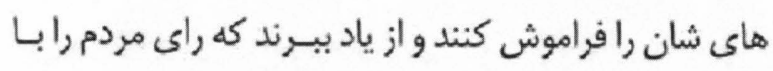

سعودى، جزاير سليمان، تووالا، امارات متحده عربي و سنت كيتس، صفر مياشد. قانون اساسى افغانستان حد اكثر اعضاى ولسـى جركمه رادي

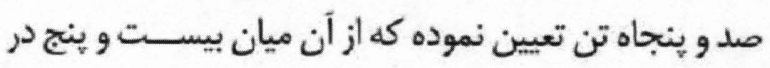

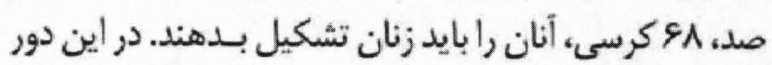

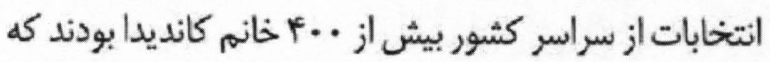
براى Dr د رصد سهم در يارلمان كشور رقابت كردند. زنان حصار هاع مردسالار جامعه را مى شكنئد

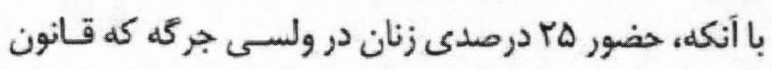
اساسى كشور حتمى دانسته است، از سوى تعدادى از فعالان

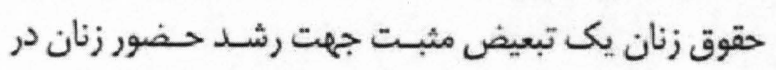

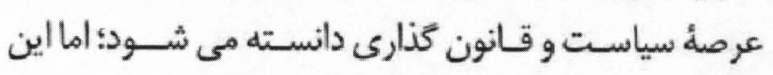

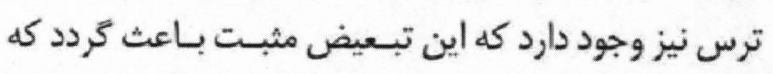
زنان رقابـت و تلاش را فراموش كنند و هيجمَّاهى جنبـش زنان خودجوش به وجود نيايند؛ اما برنده شدن دو نو حهه وعده هاى به دست آورده اند.

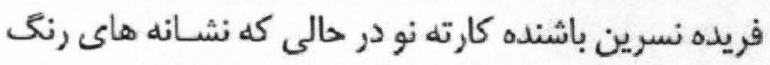

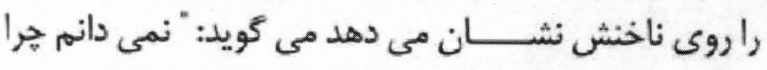

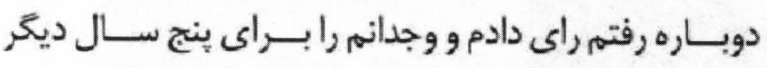

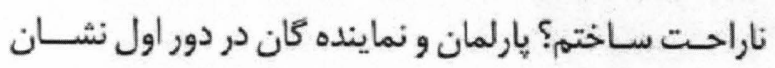

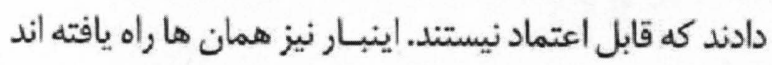
و همان ها بر سرنوشت مردم حـاكمم شــــ اند." فريده خانم

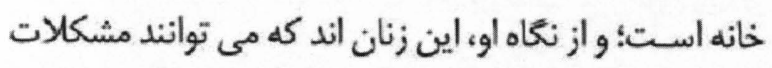

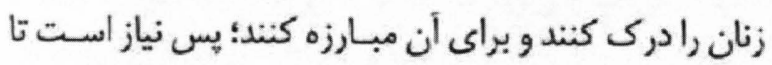
زنان از سوى زنان يشتيبانى شوند تا مردان نيز آهسته آهسته ديدكاه هاى شان تغيير نمايد.

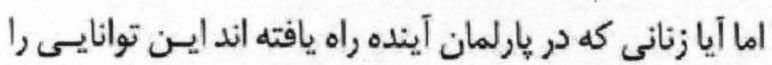

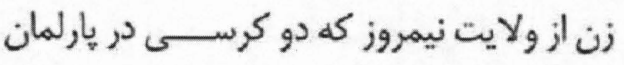

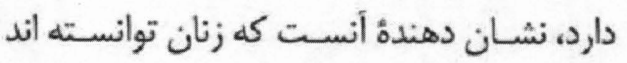
شكست در حصارهاى مردسالار جامعه بياندازند و مردم نيز كم كم بر توانايى ها، بيشتر از جنسيت دمارد

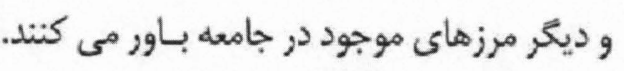

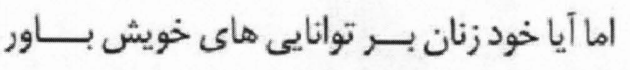

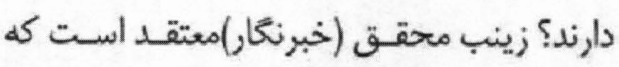

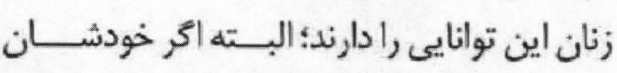

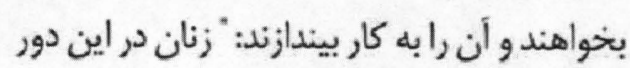

انتخابـات نشــان دادند كه توانايى تغيير ديدكاه مردم نسبت به خودشان را دارند، زنان توانسته اند با اسـتفاده از فرصت هاى موجود افكار عامه رابه نفع شان تغيير بدهند؛

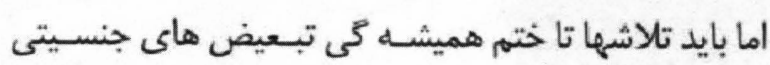

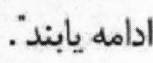

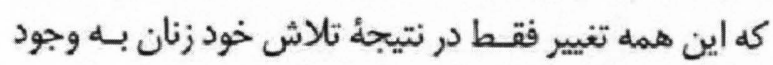

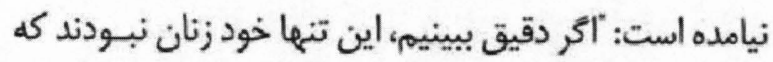
توانسته اند در يك ولايت دور افتاده تا اين اندازه تغيير ايجاد إني كنتد كه مردان، مردان مردسـالار افغانى، زنى را يـه نماينده كى از خويش انتخاب نمايند. دولت و نهادهاى حقوقى نقش

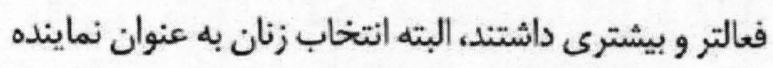

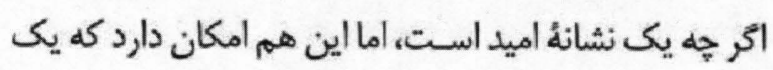

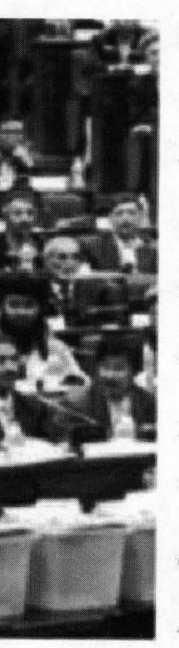
اما صوفيا نورستانى كارمند يكى از ادارات دولتى معتقد است 
كان دور قبلى هستتد، شايد كار آيى بيشترى نداشـته باشـــــ

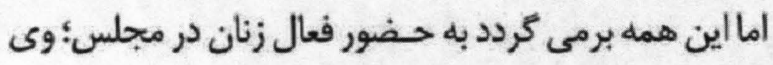

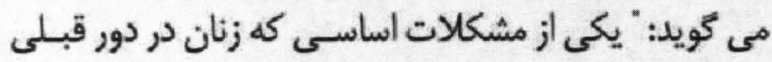

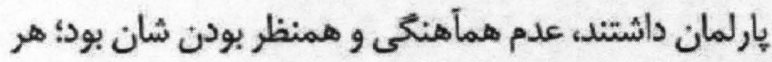

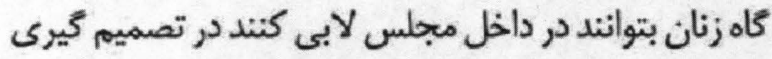
ها، نظر و ديدكاه شان موثر خواهد بود. هر نماينده به تنهايي

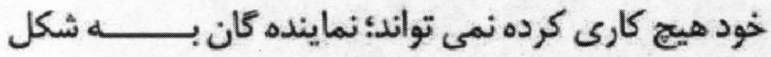
كروهى در به كرسى رساندن اهداف شـان موثر اند، اكر زنان در دور قبلى بخاطر تصويب قانون محسـو خشــونت عليه زنان به شكل دسته جمعى تلاش نمى كردند و در تصويب بودجه

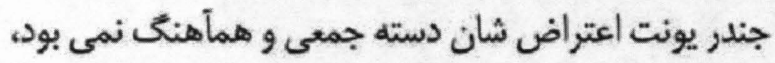

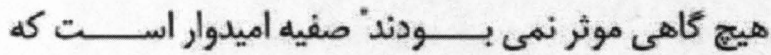
كاركردهاى يارلمان قبلى تجربهُ خوبى بـراى بارئلمان جديد

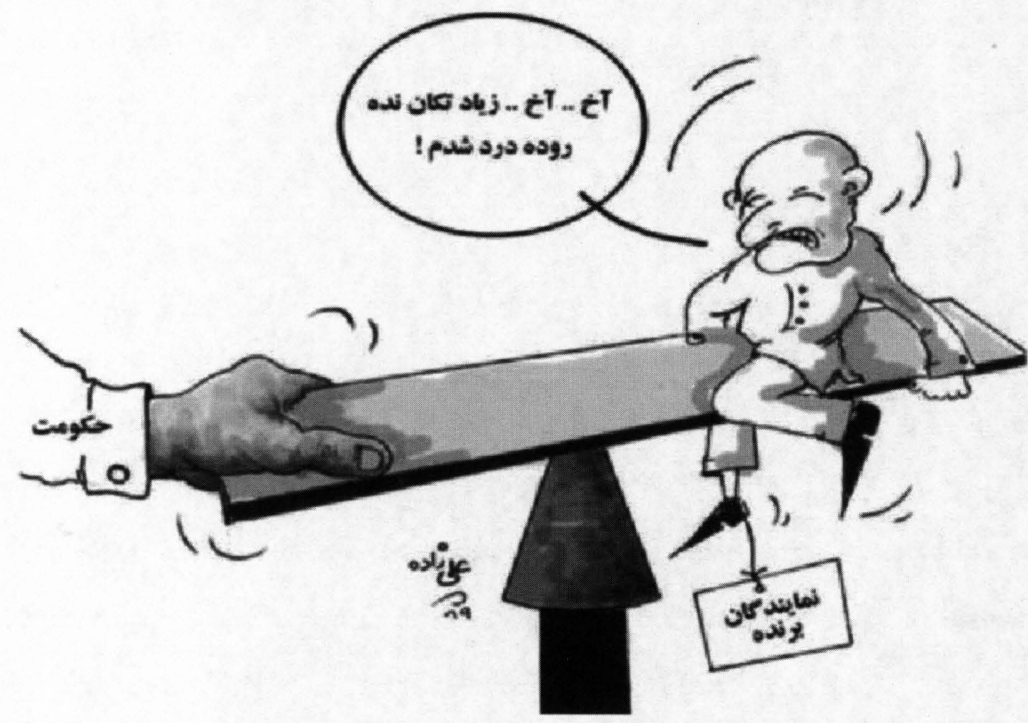

مارلمان افغانستان در دور اول تقنينيش با تصويب تعدادى از

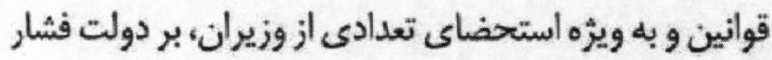
هاى زيادى وارد كردند كه در مواردى اين فشار ها منجر بـهـ

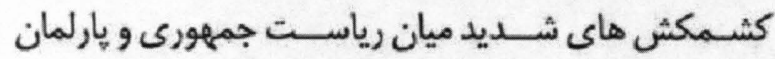

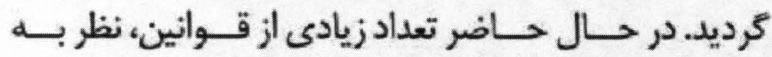

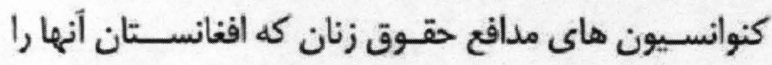

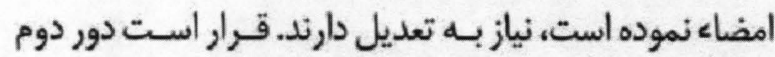
تقنينى يارلمان در شش دلو سـال روان، يس از يكى سلسـله كشمكش از سوى رييس جمهور كرزى افتتاح كردد.
دارند كه بـراى مشكلات زنان كارى انجام بـدهند؟ شـــــه

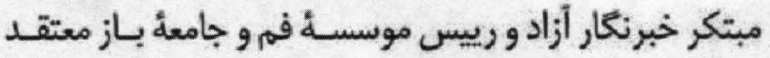

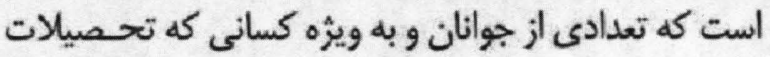
عالى دارند، اميدوار كننده است؛ اما كافى نيست: "زنان نياز به يك خيزش عظيم دارند، درست اسـت كه دولت بـراى زنان حقوقى رادر نظر كرفته است و قوانين نافذة كشور نيز حقوق

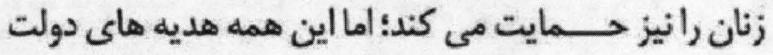
است؛ اين همه بلدون اينكه زنان تلاشى كرده باشند به به دست

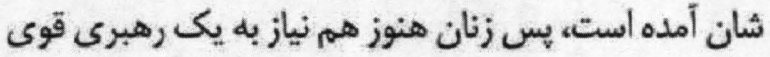
دارند كه متاسـفانه در افغانسـتان هنوز شكل نكرفتئه اسـتـان.

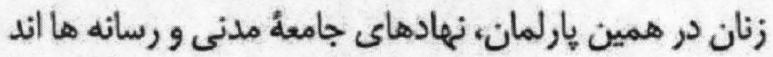

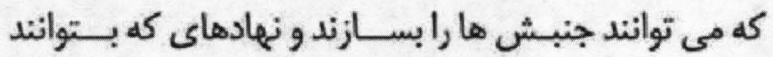

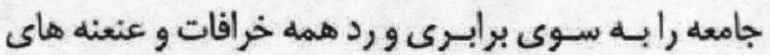

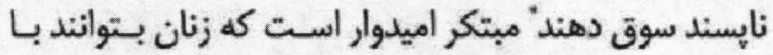
استفاده از فرصت هاى به وجود أمده سهم واقعى ماسى شان رادر دموكراسى نوياى افغانستان ادا كنتد و واقعا نيمى از يبيكر اين جامعه باشــند. بـهـ عقـيده

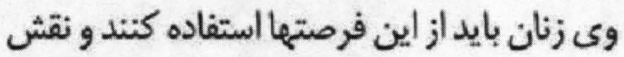
شان رااز حاشيه به متن آورند.

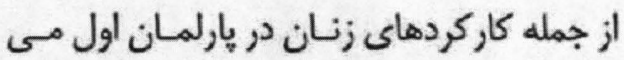
توان به تصويب قانون منع خشـونت عليه زنان و ونه طرح بودجه جندر يونت بـراى وزارت خانه ها ياد

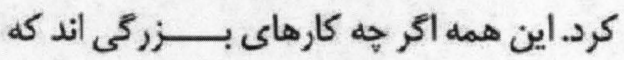

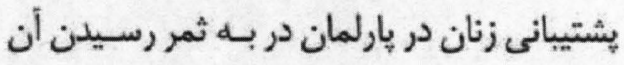

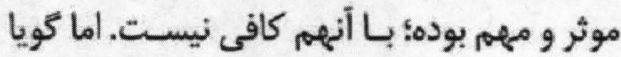
نارضايتى ها از يارلمان قبلى يايانى ندارد. مرضيه محصل دانشخاه طبى دانشعاه كابل در حالى كه

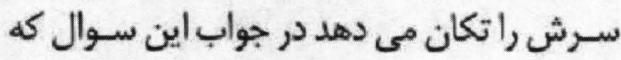
زنان در يارلمان قبلى تا خه اندازه موثر بوده است، مى كويد فكر مى كنم براى جيب و شهرت خودشان خيلى موثر بـوده

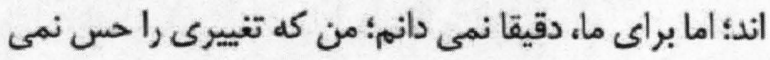

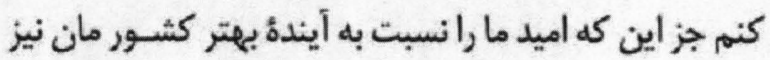
نقـش بــر آب كردند" مرضيه مى كَويد كه تقريبـاً از يارلمان

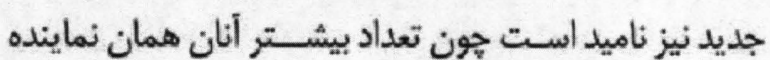
كان دور قبلى اند. صفيه يويل كارمند دولت نيز معتقــ اسـت كه از آنجايى كه تعداد بيشتر نماينده كان اين دور هار لمان نيز از جمله نماينده 


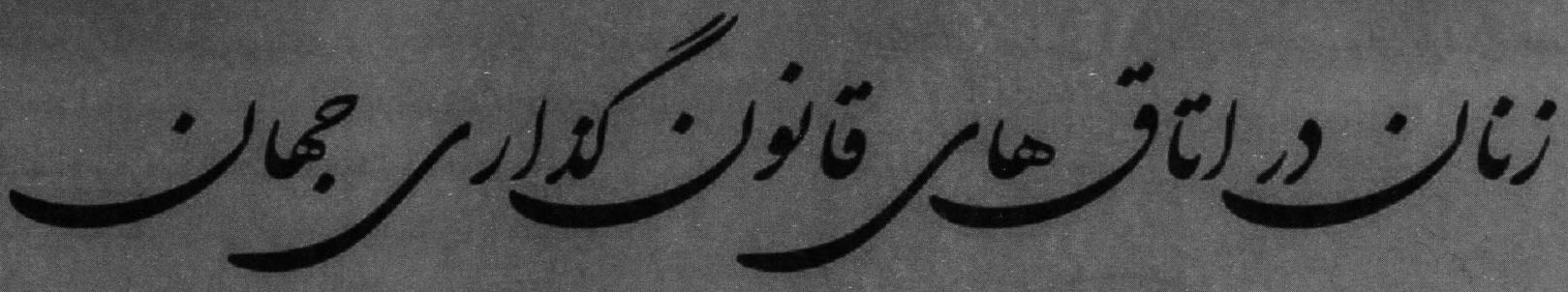

هارلمان جهان تاجكستان و ازبكستان به لحساظ نماينده كى زنان در يارلمان ها در رتبه باء هستتلد.

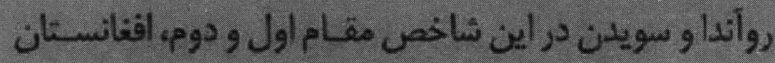

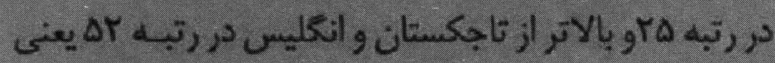
. 1 رتيه بالاتر از تاجيكستان قرار دارند.

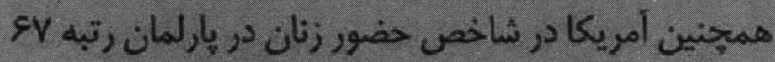
رادارد يعنى ينج رتبه يايين تر ازز تاجيكستان. بـايه اين ترتيب تاجكستان در ميان كشورهاى شوروى سايق بعد از بلاروس از زحاظ حضور زنان در بارلمان جاى دوم رالشغال مى كند. در مجموع مى توان كفت: روأندا، ييرو، باروس و و فرانسه از

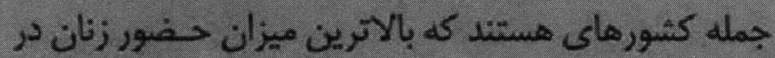

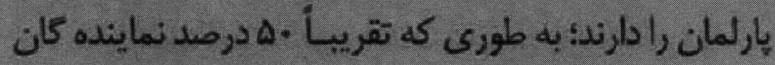
يار لمان روأندار زازنان تشكيل مى دهند. در ميان 1 ايارلمان جهان، قرغيزستان جزو آخرين كشئور

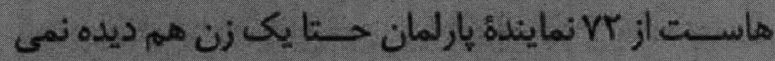

به جاي مقدمه در حال حاضر زنان رهيرى If اكشور جهان رابرعهيده دارند. ر رثورهاي فنلاند، ايرلند، فيليين، ليتوانى، شيلى و ليبريا، سويس و نيز در فدراسيون بوسنى هرز كوين زنان رييس

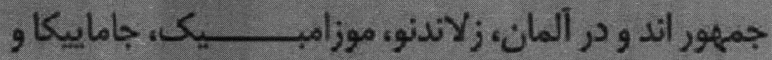

كورياي جنوبى زنان مقام نخست وزيرى رابرعهبه دارند.

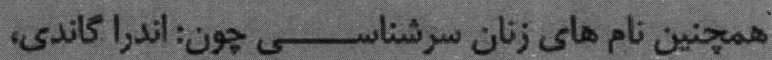

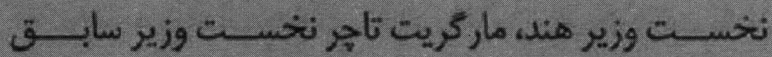
انكليس، بينظير بوتو نخست وزير سابق ياكستان، تنسو جيلر نخست وزير سابـق تركيه وخالده ضيأ نخست وزيت وزير سابـق بنعلادن تاكنون بر سر زبـان بـوده و در بـرك هاى تاريخ ثبت شدهاست.

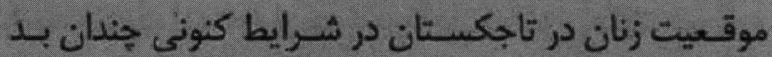

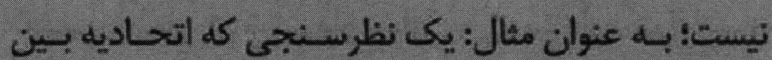

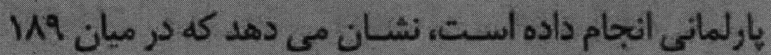


قرار كرفتن بسـيارى زنان غير آكاه در يست هاى مهم تصميم تيرى و وقانون سازى كه دانش كافى در تحليل مسايل

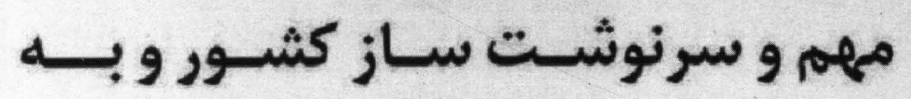

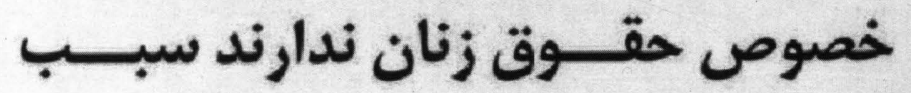

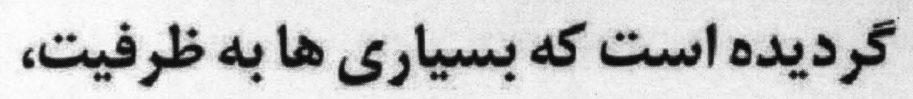
درايت و توانمندى زنان بى باور شوند و به ديد ديكًرى به زنان نكاه كنتد.

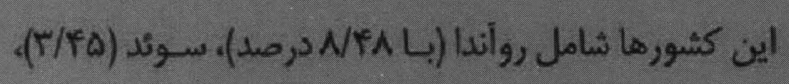

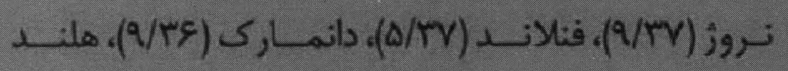

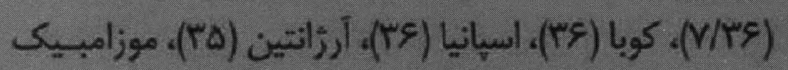
(N/TF)

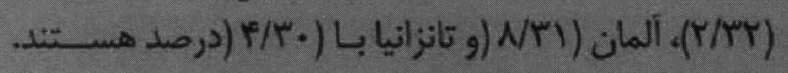
براساس كزارش IPU مشاركت زنان در بارلمان كشورهاي

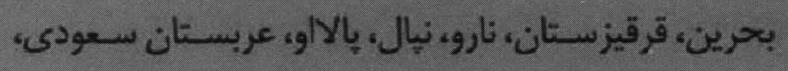

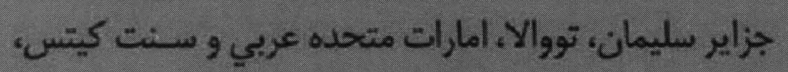
صفر مي جاشد.

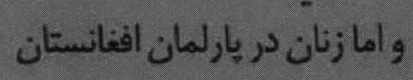

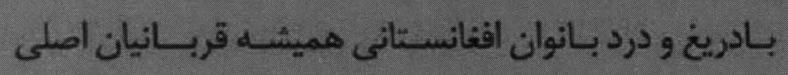

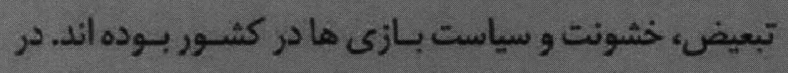

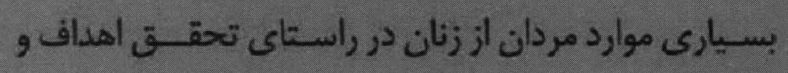
مقاصد سياسى و شخصى خود سوء استفاده كرده اند كه اين

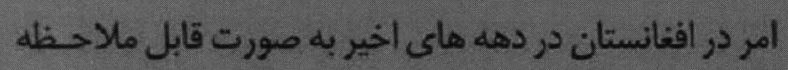
به نام دموكراسى و دفاع از حقوق زنان به صورت سميوليك داني

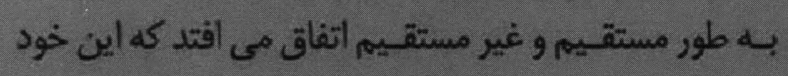

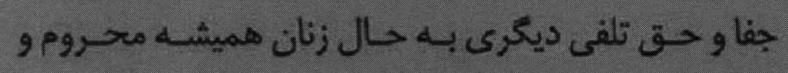

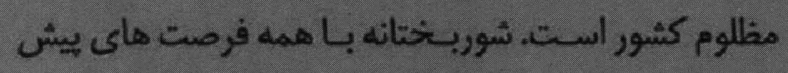
أمده بازهم سير ييشرفت زنان جندان روشن و اميدوار كنتده
هر جند جنين وضعيتى از جثـم كارشناسان دوز نمانده است؛ "جارابيك اف "نمايندة سابق يارلمان اين كثور كة ازئ اين شرايط ناراحت است: مي كويد: "البته باعث تأسف است كله

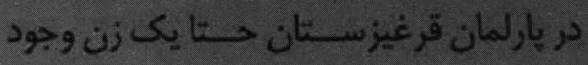
ندارد؛ در رده هاى مديريتي نيز جـ ضور زنان بسيار ناجيز استـ: در أسـانه روز جهانى زن بن

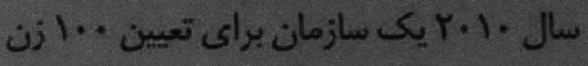
مشـيهور جهان نظرخواهى أنجام داده است: ير اساس اين نظرسنجى "أنكالامركل "نخست وزير آلمان مشيهورتوين زن جهان ثــناخته شـده استـ رايس وزير امور خارجه سابست أمريكا دومين و "وايى "معاون نخســت وزير جين سومين زن مشيور جهان دانسـته شـده اسـت تهمجنين هيلاري كلينتون وزير امور خارجه آمريكا در مقام 11 است. همبنين سيماثمر، ربيس كميسيون مستقـل حقـوق بشـر

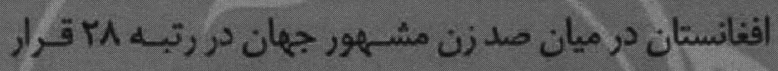
دارد. لورا بوش همسر بوش در جاي بها و كريستين امان يور خبرنعار إيرانى الاصل ثركت تلويزيونى سى ان. ان أمريكا

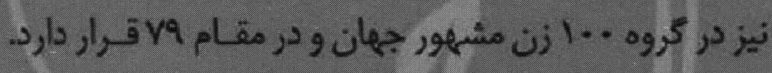

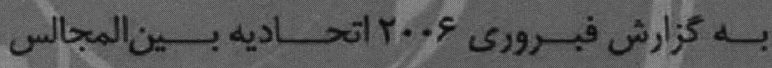

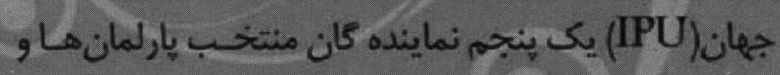

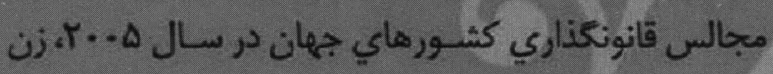

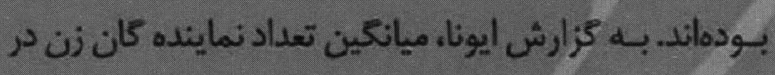

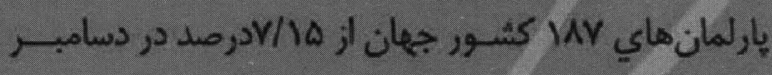

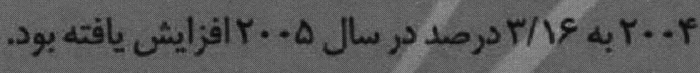

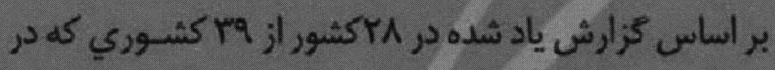

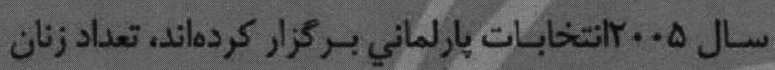
نماينده افزايش يافته است. بيشـتـترين افزايش نماينده كان زن در آمريكاى لاتين ديده مي شود. كشورهاي نيوزيلند، نروز، لـستان، بروندى، ليبريا،

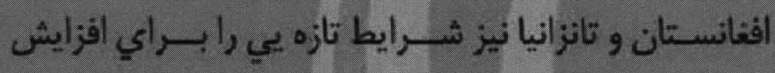
مشاركت زنان فراهم كردماند.

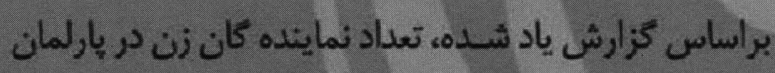

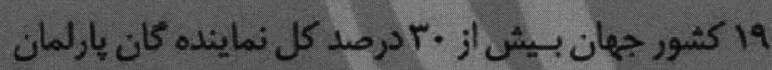


دست به تثييت جايكاه و يايكاه خويش در قوانين بـزنتد؛ تا

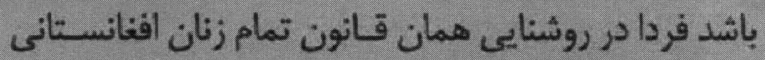
وارد جامعه شوند واز حقوق مساوى در تمام سطوح زندكى

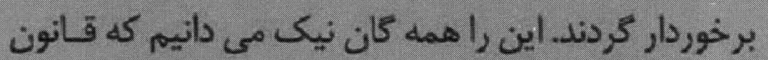

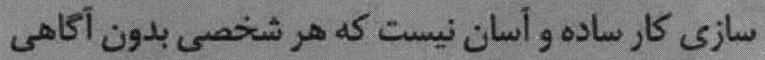

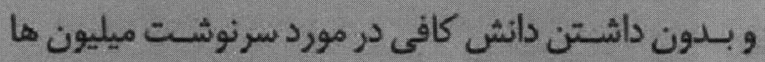
شتص تصميم بكيرد. مردان يا تصميهم كير نده كان اصلى فئل در مورد مسايل مهيم و سرنوشت ساز، جهون لياقت و كثايت

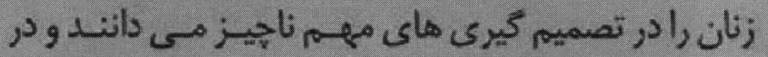

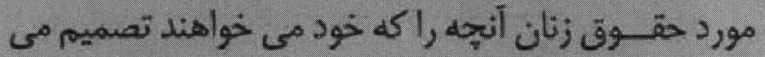
كيرند:زيرافكر مى كنتـد كه آن هايسى كه در ميـان آنـان منحيث نماينده هاى زنان حضور دارند ندى تواند بادئ دلايل

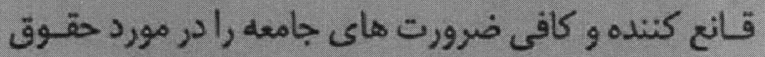

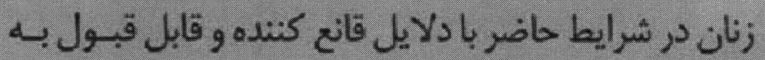

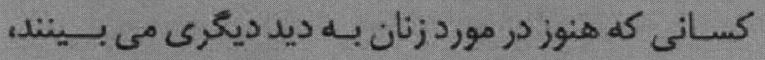

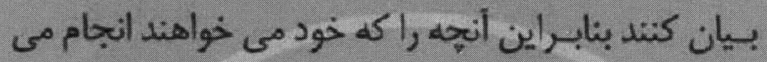

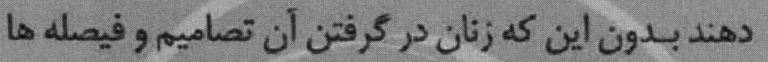

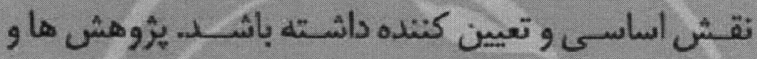

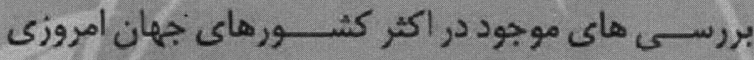

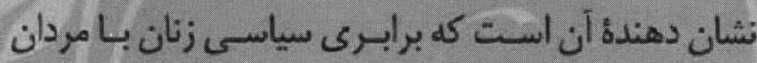
بيشتر جنبه و شكل حقوقى دارد تا واقعى. بله بـاور خيلى ها

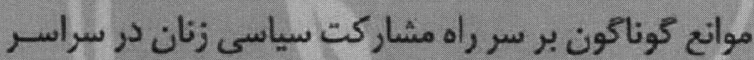
دنيا و به خصوص در افغانستان وجود دارد. از ديدكاه جامعه شناسى جنبش هاى اجتماعى زنان و جنبش هاى سياسى

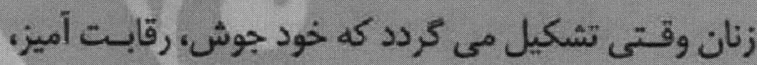

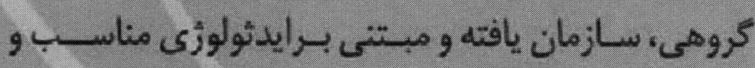

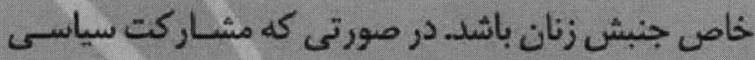

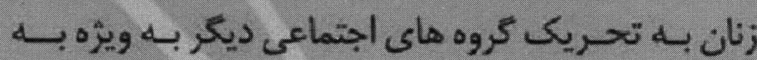
خواست مردان صورت كيرد و بــر وفق علايق و اخلاقيـيات

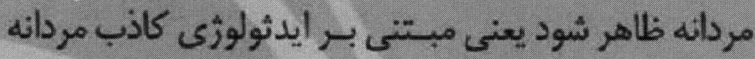

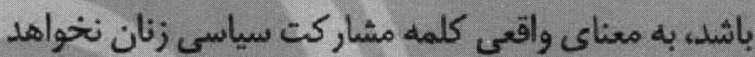

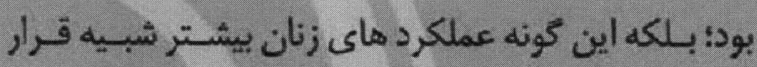

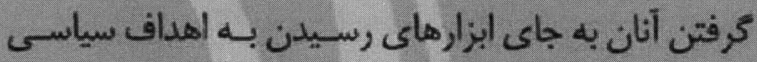

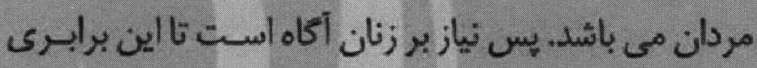

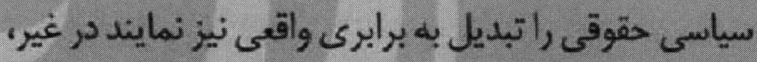

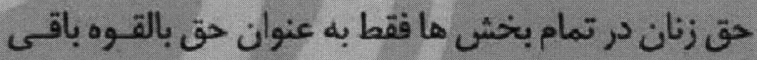

نيست و فعاليت هاى كه در ييوند با مسـايل زنان انجام مى : كي

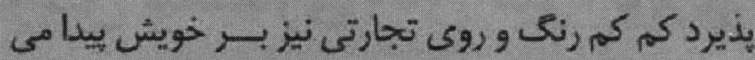

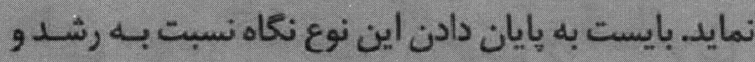

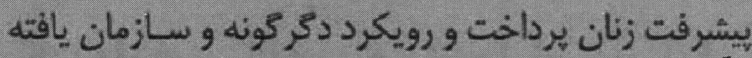

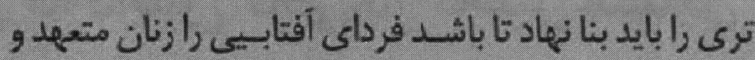

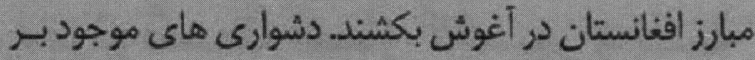

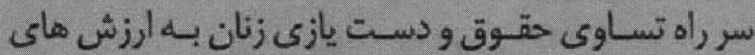

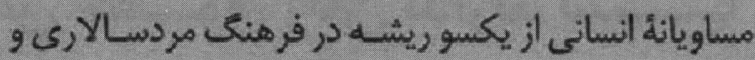

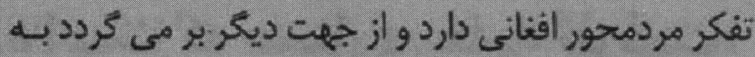

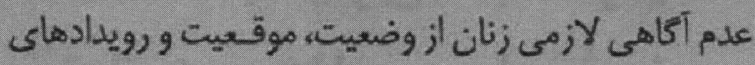

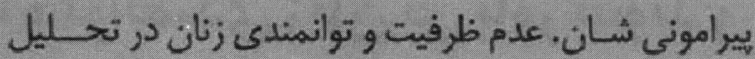

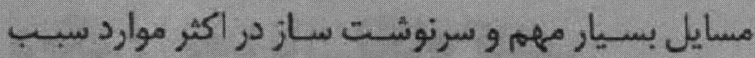

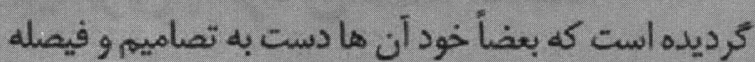

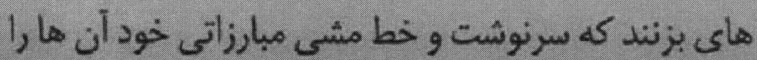

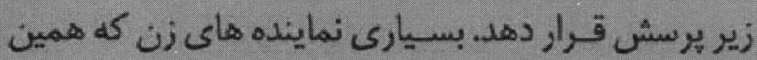
اكنون در كرسى هاى تصميم كيرى تكيه زده اند نمى دانتل كه جِكونه با مسايل حساس و سرنوشت ساز مقابله نمايند و

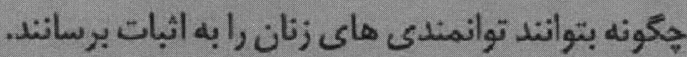

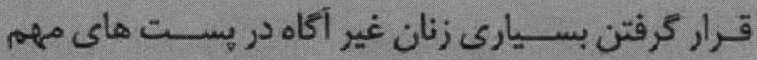
تصميم كيرى و قـانون سـازى كله دانش كافى در تحسليل

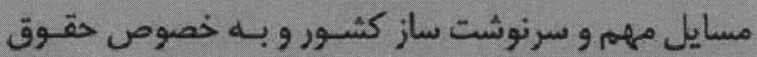

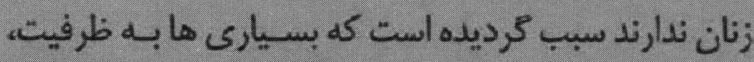

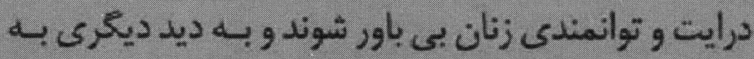

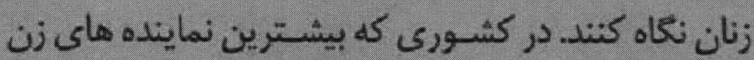
در شوراى ملى رادر ميان بسيارى كشورهاى جهان دان داشته

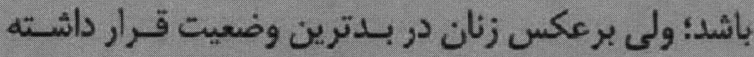

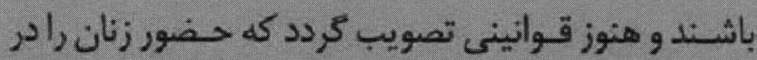

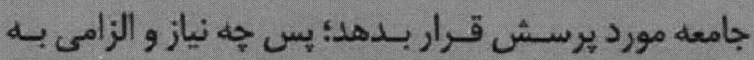

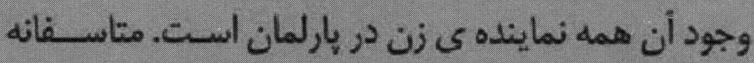

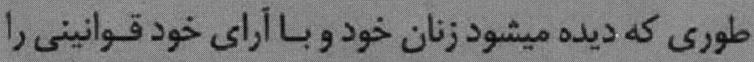

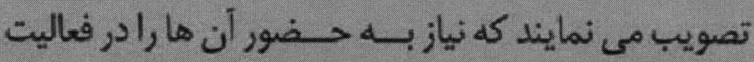

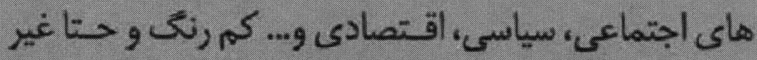

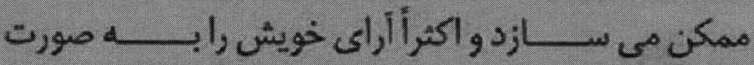

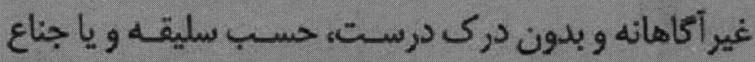
بندى هاى حزيى، قومى، مذهبى استعمال مي نمايند؛ حال

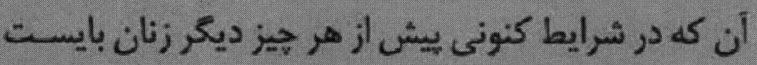


دموكراسى رادر كشور، بهتر اين است كه دولت تمام تلاش

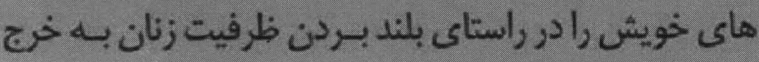

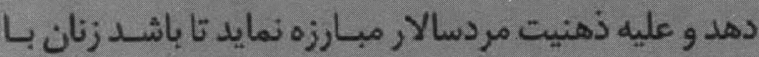
درك درست ز حقوق، موقعيت، مسـووليت و مكلفيت هاى خويش وارد اجتماع كردند و دوشاودش مردان كار و فعاليت

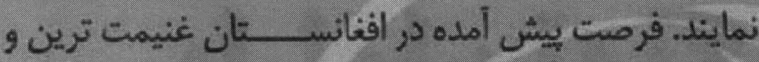

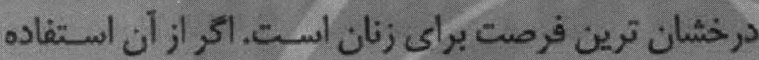

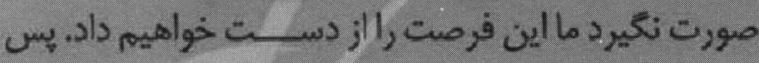

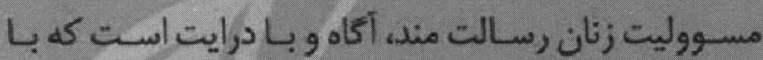

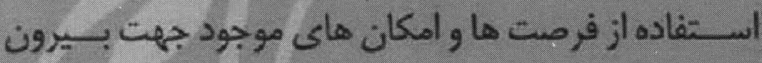
رفت از مشكلاتى كه در عرصه هاى كوناكون فرا راه زنان افغانستانى وجود دارد قلم و ق قـدم بـردارند. بدبـختنانه حـالا

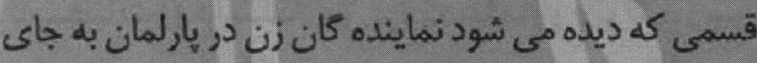

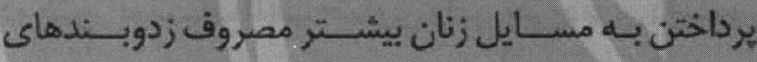
سياسى، قومى، مذهبى و... هستند. در اين هيج شكى وجئ ونود ندارد كه يارلمان كثور دشوارى هاى زيادى داري دارد و كرايش

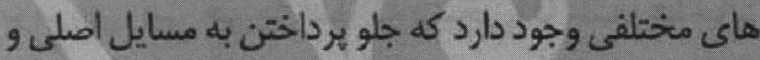

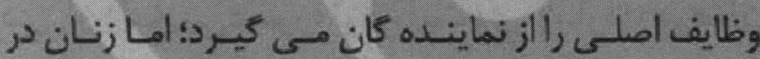
بارلمان بايسـت در نهايت مبـارزه و تلاش نمايند تا إز تمام بيمارى هاى موجود در يارلمان دورى جويند و بــــ مسـايل

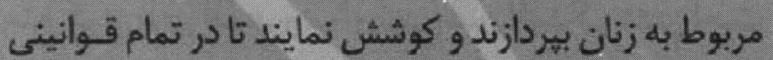

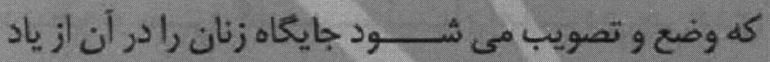

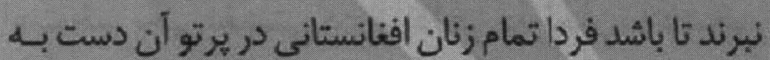
فعاليت و كار بزتند. اين خود مى تواند اساسـى ترين وظيفه

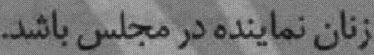

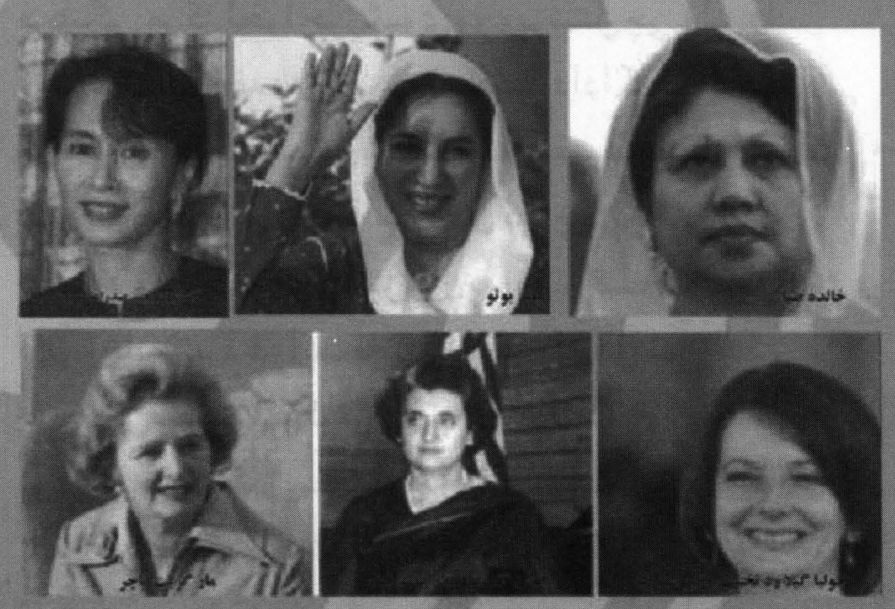

مى ماند و هركز جامه عمل در واقعيت امر بـــهـ تن نخواهد از حضور كمى تا حضور كيفى افغانستان يس از فروياشـى حكومت طالبانى وارد مرحسلة

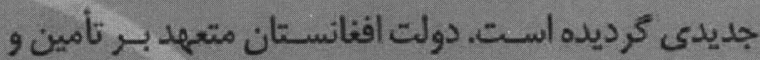
تعميهم ارزش جهاى انسانى و دموكراتيك؛ جون: دموكراسي، حقوق بشر، تساوى حقوق ميان زنان و مردان، جامعلمدنى، دفاع از حقوق زنان و... مى باشد. أما با اين همه بـاز هم ديده

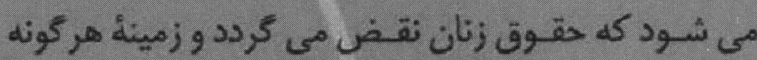

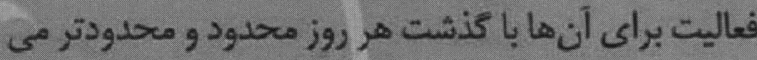

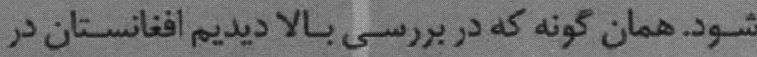

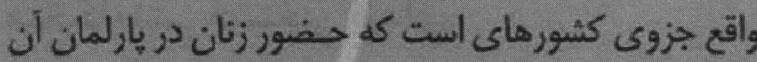
قابل ملاحظه و تقريباً رضايت بخش استـان، يس مشكل دري

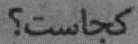
يوسش اساسـى كه حـالا مطرح مى كردد اين اسـت كه آيا

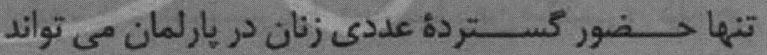

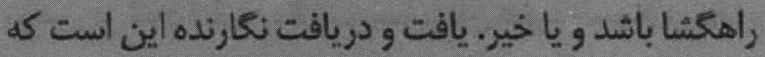

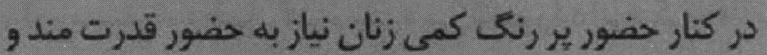

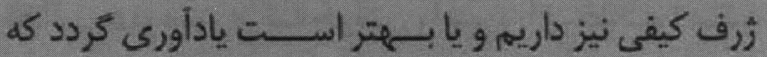

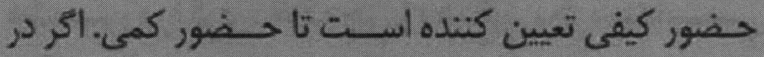
هارلمان كشور به جاي يعنمايندة زن به صورت تشريفاتى و

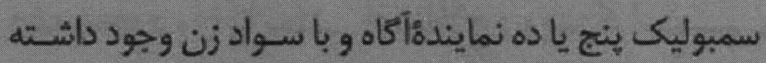

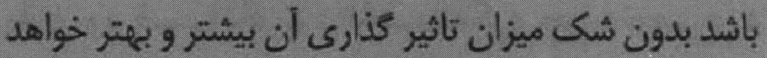

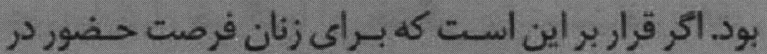
جامعه داده شود؛ يس بله جاى امتياز دادن و... بعتر و منطقى برنى تر اين خواهد كه بكار ريم زنان در روشنايى قانون و فروست هاى موجود با ظرفيت و توانايى خود دست به تثبيت جايكاه

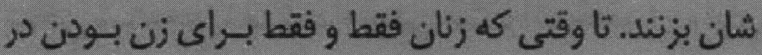

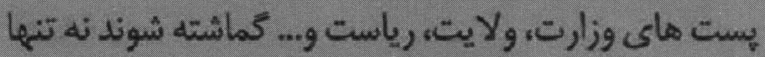

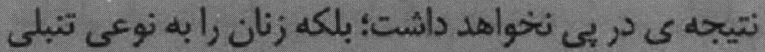

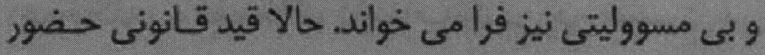

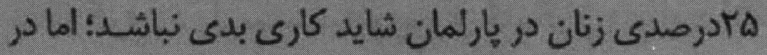

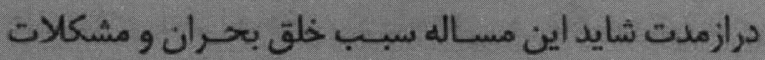

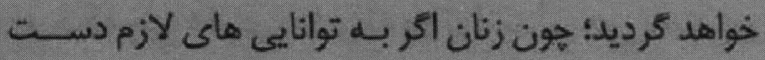

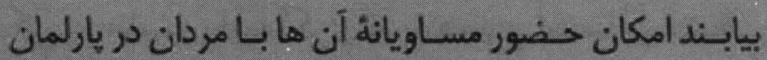
وجود دارد. يس راه حل عقلانى و منطقى اين است كه بـ بـه

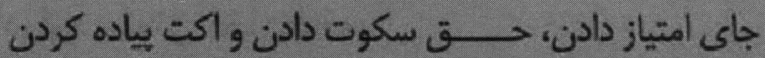


فضل ربي شيرزاد

\section{بإرلمان ته تكدبنيُحو حق دي}

هيشكلدنشي مستغني كيداي.

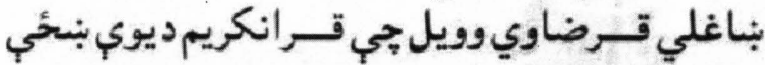

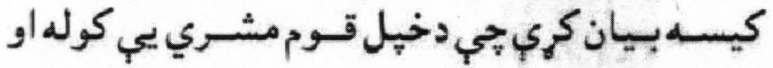

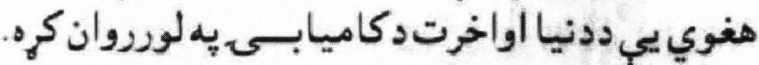

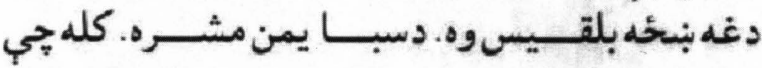

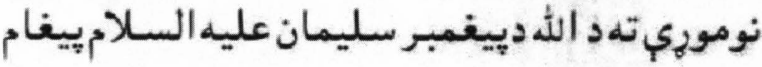

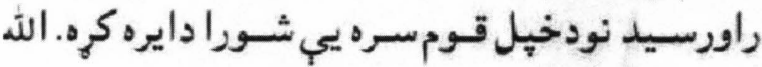

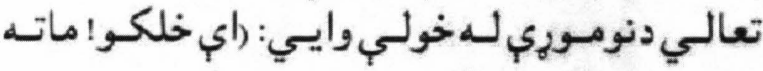

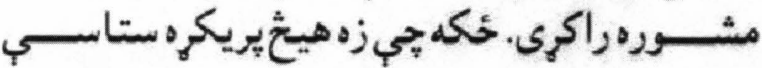

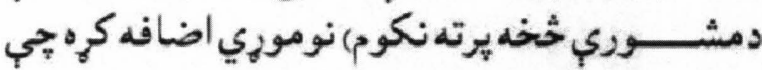

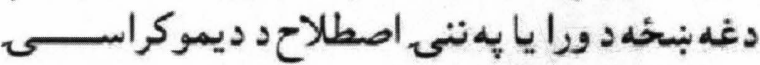

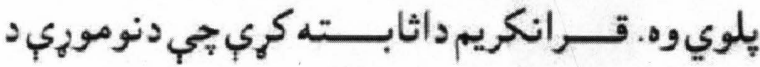

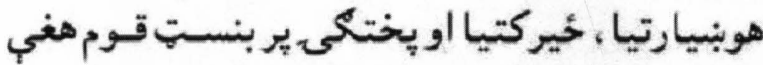

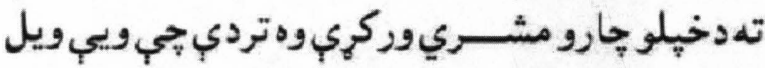

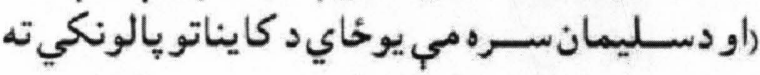

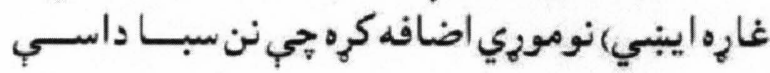

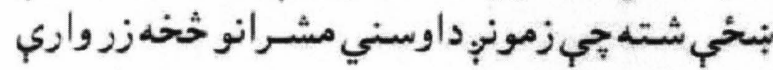

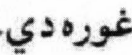

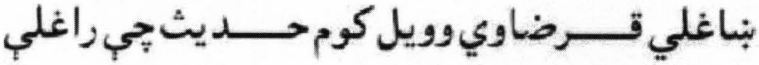

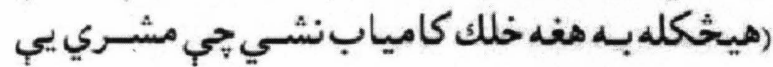

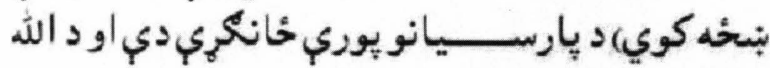

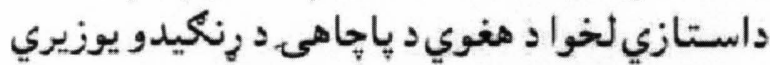

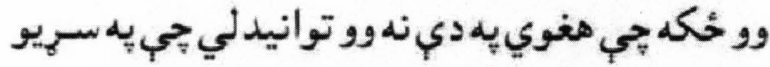

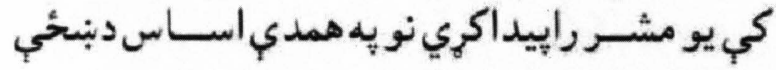

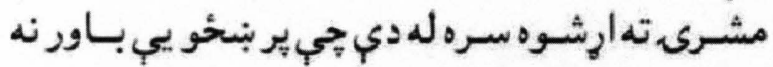
درلود ـ (له تل افغانثخه)
داوســنى اسـلامي نوى ســتر عالم د مصر قــاضي

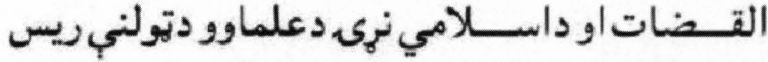

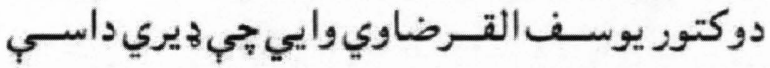

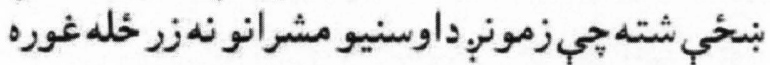

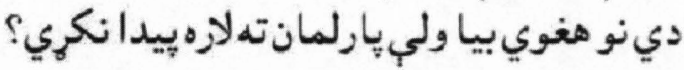

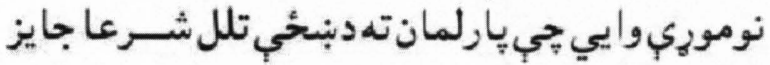
دي. او دليل يبي دسوره توبي ايت دي. زيباره : (مومنان

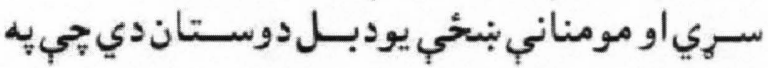

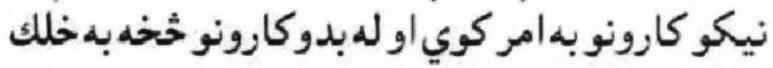

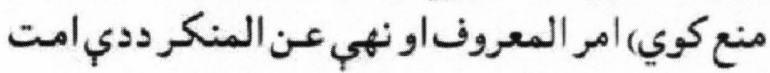

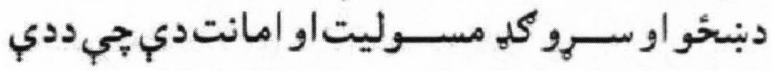

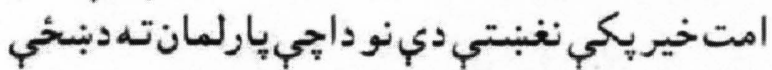

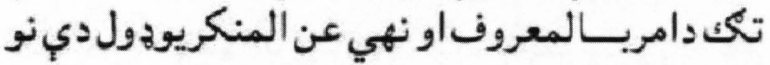
با يد ددي ستر رول دسرته رسولوخخه منيع نه شي.

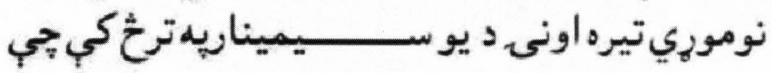

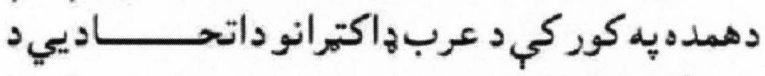

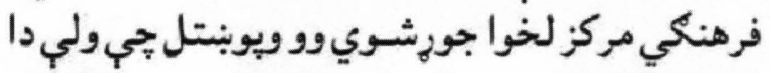

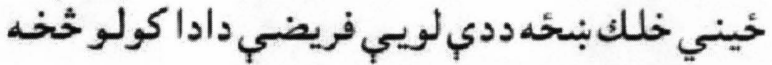

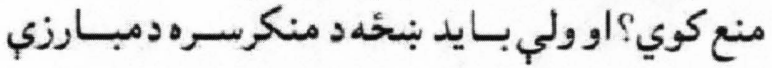

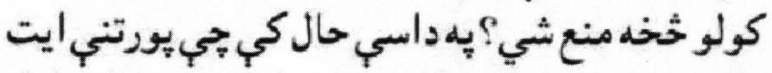
بندي

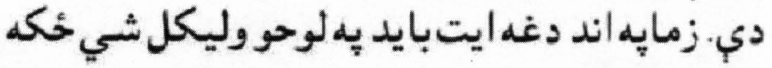

$$
\text { جي ددين بنست تشكيلوي. }
$$

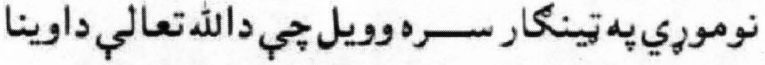

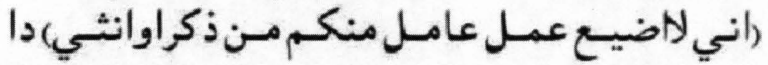

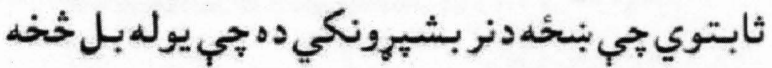


كرد آورنده مرسل اصغرى

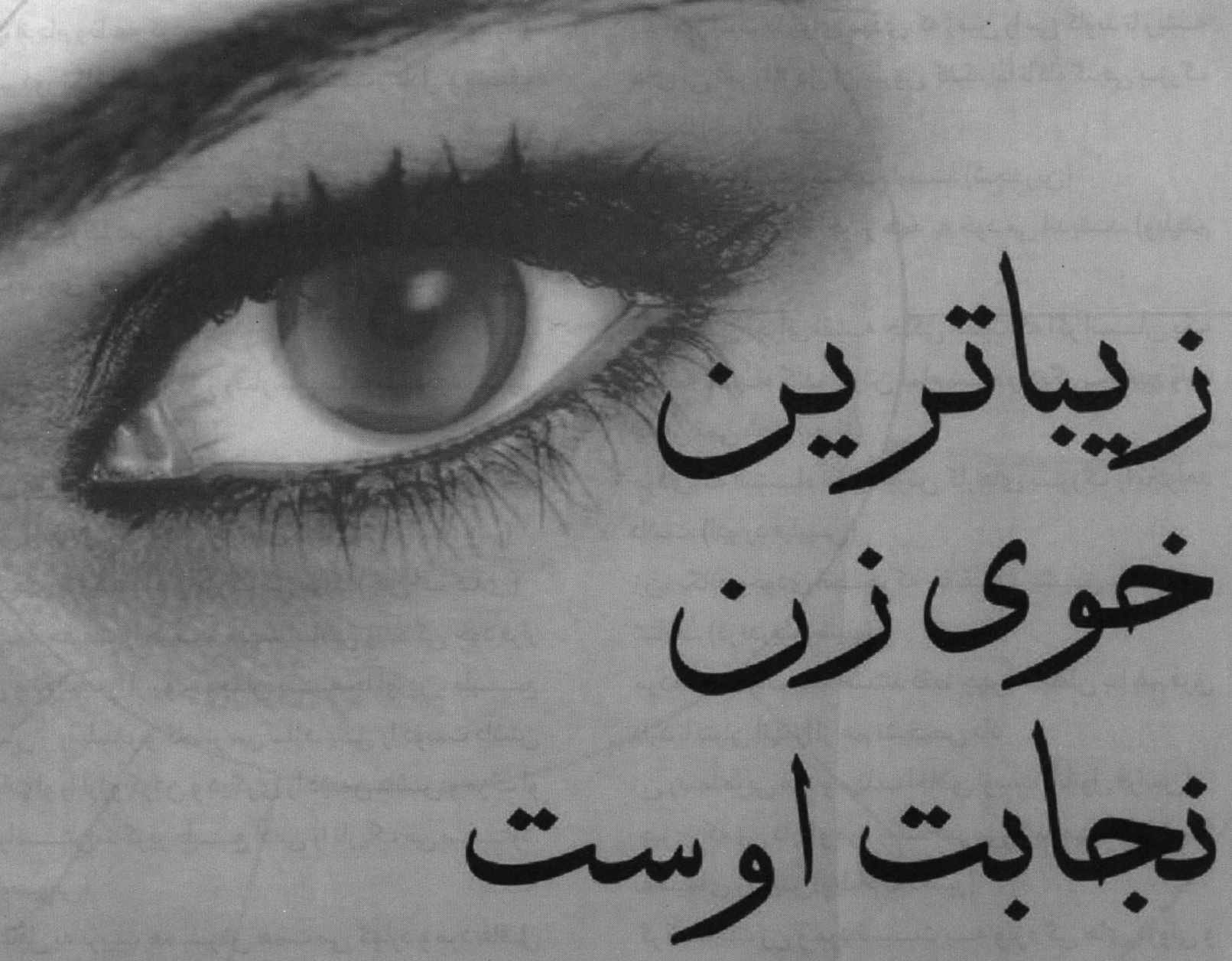

على على (ع)

براى يناهنده كى به در كاه خدا نياز به ويزانيست.

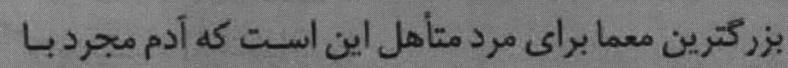

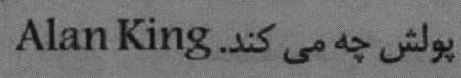

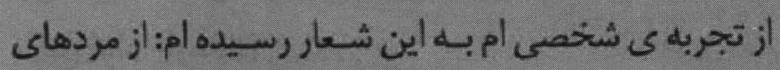
Sل به دست بر خذر باشيد! Muriel Spark

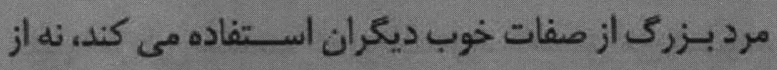

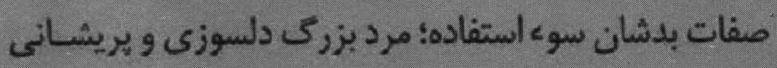

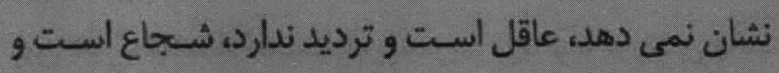
نمى ترسد. (كنفوسيوس) نيان

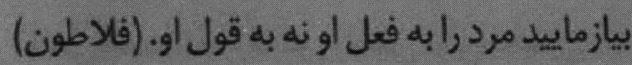
مرد بزرى يكطرفه قضاوت نمى كند. (كنفوسيوس) مرد بزرى كسى است كه در سينه خود قلبى كودكانه داشته باشد. (سيسرون) مرد عاقل همواره نه نكته رادر نظر دارد: روشن ديدن، خوب
زيباترين خوى نن، نجابت اوست (ارد بزرى)

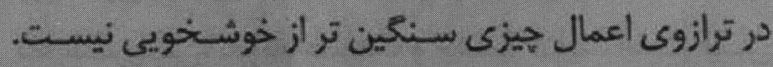
بيامبر اكرم (ص) فرق طوفان و نسيم فقط در نوع برخورد آنماست.

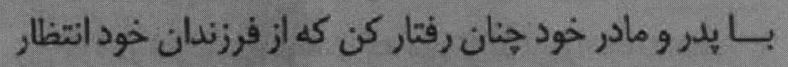

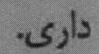

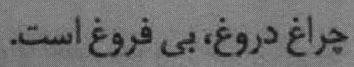

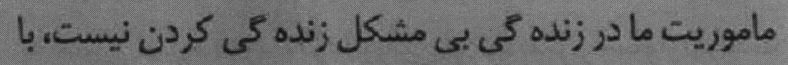

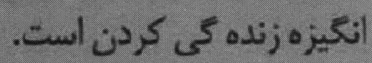

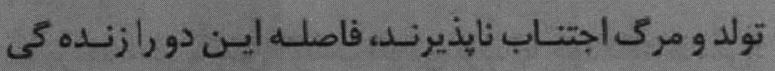
كنيه. نيكبخت ترين مردم كسيست كه كردار به سخاوت بيارايدو. كفتار به راستى. ييامبر اكرم (ص) ملردين

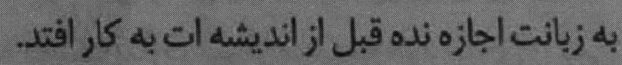

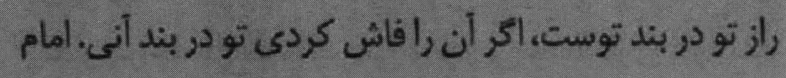


دارند. (ياتريك هانرى)

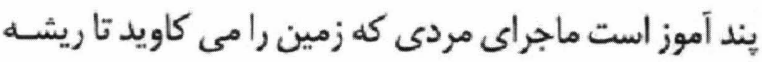

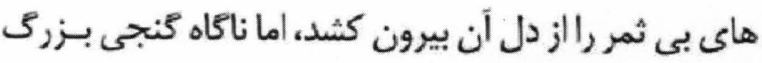

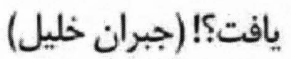

اراده مرد، باعث خوشبختى اوست. (شحهدرين)

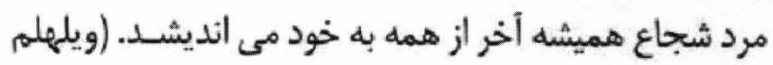

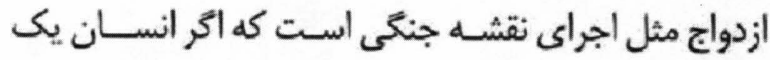

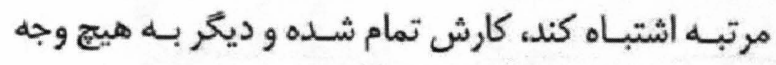

جبران نمى شود. (بورنز) هردى كه اشتبــاه نككند، ارزش كارهاى بــزرى رانى رانخواهد داشت. (ادوارد فيلييس)

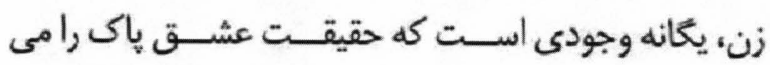
شناسد. (فريدريش شيلر)

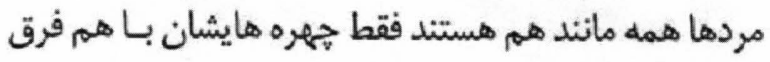

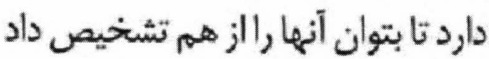

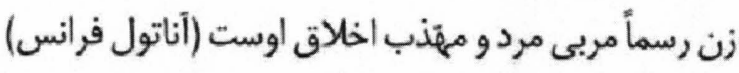

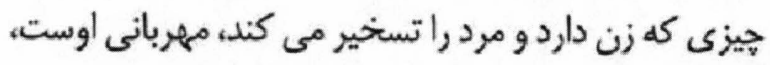
نه سيماى زيبايش (ويليام شكسيير)

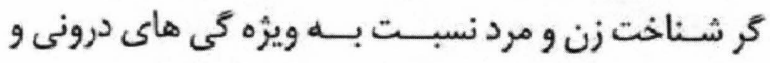

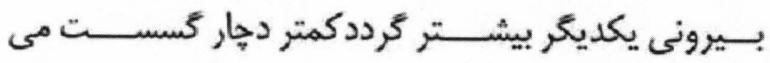

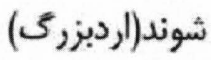

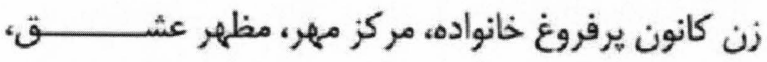

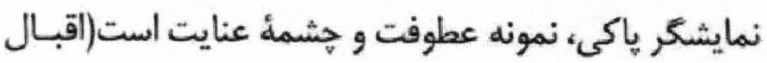
لاهورى) آيندة اجتماع دردست مادران است. اكر جهان به ميانجكَّى زن كرفتار شود، تنها اوست كه مي تواند آن رانجات جنات دهد ميان (ابوفور) به هر اندازه كه زن آرام و مطيع و با عصمت و با عفت است، به همان اندازه قدرت فرمانروايى او شديدتر و استوارتر است است

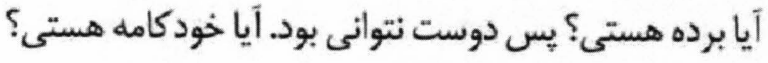
بس دوستى نتوانى داشـت درزن دير زمانى اسـت كه بـ بـرده

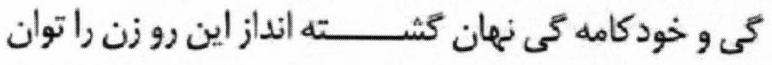
دوستى نيست او عشق رامى شناسد و بس (فردريش نيجها

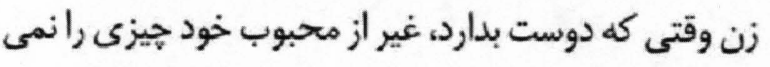

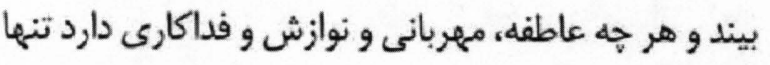

كوش دادن، مهربـان سخن كفتن، أداب داشـتن، راستَكو

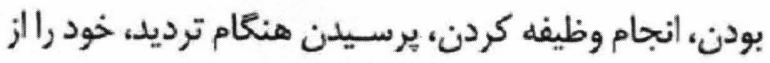

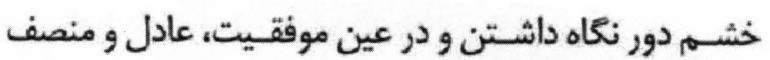
بودن. (كنفوسيوس)

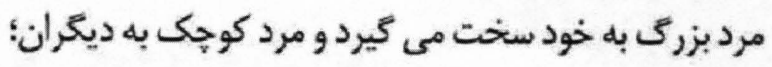

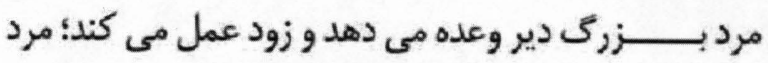

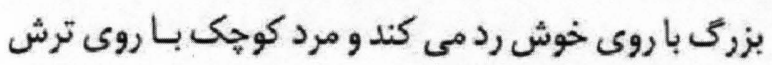
مى نيذيرد. (كنفوسيوس) بزركى مردان بزرى از طرز رفتارشان بـانـا مردان خرد آشـكار مى شود. (توماس كار لايل)

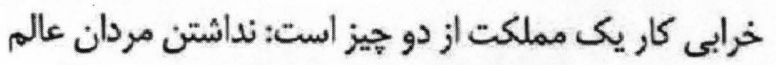
ولايق و نبودن أنها بر سر كارهاى مملكت. (فرانسوا ولتر)

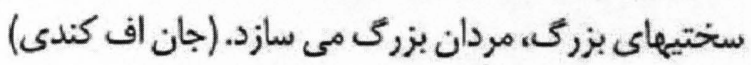

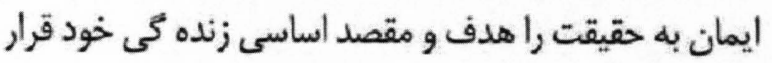

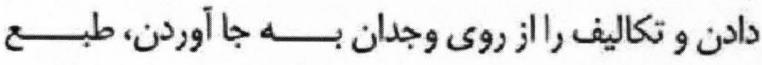

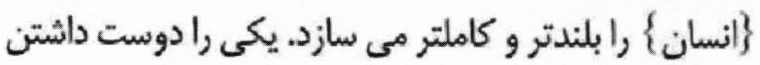

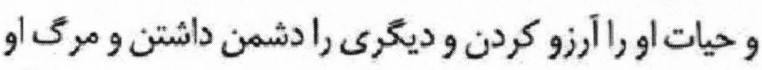

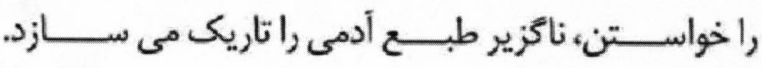
(كنفوسيوس) زن عاقل به تربيت همســرش همت مى كماردو و مرد عاقـل اجازه مى دهد كه زنش او راتربيت كند. (مارك تواين)

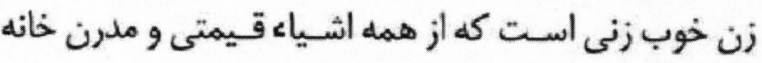
براى شوهرش بارزش تر باشد. (اقليدس)

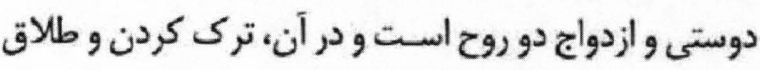

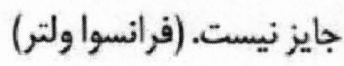
زن هميشه سـن خود را از تاريخ ازدواج حسـاب مى كند، نه نه تاريخ تولد. (الرهارد) سرانجام كشف شد كه دارنده بيمارترين افكار و خشن ترين

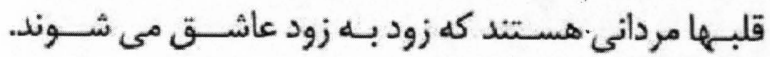

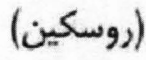
اين ديدكاه اشتباه است كه بينداريم مرد توانا فرزندى مانند خود خواهد داشت. (أرد بزرى) قلب زن يرتكاهى است كه رُرفايش رانمى توان تخمين زد.

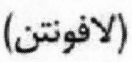
در آغاز هر كار مهمه يك زن وجود دارد. (لافونتن)

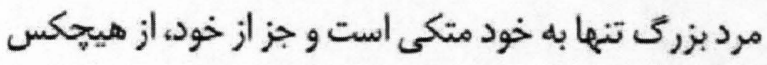

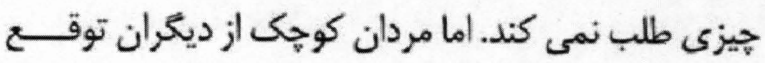




\section{يه افغاذستان}

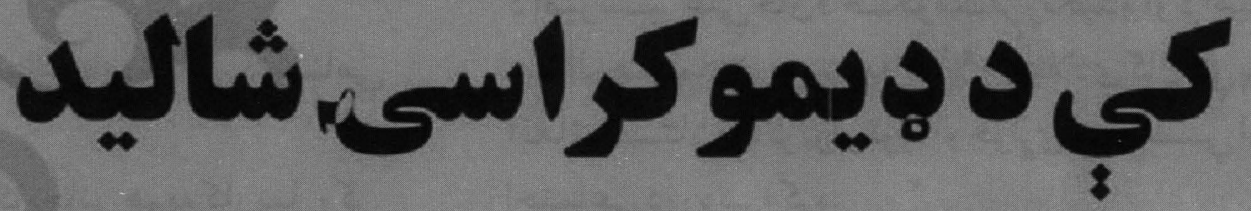

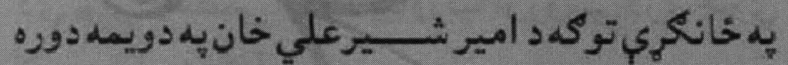

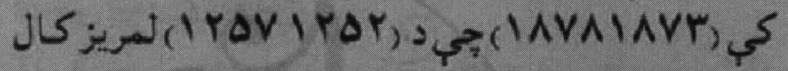

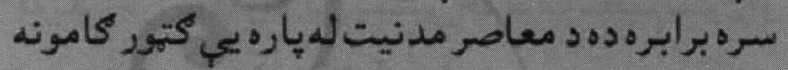
واخيستل. به همدي وخت كي وو بحي دولتي نظام تر 8 بري اندازي

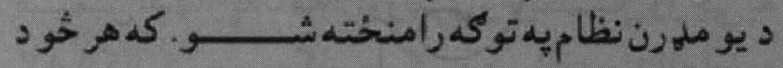

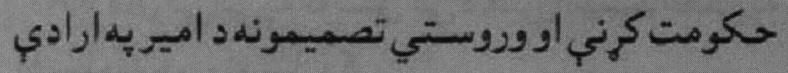

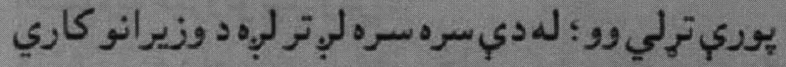
برخي مشخصي شوي. يه همدي توكى بر افغانستانيه

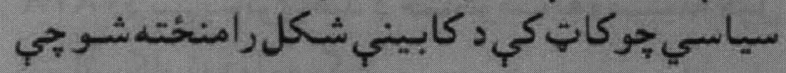

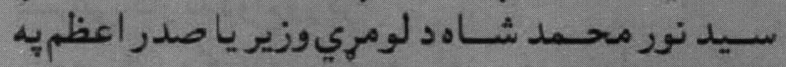
توكدقراردربود نورد و افغانستان لومرنى كابينه

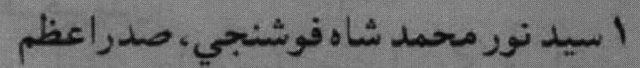

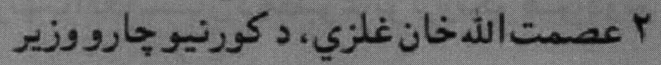

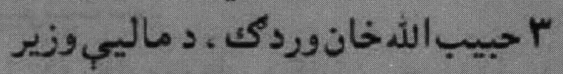

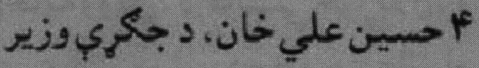

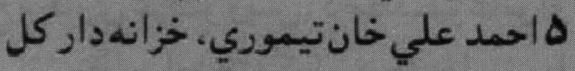

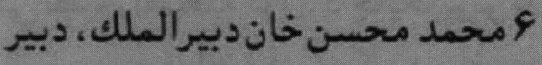

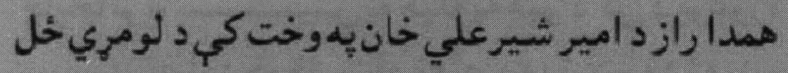

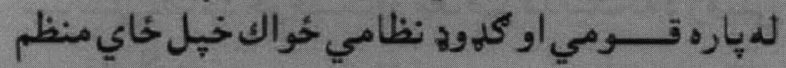

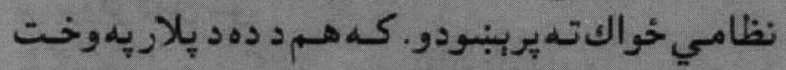

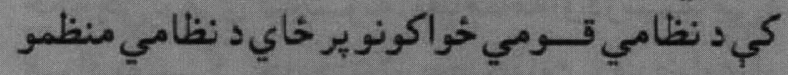

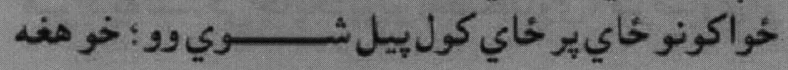

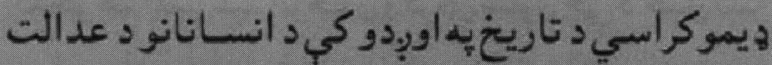

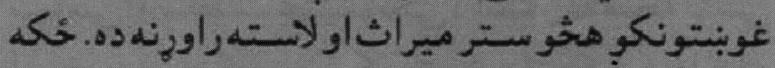

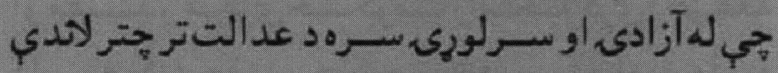
روند كول دو تولو انسانانو هيله دهـ.

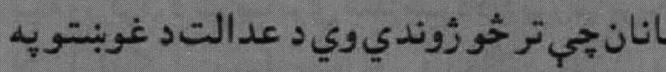

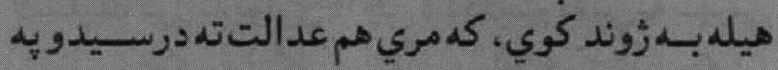

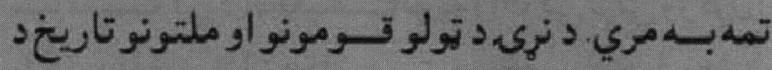

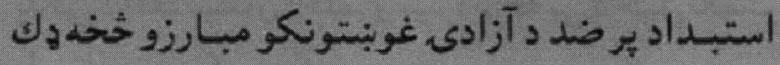

دي.

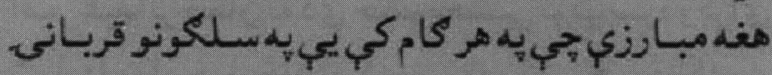
وركيدين

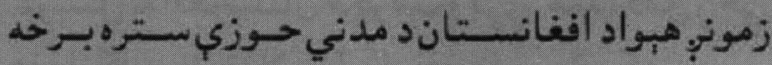

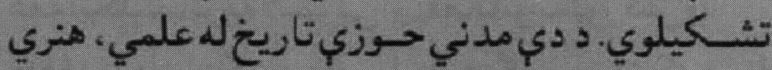
ادبي ويارونو اود استبـداد يرضد ضد دآزادي غوبنتونيكوي خوني مبارزوخخه هوكدي.

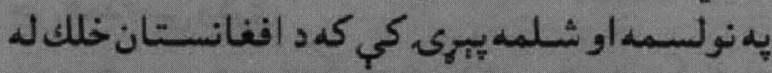

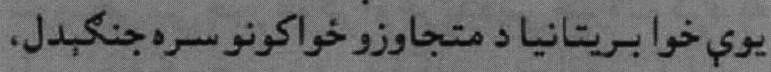
له بلي خوا دوي خاوري روني اندو د سياسي اجتماعي

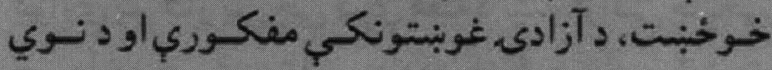

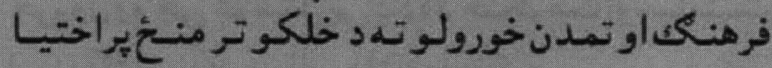

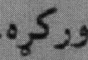

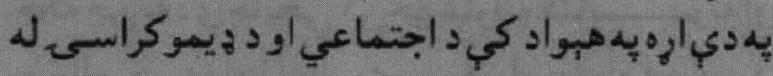

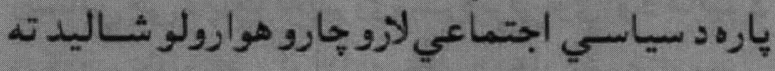

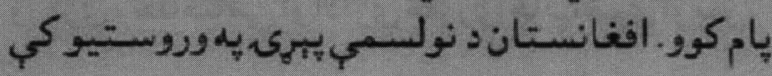


شمس النهار) كي جاب شوي دربغه جي د دي فرهنكي

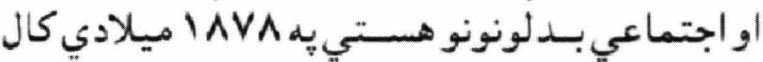

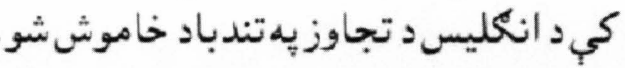

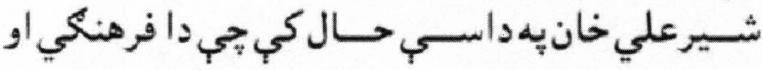

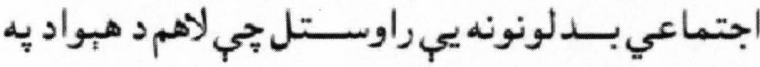

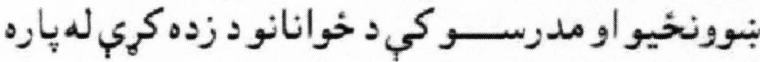

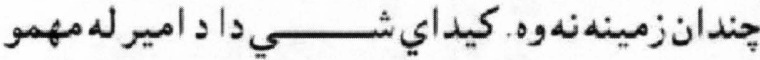
تبروتنو ثخه وو خجي بنسووني او روزني ته يبي ياملرنه ونه .0 .5 و امير شـير علي خان د حسكومت تر رنكيدو او د امير

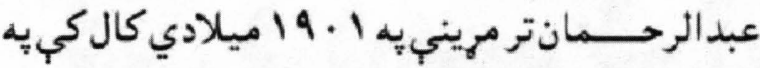

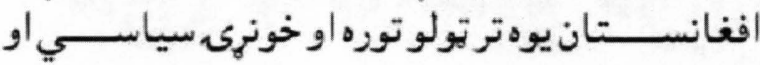
جتماعي دوره تبره كره.

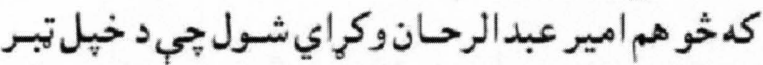

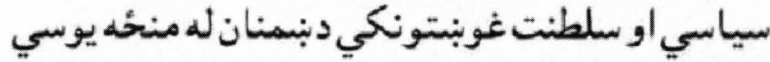

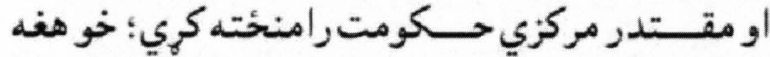
داسي مركزي مقتدر حكومت تهد رسيدو لدياره لورهن

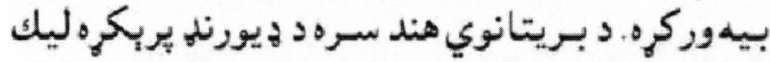

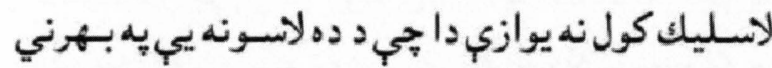

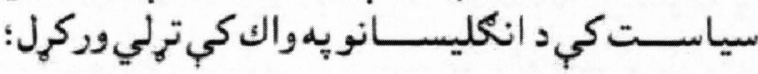

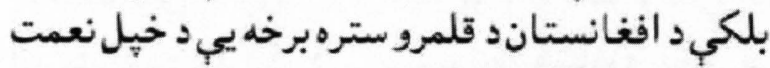
ولي تهيه واككي وركيه

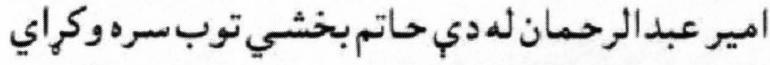

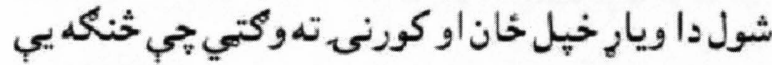

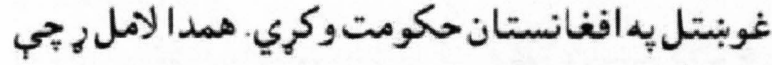

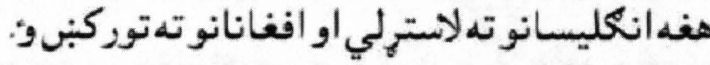

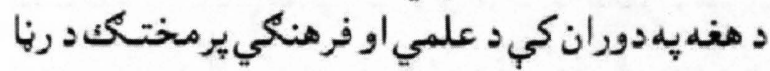

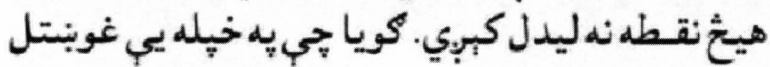

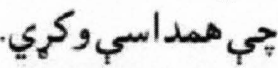

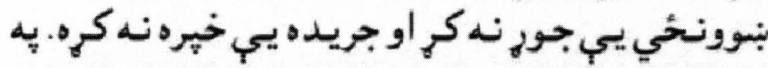

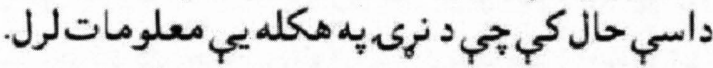

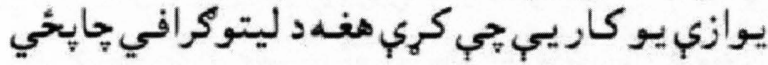

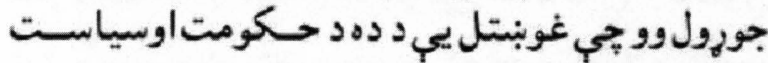

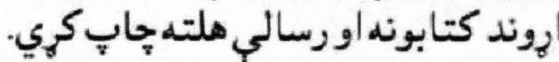

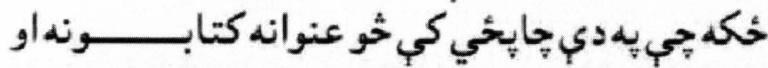

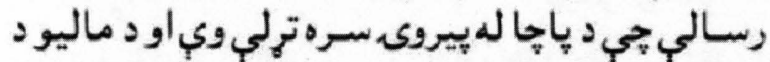

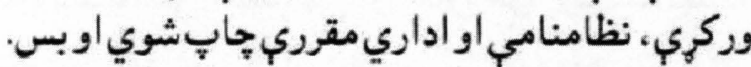

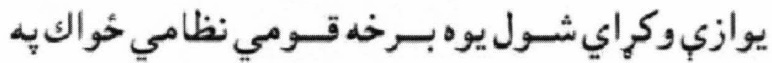

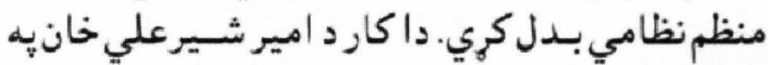

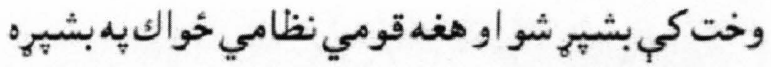

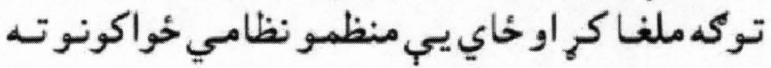
ورك.

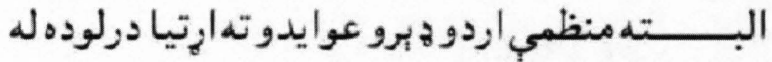
همدي لامله شيرعلي خاند جنسي ماليو بر خاي ناينقدي

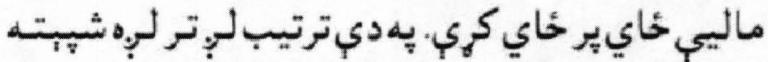

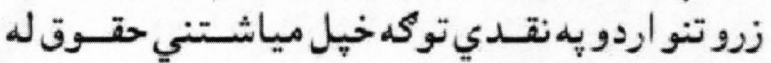
حكومت خخخه ترلاسه كول.

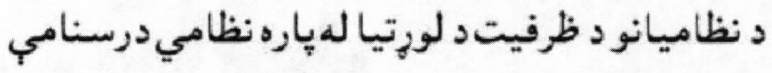
خيري شوب.

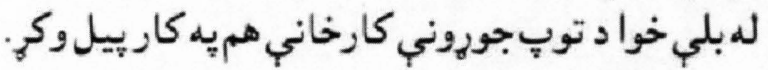
دي تولو د منظمي اردو د يبياورتيا او روزني لازي خاري

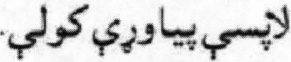

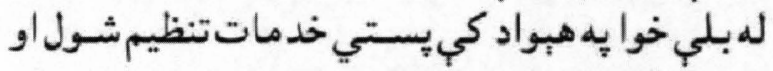

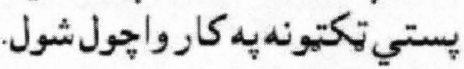
يه كارونو كي د امير شير علي خان تر تولو ستر بدلوند

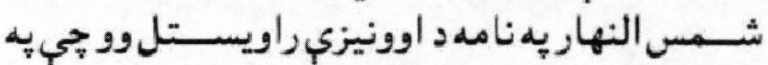

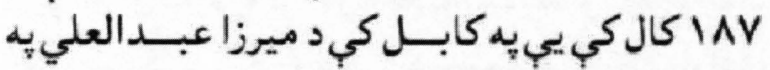

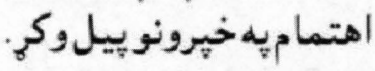

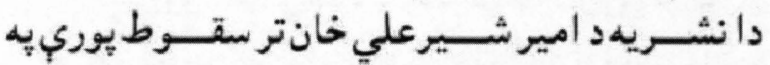
ا AVA نشراتي كارتهدواموركي. يهدي نشريه كي نه يوازي هيوادني خبرونهاوني

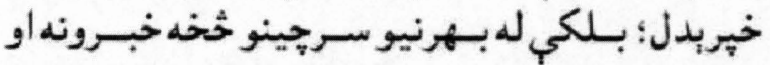
ريورتونه هم خيربدل. يه دي ترتيب افغانستاند مطبوعاتو لرونكو هبورادونو له كورنى سره يبيوست شور

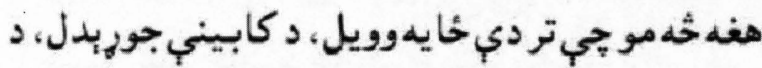

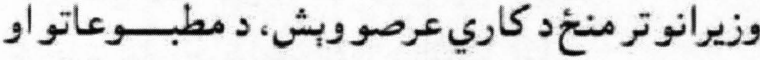

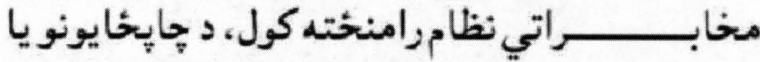

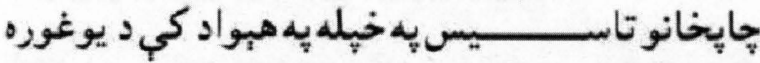
سياسـي نظام د خوخبنت او معاصر مدنيت تهد زميني برابرولو لامل شيو.

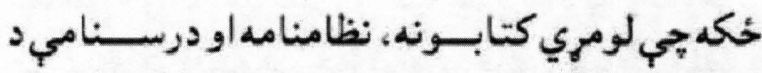

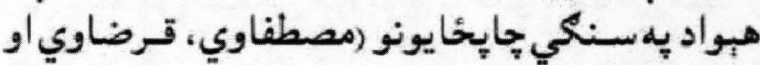




\section{نقش بانوان در انكشاف جامعه}

\section{از نكاه مراحل تاريخى و حقوقى}

\section{و ره يابى به مجلس نماينله كان}

شده استـ، و هر دو جنس در جوهر و ماهيت يكسان و يجانه اند. تمايز وفرقى در حقيقت و ماهيت انسبانى (مراد

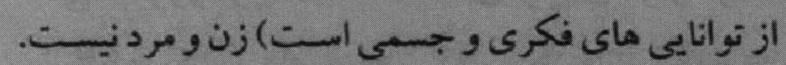

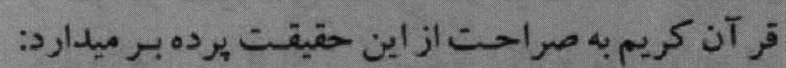

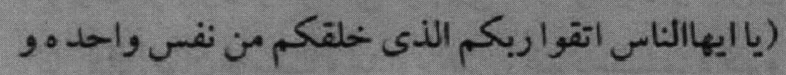
خلق منهازوجها...).

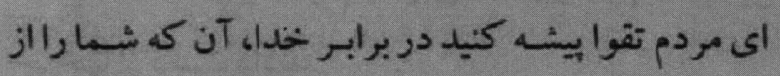
يكك تن بيافريدو از يكت تن او را - بيديد آوردو.... انديشة يكسانى و انديشه ماهوى زن و مرد انديشه قر آنى است كه قرآن در مورد خلقت زن بيان داشته است.

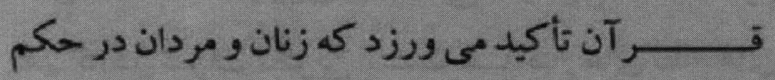

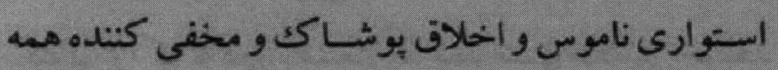

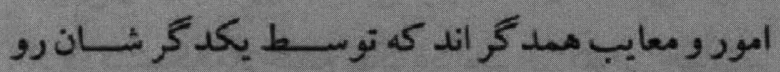

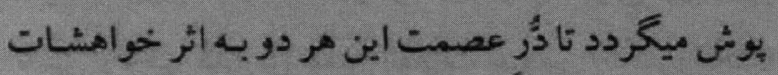

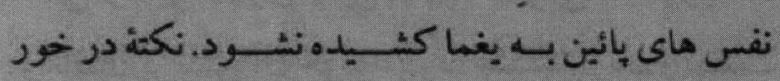

نوشتارى كه در دست خواننده قرار دارد كوششى اسـت در شـاخت بـانوان واركان اساسى تأثير يذيرى آنان كه

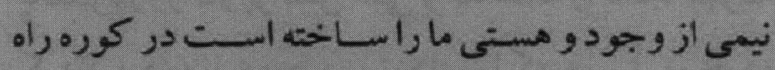
تاريخ و سـهم كيرى آن در فعاليتهاى دنيوى و انقلابـاتى

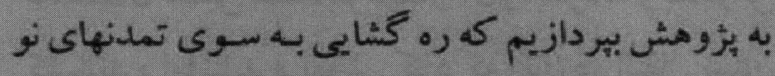

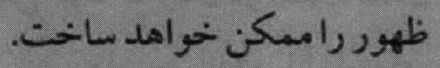
زنان از نكاه خلقت و معاد و ديد فلسفى -و بـر بايه هاى

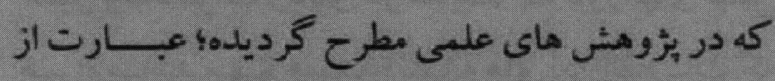

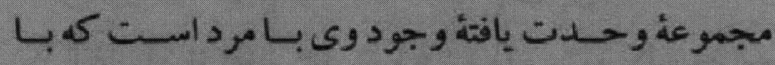

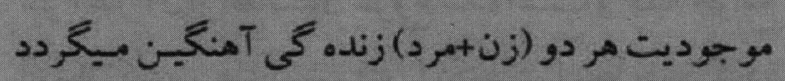
و وجانهاى تازمونسل هاى نوى بديدار ميشود.

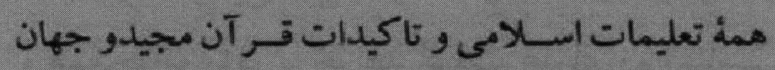

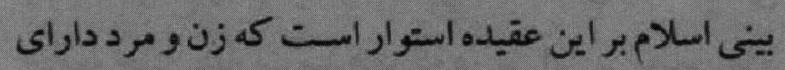

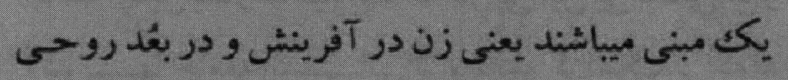
و جسـى از همان كوهرى آفريده شــده كه مرد آفريده 
جهره گُشايى: در افغانستان از جنبـش نهضت نسـوان و ها كشايعى اين طبقه بـه مكتب و مدرسـه و دانشگًاه حسدوداً نيم قرن ميكَردهر حيند در زمان امان الثه خان اين جنبش با كشادن جهره ملكه ثريا و جند بانوى سرشناس ديگر به

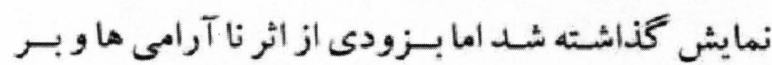
جيده شـدن نظام امانى اين نهضت نيز خاتمه بـذيرفت كه بعدأ در زمان محسمد ظاهر شـاه كه تاريخ دقيق آن بيادم نيست شايد سـال MرA ا مسئله كشـف حسجاب يا آزادى زنان نگًرانى عجيبى رادر ميان مردم سبب شدو شايع بود كه در جشن استقلال آن سال همه قريه دار ها ملا امامان، مامورين دولت، معلمين بــا خانم هاى شــان در مراســـم جشن اشتراكك ميكنتد، البته زنان بـا جهره بـاز بـايد ظاهر شوند. و همانطور هم شد. اين نقطه آغاز جر خش نهضت زنان در افغانستان بـانوان را توانمندى بخشيـيد تادر مدت

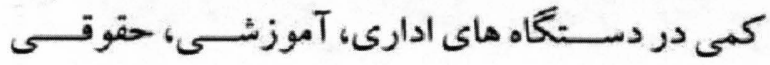
اشــتر اكت نمايند كه موجوديت هزاران متخصص، د كتر وانجنير و محقق علوم انسانى و طبيعى از جنس بـانوان در افغانستان مؤيد اين ادعا ميباشد. اشتراكك بـانوان در جالش هاو تعارض ها: زنان بـا مردان يكسـره روز كار ير تنش سـى و اند سـاله را يكجا تجريسه كردند و همه نوع محروميت هاى راكه به نسـل موجوده

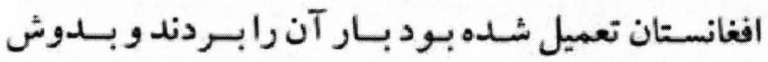
كشيدند و اما نبايد فراموش كرد كه زنان در انتقال تمدن جديد كه بـا تعارضات و تنش ها، بحـر انها و نا آراميهاى عميق ومخاطرات زيادى در مقايسـه بــا دورانهاى قبـل همر اه ميباشد سهيم هستـند؛ نشـانه هاى اين انقلابـات كه سر آغاز آن از افغانستان شروع شده اسـت و كليه جوامع

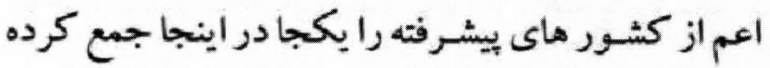
است سر انجام اين تنش ها از محدودة افغانستان بدر شده

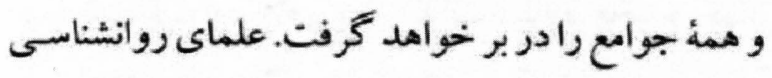
جامعه جنين بشارت ميدهند كه در بيى اين بى نظمى ها و

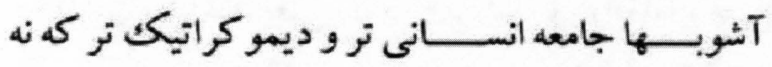
آرمانشـهر اسـت و نه هم ضد آرمانشـهر بـلكه ارمانشـهر
اهميت اين نكته است كه به قول ويل دور انت فيلسوف و تمدن شناس امريكايى در صبح شـروع زنده كَى انسـانها يا كمون اوليه كه بشـر اولين مرتبـه تشكيل خانواده داد؛ خانواده توسط زنان ادراره و كتترول ميشــه اســت كه

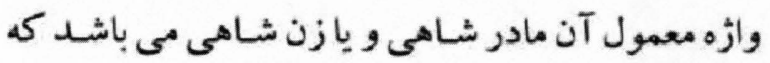
بقــول ويل دورانت زن شــاهى و يا مادر شـــاهى جامعه ابتدايى بشر را شكل داده بـود. ما از دور تسلسـل مراحل تمدنى انسـانها كه اكثراً در هاله يى از تاريختى و شبـهات

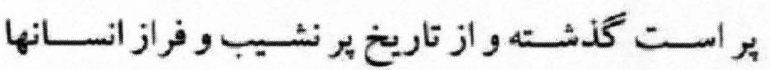
ميگذريم و صرفاً از دو انقلابــى نام مى بـــريم كه زنان و مردان در آن نقش فزاينده يع داشسته اند: جامعه شناسـان معتقد بر اين هستيد كه تاريخ بشر دو انقلاب را بشت سر سرد كذاشته اسـت: انقـلاب كثـاورزى و انقـلاب صنعتى، و اكنون بشردر آستانه سومين آن يعنى انقلاب الكترونيك قراردارد. زن در انقلاب كشـاورزى بـزركترين نيروى كار انسـانى

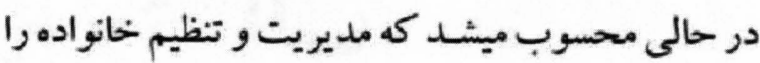
نيز بــــوش مى كثـــيد ودر انقــلاب صنعتى زمانى كه ماشـين بـاصد ها مشـاغل با در ميان كذاشــت مليونهازن حتى تا امروز در يشت دستًاه هاى توليدى قرار مرفت

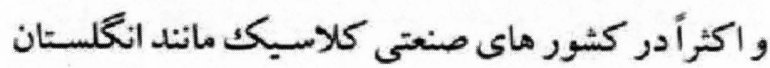
هزاران هزار زن از اثر بـى توجهى كار فرمايان و اجراى

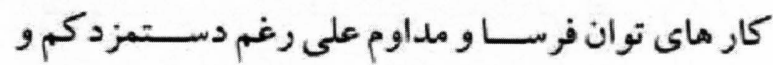

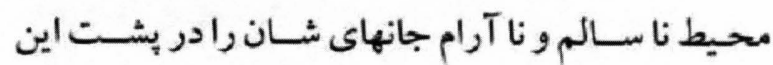
جر خها از دست دادند. واما اين انقلاب سوم (انقلاب الكترونيك) همانكونه كه انقلاب صنعتى با آنهمه كمبوديهايش توانسـت سـاختار هاى انقلاب كشاورزى را متلاشى سازد اين انقلاب سوم هم كهدر شـرف تكوين اســت مــاختار هاى نظام هاى كنونى را كه به دوره صنعتى مرتبط است متلاشى خواهد

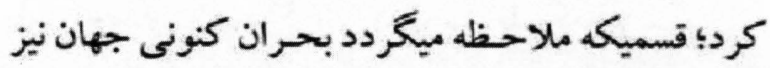
ناشى ازتأثير كذارى همين انقلاب سـومى (الكترونيكك) و انتقال بِر تنش آن خواهد بـود. جنبـش زنان و نهضت 
كَذائـت مى بينيم كه اروياى فاخر بـعد از جنغك رابـــ

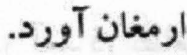

اين موج تازه كه با نا آراميهاى انباشتهـه در اكثر كثشور ها

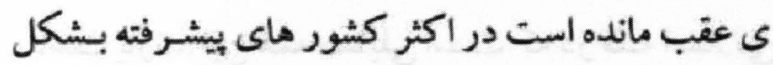
ركود هاى عظيم اقتصادى ظاهر گُ ديده اسـت كه تكانه

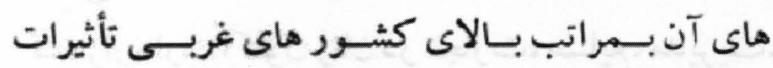

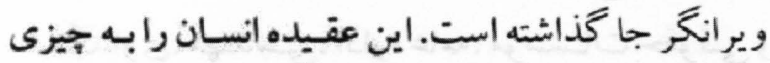

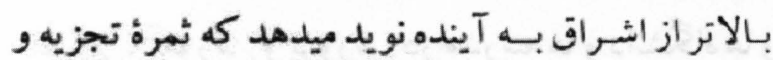

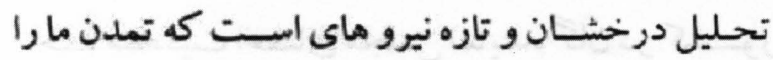

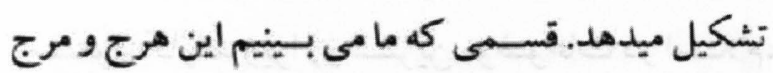
موجوده بــاعث اين ميخر دد كه ما رابــراى يكك انتقــال

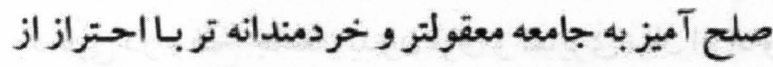
مخاطرات گونائونى كه اين انتقال بهـمراه دارد، بـه فردا

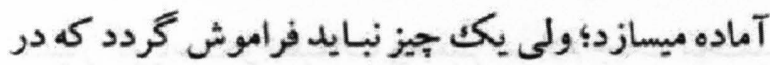

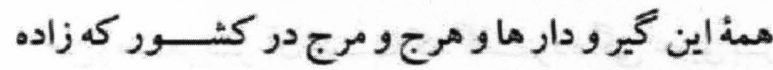

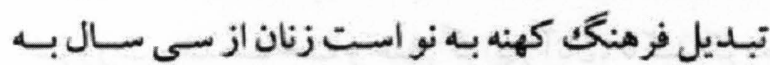
اينطرف نقش فزاينده داشته و همه گونه مرارتهاى راكه

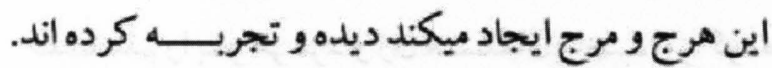
زنان كه در بر اندازى شـوروى سهـم اساسى داشـتند در

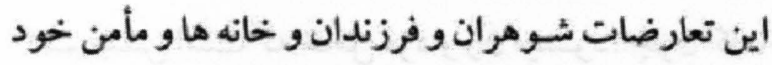
رالزدست دادند و يكجايى باشوهران شان ويا بـصورت انفرادى آواره كرديدند و يا در داخل كثـور مجبور به كوج كشيى هاى اجبارى شــدند كه تلفات زنان در اين هرج و مرج ها كمتر از مردان نمى باشد. حق زنان در اشتراكك ميدانهاى سعى و تلاش: و اما همين

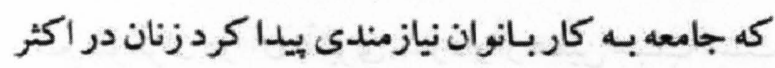

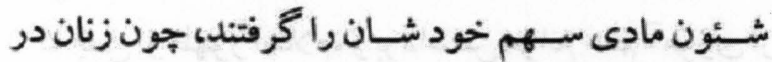

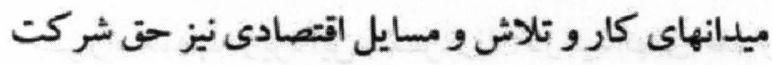
و در همة اين زمينه هاحقوق همسـان بـامردان دارند زيرا

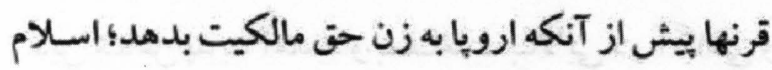
بـه زنها اين حسق راداده اسـت، زيرااز نظر اسـلام زنان

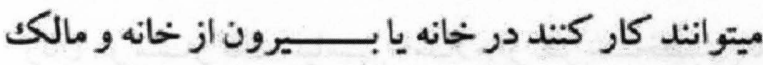
محصول كار خويش باشند، ارث ببرندو ارث بعذارند،
عملى است كه نه بهترين و نه بـدترين دنياى ممكن بـلكه

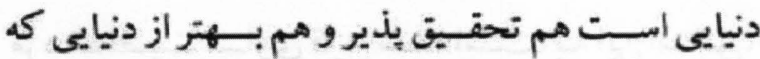
يشت سر كذاشتيم ظاهر خواهد شد تهد

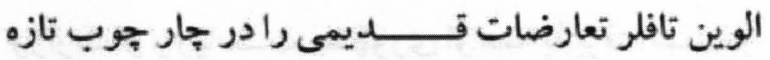

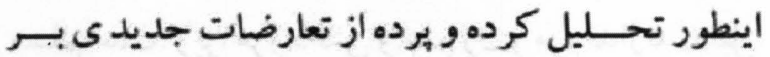

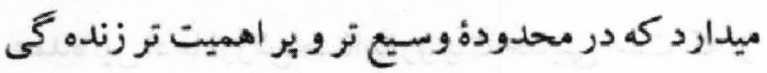
ما را تحت تأثير دارند كه اين تعارض بين مدافعين تمدن

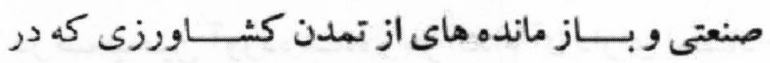

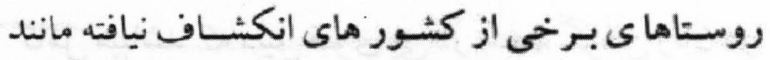

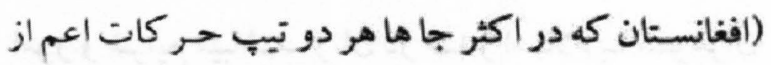

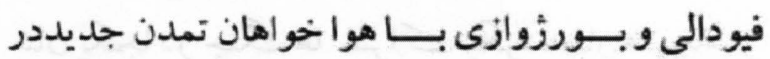
تعارض بمشاهلده ميرسـد) و هوا خواهان تمدن جديد كه

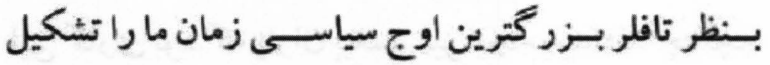

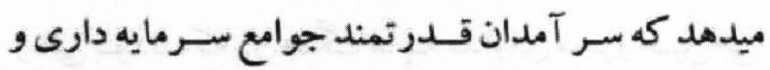
سوسيالست و فيودالى را بمعارضه و جالش مى خواند. در كثــور ما نيز كه توجه دنيا را بـه اهميت نظم و تحكيم وسيم

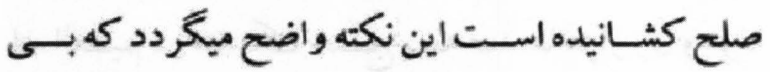
نظمى و تصادف در تكامل و تكوين يديده هـا معطوف

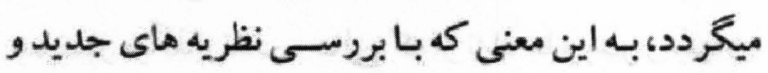

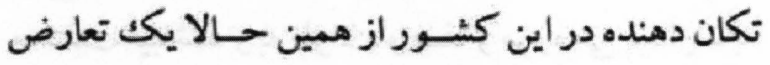
وســـع در مقابــل عمل كرد كثــــور هاى كه در اينجا

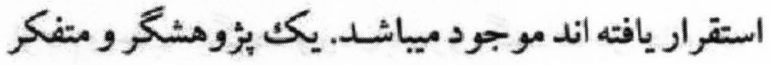

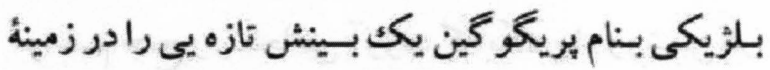

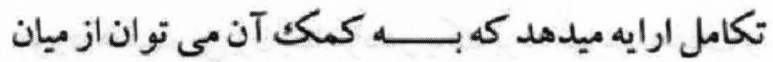
آشفته گى هاى موجود و هرج و مرجى كه مردم رازمين

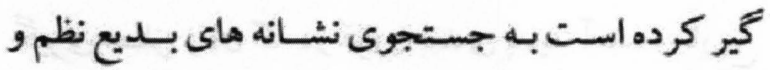

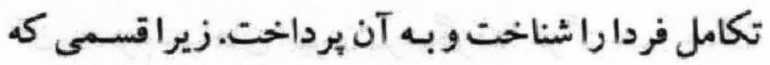

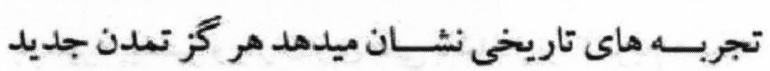

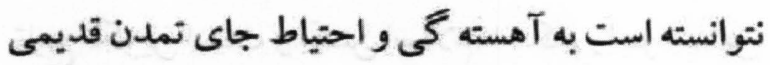

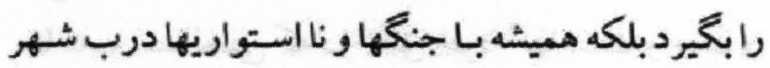
هار اكوبيده و در فرجام جيز نوى رادر خرابه هاى آن به

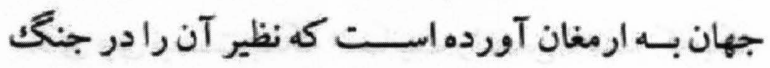

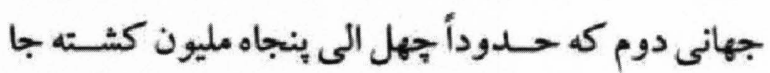


يكك مورد نه دو مورد بـلكه در موارد متعددبسـراى زن و مرد شخصيت مساوى قايل شـده اسـت بــــ اين اسـاس، اقرار زن، قضاى او، مرجعيت او، رهبـرى او، وكالت او، وزارت او و رياســت جمهورى او همه بذيرفته شــده و . مسلم است. زيرا مرز دانش و علم زن و مرد ندارند. دليل عمدة اين ادعا ارزش صداها روايت حديثى است كه از حضرت عايشه صديقه (رض) خانم بيغمبـر اكرم (ص) در صحيحسين آورده شـده و هر كدام آن داراى اســاد كامل ميباشد كه دليل قوى ييى در سـهم كرفتن زنان در امور و شر ايع ميباشـــــ زنان در صدر اسـلام بـا شـوهر ان شان يكجا در جنكَت ها اشتراكت ميكردند بار ها يِيغامبر اكر ميكى از زنان خود رادر جنخّها بـاخود ميبـر دندو اين كارى بود كه يار ان بيغمبر نيز انجام ميدادند جنانجه

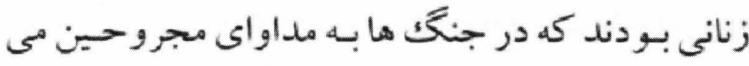

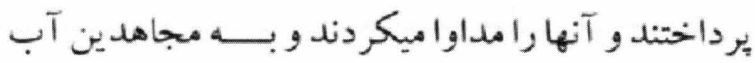
آشـاميدنى و غذا فر اهم ميكر دند. همين اكنون در بـيت

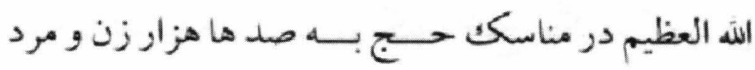
مناسك حسـ را يكجاو بهلوى هم ادا ميكنتد و بهلوى هم نماز ميكذارنددر حسالى كه از نثراد ها و سـر زمينهاى مختلف ميباشند و به طواف و صفا و مروه مي بردازند به ترتيبى كده اكَر رو يوش زن به رويش تماس بيدا كند بـه

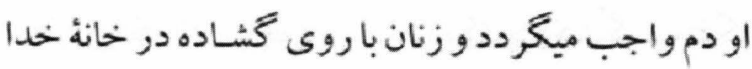
مر اسـم حسج رابـسجا مى آورند كه يكك بيام روشـن در مورد همسـويى زن بـا مرددر يكك يردة نهايت عفاف و و تز كيه روح و نفس ميباشد. بنا بر آن خانه نشينى و گوشه

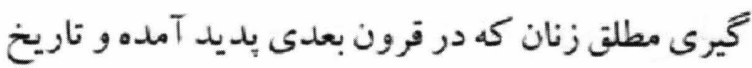

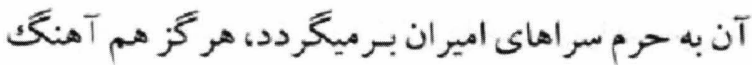
به سيره ييغمبر و يار ان وى نمى باشد. زير ا تشريع هميشه

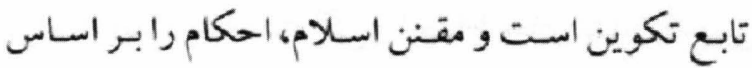
مفاسد و مصالحسى كه در تعلق خود آنها سـت واجب و حرام مى شمارند، زير ا حقيقت انسـانيت انسـان بـهـ بــندن مادى وى نيسـت بـلكه انسـانيت رانفس ناطقـه كه يك
و بهر نوع تلاش سازندة اقـتصادى دسـت زنند. سـرمايه دارى كثند و به تاسيس مديريت هاى ير در آمد در نظام اقـتصادى و اداره كثــورى، در امور حقوقىى وقـانونى دست يازند. اين همه مسايلى اسـت كه در فقه اسـلامى معرح كُرديده و قوانينى است كه در متن تعاليم اسلامى قـــــار دارد. اكثون زنان در تجارت، صنايع، مديريت، بـانكدارى، مهندسىى، اداره عامه، موسسـات حقوقى و قضايى، آموزش و برورش در مدرسه ها و دانشگاه ها و

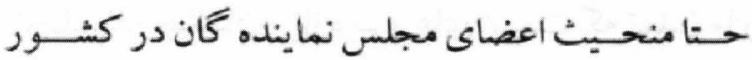

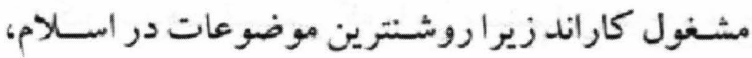

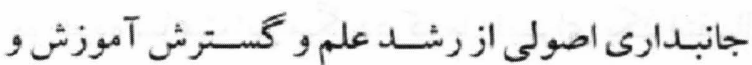
دانايى در سطح جامعه، بدون فرق و تمايزى ميان افر ادو و

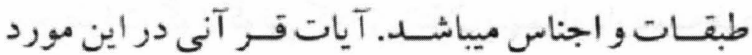
بسيار كوياست و تعليمات بيغامبر اسـلام جناب محسمد

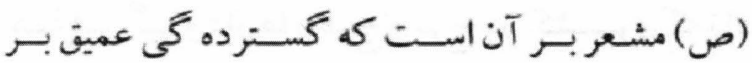
ضرورت رشد شناخت و عقل كر ايى آنان، تاكيد كرده اسـت و از همين سبـب اسـت كه بيغامبـر كر امى اسـلام طلب علم را بــر هر مردو زن مسـلمان واجب امر كرده است و كلمه مسلم كه در نفس حديث آهده است مسلم اسم جنس است كه شامل مرد و زن ميشـود؛ جهون كلمة مؤمن و ساير كلمات كه در قر آن تكراراً آمده است كه اين موضوع ترديد نا يذير ميباشد.

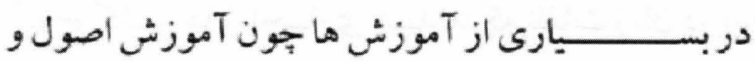
اعتقـادات، واحكام شـرعى كه زنان بــايد بــــانتد، اذن شـوهر نيز شـرط نيســ، جون ديخًر اعمال تكليفى كه منع شوهران در آن تأثيرى ندارد و از همين سبـب اسـت كه يس از ظهور اسلام، و برداشـتن موانع علم آموزى از مهري سـر ر اه همه بـه ويثره اين قشــر، زنان در ميدانهاى علم و

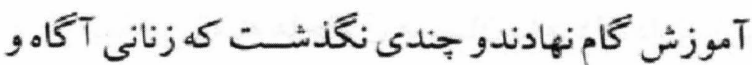
دين شناس بديد آمدند و بمقـامات بـالايى در آكاهى و دانش رسيدند. زنان در مشـار كت سياسىى: اسـلام از نظر شــخصيتى نه 
با احسـاس ودانشـور كشـور از طريق انتخابـات آزاد در

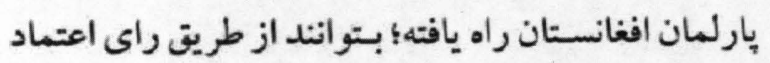

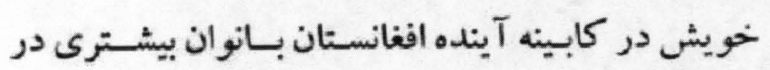

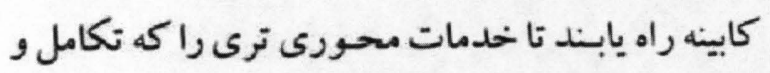
تكويسن يديـده هـاى نـو ظهـــور در ميدانهـاى تكامـل اجتماعى كشور به آن نياز مندى دارد با تصويب قورانين نافع كه جامعه را بسـوى رفاه همخانى خواهد بـ بـرد توجيه

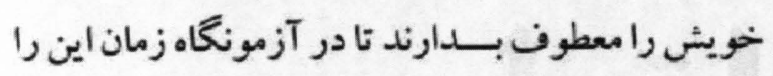
ثابت سـازند آنطورى كه در صدر اسـلام زن داراى كار

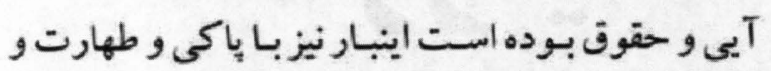

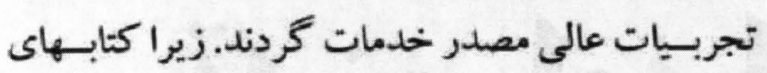

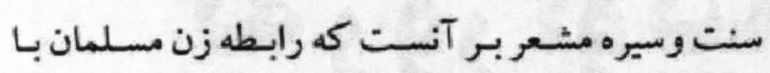

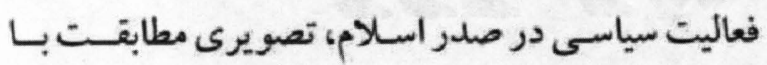

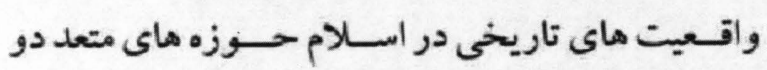
متنوع دارد و ورود زنان باصلاحيت رابه تمام اين حوزه ها باز ميخذارد و منتفى نمى داند.

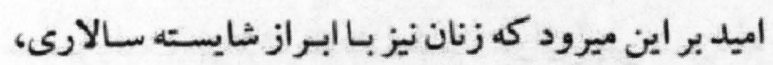

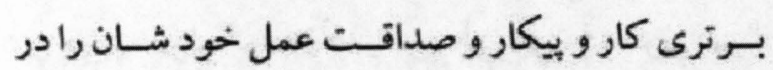
دستكاه هاي مجلس بارالمانى بـه اثبـات رسـانيده از اين دريجه وطن راو مردم را كمك و آباد سازند. منابع |F/1 |

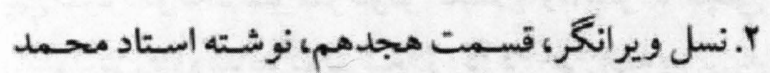

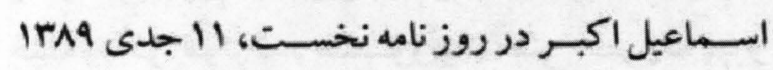
كابل. ז. مقـدم ايى بـر كتاب موج سـوم اثر الوين تافلر، توسط

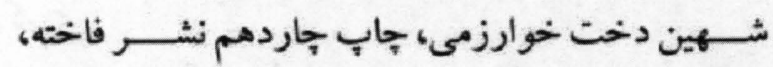
IrvF

f. شهين دخت خوارزمى ص، هشت مقدمه موج سوم.

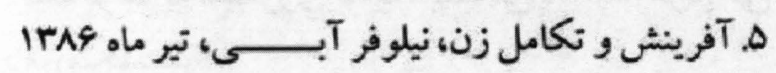
خورشيدى.
مرحسله بـالاتر و و الا تر از مذكر و مؤنث بــودن اسـت

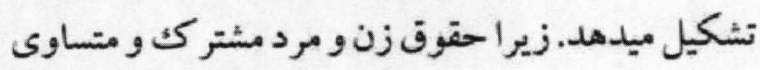

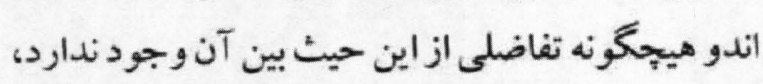
مخر در جاهاى كه حقوق قسماً به زن تعلق مى كيرد دو ويا

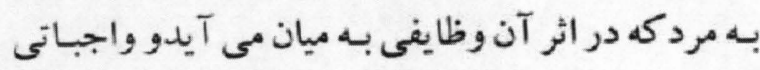

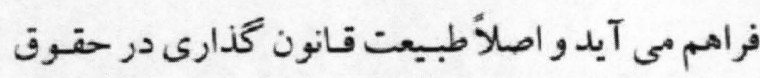

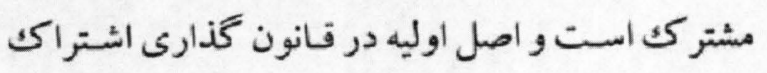
حقوق است. همان طور كه يك زن حق دارد در رشته يزشكى مرجع

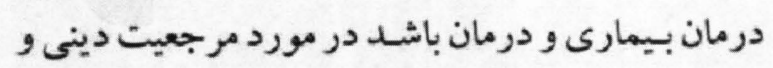

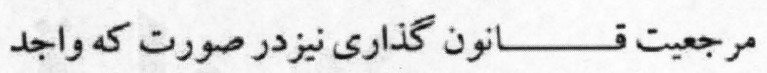

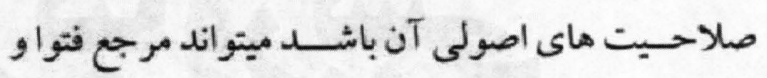

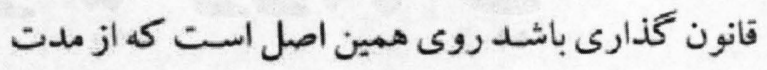

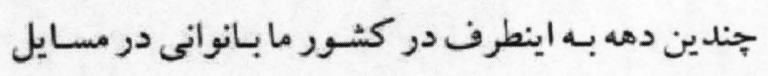

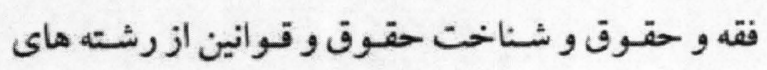
شرعيات، حقوق و اداره عامه اقتصاد، انجنيرى و معدن،

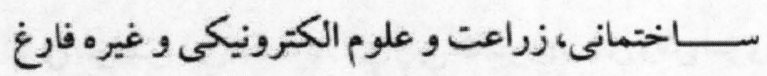

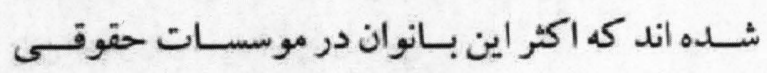

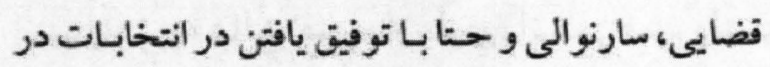
يارالمان يا مجلس نماينده كان كشور راه يافته اند.

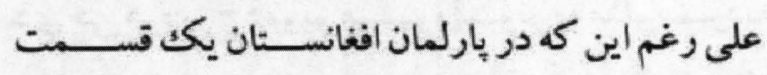

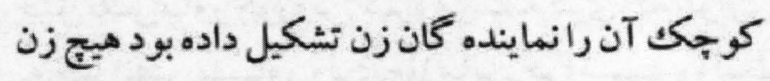

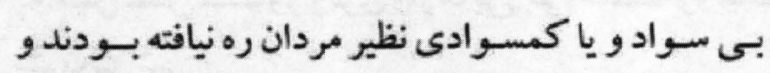

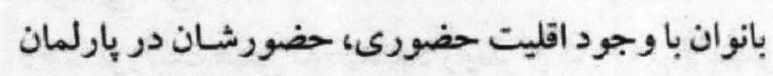

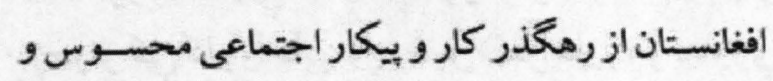

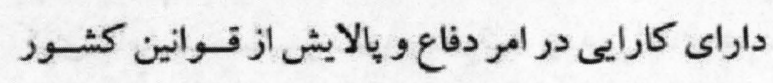

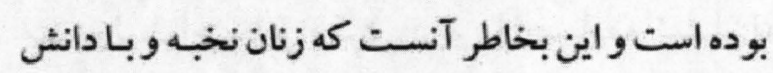

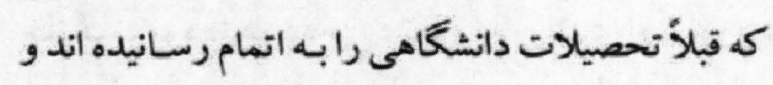
در جامعة افغانسـتان مصدر خحدمت و مطرح بـوده اند بـانـا يكك كيفيت عالى و كميت انكشت شمار، بـه بارلمان را

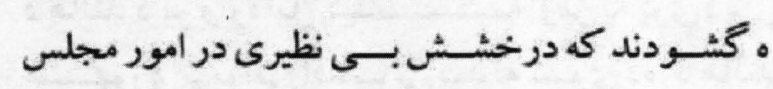
نماينده كان داشته اند. اميد واريم كه اين مرتبه نيز زنان 


\section{مسووليت انساز تد زور اوِياورتياوربنبي}

يري موافق دي هغـهـدا دي يجي هغوي د دي وس لري جي بي مسووليت يه غارن واخلي.

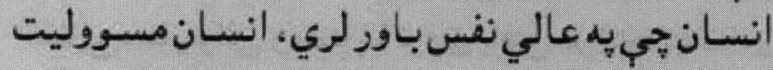

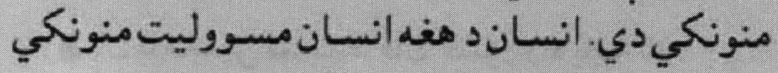

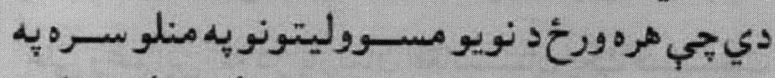

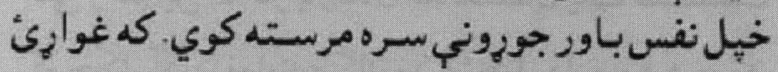

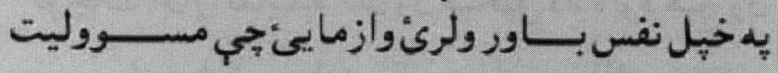
منونكي بنئ.

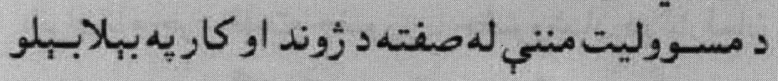

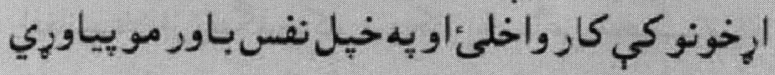

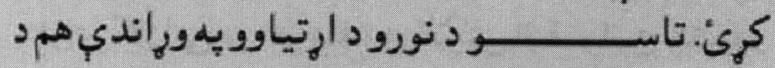

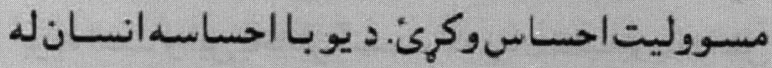

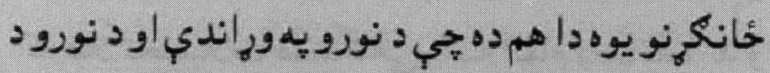

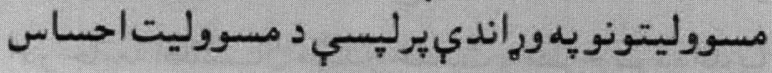
كوي اوتروسي ورسره مرستهكوي.

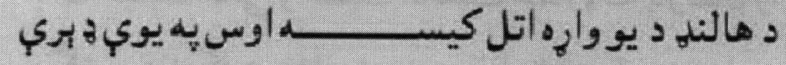

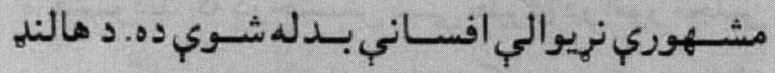

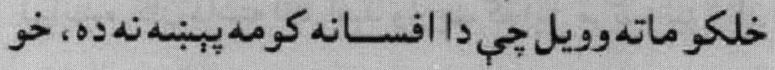

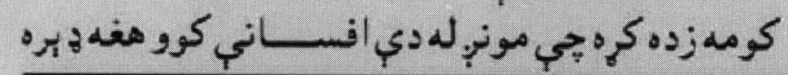

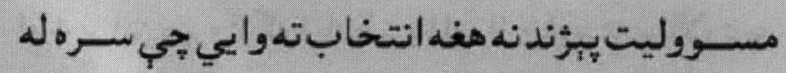

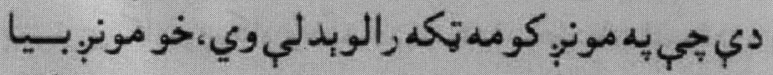

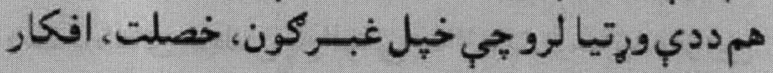

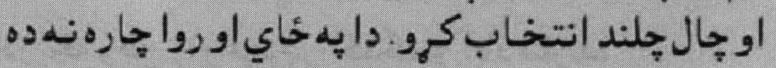

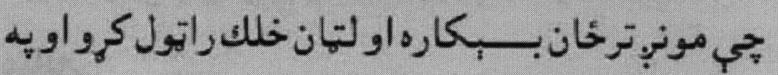

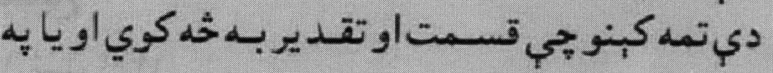

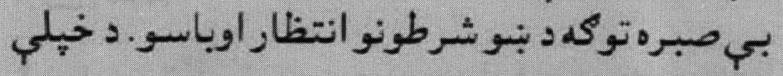

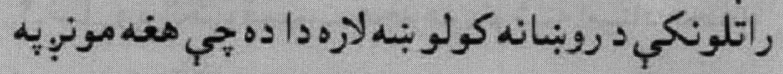

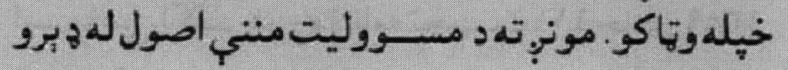

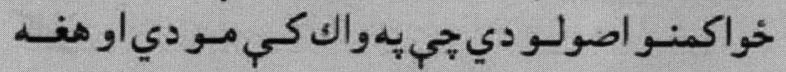

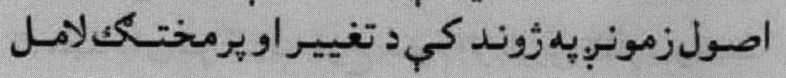
كيبري.

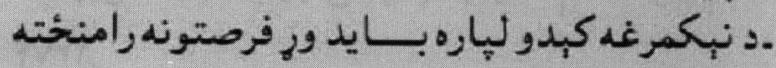

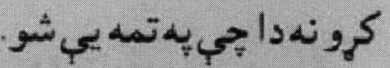

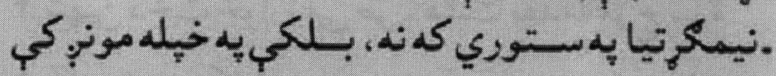

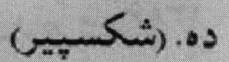

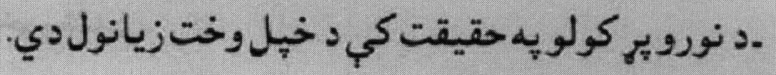

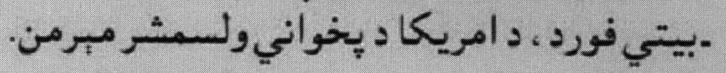

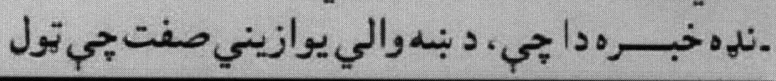




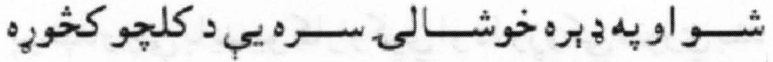

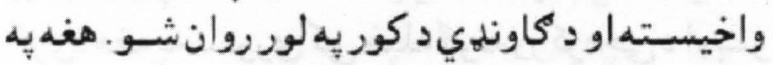

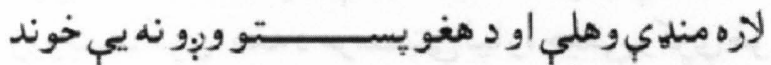

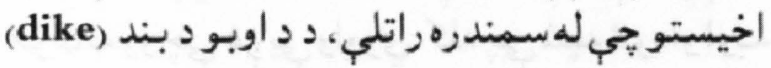

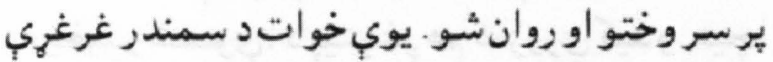

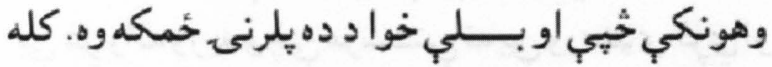

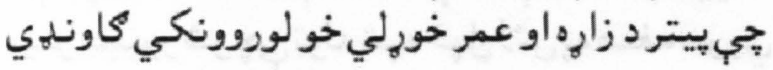

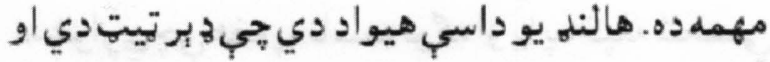
حتي حُيني برخي يب تر سمندر هم تيتيب دي. د هالنه

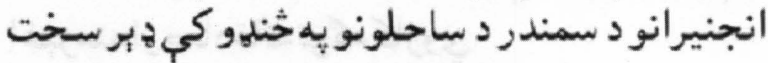

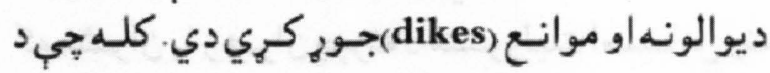

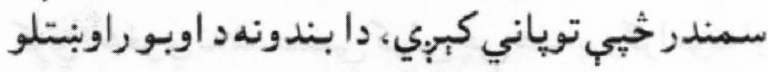

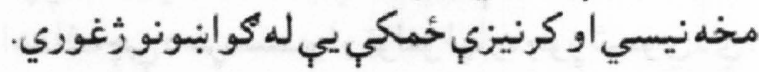

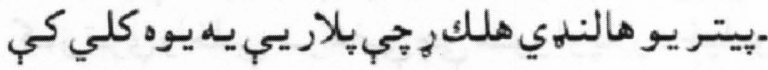

\section{د مسووليت منني له صفته د زوند او كار به بيالاتبلو أرخونو كي كار واخلى أو يه خيل نفس باور مويباوري كرى.تاسو د. نورو د الهتياوو يه وروانلدي هم د مسسووليت احسباس وكئ. د.

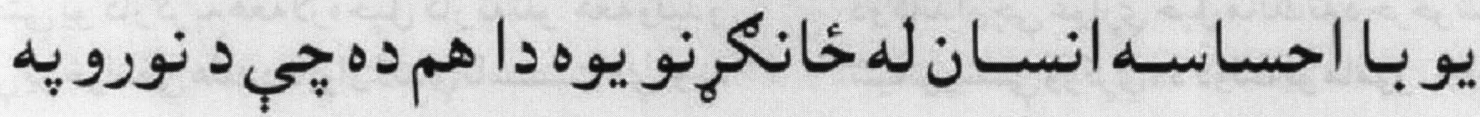

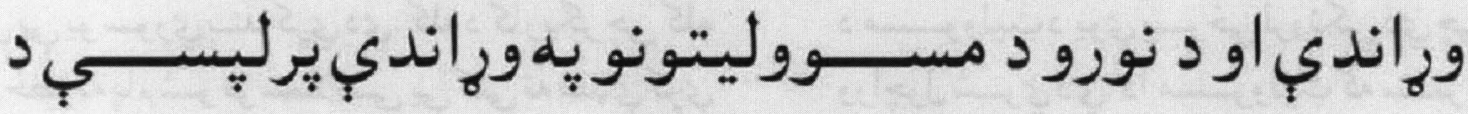 مسووليت احساس كوي اوتر وسي ورسره مرسته كوي.}

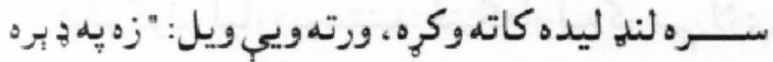

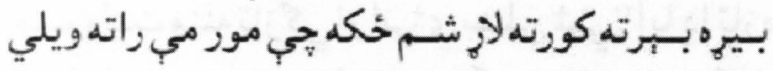

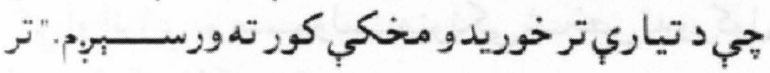

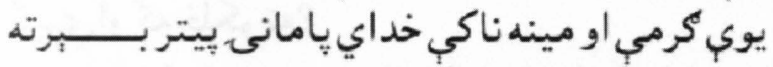

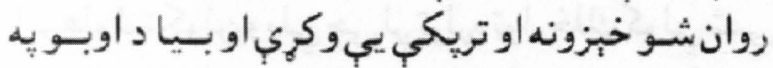

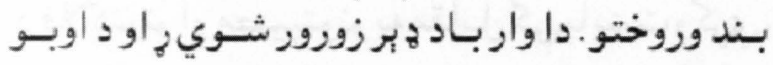

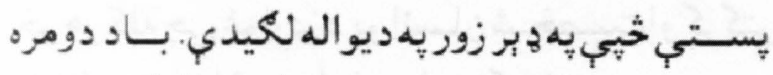

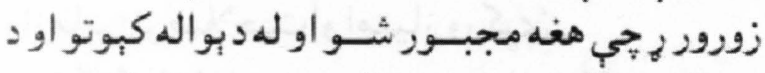

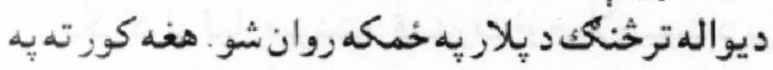

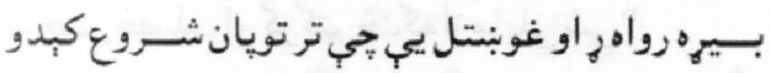

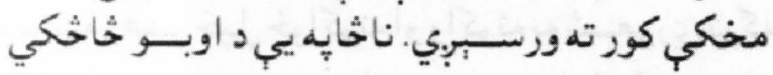

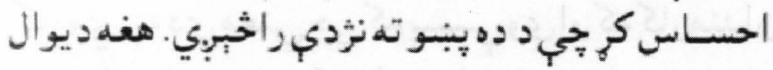

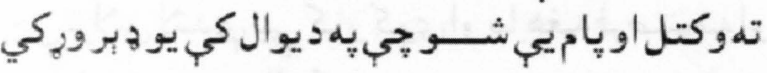

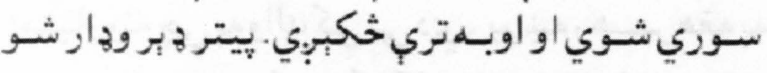

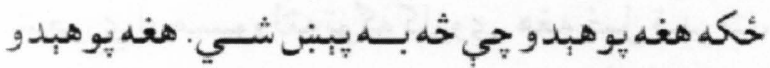

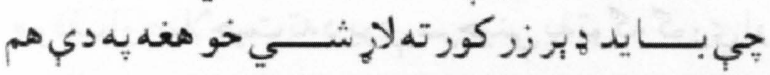

زوكري كوله. هغه د هالنه د نوزو وروكو غوندي

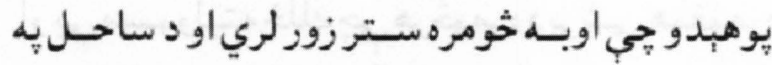

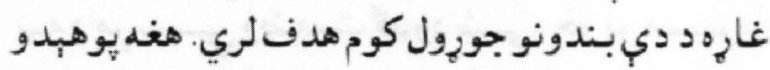

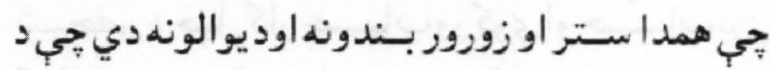

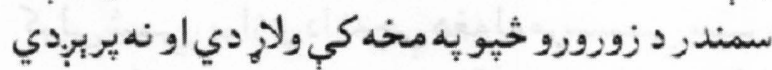

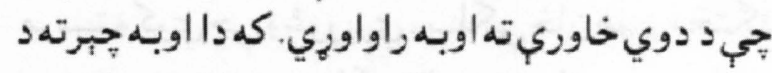

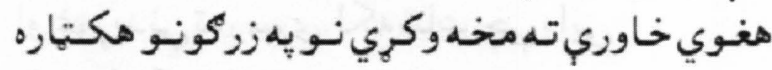

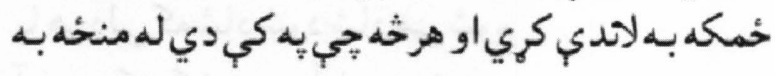

يبي يوسي.

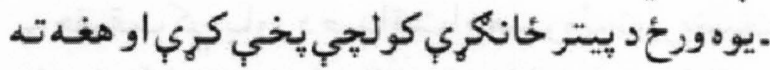

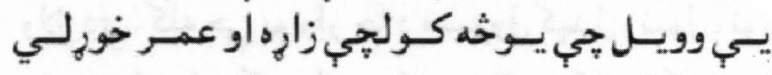

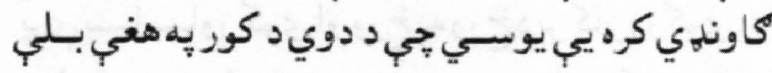

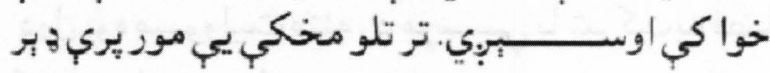

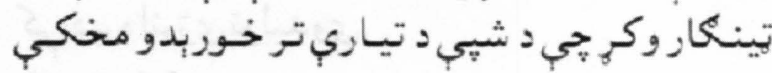

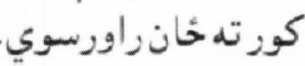

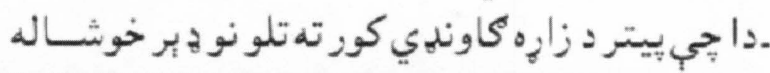




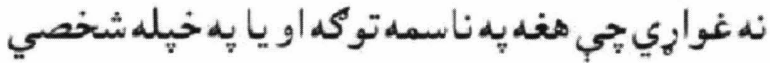

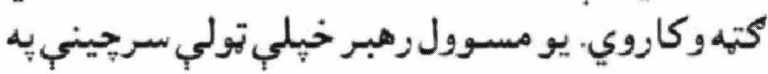
اغيزمنه اوصادقانه توكم كاروي.

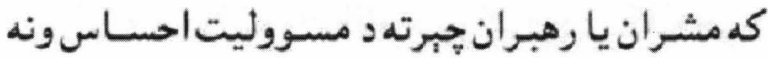

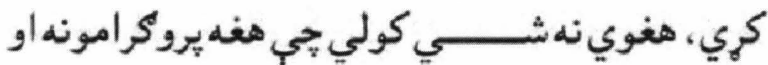

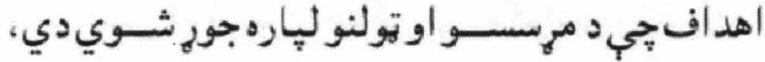

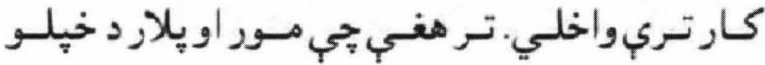

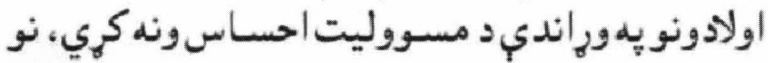

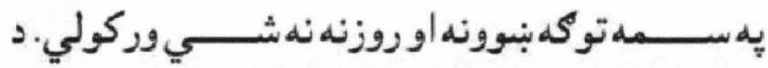

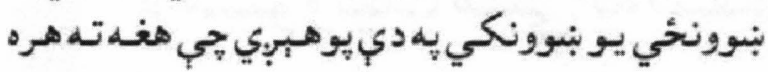

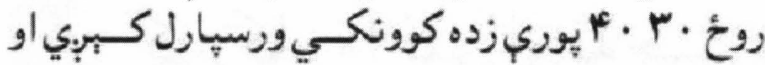

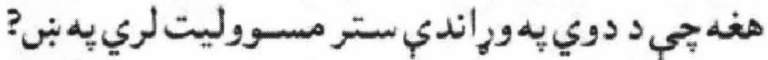

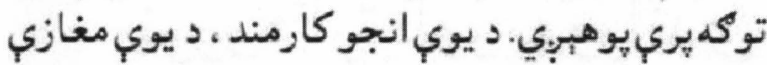

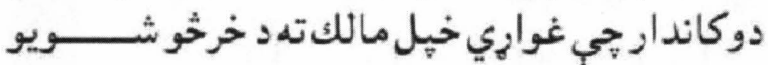

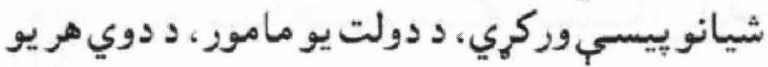

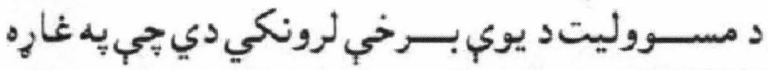

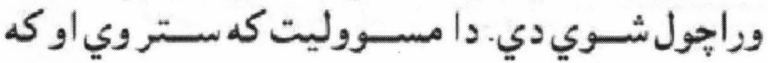

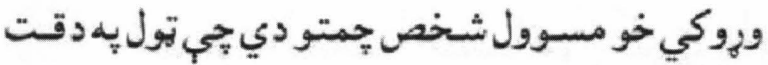

$$
\text { سره ترسره كري. }
$$

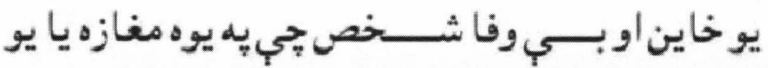

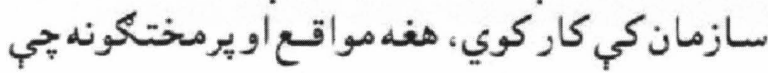
د هغي مرسسي لياره شتون لري له له لاسه وركوي. خاين

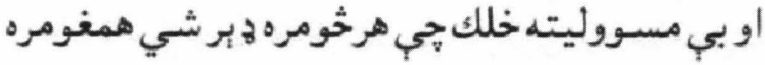

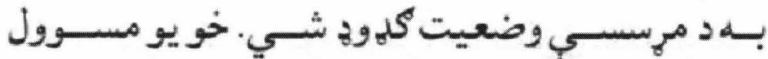

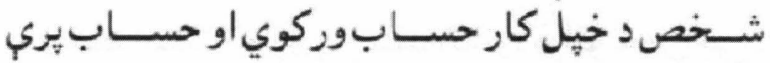

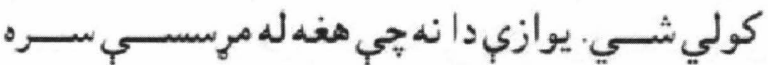

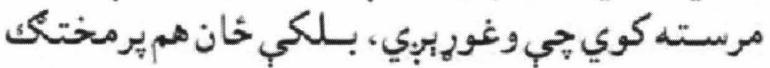

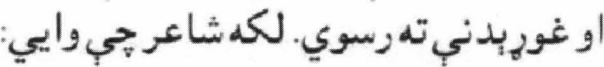

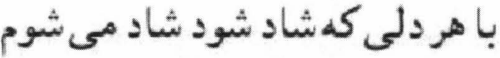

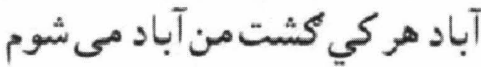

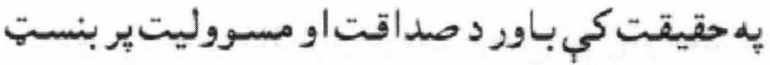

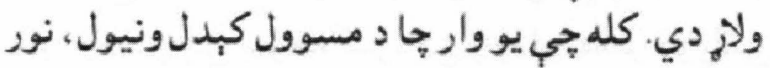

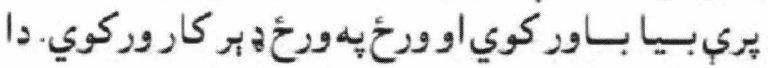

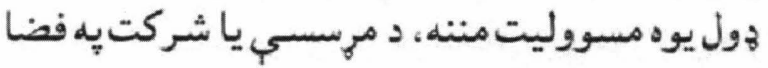

$$
\begin{aligned}
& \text { كي ذا بره انرثي توليدوي. } \\
& \text { (لهنوي }
\end{aligned}
$$

يوهبدو يجي بايد يو كار وكري او دا وروكي سوري بـند

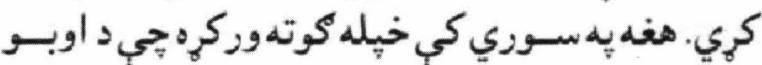

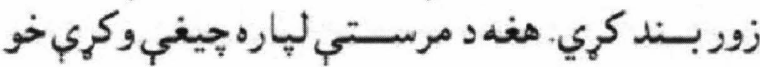

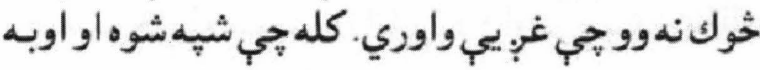

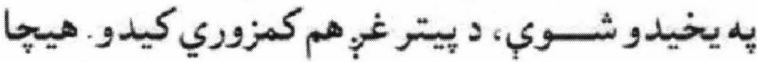

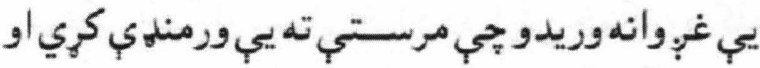

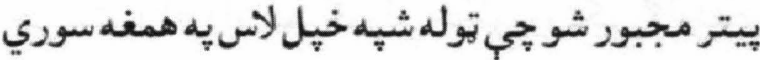
كي وساتي او شيه هملته تبره كري.

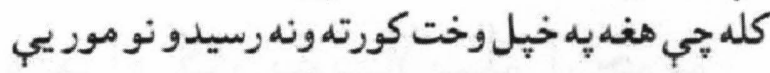

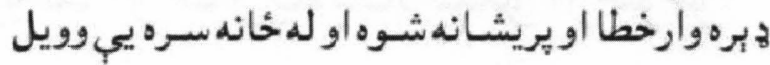

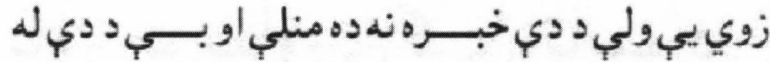

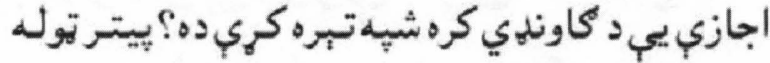

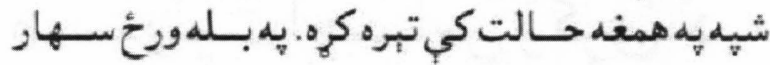

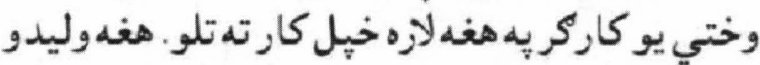

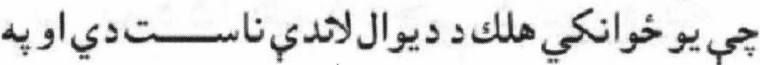

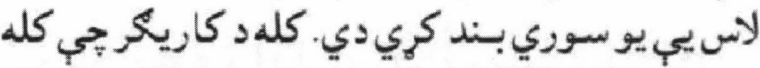

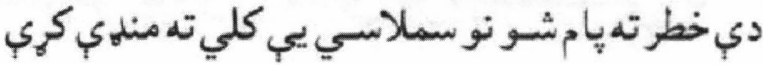

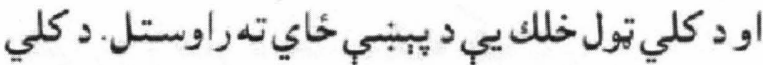

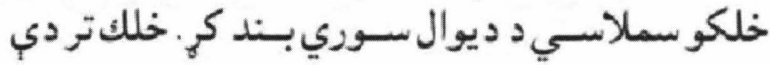

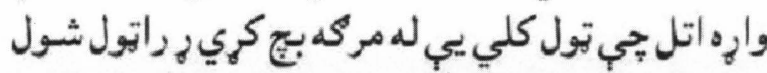
او ود هفه داكار ييب وستايه"

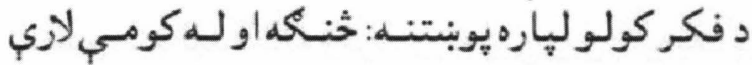

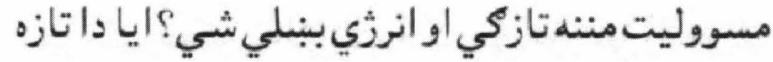

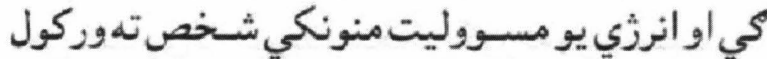
كبربي او كه خلكو ته؟

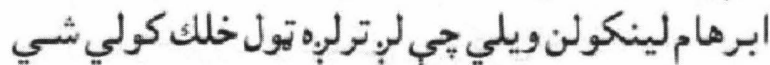

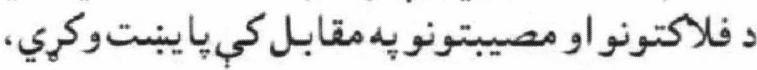

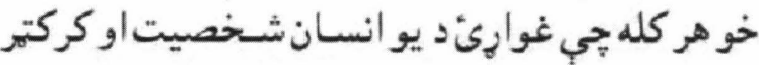
وازما يئنوصلاحيتاو امتياز وزئئئ

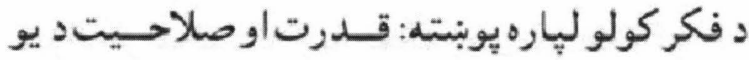

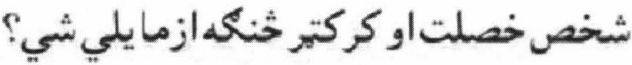

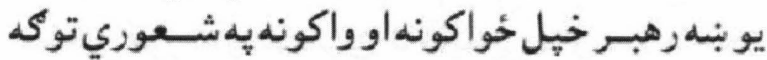

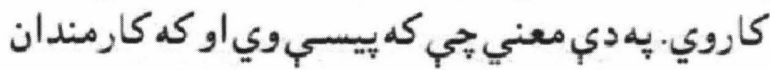

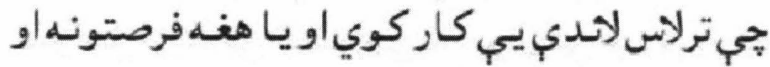

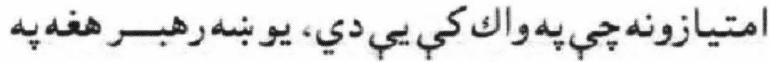

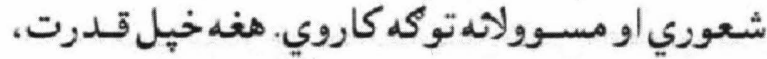

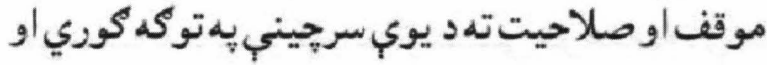




\section{نوشته: ص}

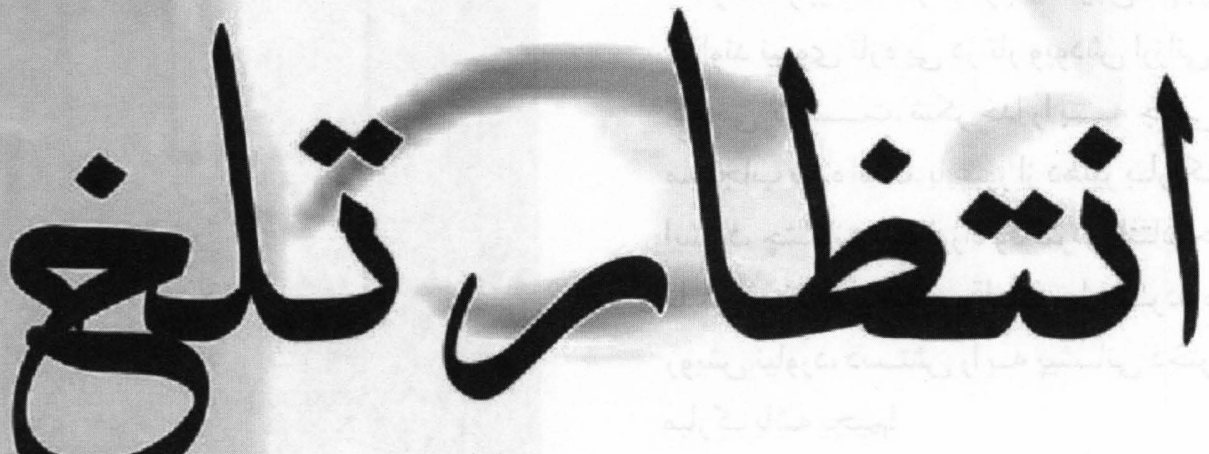

كشيد. آه خدايا!... تو به همه جيز واقفى... همه خيز به دست

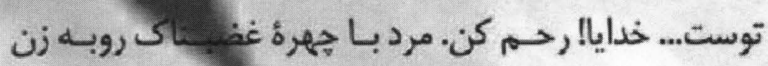

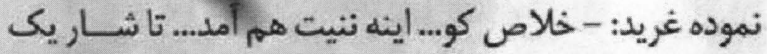

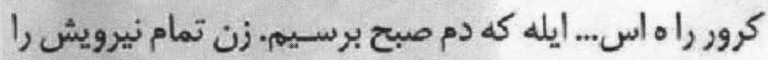

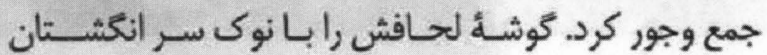

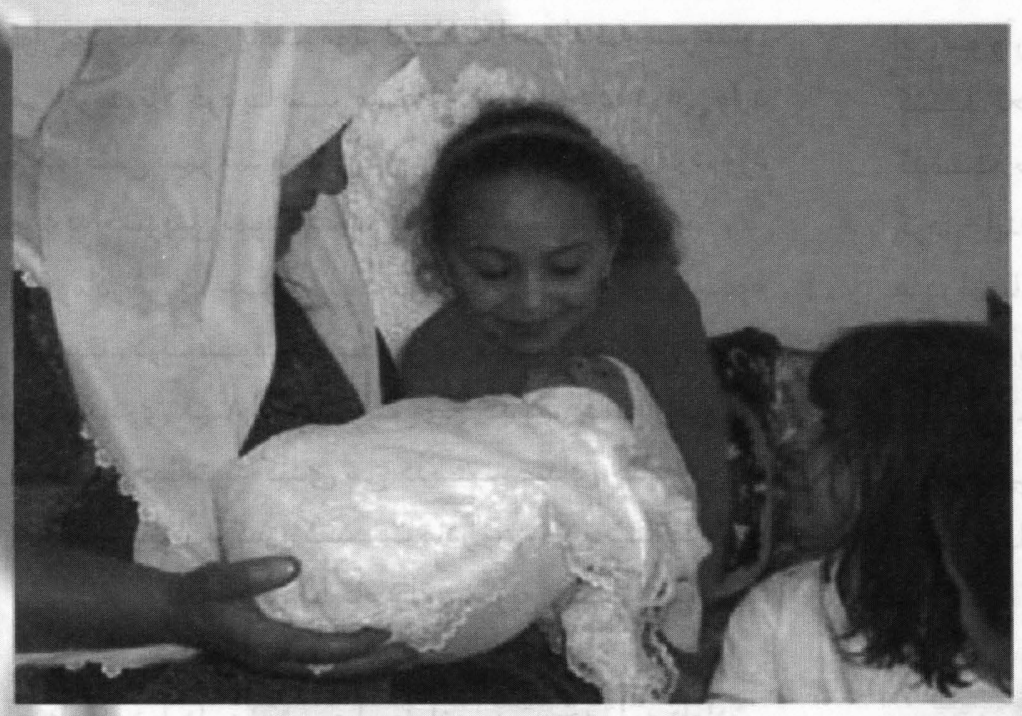

لرزانش يس زد، توان ايستادن از وجودش رفته بود، به كمى

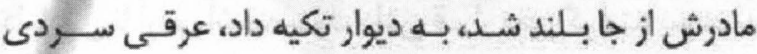
سرورويش راتر ساخت. مرد دوباره بركشت، ديد زنش خيلى

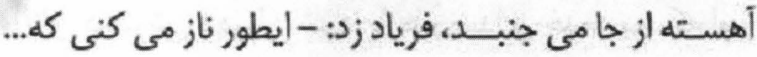

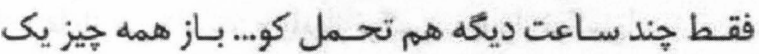

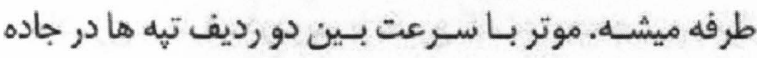

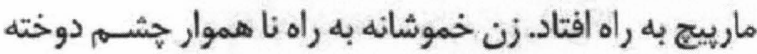

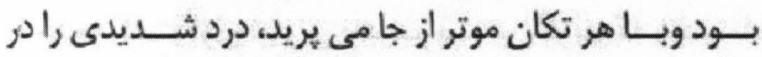

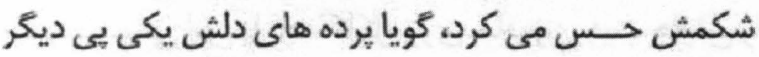

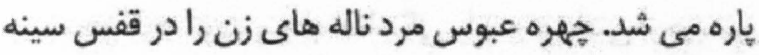

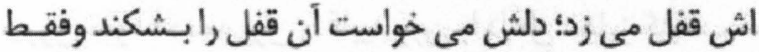

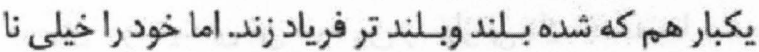

زن از شدت درد زايمان به خود مى بييجيد، اما دردش راقرت

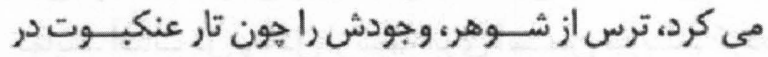

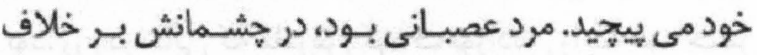

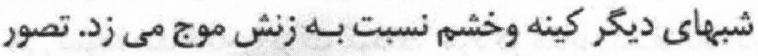

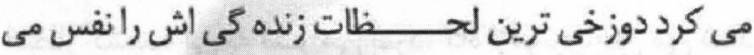

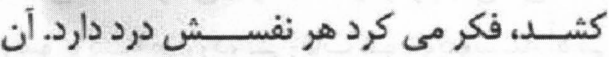

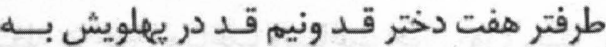
خواب رفته بودند، لحظه به لحظه مرد متشــنج تر

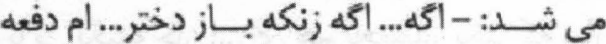
سـرش ره داغ خات كدم... هيرازن ديخّه نكيرحم.... فقط يك كله دختر... لعنت خدا به ائ زن... لعنت

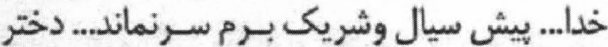

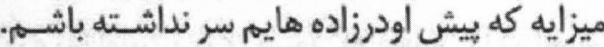

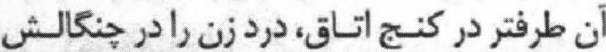

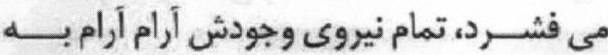

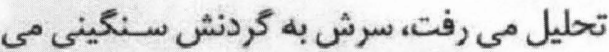

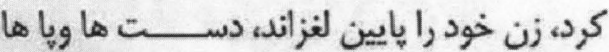

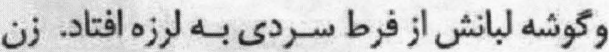

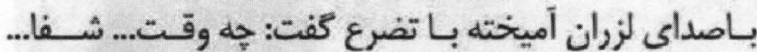

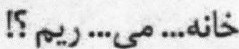
صداي لرزان زن ثهون صاعقه بر تارك مرد اصابـت كرد، مرد

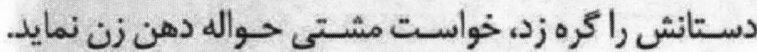

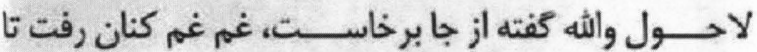

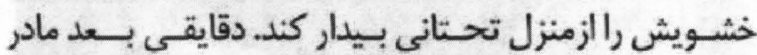

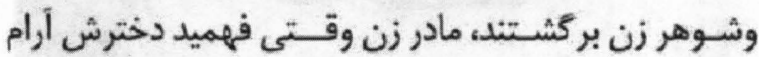

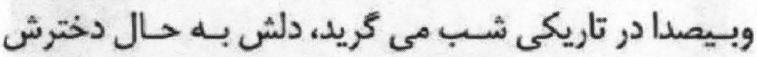

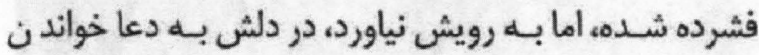

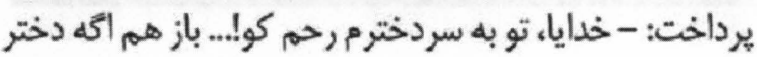
باشه... سـر دخترم كل خاد شـد... مردكه دختر مه از خانه خاد 


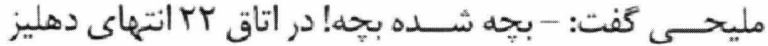

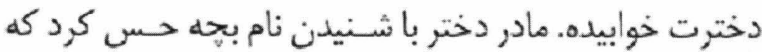

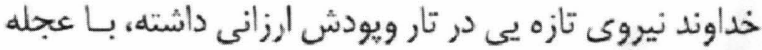

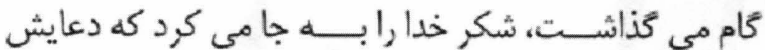

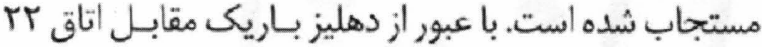

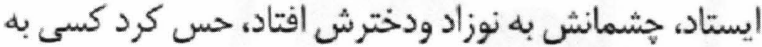

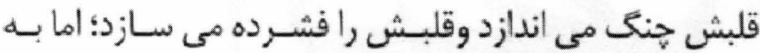

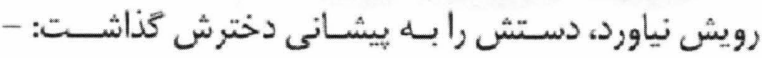

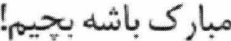

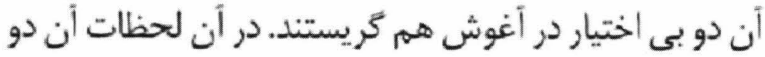

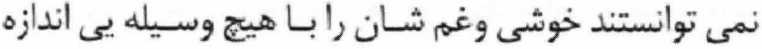

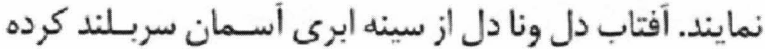

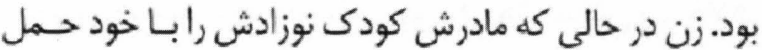
هى نمود، شفاخانه راترى كردند. مرد در مقابل شـفاخانه در

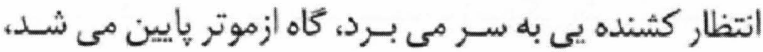

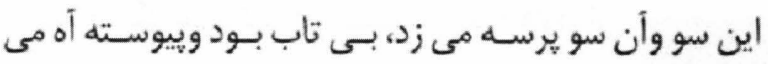

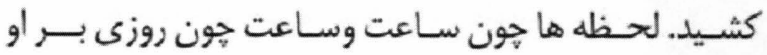
كذشـــ صداى مادر زنش او را از دنياى درونى اش بــيرون

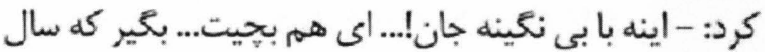

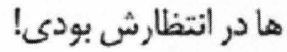

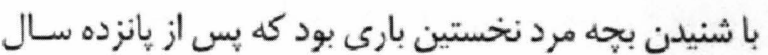

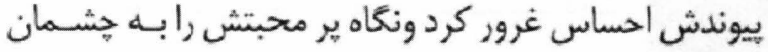

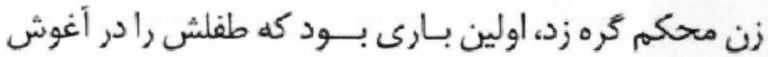
فشرد، ينداشت كمر خميده اش راسـت شــــ اسـت، غافل از

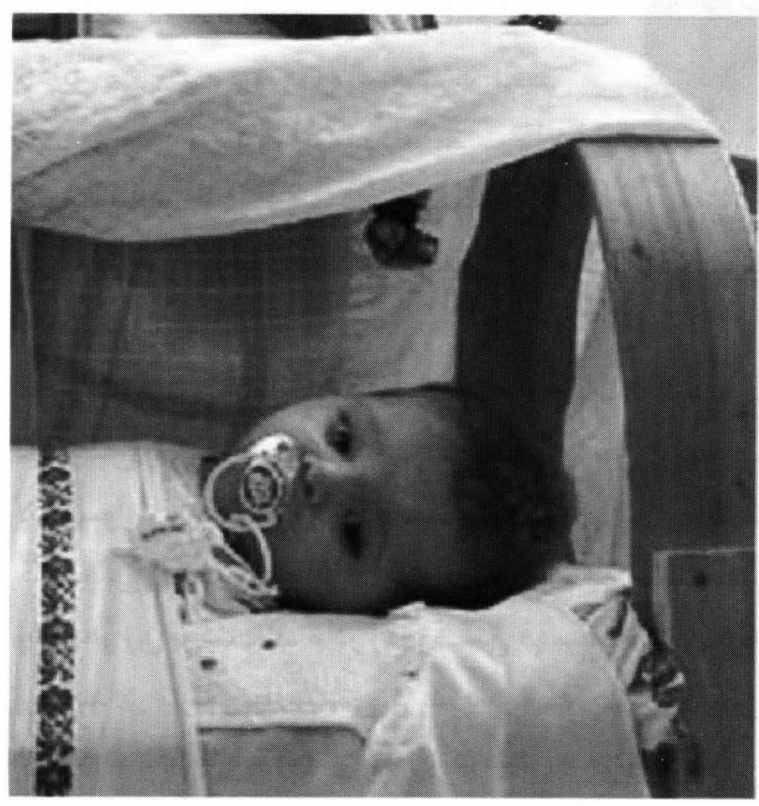

آنكة نوز اد يسر مرده به دنيا آمده بود.

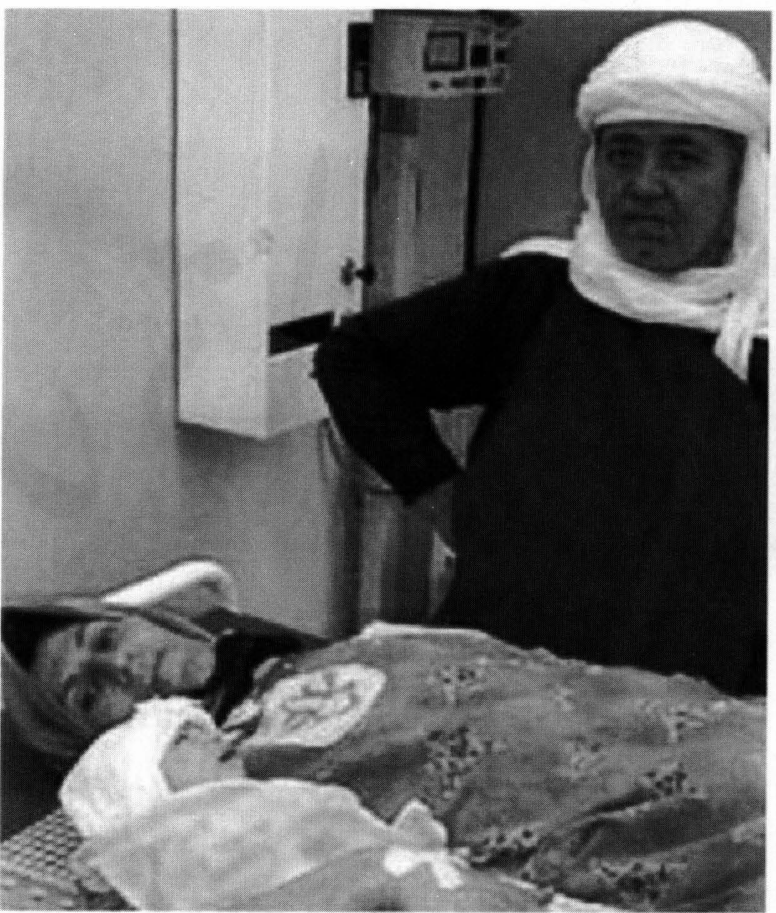

توان ودرمانده مى يافت. موتر لحظه به لحـظه بـه سـرعتش

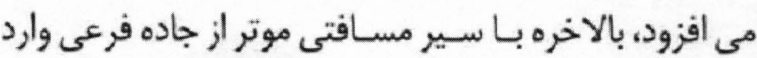

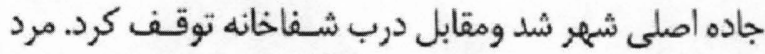
روبه به خشويش نموده كفت: - يايين شويين!

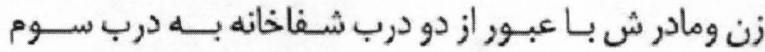

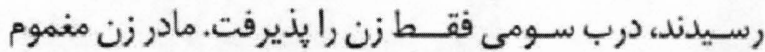

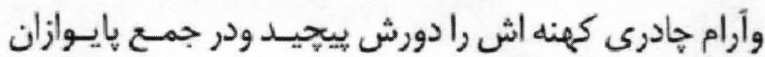
نشست، لحظات به كندى مى كذشـت. صداى خدمه يى كله

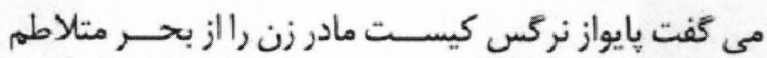

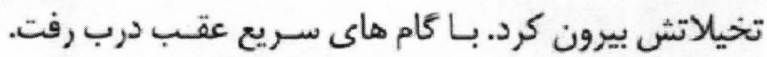

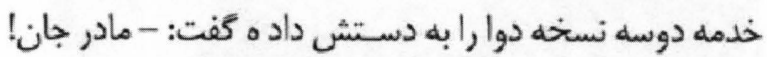

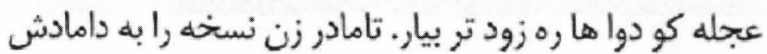

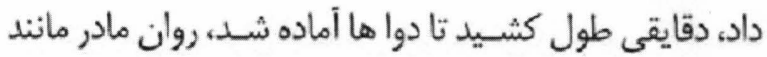

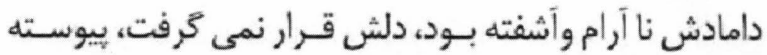

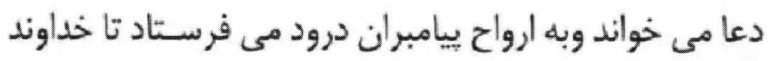

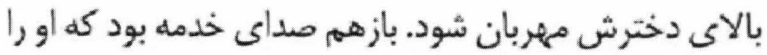

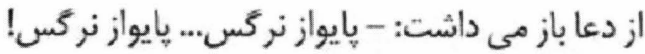
- مادر زن با طرف دردويد، با تضرع كفت: - مه هستم هايواز

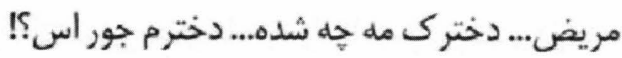

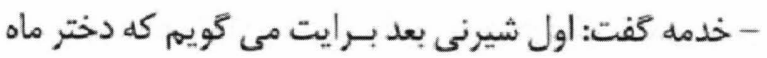

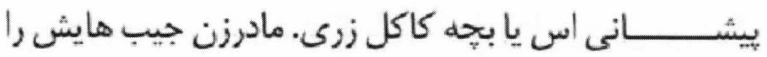

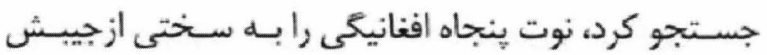

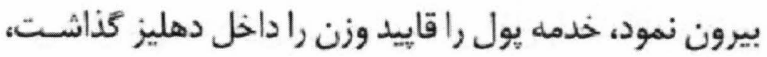
كرماى خوشايندى تن سرد زن را نوازش داد. خدمه بـ بـا خنده 
تجلى ارزش دوحقوق انسان در سياست نامهو

\section{خواجه نظام الملكك}

شـورش و اغتشـاش ولشكر كشـــ و خطر صدمه اغفال و سرگرمى انسان بوده باشـند، ناممكن اسـت كه حكايت در

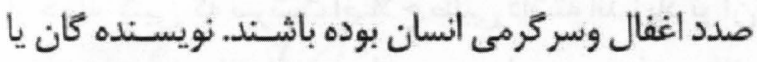

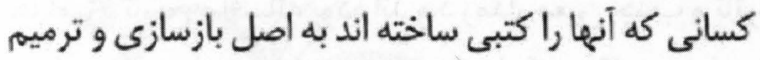
تعمير حيات سعادت مند و قدم كذارى در جريان موافق بـهـ

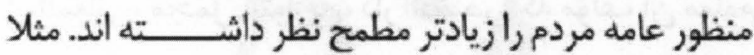

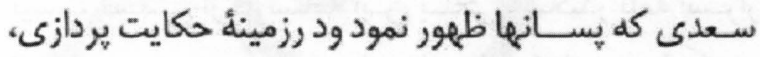
كوى سبقت را ربود، در بسيارى حصص كتاب ار جمند خود

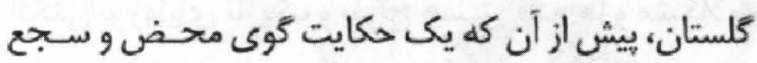

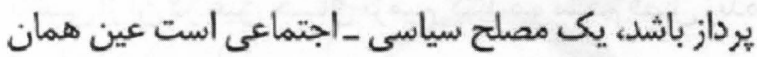

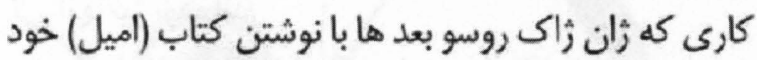
در فرانسه نمود البته (اميل (كتاب حكايت صرف نيست. اما

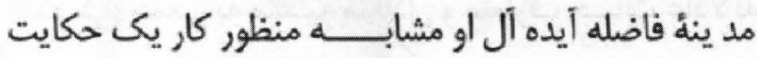
نويس كلاسيك زبان درى است. قطعى اسـت كه حكايات كالاسـيك اديـيات درى هويت كاملاويثره وســـوايى دارند.

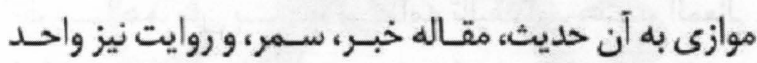

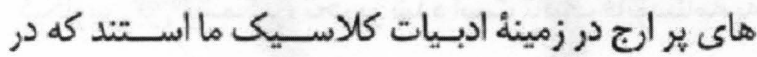

حكايات در جميع انواع منثور و منظوم ادبى بـار مسـووليت

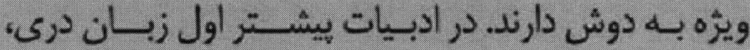
حكايت و قصه هاى انتباهى تاثير هماهنك و يكرو در خيخته

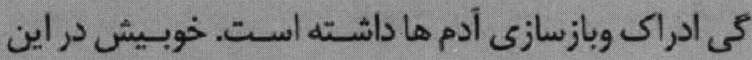

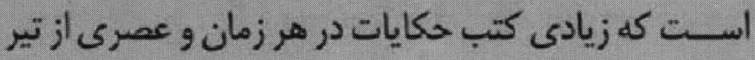
سانسور سوء قصد و اتهام بـهـ دور مانده استـت زيرا حكايات

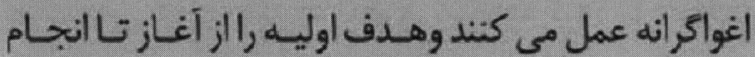
تحت يوششى از صميميت جادويى حفظ مي نمايد. ممكن

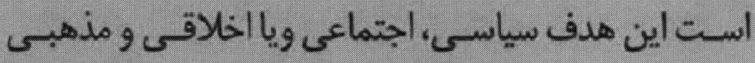

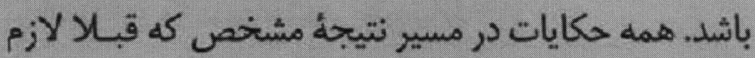

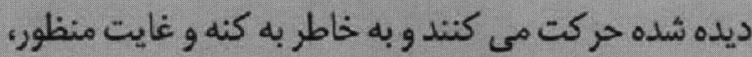

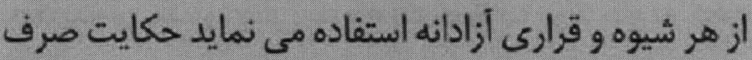
جعل موضوعات تاريخّى نبـــوده ونيز تقــليد صرف اعمال جدى آدم ها نيست بلكه هدف أنها برانكيختن حس احترام به قواتين سازنده و يا فراموش شده حيات بشر است.

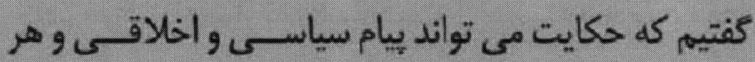

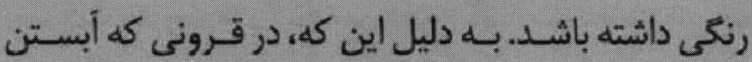


خاطرتربيت بهتر فرزندش برسبيل نصيحست نوشـته شـده

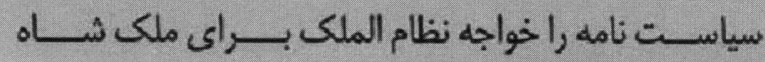
سلجوقى يسر آلٍ ارسلان سلجوقى كه نويسـنده كتاب در نر

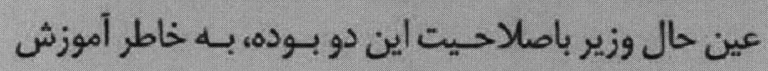

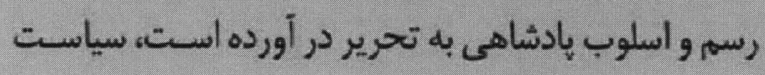

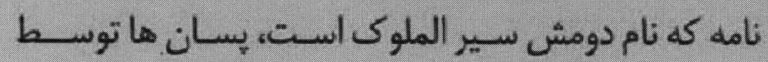

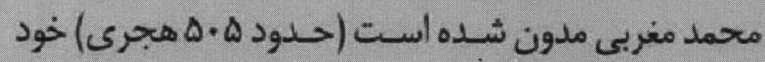

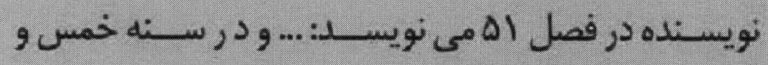

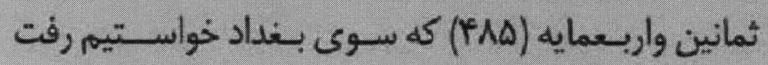

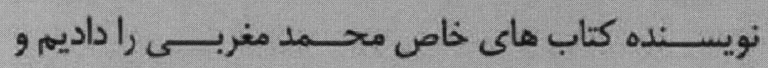

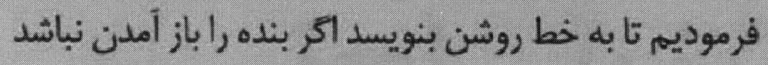

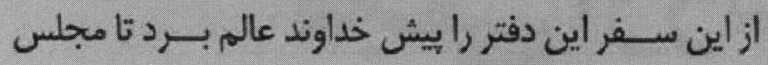
عالى راتنبه افزايد و كوش به خويشتن دارد.....

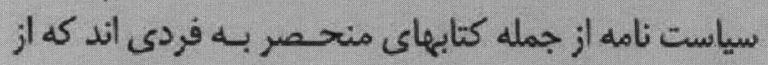
ثثر روان بى تكليف بـهره ور است. اين اثر داراى اله فصل

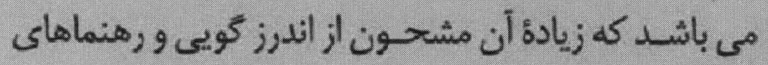
يرمنفتى است كه ضمن حكايات مى آيد. در يك مورد آغاز

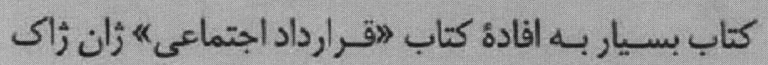

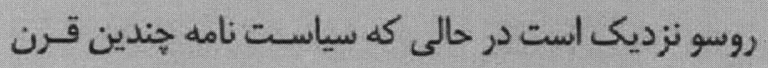

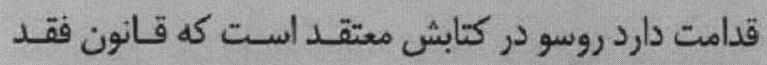

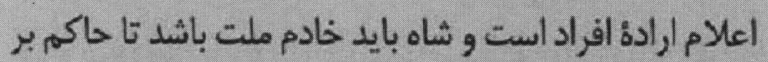

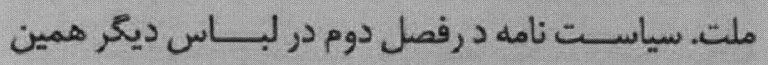

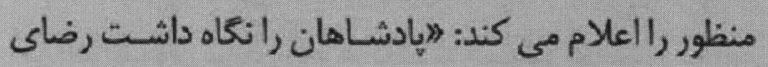
اوست تعالى و شانه و رضاى حق عزاسمه اندر احسـان بـود كاند

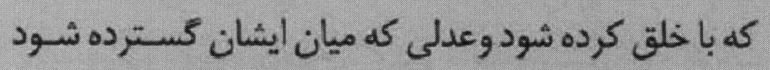

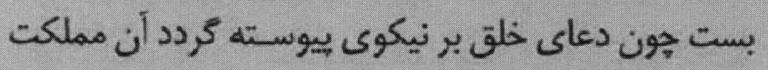

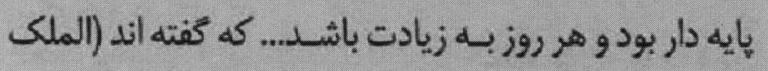

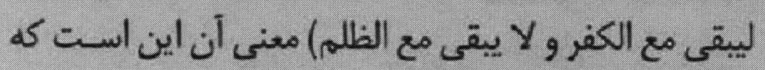

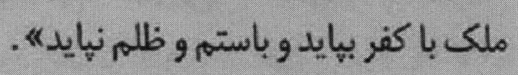

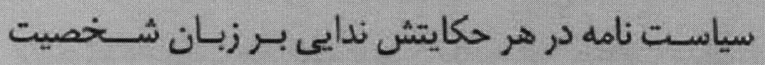

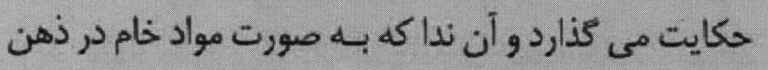

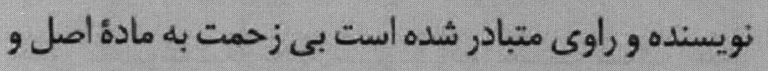

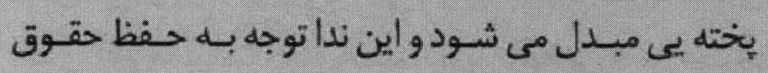

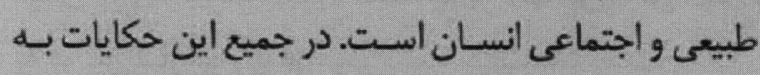

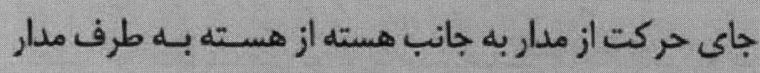

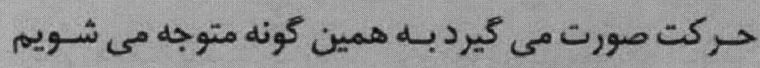

ادبـيات بــيكانه نظير ندارند. تفاوت ها و مشابــهت هاى ساختمانى در رابطه، مضمون وموضوع، هدف و ي ييام و نحوة

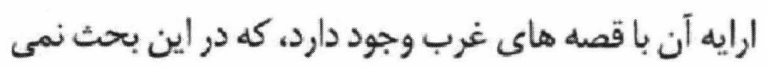

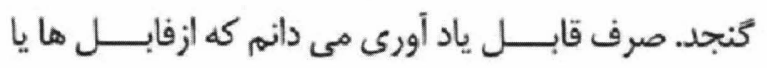
حكايات تمثيلى از زبان حيوانات ايسـوفوس (ايزوب) كرفته

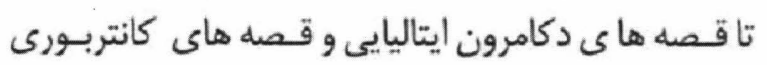

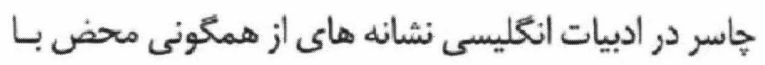
حكايات درى مشاهده نمى شود.

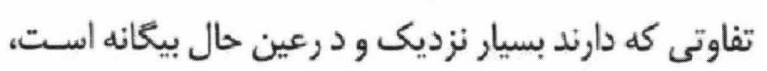
درست مثل تفاوت هار خه هاى ادبـى زبـان درى (prose

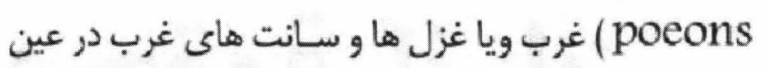

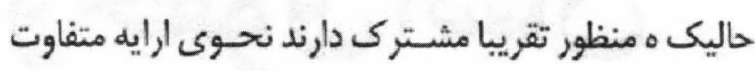
نيز داشته اند. بـارى بـه هر جهت، از زمرة آثارى كه بــــه قــالب حكايت

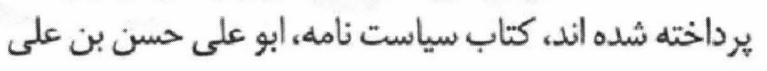

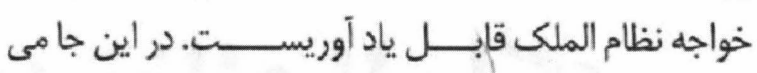

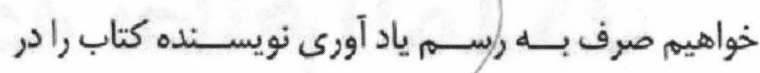
برخورد با جنبه هاي ايمنى براى انسان و قانون و حقـوق در اثر مزبور به صورت شتاب زدمهعرفى جنى نمايم. در آغاز مى خواهمرخاطرنشـان سلهازم كه در تاليفات منثور قرن ينجم هجرى كه سياليت نامه نيز شامل آن مى شود و از جمله كتبي كه سرشم الصلاح طلبى داشته اند زياد تر آن

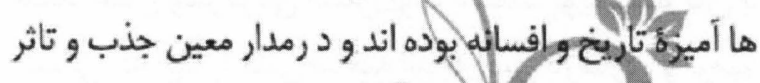

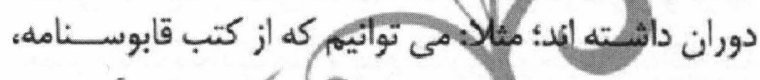
ابوالمعانى، مجمل التواريخ، دار القطصل كه مولف آن معلوم

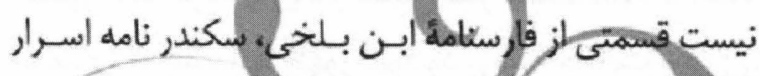

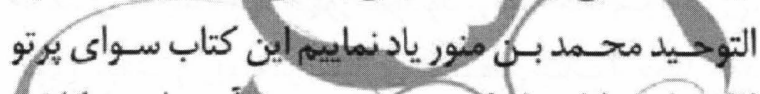

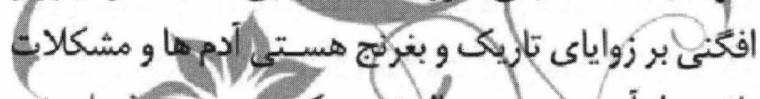

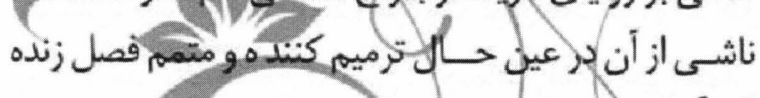

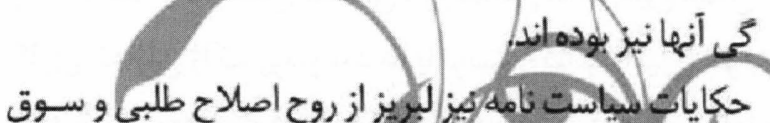
حكايات بياست نامهاهيز لبريز از روح اصلاح طلبى و سـوق زنده كى جمعى به مسـير متعادل و وتعارف جـيات عادلانه سياست كامه در زميئه حكايت كوى منون قـديم فارسـى

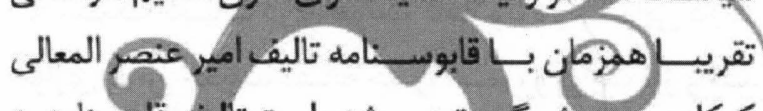
كيكاوس بن وشمكير، تحرير شده است تاليف قابوسنامه به 
أخرى هاى تعصب بـر روش عادى نظام الملى ييشـى مى دى كيرد) روبه رو مى شـويم. در جميع حكايات يك آواى شـور

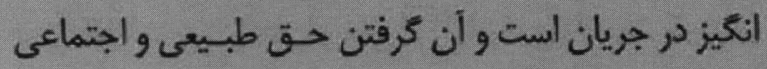

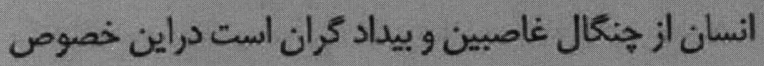

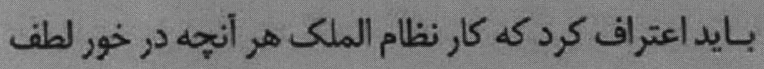

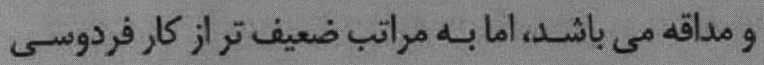

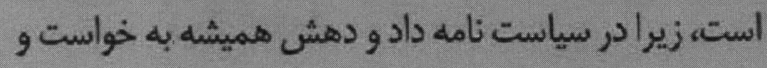

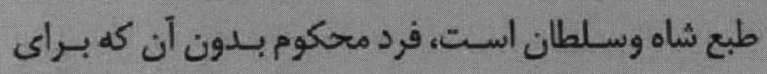

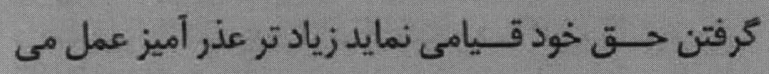

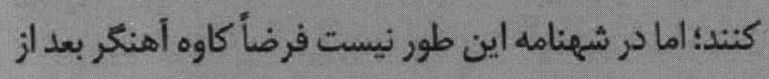

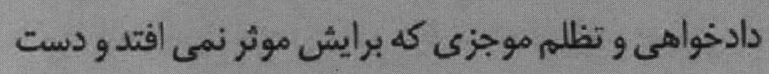

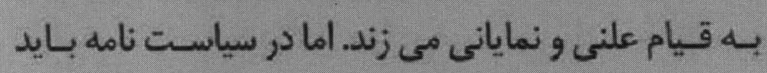
رعيت جشهم وكوش بسته منتظر عدل شاه باشد و اين كونه

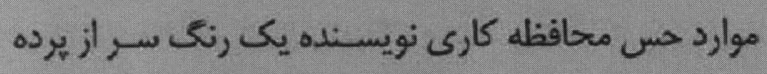
بيرون مى كشد اما خرد حكايات سياست نامه كوشش براف براى تعيين و تثبيت يك معيار عدلى براى أدم هاسـت إين معيار

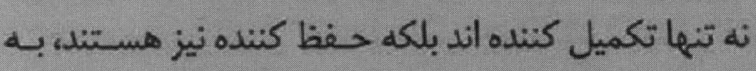

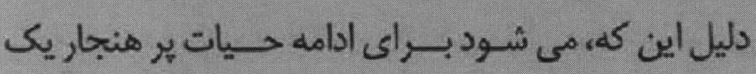

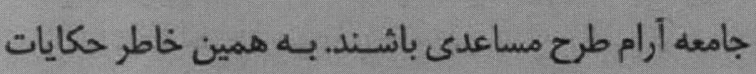

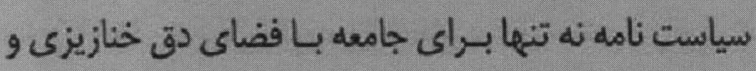

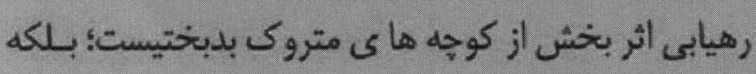

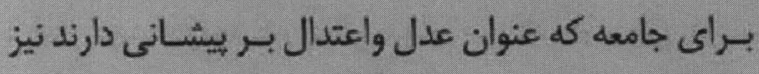
وظيفه حفظ كننده يـى دارد. از جانب ديكر در اكثر حكايات سياست نامه موازي با روش هدف مندانه شيهنامه فردوسىى دردي

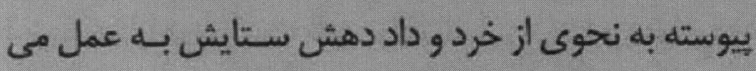
آيد و د رمذمت ظلهم و بى عدالتى صدا بلند مى شـود. در اين

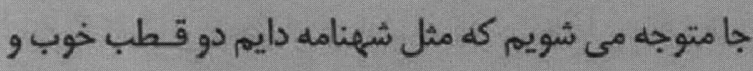

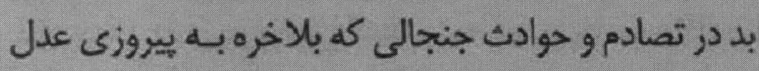

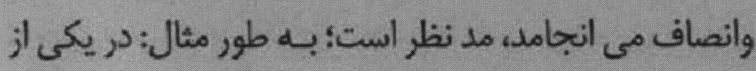
حكايات، وزير بد سكال و بدكردارى كه دور از خشمه بـهرام

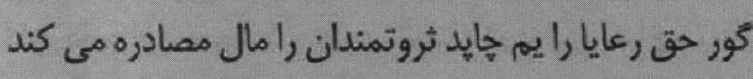

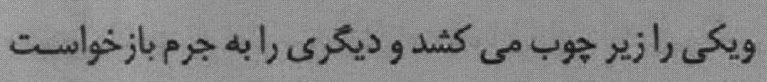

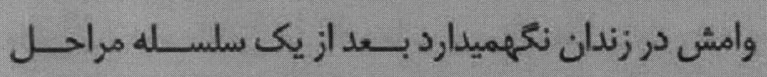
تكوينى حكايات مشتش بيش بعرام كور بـاز مى شـود و ودر

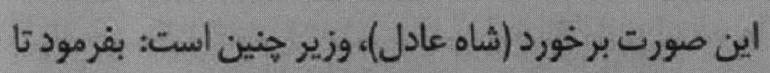

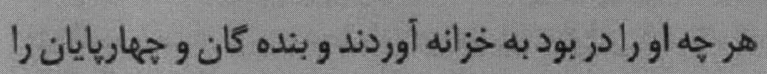

بجاى كنايه سمبول هاى جانبى راساً منظور عالى بـيشش و خواست نويسند ه ييشكش مى شود؛ به نمونه مثال از زبـان

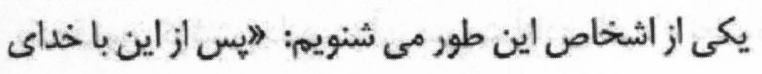

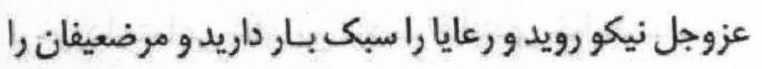
مياز اريد و دانايان راحرمت داريدو بانيكان صحبت كنيد واز رواز رندان بيرهيزيد وخوشكاران رامييازاريده .

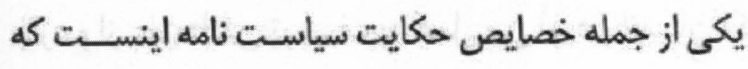

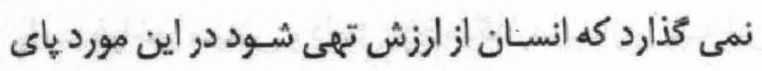

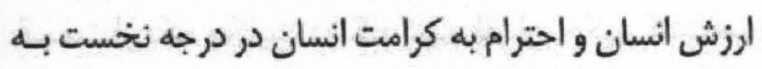

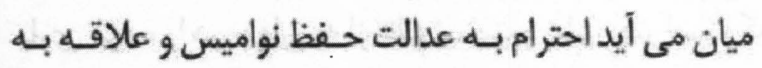
خوشبختى انسان از موارديست كه از لحاظ هدف استخوان

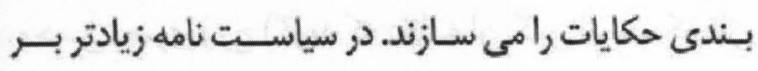
طرز العمل انسـان تاكيد صورت مى كيرد تاهرخش در مدار

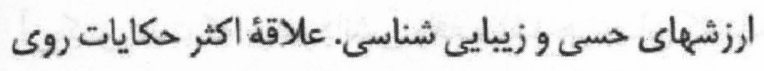

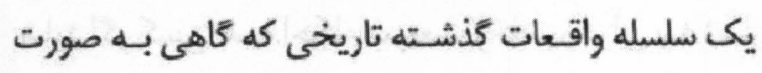

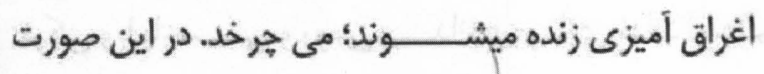

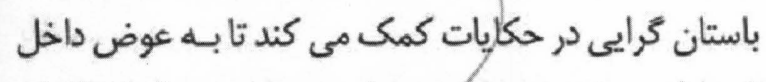
شدن از در عقبى همه هيّيز عريان و در عين حسال اغواكرانه

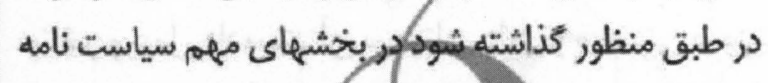

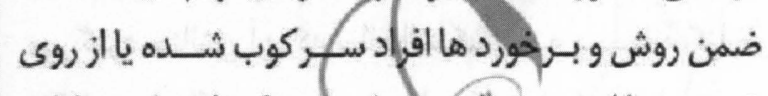

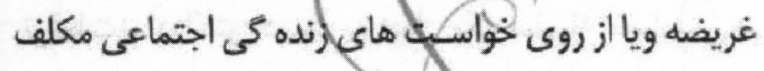

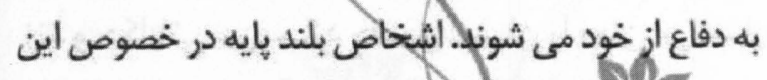

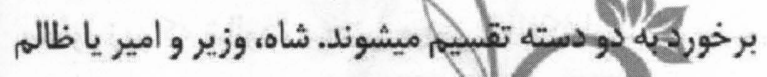

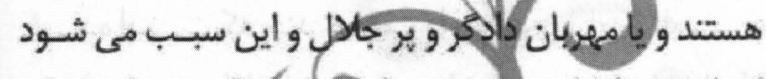

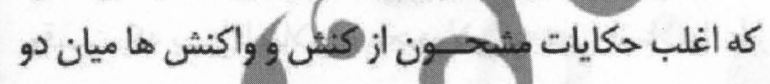

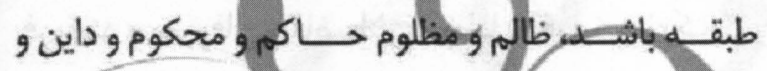

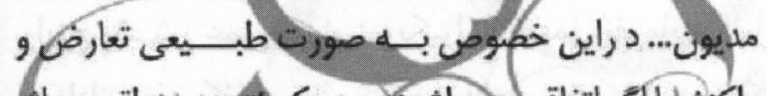

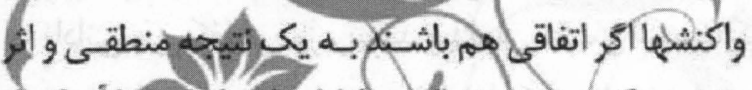

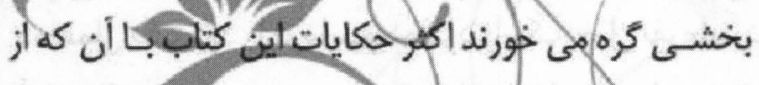
واقعيت تاريخى فاطله دارد اما هر نمونه و شخصيت، خواه

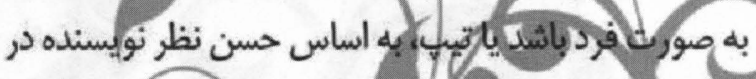

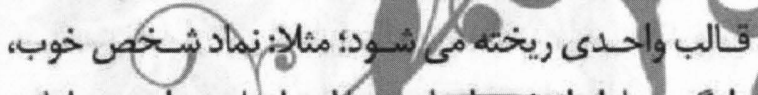

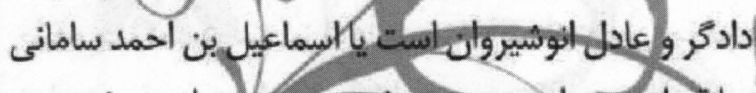

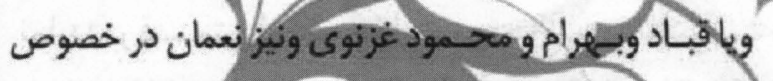

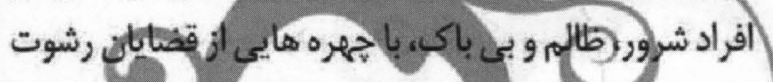
كير، دزدان، مثاه ظالمهم قرمطيان وبا طنيان (كه مر مورد اين

$r \wedge$

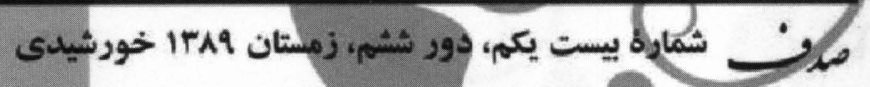


شخص مجبور نشود بر خلاف مقررات قانون عمل نمايد و

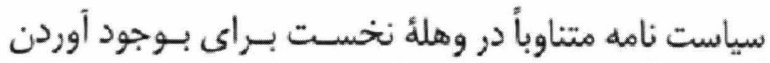

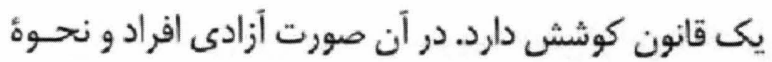
برخورد اجتماعى شان بى درد سر قالبندى خواهد شد.

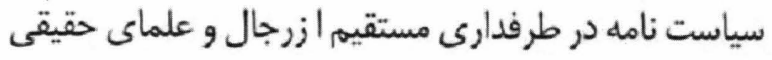

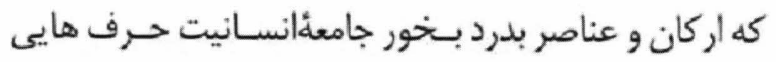
دارد و از علهم دانش توصيف به عمل مى أوردو وانسـان آكاه

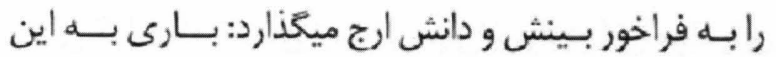
قسمت از يك حكايت درنغ كنيم لقمان حكيم كفت هيج يارى مردم را در جهان به از علم نيست و علهم بهتر است كه

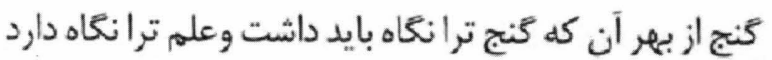

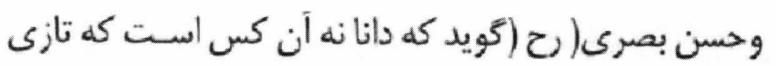
بيشتر دارد [داند] و بر الفاظ لغت عرب بـ قـادر تر باشـــ كه دانا آن كس است كه بر هر دانشى واقف باشد هر زبـان كه داند شايد اتر كسى همه احكام شريعت و تفسير قراً بـ بـه زبـان

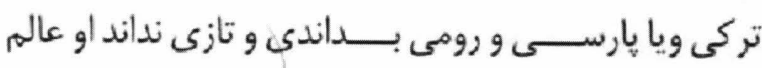

اعتقاد بــر اينسـت كه در منظومه حكاياك سياست نامه اثر

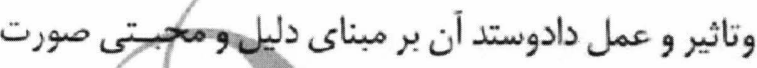

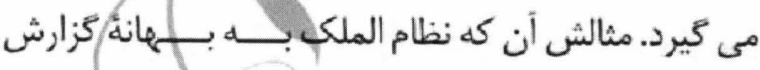

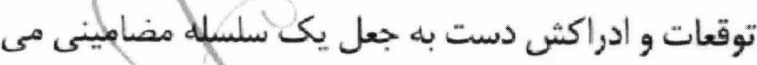

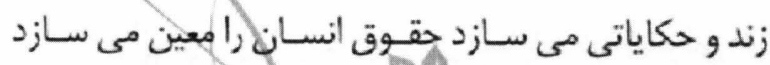

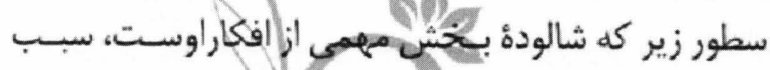

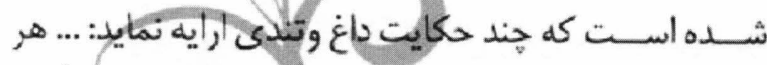
وقـت كه بــى اصلان و مجهولان وبهـ فضلانرا عهل

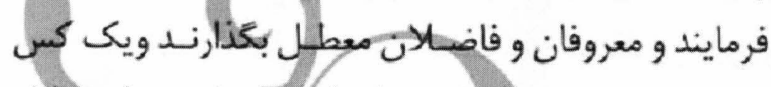

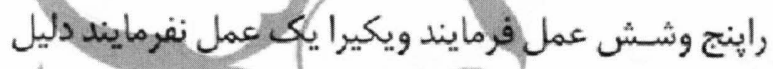

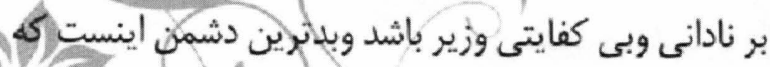

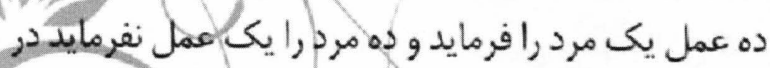

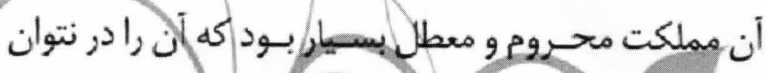
سياست نامه ارزش انسان عالم و هدفمندرامى داند وبراقى

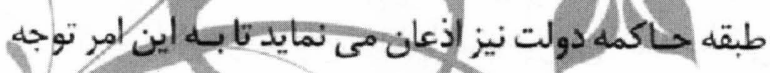
نمايد؛ در قسـمتيلز يك حكايت مى خوانيم: مملكت بـلـ

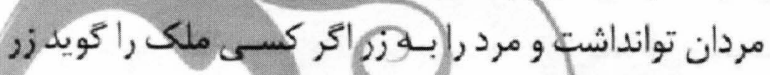

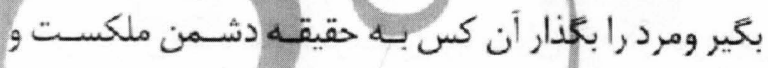

به دست آورداند وهر حهه از مردمان برشوت و ظلمه ستده بود

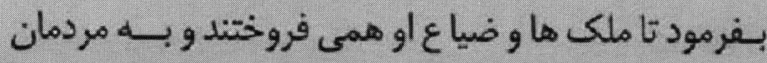

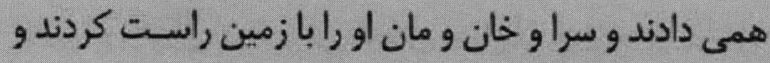

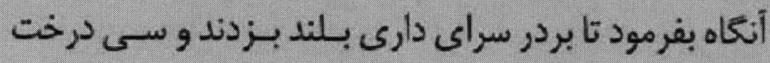
ديخر در ييش آن بزدند نخست راست و روش (لقب وزير) را

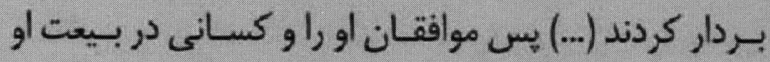

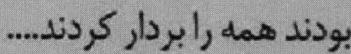

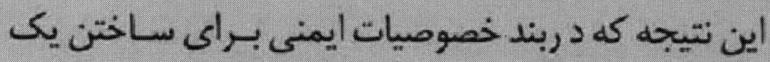

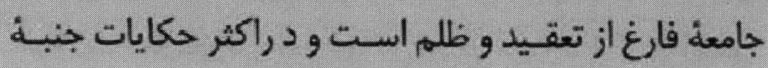
استمرارى دارد، به يك حركت ابتدايى اما جدى د در رساختن

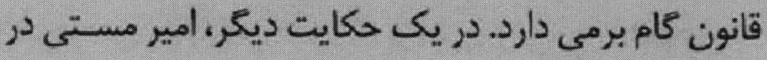

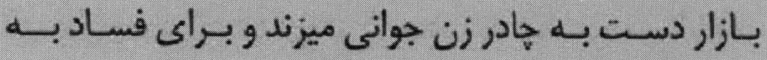

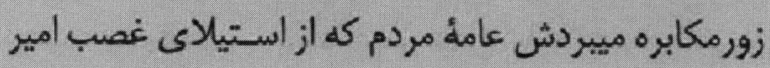

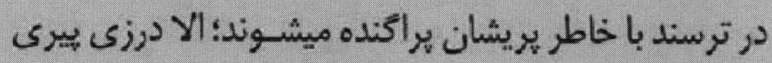

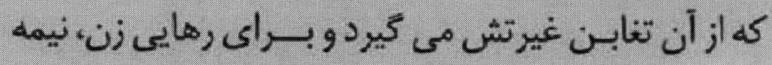

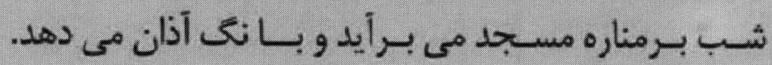

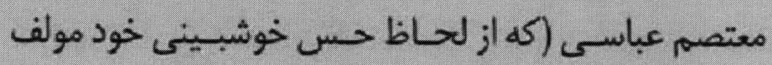

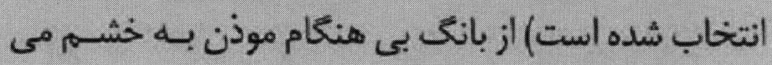

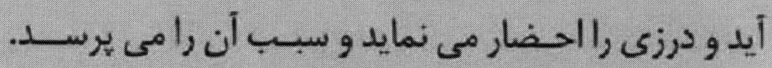

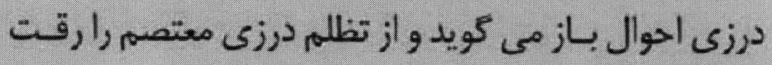
فراكرفته امير راكرفتار وبه سزائ رساند. به اين كونه: فرمود كه جوالى بـياوريد و اورادر جوال كر كردند

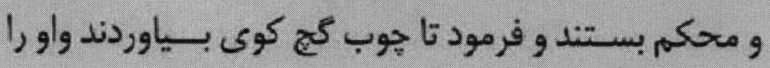

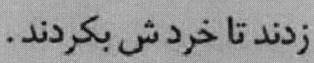
اغلب حكايات سياست نامه براى انسان در برابر مقوله جود برد

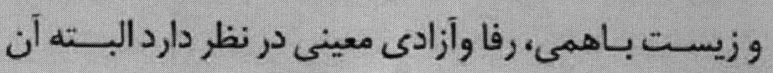

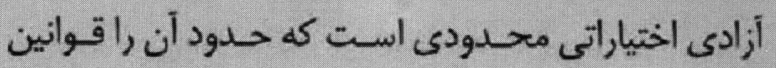

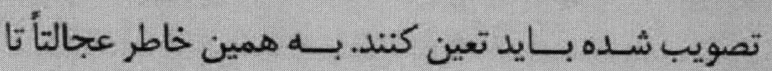

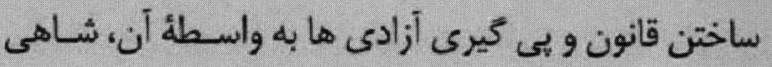

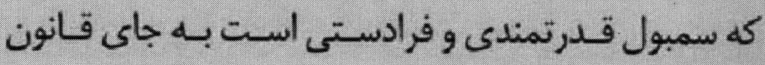

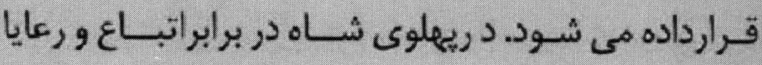

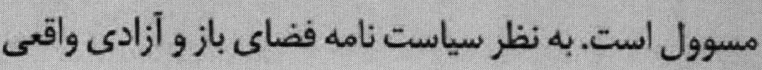

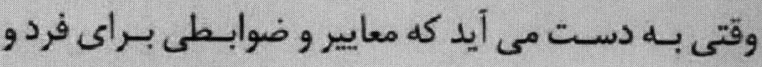

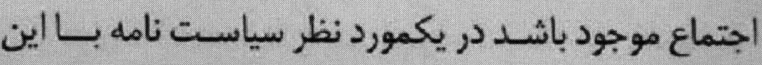

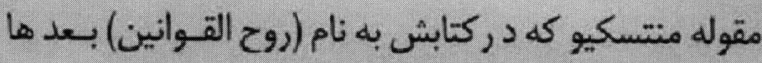
كفته است بسيار شبيه است آزادى عبـارت از اين است كنه 
نيست كله مردم به خاطر ييداكردن ياره نانى دست بـه انواع

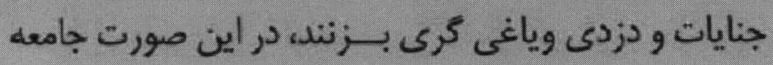
يى كه تشكيل ميشود، ناقص، ابتر و مسدود است سياست برتس

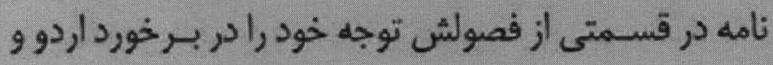
لشكر كه نظام مسلط به كشور را حمايه مي نمايد ويا اتبـاع

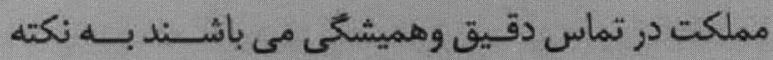

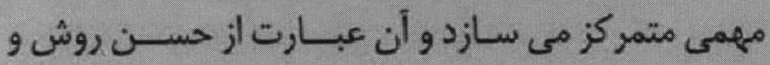
رحمت و احتياط بامر دم مى باشد. جون ملكى، بادشاه يا ميامير

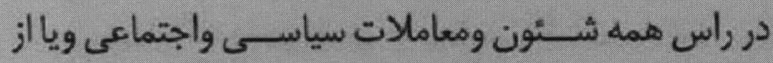

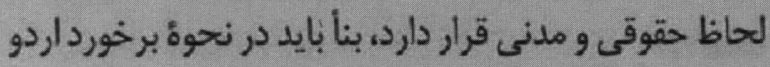

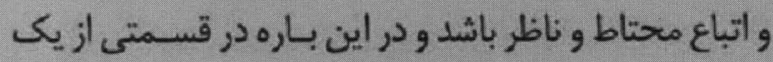

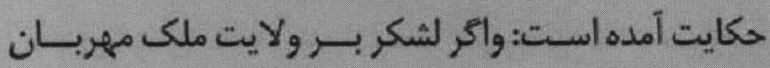

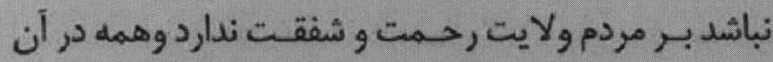

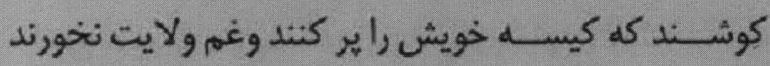

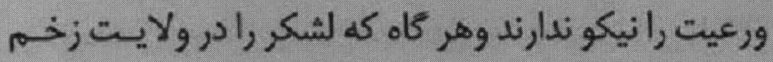
وبــند وزندان وغضب وخيانت و عزل و و توليت كند آنغاه جهاه فرقى باشد ميان ملى ولشكر كه هميشـــ كار ملوكى بـوديه

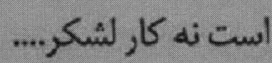
به اين ترتيب حدود و ثغورى كه بعد اين سـطور در حكايت

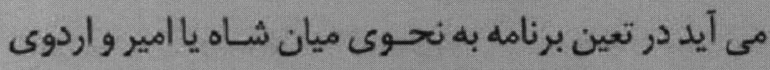

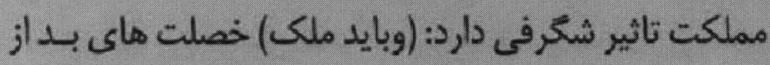
خويش دور كند و خصلت هاى نيك رابكيرد و خصلتهاى بلد اين است حقد و حسد و كبر و غضب وشـهـوت و وحـرص

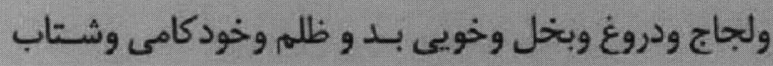

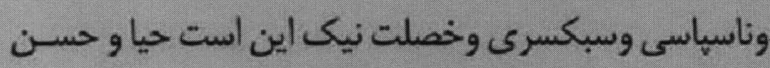
خلق وحلم و عفو و تواضع و سـخاوت و صدق و صبـر شكر

$$
\text { ورحمت وعلم عقل عدل و.... }
$$

در فصل ششم كتاب كه (اندرقاضيان و خطيبان و محتسب ورونق كار ايشان) عنوان دارد به اين سـه قشــر كه مدام بـا مردم در تماس اند طرز العمل مشخصى روات راتوصيه مى نمايد.

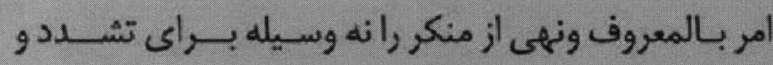
فرونشناندن آتش غضب محتسبين و قاضيان بـلكه مجرى

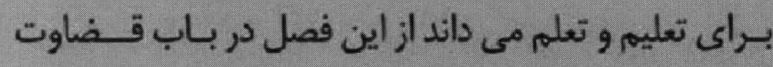

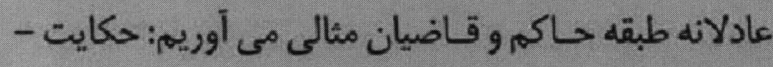

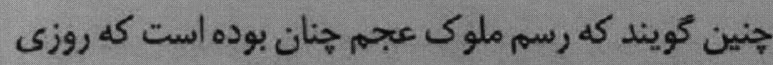

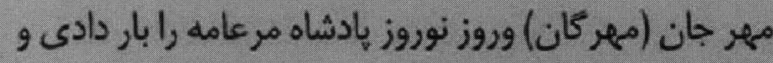

شروشور مى طلبد كه زرهم أزمرد بــه دســ آيد سـخن آن

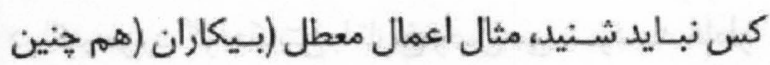

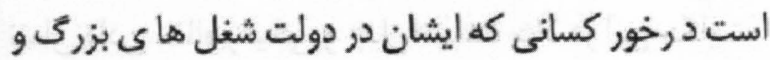

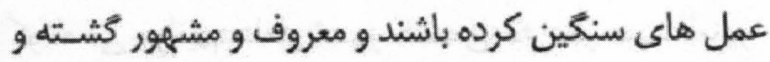

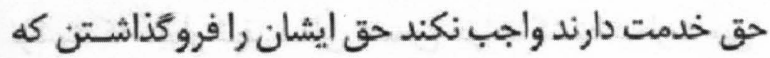
نه مصلحت بود و مروت واجب كند ايشـان را عمل فرمايند

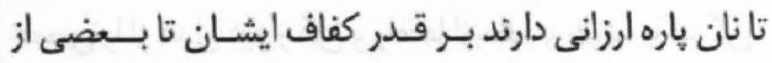
قضاى حقوق ايشان و بعضى از دولت بى نصيب نباشند....

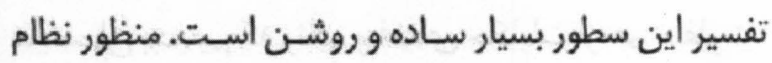

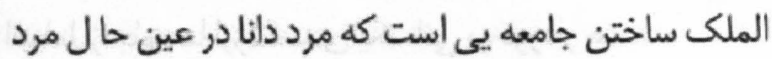

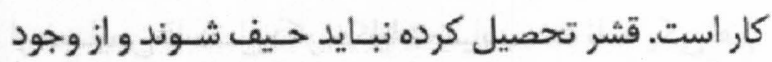

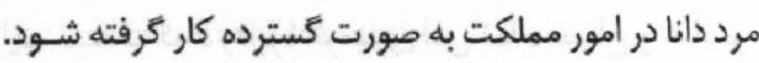

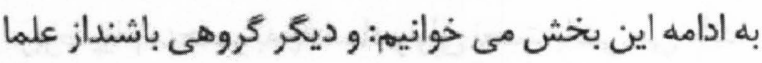
و فضلا و از دنياى مروت با حفظ و اصل شرف كه ايشـان را در بـيت المال نصيب بـود و مستحقــــ نظر وادرار [وظيَفه مقررى ماهانه و سالانه] باشند نه كسى ايشانرا شغل فرمايد مايد

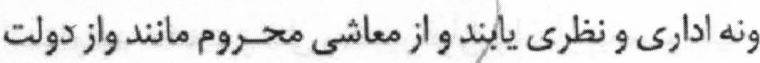

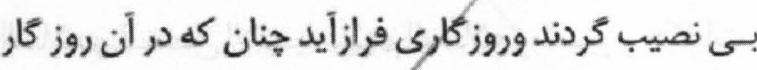
ييش كاران يادشاه بي خبروكي توقيف باشند كه احـوال اين

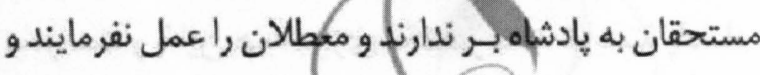

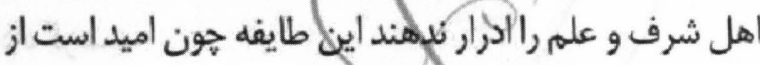

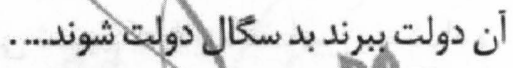

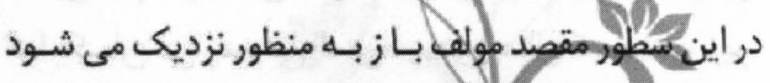

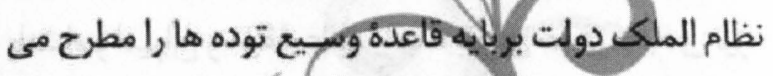

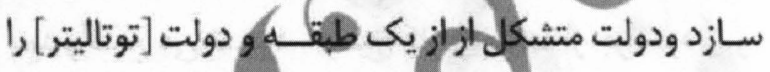
مردود مي شمارد. وى همهينان عصبـيت و ناهنجارى رادر يك مملكت را به مكحروميت عامه ـ مردمى نسبت مى مهد

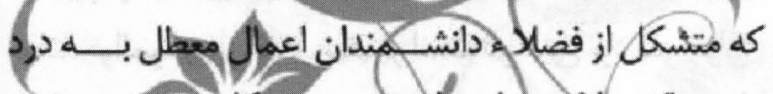

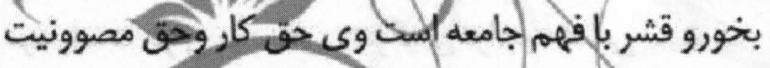

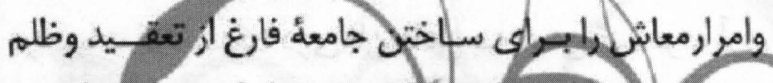

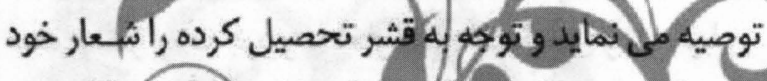

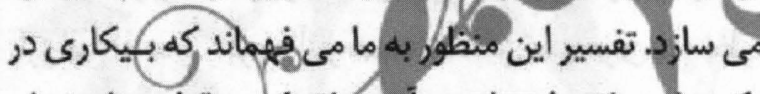
يك جامعه فقروابه بارمى أوردوفوقر كه به قول برناردشـاو

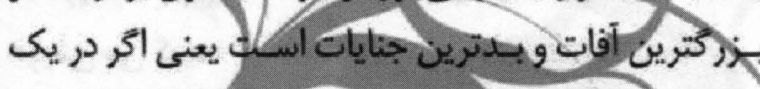

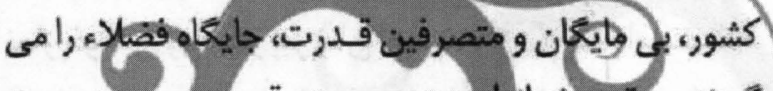
كيرند وحقوق شـانرا بـاه زور و سـتم قـورت تميدهند، بـعيد 


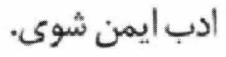
در اكثر موارد اكر حكايتى با تاريخ وصل مى شـود بـه خاطر

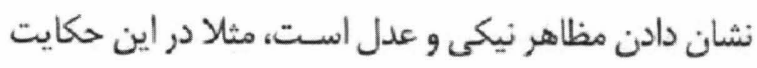

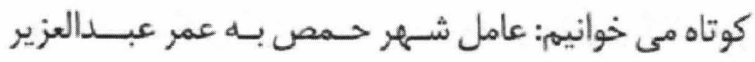

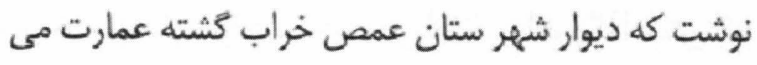

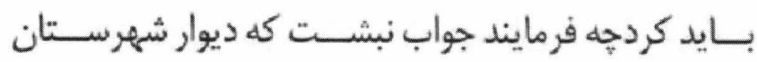
حمص را از عدل ديوار كن و راه ها از ظلهم و خوف بإك كن ئن كه حاجت به كل وخشت و سنك و كج....... بدينسـان ببـينيم كه رنك و فضاى حكايات از هم متفاوت اند اما از جلوه ها ارزشمندى يكسانى برخور دار هستند. بندي

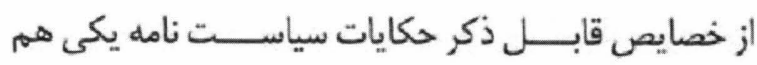

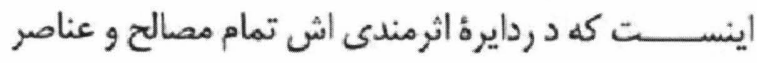
مربوط يِيام منحصر به يادشـاه و ولى نعمت باقـى مى ماند. فضاى حكايت رو به فراخى ميرود و د رموارد مختلف شاخه

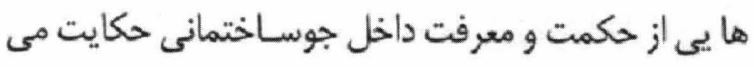
شود خود مولف در آخر كتاب مى نويسد: اين كتاب همر دين است وهم حكمت و مثل وتفسير قر آن و اخبار ييغمبـر عليه السلام و قـصص الانبـيا عليهم السـلام ومسـير و حكايات

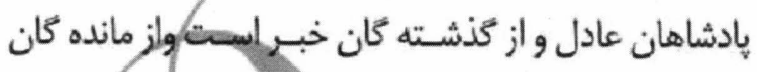
سمر ست و با اين همه درازى مختصر است ثايستئم يادشاه

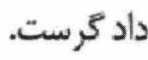
به اين نحو متوجه مى شـويم كه فايده مضامين بـه شـاه و

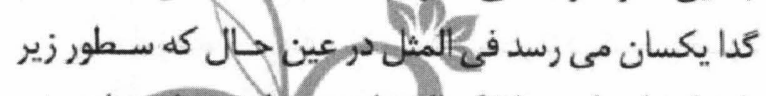
يادشاه و اميران و طبقة عاليه راست بـ إع هر فردمادى نيز

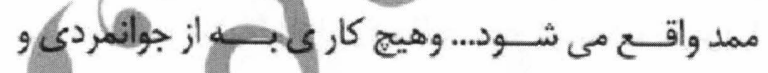

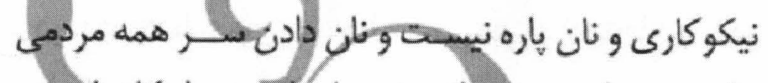

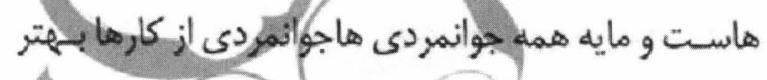

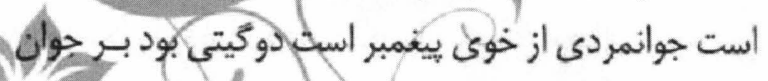

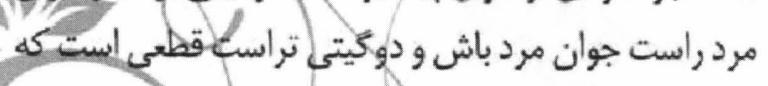

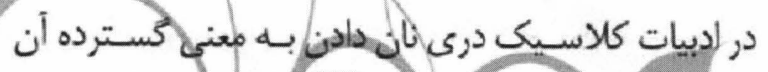

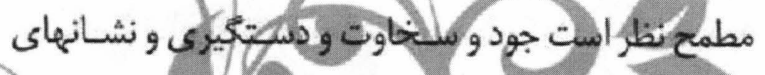

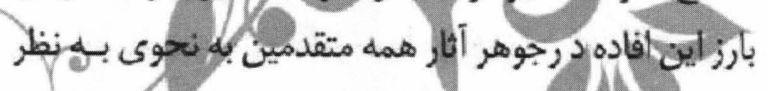

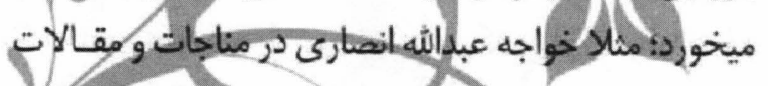
خويش مى كويد:

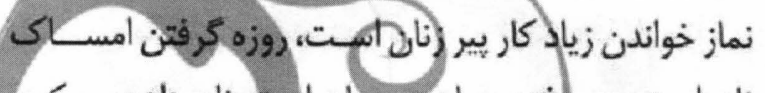
نان است، حج رفتن سياحت جهان است، نان دادن مسكين
كس را بازداشت نيودى و ييش بـه هند روزمنادى فرمودى

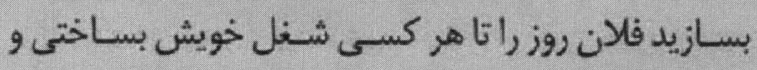

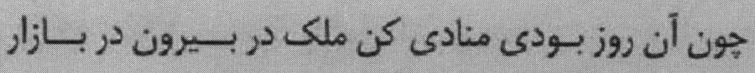

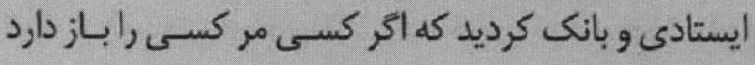

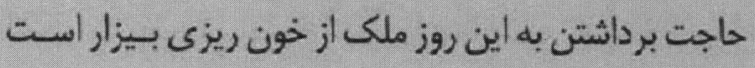

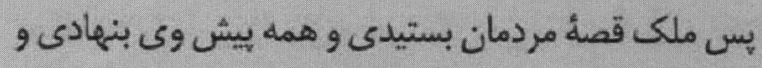

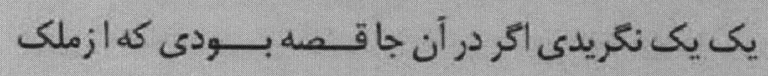

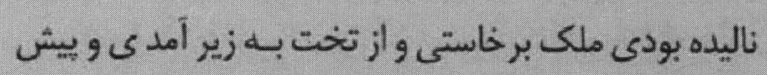

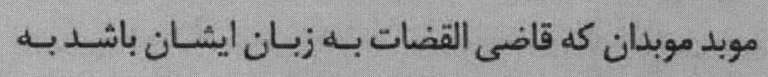

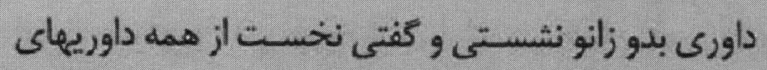

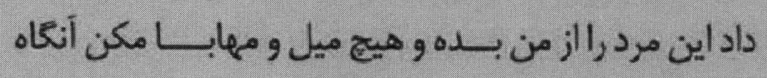
منادى كردى كه هر كه را باملى خصومتى اسـت همله بــه

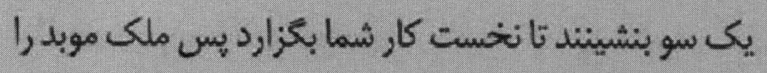

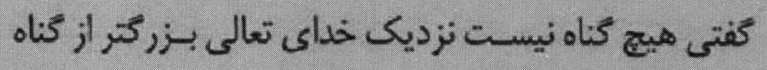

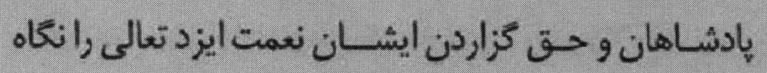

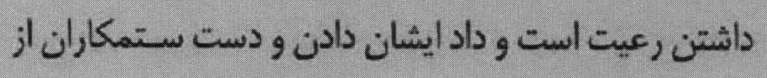

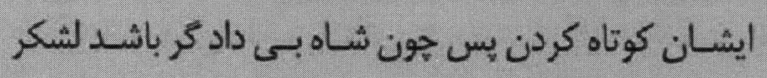

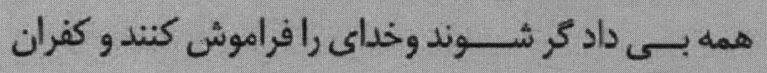

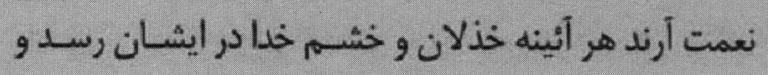

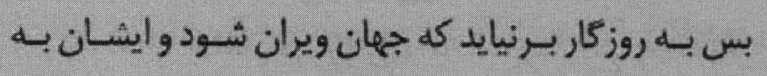

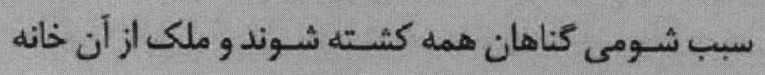

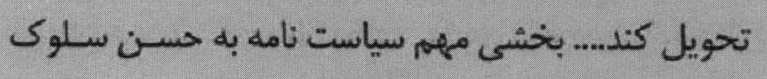
حلم و برده بارى و كظم غيظ اختصاص داده شده است.

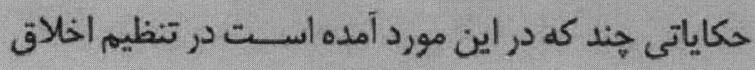
انسانى دوران متعارف مفيد واقع مى شود.

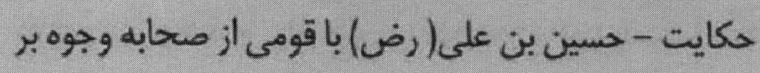
خوان نشسته بودند و نان مى خوردند حسين جامه كر انمايه

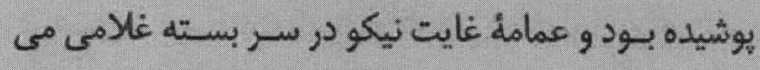
خواست كه خوردنى در بيش او نهد از بالاى سر او ايسـادهاه

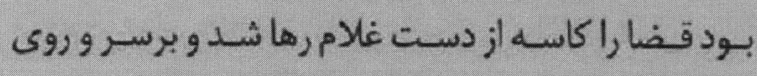

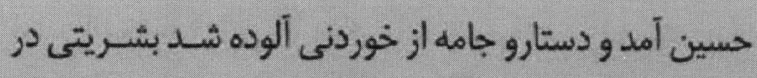

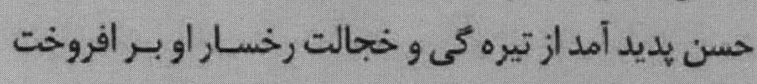

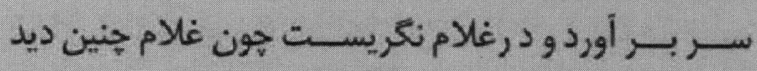
بترسيد كه او را ادب فرمايد كفت الكاظمين الغيظ و العافين

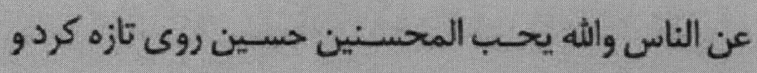
كفت اي غلام تو را آزاد كرده ام تابـه يكبـاركى از خشـهم 
كرد وافشين به حرب بابك لشكر بردانشت وروى بـه حـرب

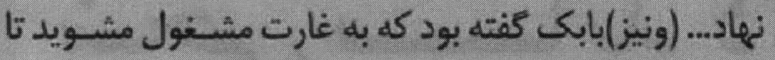
يك بـاره كى دل از افثـين ولشكر او فارغ كنيه (وبـاخلاخره

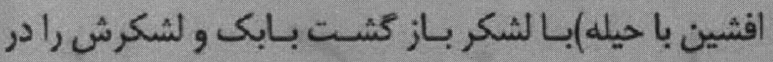
ميان كرفتند وهر جند كوشيدند بـابك راه نيافت كه بكريزد بـاني افشين در رسيد واو رابكرفت وتا شـب ميتاخت وميكشت.

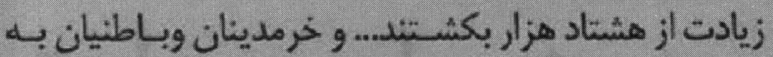
يكديكر نزديك باشند... واين ملحدان خويشتن بـه محبـت

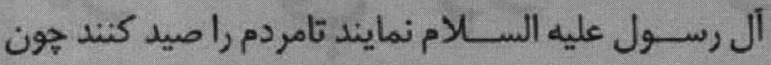

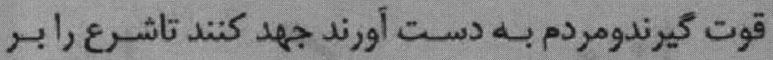

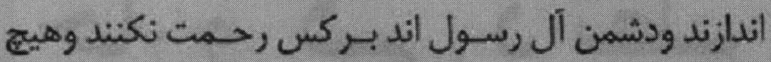

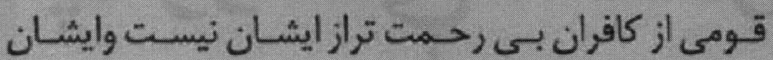
معاونت ياديكر ميكنند.....

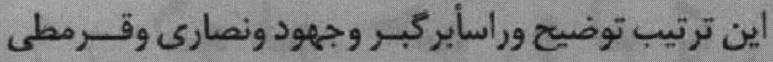

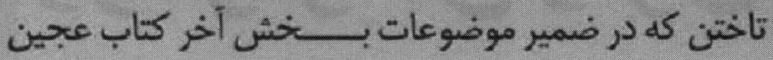

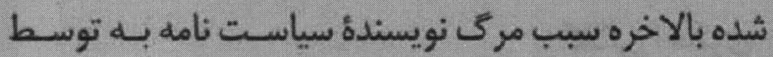

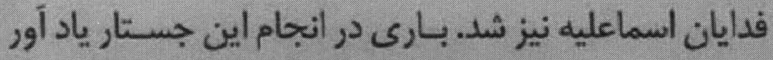
مى شـوم كه در كل، سياسـت نامه كتاب ماند كارى خواهد بود، روش نوشتارى كتاب نثر ساده وخالى از تكلف دارد وبه

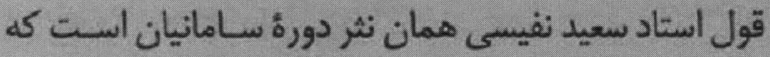
به كار كرفته شده است.

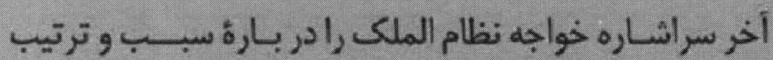

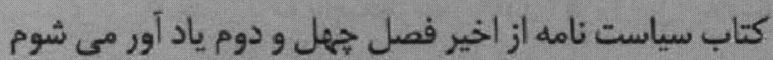
تابراى تطبيق منظور نهايى ماواثر مذ بور واسطه باشد:

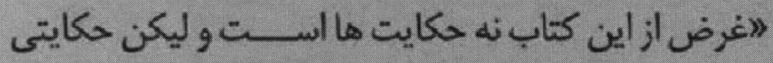
غريب و عجيب بود و موافق افتاد يا د كرده شد. مقـصود از

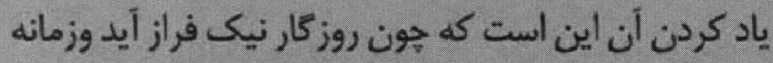

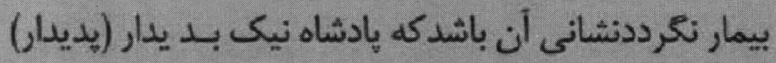

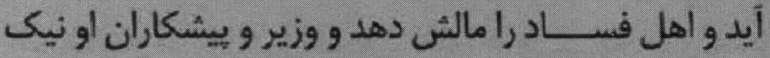

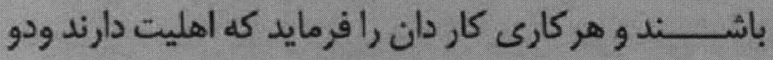

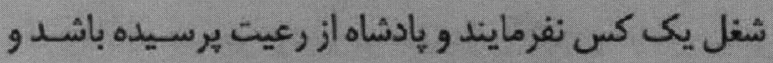

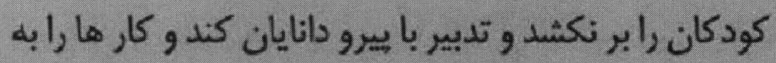

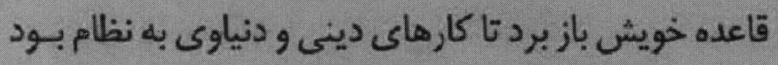

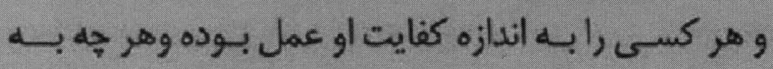
خلاف دين رود رخصت ندهد و كما بيش كارهاى بـترازوى عدل وسياست راست كر داندها.
كه نان ده الى مسكين كه نان دادن كار مردان اسـت . بـــهـ

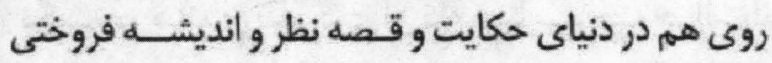

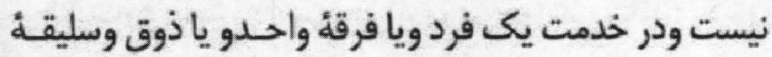

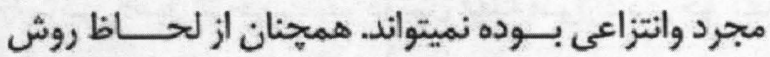

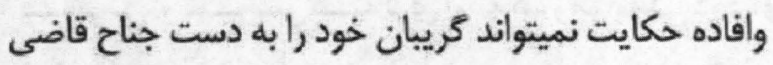

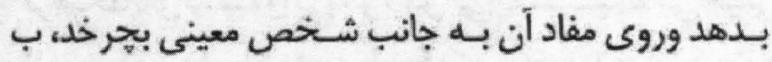
همين خاطر بـخش مهرم سياسـت نامه كه در بـارة أحسوال تاريخى خروج وقيام هاسترنى عينى وتاريخى داشته است. نويسنده از كفتن يك جزو حقايق نائزير است كه در قـالب قصويت محض نمى كنجد، بنأ وزير نظام الملى فصولى رأى رأ بدون نامكذارى حكايت برآن تعقيب ميكند، بـا آن كه نظام

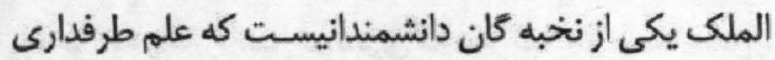

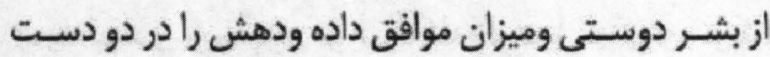

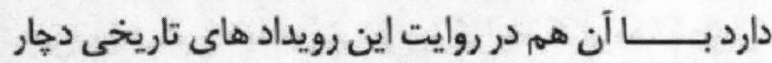
عصبيت مفرط ميشـود؛ فى المثل: در هنكام تشــريح قـيام

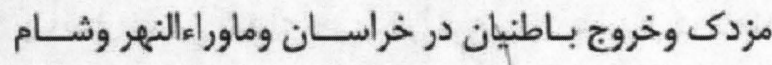
ومغرب وخروج سنبادكبر وخروج على بن محمدبرقعى بـر خوزسـتان ومصر ويا خروج بـابك خرم دين در آذريـايجان يردهاز عصبيت روى حشمانش مي افتد. اكثر اين قيام ها

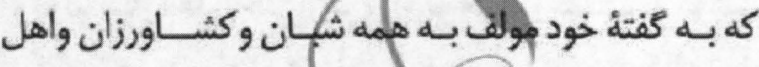

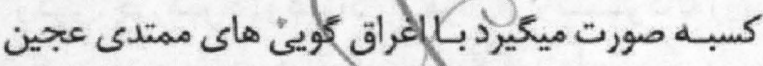

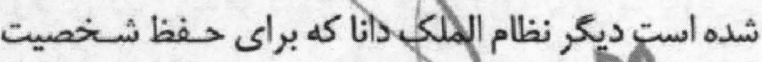

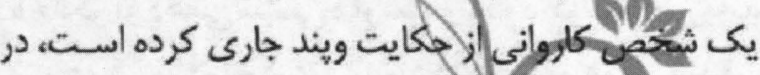

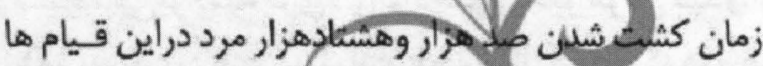

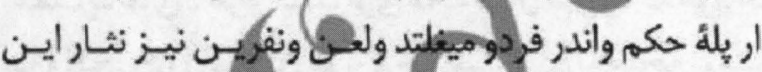

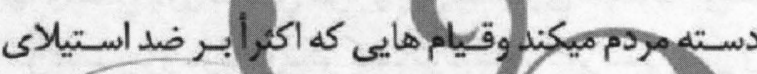

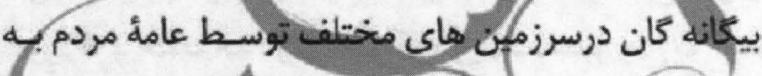

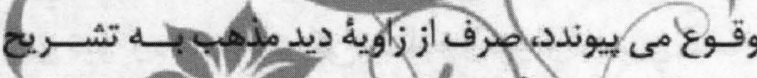

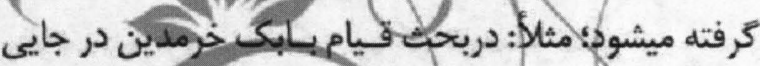

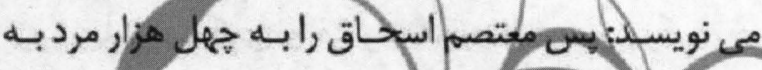

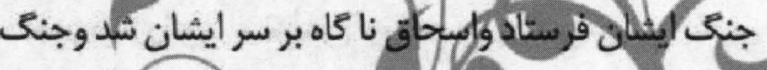

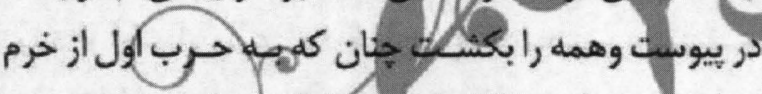

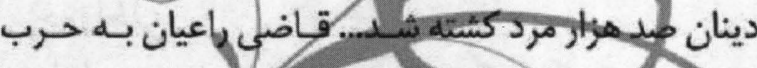
إيشان شـأند واز جوانب فرو كرفتند وكلفر يافتند وبسـيار

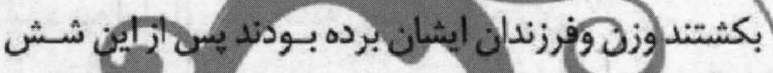

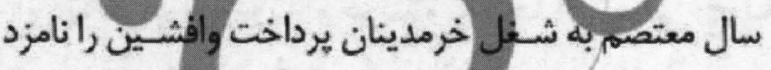




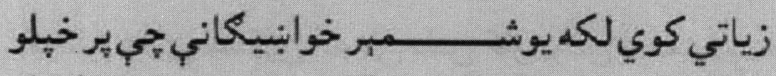

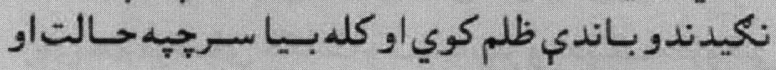

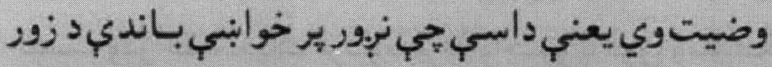

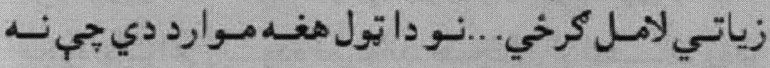

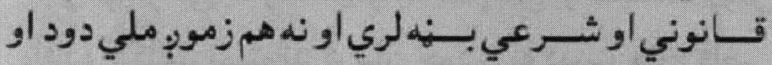

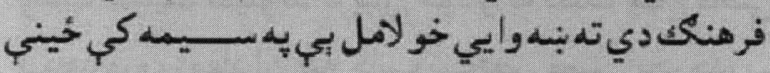

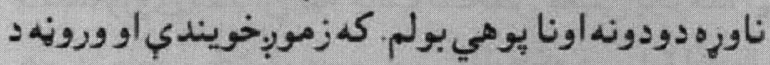

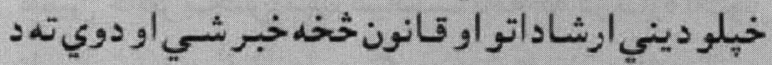

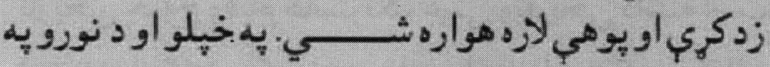

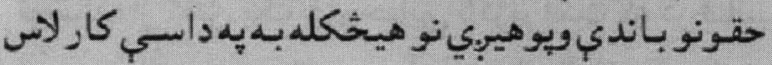

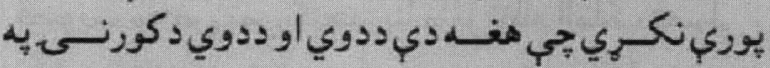

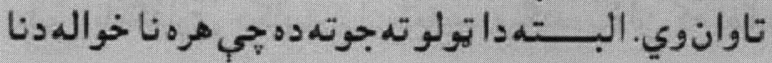

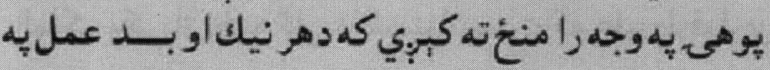

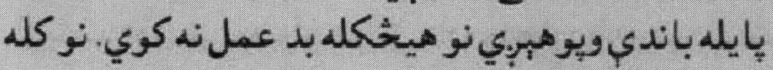

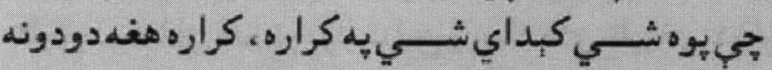

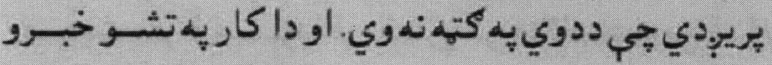

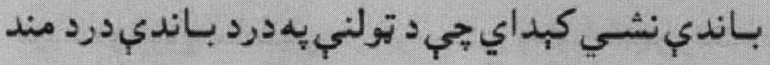

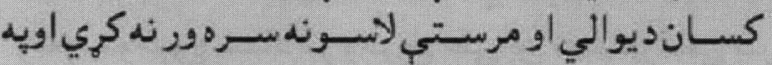

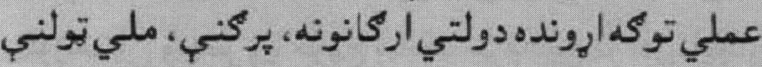

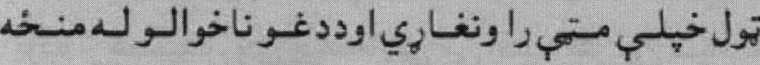

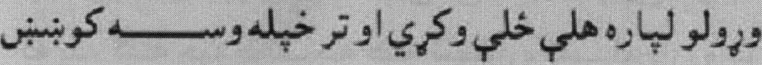

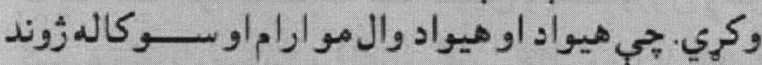

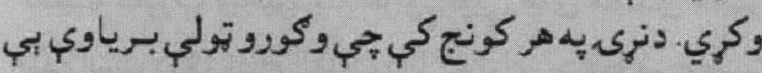

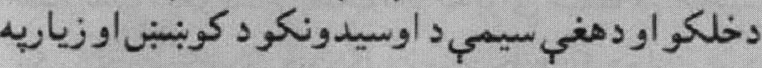

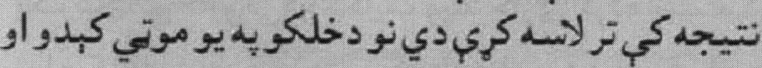

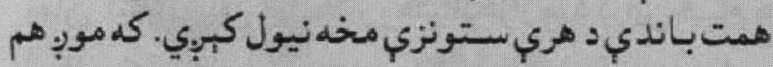

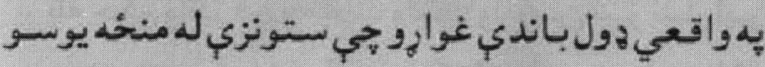

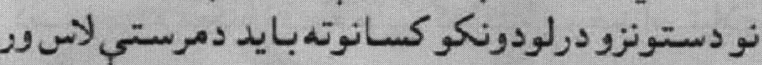

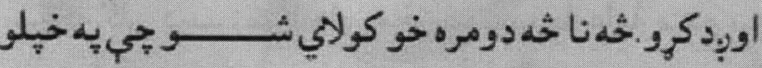

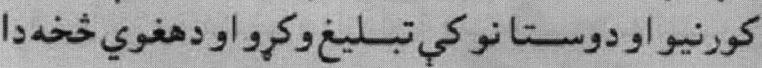

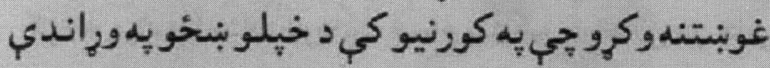

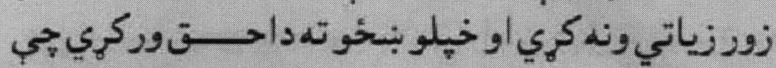

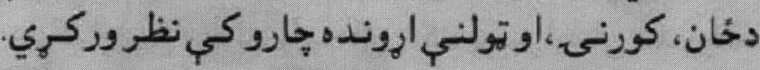

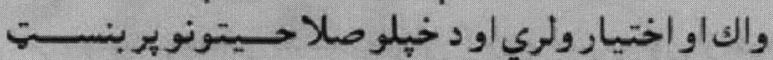

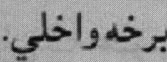

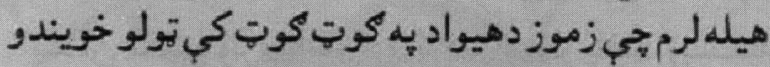

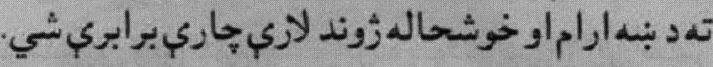

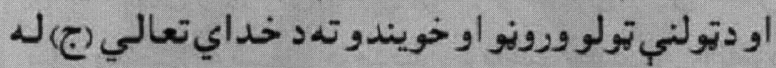
دربار خخهد سترو خدمتونويه لارمكي توفيق غواريم

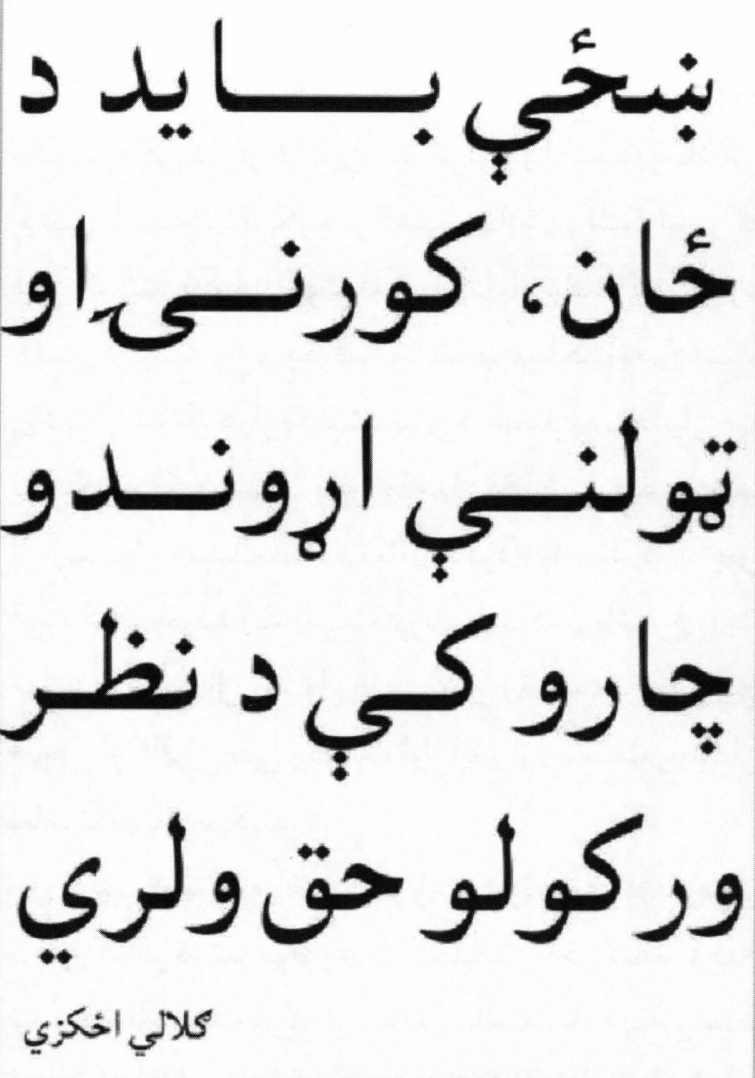

دا تولو ته خر كند حقيقت دي جيد داسلا مد سبخليدين

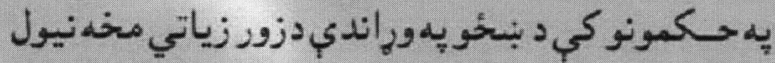

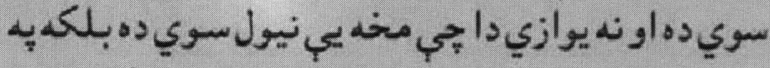

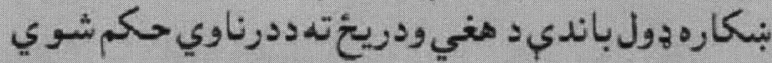

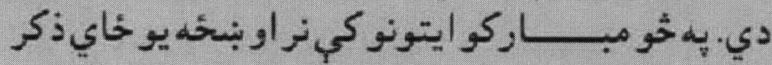

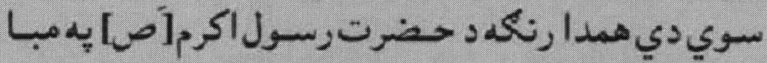

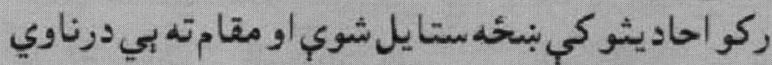

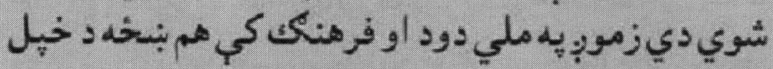

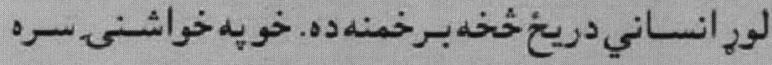

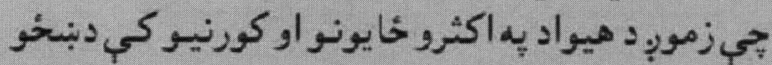

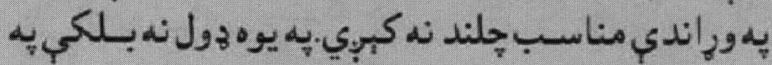

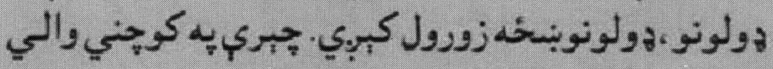
كي يد بدوكي وركول كبربي، يد بل خلخاي كي يه

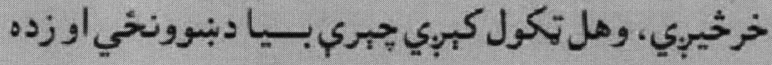

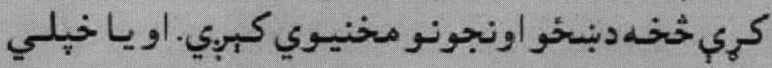

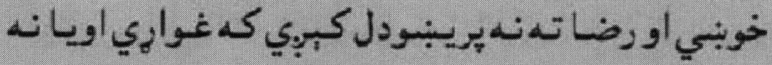

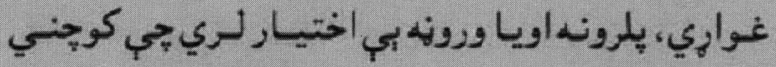

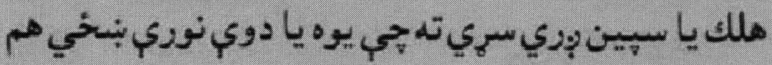

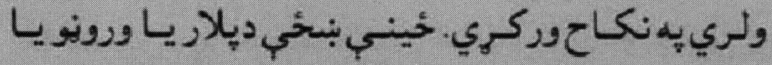

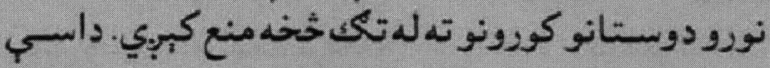

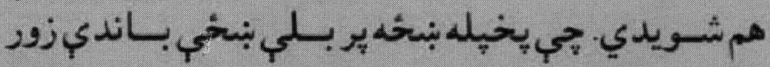




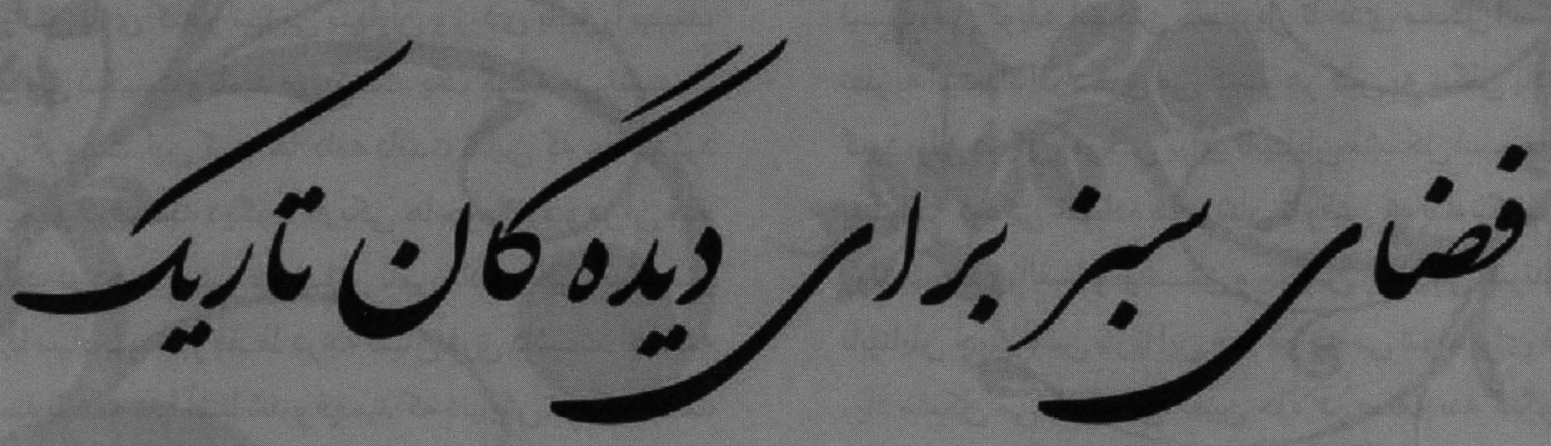

IFFF به شكل يك نهاد غير دولتى ايجاد شد و ازسوى دفتر

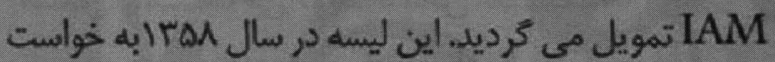

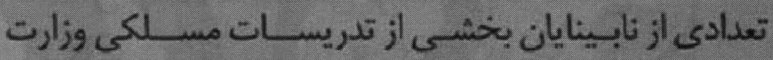

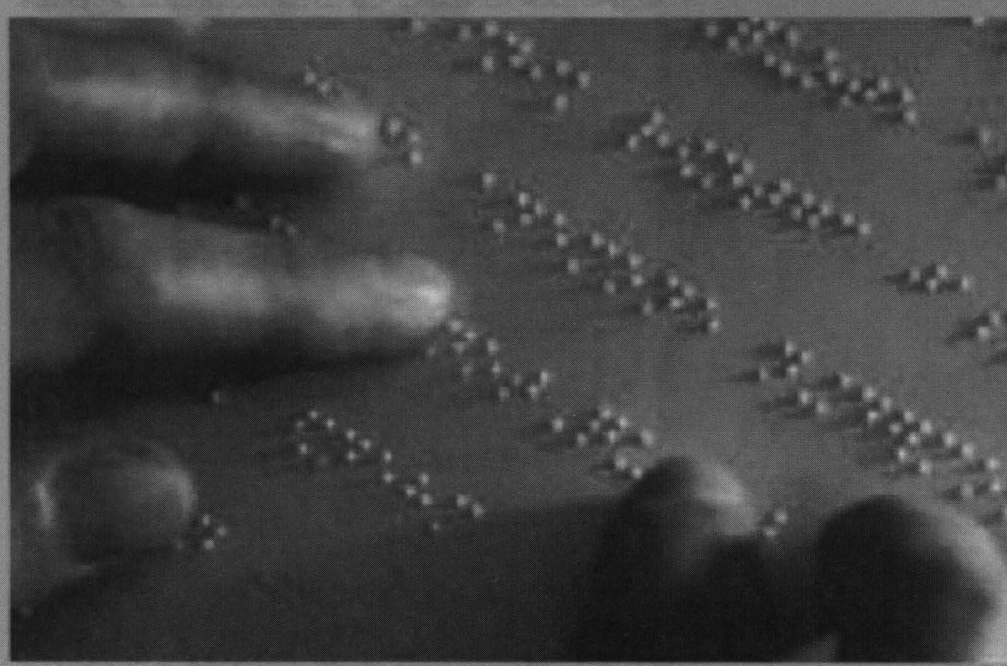

ساختمان سخت و استوار سنكى، زير آفتاب سوزان جاشتكاه

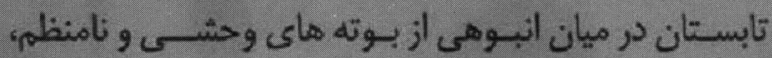

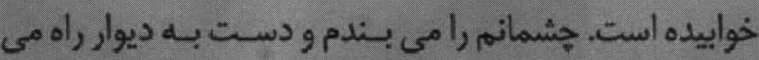
افتهم، ديوار بـامن راه مى آيد، درشـت و وناهموار،

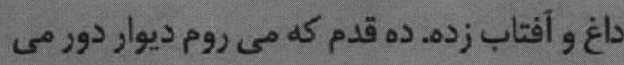
خورد، همراهيش مى كنه. حسالا صاف و هموار

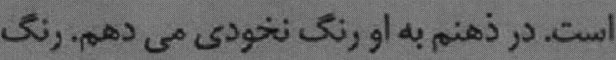

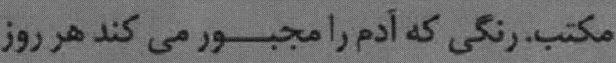

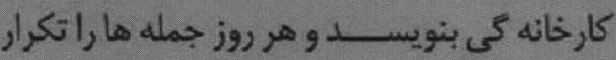

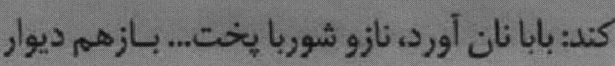

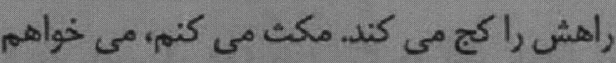

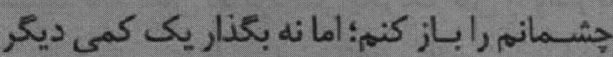
نيز حس كنم. ديوار راميكيرم و قدم بـرمى دارم.

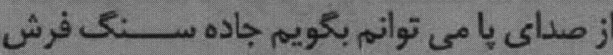

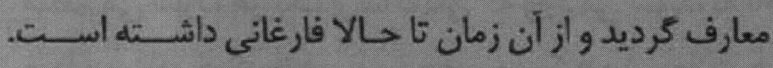

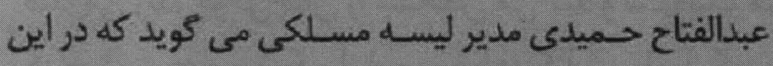

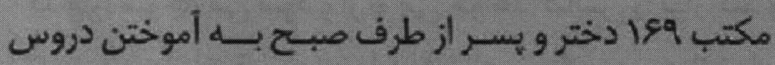

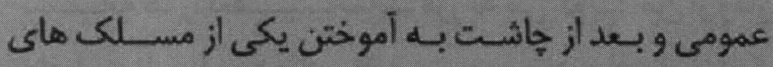
خياطى، موسيقى و جاروبافى مى يردازند.

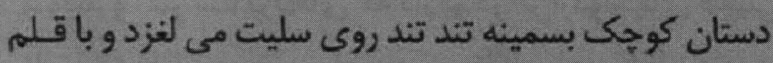

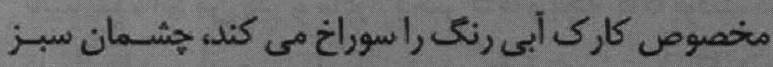

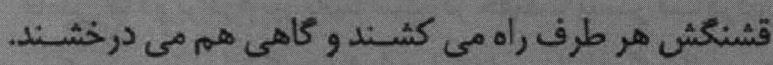

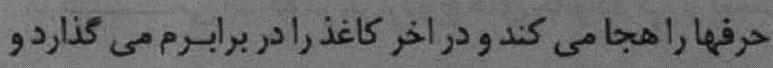

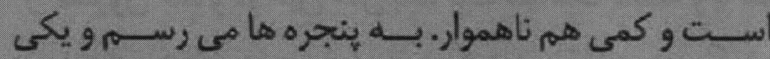

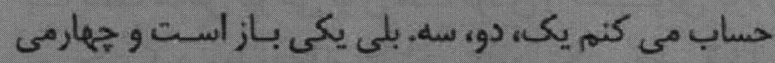

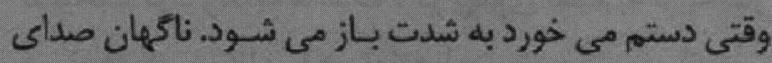

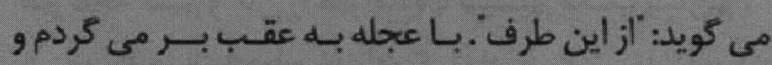

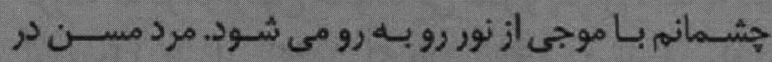

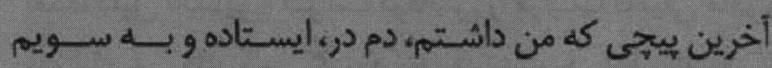

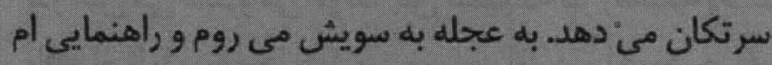
مى كند.

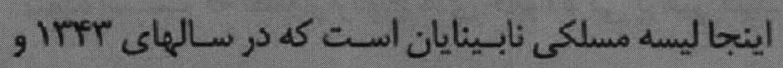


ديدن بى نصيب شده اند."

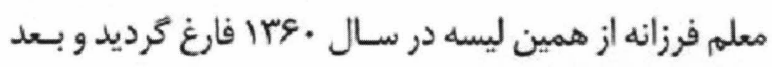

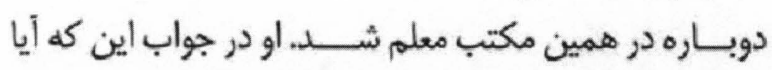

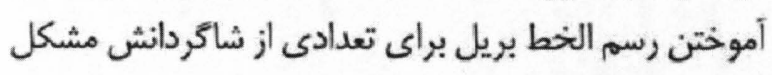

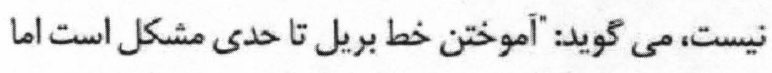

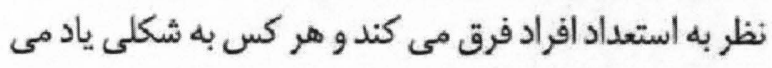
كيرد. ولى در كل أموختن براى نابينايان مشــكل اسـت افت افراد

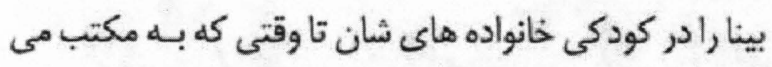

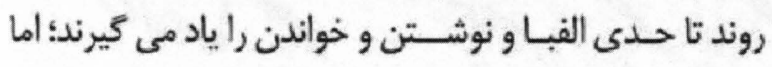
نابينايان جون اولين بار با اين خط مواجه مى شوند براى شان شان

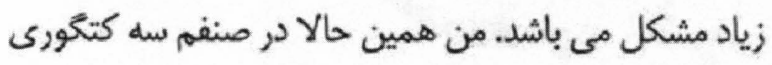

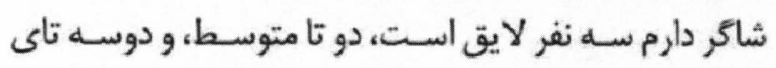

$$
\text { ديغر اصلا درست يادنمى كيرند". }
$$

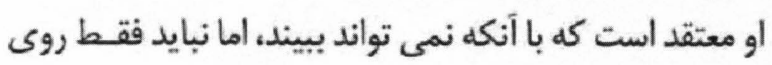

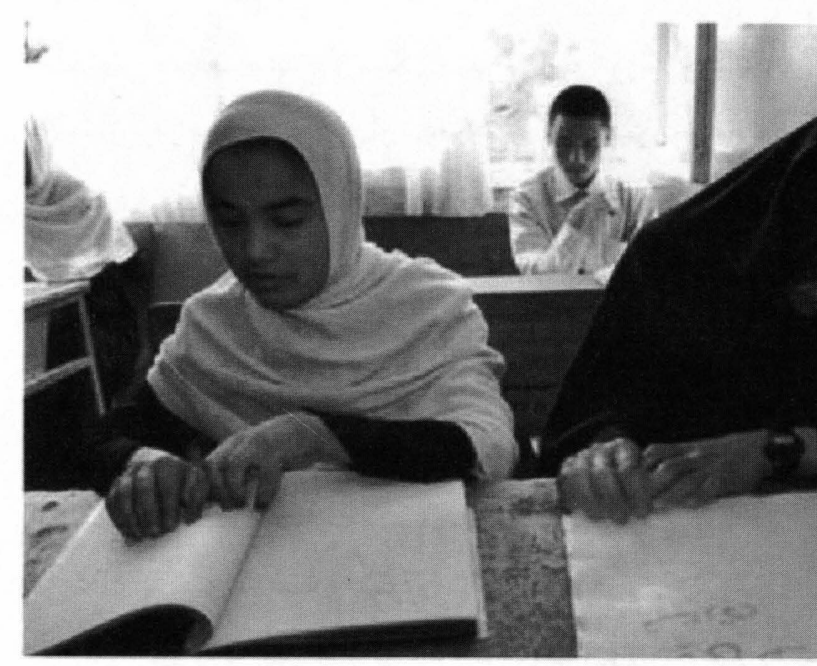

جوكيش بنشنيد. بايد ميان شاكر دانش بكردد، آنان راوادار به

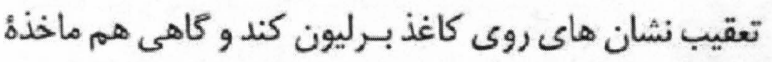

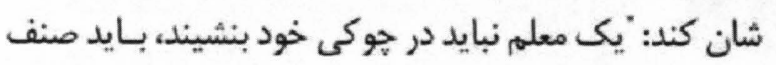
راكنترول كندو در عين حال بايد يكى سياست داشته و يا هم

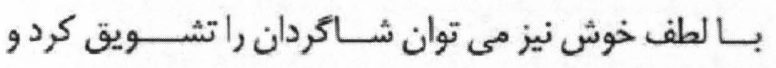
نصيحت كرد. وظيفه ما است تا در يهلوى تعليم به تربية شان ستران هم توجه كنيم و آنان راهم أماده با سيستم مكتب بسازيم.

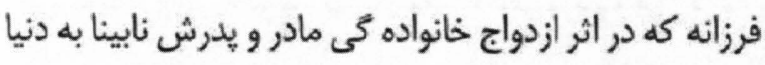

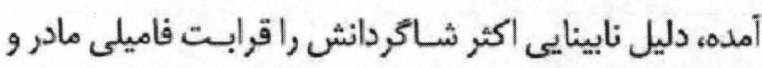

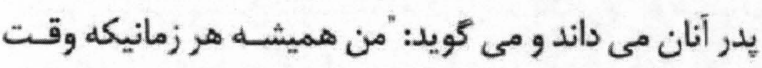

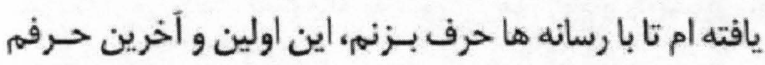

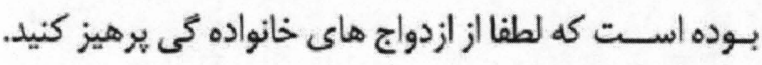

مى كويد: "اينه نامت" و بعد با انكشتانش حروف را يكى يكى مى خواند. بسمينه از كودكى نابينا بود. وقتى كوحى بود و نمى توانست

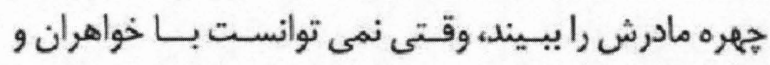

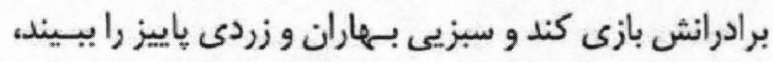

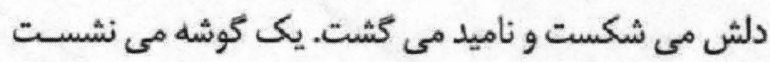

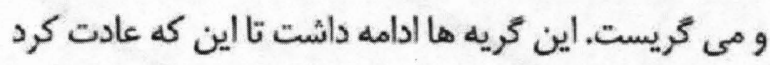
و تصميم كرفت كه ديكر با تاريكى ها خو بكيرد و ودر آن قدم

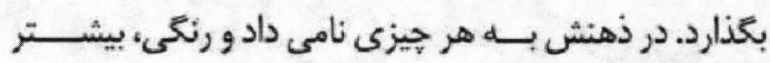

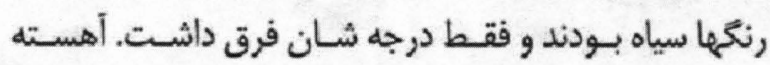

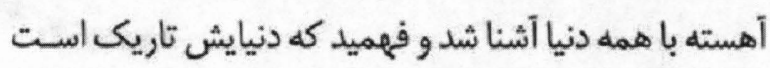

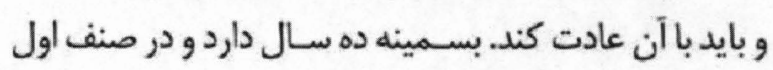

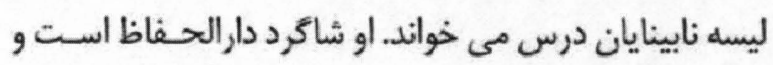

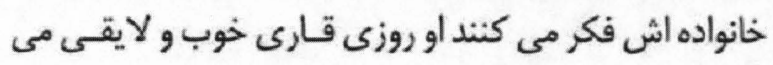

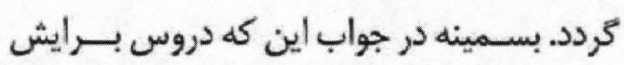

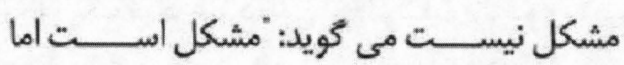

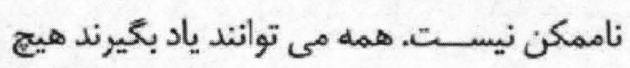

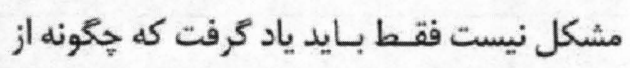

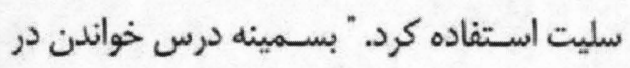

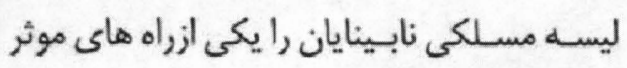
كنار آمدنش با مشكل نابينايش مى داند.

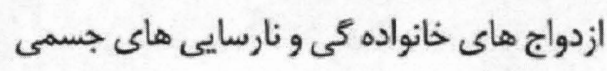

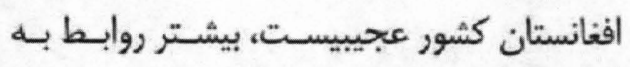
شكل كليشـه يى در سـطع فاميل، قـوم و قبـيله

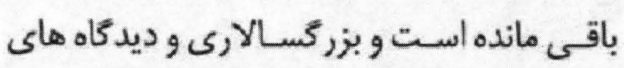
بزركان حتا بر خصوصى ترين موضوعات زنكى اعضاى يكى

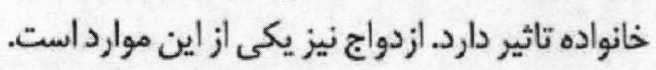

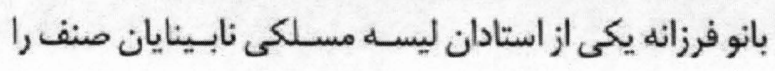
منظهم مى سازد، هر يك از شاكر دان كه وارد مى شوند، به به نام

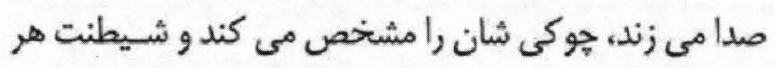

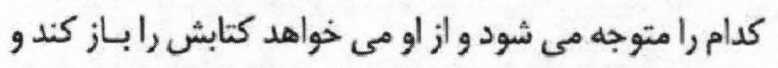

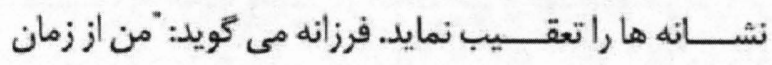

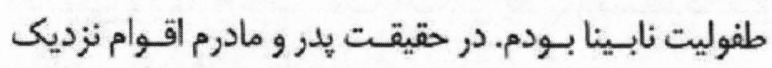

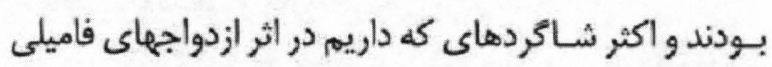

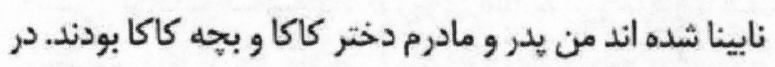
فاميل ما دو برادرم نيز نابينا ست. در حقيقت بيشتر شـاكردان

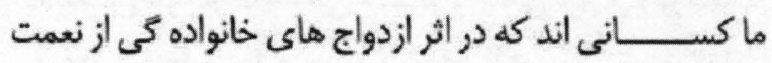


كنند. من كاهى ناميد مي شـوم؟ اما حاره نيســ

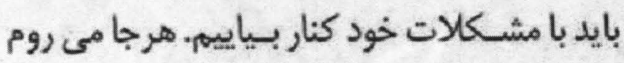
بايد يكى با من باشد تا مشكلى نداشته باشـهم. در

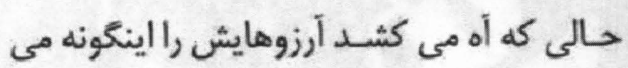

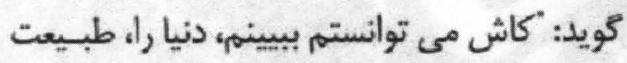

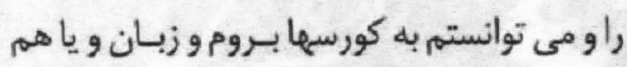
هنرى ياد بكير م. استادانم معتقد اند كه نابينا نمى تونى

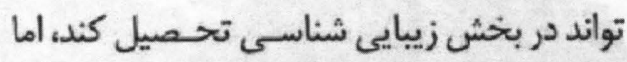

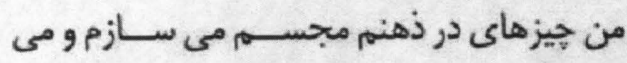
تواثم درختها راو طبيعت رالحساس كنه". به كفته دمنه

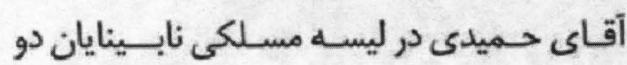

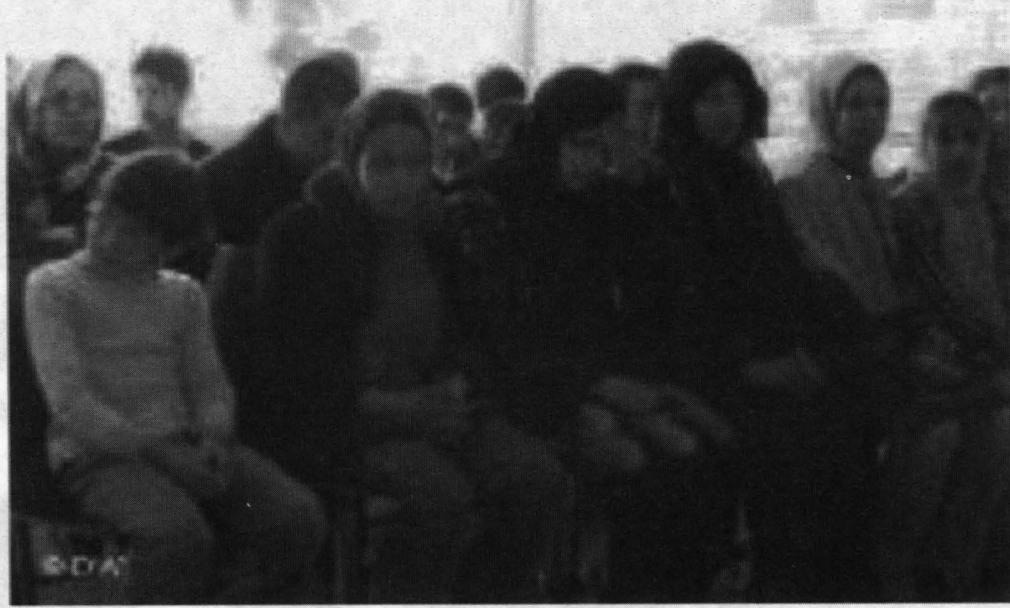

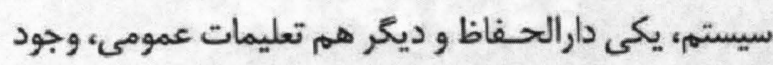

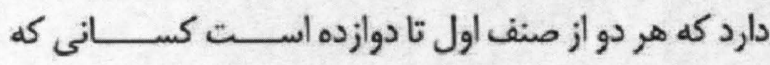

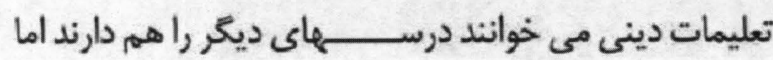
ساعات مضامين دينى شان بيشتر است. او مى كويد: "در اين مكتب امكاناتى از طرف دولت داده ميشود و ينج موتر كاستر

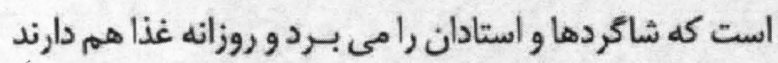

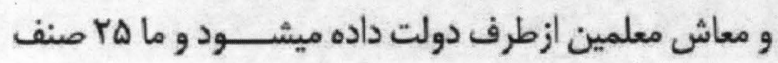
درسى يكى سـواد آموزى و ديكرى درسـهماى مكتب اسـتـ.

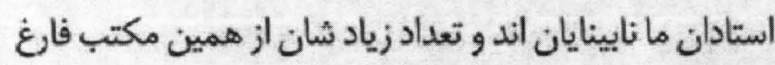

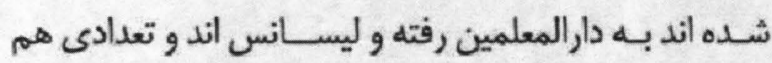

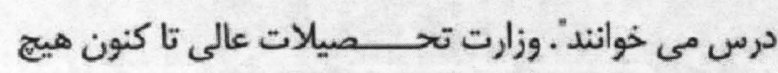

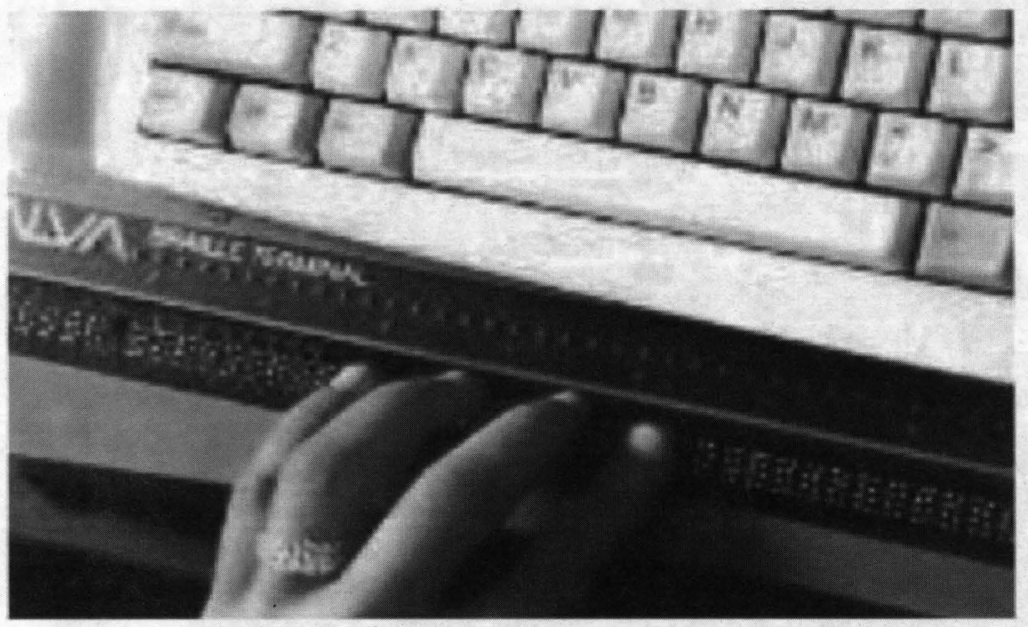

بـرنامه بـراى اخذ امتحــان كانكور اختصاصى از نابـينايان را

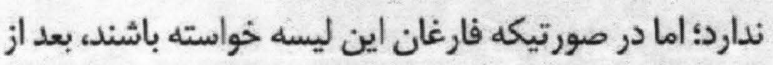

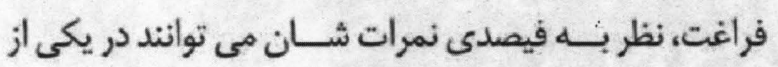
دانشـكده هاى علوم اجتماعى و دانشعاه تعليم و تربـيه ادامه فيه تحصيل بدهند.
بزركيست:

بزركيست:

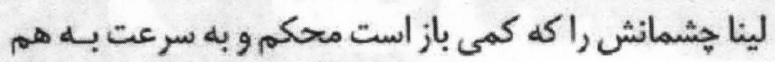
مى زندو مى كويد: من شما را مى بينم، خيلى كمرنى، خيلى دور. لينا نيز از كودكى نمى توانست بيبند. هشت ساله بود كه مانه

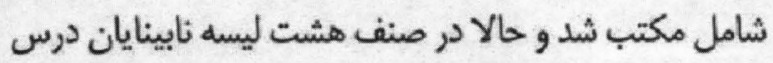

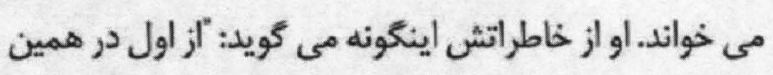

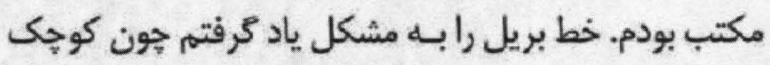

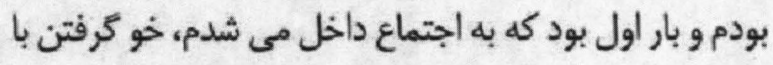

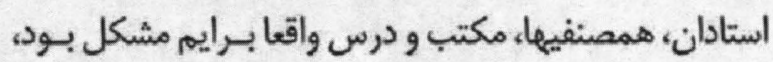

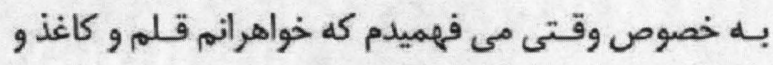

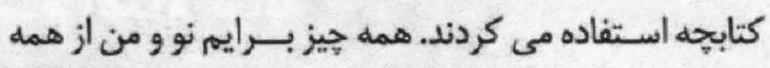

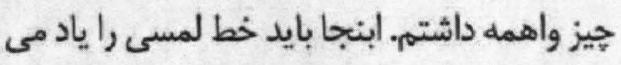

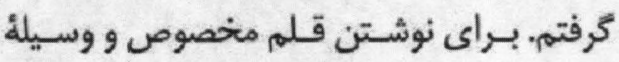

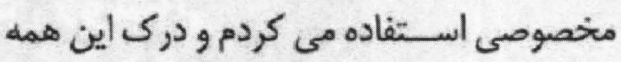
براى من كه كوخى بودم مشكل بود. كتابهاى كه لينا و همصنفانش استفاده مى كنتد.

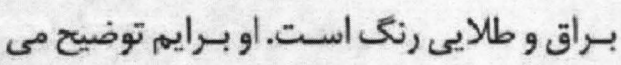

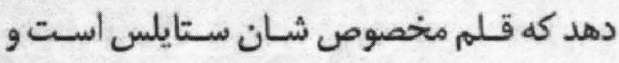

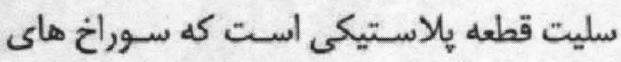

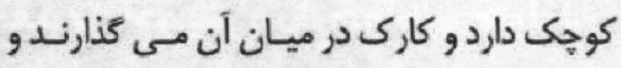
مى نويسند: اما كاغذها مخصوص كتارديهاى شان به نام برليون يادمى شود.

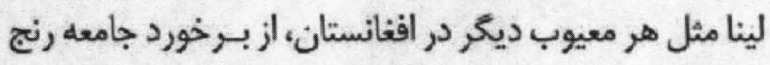

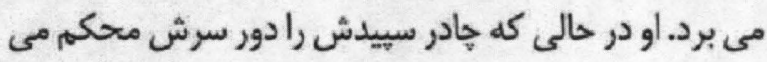

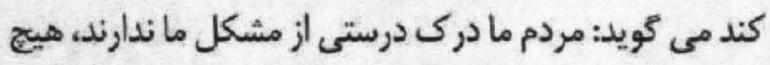

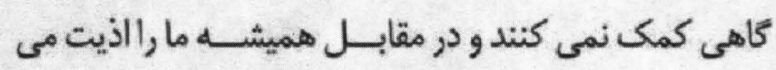


سراج الحق ببرك زي خدران

\section{ديرش كلنه جكيركي \\ د افنان ماشومانو حقوقي وضعيت

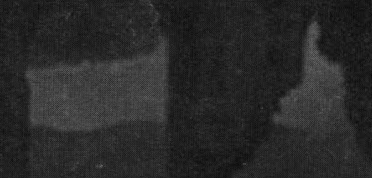

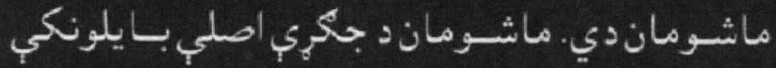

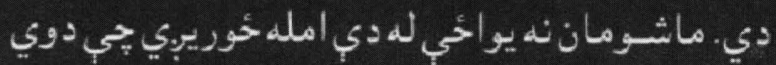

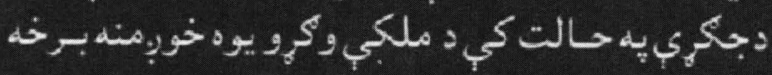

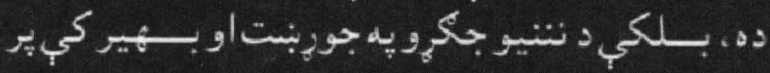

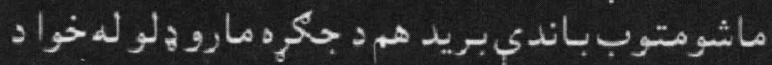

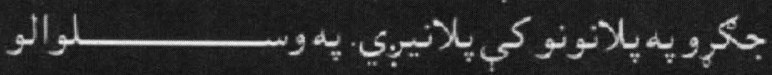

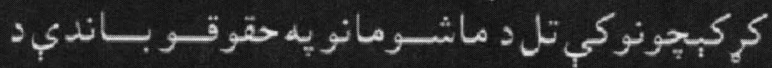

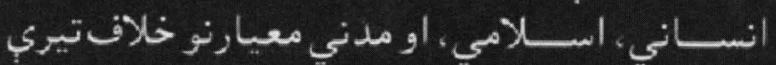

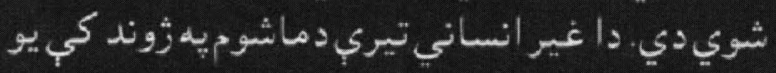

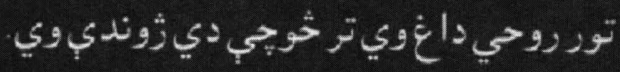

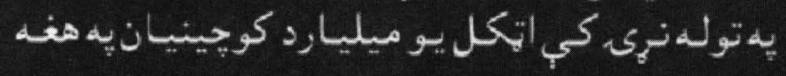

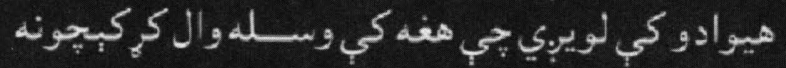

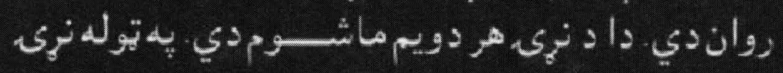

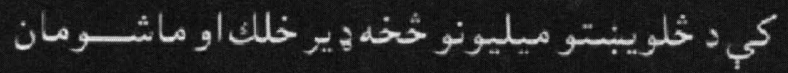

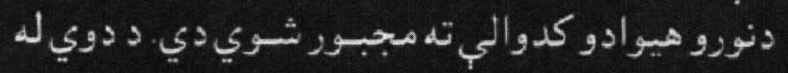

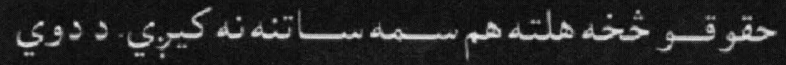
حقوق دجدي كوانب سره مخامختدي. 


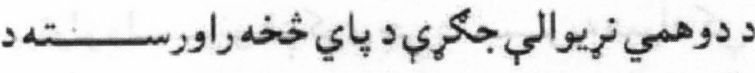

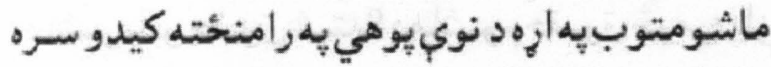

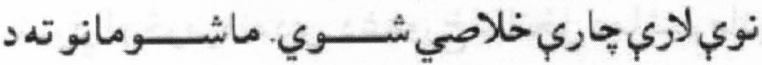

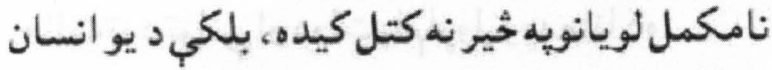

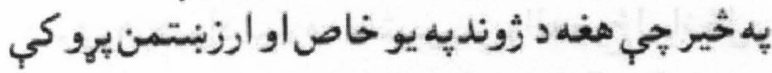

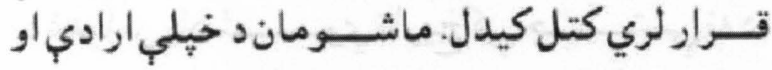

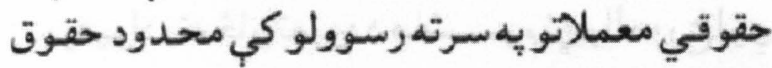

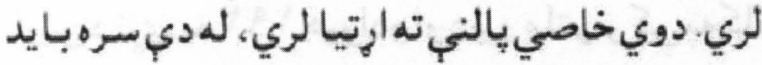

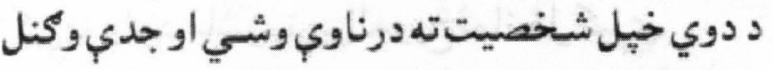

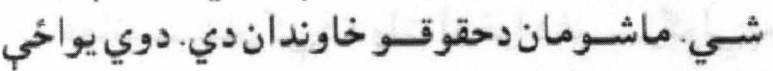

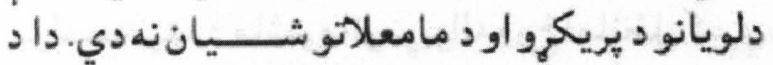

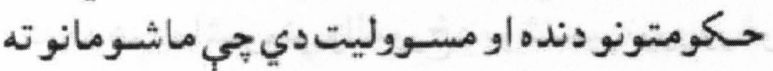

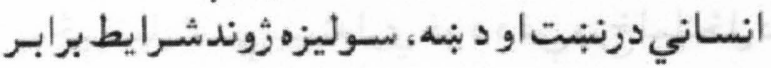

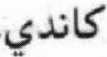

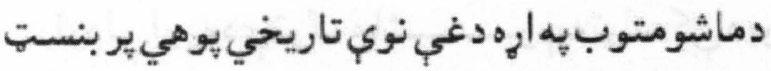

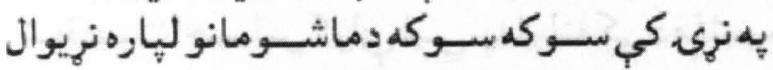

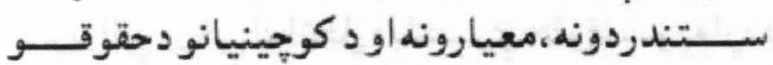

$$
\text { كنوانسيونونهرامنخته شول. }
$$

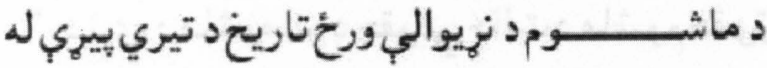

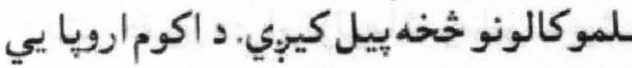

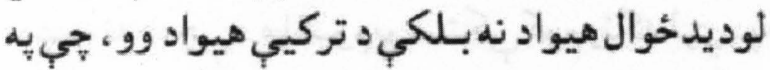

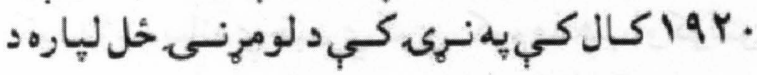

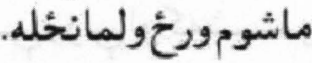

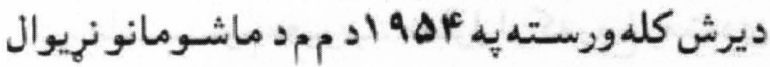

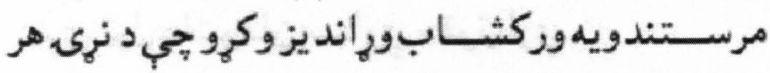

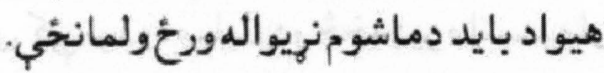

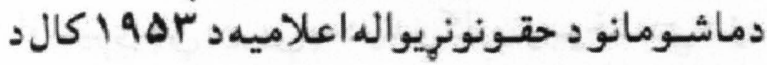

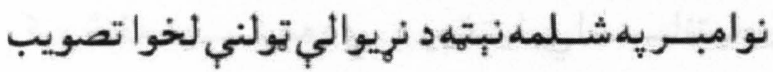
شون.

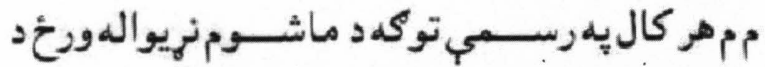

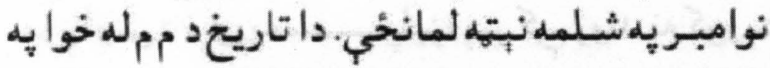

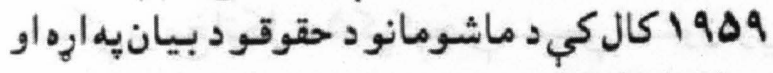

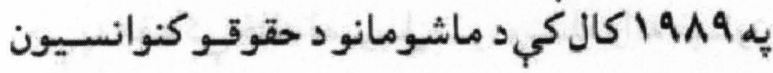

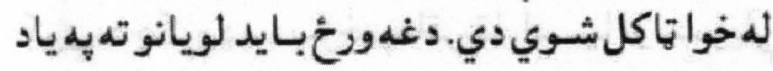

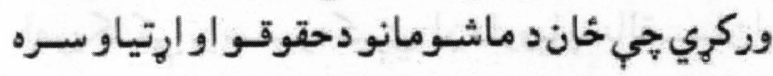

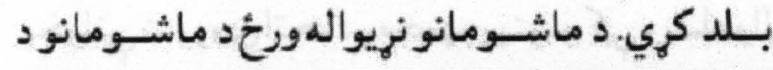

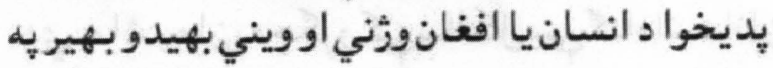

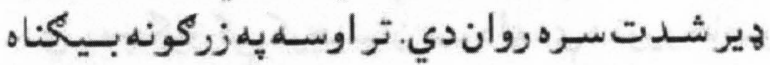

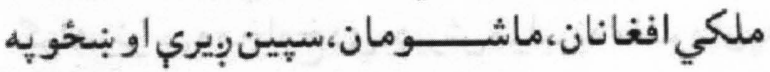

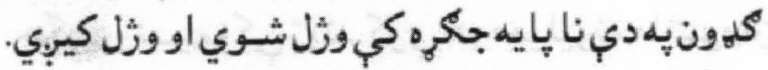

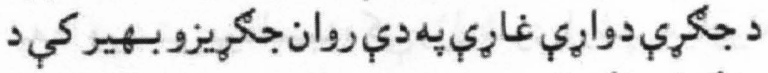

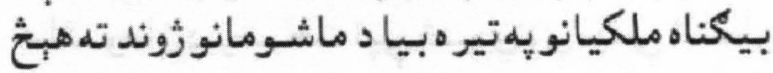

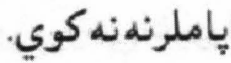

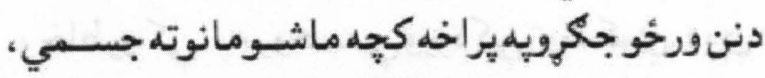
روحي، مادي او معنوي تاوانونهارولي دوئي

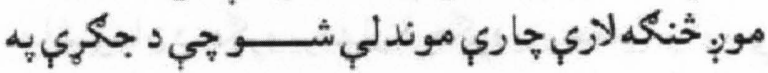
حالت كي د ماشومانو حقوق خوندي كرئ مارو يونيسف

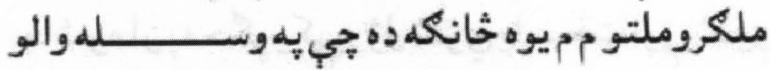

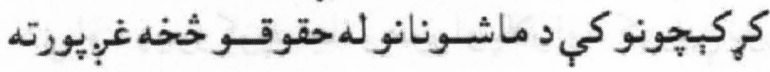

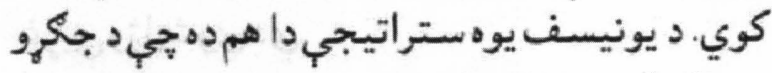
يه حالت كي د ماشومانو د حقوقو ساتنهوكي ئري.

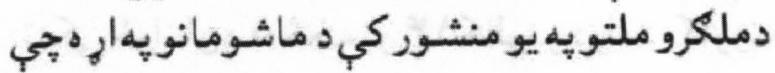

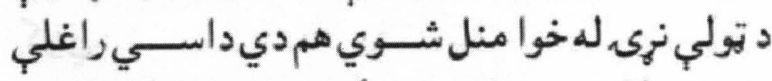

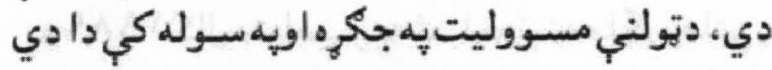

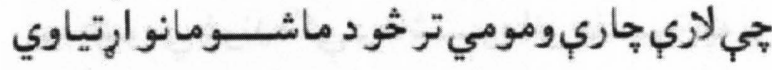

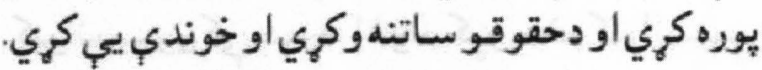

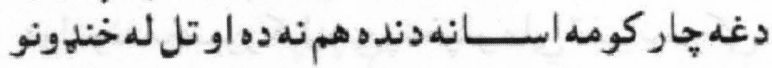

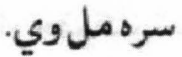

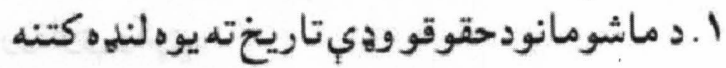

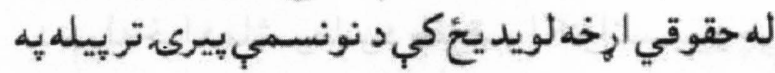

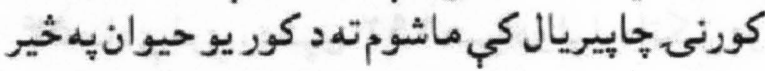

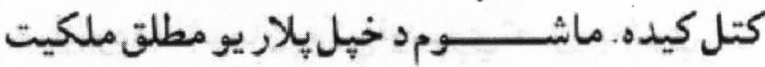

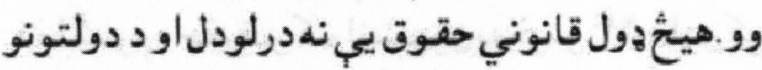

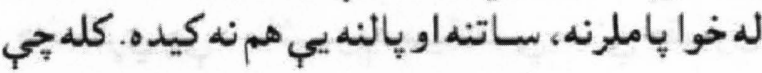

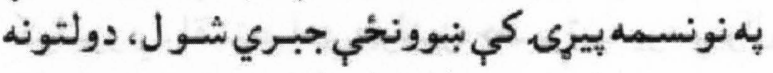

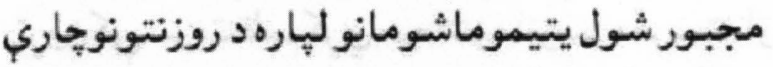

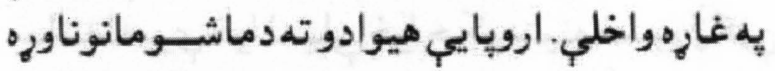

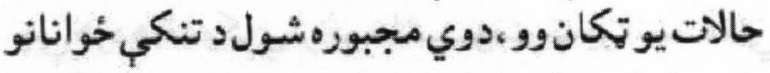

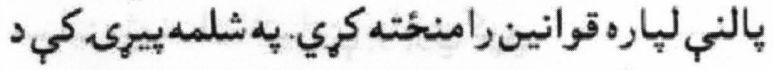

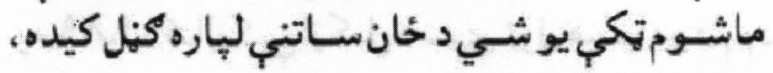

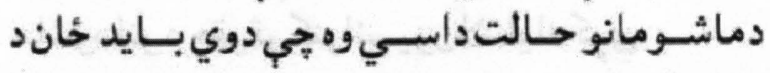

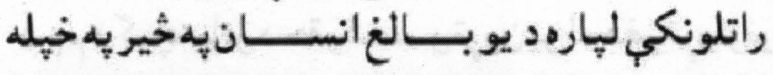


كركبحهونه شـته دي. د جكرو اكثره قربـانيان ملكيان

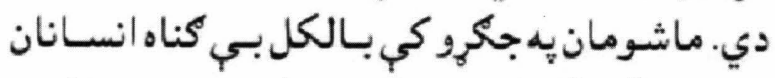

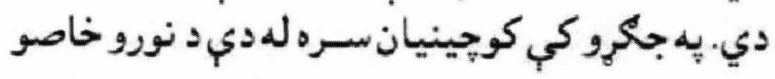
كوابنبونو سره مخامخ دي. ديرش ميليونه ماشومانيه جككيزو سـيموكي ثزوند كوي. دوه ميليونه ماشـومان يه دا ورستي يوه لسـيزه كي وزل شيوي اوشيبر ميليونه

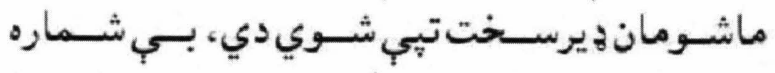
ماشومانخيل تول عمر د جكرو يه ناوره روحي اغيزوا

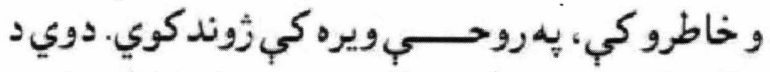

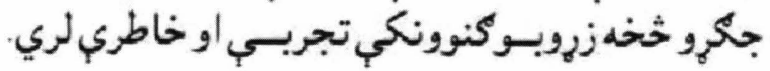

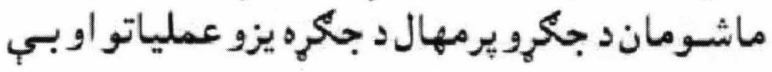

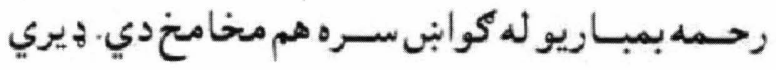

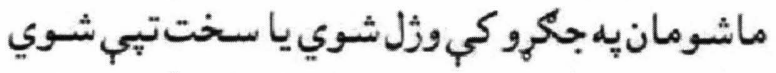

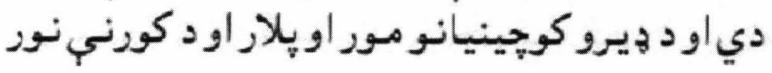
غريبي وزلشوي ودي.

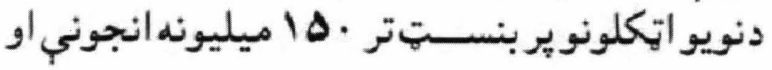

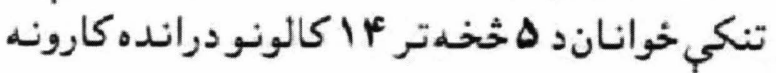
كوي.

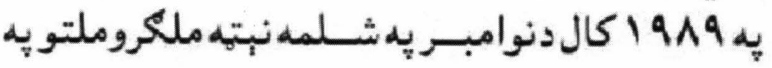

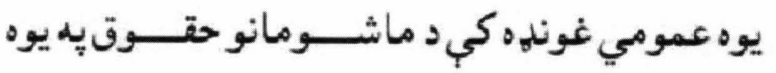

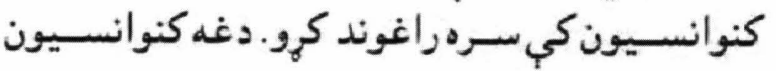

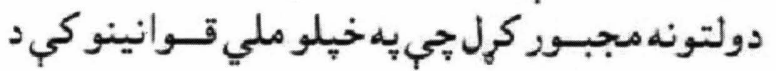

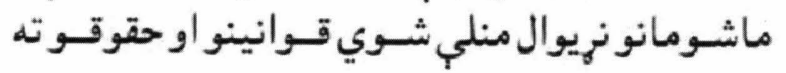
دروناوي وكئي.

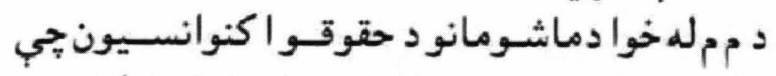

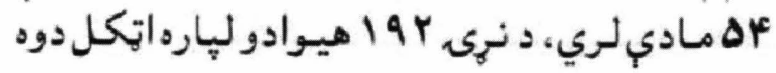

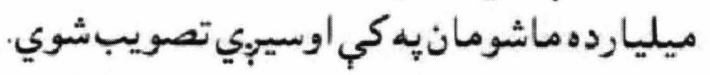

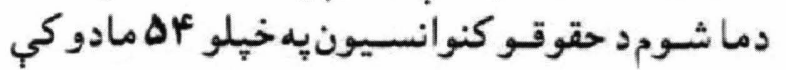

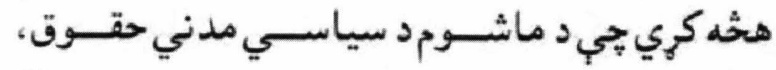

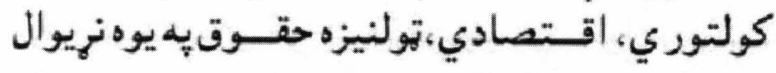

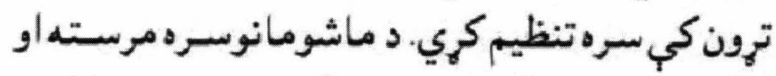

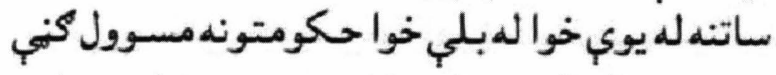

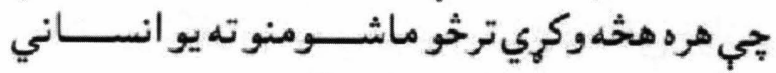
سوليزه زوند اسانتياوي برابري مئري.

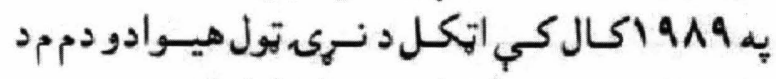
ماشومانود حقوقو كنوانسيون لانسليك كري.

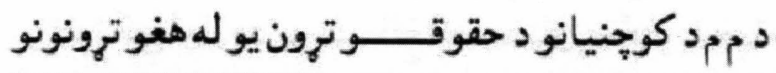

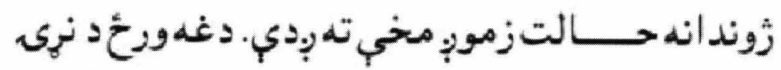

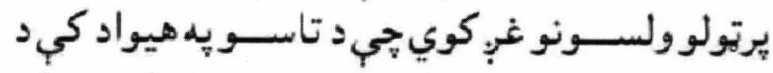

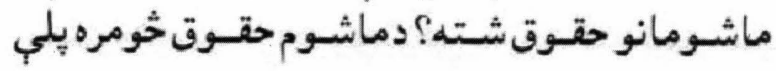
شـوي اوخومره نهدي. دغهورخح لمانخل دماشــومانو

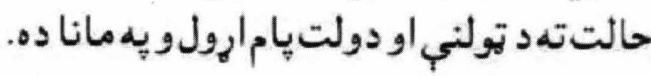

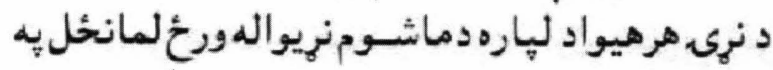

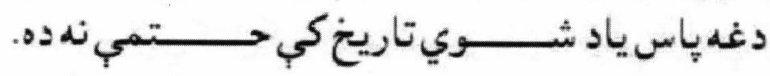

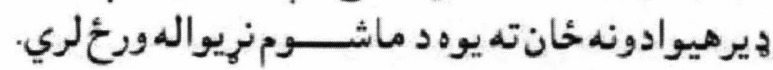

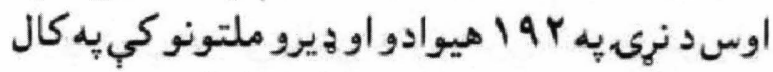

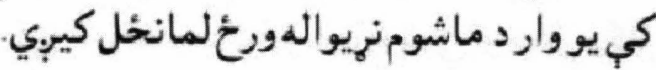

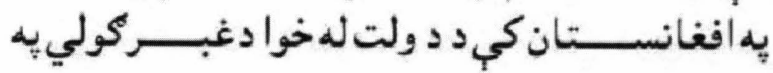

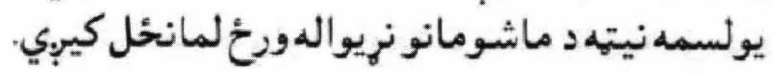

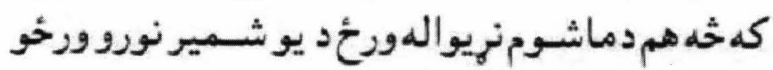

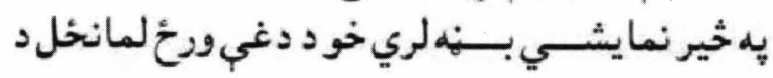

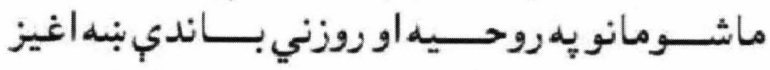

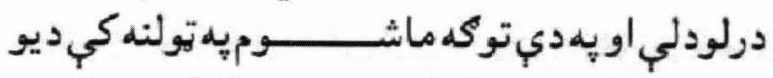
شـصيت احسـاس كولي شي. يه تولنه كي دماشيسوم

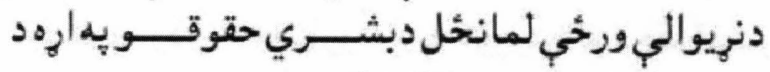
سياسي مبارزو يوه ورخ كنبل كيربي.

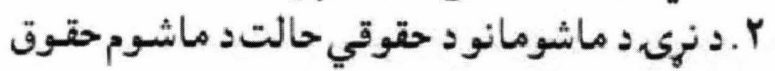
د بشر حقوقدي او تولوماشـومانو ته يوشـاندي، دان دا

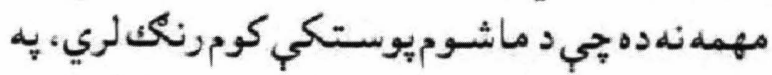

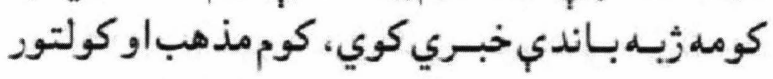

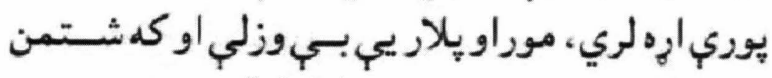

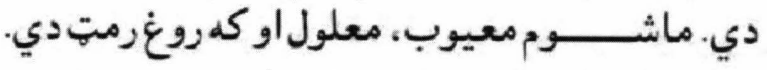
دنرى تول ماشومان مساوي حقوق لري.

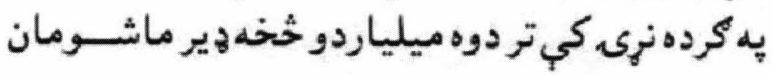

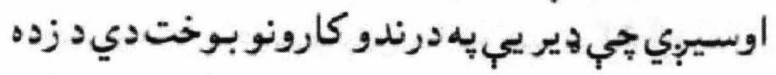

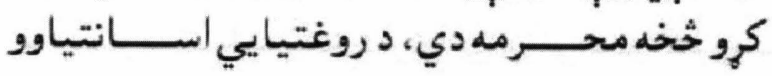

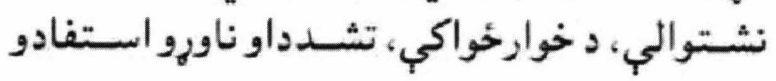
سره منخامخدي.

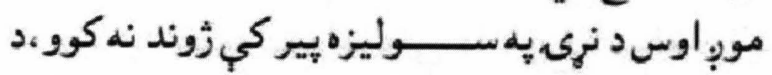

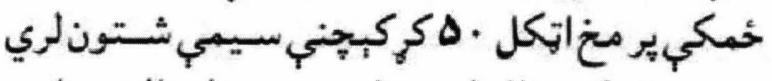

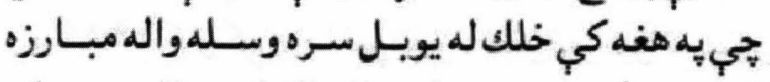

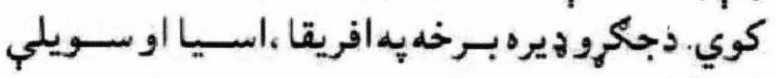

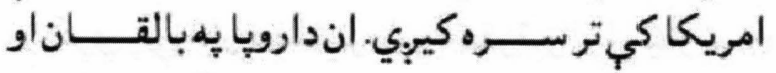
يخوانب شوروي اتحاد يه جمهوريتونو كي وسـله وال 
واكسينونه ده يرونور ناروغيو يه مخنيوونهكي ستره

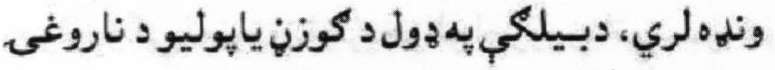

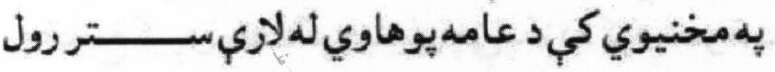

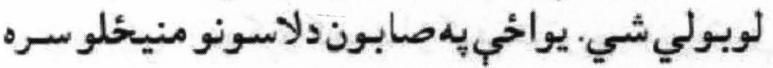
شل يه سلو كي

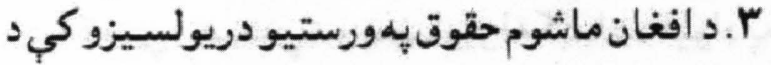

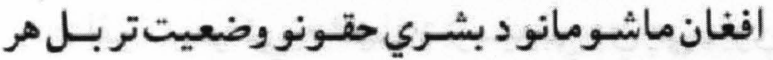

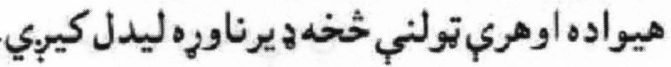

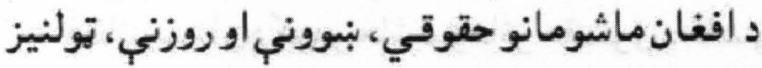

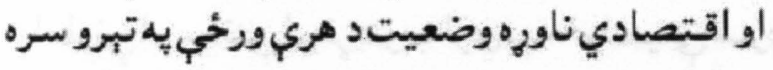

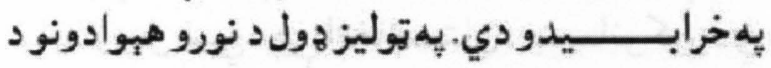

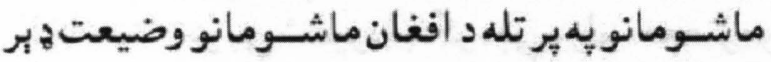

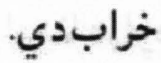

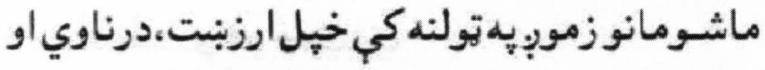

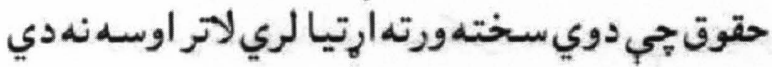

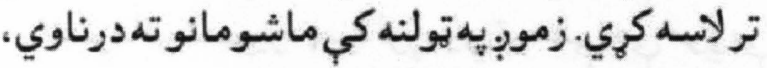

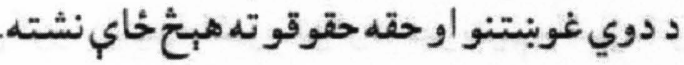

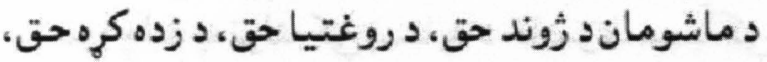

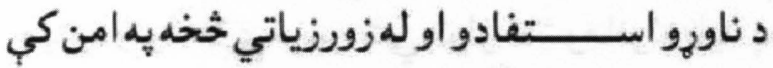

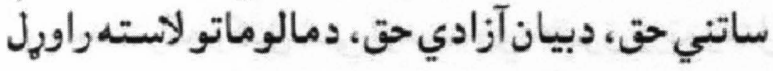

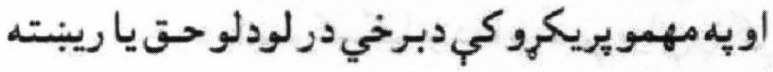

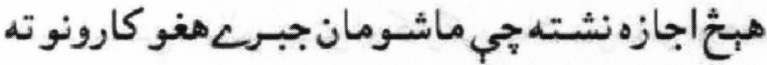

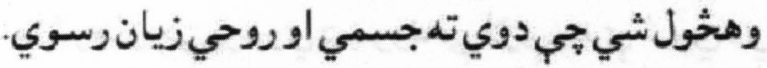

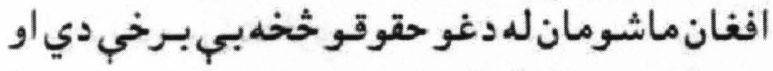

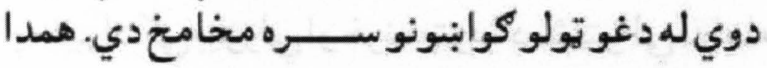

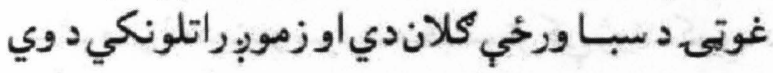

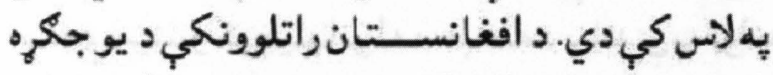

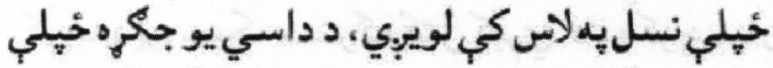

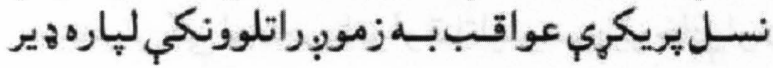
كرانتمامشي.

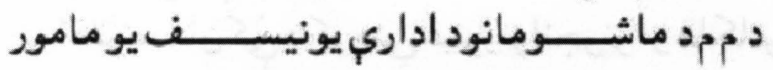

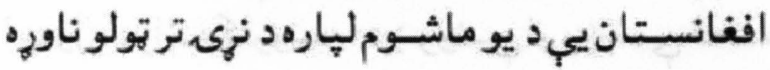

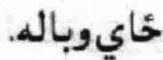

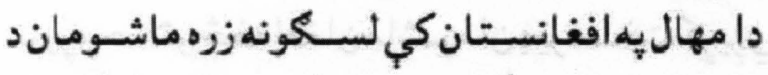

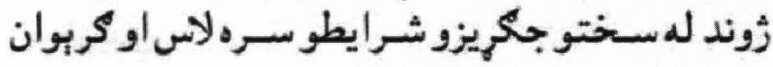

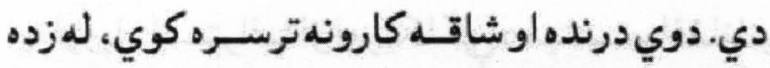

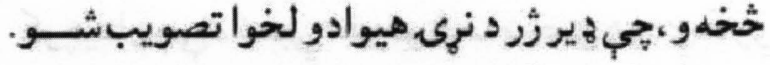

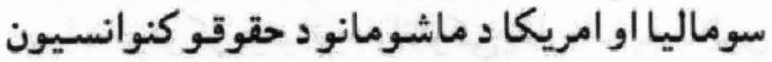

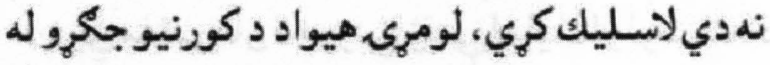

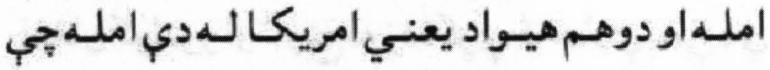

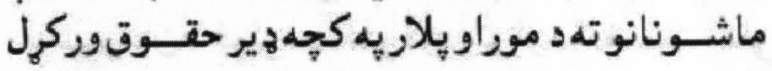
شوي نهيب لاسليكوي.

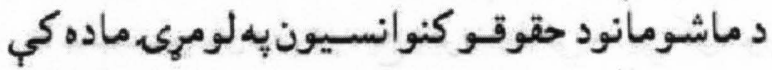

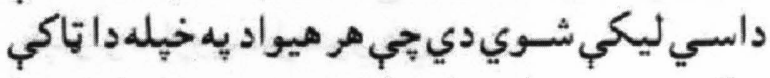

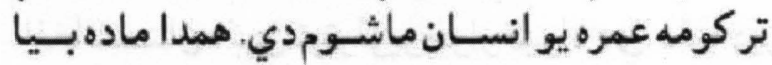

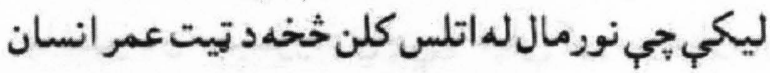

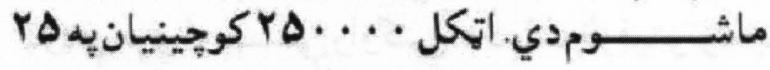

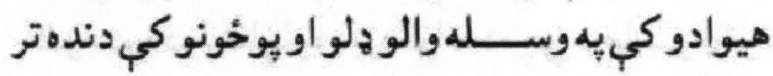

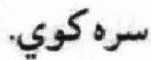

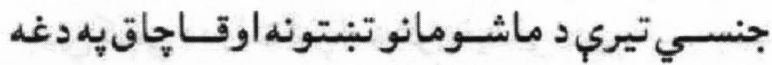

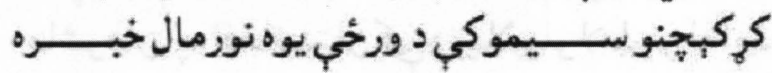
كرخيدلي دهو

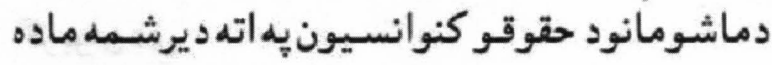

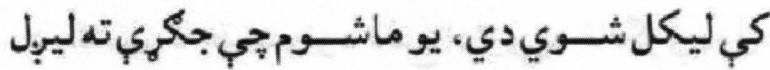

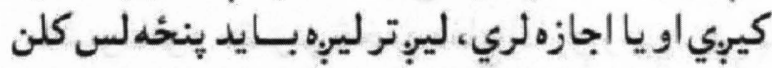

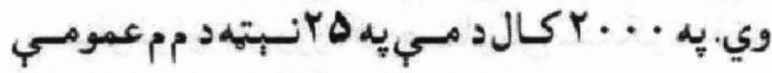

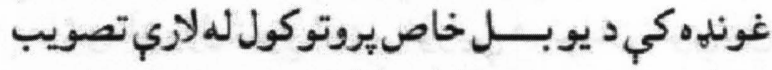

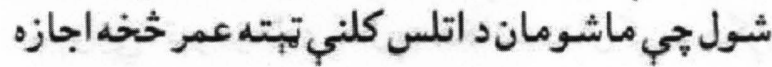
نه لري جي جبري يوخي خدمت جلب شئشي.

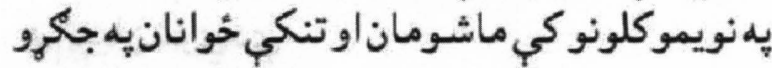

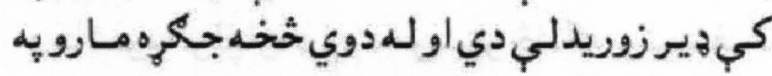

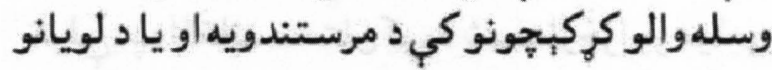

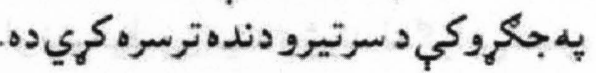

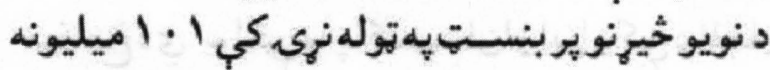

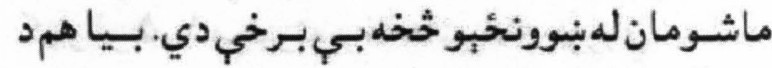

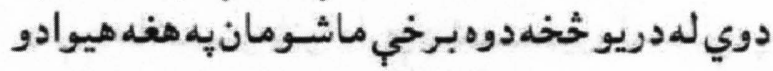

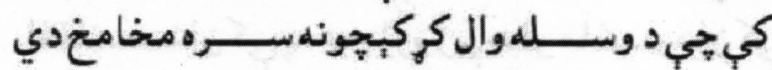
وسييبي لكديه افريقا او اسياكي.

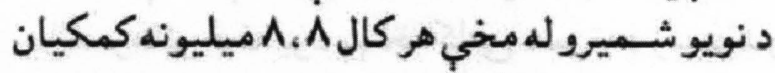

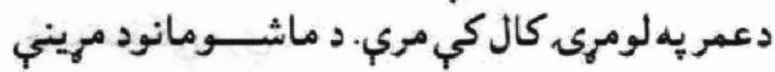

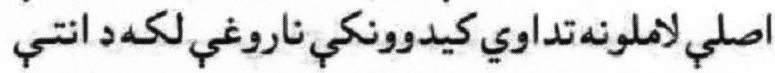

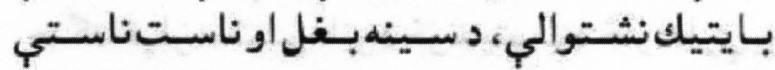

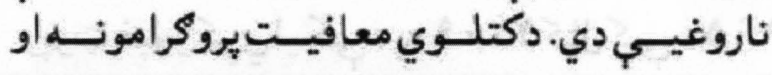


كوجينان خي د نسبي حقوقوشخه برخمن هم دي. دوي

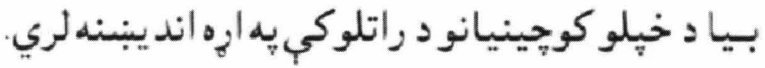

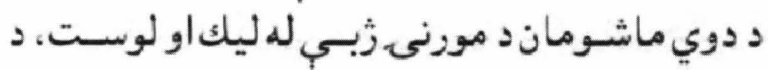

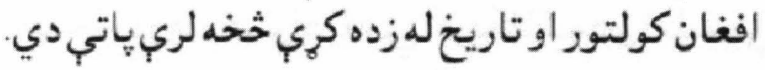

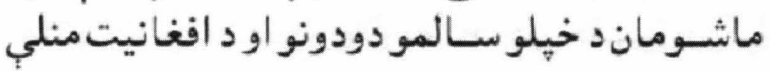

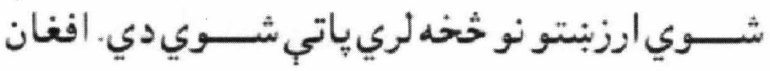

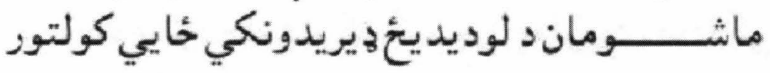

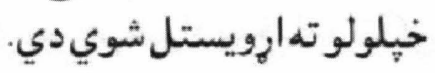

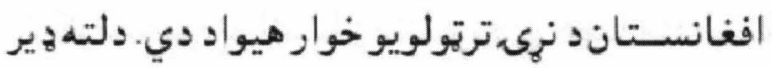

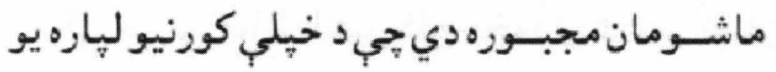

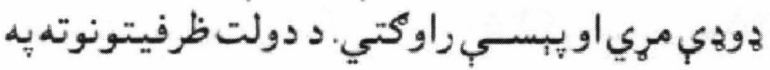

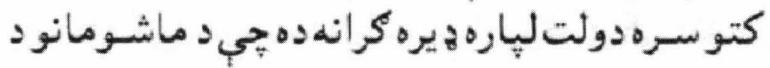

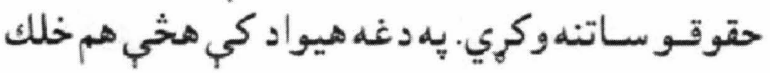

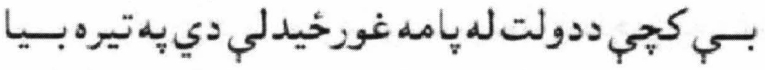

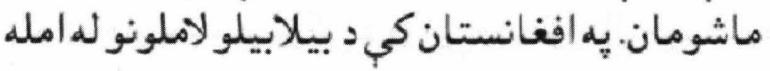

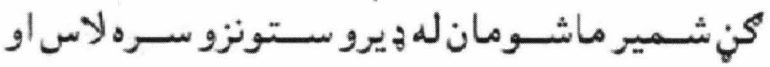
كريواندي.

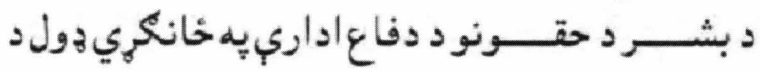

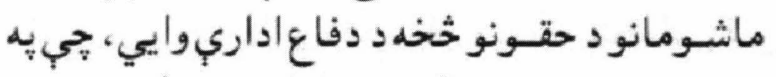

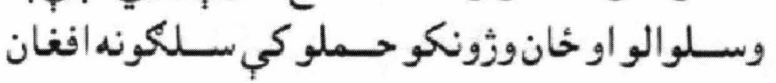

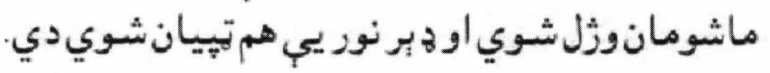

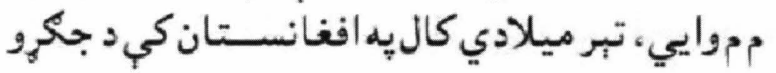

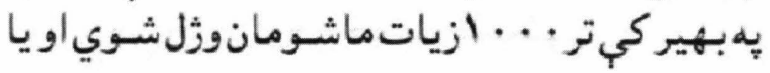
هم تهييانشويدي.

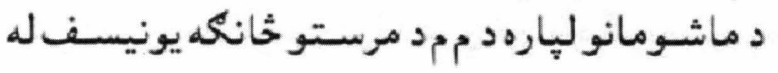

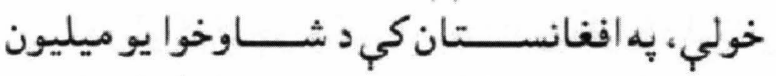

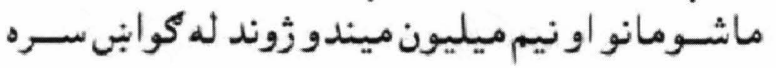

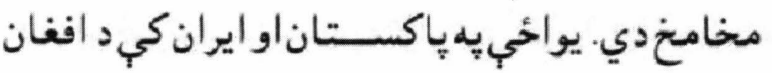

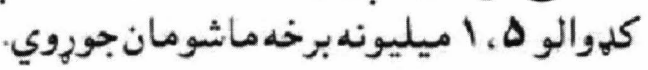

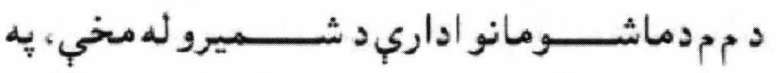

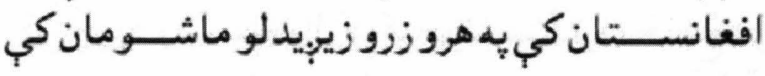

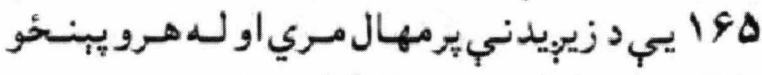

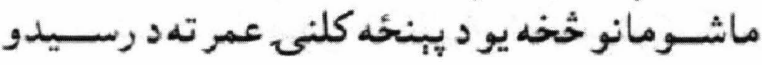
ثخده مخكي مري.

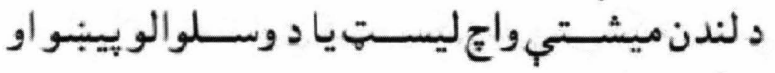

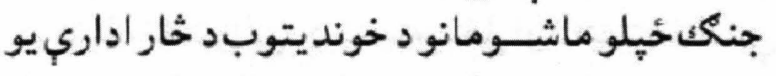

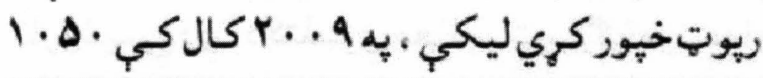

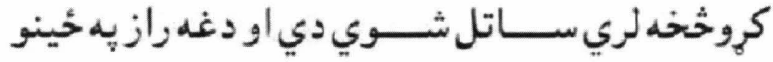

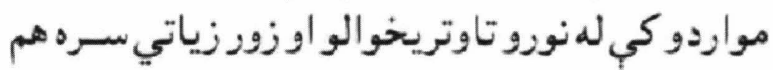

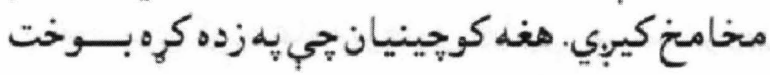
دي دوي دزيده كرو كميت او كيفيت تر يوبنتيتنو لاندي

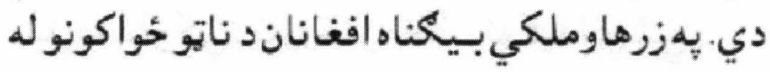

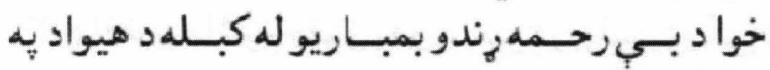

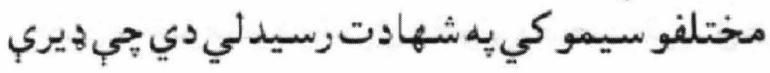
كوخني ماشومان او بندخي دئي.

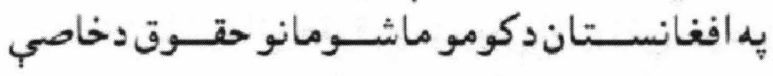

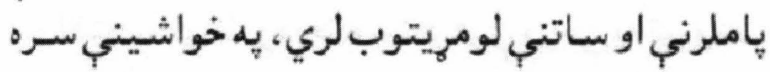

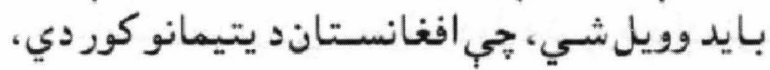

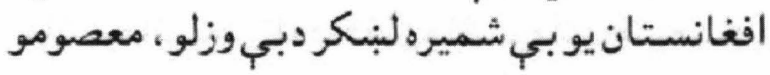

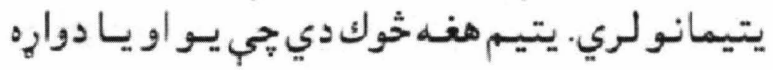

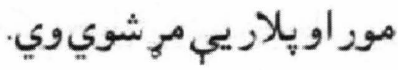

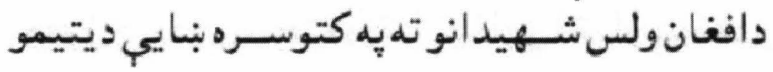

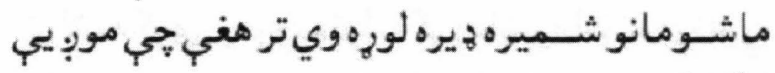

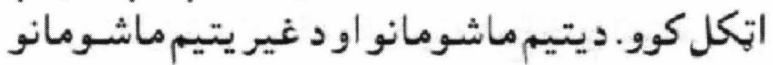

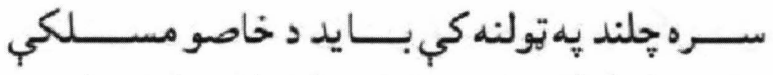

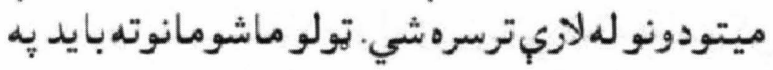

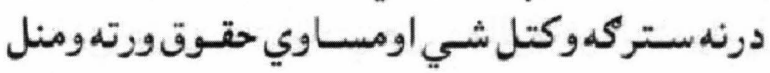

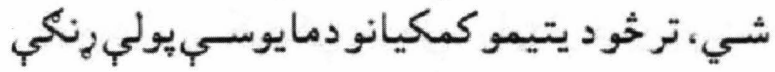

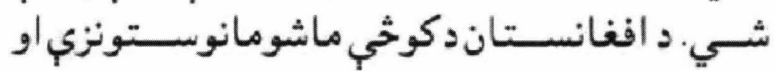

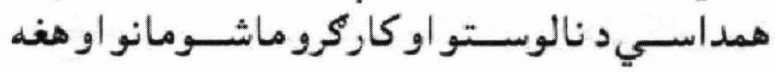

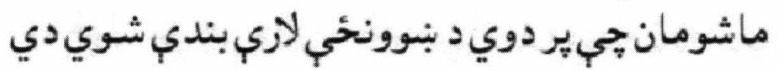

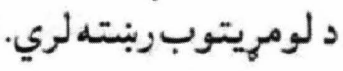

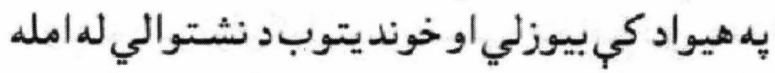

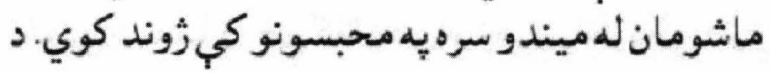

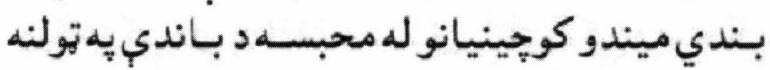

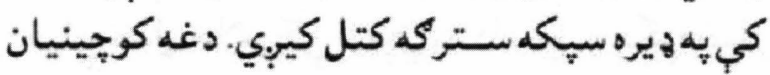

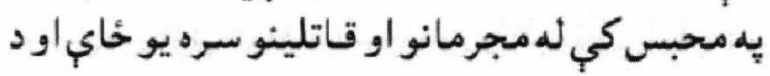
دوي يه منتخ كي لويبِي.

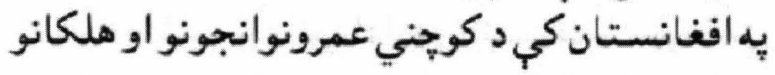

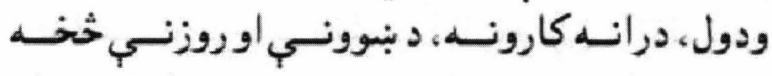

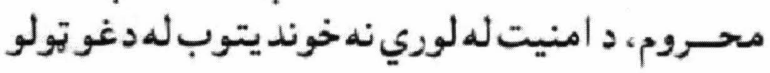

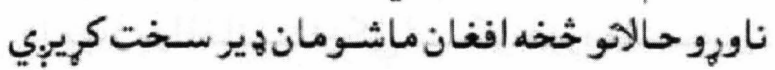

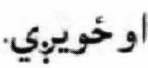
يه اروياً، اسـتراليا او امريكاكي د ميشـــو افغانانو 


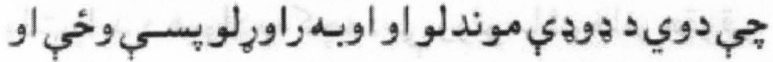

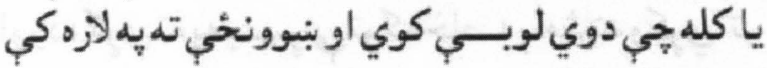

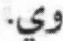

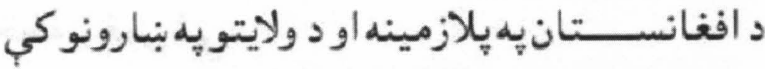

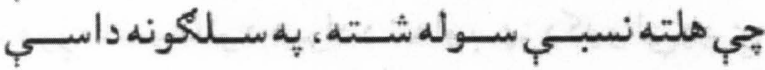

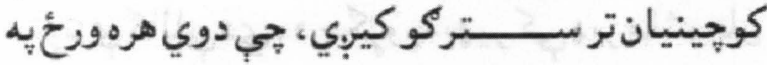

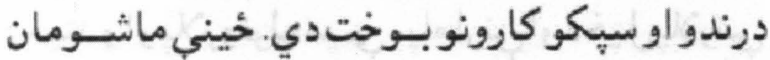

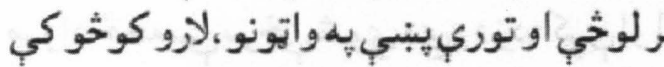

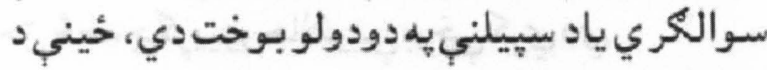

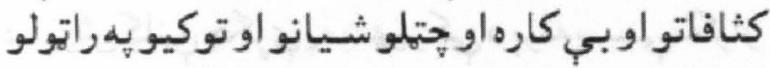

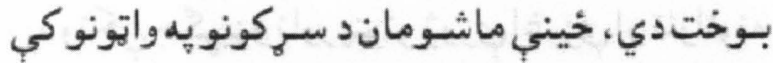

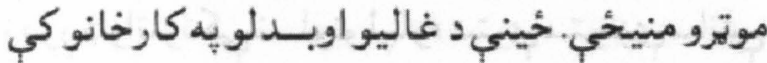

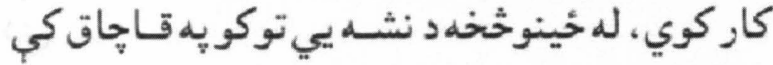

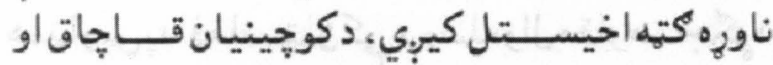

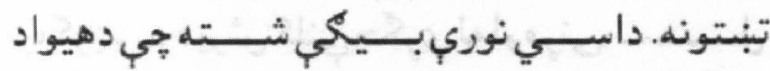

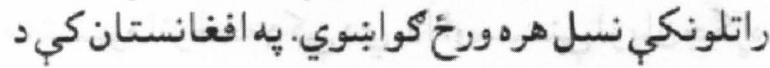

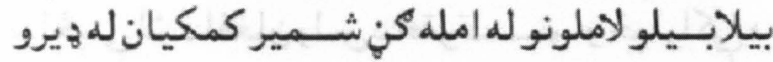

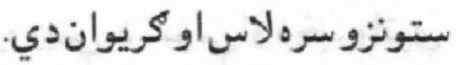

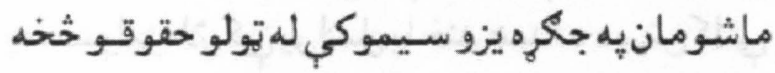

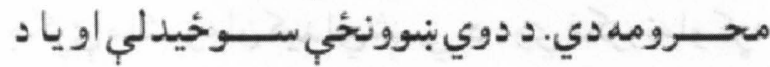

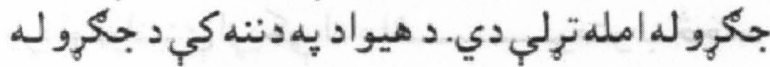

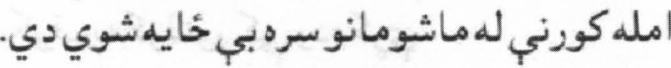

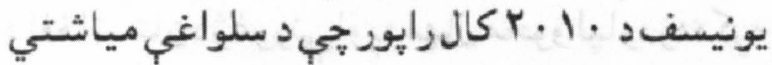

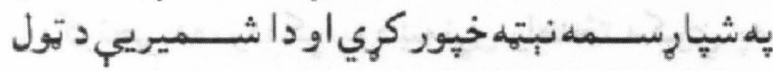

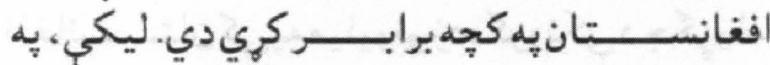

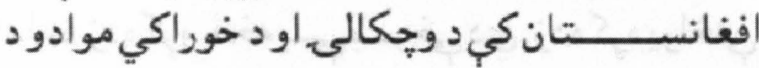

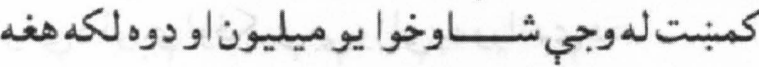

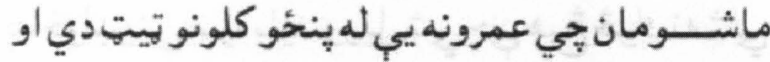

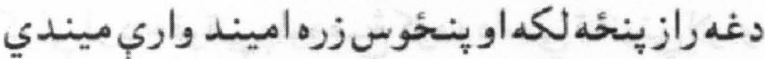

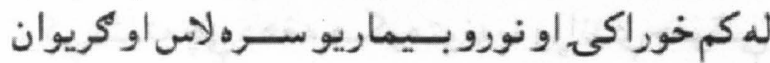

دي.

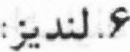

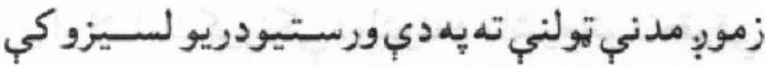

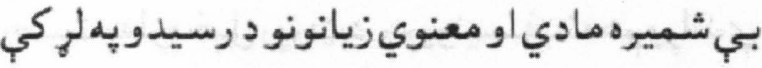

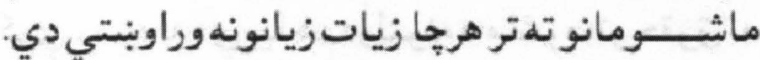

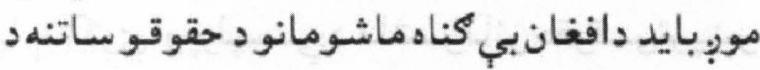

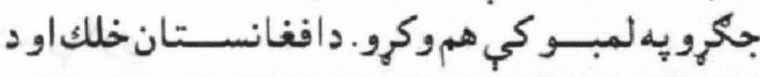

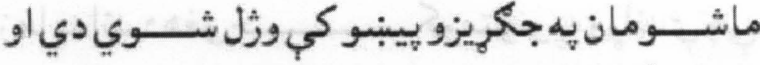

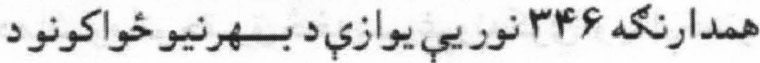

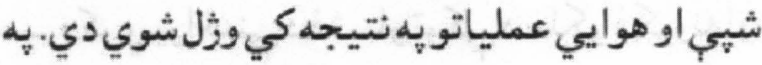

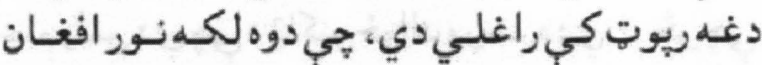

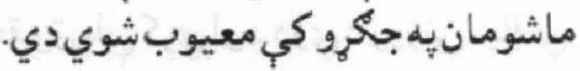

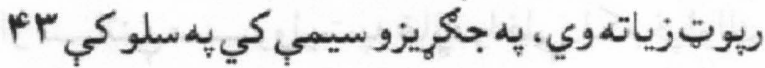

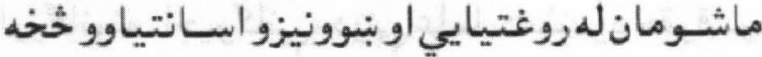

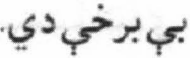

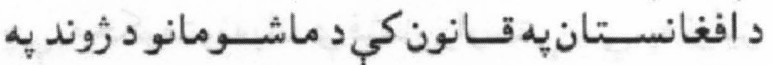

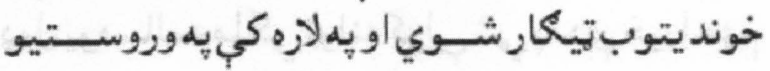

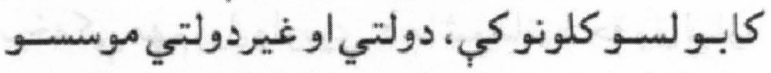

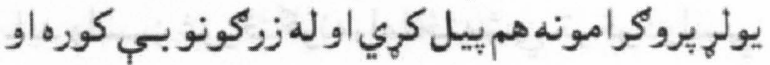

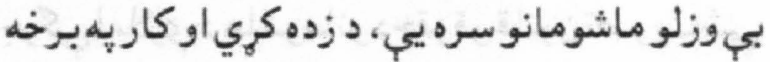

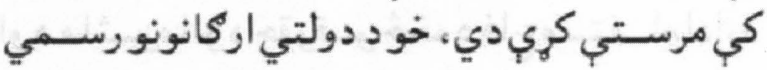

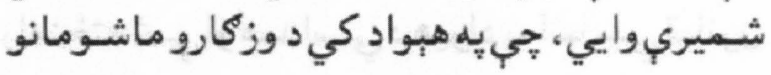

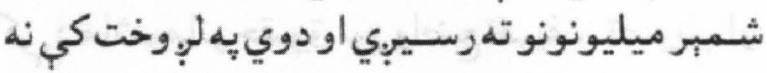

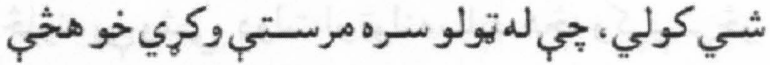

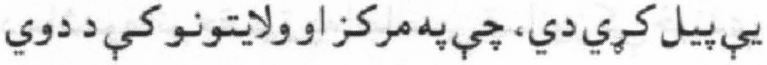

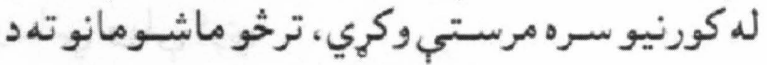
قانوني كار اوزده كري شرايط برابره شي.

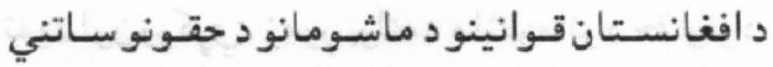

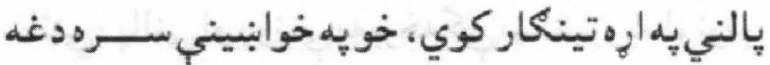

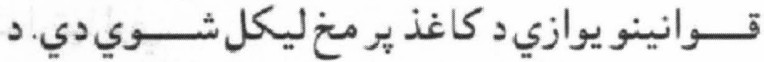

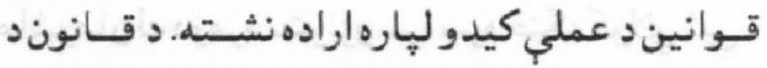

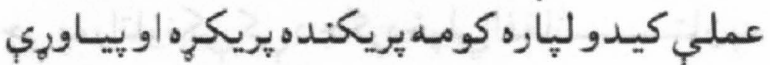

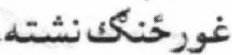

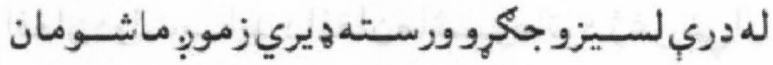

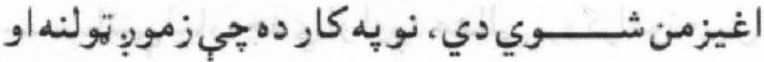

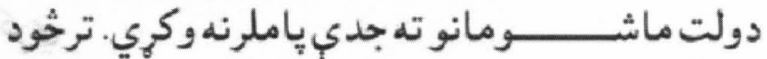
ماشومانو روح او روان نورهاغيزمن نهشي، ماشوماندان

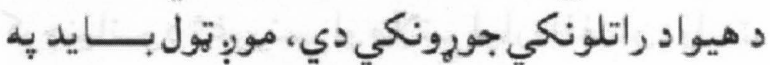

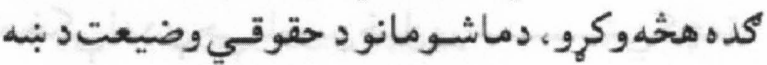

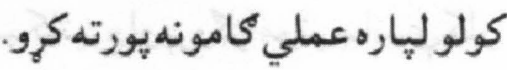

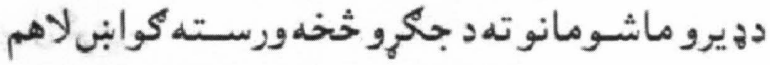

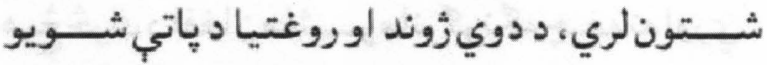

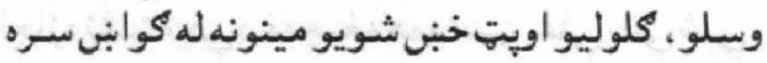

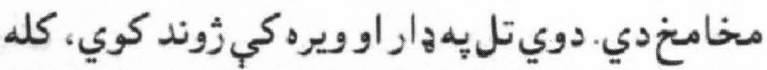




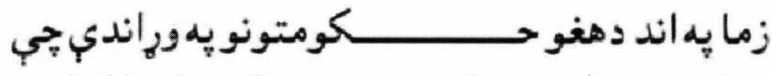

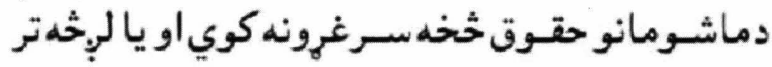

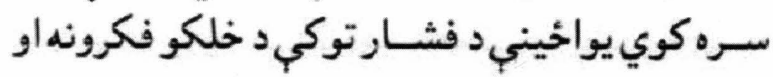
عام ولس دي يجي د تاكنو حواك ورسبره دي. تر ثو يجي د ماشومانو حقوق يلب كري او د دويد روزني، خالني

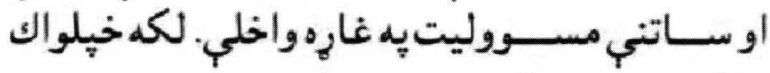

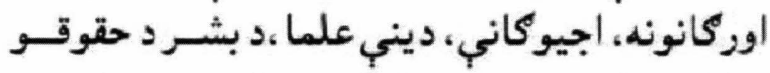

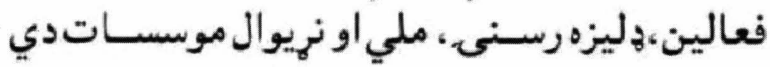

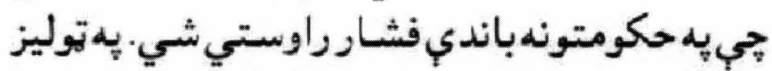

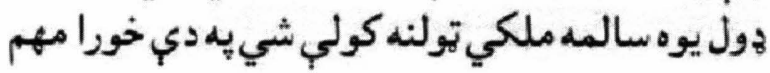

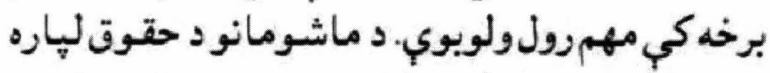
بايد ولسـيز غورخنكونه رامنتخته شي. ترخو دولسي جركي له لازيد ماشومانو دحقوقو قانون تصويب شي شي

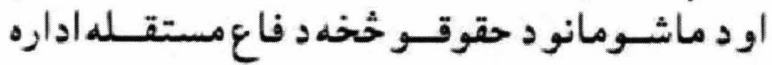

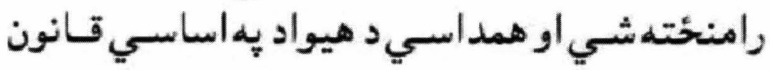
كي د ماشـومانو حقـوق نور واضع تعريف، تصويب اوندي

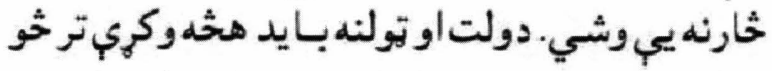

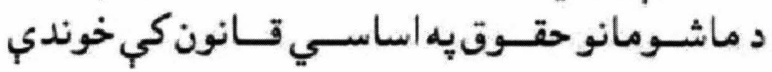
وساتي اويلب كري.

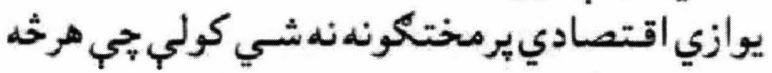

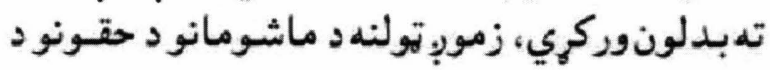

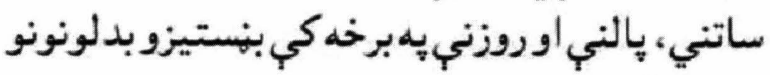
تهارتيا لري. ماشومان له دومره ستونزو سره سره ثنكانه كولائشي،

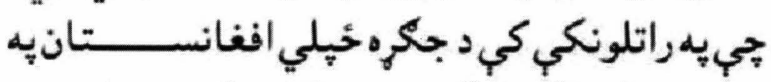

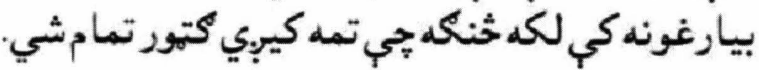

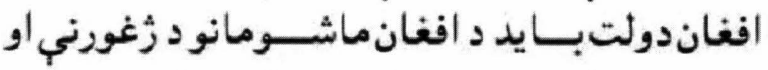

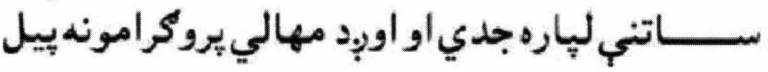

دهيواد يدليري او جيكه يزو سـيمو كي بــايد د افغان

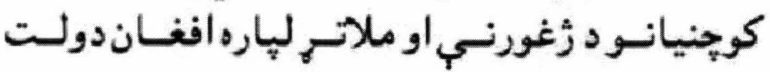

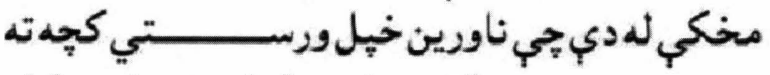

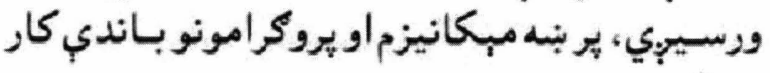

يبيل وكري.

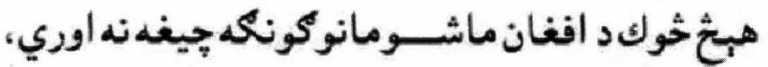

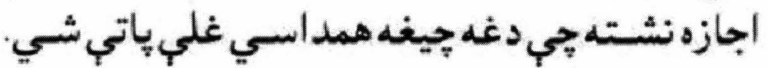
ياى
ولتبايد د هيواد يه كجهد بي وزلو ماشومانو حقوقو

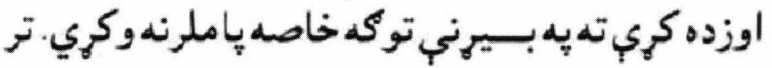

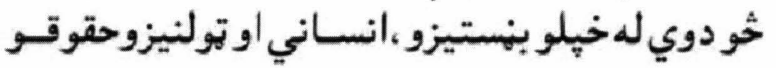
خخنه برخمن شي.

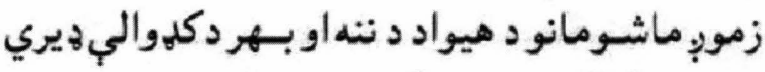

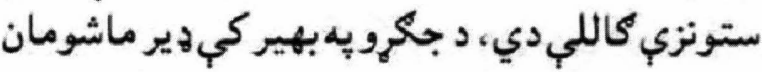
د ميندو اويلارونوله ميني، ياملرني او دخيليّيلارني

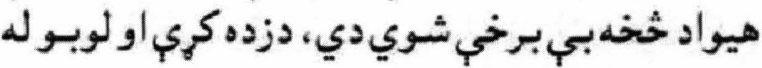

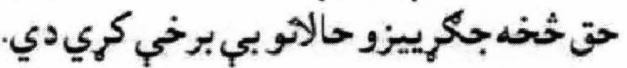

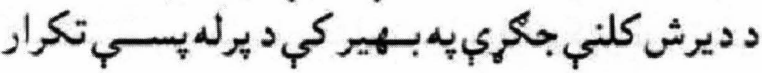

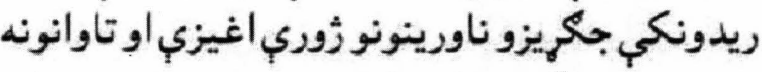
زموبجد راتلونكي نسلونو لياره ستري ستونوينوي ساتلي

همداوس يه افغانستانكي د وسله وال مقاومت جكره

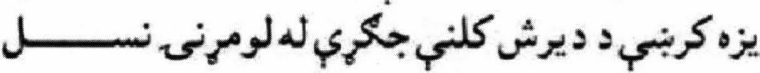

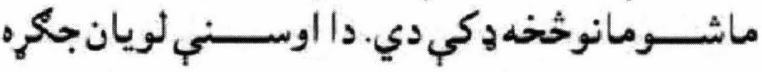

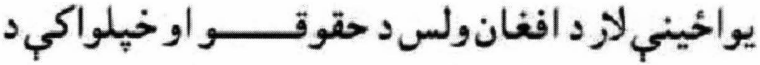
بيرته لاسته راورلولينياره ويني. د سولي اود دخبرواتري

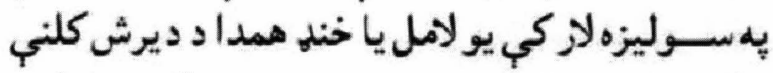
جكي ماشيسومانكيداي شئي د دوي فكرونهاو كره

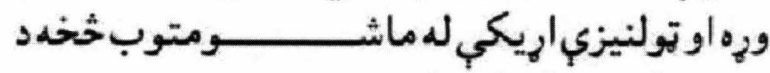
كلاشينكوف يه كولتور كي وده كري.

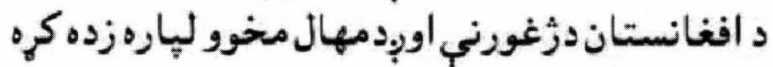
يوه كونجي ده، زده كره يوه بنه نهى رامنحتـه كوي. يه

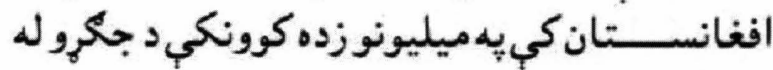
امله زد زه كروخخه بــي بـــرخي دي. زده كره يواخنبي

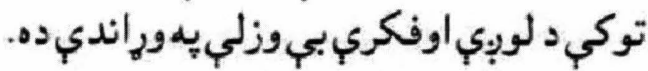

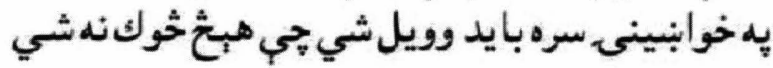

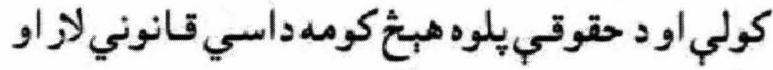

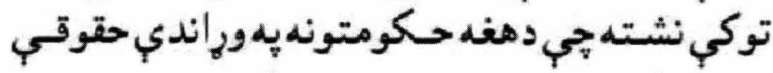

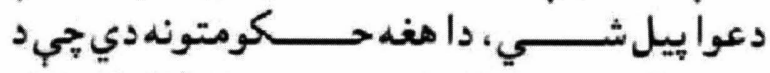

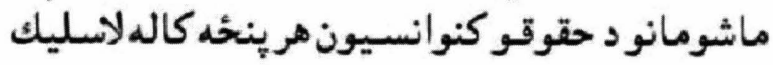
وي اولاسليك كوونكي دولتونهد ماشومانو د حقوقي

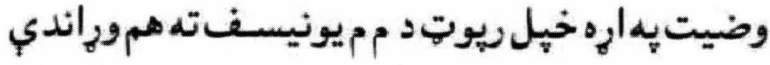
كوي ، سره له دي بيا هم دولتونه د ماشومانو حقوق ته

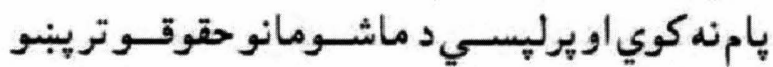

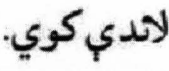


منيزٔه باخترى

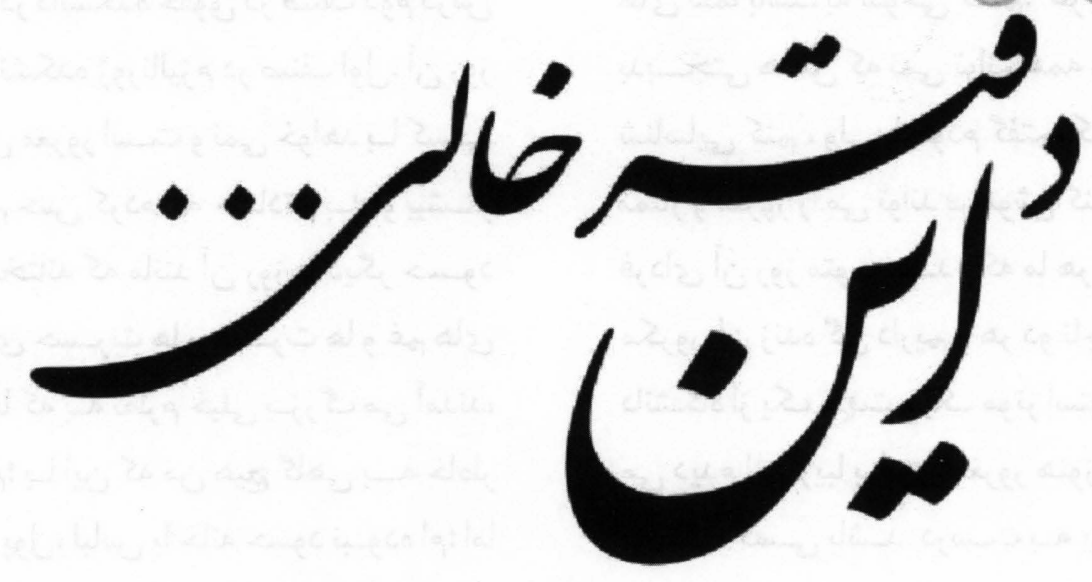

به جستجوى تو بر دركاه كوه مى كريم در آستانئ دريا و علف

به جستجوى تو منتون راعزيز مى داشتند، همراه شدم تا اكر ورزشكار شوم. بايست بكويم كه با ورزش ميانه يى نداشتم ولى براي ابراز

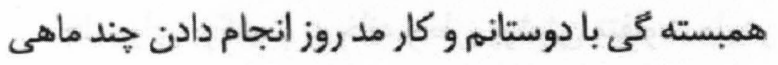
صبحانه وقت، به جمنازيوم مى رفتم ولى به زودى دئ دريافتم

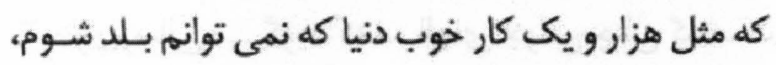
يكى هم بد منتون اسـت. تصميم كرفتم كه ديكر بـه آنجا نروم. حس حسادت خفيفى هم نسبت به دوستانم كه با بـــ

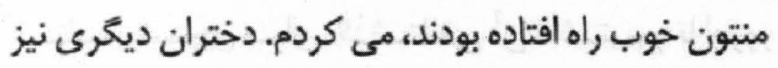

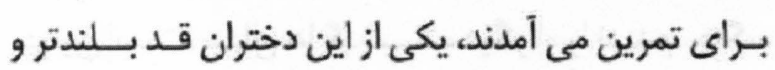
موهاى درازترى نسبت به ديگران داشت و خيلى هم خوب

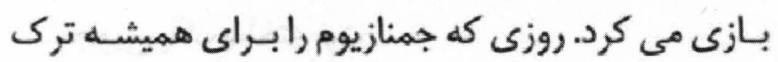

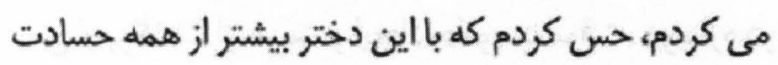

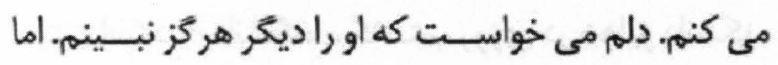

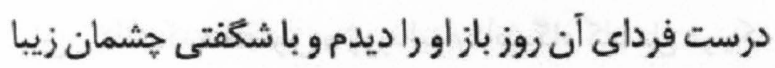

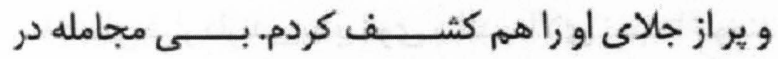
جشمانش آميزه يى اززيبايى، مهربانى و شكوه موج مى زد.

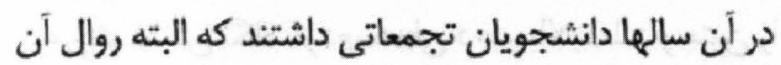

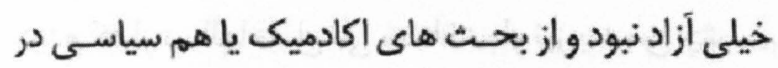

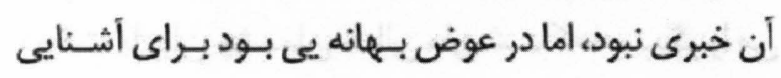

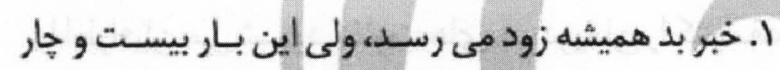

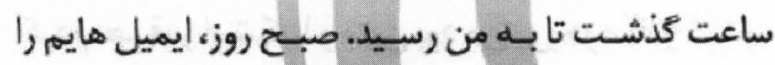
مرور مى كنم. ايميلى دارم از دوست خوبهم اصيلا وردى بـ بـا

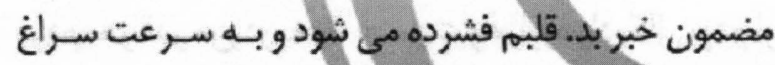

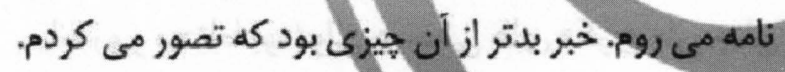

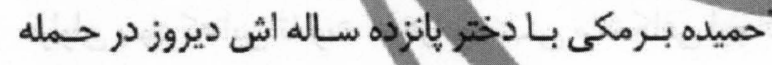

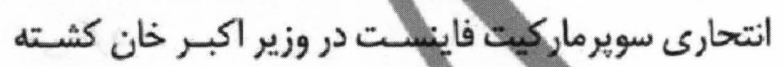

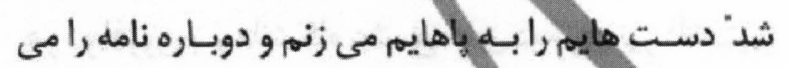

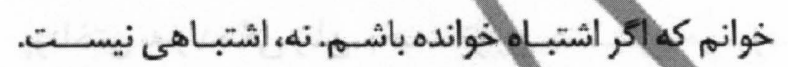

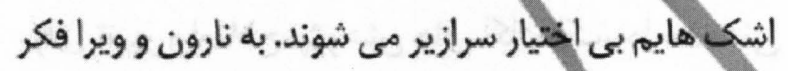

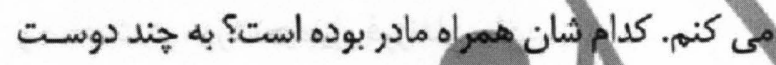

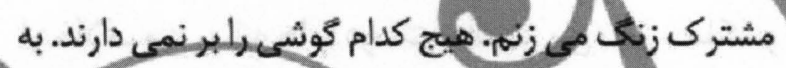

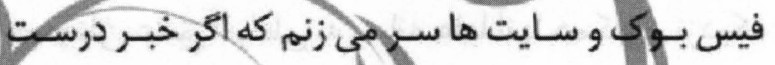
نباشد. هي خواهم خود را فريب بدهم. در فيس بوك به خبر

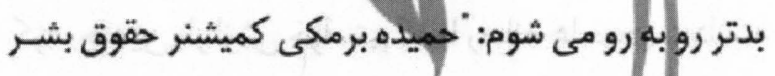

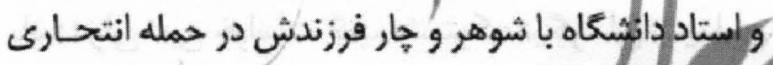
كيروز كايل كشته شدند... 


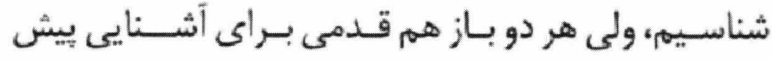

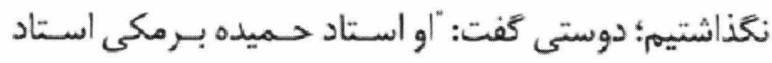

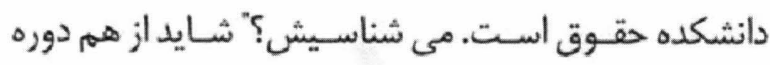
هاى شما باشد. به شوخى كَفته: "عزيز جان بعد از اين همله

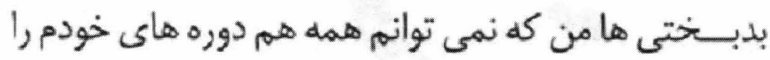

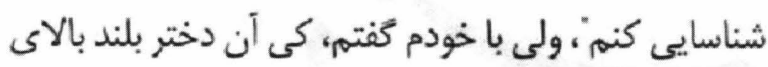

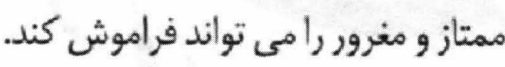
فرداي آن روز متوجه شـدم كه ما هر دو در يك بـ بـالاكى در

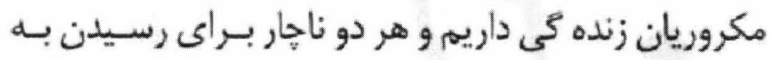
دانشكاه از يك جهت و يكى موتر استفاده مى كنيم. بـاز هم مى ديدم إين زيبا بـانوى مغرور هنوز هم دلش نمى خواهل دوسـت كسـى باشـد. درست بـه ياد ندارم كه كدام ما در

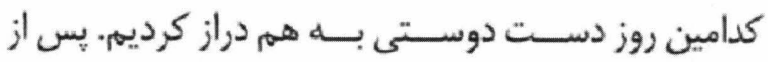

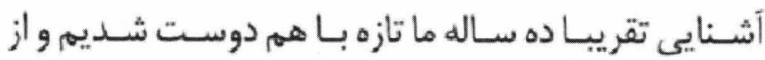

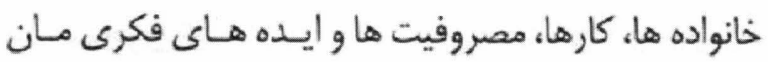
صحبت كرديم. خلاف باور من، او اصلا مغرور نبود؛ اما خنان آرام و صبور و

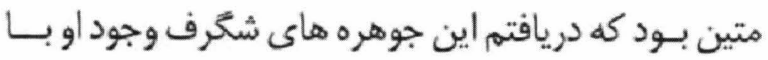

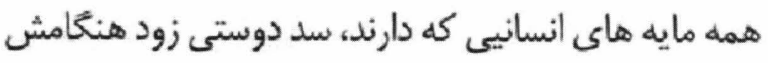

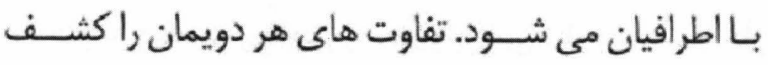

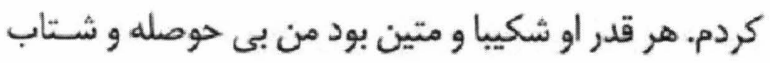

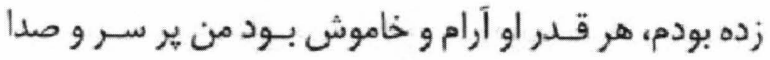

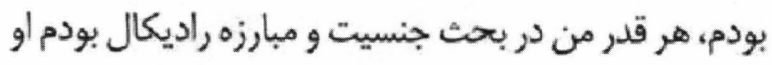

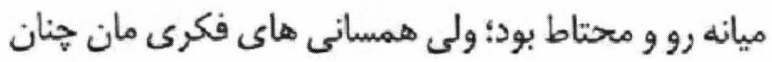

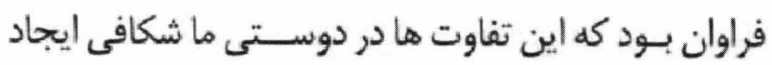

$$
\text { نهى كرد. }
$$

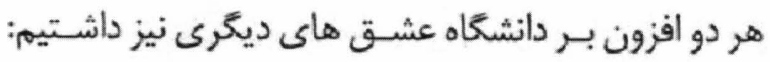

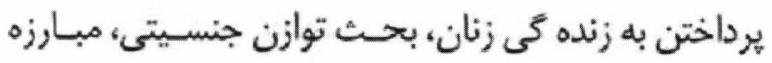

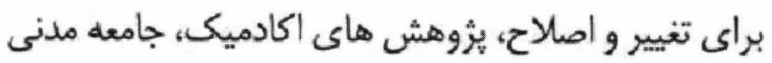
و صحبت در مورد تحصيل فرزندان مان... او خلاف من رسانه ها را دوست نداشت. من بنابر مسلك و وردئ.

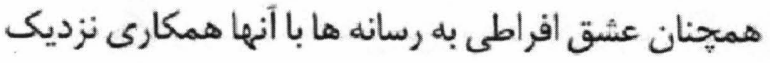

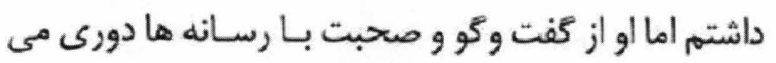
كرد. جندين بار ازش خواستم كه با رسانه ها صحبت داش داشته باشد: ولى نمى خواست. كي مشـترك ديخر مان، بـيمارى

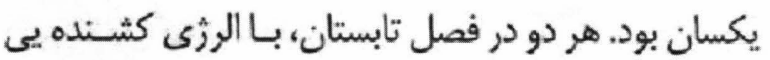

بيشتر دانشجويان كه آن هم در آن زمان و فضاى مختنق و

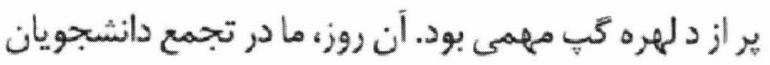

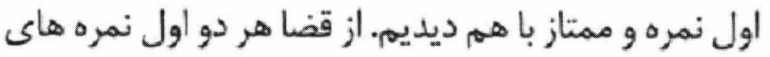
صنف خود بوديم؛ او در دانشكده حقوق در صنف دوم درس

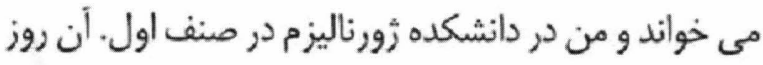

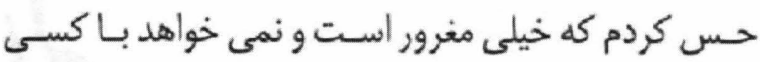
همكلام شود. باز هم حس كردم كه حسادتم بــه او بيشـتر

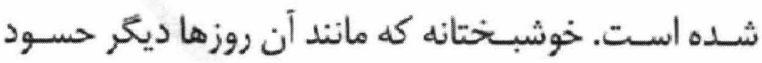

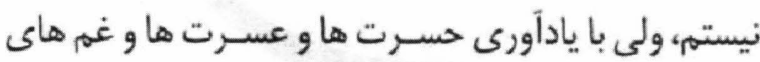

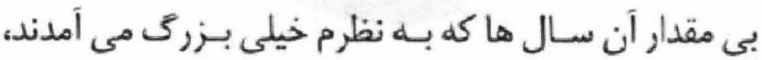

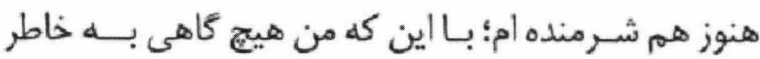
مظاهر مادى؛ حون: يول، لباس يا خانه حسود نبـوده ام؛ اما

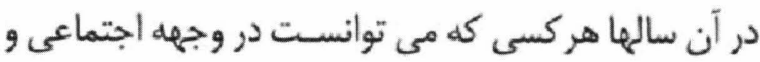

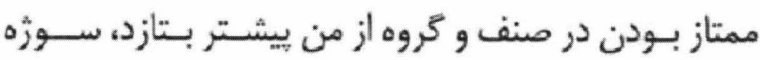
حسادت هاى ظريف من مي شد، بلون اين كه خود بداند.

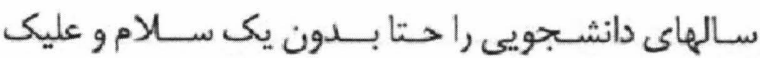
معمولى كذشــتانديم، و هيج كدام در شــاخت و يا ايجاد

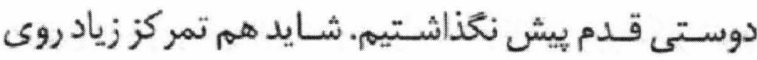
درس، اصابت راكت ها به صورت متواتر در حـومه دانشكاه و عجله براى بركشت به خانه و طرز يوشش متفاوت ما، در

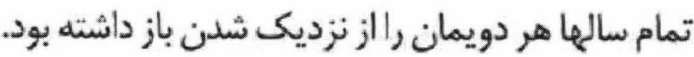

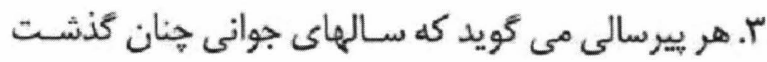
كه هيج ندانستم. ولى سال هاى كودكى، نوجوانى و جوانى نسل من با خنان بدبختى هاى عجين بـوده اسـت كه خود شـتاب بيشـترى بــراى كذشـتاندن آن داشـتيهم و تا امروز

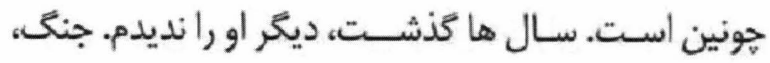
مهاجرت و غربت، حافظه ام رالز همه آشـنايان سـال هاى داتشجويى هاكى ساخته بود. يس از بركشت از غربت و ايجاد حكومت موقت، دوبـاره در هيئت استاد به دانشخاه بركشتـته. روزى در دهليز دانشكده

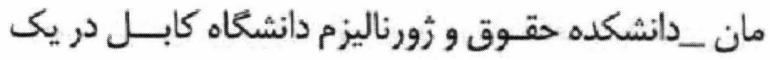

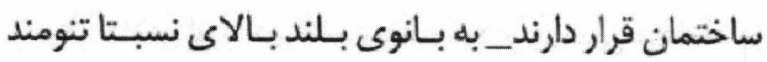

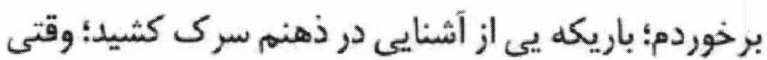

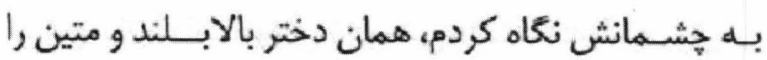

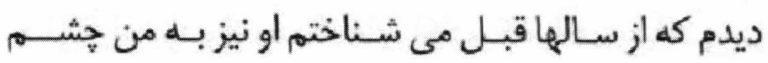

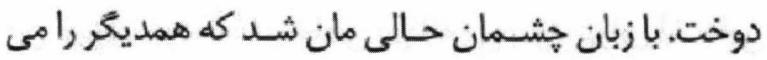


مدنى يرداخت. كتاب نوشت، مقاله ها خاب كرد، خيتر هاى درسـى آماده سـاخت، و در فرجام هم بـا عنوان كميشـــنر كميسيون مستقل حقوق بشر بيوست تامبـارزات و فعاليت

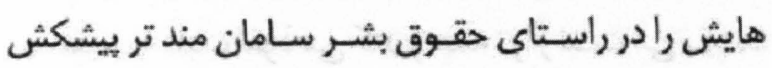
نمايد. او عضو فعال مركز ملى تحقيقـات ياليسـى دانشكاه

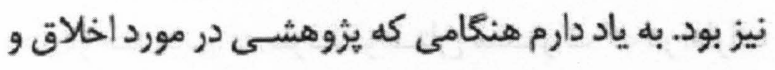

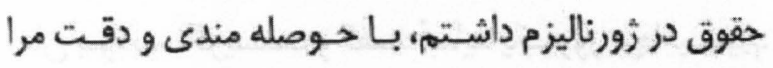

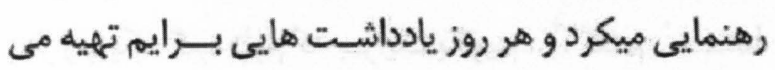
نمود.

دوست متين من با اين همه كارنامه هاي درخشان، به قول

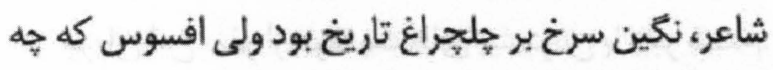
زود بر افتاد.

داغدار مرك عزيزى جون توييم، دوست من!

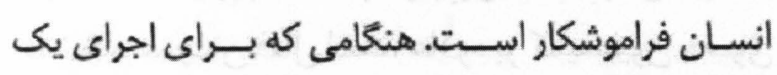

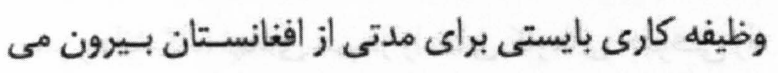
شدم، فرصت نكردم كه از استاد حسميده خداحسافظى كنهم.

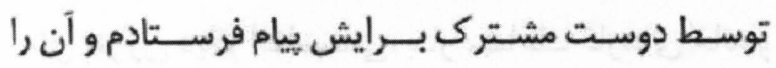

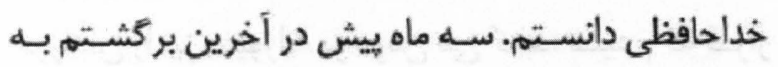

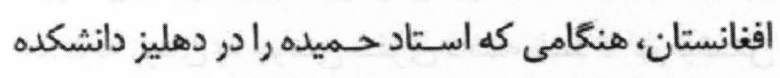
حقوق ديدم كله مند برايم كفت كه خطور توانسـتى بـداند خداحافظى بروى، من يك هزار كِي برايت داشتم. من من

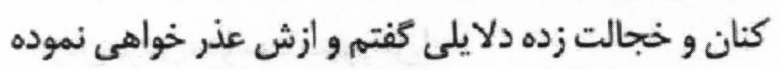
شوخى كردم: "من فكر مى كردم كه غيبت صغر امى كنهم و

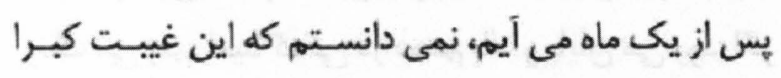
ست و بيشتر از يكى سال به درازا ميكشد". كفت: "مى ترسيدم ازم خفه باشى"

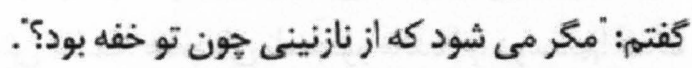

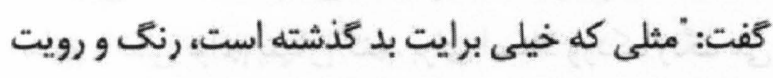

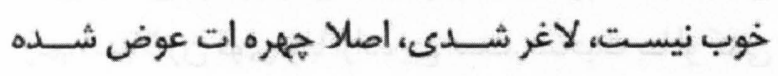
است:

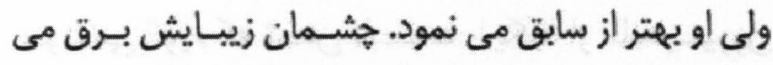

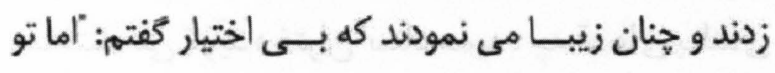

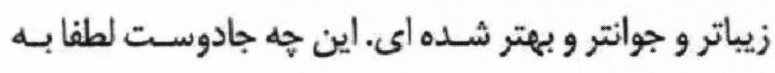

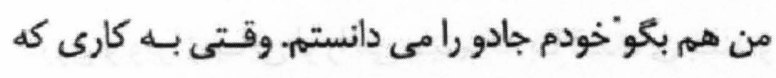

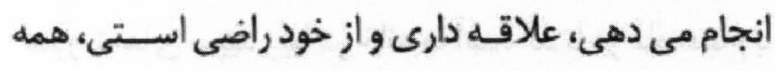
جيز خوشايند است، همه جيز رازيبا مئى بينى وارئ واين زيبـايى
نسبت به هوا عذاب مى كشيديم و نسخه ها و داروهايي به

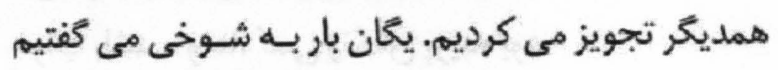

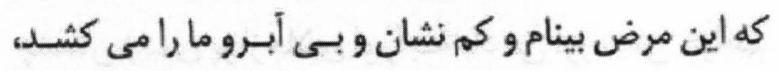

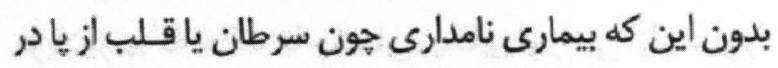
أوردمان. اين الرخى سـخت آزار دهنده، در فصل تابستـان

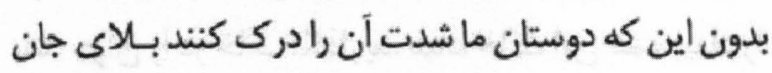
جسم و كار هايمان مى كرديد. و او همواره به صبـر دعوتم

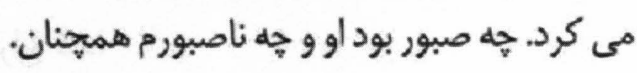

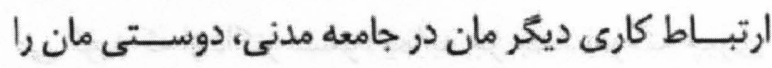

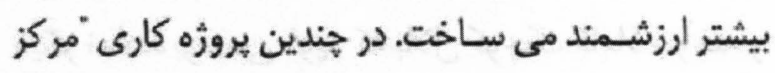

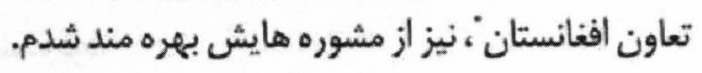
دوستى ما آرام آرام ييش مى رفت و من حس مي مى كردم كه

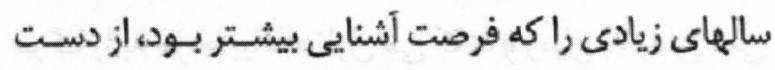
داده ام و ديكر نبايد كم بياورح.

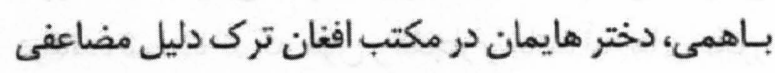

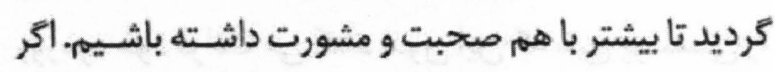

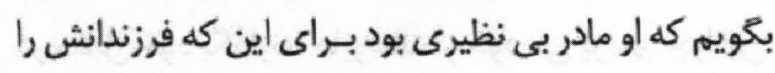
عاشقانه دوست داشت، شـايد دليل مناسبـى نباشـد، جهون همه مادران فرزندان شان را عاشقانه دوسـت دارند. او مادر

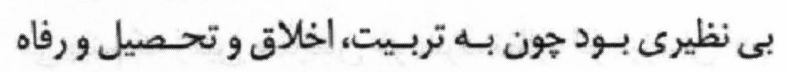

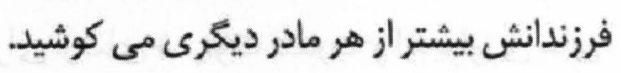

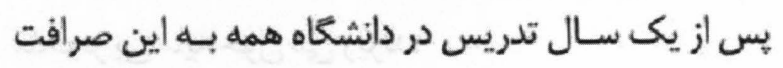
افتاديم تا صادق لــانه اعتراف كنيهم كه نام (اســـتاد دانشكاه (كمى براى مان زيادى است. تحصيل در شرايط نامناسب،

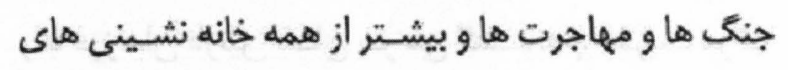
دوران ناشريف طالبان دست به دست هم دماد داده بـودند تا ما

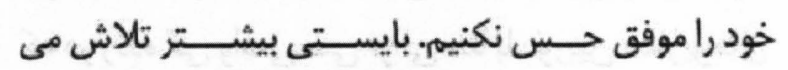

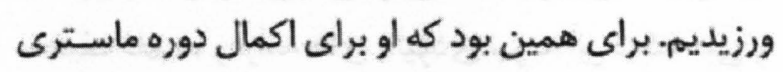

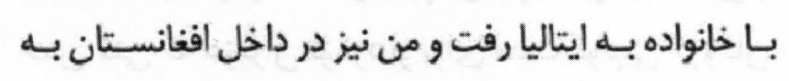
درس خوانى و تلمذ بيشتر در دوره ماسترى يرداخته.

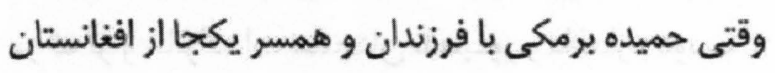

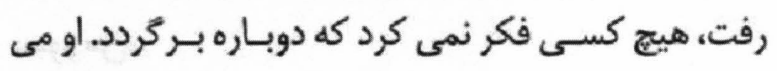

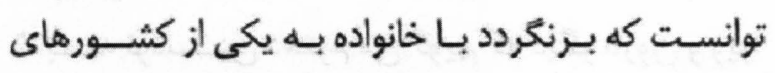

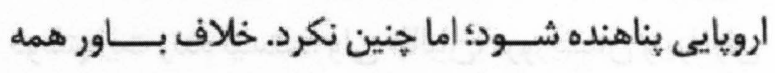

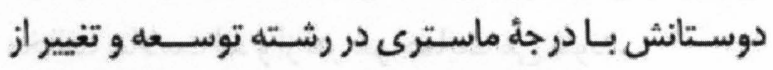

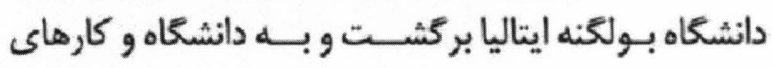


مى كويد جشمان استاد حميده نيمه باز مانده بود ولى انكار

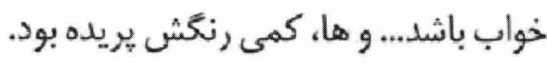

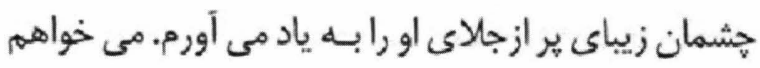

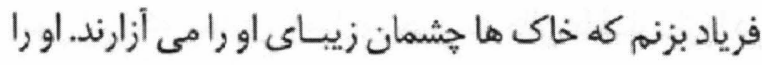

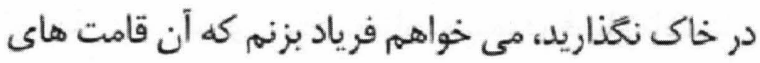
بلند جوان را در خاك نكذاريد. مبادا خاك اين همه بيداد را ران تحمل نكند، مبادا زمين از بلعيدن يك خانواده خوشبـخت

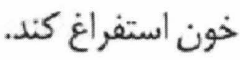
مى كَّيد كه از داكتر مسعود يما به جز جسد سوخته جهيزى

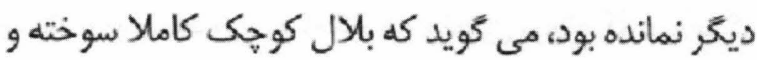
يران شده بود.

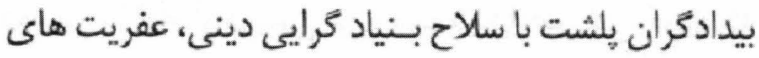

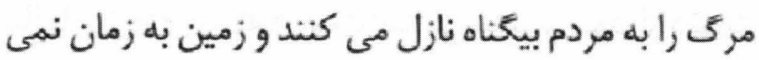

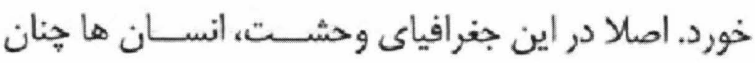

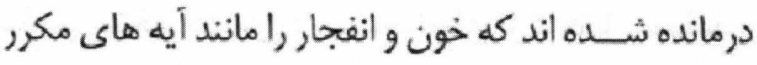
روزمره خود قرائت مى كنند بدون اين كه هيج يرسشى رانس در مقابل خود بخذارند. مايوسانه از خود مي يرسم: حرا هراين

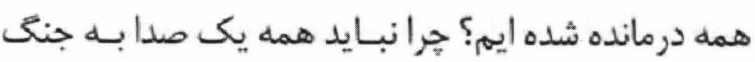

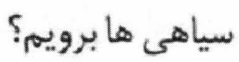

مى بينم كه زمين همخنان خونسرد، نظاره كر فرزندان آدم است كه بـراى ارضاى شـهوت قـدرت و ايديولوزى هاى متحجر بى مايه خون مى ريزنلد.

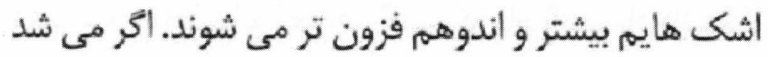

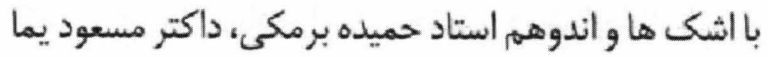

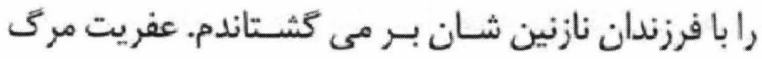

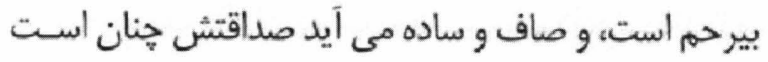
كه در زنده كى واقعى نمى توانى حتا با دوربين سناريوهاى

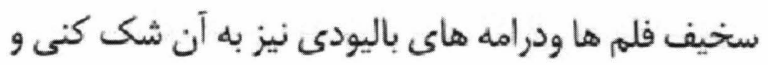

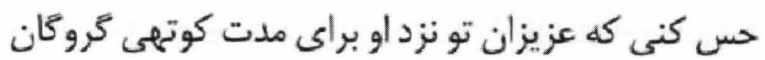

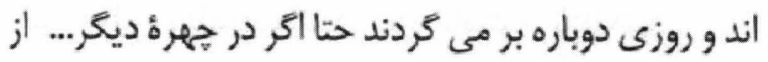

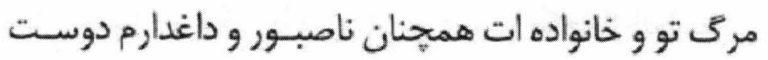

صبور من.

ه. بـــــه نوشـــين دخترم مى كَّيم كه ديخر نارون و ويرا دوستهايت زنده نيستند؛ ولى طالبان، تروريستان و برادران مخالف سلامت اندو واز هر سو حمايت مى شوند.
مستقيهم بـه قلبـت نفوذ مى كند و همه تر ازيبـا مى بـينتد،

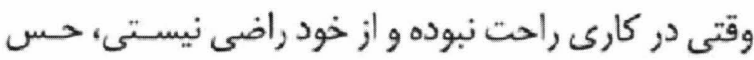

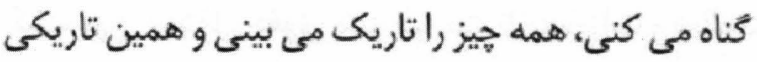
مستقيم به قلبت نفوذ مى كند و همه ترا زشـــ مى بــينتد. اين راز زيبايى تو بود دوست صبورما

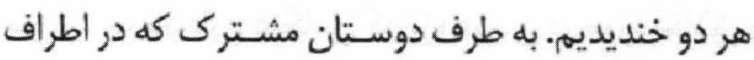

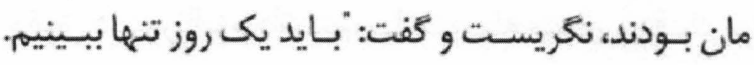

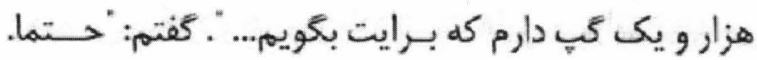
كوشش مى كنم كه ببينمت".

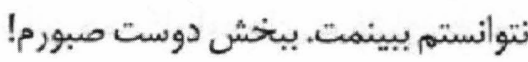

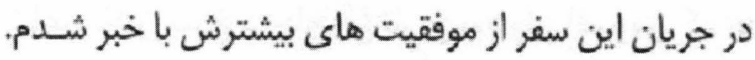
ديدم كه خلاف سالهاى قبل با رسانه ها ييوند خوبى ايجاد

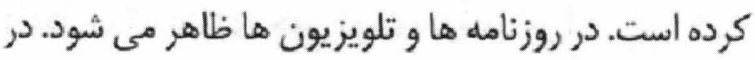

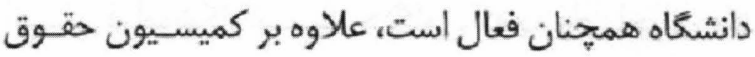

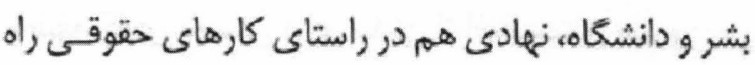

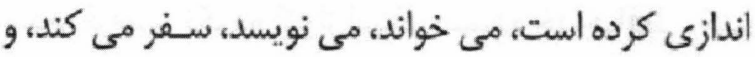

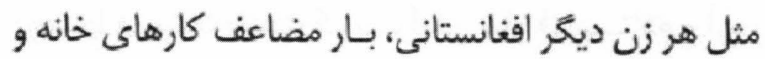
فرزندان را نيز صبورانه بر دوش مى كثلد. شنيدم كه قـرار است به زودى به جرمنى سفرى داشته باشد تا كار نبشـتن فئن رساله دكتراى خود را در انسـتيتوت ماكس هيلانج بـيـاغازد.

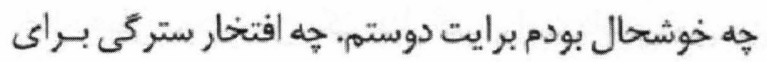
ما زنان بودى، دوست صبور من! f. به دوستان مشتر مانى مان جاويده احسمدى دونى و شـهمال فريد

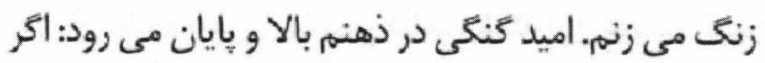

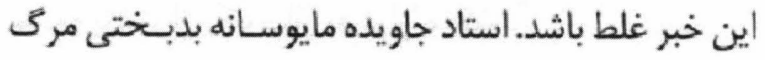

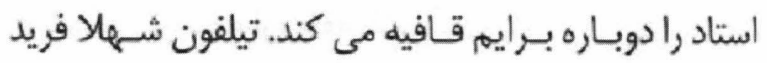

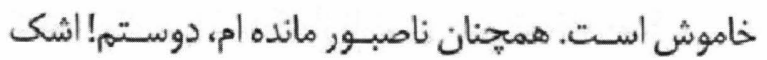

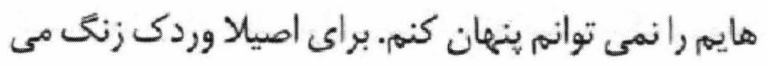

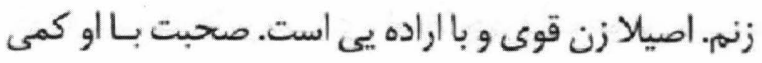

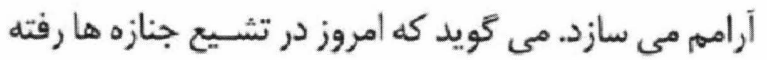

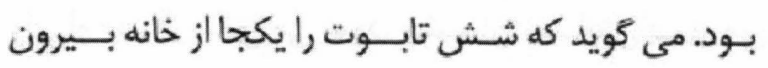

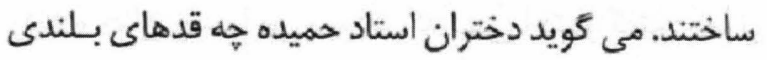
داشتند. نارون و وير زيبـايى او رامى بــينهم كه بـا قـدهاى بـلندو صورت هاى سييد زيبا در خانه ما آمده اند تا در ماه صيام با بـا نوشين از استادان ترك شان هذيرايى كنند. 


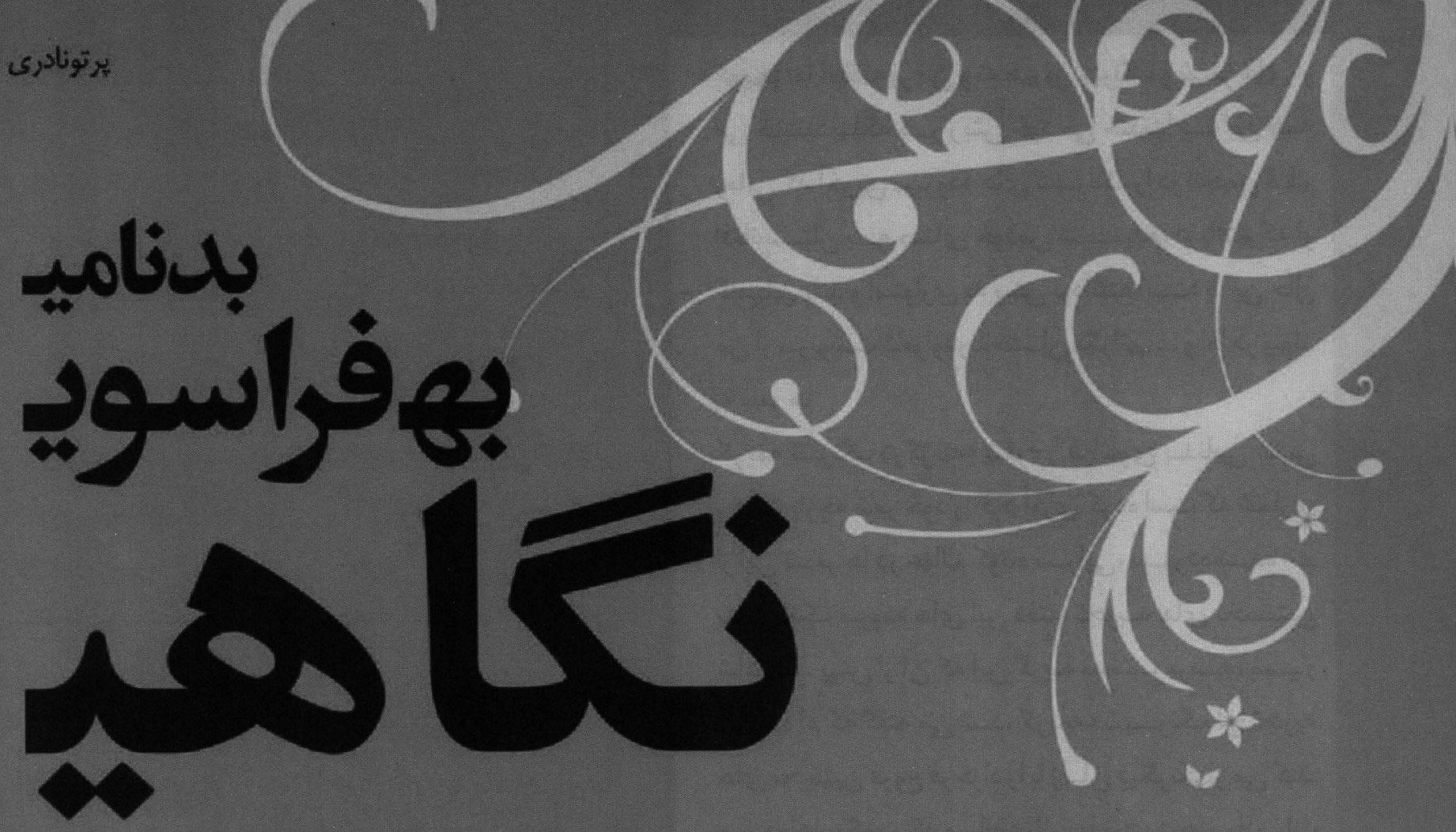

رها شده است به سوى اين ايتذال مسـلط روز كار كه خون

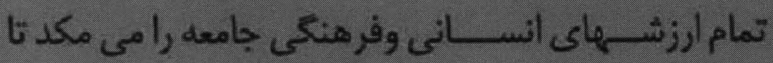
هستى ما رابا يوسـيده كى ييوند زند. از روزكاران بيشـين

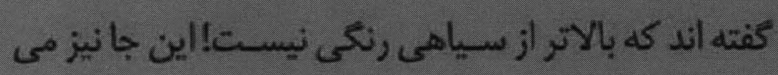

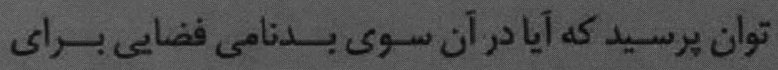
زيستن است؟ اما جيكونه شاعرى در نخسـتين كام بـهان آن سوى بدنامى رسيده است! أن كه به سياهي مى رسل ديكر درجستجوى رنكى نيست. رنك ها يايان يافته اند و شـايد

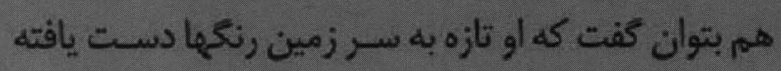

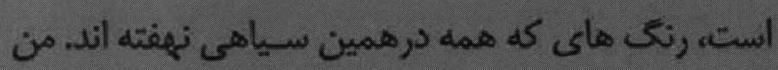
فكر مى كتم كه شبرنغ با باين نام كذارى تمام نيك نامى

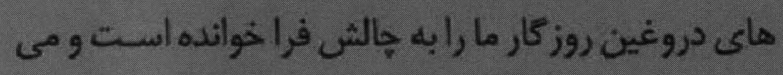

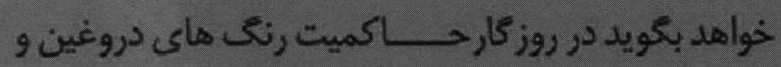
نيكنامى هاى كاذب، همان سـياهى صادقـانه بهتراست

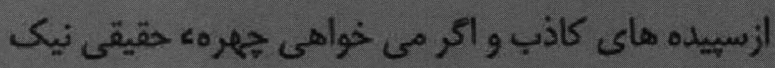

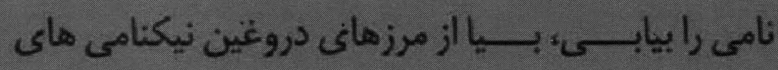

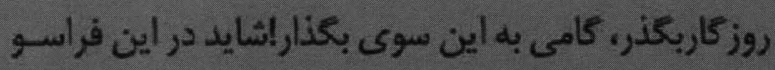

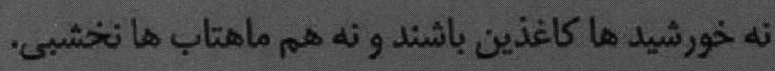

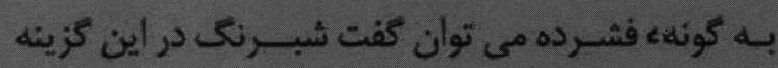

"فراسوى بدنامى" شايد دهان كجيى است بـه سـوى تمام

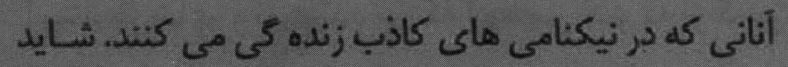
ti

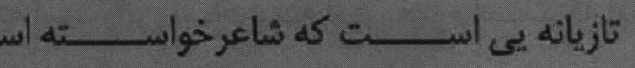

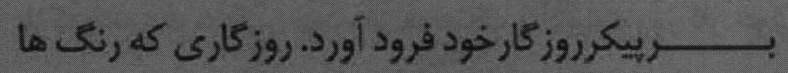

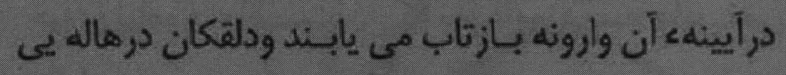

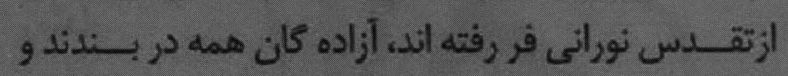

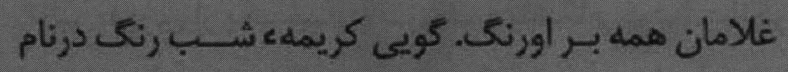
نخستين كزينها شعرى اث فر اسوى بدنامى "تمام مفنوم

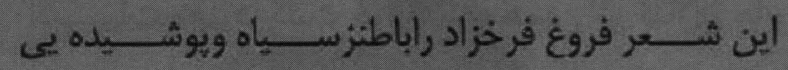
متبلورساخته است: در ديده كان آينه ها كوريى

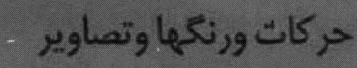

$$
\begin{aligned}
& \text { وارونه منعكس مي كَّت } \\
& \text { و بر فرازسردلقكان يست }
\end{aligned}
$$

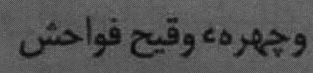

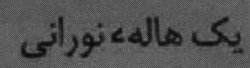

$$
\begin{aligned}
& \text { مانغد جتر مشتعلى مى سوخت }
\end{aligned}
$$

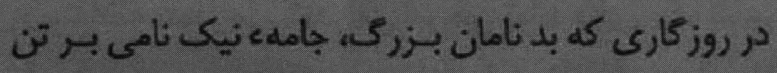

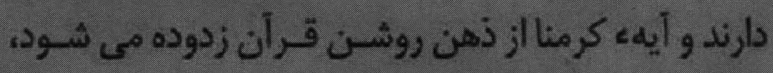
فراسوى بدنامى يك فرياد است، فريادى كه جنان تيرى 
كويند؛ اما آنها نه بر من و نه هم بر شبر نغ و شعبر هاى او

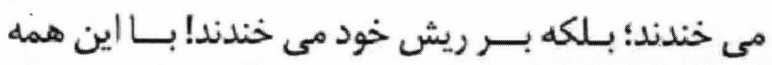

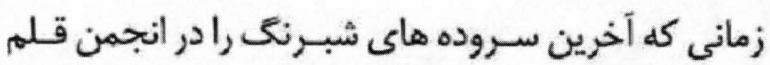

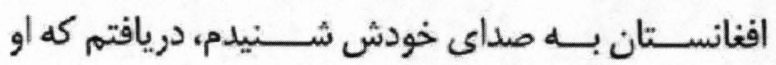
كامهاى بلند و استوارى به بيش برداشته است؛ با باين حال

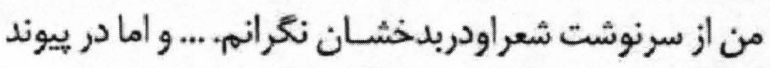
به شعر ها كريمه شبرنك دركزينهء شعرى" فراسوى بــنامى" سـى

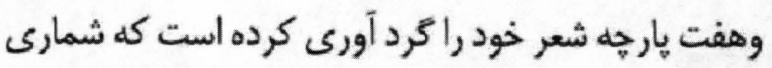

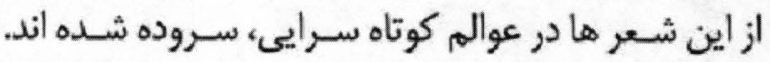

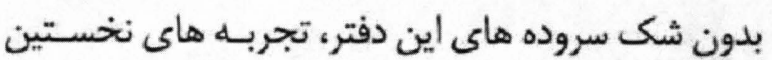

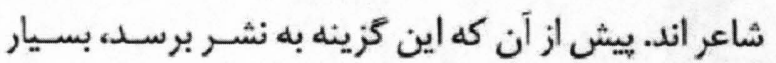

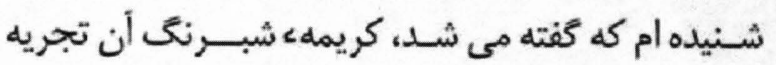

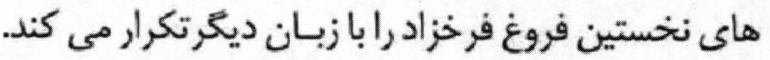

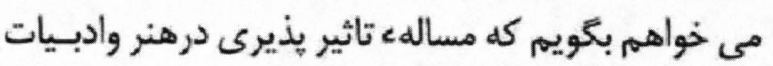
يك امر بديرى است. شايد در جهان شـاعرى وهنرمندى را نتوان يافت كه درمرحله يیى متاثرازيبيشكامان خود نبون

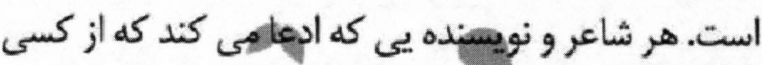

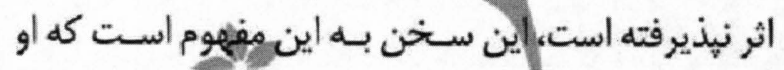

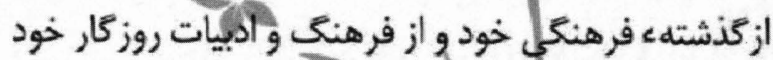

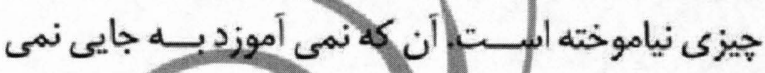

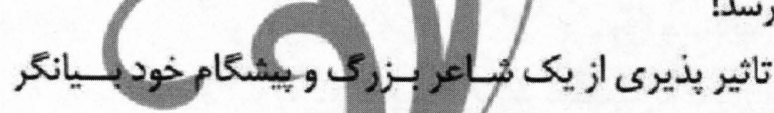

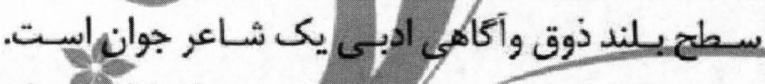

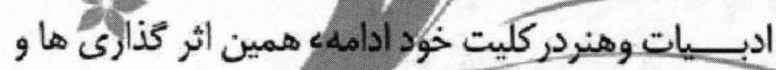

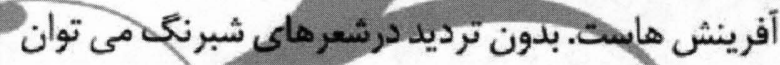
جاى بائ نكرش شاعرانه وزبان فروغ فرخزاد ويا شاعران

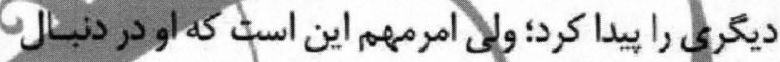

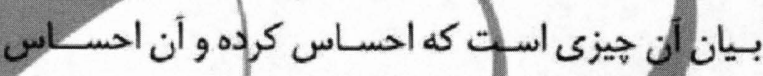

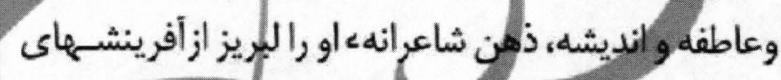

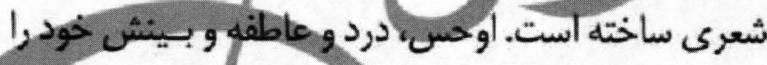

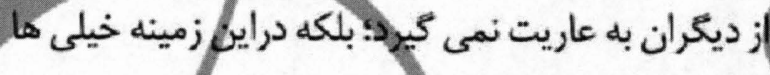

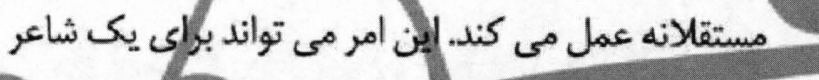

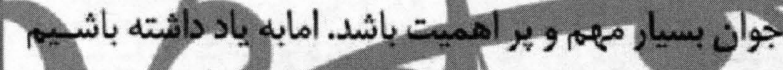

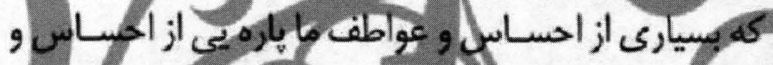

تلخترين ييام رابـراى ما فرسـتاده اسـت وآن اين كه اين

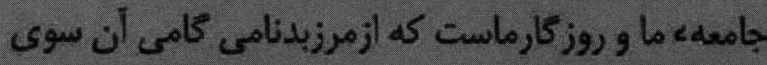
نهاده است. نتختين ديدار روزى شـاعر دخترى بـــه دفتر من أمد. خاموش، آرام ودر خود فرو رفته، اندوهكين مانتد يكى درياجه يى كه كويسى

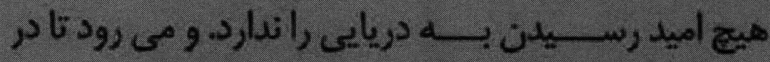
ريكستانهاى سوزانى بـخشكد. سيماى اندهكين، صداى

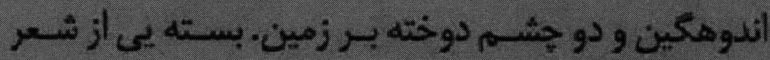

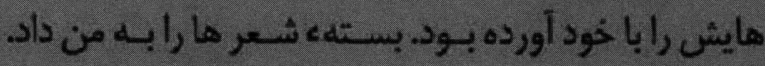

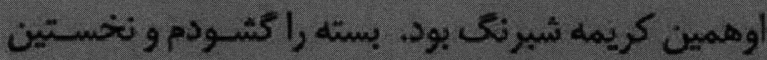
سطرهاى نخستين شعر راخواتدمه سطر ها مرابا خود مى بردند، آرام أرم صدايم بلند وبلند ترشد وبعد تمام شعر رابـا بـا صداى بـلندى خواندم. من از خواندن شعربـا صدائ بـلند

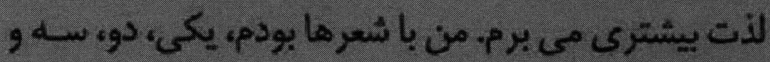

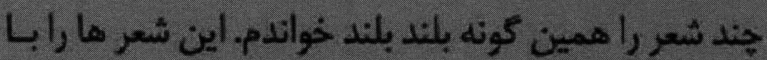
حس، عاطفه و زيان خود بسيار نزديك احساس مى كردم و مى خواندم. ديكر حس من حضور شبـرنك را يس زده

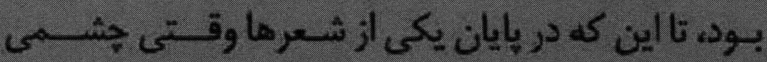

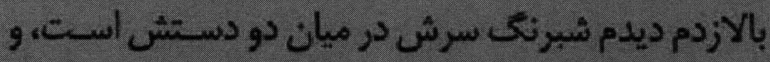

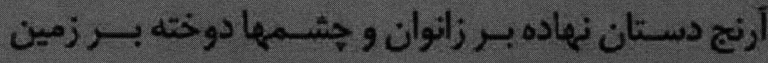
وسرايا كوش. فكر كردم مى كريد. شايد هم در دلش مى كريست. تامن خاموش شدم اوسرى بالا زد وتقريباً جنان

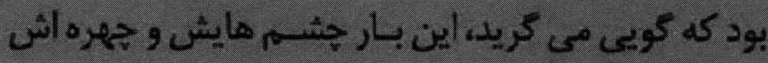

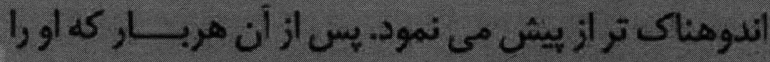

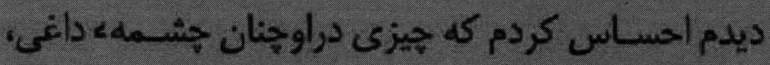

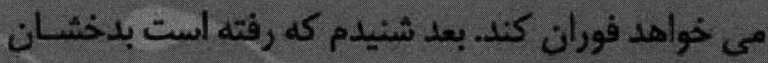

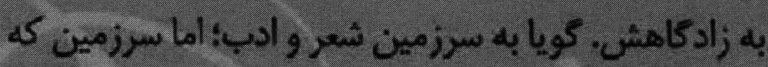
شعر به مشكل در آن مى تواند به بـالنده كى و ثمر برسيدا.

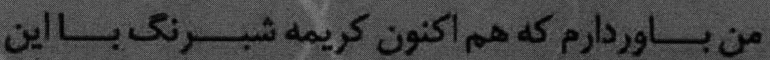
شعرهايش درأن جا با مشكل بزركى روبه رو است و يا هم

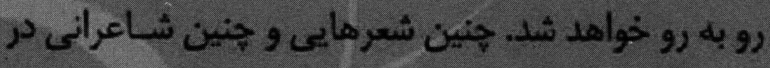

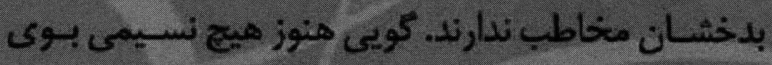
تجدد اديى را به دره هاى تثك بلخشان نبـردهاست. مى

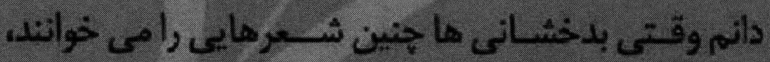

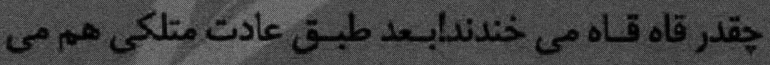


در فرهنك هاى كونـائون وجوامـع كونـاكون از مفنهوم

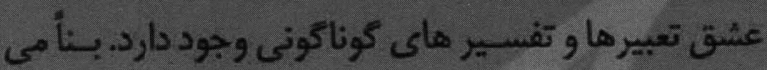
توان كفت كه عشيق خود يك مفهوم اجتماعى وفرهنكي

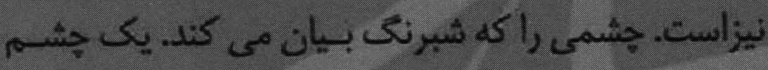

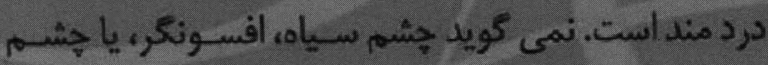

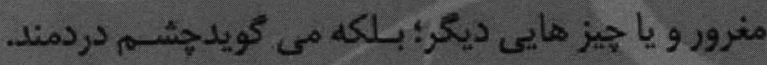
اوسرنوشت خود را وسرنوشت كسى راكه دوسـت دارد بـا إيرها و كبكشان هاي دلكير درميان مى كذارد. درحقيقت

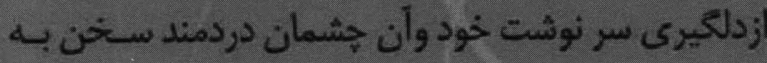
ميان مى آورد. اما جرا جنين است؟ براى آن كه ديوارهاى بست و بلثد اجتماعى كاهى سدى در ميان دلهاى عاشئق

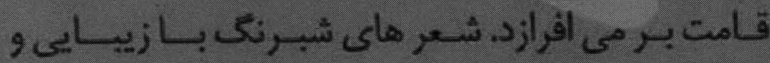

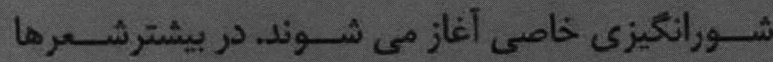

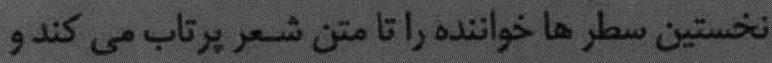
خوانده رامى برد تا يايان شعر. با اين حسال كاهي در ميانه

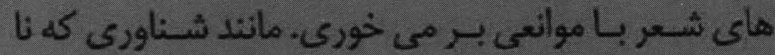
كمان با كردابى رو به رو مى شـود. اين كردابههاى خوردي

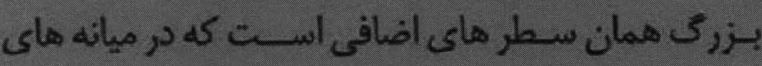
شعر ويا هم يس از استكمال يك تصوير ظاهر مى شونل. بكنار دكمه هاي ييراهنت باز باشد بكذاريه جشم هايت نكاه كنم بعد كمى يإيين تر وسعت كرماى خورشيد رادر آغوشت تفسير كتم ترمت راز ألوده تر مى شوم كرما خورئر وقتى به جثميهايت مى انديشم جشمباى از جنس عسل جنس جشمه هاى فراتر از ديد 5 اه بشر كه حادثه اش رامى نوشم هر نفس

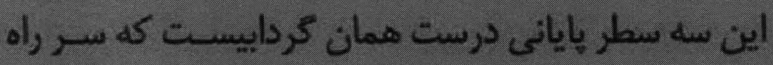

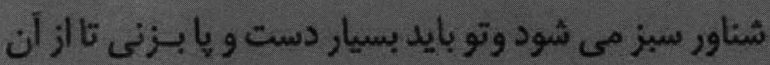
بكذرى. اين سه سـطر تشــريح و توضيح همان حشــان رازاكاك است كه شـاعر بـا انديشـيدن در بـارهء آن نيز راز آلوده مى شود. اين خود بيان زيبايست، أمادل شاعل شاعر باين توصيف قرار نمى كيرد و مى رود تا جند سطر توضيحسات ديكر نيزينويسد. البته در سطر أخرى نوشيدن حسادئه خود

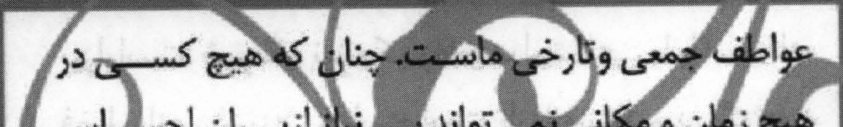

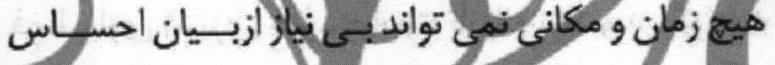

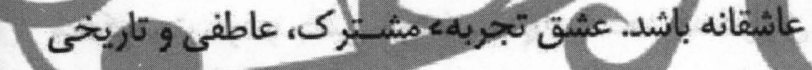

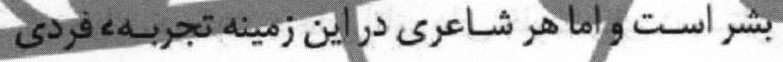

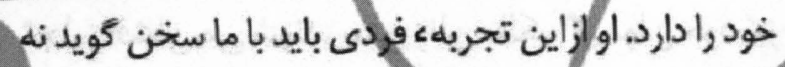

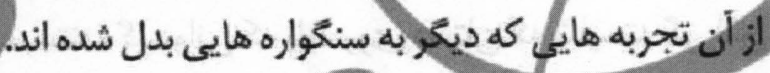

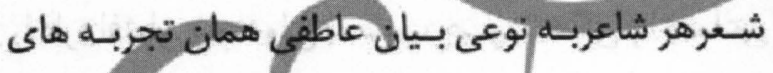

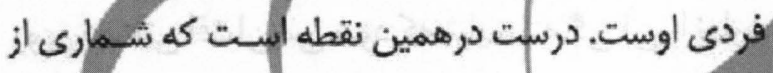

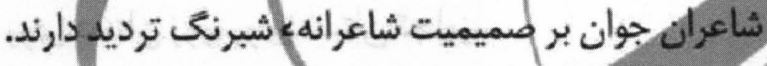

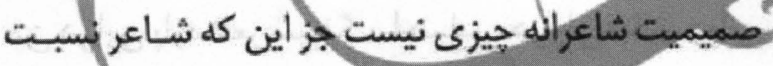

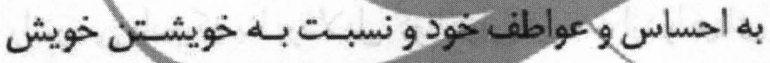

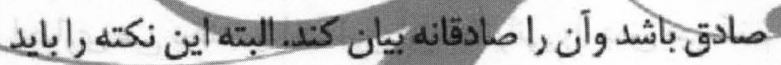

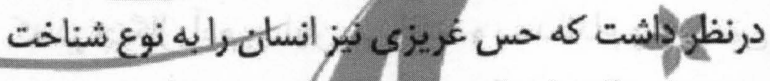
مى رساند، البته انسان هيجاهاهى دمر مرز شـناخت غريزى

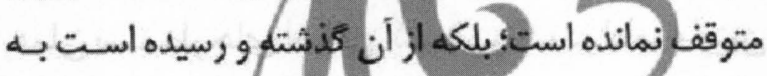

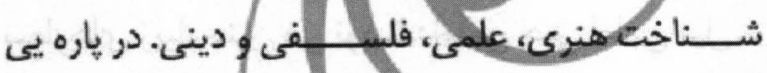

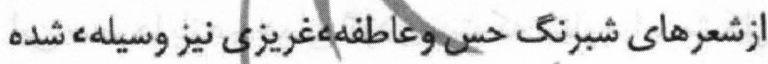

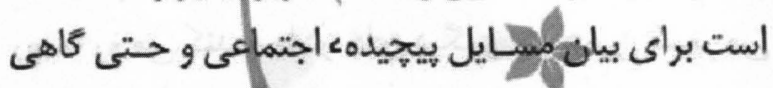
سياسى. انسانى كه تخيل نداشته باشد نمى تواند بيافريند.

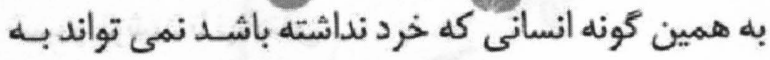

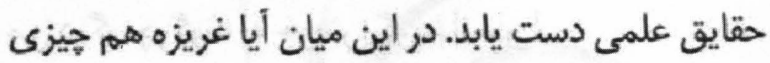

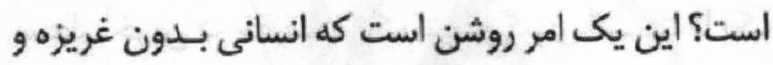

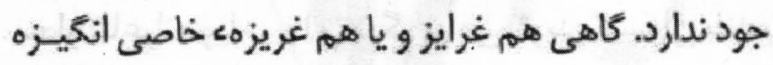

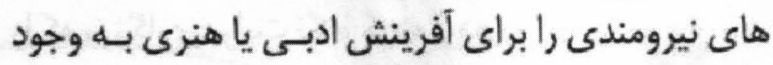

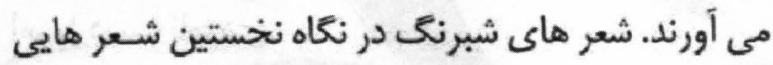

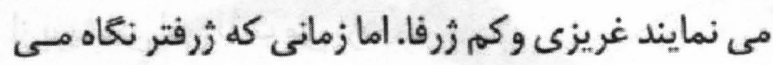

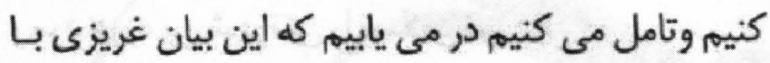
مسايل ديكرى اجتماعى در آميخته وبه شـعر او محستواى كسترده ترى بخشيده است. بكذار راز حشمعاى دردمندت راتفسير كنم

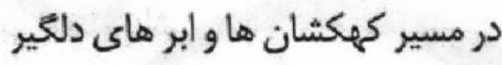

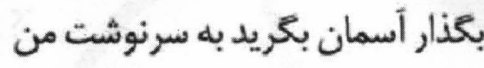

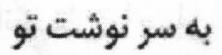
بكذار دكمه هاى بيرهنت باز باشد

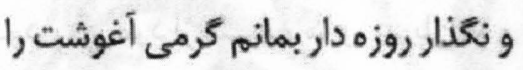


بيزاراست، شبرنى نيز يك واقعيت اجتماعى را با اسـتفاده

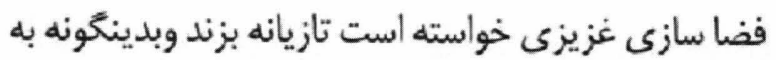

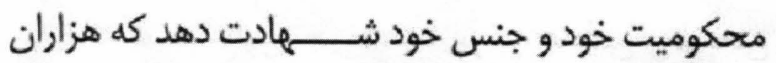

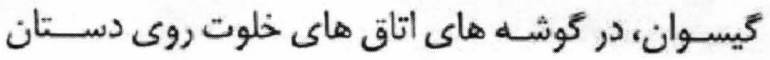
تجاوز افشان مى شوند. يعنى زنان مالك گيسوان خود دود نيز

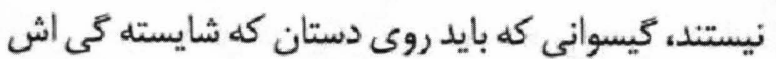
را دارد افشان شود؛ ولى به سبب جبـر زنده كى و واجتماعى لئى روى دستانى افشان مى شود كه شايسـته كَى آن راندان لدارد. روى دستان زور، روى دستان تجاوز.

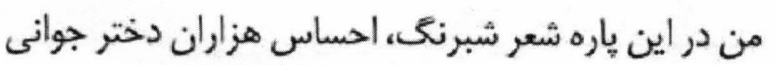

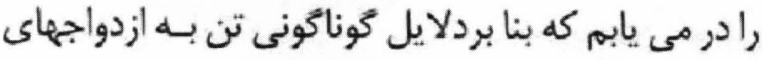

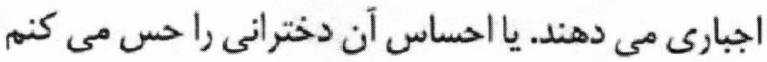

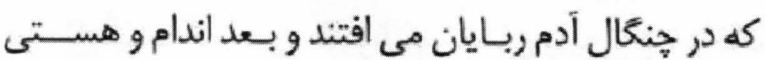
شان به فروش مى رسد. بـاز هم بـر مرديم بــه موجوديت

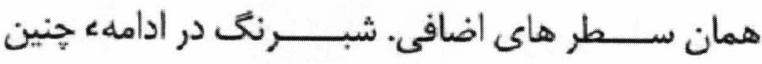
سطرهاى زيبا، جنين مى نويسد: اما بى حس اما بى ميل سلى

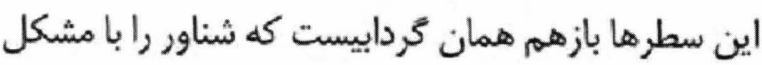

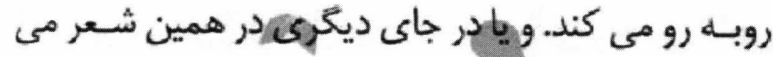
كويد: ومردى بيهوده لذت خواهد برد ازيشانه هاى عريانم Co. من ديخر حوكونه له خويش كويم انسان!

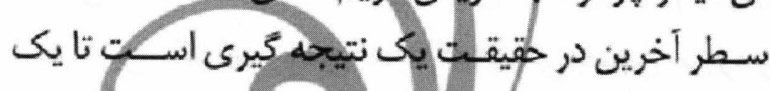
سطر شاعرانه ويا در راى ديخرى مئكويد:كيسوان بلندم $x^{\circ}$

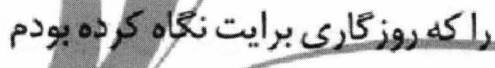

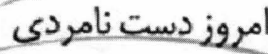

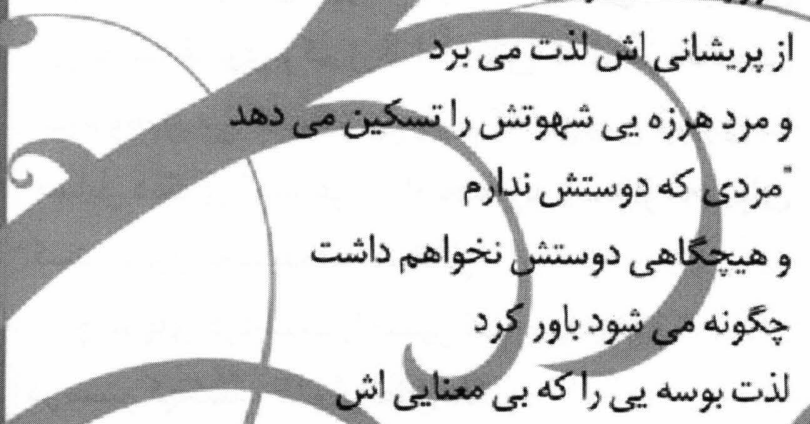

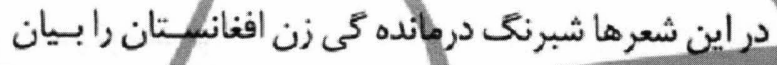

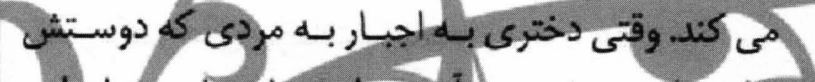

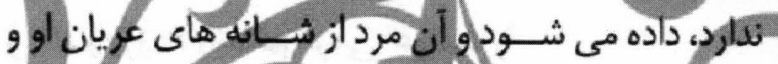

تصوير زيبا و تازه ييست. ويادر جاى ديكرى كه مى كويد: آن كونه كله موهايت رابه دست بادمي كناشتي

إن لبخند كنارت راباريار تجربه كنم

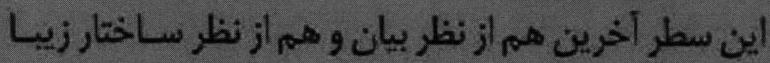

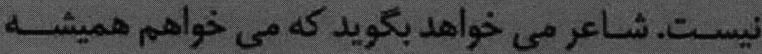
خندان در كنارت بمانم: اما اين حس بيان زيباى شـاعرانه يبدا نمى كند. آن كونه كه كفته شــد كاهي در شـ عرهاي شبرنك نوع نكرش شـاعرانهـ فروغ فرخز اد بـه هسـتى و زتده كى رامى توان ديد. خنان كه من وقتى اين ياره شعر شبرنى را خواندم: آرى مي شود به بيهوده كي تن داد وبا كسى كه باورش ندارى در انتهاى اتاق تشسيت ساعت ها كيسوانت راروى دستانش كناشت در فشار بازوانش مرد مرابـهله ياد اين ياره شـــر فروغ فرخزاد انداخت: مى توان ساعات طولانى با نغاهى حون نكاه مردكان ثابت خيره شد در دود يك سيكار

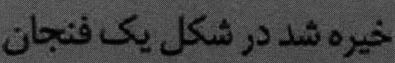
در كل بيرنك بر قالى در خط موهوم برديوار مى توان فريادزد با صداي سخت كاذب سخت بيكانه دوست مى دارم به نظر من بزركترين همسانى كه مى توان در ميان اين دو شعر يافت، اين است كه هردوثشاعر بر ابتذال، بينوده كئى 9 يوجى مسـلط اجتماعى تازيانه مى زنفد. ثلـعر شبـرنى ظاهرأ يك شعر غريزيست. از اتاق خلوت، كيسيسوان افتاده

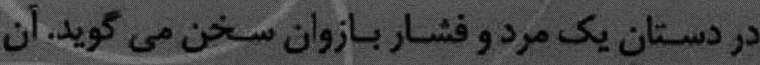

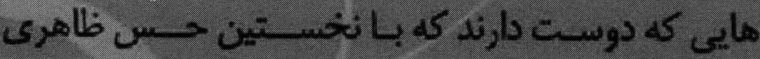
حكمى صادر كتند خواهندكثت كهاين يك شعبر غريزى است و يك حس دروغين!

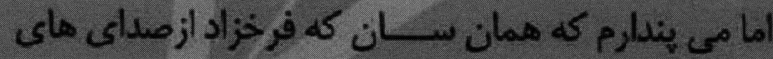
بيكانه و دروغينى كه بيوسـته مي كويند كانه دوسـت دارم، 
است. ظاهرأ أو را يافته: اما او در دام شهوت كير مانده است و به او هشدار مى دهد كه دست روى دست كس ديكرى

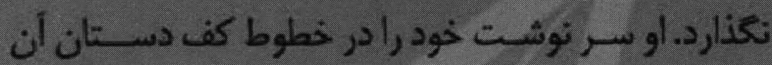

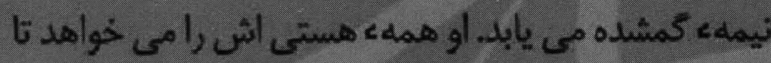

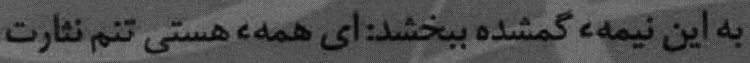

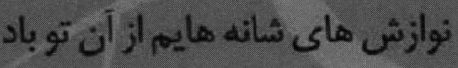

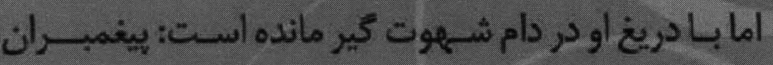
شهوت از ديار كدامين خدا تنت رالين كونه تسخير كرده اند؟

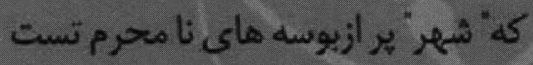
او بدون اين نيمه كمشده نا مكمل است. نامش نا مكمل است و مى خواهد نامش را بـانام او يبوند زند و او رانجات دهد. او مى خواهد بكويد كه دريك جامعله بسته سـنتى زن نمى تواند شخصيت مستقل خود را داشته باشـد و بــــا مفهوم ديكر زنان ييوسته جنان سايه يى بــ دنبـال مردان

نامت را ييوند بده به نامم تا هميشه هاى سبز دست هايت راساده به كسى نكذار كه مفهوم سر نوشت من درخطوط دستان تو يبجيده است

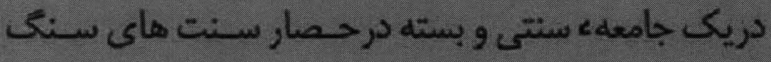

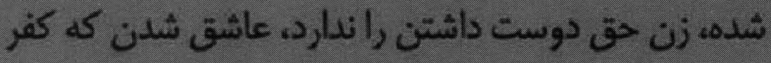

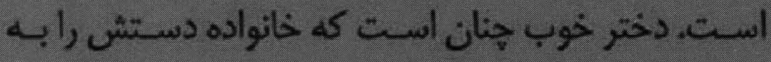

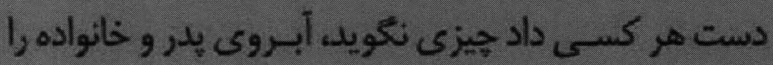

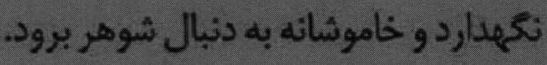

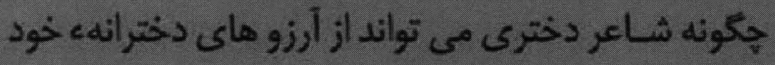

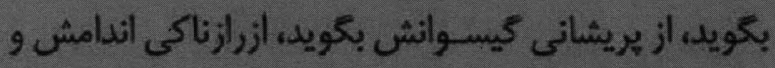

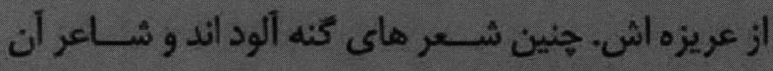

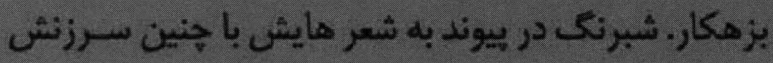

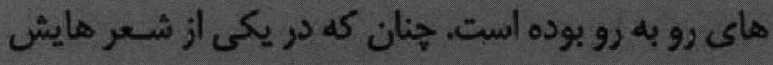

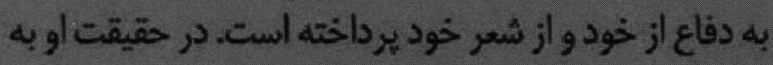

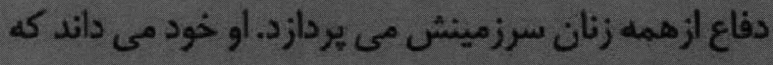

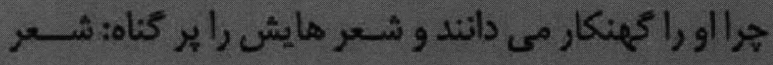
هايم رايركناه مي كويند

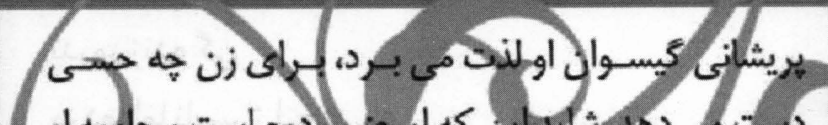
كست مي دملدمشايداين كهاو جنسل دوم است و جامعه او

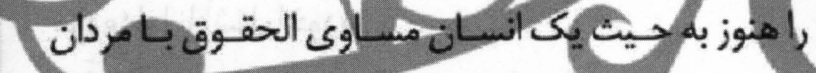

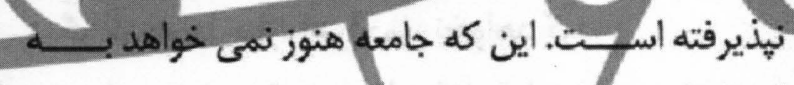
احساسات و عولاطف زن احـترامى بكذارد. حـالا مى توان أن بعد ديكرش / كه دردياك تر ازاين است نيز تصور كرم

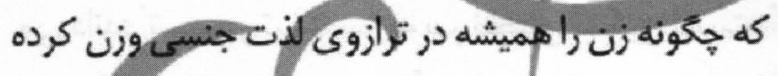

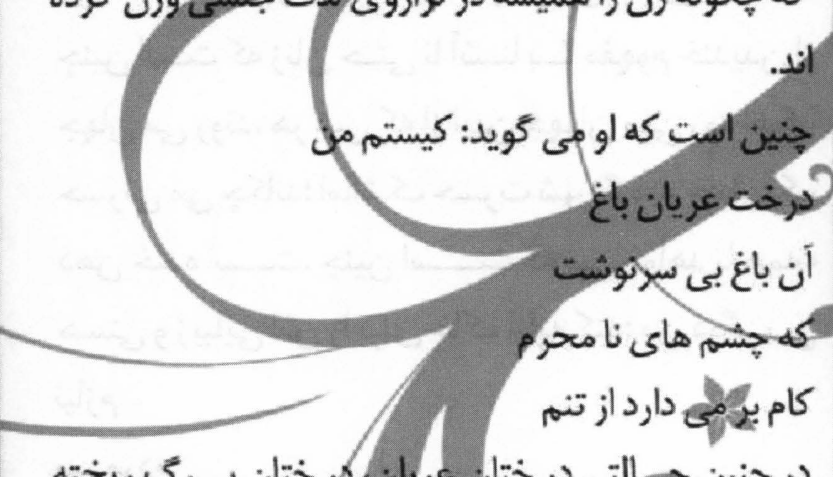

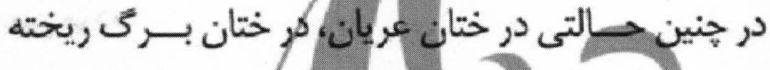
تصويري است از خنينزنانى! ايئ درخهان در باغ هاى بسى

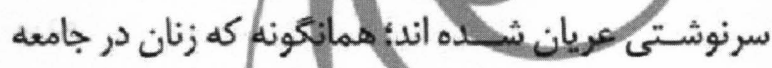

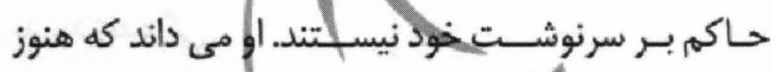

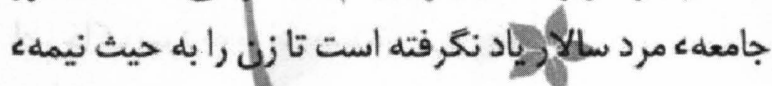
مساوى خود بيذيرد و جنين است كهبار بار بـراتى تثبـيت هويت انسانى خود فرياد مى زند: باد! دستم رابكير وبا خط قرمزدرشت در تن ديوار يیداييى ام بنويس انسبان انسان انسان

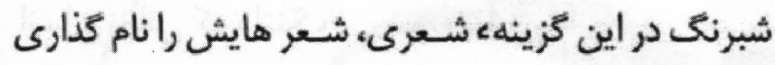

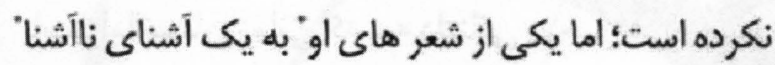

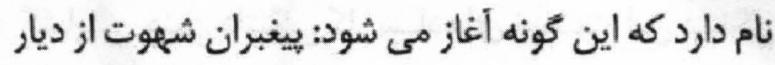
كدامين خدا تنت رالين كونه تسخير كرده اند دست هايت راين كونه ساده به دست كسى نعز ائهار مفهوم سرنوشت من در خطوط دستان تو يبهيده است در اين شعر شبرنغ به دنبـال آن نيمهء كمشـدهء خويش 


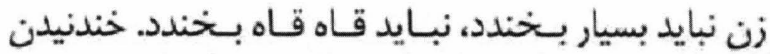
نشانهءوقار نيست. حتى بيدل تبسم را نيز نقـصان تمكين

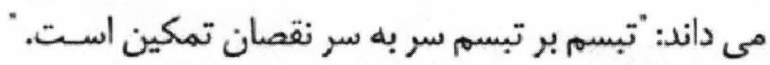

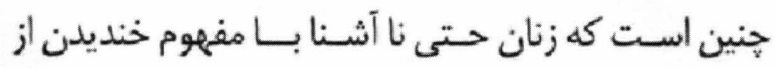
جهان مى روند. هركس كه از ايـن جهان مس رئ رود اشكى

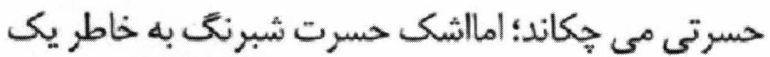
دهن خنده اســت. خنين اســـت كه مى خواهد تا همهـ هستى و زيبايى اش رابراى خاك ارايه كند: من ديكر بـ سخن بر سر اين است كه اكر جنين جيزى را شـاعر مردى

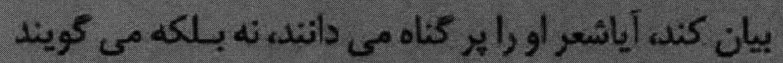

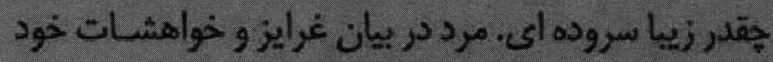

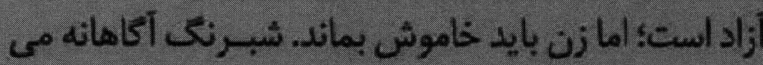
خواهد تا نياز هاى درونى خود را بـيان كند شـايداين نياز هاي درونيست كه او رابر مى انكيزد تا جنين شعبر هايى رابسرايد واز فرجام آن نيز نمى هراسد. شعر هايمراير كناه مى كويند

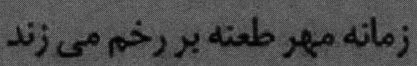
بكنار زاهدان نقابى شهر سنكسارم كنتد وداغترين موضوع روزنامه ها تكفير من باشد من زنمه زت آزادها زن عريان وبوسه خواه

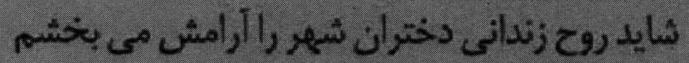
بكنار زمانه نا نحرم جار يزند شعر هايم ير كناه است

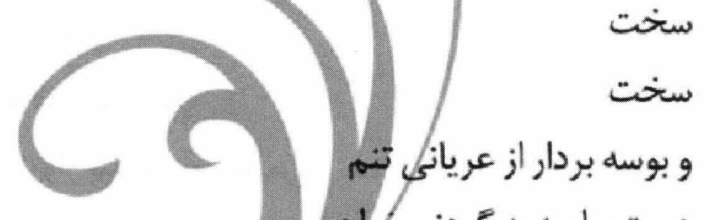

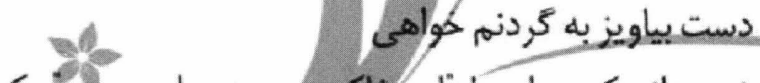

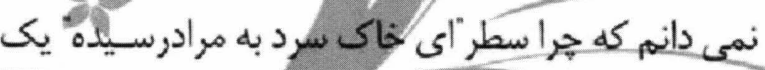

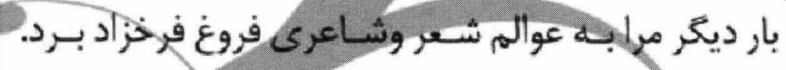

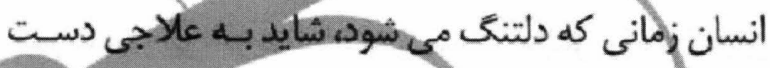

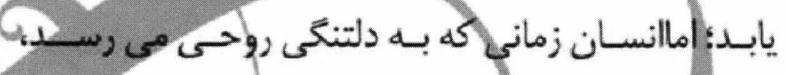

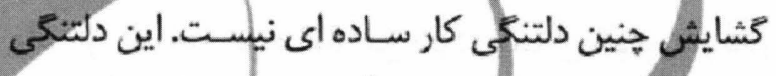

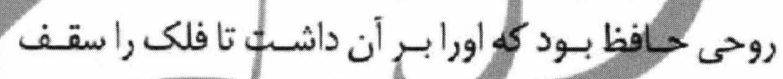

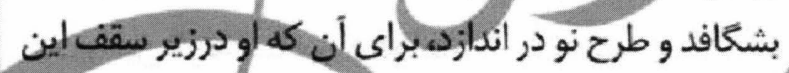

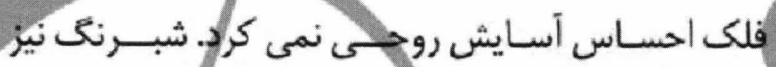
دلتنكى روحى دارد و همه جيز و حتى آزادى برايش تكرار

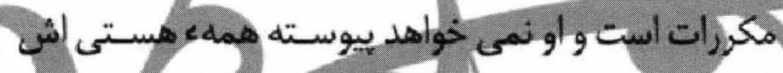

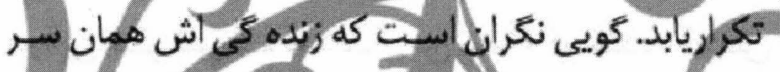
سنخ w

سنخ 
كوتاه سرايى درشعر يس ازرطالبان درادبيات فارسيى درى

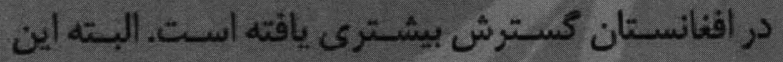

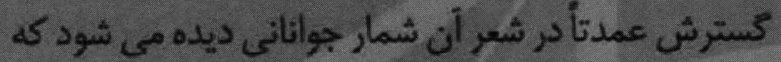
مى توان آن ها را شاعران يس إز طالبان كفت. بـايد كفت كه شمارى از اين جوانان در كوتاه سـرايى منزل هائ دراز موفقـيت وزيبـايى را ييموده اثد. من فكر مى كنم كه در

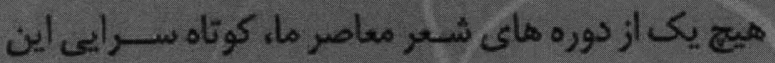
همه كسترش و رونق نداشته است. شبـرن نق در اين زمينه تجربه هايى خوبـى دارد. جنان كه در بايان كتابش نمونه هايى از كوتاه سرايى خود رانيز آورده است. به هوش باش برندا كه در خم كمر صياد مرك جن زواند تا همين كه اين شعر شبرنى راخواندمه اين بـيت معروف

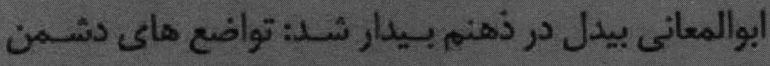
مكر صيادى بود بيدل كه خم خم رفتن صياد بعرقتل مرغان است بردي

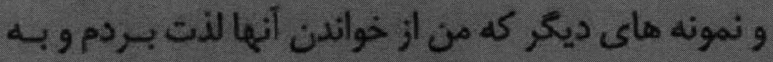
اين باور رسيدم كل شبرنك مي تواند در كوتاهسيـرايى نيز موفقيت هايي داشته باشد. نيامن جاى دستانت خالى رو

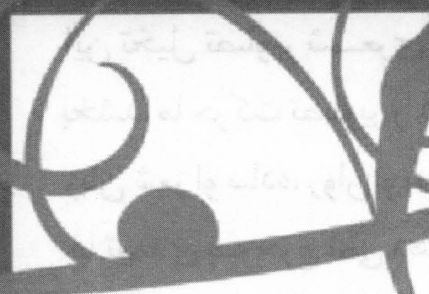

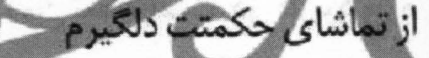

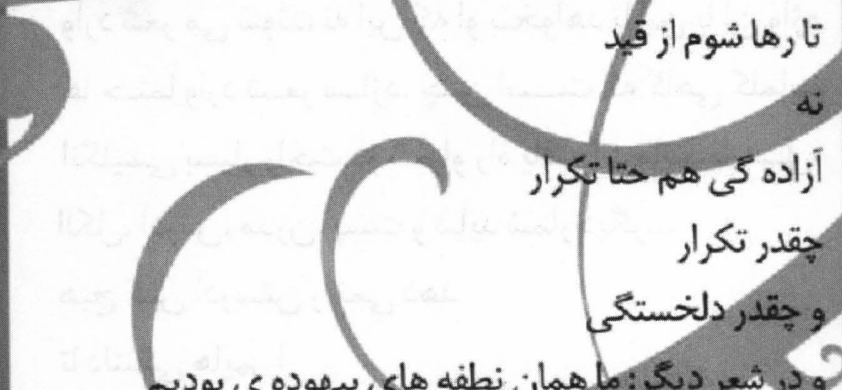

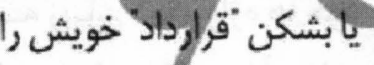

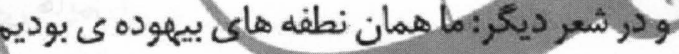

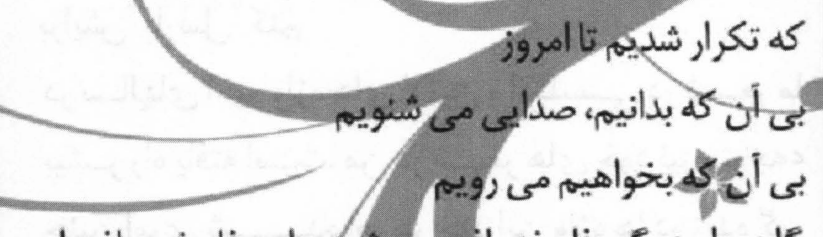
كاهى او مركير فلسفه بافى مى شولو واين فلسفه بـافى او رابه كلي كويى هاي دالكير كننده مى/كشاند و ابـهامى در شعر سايه مى اندازدكة حتى خهوانش شعر رانيز دشوار مى دي فازد. وبا هر هى خسته كيست آسمانش را به دوش مي مي كشيم مصرف "اعتياد" غريزه ييست كه تنهيا خود خدامى داند

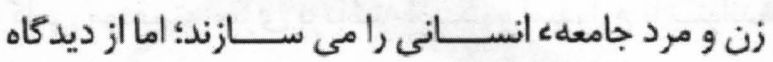

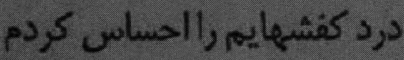

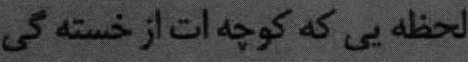
فرياد كشيد

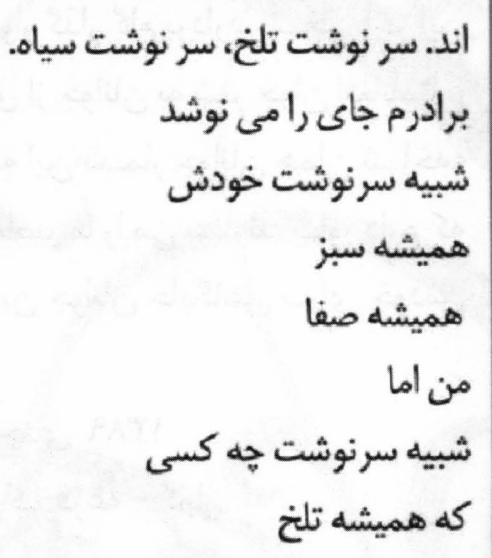

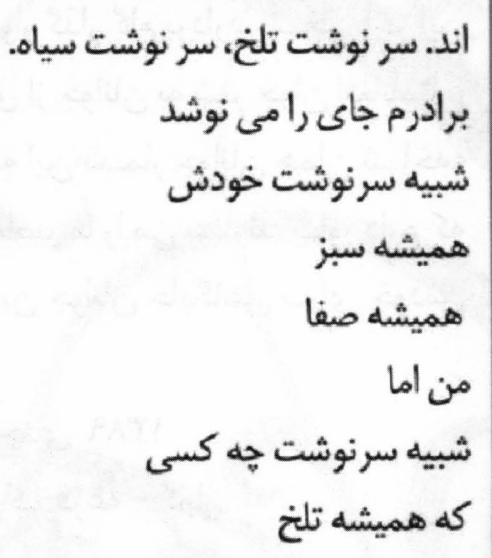

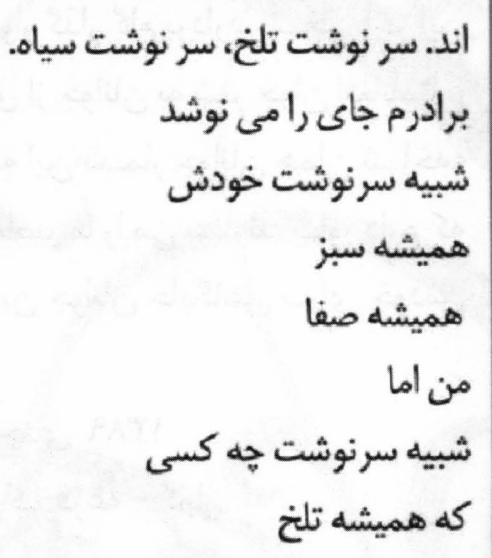
قنارى ها رفتند

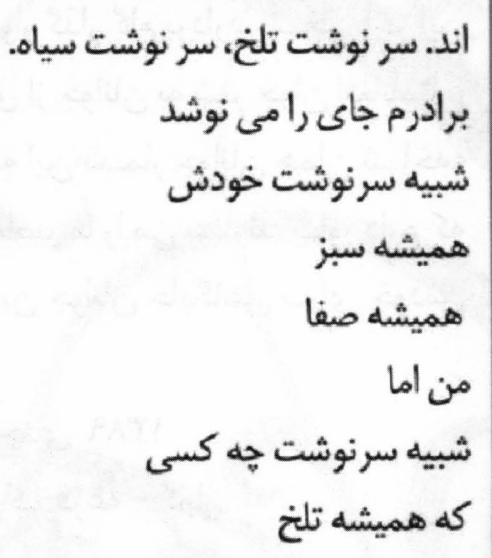
ثير خسته تر شد

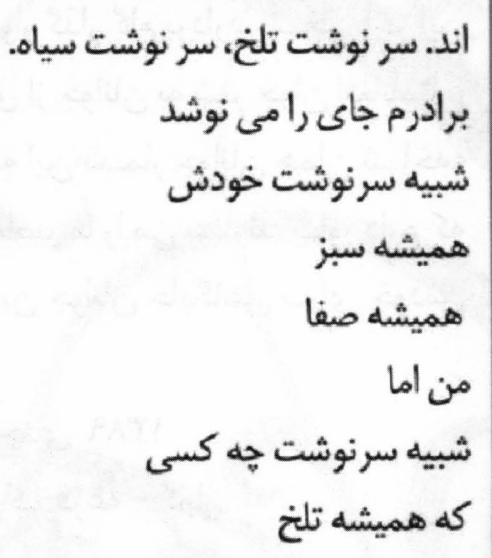

فاتحه باغ راكي خواهد خواند؟

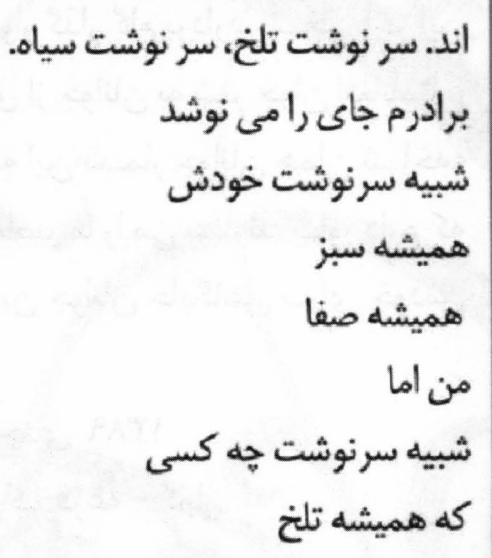
وإيسين كفته ها شبرنك زنان هميشه سرنوشـت جداكانه از مردان داشـته 


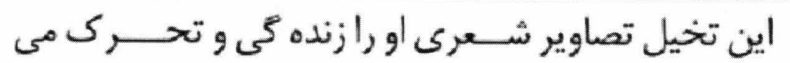
بخشد. ما حركت تصاوير رادر شعر هاي او او مي بينيهم.

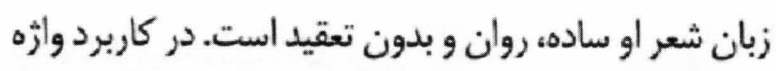

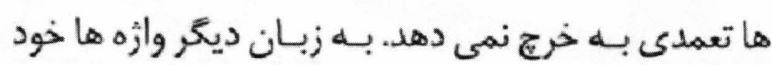

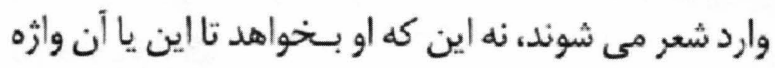

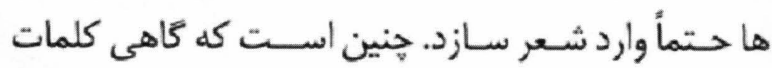

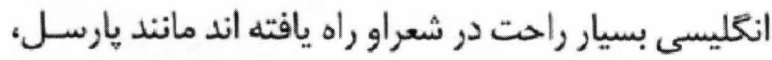

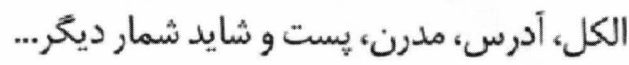
هيج كس آدرسش را نمى دهد الدي تا دلتنكى هايم را برايش "نارسل" كنم

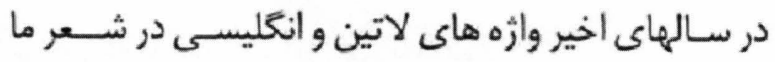
بيشـر راه يافته اسـت من در شـــر هاى خود نيز متوجها

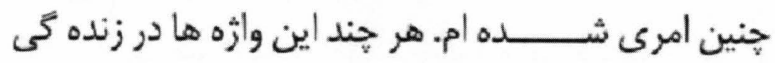
روزمرهء ما راه يافته اند با اين حال كار بـرد بـ بـيدريغانهء آن آن

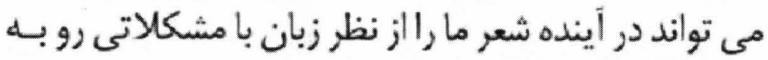
روسازد.

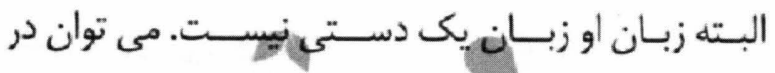
شـعرهايش سـطر هايى رايافت كه داراي نق يصهء بـ بـيان

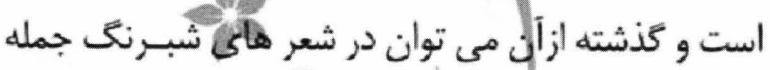

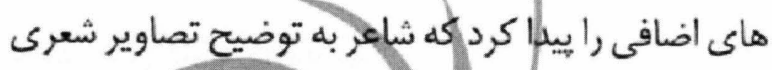

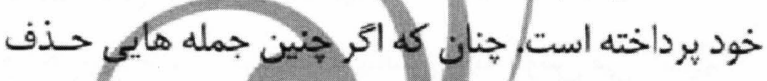

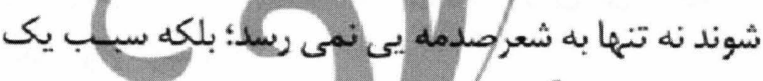

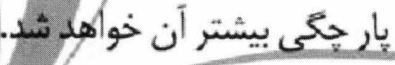

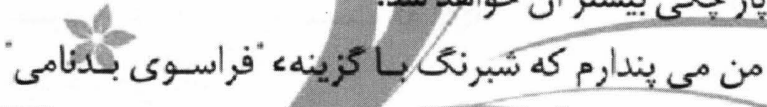

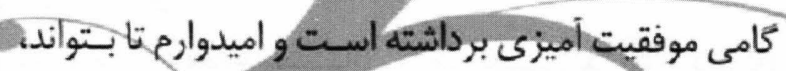

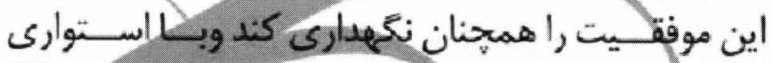

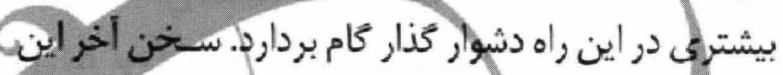
كه من در وجود شمارى از جوانان به شعر جوان افغأستان

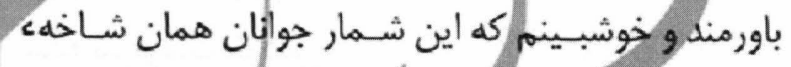

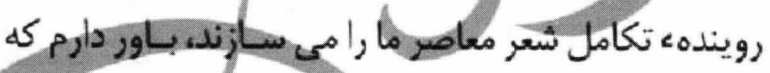

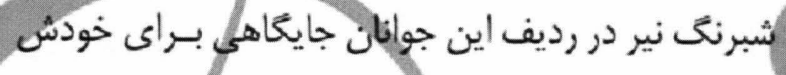
بيدا كرده است. يايان
شعرهاى او از اين زاويه شكل مى كيرد. اين بد يينى براى

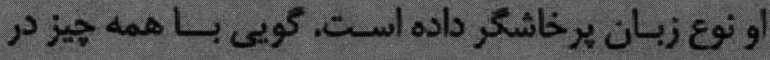
جنك است. كاهى با خدا ركر كفتكوست وكاهى با خويشتن

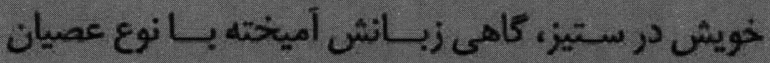
شاعرانه است. درشعر أو برسشهايى در برابر هويت انسانى

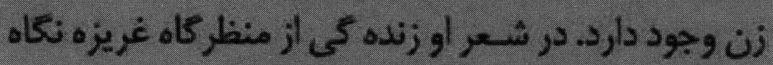

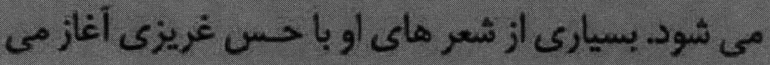

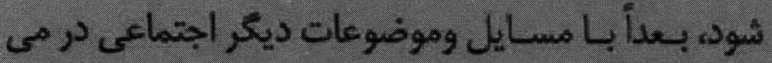

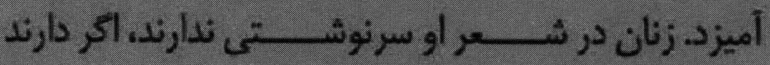

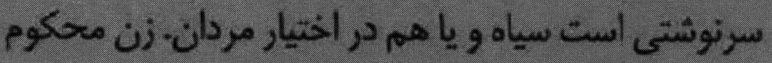
سر نوشت است، سر نوشتى كه ديكران بـرايش رقـم زده اند. جامعه يى كهة او توصيف مي كند جامعها مرد سيـالار بيرحم است و هنوز اين جامعه نهذيرفته است كه زتان نيم هستى جامعه رامى سازند و داراى عشقى عاطفه و انديشه نانه

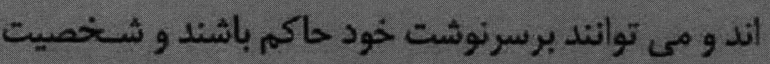

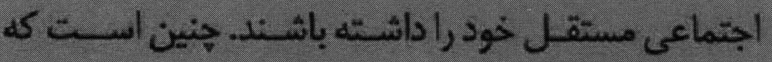
جامعه و زمائه ييى راكه شبـرنكى در آن زنده كى مى كند تاريك مي بيند مانتد يك شام تاريك ماند يك شام تلخ: اين شام تلخ عجييى ستا شام اعدام ترانه شام بلعيدن فرياد شام بستن روشنايى اين شام تلخ شام عجيبى ست من در كذر كاه يك شام تلخ جنازهـ تقدير خويش راخواهم خواثن

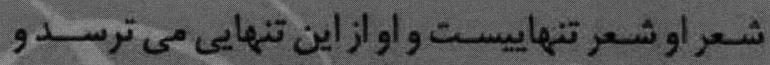

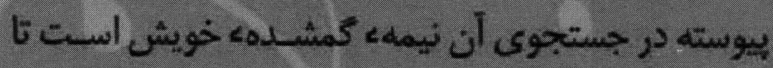
خويشـتن راتكميل كند. احسـاس مى كند كه تازمانى كه

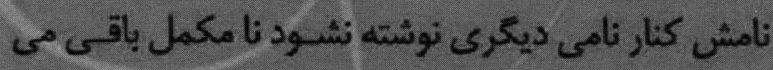

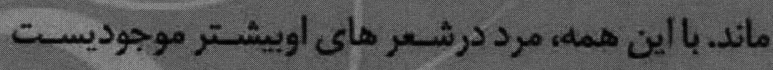

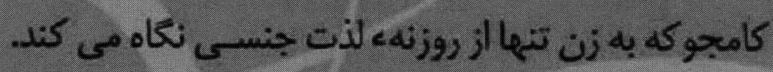

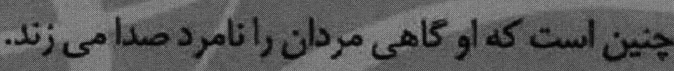

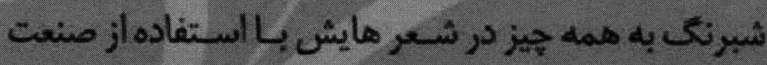
تشخيص بار عاطفى و خصوصيت انسانى مى دهد، حـى

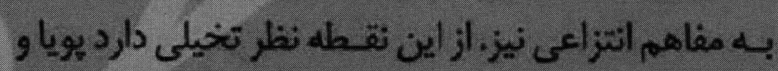


حبي الله غمخوز

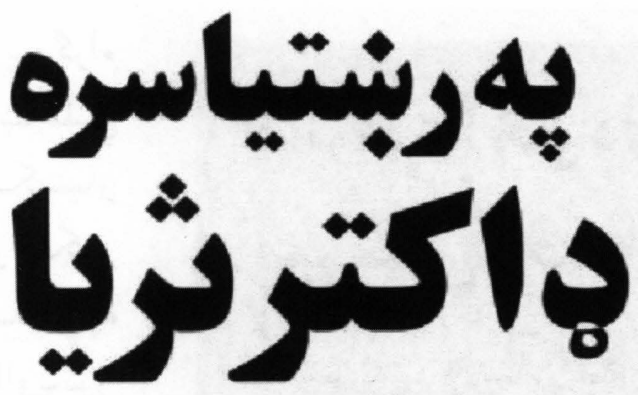

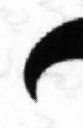
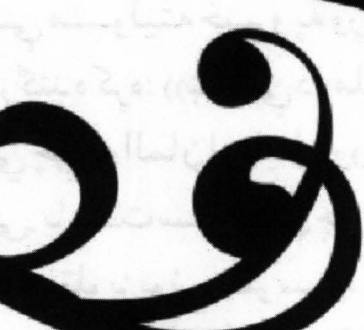

1

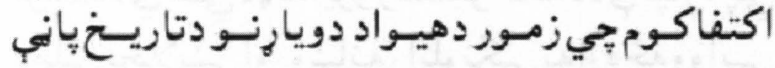

$$
\text { ددوي يه نومونو هم ذكي دي زومي. }
$$

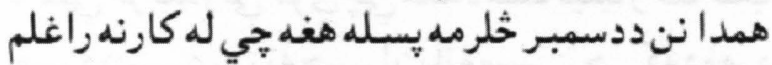

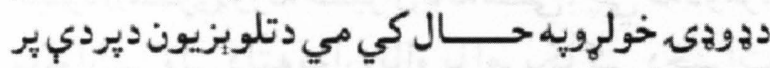

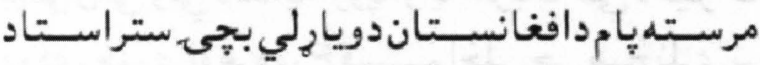

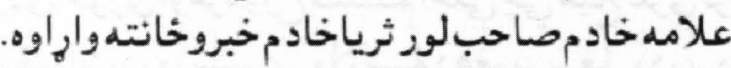
دونو دوستانو قيصه داسيوها

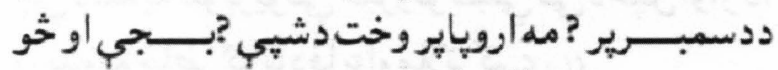

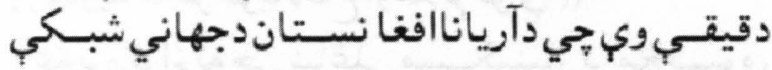

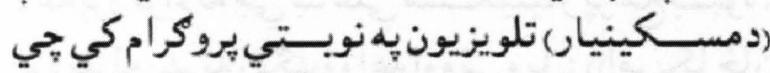

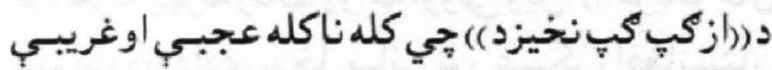

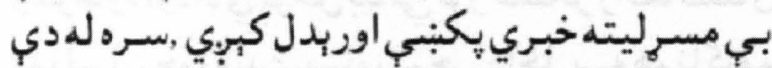

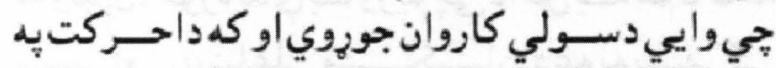

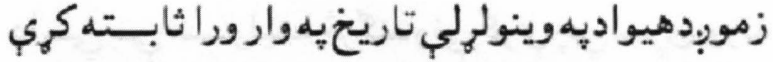

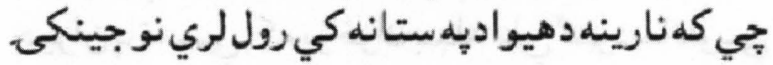

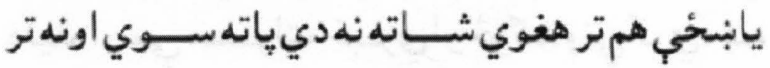
هغوي كم رولن بلري.

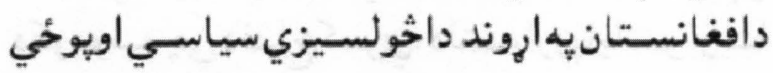

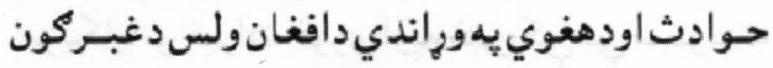

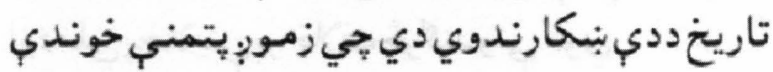

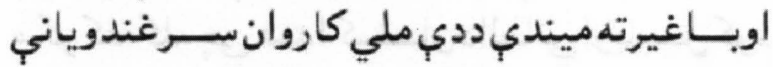

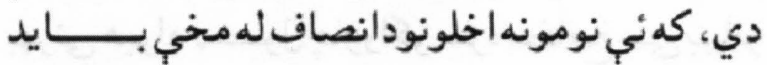

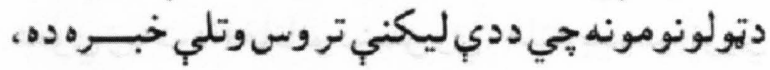

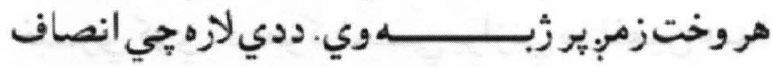

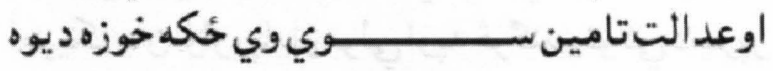

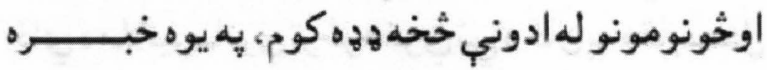


اوسـبدونكي دبسي مسـوليته خبـرو يه وراندي يه يوه

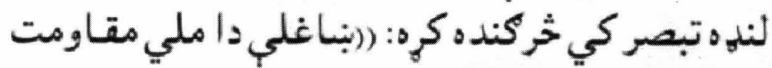

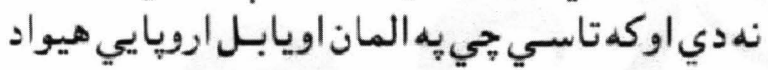

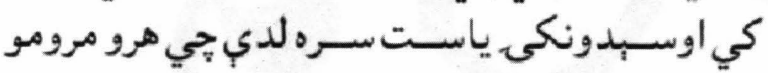

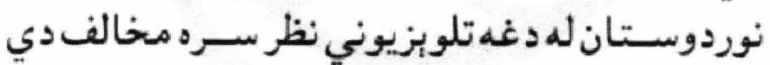

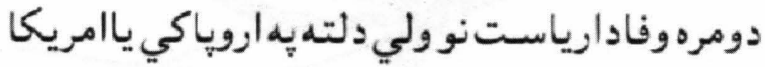
كي دكافرانوخيرات خوريولإز سـي هلته اوددوي ونيه
ربنتيا سـره ملي وي زه ئي ملاتر كوم خويه حقيقت كي

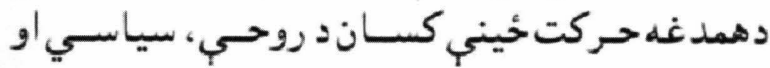

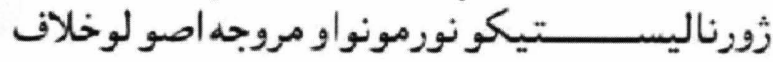

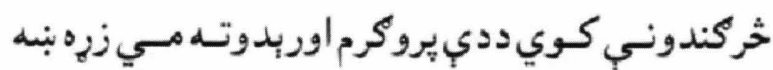

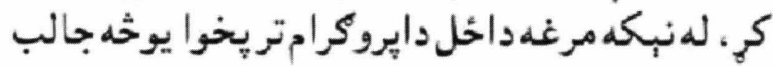
داجي ولي تر يخوا جالب و ، اوس زما دليكني موخه.

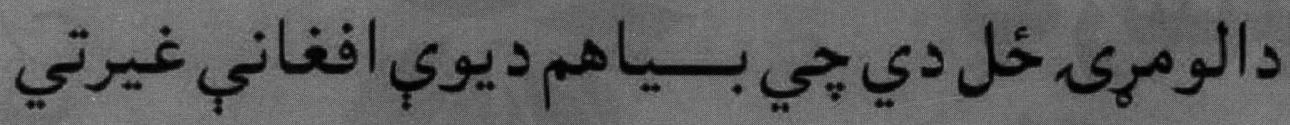

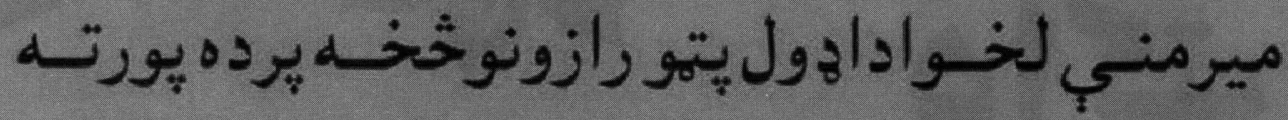

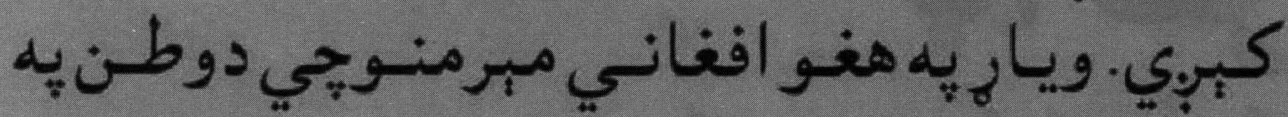

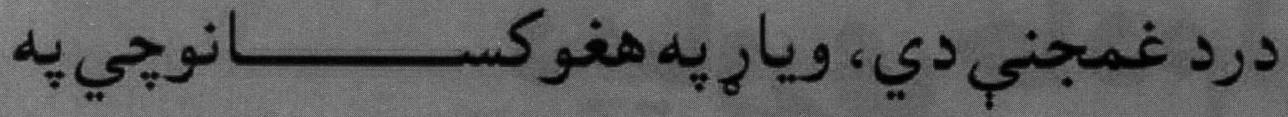

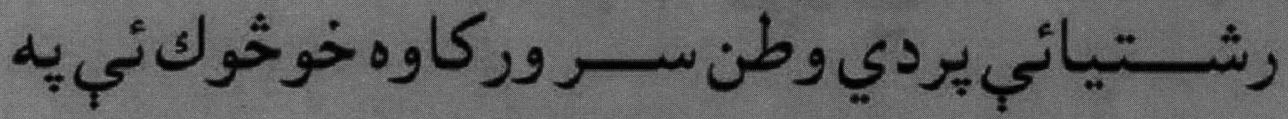

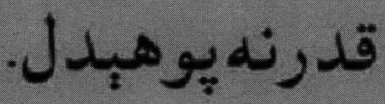

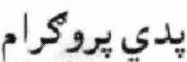
كي بنـاغلي مسـكينيار هغـو خلكــو

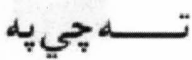
ارويااويانور توبه

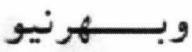
هيوادوكـي اوسببري اويه

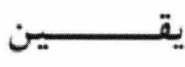
دمهاجسرت دوترلانس كولـــو لياره

بغل كي ودوبربِي...) ()

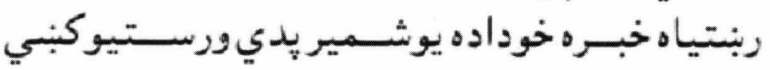

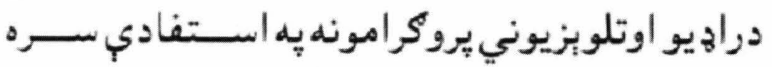

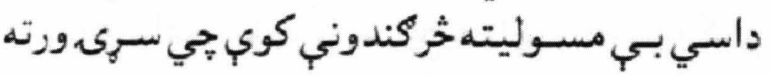

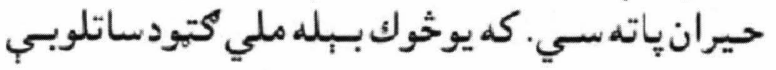

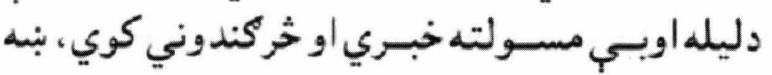

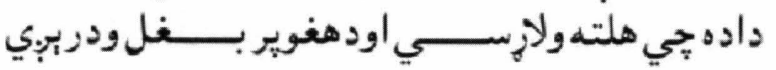

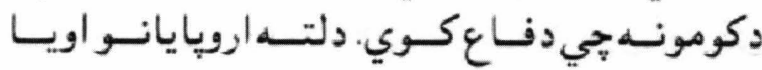

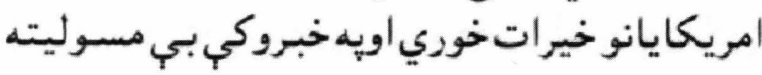

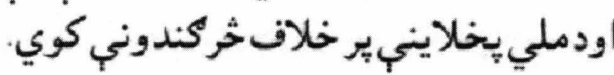

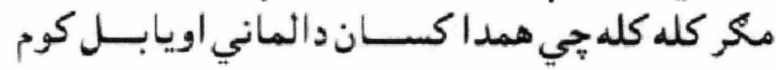

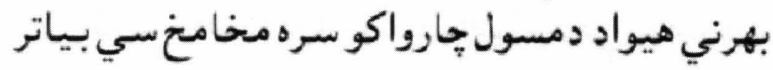

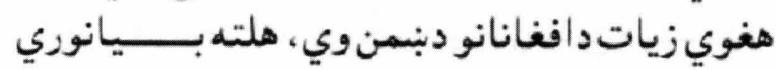

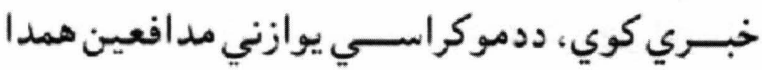

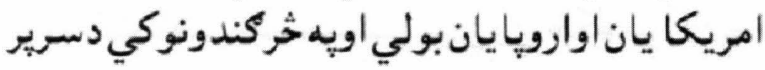

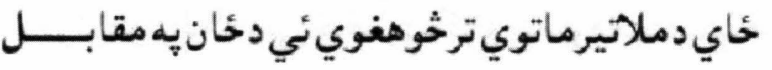

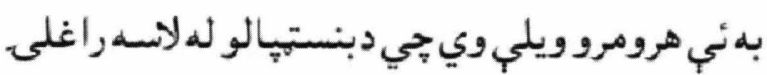

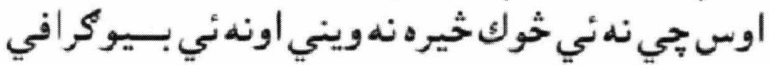

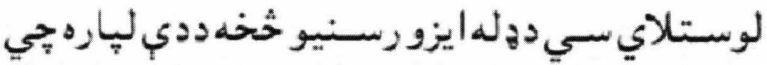

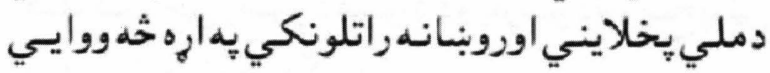

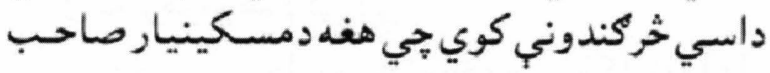

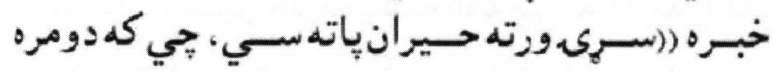

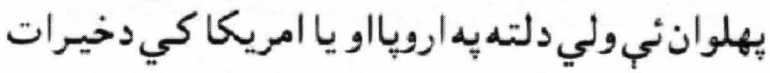

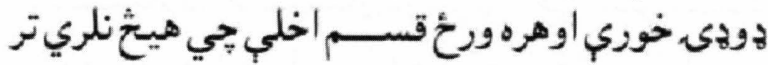

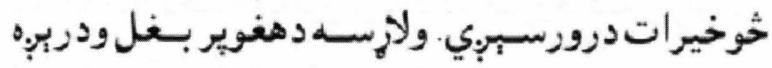

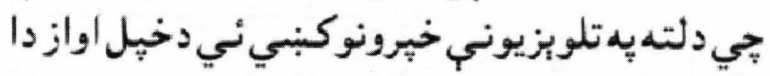

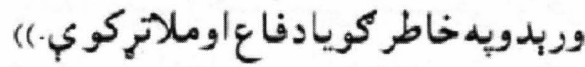

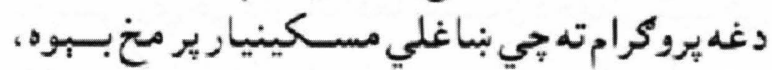

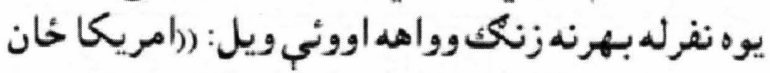

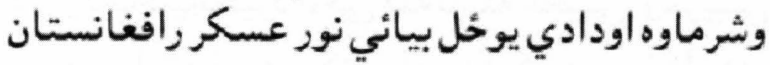

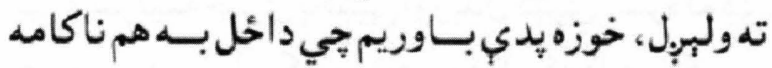

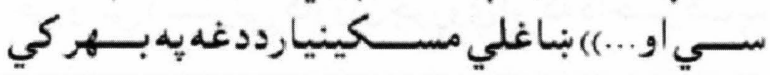


راسي تول افغانان، كه مجاهد اوكه دجايه وينا ملهد

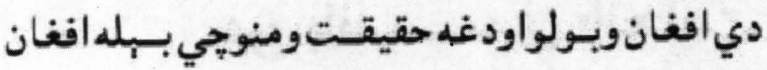

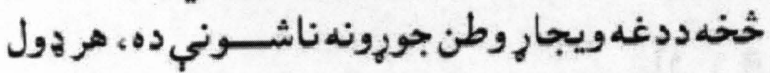

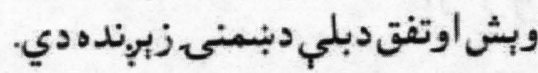

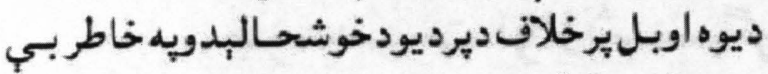

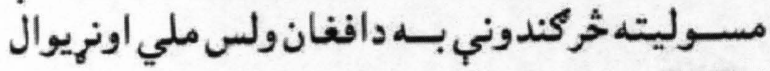

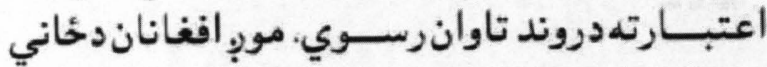

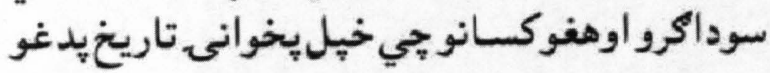

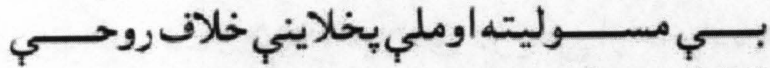

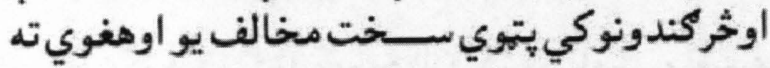

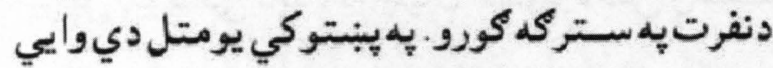

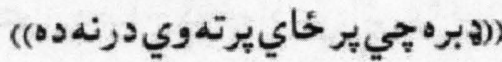

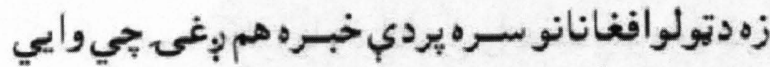

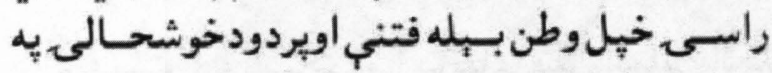

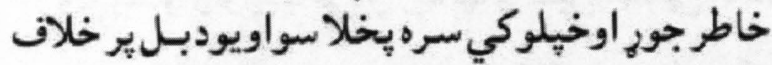

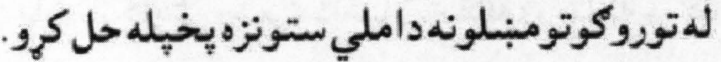

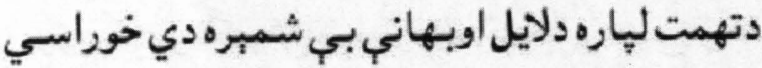
جي دخيل كوردجـوريدو اوملي يخلايسي لياره دلايـل وتراشواويودبل يه مقابل كبني ديبي خايه غرور اوبي كتي دبنمنيونهتيرسو.

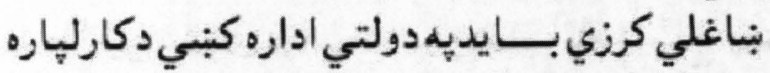

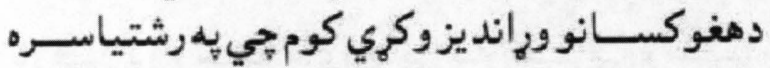

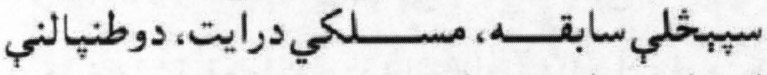
احساس، ملي غرور اونوع يرستي باندي بيوهاوير هغه

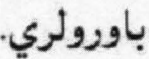

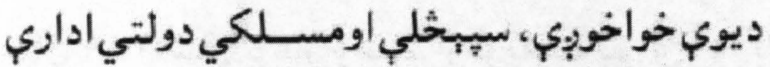

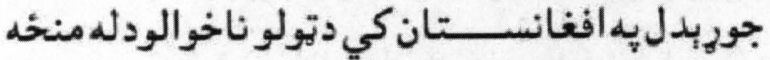
ورلو اساسي لامل كرخبداي سئي.

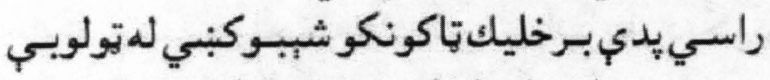

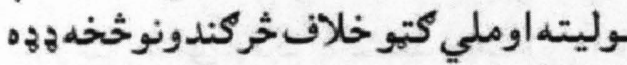

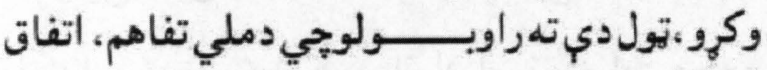

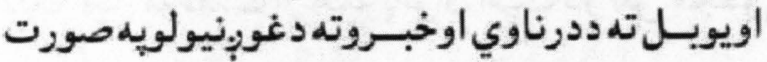

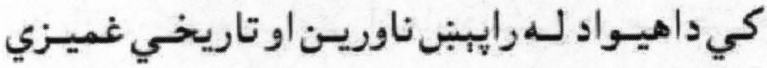
خخخدزغورو.

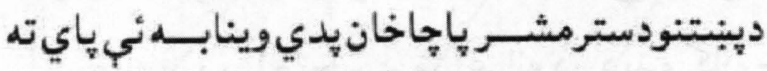
ورسومجي وايي: راخى يوكبروكنه وركبروب.
كبني احستراماودوفاداري احسـاس ثركندوندومني.

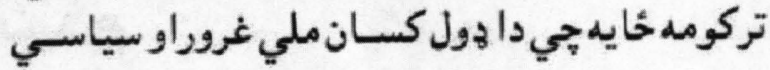

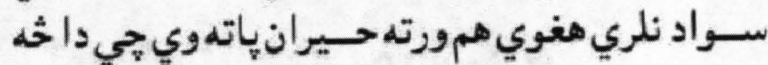
ينبنه سويدها.

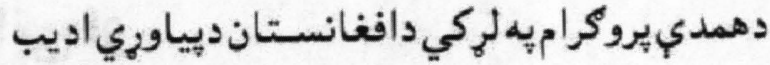

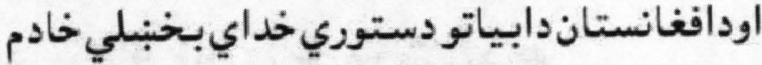

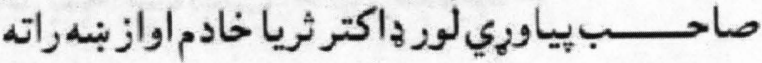

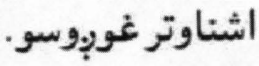

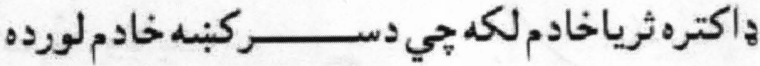

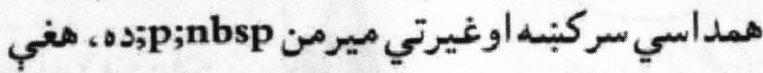

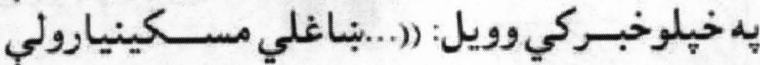

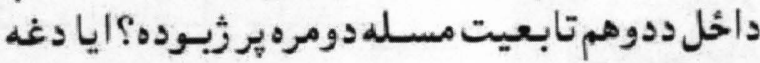

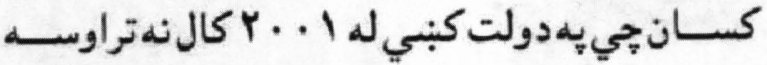

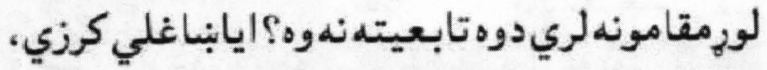

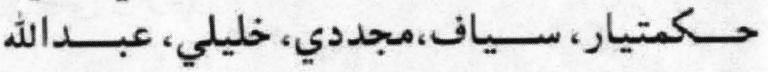

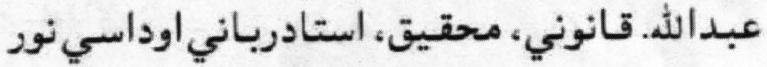

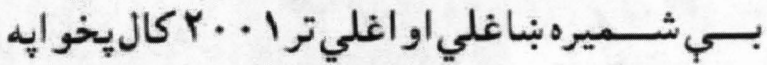

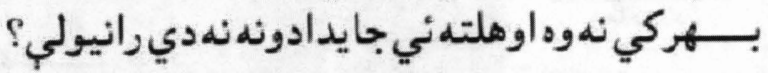

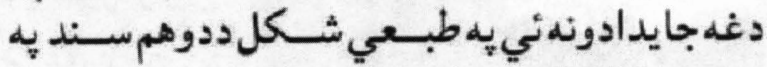

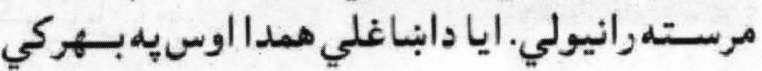

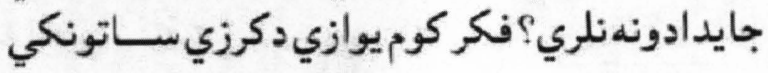

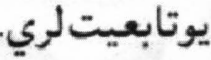

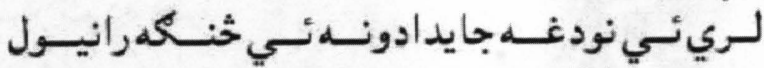

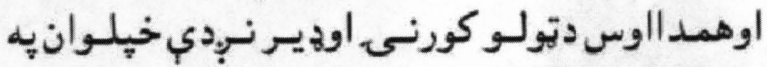

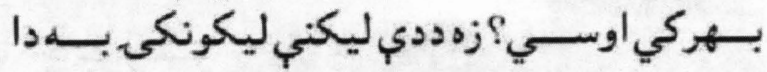

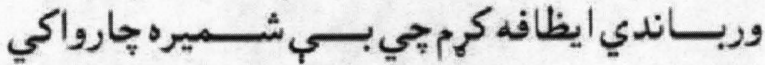
دوكوريزدي. هغي ديوشمبر كسانو نومونهو واخيستل

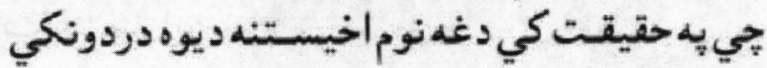
حقيقت روبناندبيلكهدوه.

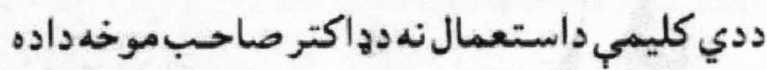

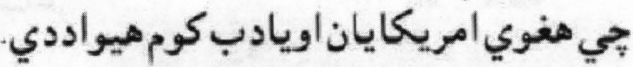

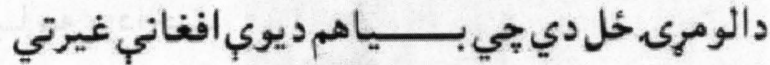

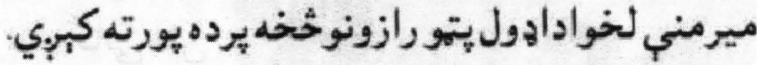
وياريه هغو افغاني مبرمنويجي دوطن يه درد غمجني

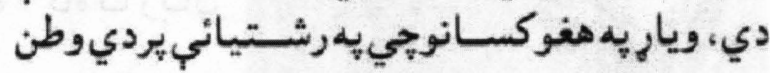
سر وركاوه خوخوكنئي يم قدرنهيوهيدل. 


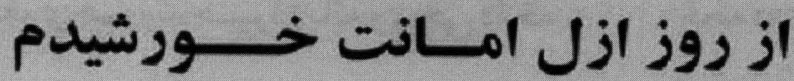

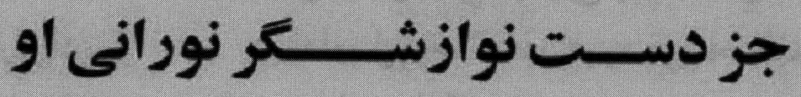

دستى نوسل بـه قـامت خورشـيلم
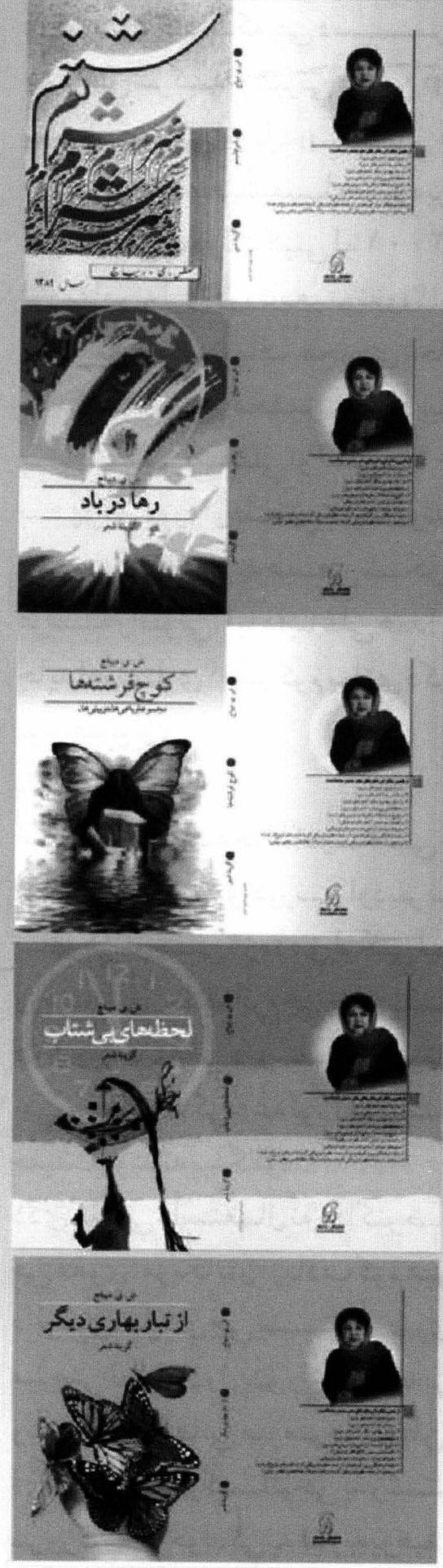

درنوامبر سـال هه 19هيلادى در يكى ازخانواده هاى روشـفكرولايت سر يل كود كى ديده به جهان كُود نامش راشفيقه كذاشـتند. رفته رفته

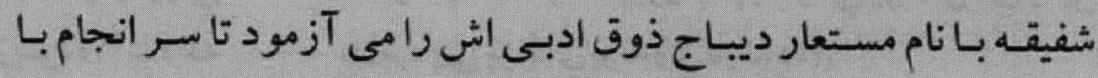
اكمال دوره بكلوريا وليسانس واخذ دييلوم ماسترى واكثاهى به زبانهاى

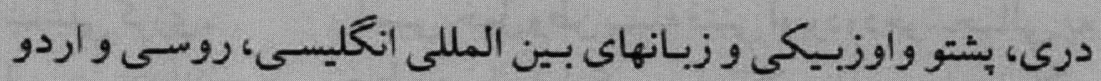

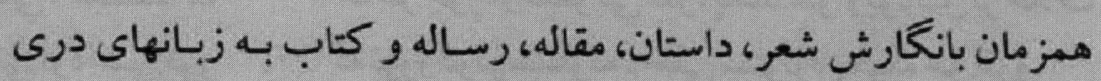

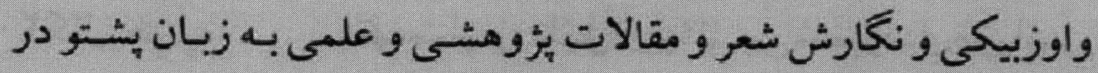
فبرورى سـال 1994از انستيتوت زبــان و ادبـيات امير عليثـير نوايى اكادمى علوم جمهورى ازبكســان بـهـ دريافت دييلوم دكترانايل آمد.

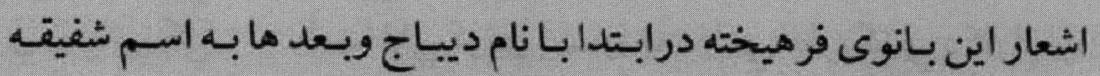
يارقين در رسـانه هاى جايى بـه نشـــر مى رســيد وامروز نام اين شـاعر فرهيخته (شفيقه يارقين ديباج) نام آشنا براى فرهنگيان كشـور بـوده حستا در بيرون از افغانستان نيز نام نا آشنا نيست.

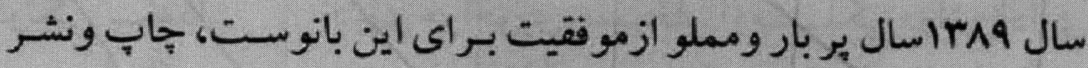

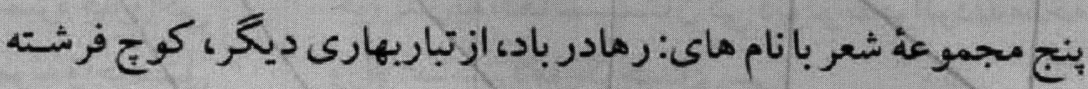

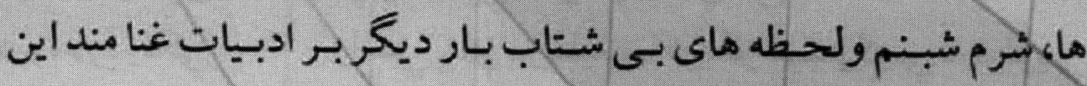

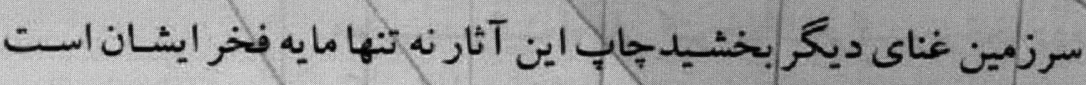
بلكه اين موفقيت از همه بانوان است در إين مجموعه هاى شعرى، شاعر

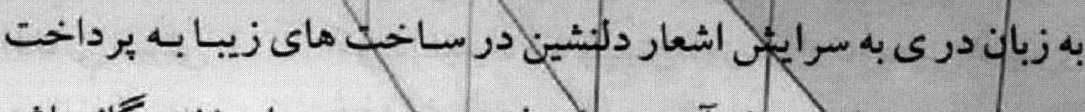

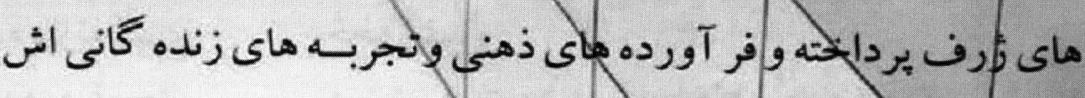

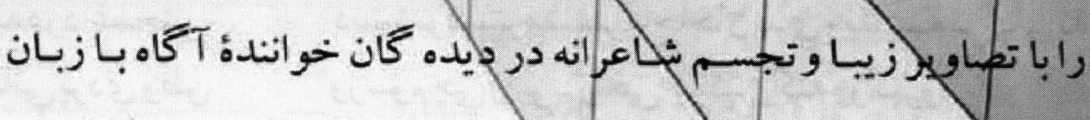

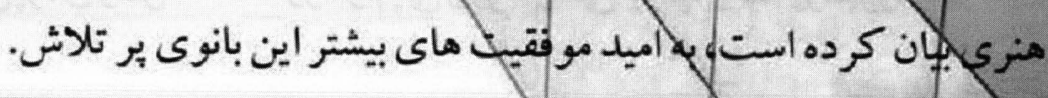




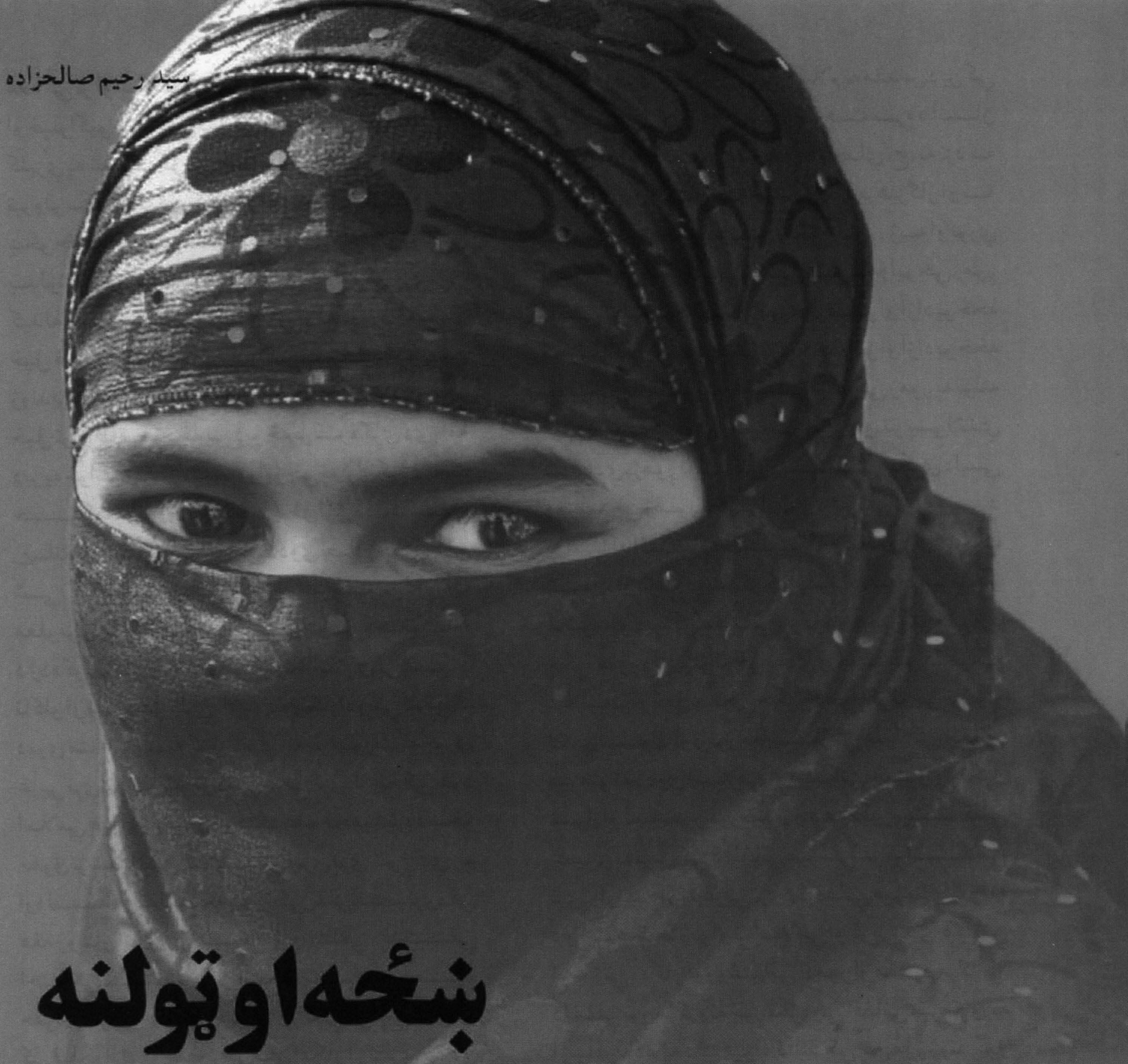

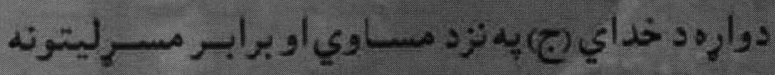

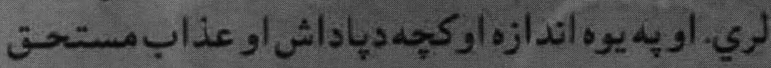

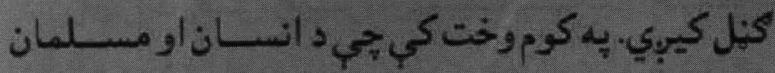

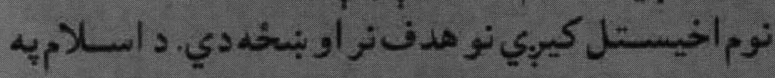

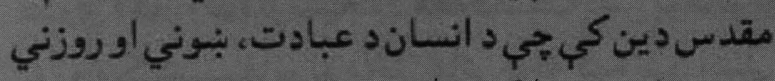

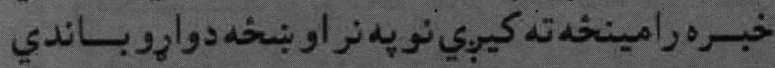
فرض كنيل كيري.

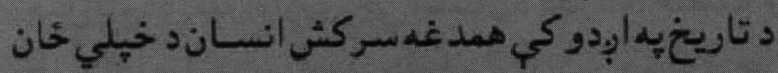

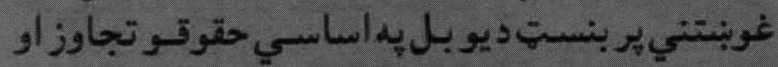

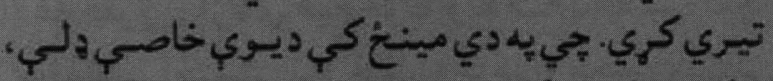

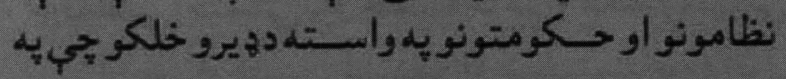

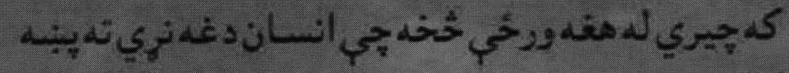

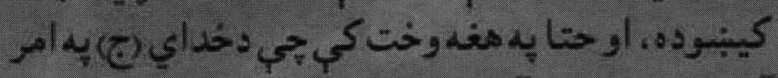

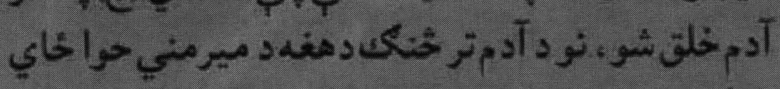

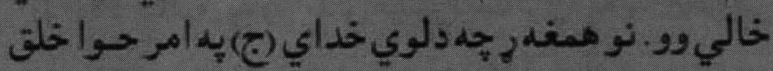

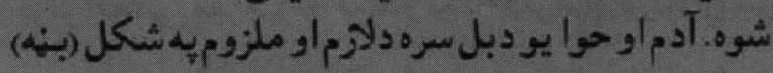

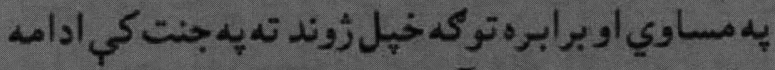

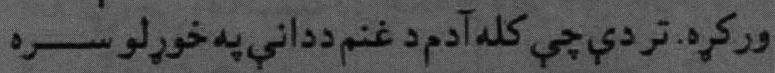

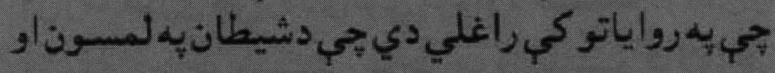

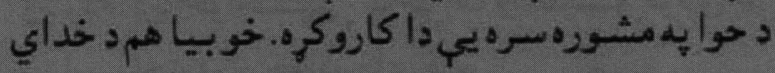

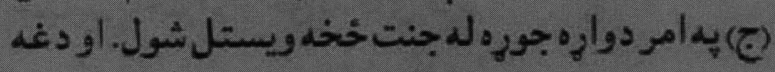

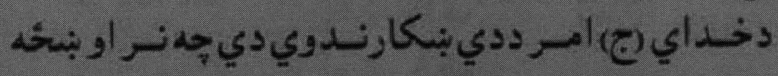


دبرابرو حقوقو خاونداندي. 2 اسلاميه مقدس دين كي

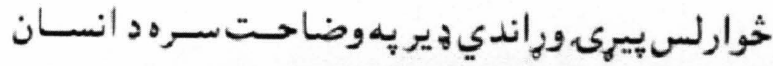

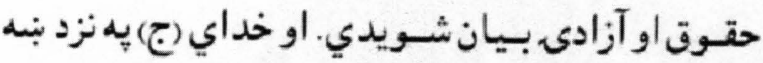

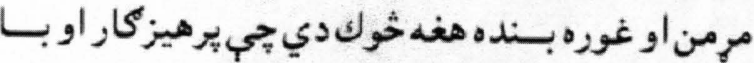

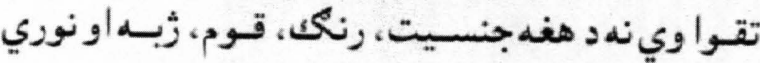

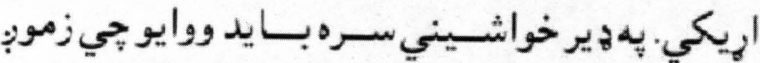

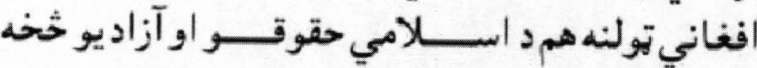

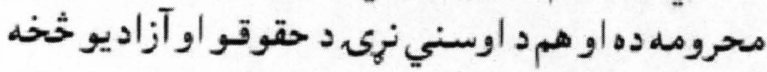

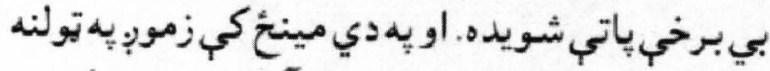

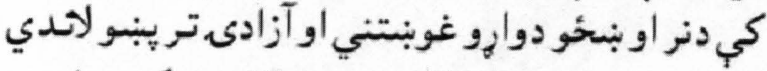

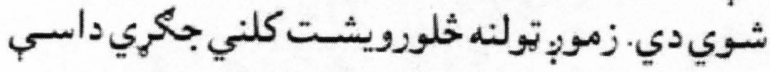

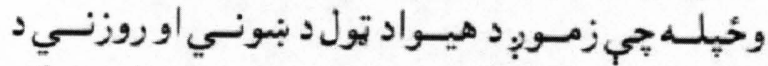

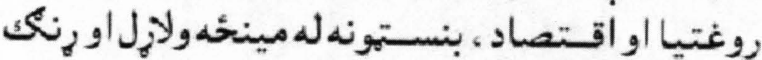

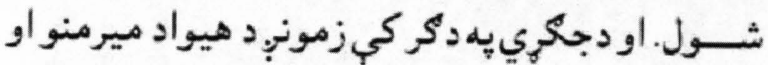

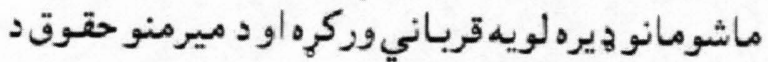

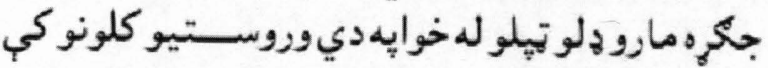

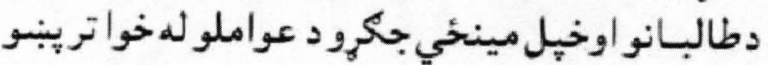

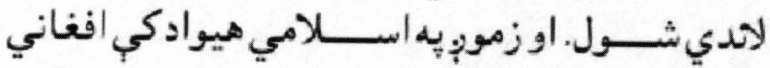

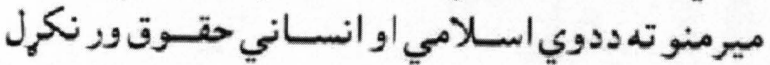

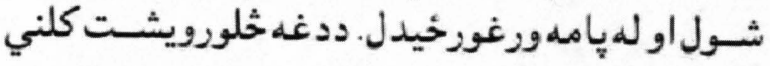

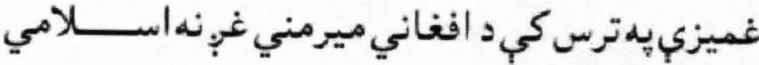

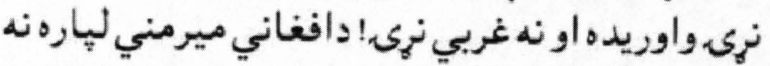

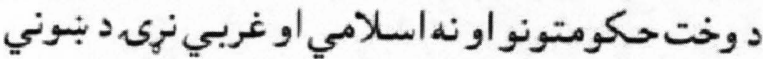

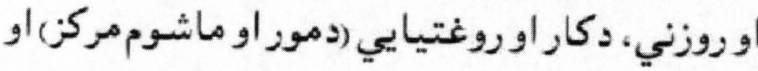

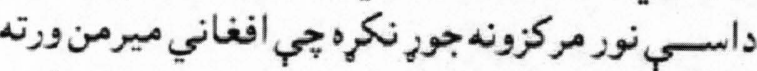

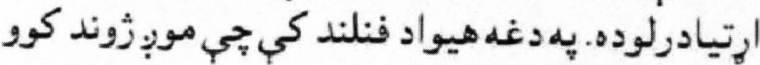

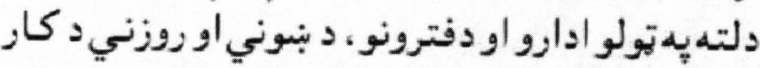

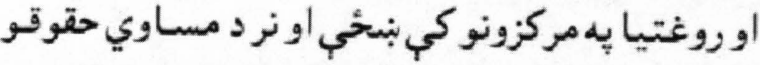

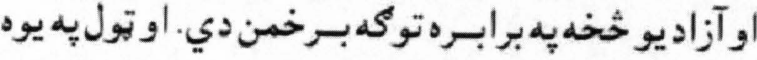

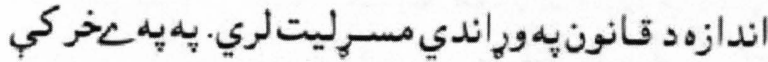

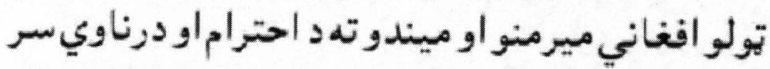

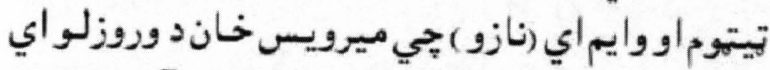

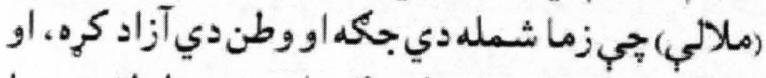

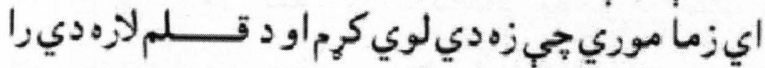

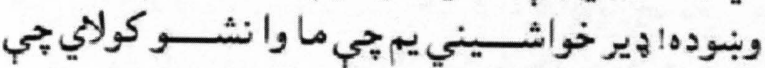

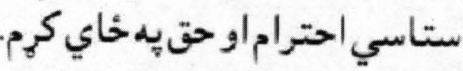

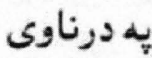
له ني ثخد اوته

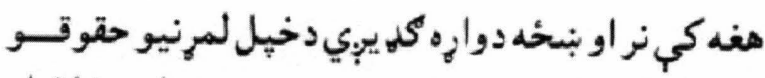

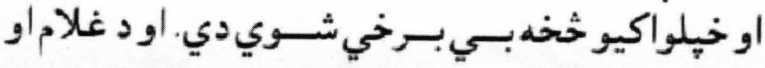

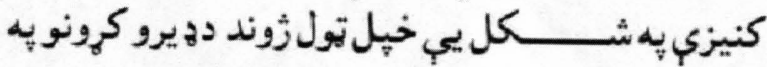

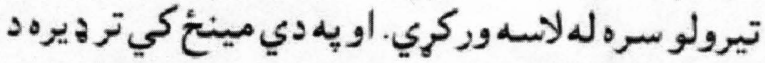

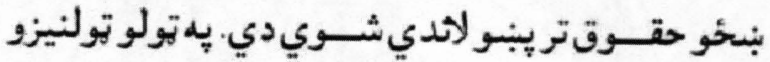

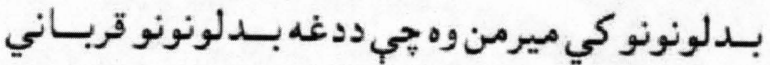

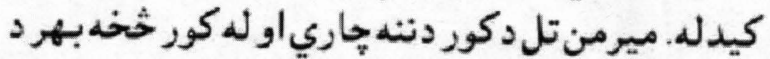

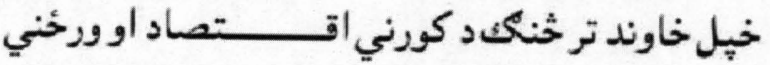

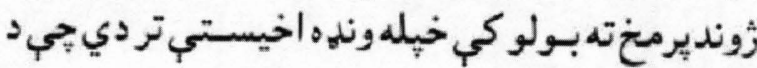

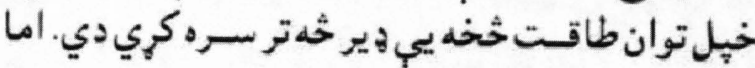

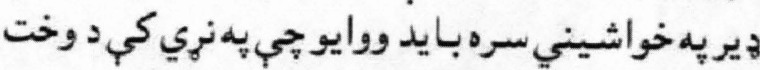

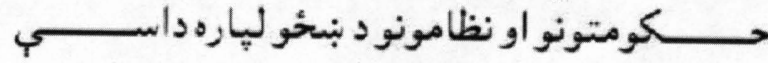

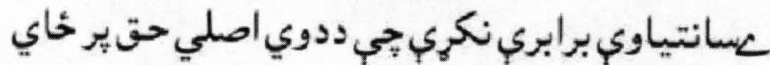

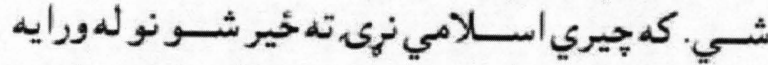

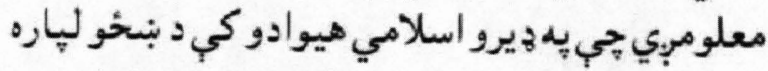

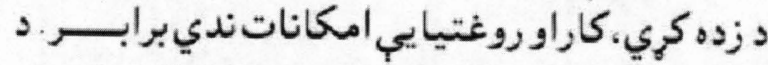

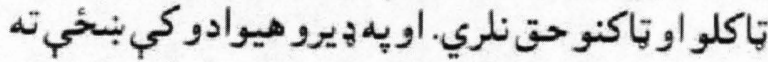

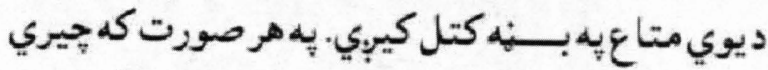

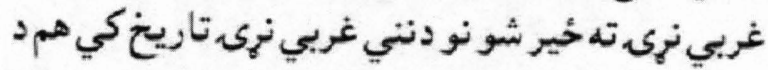

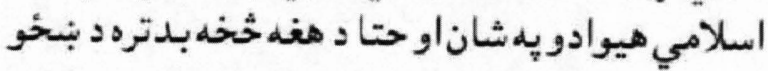

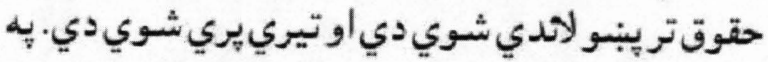

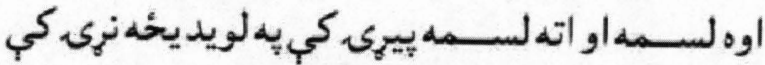

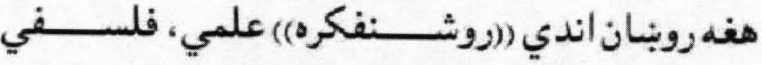

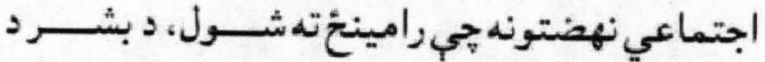

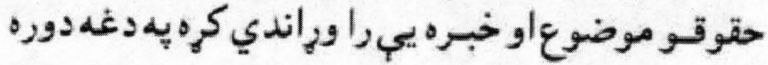

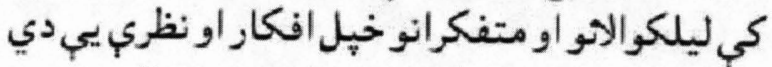

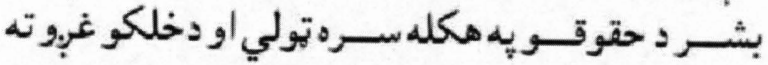

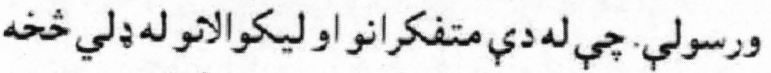

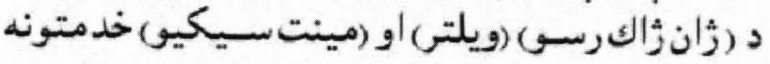

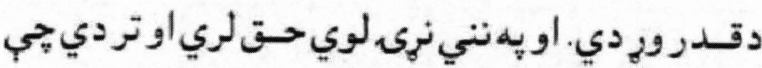

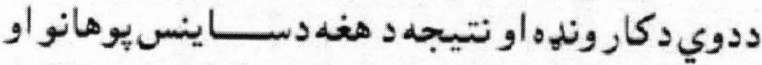

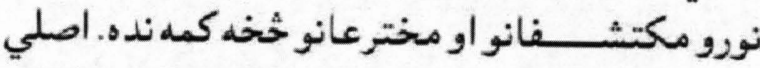

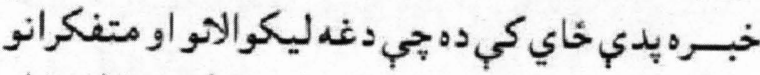

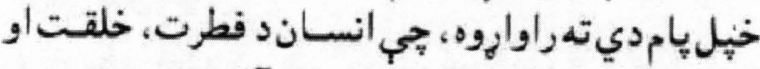

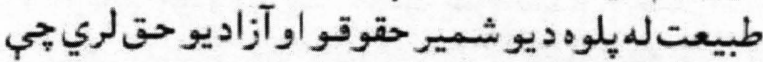

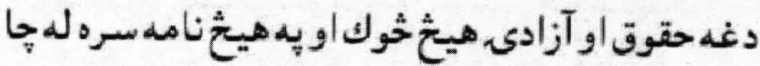

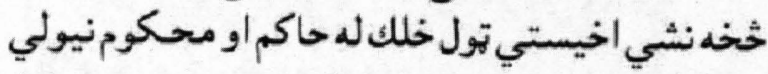

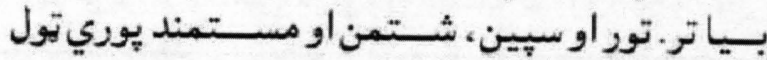



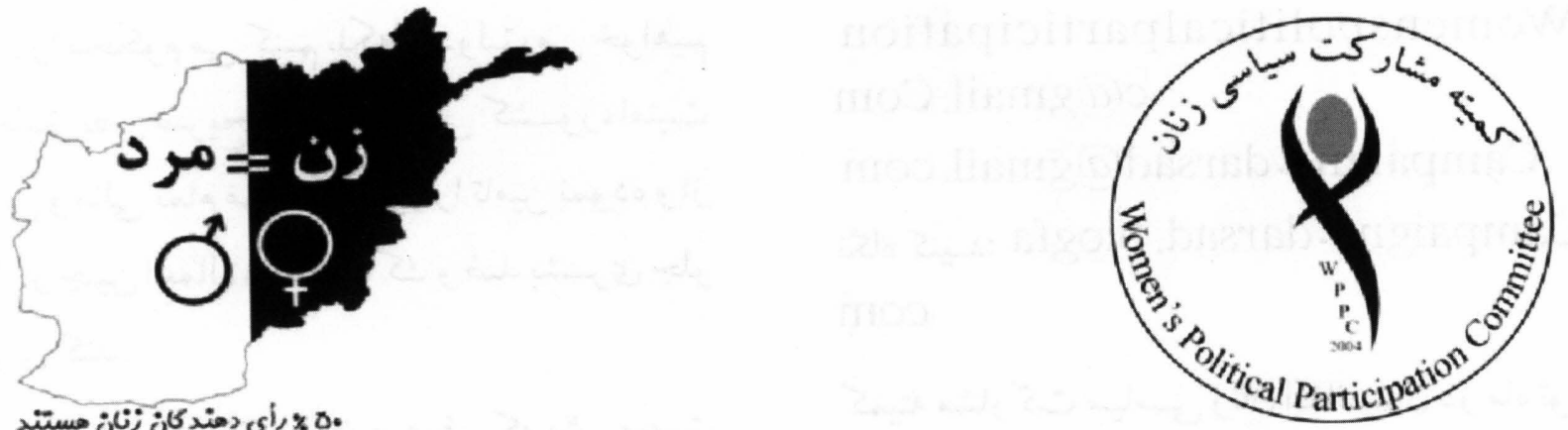

بيانيه مشتر ك كميته مشاركت سياسى زنان افغانستان و كمياين •ــ\% زنان افغانستان در مورد شلاق زدن يك دختر در ولايت بادغيس جر كه ها و شوراهاى عرفى در مغايرت با قانون اساسى و تعهدات بين

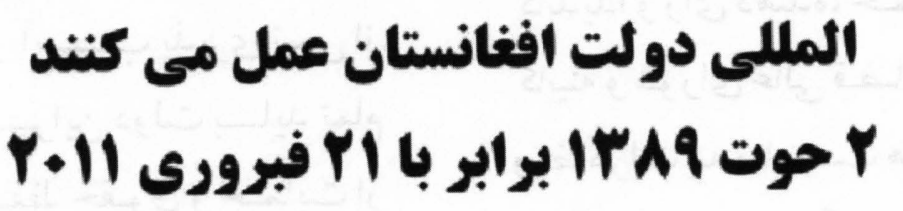

مولوى خـداداد صالـح، نـه تنهـا ايسن عمـل راغيـر

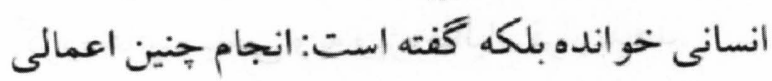

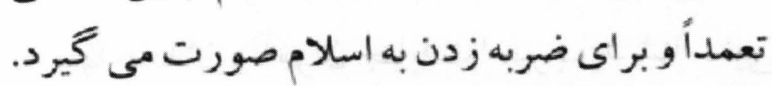

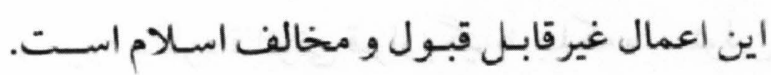

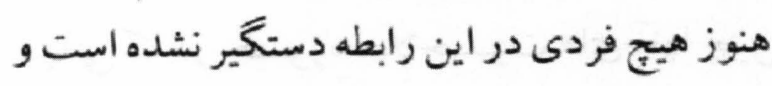

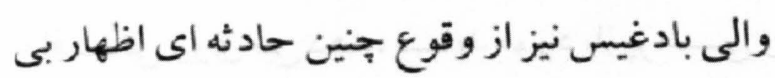
خبرى مى كند.

واقعات اخير جون موارد متعلدد سنگسار، به شـلاق

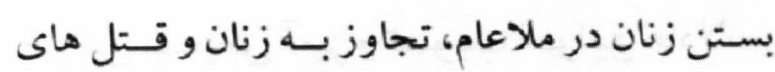

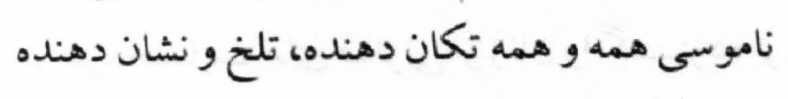

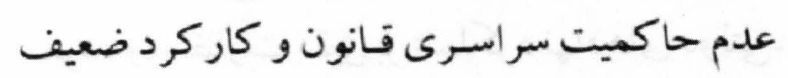

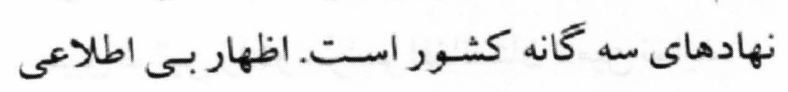
بالاترين مقام اجرايى در ولايت بـادغيس نيز نمونه

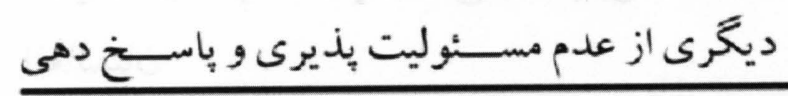

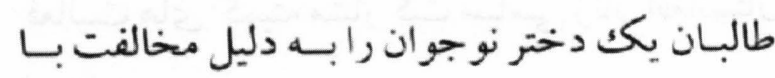

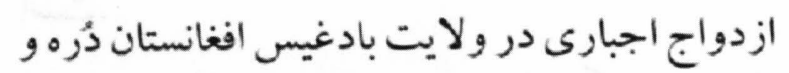

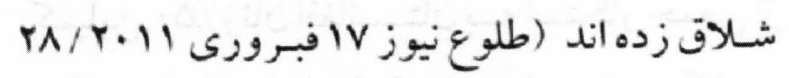

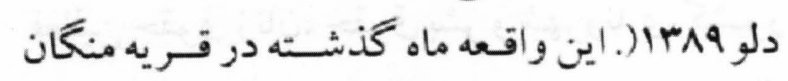
واقع در ناحسيه بـالامرغاب اين ولايت اتفاق افتاده

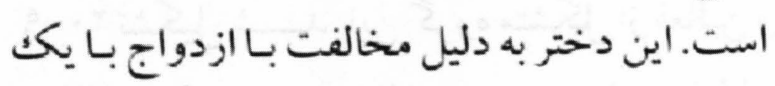

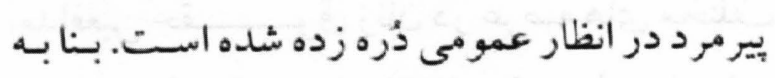
كز ارشهاى موجود، دستور شلاق زدن به اين دختر

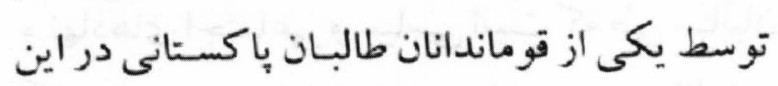

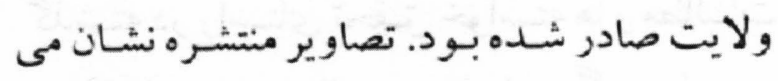

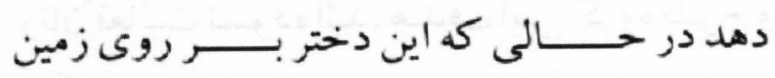

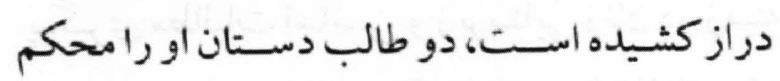

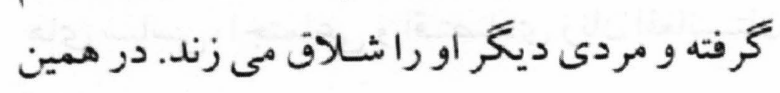

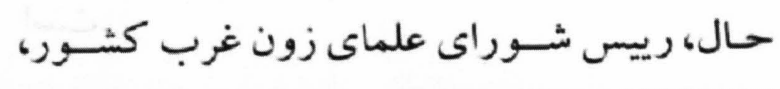


كابل ، افغانستان

تماسم:

Womenspoliticalparticipation

c@gmail.com

Campaigns.darsad@gmail.com

نغاه كنيـد: Campaignه.darsad blogfa.

$\mathrm{com}$

كميته مشار كت سياسـى زنان افغانستان در ماه ثور

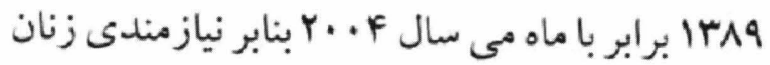

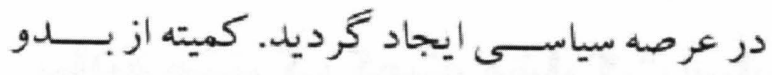
تاسيس به مثابه اهرم فشـار بـر نهادهاى دولتى عمل

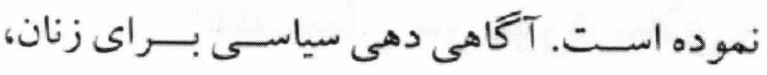
تشويق زنان جهت اشتر اكك در انتخابـات بـه عنوان كانديدا و راى دهنده، حسمايت از حسور زنان در

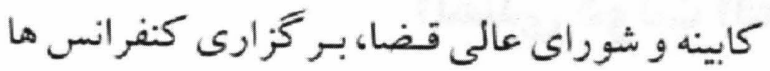

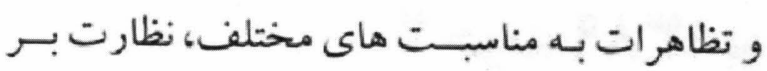
عملكرد بارلمان و حكو مت در قبـال مسـاله زنان از فعاليت هاى كميته مشار كت سياسى زنان افغانستان

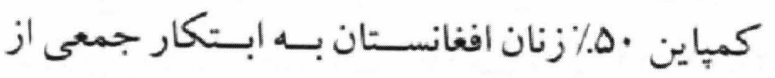
فعالين حقوق زنان، حقوق بشر و شهروندى كشيور

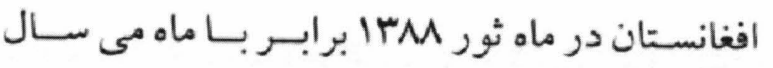

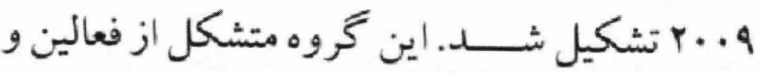

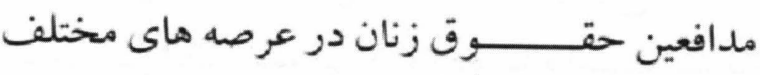
صنفى، مطبو عاتى، ساز مان هاى غيردولتى، احزاب و نهادهاى اجتماعى و سياسى است كه طى سـاليان كذشـته در راسـتاى تحقـق خون اسـته ها و مطالبـات

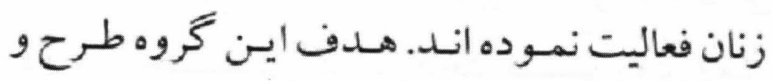
بيگيرى مطالبات اساسـى و زيربـنايى زنان در زمينه هاى سياسى، اجتماعى و اقـتصادى زنان افغانسـان
مسئولين اسـت. مازنان كميته مشـار كت سياسىى و

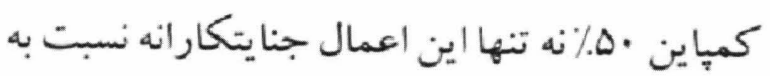
زنان را محكوم مى كنيم بلكه از دولت مي خواهيم تا: طبت نص صريح قـانون اساسـى كثــورو، امنيت جانى و مالى تمام مردم كشــور را تامين نموده و از

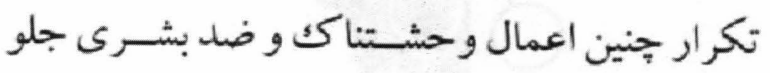
كيرى كتد.

از رسميت بخشيدن به قوانين عرفى كه مشـروعيت قانون اساسى و تعهدات بين المللى دولت افغانستان رازير سوال برده و سبب ترويج عدالت سنتى كه حقوق زنان نخستين قربـانى آن اسـت - جلو كيرى كنيد. اعمال غير انسـانى اخير عليه زنان اين كشـور نشــان

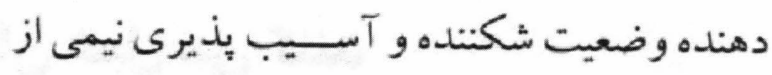
نفوس جامعه اســت بنابـــراين دولت بــــايد تمام كوشش خود رابـراى حسف حقـوق و حسمايت از آنان بـه كار بـرده و تامين حقــوق انســانى كامل و و

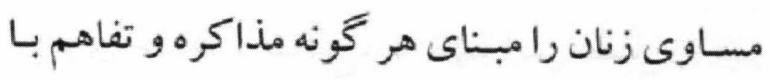
كرو هوه هاى سياسى و به ويثره طالبان قرار بدهد. نه تنها عاملان و آمران جنايات اخير بـايد شناسـايى

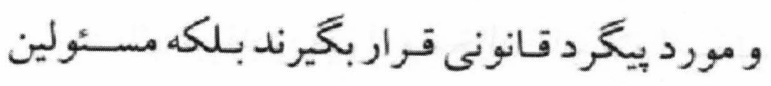

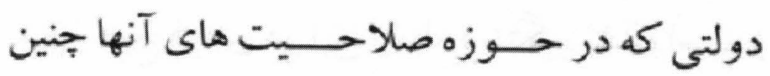

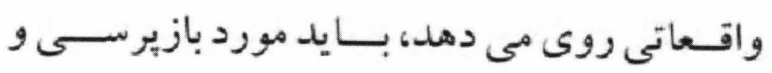
يبكير د قانونى قرار بكيرند. مجلس نمايندكان جديد افغانسـتان بـايد بـا زدودن قـوانين تبـعيض آميز و تصويب قــوانين عادلانه و

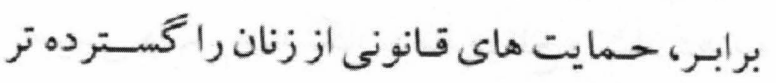

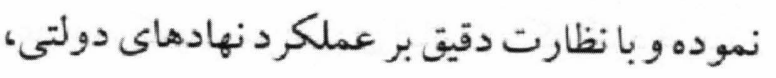
تطبيق قوانين رادر سراسر افغانستان تامين نمايد.

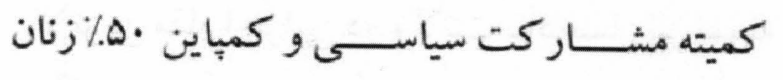




\section{حالت روانى و ثربيت اطفال نَاهى به مسووليتهاى والدين بر تربيت سالم اطفال}

در سـاختمان اعضـا جون بـينى و خشــم و كاســ روى طفل شبييه يدر و مادر و يا ديكر اقارب نزديك وى مي باشد.

ما در محيط خويش مى بينيم كه شكل و قيافه اقوام مختلف بـاهم اختلاف داشــته و بـه صورت اكثر

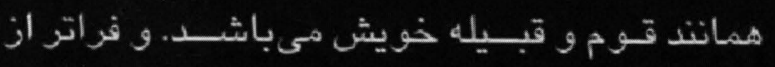
كشور خود اين تباين و اختلاف در بين كثو رهاى مختلف نيز به وضوح ديده مي شيود. يس در عادات و اخلاق و سلوك نيز خنين تشابه و
نخست بايد به صورت عموم بالاى ارتبـاطات ارثى

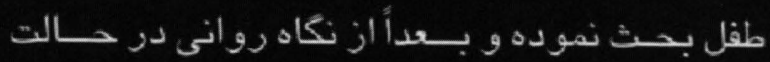
مهاجرت به نفسـيات و سـايكولوثيآن بير دازيم. و در محيط بـيكانه، اخلاق، عادات و ديكر كو ايف وى بـ بـ را بررسبـى نماييم. طورىكه بـــه صورت آشكار

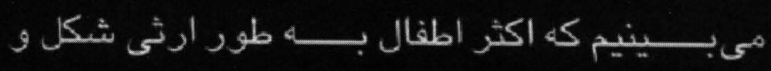

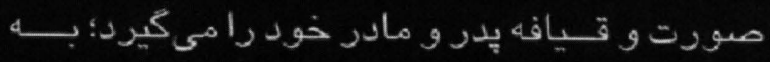

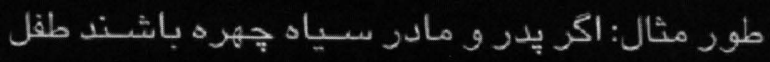
وى نيز همان جهره را بـ خود مي كيرد و همجنان 
بيوندند و راه ديكر را اختيار نمايند. ماهر ان علم نفسيات به اين بـاور اند كه عدم تشابـه اطفال به بدر و مادر و يا ديكر اقرباو خويشاوندان

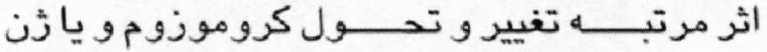
مي باشد و يا هم طفل از نياكان دور و بعيد خود اين ميراث ظاهرى در شكل و يا هـ عـادت و اخـلاق را كرفته باشـــ. بِس ديده مي شــود كه اين وراثت طفل از نسل قريب خود نكرفته بـلكه از نسـل بـعيد خود اخذكرده باشــ. و يا هم نقص كروموزوم و سـلول تناسلى بوده باشد كه اين نقيصـه و عدم تشابـه را به بار آورده است. كه در تـيافه و اخلاق نسـلهاى آينده هويدا و آشكار كرديده است. علماى قديم اين تغيير و تطور را ميدانستند ولى يك عالم نفسـيات بـه اســم مولر در سـال I I FV ميلادى اين تغيير در

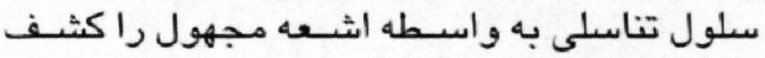
نموده است. و بعدأ به وسيله شعاع (اكس) نتايج مثبتى را بـ بـار

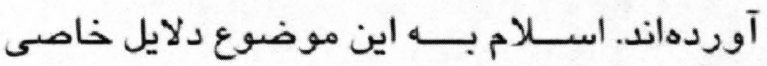

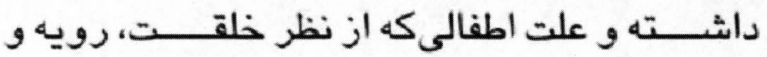
عادات بـــــه بِدران و نياكان خود مشـابــــــت بيدا نمى كنتد واضع ساخته است. امام باقـر رضى الهه عنه ميفرمايد: انصارى همراه بـا خانمش بـه حضور حضـرت يـيامبـر متعرف شــــداند و آن مرد كفت: ايى بيّامبـــر خدا! اين خانم دختر كاكايم مي باشـــ. عفيف و هاكدامن بـوده و از وى اخلاق سو سر نزده اسـت مكر همين زن، طفلى را به بار آورده كه هيت بـه ما و خاندان ما شبـاهت نداشته است. رنكش سياه بـينى اش بخخع و موهاى جنك و باهم آويخته دارد. خلاصس اين كه يك حنين طللى را به بار آورده است. بيامبر خدا از زن برسـيد كه كيفيت جه اسـت؟؟ زن قسم بـ خداوند بجا ميى آورد كه من يك زن عفيفه و

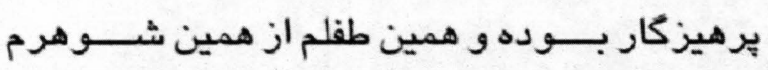
مي باشــ. بيامبر خدا انديشـيد و سيس سـر خود را
همرنكي در وراثت به صورت بديهى و آشكار ديده

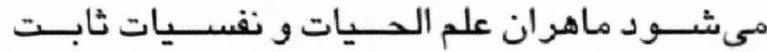
كردهاند كه در جســم آنان ^ع كروموزوم موجود بوده كه اين كروموزوم در ديكر حـيوانات مختلف بوده و يكسان نمىباشند.

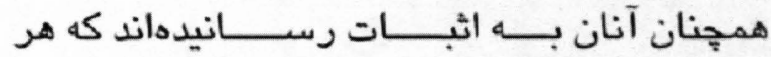
كروموزوم داراى ذرههاى خورد بـوده كه بــه نام ذن ياد مي شود. و عامل وراثت حقيقى همين ذردها بـوده كه در تشكيل بــينى، جشـــــ، موها و ديكر اعضاى انسان رول مهمى را بازى مىكند.

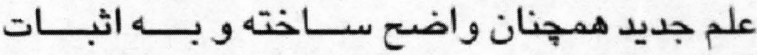
رسانيده است، طورى كه در ظاهر اعضا وراثت اثر مهمى دارد در اخلاق، سلوك، رويه و عادات نيز اثر

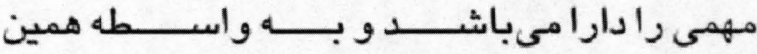
كروموزومهـا وراثت از يكى بــــه ديكرى انتقـــــال

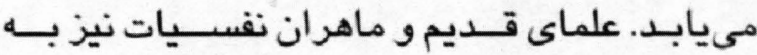
وراثت عقيده داشتند، مكر به حنان نتايجى نرسيده بـودند جنان كه امروز علم جديد بـــه آن بيى بــرده است. دين مقدس اسلام هم به همين قانون خلقت و طبيعت دقت نموده، مكر بــه اين اختلاف كه علماى

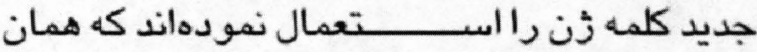
مفهوم و معناى عرُق را مي دهد. بــــا اين تفاوت كه زن كلمه لاتينى و عرق كلمه عربى مى باشــ. يبامبـر

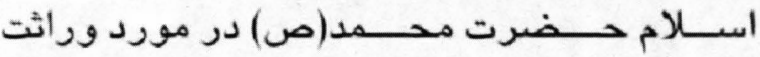
مي فرمايد: انظرفى اى شـئئ تضع ولدك فان العرق وسـاس ترجمه: بيـين كه در كدام محـل طفل قـرار مى كيرد زيرا كه عرُق نقل دهنده است. از اين حديث شـريف استنبـاط مىكردد كه از زناو فحاشى بايد برهيز نمود تا اختلاف انساب بـه ميان

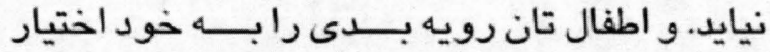
ننمايند. كرجهـ موضوع ارث و وراثت ثابت بـوده و

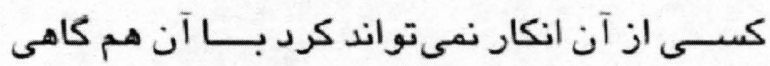
اتفاق مى افتد كه اطفال از قــانون وراثت مســــثنا كرديده و به يدر و مادر و دكر خويشاوندان هيج نه 
روحى قـرار بــهند. زيراكه در اين صورت كانون

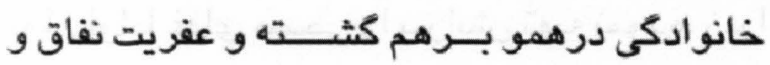

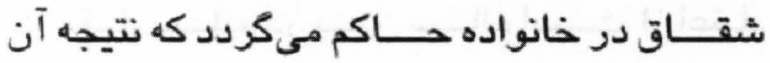
خواهى نخواهى بـه طلاق و تفريق منجر مىكردد و

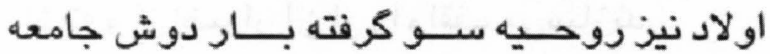
مى مىردن.

دانشمندان عصر حاضر وراثت را فقط به نسلهايى نزديك ارتباط نمى دهند بلكى به نظر آنها نسـلـهاى دور و بـعيد در وراثت رول مهمى را بــاز ميكند و

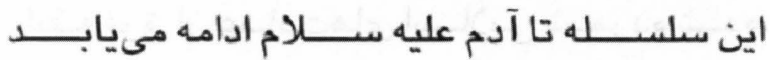
طورى كه كفته آمـده وراثـت در رنك و صـورت و

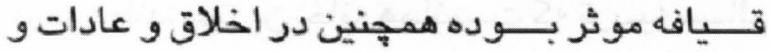
سلوك نيز موثر بوده ميتواند كه موضوع بحث ما

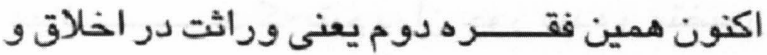
عادات مطرح مي باشـــ كه بـهـ اســـاس وحــى الهى ذريعه حـضضرت رسبــول اكرم(ص) بــه ما ابــلاغ

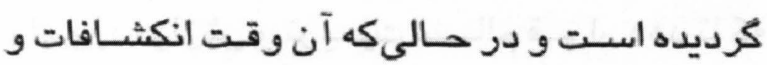
وسايل امروز هم در دسترسى مردم قرار نداشت. البته علاوه بـر ارث بـردن اخلاق و عادات علت هاى ديكرى هم وجود دارند كه بــالاى صـحـت و روان اطفال تاثير بـه ســزايـى دارند جنانجه لازم اســـت وقتى كه طفل در شكم مادر مي باشــــ مادرش بـايد

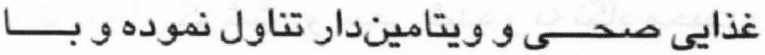
احـتياط خيز و نشسـت نمايد. وقتـى كه طفل تولد شـود بـه تربـيت بـدنى و صحسـى وى توجه كامل

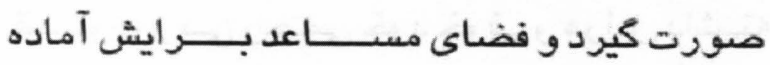

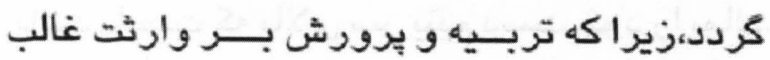
مىباشد. در تربيه سالم استعدادها و كمالات تبارز و انكثـــــاف مي نمايند اخلاق و دوش انســـــانى و اسلامى را برايش مى آموزاند و از سخنان عقدهاى

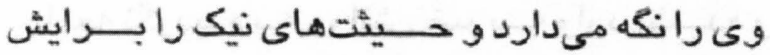
تلقـين مي كند. از مواخذه اله تعالى او راترسـانده و از حشـر و كتاب حـا موصوف را باخبـر مىكنت، روز جزا را به يادش آورده و به طرف ايمان و خدا
بالا كرده و به آسمان نكاه داثت و بعد بـه شـوهر خانم رو كثـتاند و فرمود: هر انســان تا آدم عليه

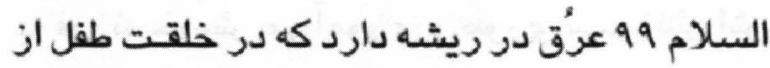

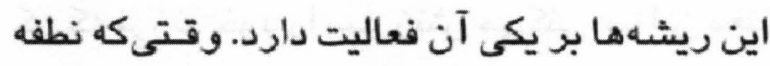
در رحم قرار كيرد هر ريشـه از خداوند متعال طلب دارد تا اين طفل ارث همان ريشـه را بـه خود كيرد. يس اين طفل از همان ريشــــــهـها يكى آن را راختيار كرده است. بدين اساس اين طفل از نسل شما است و وى رانكهداريد. سبس آن زن كفت: ایى بيهامبر خدا صلوات بـرتو كه

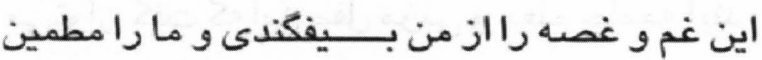
ساختى. وقتى كه يك انسان تا آدم عليه السـلام 99

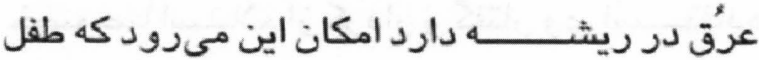
وراثت قيافهاى وى خصلتى را از نياكان بـعيد خود

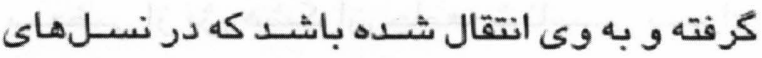
آينده شكل و خصلت وى مقايسه شده نمي وتواند. و

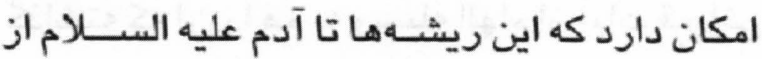
99 زياد بـوده باشـــ كه جهنين اعداد در قـر آن كريم

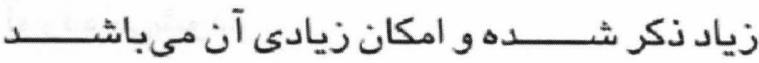
طورى إكه در قر آن كريم آمده است: ایى خيامبـر خدا اكر به اين كفار •Vرتبـه مغفرت بـخواهى خداوند

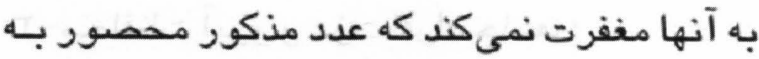
نبوده و امكان زيادى هم دارد، يعنى در صورت V. زيادى از هفتاد مرتبه هم خداوند آنها رانمى بخشد.

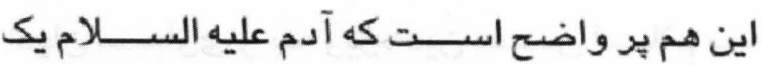
شـخص بـوده و خداوند وى را از (طين) (كل) خلق نموده است و نسل بعدى وى بـ اثكال، قيافهها و اخلاق و عادات مختلف متشكل و خلق شدهاند, يس

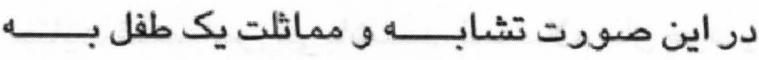
نسلهاي بسيار بعيد امكان بيرون نيست. بـايد كفت كه بـه اسـاس هدايات اسـلام اين شك و ترديد بيهوده و اين ظنى كه طفل با قـيافه متفاوتتر از يلدر و مـادر را اولاد خـود ندانتـد از اذهــان دور كنتد و نه خود و نه هم خانم خود راتحست فشــــــار 


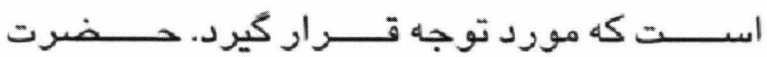
على (رض) مي فر مايد: به يتيم همان ادب بـياموز كه

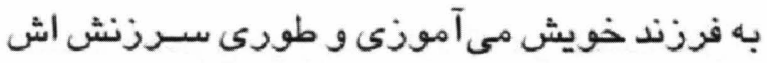
كن كه فرزند خود را سـرزنش مسىكنى، بـا اين معنا كه وى را با يسرانت شريك ساز و فرق و امتياز در بين قايل مشو ـ در تربيه طفل نخسـت تربـيه فاميلى دول دارد و هيس از آن مكتـب، يرورشكاه و غيــره مر اكز تعليم و تربــيت. طفلى كه در خانواده مودب تربيه بكيرد و از خانواده نيك و با تربيه باشد و در محيط با تعليم تربيه دوحى و جسمى كرفته باشــ. مىتوان كفت كه اين طفل مربى و معلم جامعه آينده

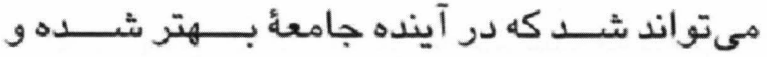

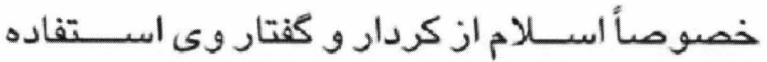
مي نمايد.

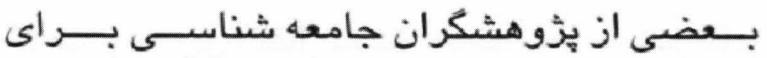

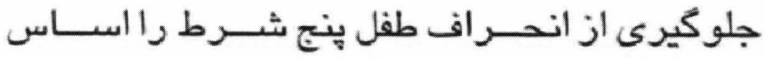

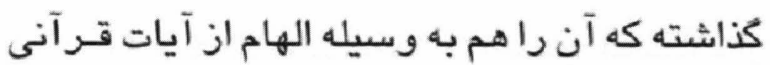

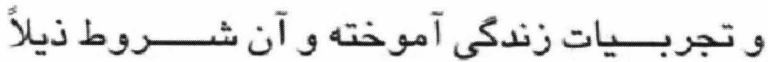
آورده مي وشود: 1- محافظت جسمى افراد جامعه؛ Y-محافظت مالى افراد جامعه؛ r-محافظت آبرو و عزت افراد جامعه؛ ع- محافظت تفكر و محبت و صفايى افراد جامعه؛ 0- محافظت عقايد و اخلاق افراد جامعه. اديان سـماوى و بـه ويزّه دين مقـدس اسـلام بـــ

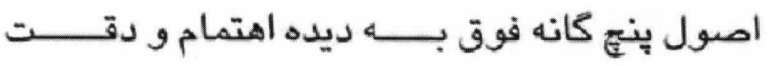
نكريسته است. اسعلام قـتل يك انسـان را منع قـرار داده در صورت بـــروز واقـــــه جزاي اين بديده جنايت قــصاص مي باشـــــــــــــام مال مرد را محفوظ نكه داثـته و در صورت سرقـت و دزدى سارق جزاي معينه خويش را ميىبين. اسـلام آبـرو و عزت مردم را محسترم شــمرده و در صورت تخلف مستورى جزاي تعزيرى را مىبيند. اسلام عقايد مردم را محـترم دانسـته و تجاوز بـر
برستى وى رار رهنمايي مينمايند. به اندازه وسبع و توان اوليا غذاي صحى را بـرايش تهيه نموده، زيرا

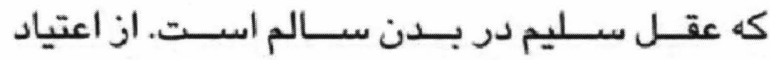
هيرويين، شـراب، سكرت و غيره وى را بـر حـــر داشته و از اضرار آن او راواتف مىسازند. به طور خاص توجه جدى در مورد مهمانى مبــول كردد كه در ديار مهاجرت زيسـت مينمايند و بـهـ صورت اخص تربيتيت در محسيط هجرت رازيادتر مورد توجه و دقت قـرار دهند. نوازش و تربـيـ اين طبقـه فوق از عبـادت هـاى اسـلامى شــمرده شــده،

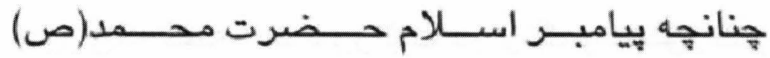
فرمودهاند: بهترين خانه همانسـت كه تربيه سـالم

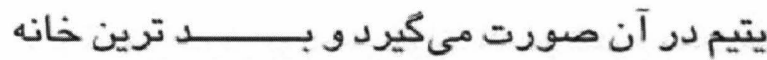
ت كه يتيم دران جور ديده و متضرر

ميكردد.

همجيجان ميفرمايند: كسـى كه در خانه خويش يتيم را مورد نوازش و تربــيت ســـالم قــــرار دهد تا كه بزرك شود، الشه تعالى براي تربـيت دهندهُ وى جنت

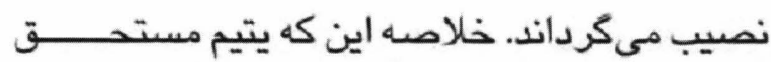
عطوفت و نوازش بـــوده كه در اين مورد احـــاديث

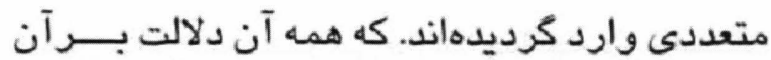
ميكند كه بـا يتيم رويه نيك صورت كيرد در تعليم و تربيه آن كوشش و سعى شده و به نكاه محبت و عطوفت بـه وى نكريسـته شــود. همجينين درجاى ديكر حسرت محسمد(ص) مي فرمايد: كسـى كه از قســاوت و بـى رحسمى خود خوف و هراس داشـته باشد بايست كه بالاى سر يتيم دست خود را بمالد. اميد است كه در قلب وى رحم و عطوفت بيدا شود. بادي در اجتماع يتيم ســزاوارتر از آن اســـت كه مورد

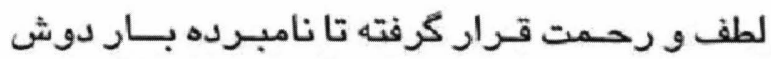

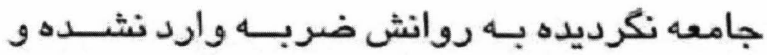
معلم تعليم و تربيه وى مستحق اجر ضرودى شده بتواند. در جامعهُ اســلامى اولتر از همه يتيم مستحــقتر 
نيك و رهنماى خوبسى كرديده كه اجتماع از افكار و كردار وى بيروى مي نمايد. عدهايى از روانشيناسان

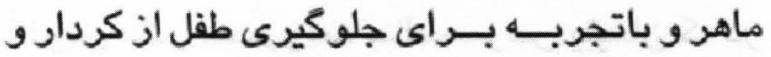

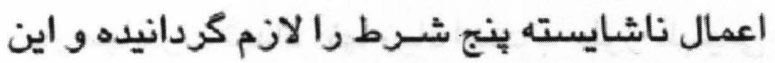

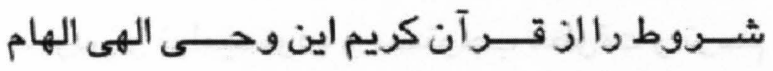

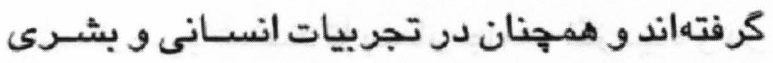

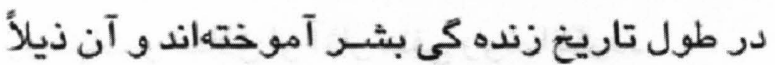

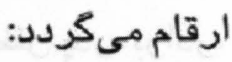

1-امنيت جسم و جان انسانها؛

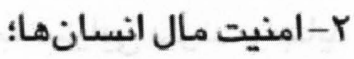

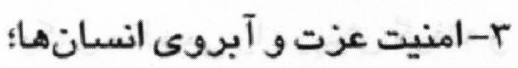

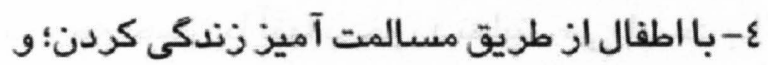
0-امنيت و حفاظت اخلاق و عقايد انسانها.

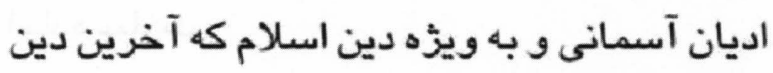
سماوى بوده به عناصر فوق اهتمام زيادى را قايل

شدهاند.

اســلام قـتل انســان را منع قـرار داده و در صورت

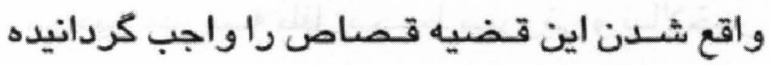

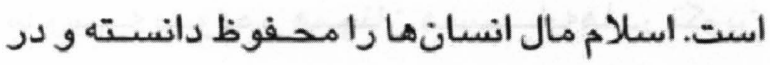
صورت سرقـت و دزدى ســارق بـه جزاى اعمال

$$
\text { خود مىرسد. }
$$

اسلام عزت و آبروى انسـان را محسترم شـمرده و در صورت بـروز واقـعه متعددى جزاي خويش را مىبيند. به نظر اســام عقـايد انســانهـا از تعرض مصـوون

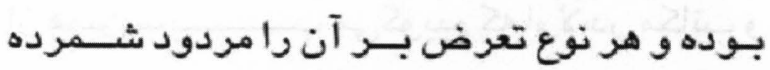

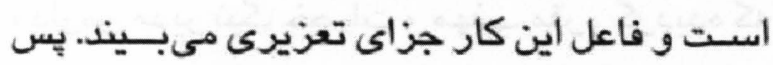

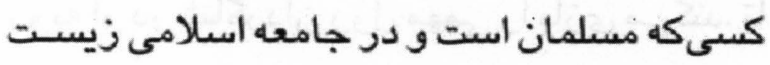

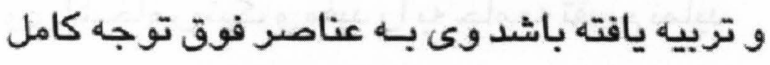

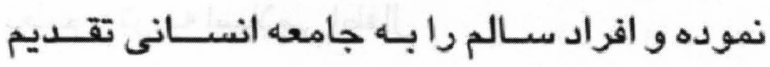

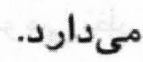

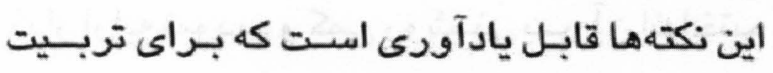

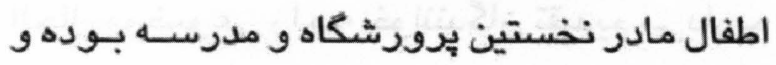
وى هم معلم اين مدرسه است، آغوش مادر محسيط
عقايد يك ديكر را منع قرار داده است و در صورت بروز جنين حادثه مرتكب مسـتوجب جزا شــاخته

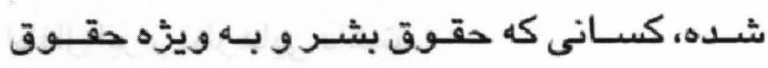

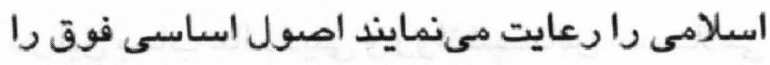

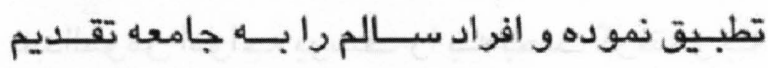
مىنمايند. بـايد كفت كه مهر نخستين تربـيه طفل آغوش مادر بوده و او معلم اولين مدرسـه تربيـيت

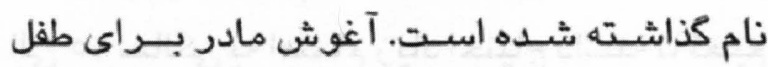
محيط طبيعى بوده كه از همين جا تربيه سبـالم و يا

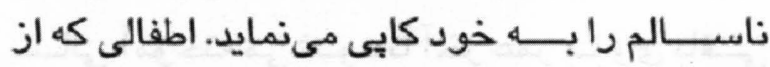
آغوش مادر محروماند بـه ويزٔه يتيمان كه در ديار

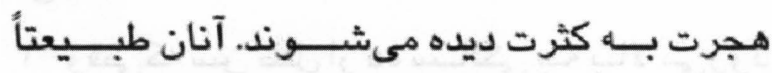

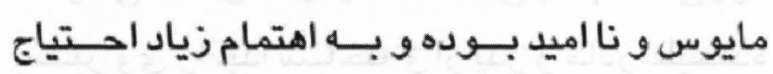

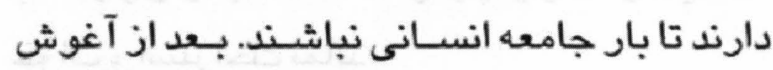

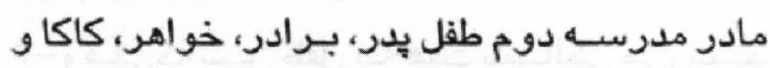

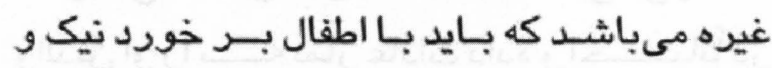
حسنه نمايند و از تربيه طفل غافل نباشد. حالت روانى طفل در مهاجرت

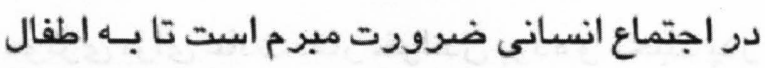

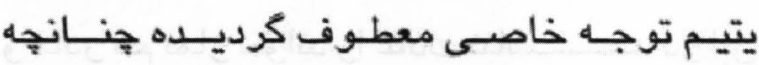
حضرت على(رض)در اين مورد مىفرمايد: به يتيم

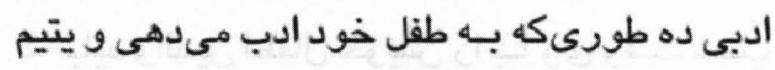
را سرزنش كن طورى كه يسر خويش را سـرزنش

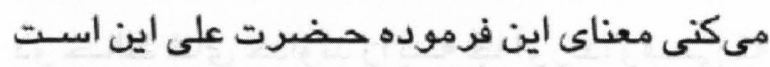

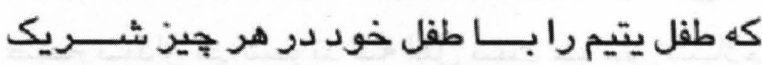
بكردان و فرق و امتياز بـين اين دو قـايل مشــو. در

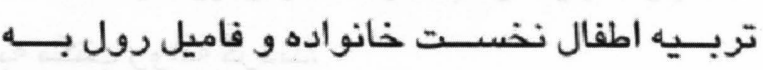

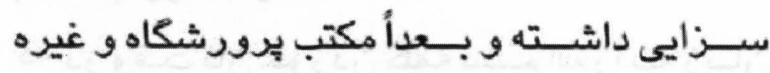

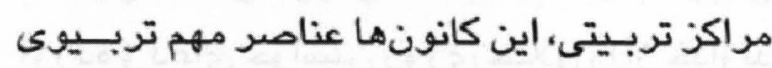

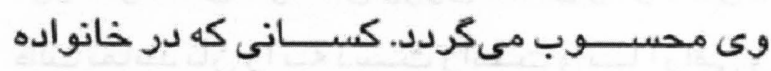

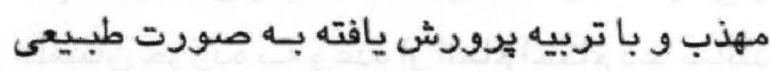

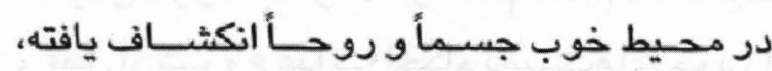

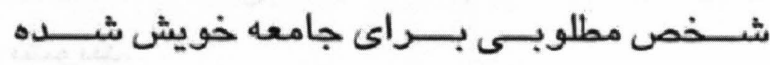

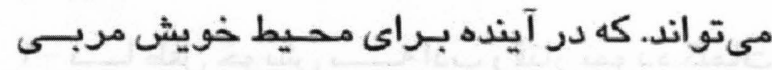


و تربيه اطفال ارايه داشتئد و به ويزّه موضوعى را به بحث مى بىيريم كه در مورد اخلاق و روش سالم اطفال ابر از نظر هايي داشتند. در اين بــاب عالم دينى و دوانشـــــاس اســــلامى

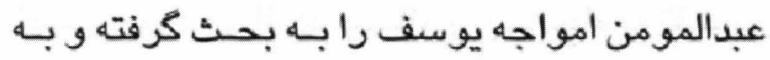
طور خلاصس نظريات وى را تقديم مىداريم. 1- دانشمندان تعليم و تربيه بـه اين نظراند كه طفل الى 10 سالكى بـ اهتمام زياد احتياج داشته تا تعليم و تربيه خوبى را فراكيرد، زيرا جيزى به در خورد

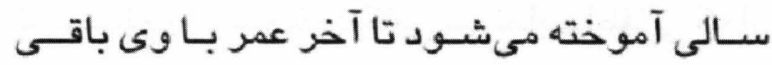
ميىماند.

Y- وقتىكه سن طفل از ده سـالكى بـه بـالا مىرود بسـتر وى را جدا سـاخته و از بدر و مادر عليحـده خواب و استر احت نمايد. r- وقتـى كه سـن طفل بـه هفت ســالكى مىرســـ

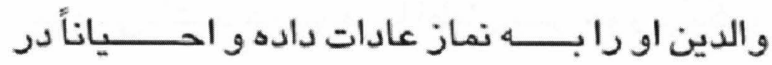

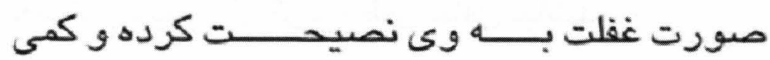
اخطاريه بـدهد. لاكن ترغيب و تشــويق و روحــيه موثرى براى عادت نماز خواندن بوده و محبت يدر

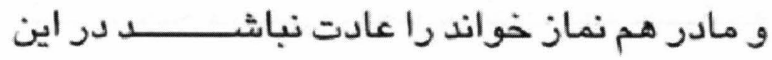
صورت نصحيت و ترغيب سودى نمى بخشد. ع- بايد والدين اطفال خويش را بـا وى وقت شـب خوابانيده و صبحكاه وقتتر خيزانتد و در اين هر

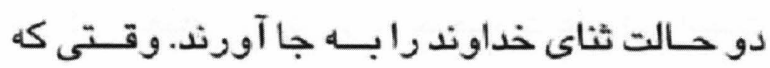
صبع بـيدار ميىثـوند بـه اهل بـيت خويش سـلام

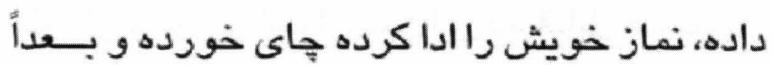
به مكتب روانه كردند. 0- در وقـت نان خوردن كلمه بســم الشه را بـه زبـان آورده و دعاي خواستن دوزى حـلال را از خداوند

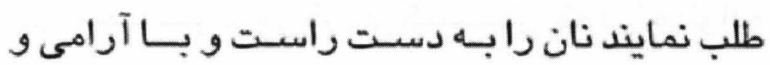
اطمينان خورده بـه و عده از اتمام احكام دعا نمايند و قبـلـ از شـروع غذا بـه احكام دســــهاى خود ردا بشويند.

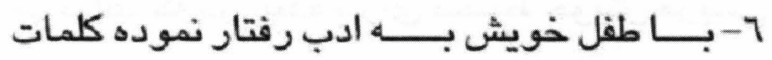

طبــيعى اطفال بـــوده كه از اينجا عكس العملهاى مثبـــــــت و يا منفى اخذ مي دارد. يس اطفالى كه از آغوش مادر محسرومند بـالخصوص يتيمان كه در ديار مهاجرت تعداد آنها زياد است به طور طبيعى مئى مايوس و نواميد بوده و مستوجب عطوفت و ترحم

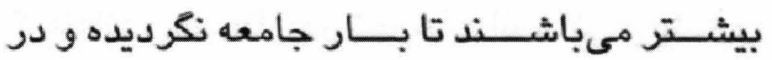
روحيات و اخلاق او آثار منفى رونما نكردد. بعد از آغوش مادر دومين مدرسه طفل يدر، برادر، خو اهر، كاكا و غيره خويشـــــاوندان بــــوده كه در تكوين اخلاق و روش رول به سزايى دارند. و بـايد كه با اطفال رويه نيك و مناسبى را درييش كرفته و به وجه احسن با آنها برخورد نمايند. مي بايست بـا

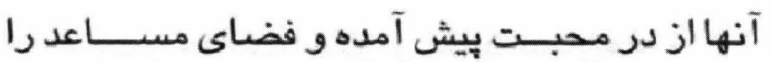
آماده سازند.

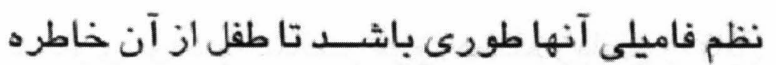
نيك و بِنديده داشـته روحـيـات و روان او صدمـه نديده و بــاعث رنجش وى نكرديده باثــــــ سيس رونس سـومين مدرسـه طفل محـيط بـيرونى و بـالاخص مدرســه بــوده و همجنان همســــايهـا در تكوين شخصيت وى رول سـازندهاي دارند. بايسـت طفل

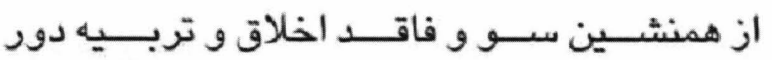
نكهداشته و در مدرسـه هم اولياى وى نامبـرده را مر اقبـــت و مواظبـــــت نمايد، بـــــالاى معلمان و و

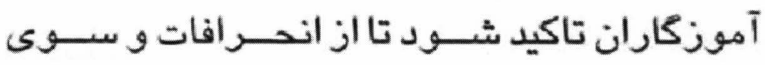
اخلاق دور باشد.

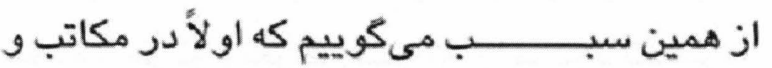
مدارس مدير نيك خصلت و مهذب مقرر كرديده كه رويه او در شاكردان دول مهمى را بازى ميكتد. تا وى اشخاص نيك و مفيد را به جامعه تقديم نمايد. تعليم و تريبه اسلامى اطفال وقتى كه از تعليم و تربيه اطفال به طور عمومى نظر

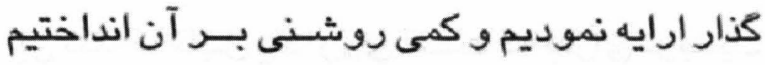
الحال موضوعى را بـه خو انندكان تقديم ميى داريم كه روانشناسـان و عالمان اسـلامى در مورد تعليم 
ع ا- بـعد از وقـت شـــام طفل بــايد بــه خانه طلب كرديده، نان خورده كمى درس بخواند و سيس بـه

$$
\text { خواب و استراحت رود. }
$$

10- بــايد والدين يـى ببـرند كه سبورت و بــازى ضرورت اهم طفل بـوده نبـايد وى را بــ كارهاى ســت و طاقـت فرســا وادار نموده بـلكه بـا اطفال ديكر بـــازى هاى مناســــب و از جوكات ادب اجرا نمايد. 7 ا -نبـايد والدين طفل خود راناز و برورش بـدهد بلكه بايد از اعتدال كار كرفه نه از حد زياد شفقت به وى كند و نه از حد زياد رويه درشـت بـا وى كيرد، زيرااين هر دو بـ آينده وى اثر منفى دارد.

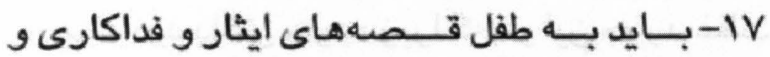
شـجاعت و حماســه آفرين نياكان و اسـلاف بـيان كرديده از مخترعان جهان به وى ياد آورى شده و از كسان نيك و صادق به وى حكايت صورد مكيرد تا موصوف نيز مانتد اســــــــــلاف خويش مصدر خدمت به جامعه شده باشد. 11 - وقـتى كه طفل بــا طفل ديكر در جنك و جدال باشــــ والدينش او را نكويد كه تو مظلوم هسـتى او آن ديكر ظالم كه در اين حالت وى استقامت خود را از دست داده و خود راناتواناحساس مىنمايد. 19 - بايد به طفل در مورد بعضى اثـياء، و رنكها

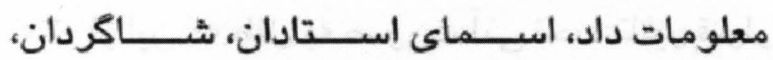
حيوانات، ميوهها و ديكر هيزها آموخته شود. •r-بايد به طفل سـاز و سـامان و ترتيب و تنظيف خانه آموخته شده، فرقى ندارد كه طفل بـايد او بجه باشـــ يا دختر را شـريك كار خود سـازد. بـه طور مثال دسـت شســتن، دســـرخوان هموار كردن و غيره. ا اب- بايسـت بـه طفل مطابـق ســويهاش مسبــايل اقـــصـادى، بِ انداز بيولى، بـــجا مصرف كردن و غيره آموخته شود.
بى ادبـى را اســتمعال ننمايد بـه طور مثال بــرايش نكويد: (به فلان دو و دشنام بده) زيرادر داين حسالت طفل بي ادب كثــته و احـترام بـزركان را طورىكه شايسته است بجا نمى آورد.

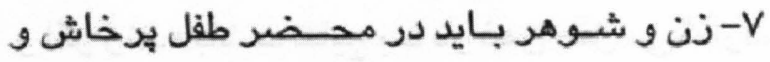
جنك و جدال ننمايند جراكه اين كار بالاى دوحيات

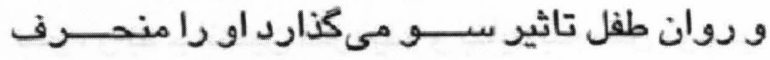
ساخته و اسباب بريشانى برايش آماده ميثود. ^- عواطف و احسـاسـات زن و شـوهر بايســت از اطفال در ينهان در بـين همديكر بـروز نموده. زيرا در حــضور اولاد اظهار محبــت و عشــق و ديكر شوخىهاى عاشقانه طفل راكستاخ تربيـ نموده و او را بـ اهراه ســاخته كه اين كار سبـب اخلال جامعه

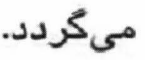
9- والدين بايست بـه اولاد خود سـخنهاى ضد و نقـــيض نكويد مثلاً يدر بكويد: اين كار را بكن و در همان لظحه مادر بكويد كه: نى اين كار مكن. در اين صورت طفل متردد ميىشود كه حِه كتد. • 1- والدين بايد بـه اولاد خود هر حهـ را بـياموزاند مانتد خوردن، يوشـيدن، نوشـيدن و او رادر امور روزمره عادت بدهد تا بـه نفس خود اعتماد داشـته بوردي باشد. Iا - بايد والدين به اولاد خود تـصههاى حماسـى، اسلامى، اخلاقى، ايثار و فداكارى و بالاخص تاريخ و كارنامههاي اجداد مسلمان را تشريح نمايد. Y I - بـايد طفل در فاميل خود همكار و معاون نيك باشد و تا حدى هم در خدمت همسـايكان نيز بـوده

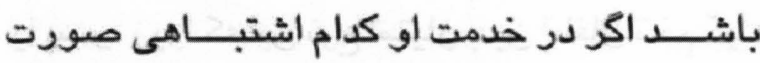
كرفته باشد وى را اخطار نداده و تهديد نتمايد بـلكه به اشتباهش متوجه ساخته و به كارهايش تشويق نمايد. rا - طفل بايسـت از اطفال ديكر نترســــ يا از جن، بلاو غيره. هراكه در اين صورت ترس و وحشـت بـا با وى هميشه توام بوده و خود راناتوان احسبـاس 
ير اكندكى آن ممانعت آيد.

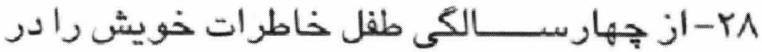
ذهن نكه داثته و تا آخر عمر باوى باقى مى ماند. اكر اين خاطرات نيك باشد نتايج آن هم نيكو بـوده و اكر زننده باشـــ نتايتج بـد در ذهن طفل ميكذارد، هب و الدين كوشش نمايند تا در ذهن طفل خاطرات سوء و بل جانشين نكر ديده و بـايد بـه طفل توصيه نيك و اخلاق حميده تلقين كردد.

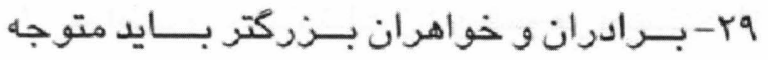
حركات و روششان باشند زيرا كه اطفال از كردار رفتار و اخلاق او يبيروى مى كنتد و طفـل اول از يدر

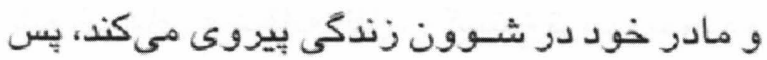
بايد موضوع يبر و مادر بايد زيادهتر متوجه بـوده بـايد كه طفل خود را طورى كه لازم اســت تعليم و تربيه اسلامى بدهد. • r-اكر طفل از آغاز از طـرف والديـن رهنمايسى و. تربـيه نيك نكردد بـه ركود و انجماد دماغى مبـتلا كرديده وقتى كه بـه سـن بـلوغ ميىرســ بـه عدم انكثاف دماغى دجار ميكردد، يس اولياى طفل به

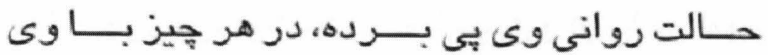
صحبت نموده و وى را معلومات كافي بـدهد نه اين كه سـوالهاى او را رد كرده و يـا جواب منفى و تند بـدهد. البـته بـعضى اطفال ســوالاتى زيادى مطرح

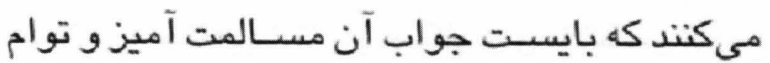
با حكمت بوده باشد. اب- اعضاى فاميل و بـه ويزٌه و الدين بايست بـين اولاد خود تبعيض قايل نشود كو يا كه دختر است و يا پِسر، زيرا كه اين نوع امتياز بـين اطفال تخم كينه

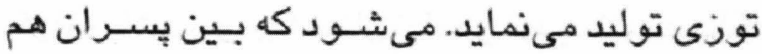
نظر به كركتر و اطلاق او نزد والدين مفكوره امتياز ييدا شــود. بايســت والدين در بـين اولاد در لبــاس خور اك و جاهاى تفريحى فرقى تـايل نشـوند. زيرا كه اين كونه امتياز عواتـب بـــى رالدر بــــر دارد وسبب اختلاف دامنه دار ميكردد. r r - بايد به طلفل هنر خطابه و اخبـار كفتن ياد داده و والدين خطابـه او راكوش بكيرند و خطاى وى را اصلاح نمايند. זr- در هنكام درس و مذاكره طفل بايســــت بــــ طريقــ اسـلامى نشســه، بــين وى و كتاب فاصله مناسب بـوده در روشـنـى درس خوانده و در جاى

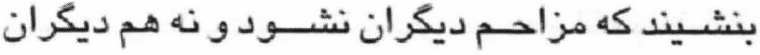

$$
\text { مزاحم وى شيوند. }
$$

ع ب- بايد والدين جاي مناسب بـراى درس وى تهيه داثته، از غوغاو قيل و قال دور نكه داشته شـده و در وقت درس خواندن به اتاق او كسى داخل نشود تا فكرش اخلال نكردد. 0- - وقتى كه طفل مريض مىشـود بــه زودترين فرصت نزد داكتر بـرده زيراكه در اين مورد غفلت و جسى توجهى نتايتج ناكوارى در يى داشـــه و امكان ميرود كه طفل مريضى اش صعب كرديده كه عـلاج آن مشكل خواهد بود. TY - والدين بــايد بــه كودك نصـايع نيك و عادات يســـنديده القـــاء نمو ده، در مقابــل كســـــ وى را احساساتى ننموده. اكر تربيه نيك كردد و در آينده داكتر، مهندس، قوماندان و عالم دين شـود مردم از

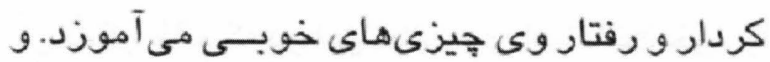
اكر برخلاف اين باشـ جاهعه بشرى توقـع نيكى از وى ندارد، وى غرايز شخص را يَرورش مىدهد. YV - از اين كه طقل به صورت آنى تحت تاثير قـرار مىكيرد بايست از تماشـاى فلمهاى مبتذل و خلاف ارزش هاى اخلاقى جلو وى كرفته شد. و فلمهاى به بـ

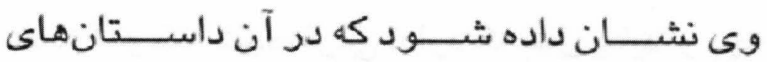

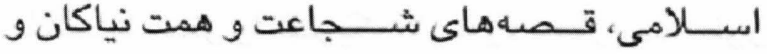
اشخاص برجسته عصر حاضر بـوده باشـــ و در

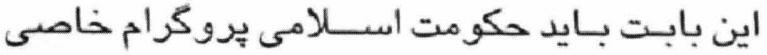

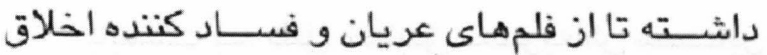

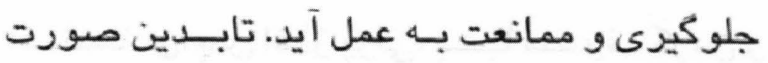
اجتماع اســـــلامى منظم كُرديده و از تشــــــت و 


\section{بازشناسى نقش زنان افغانستان در مبارزات آزاديخواهى زنان}

أنان بير دازم. نخسـتين موضوعى كه ميتوان بحـث را بـآن آغاز كرد، بروسى مولفه هاى جنبــش زنان و رفتار هاى آزاديخواهانه است.

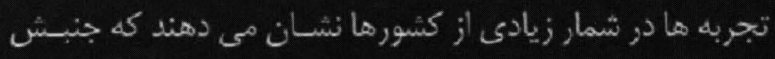
زنان از كر كتر هاى متفاوت فكرى و سياسى تشكيل شده است زئ.

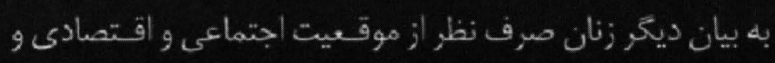

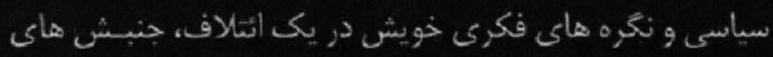

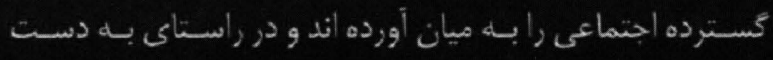

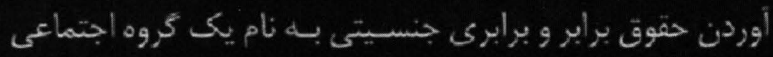

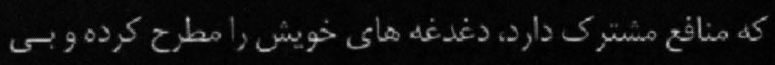

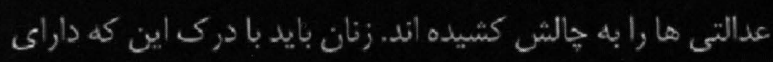

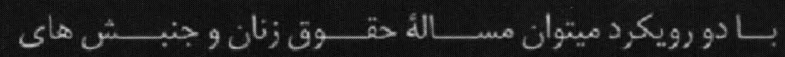

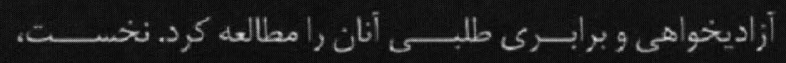

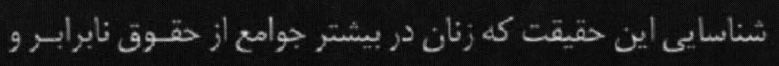

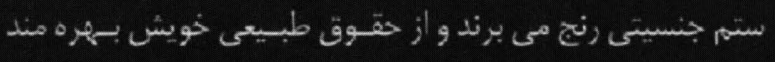

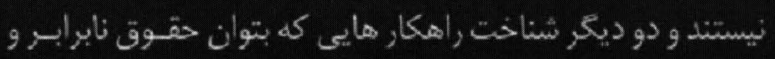

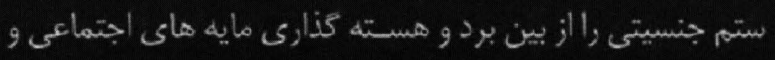
أغاز مبارزه براى از بين بردن بنى عدالتى ها.

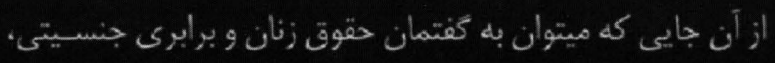

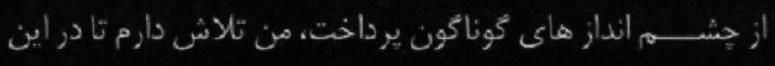

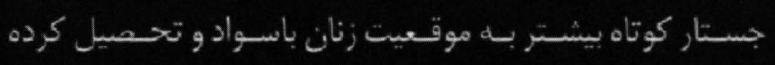

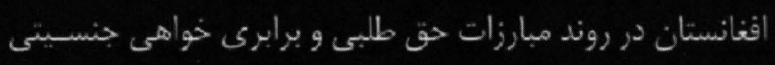


نشـانه هاى كوياى اين مدعا اند. تاريخ جنبـش هاى زنان نشـان

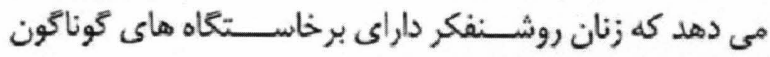

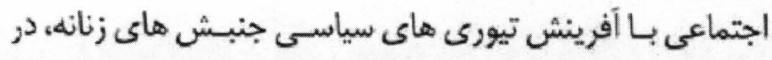
تعميم تجارب مبارزاتى زنان نقش به سز ائى دائ داشته اند.

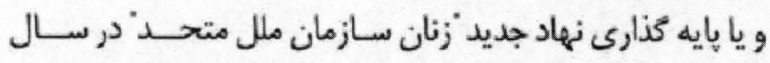

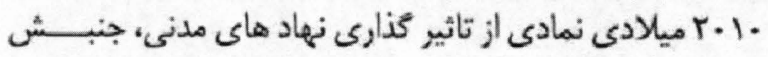

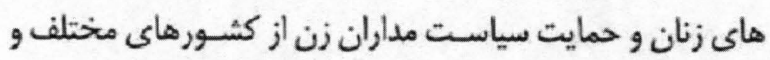

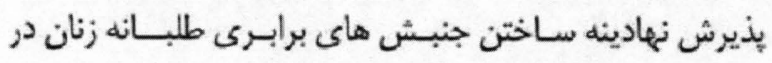
ساحت جهانى مى باشد.

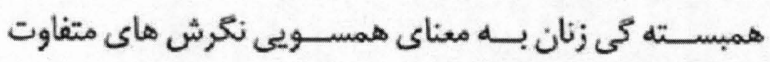

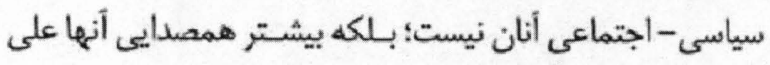

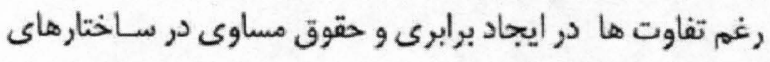

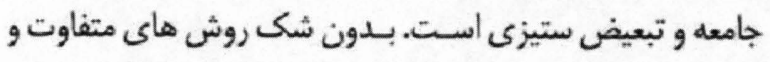

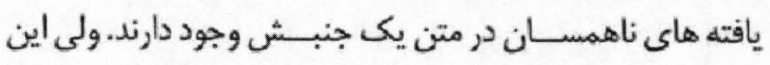

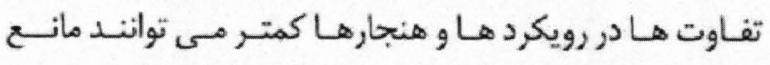

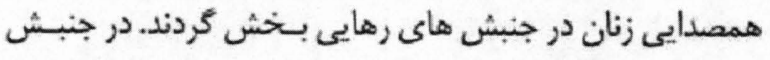

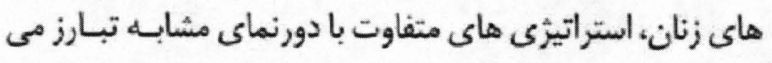

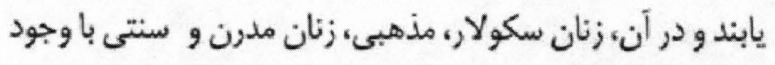

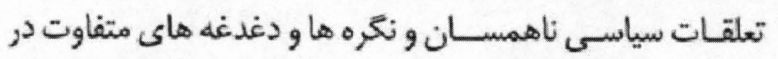

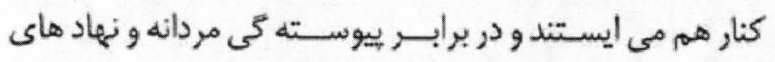

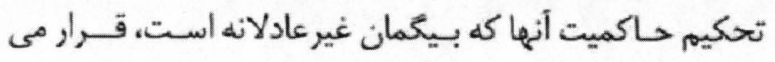
كيرند.

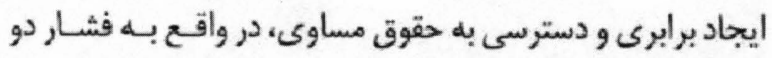

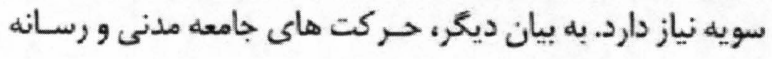
هاى يرسشكر و كفتمان اجتماعى آثاهانه و مشاركت در مبارزات و مقاومت هاى فراكير از يكسو و تامين حمايت و حاكميت قانون و دولت سوى ديڤر اند.

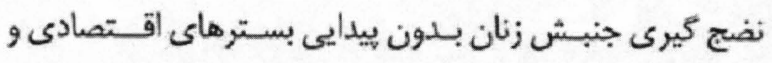

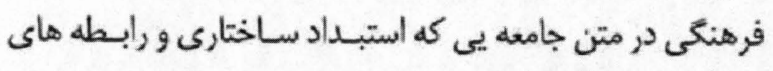

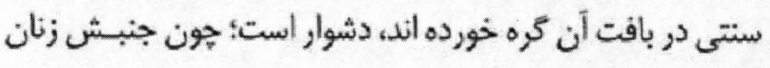

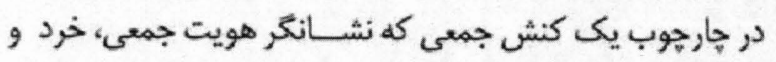

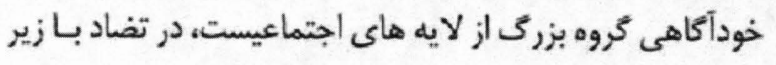

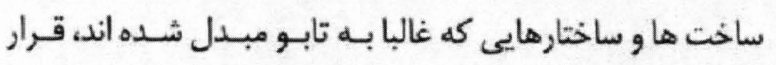

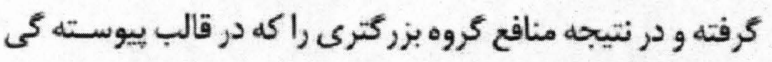

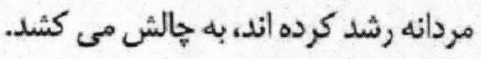

با توجه به تاريخ صد سال اخير افغانستان و مولفه هايى كه بـراى

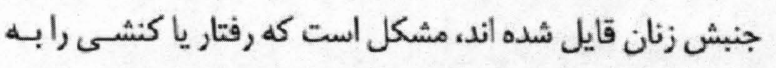

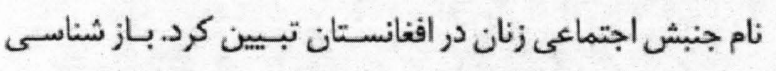
تاريخى موقعيت زنان در افغانستان نشانكر اين حقيقت تلخ است أست
خواسته ها و منافع مشـتركى اند كه تنها بـا همبسـته كى و درى

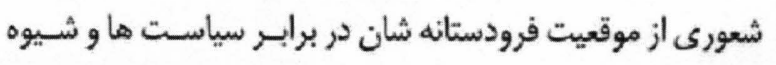

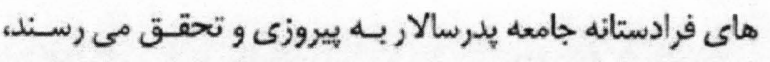

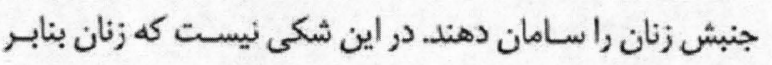

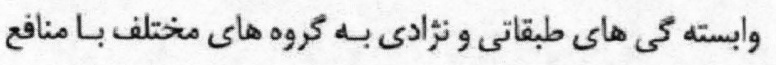

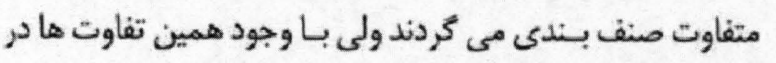

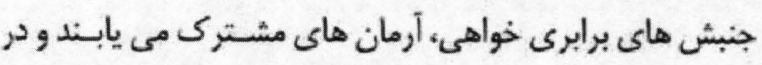

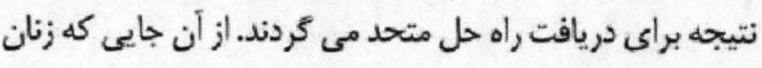
يكى كروه اجتماعى اند ته طبقه، برخى بيروهشكران بر ائ اين باور اند

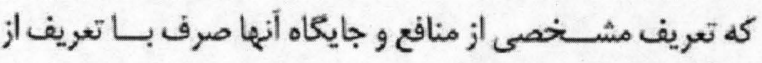

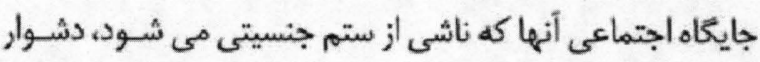

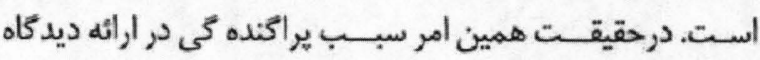

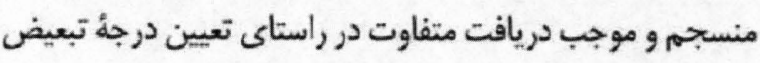
جنسيتى و ستم اجتماعى مى كردد.

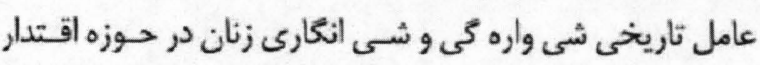

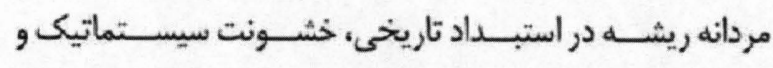

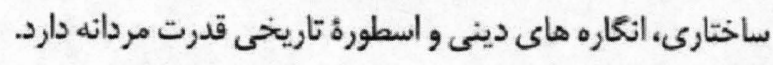

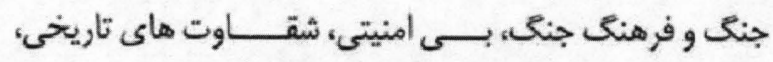

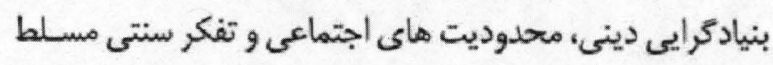

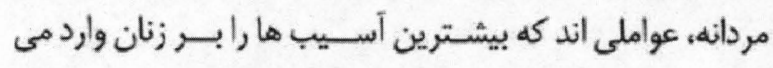

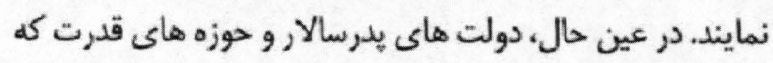

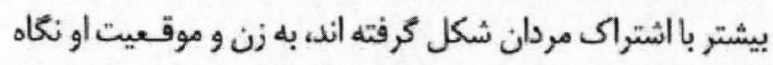

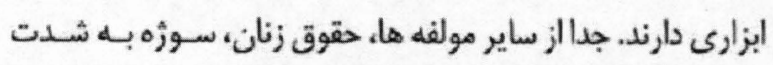

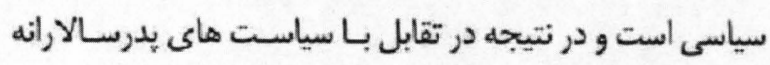
جوامع قرار كرفته و در تقابل با قدرت و تفكر سياسى حاكم و ونهاد

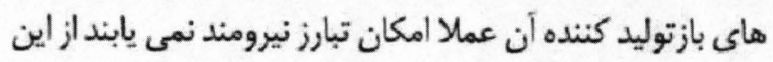

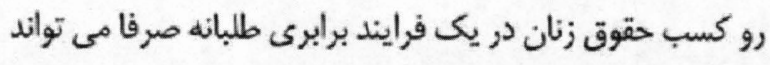
در متن يك كارزار فراكير سياسى و اجتماعى معنا و مفهوم بيابد.

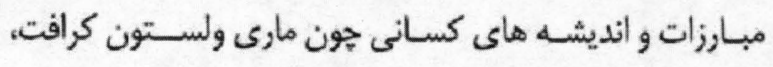
ويرجينيا ولف، كلارازتكين، سيمون دوبوار، جوليا كريستواو ويا به سخن ديكر مبارزات برابرى خواهى موج هاى سه كانه فمينستان

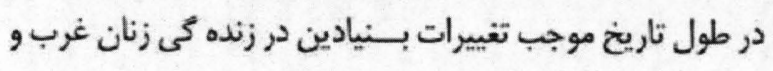

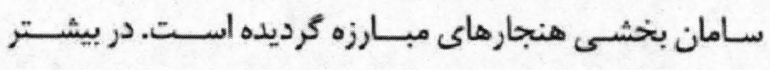

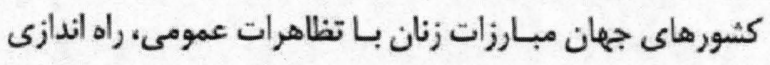
كفتمان هاى اجتماعى در حوزه عمومى، تشكيل حزب هان ها و كروه

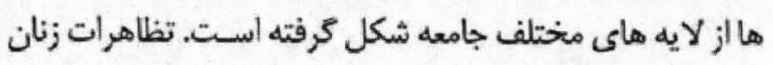

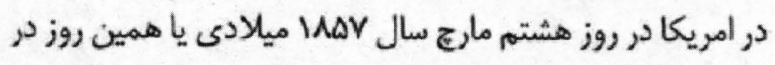

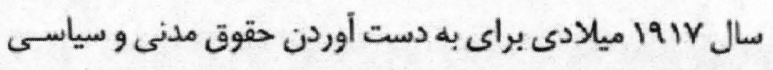
و برابرى جنسيتى، و در فرجام به رسميت شـناختن روز همبســانه

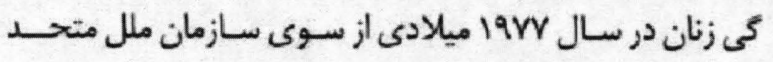


اثر جنك هاى طولانى و عدم امنيت فزيكى و فكرى، همراه با آن

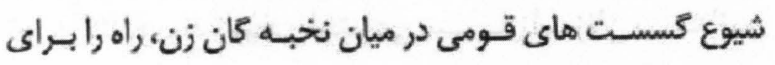

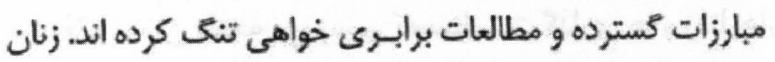

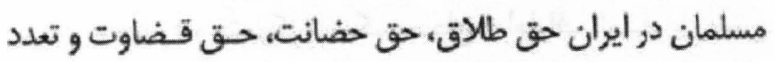

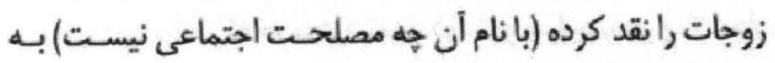
يرسش كشانده و در اين راستا بيروزى هايى هم داشته اند؛ اما در

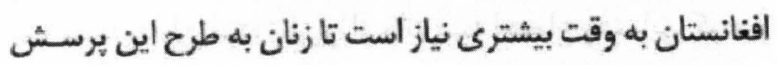
ها بيردازند. در افغانستان تنها مساله تبعيض جنسـيتى بــه عنوان يك معضله

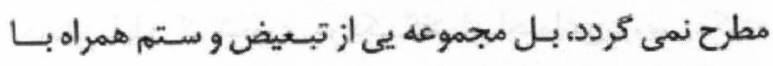

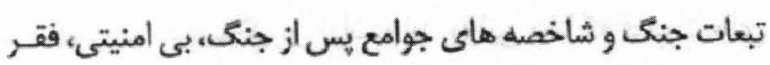

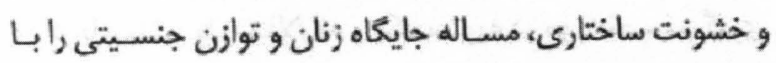
دشوارى جدى مواجه ساخته است.

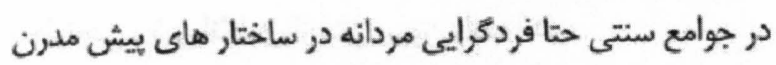

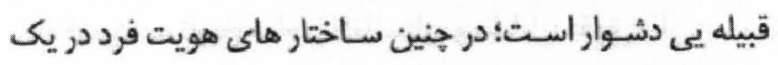

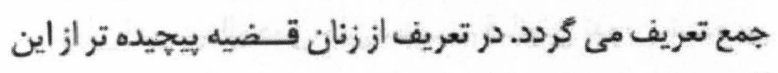

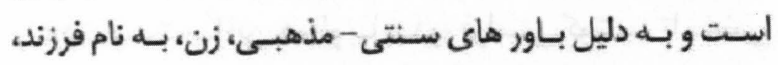

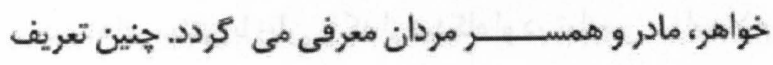
مبتنى بر جنسيت هويت مستقل زن و زن باورى مارى را النكار مى كند.

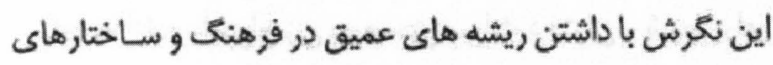

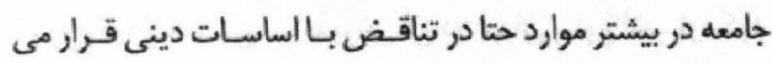

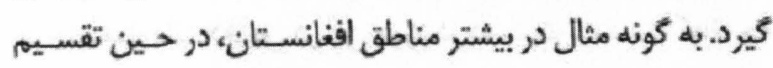

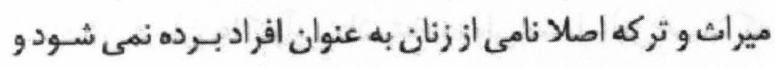
تنها كركترهاى مرد خانواده در مورد ميراث تصميـم مسى كيرنسئ.

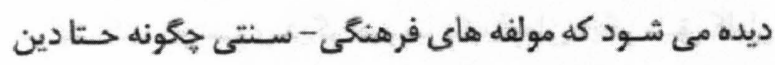

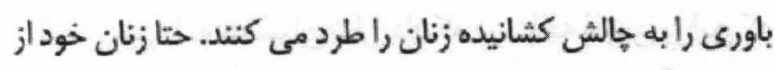

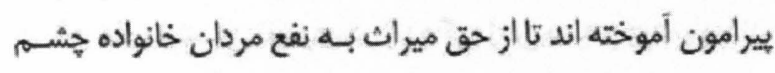

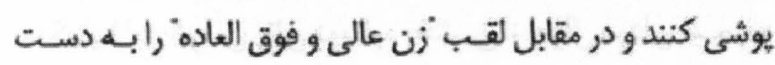
بياورند. از أنجايى كه نقد فرهنكى كتش هاون و رفتارهاى سنتى اين جنينى،

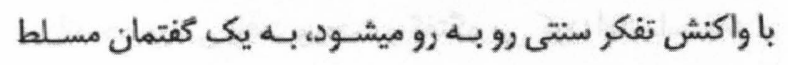
اجتماعى مبدل نمى شود. از تاريخ معاصر افغانستان اين مهم دسـتياب مى شـود كه يكى از

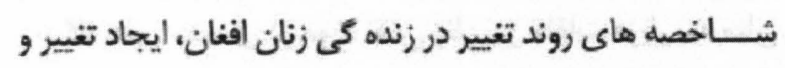

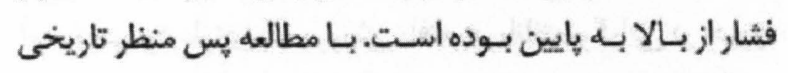

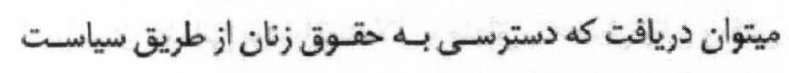

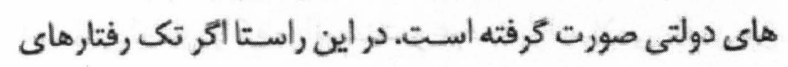
معدود و ركر كت هاى ضعيفى هم ديده مى شـوند، نميتوان از آنها به نام اهر م فشار اجتماعى ياد كرد. با اين هم، هر كاه باليسـى هاي سياسـى - دولتى و تكى رفتارهاى
كه تا حال جنبـش هاى زنانه خودجوش بـا مايه هاى لازمى آن و

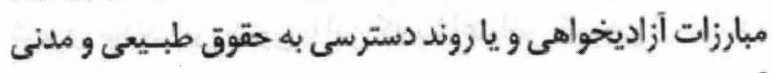

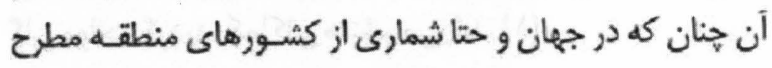

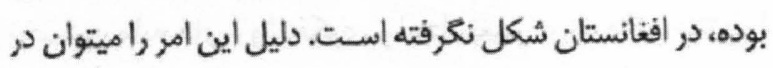

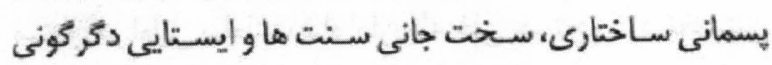

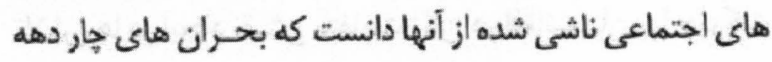

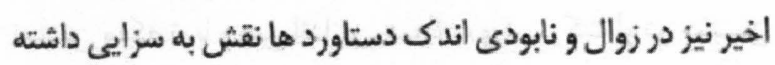

مبناى فكرى فمينيسم سياه با فمينيسم زنان سييد يوست تفاوت

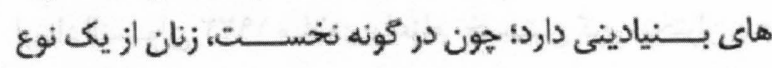

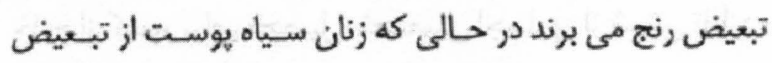

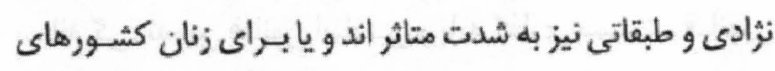

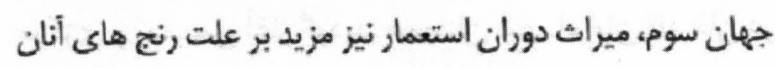

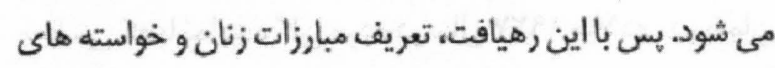

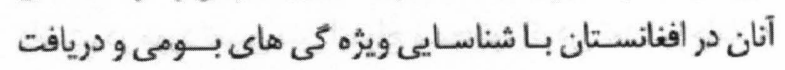
دشوارى هاى محلى توام با شـاخصه هاى جهانى امكان يذير مئى كردد. تفاوت هاى فرهنكى و ساختارى، مبارزات و خواست هاى زنان را

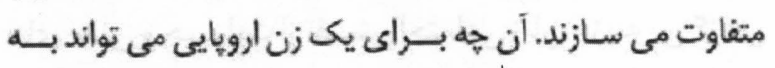

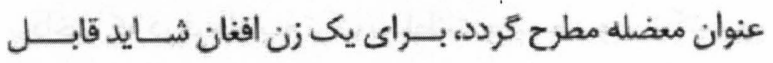

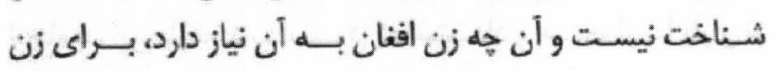

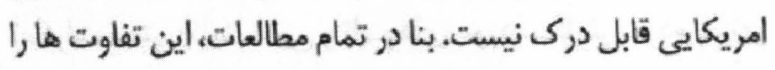

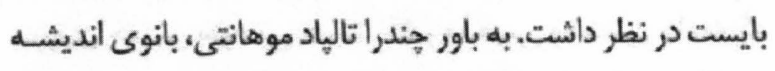

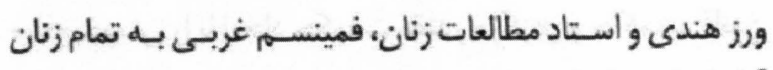

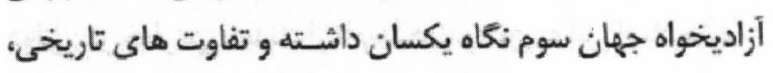

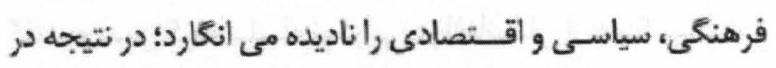

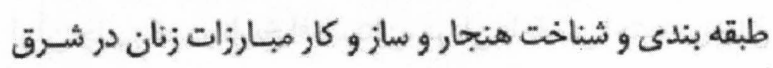
دجار توهم و خطا مي كردد.

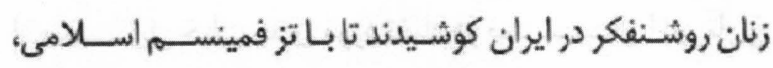

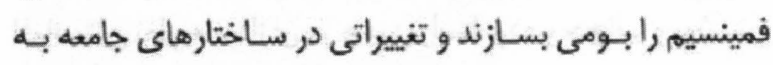

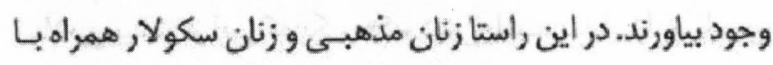

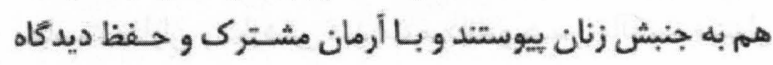

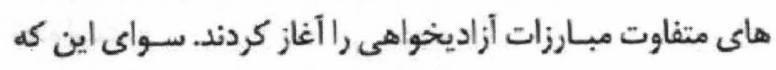

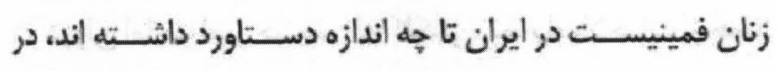

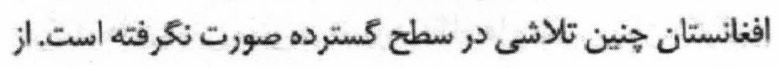
يكسو تصور تباين ها و تناقض هائ فلسفه فمينيسم با اسلام و الز

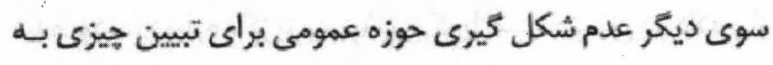

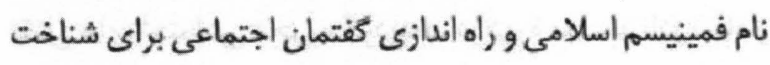

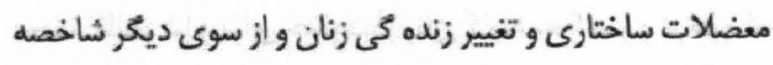

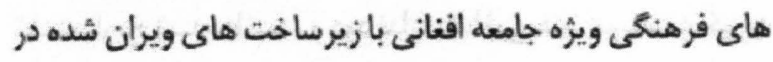


مخاطبان اين نشـريه غالبـا حلقـات دربـار و معدود خانواده هاى

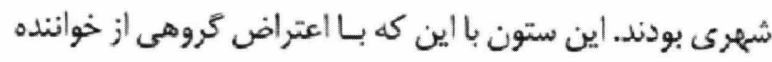

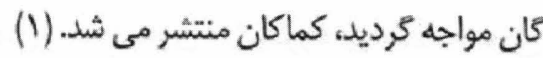

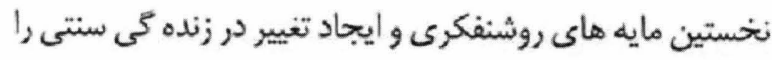
ميتوان در اوايل سلطنت شاه امان الهه خان جستجو كرد د. نخستين

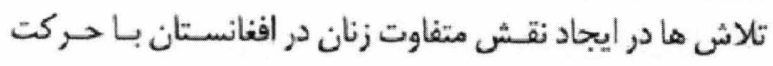

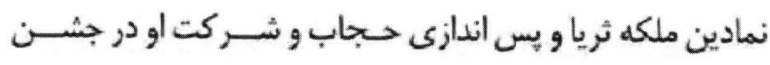

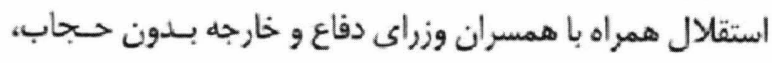

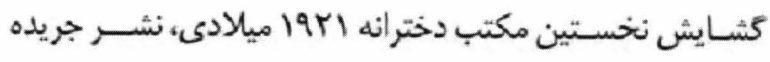

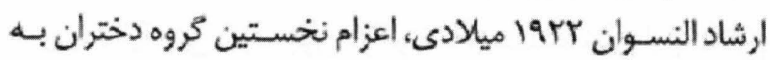

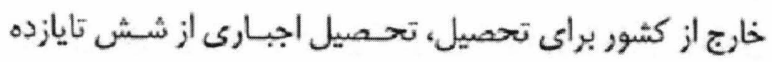

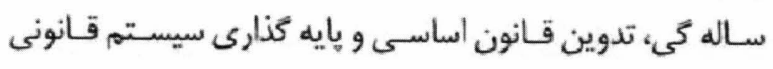

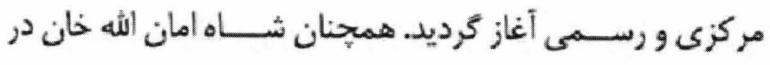

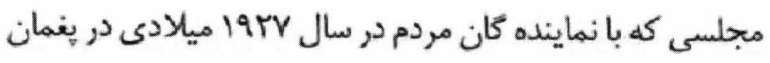

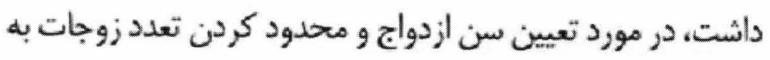

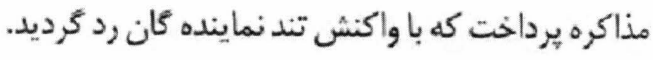

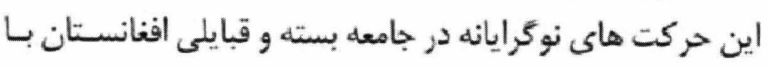

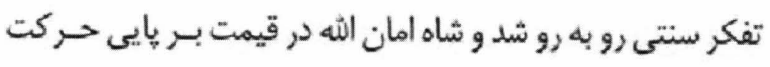

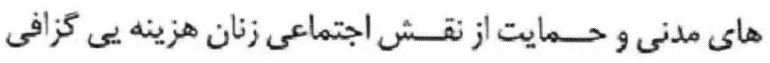

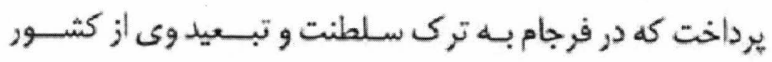

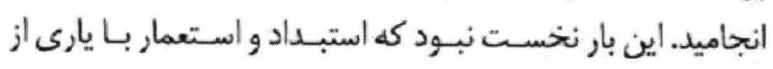

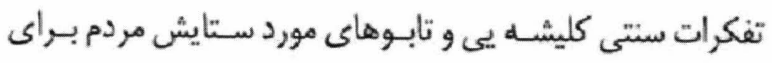

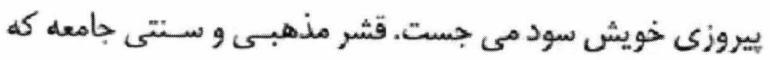
منافع خويش را با ايجاد حكومت مقتدر مركزى و حاكميت قانون

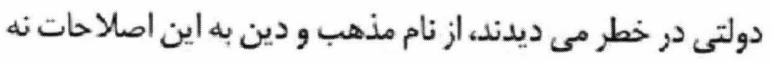

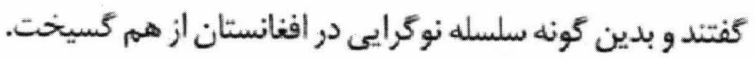

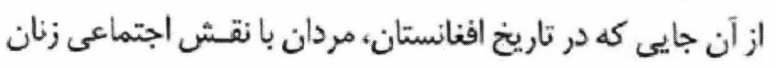

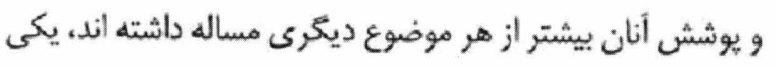

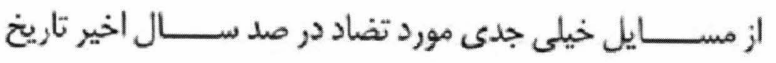

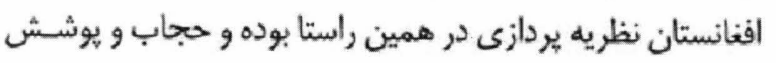

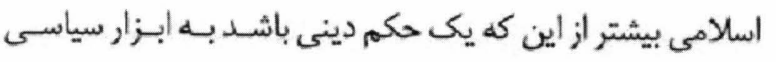

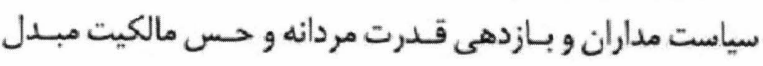

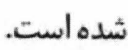
در دروان امارت امير حبـيب الله كلكانى، تمام اصلاحسات از جمله

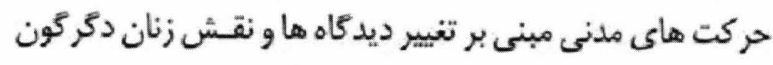

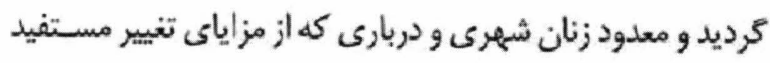

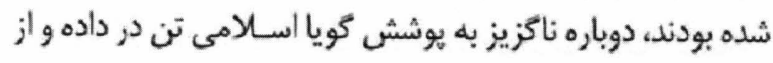

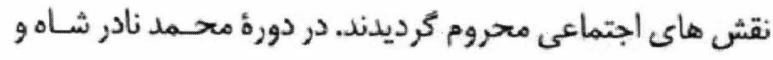
محمد ظاهر شاه، براى حمايت از زنان كار همه كُّتر و درخور كه

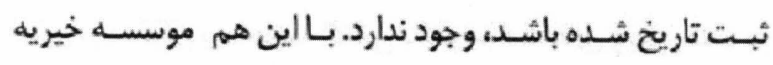

معدود زنان را در بسـتر زتنده كى اجتماعى بــــه عنوان هنجارهاى

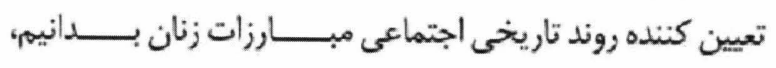

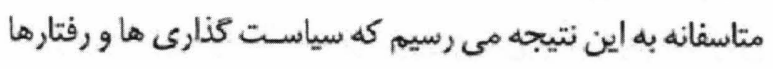

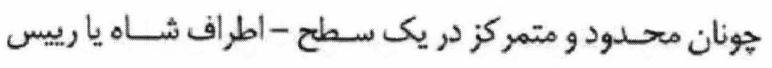

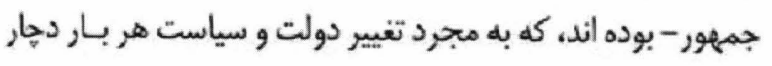

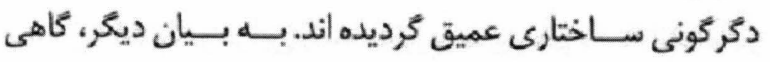

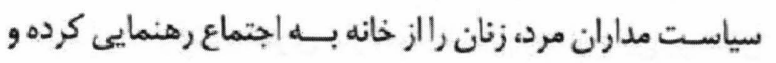
كاهى با بينش و نكره سياسى - دينى دوبـاره خانه نشـين سـاخته اند. اين در حاليست كه زنان تصميم حضور در حوزه خانه و حسوزه

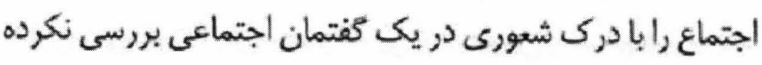

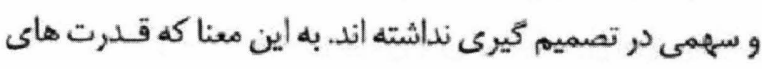

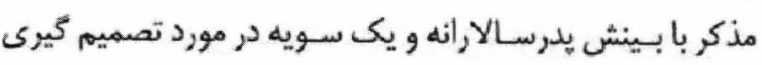

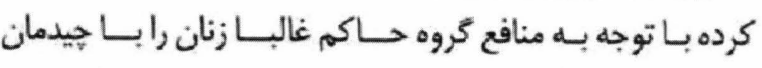
شطرنجى و شى انكارى از متن بيرون رانده اند.

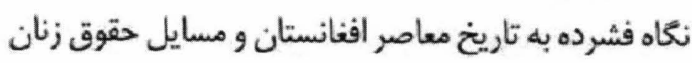

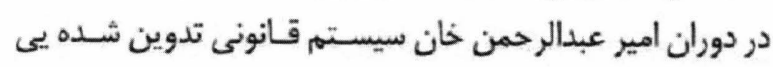

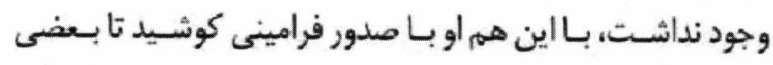

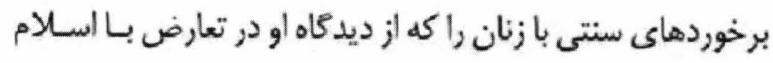

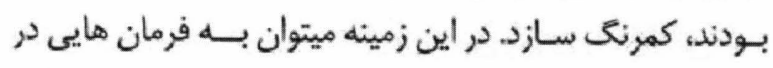

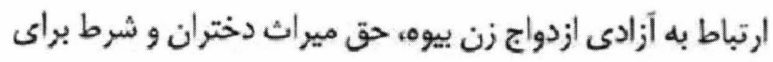

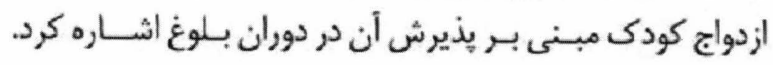

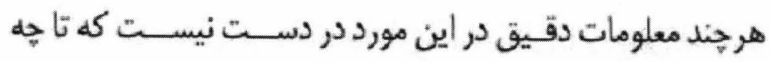

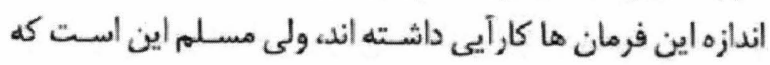

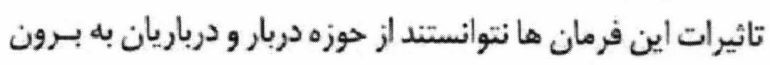

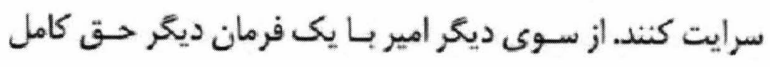

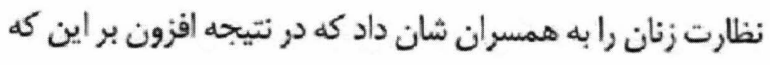

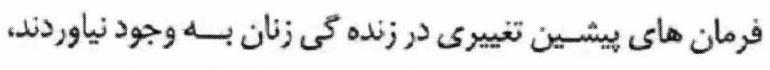

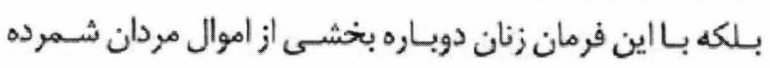

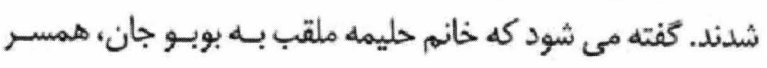

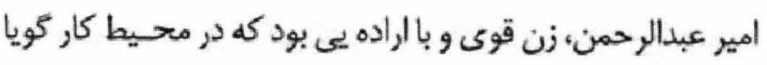

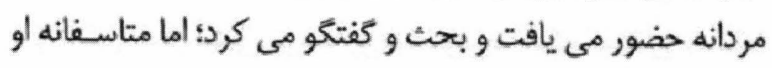

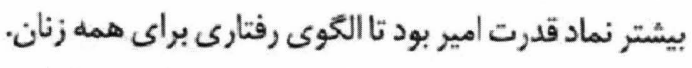

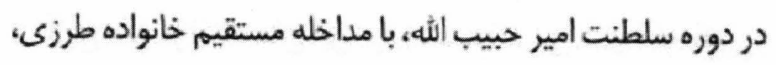
ديدكاه هاى جديدى در مورد نقش زنان در حلقات دربار بـهـ ميان

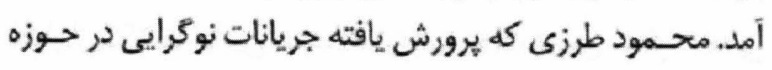

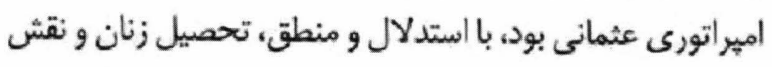
اجتماعى ايشان را كه بر اثر سنت و عرف غير اسـاملامى تلقـى مي إنى

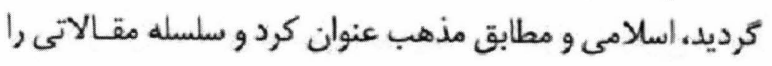

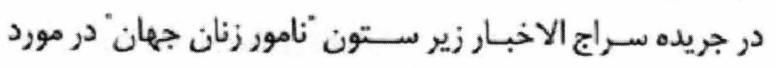

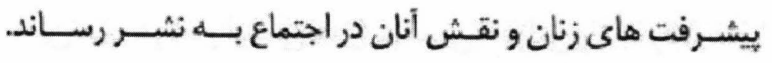


حقوق زنان بـرخورد كردو بيشـتر مصروف خنثا سـازى توطئه ها

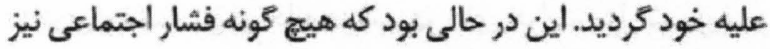

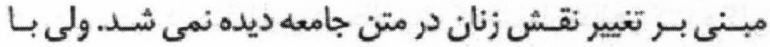

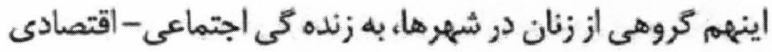

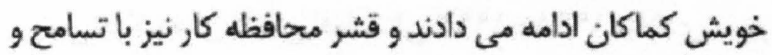

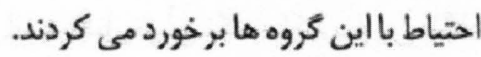

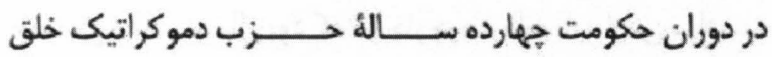

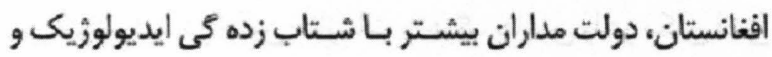

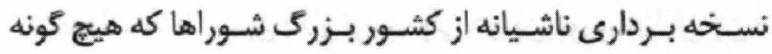

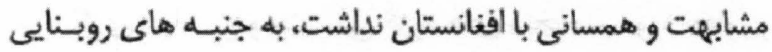

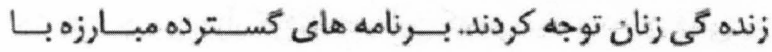

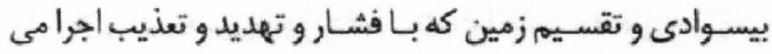
كرديد با شورش و واكنش اكثريت مردم در محلات غير شهيرى

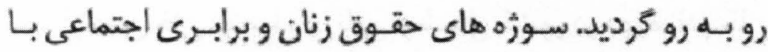

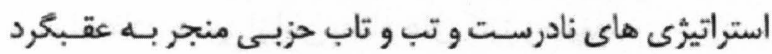

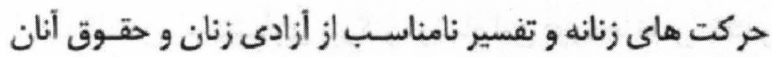

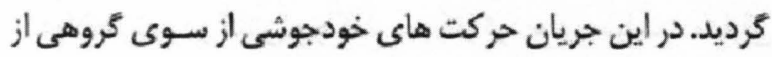

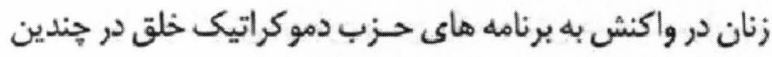

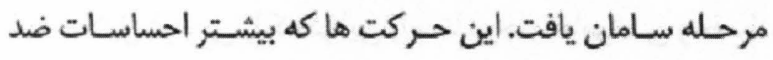

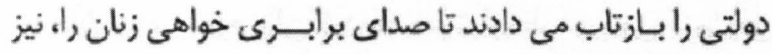

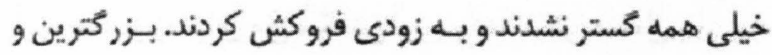

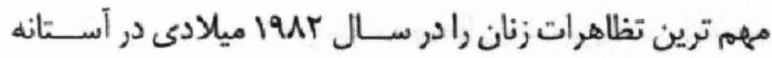
تبجيل از دومين سالكرد انقلاب ثور در شهر كابل ميتوان مشانهاه

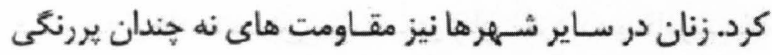

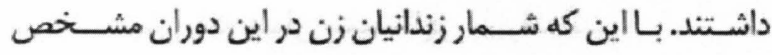

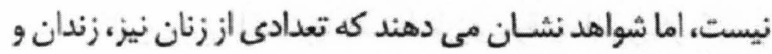

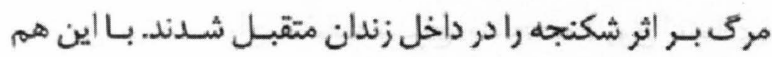

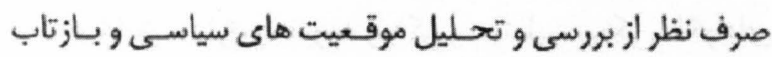

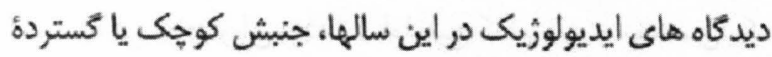

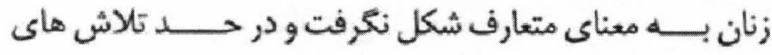
سازمانى و فردى باقى ماند.

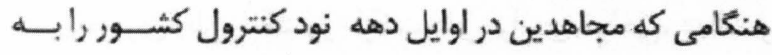
دست كرفتند، نقش و يوشش زنان شهرى و و باسواد را كه در حوزه

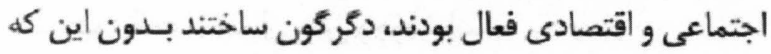

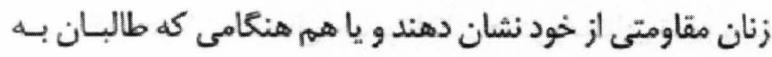

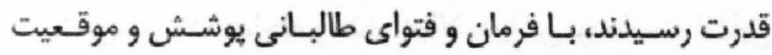

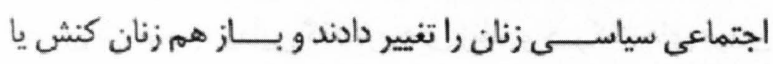

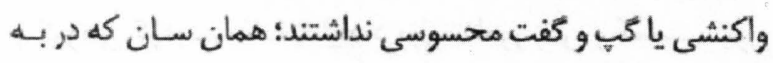

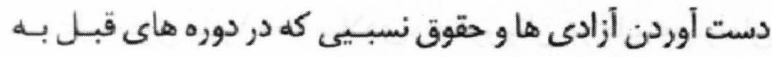

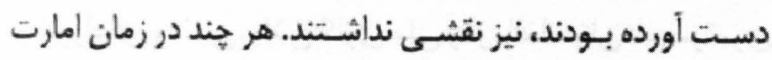

نسوان (موسسه نســوان و بـعدها ميرمنو تولنه) و أو ميلادى در

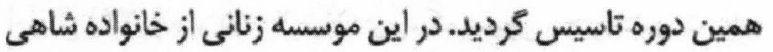

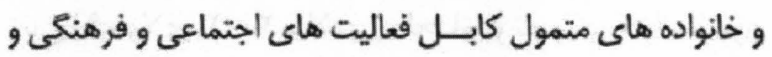

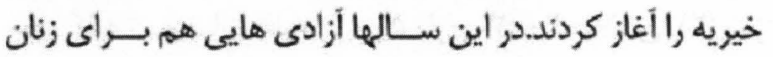

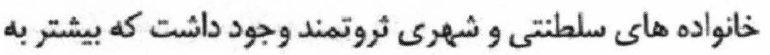

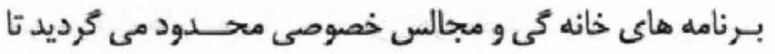

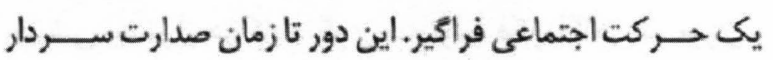
محمد داوود تا سال سه آ إدامه داشت.

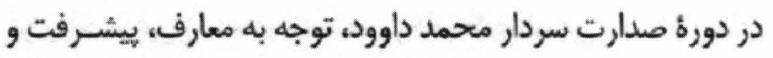

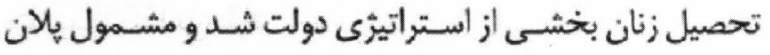

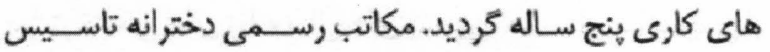

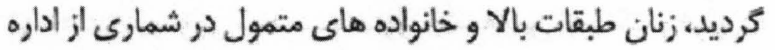

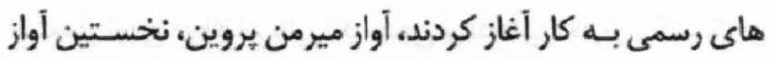

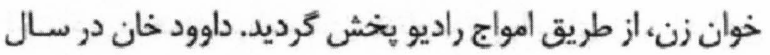

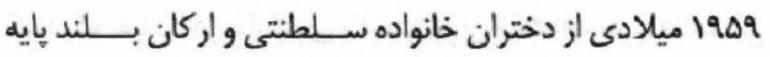

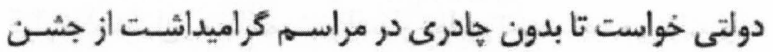

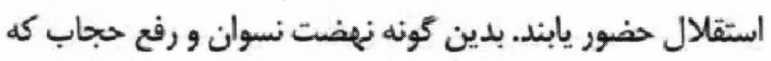

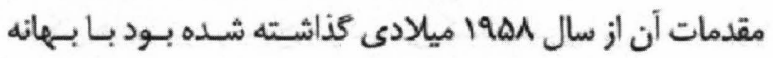

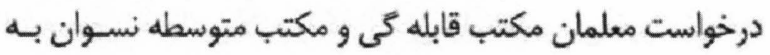

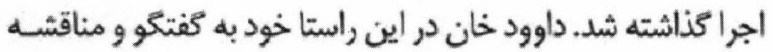

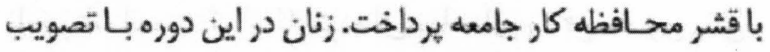

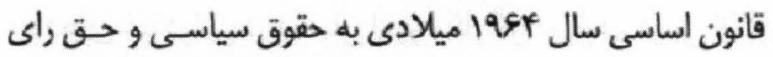

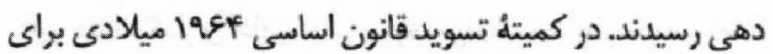
بار نخسـت دو خانم حضور يافتند و در انتخابـات بهارلمانى سـال

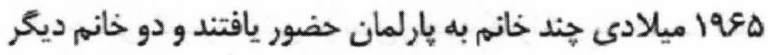
به عنوان سناتوران انتصابى تعيين شدند.

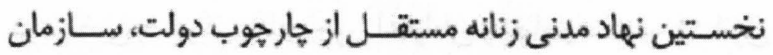
دموكراتيك زنان كه شاخه يى از حزب دموكراتيك خلق به شمار

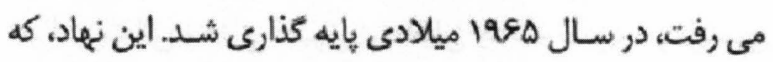

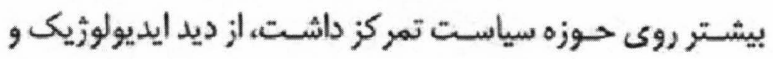

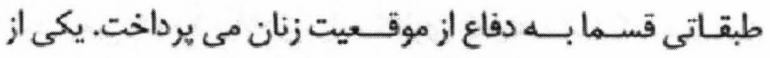

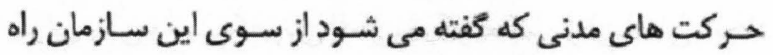

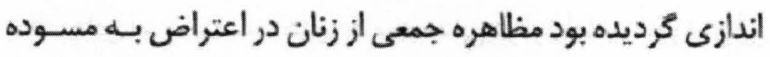

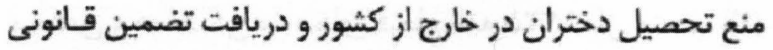

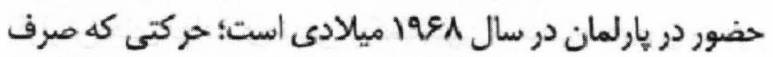

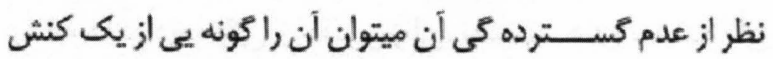
اجتماعى ناميد. خلاف دوران صدارت، سردار محمد داوود هي ازئ كودتاو كز ينش

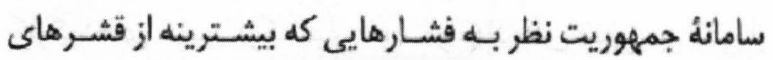

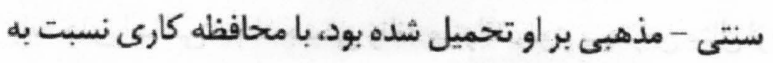


انكشاف ملى افغانستان، يروتو كل مجــو ازدواج اجبـارى و ازدواج

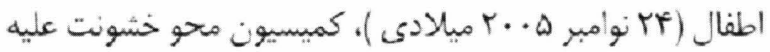

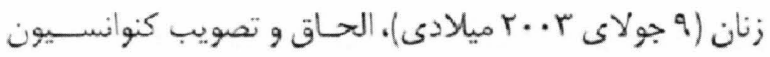

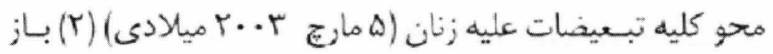
هم حركت هايى از بالا به بإيين اند.

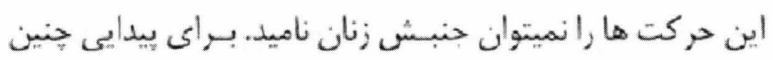

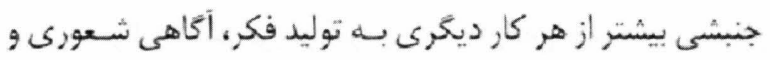

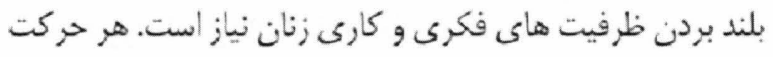

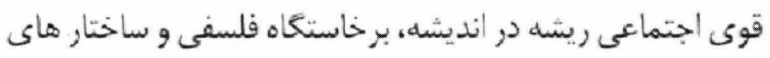
متناسب اجتماعى دارد.

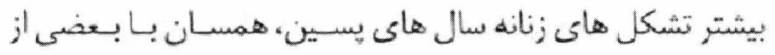

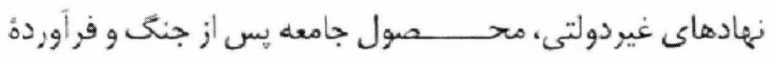

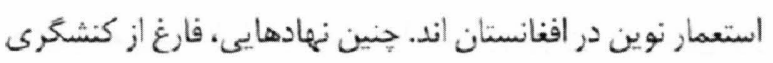

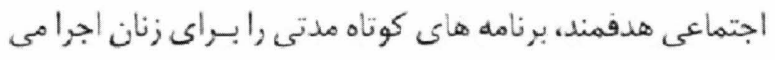

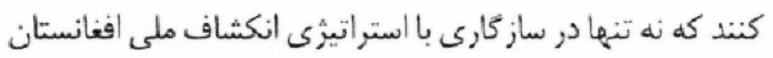

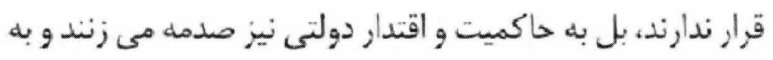

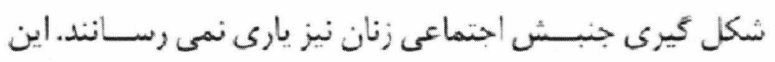

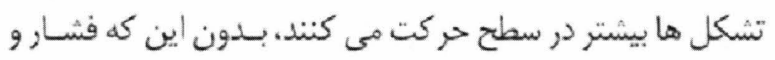

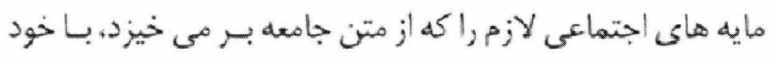
داشته باشند.

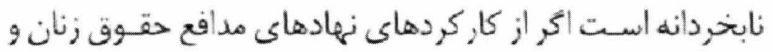

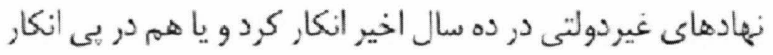

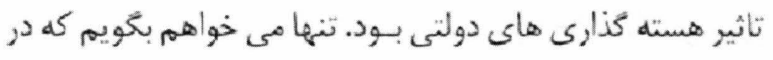

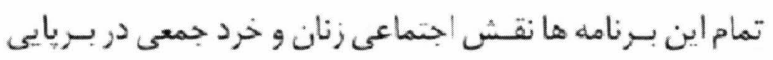

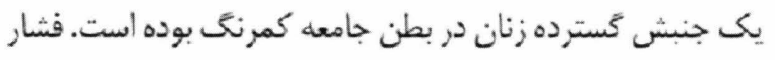
اجتماعى و شاخصه هايى از حركت هاى جمعى را در ده سال اخير

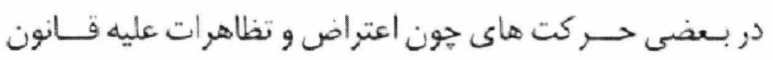

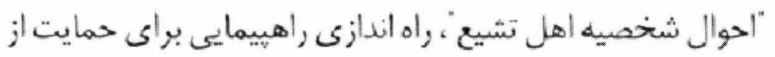

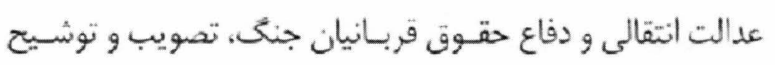

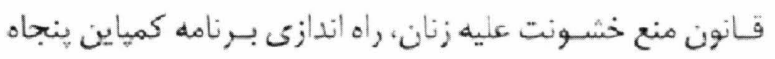

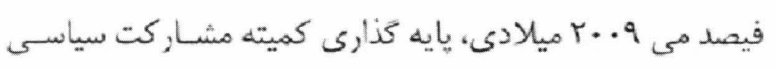

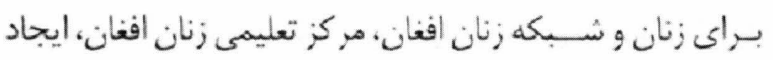

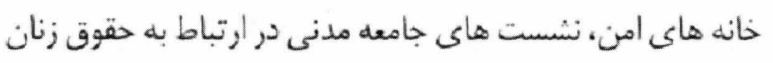

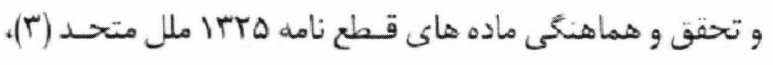

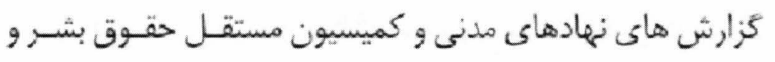

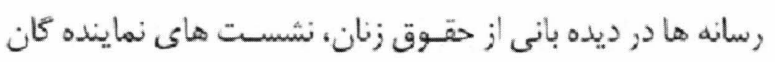

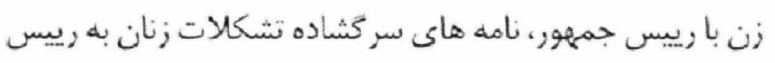
جمههور و يا حركت هايى از اين دست ميتوان ديد.

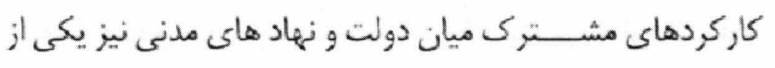

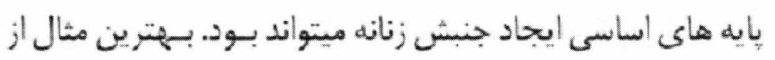

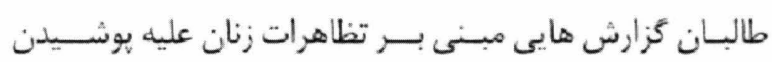

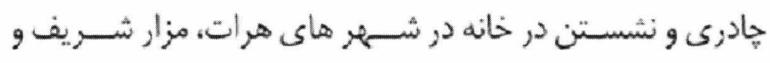

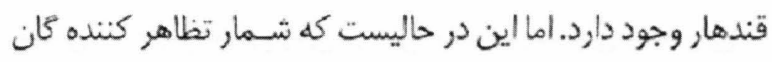

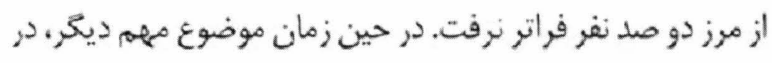

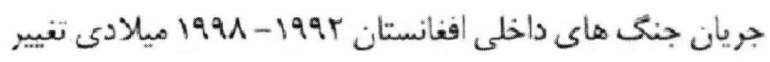

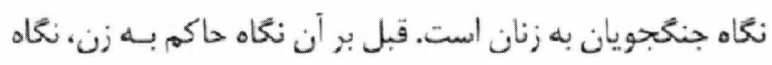

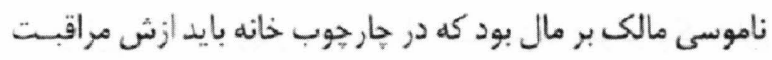

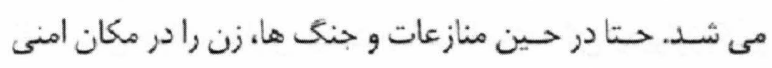

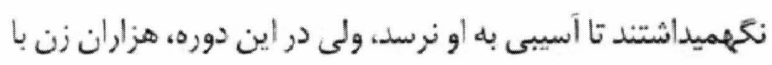

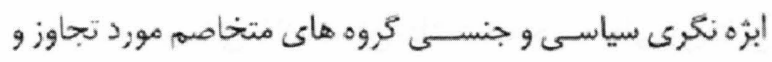

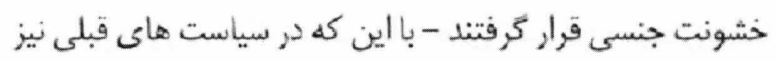

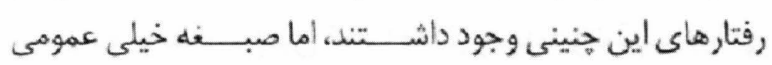

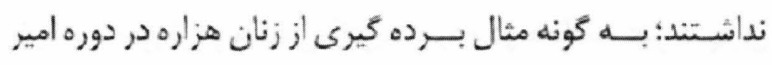

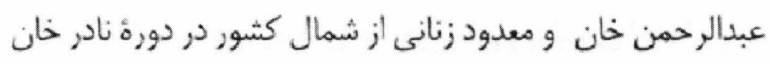
و سو استفاده جنسى از آنان به نام هاى كنيز و و صيغه.

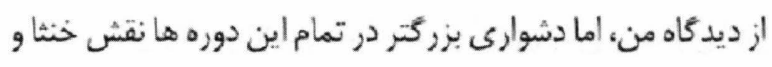

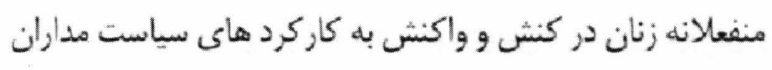
و زورمدار ان و ناتوانى در طرح بسيج يك جنبش همل كستر است.

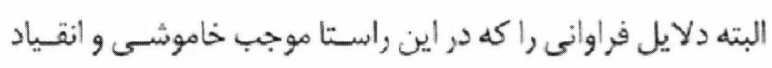

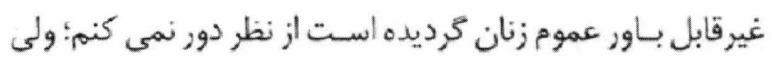

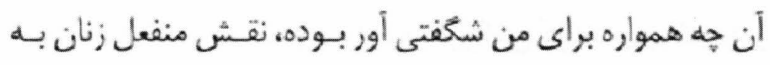

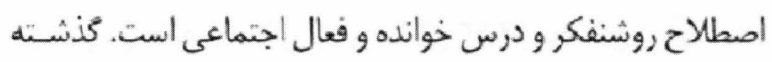

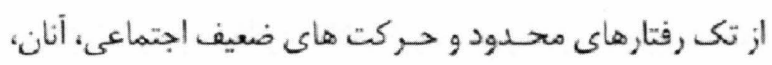

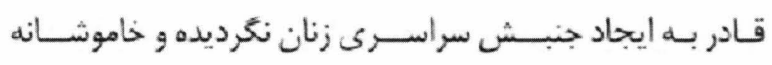

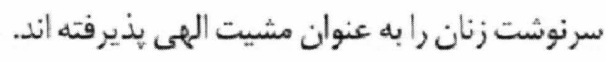

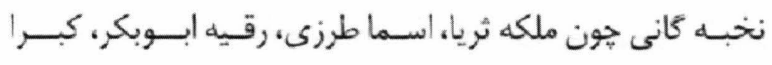

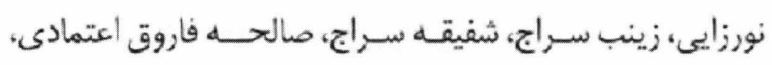

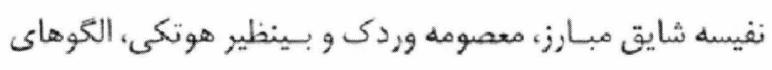

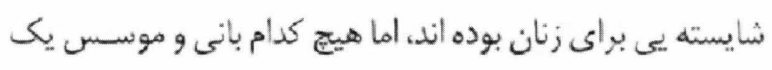

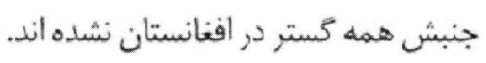
با تاسف كه تاريخ صد سال اخير افغنانستان نشان مى دهد كه مايه

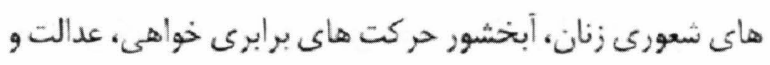

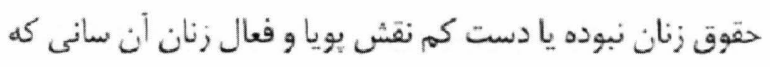

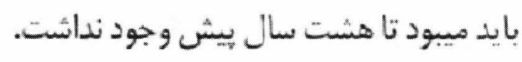

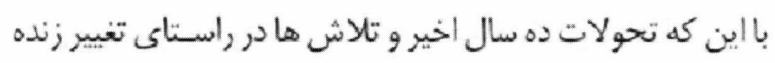

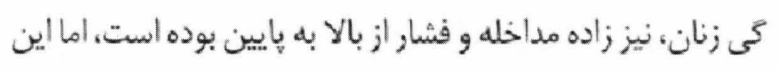

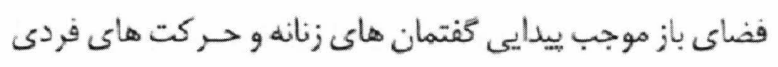

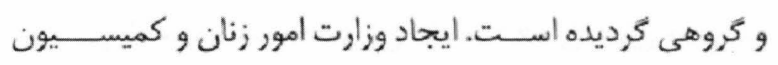

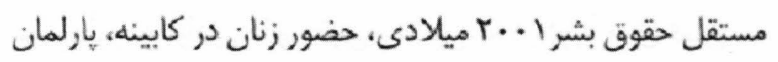

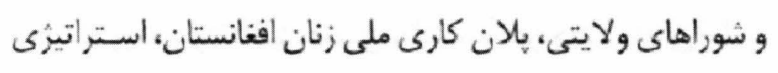


سوى هارلمان مثاليست از عدم رويكرد بـانو وكيلان بـه قـضيه از

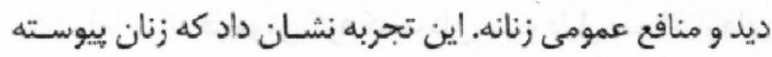

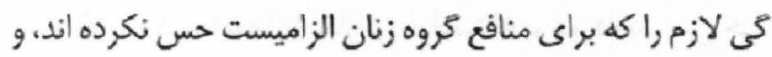

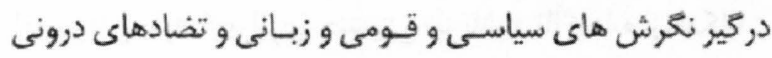

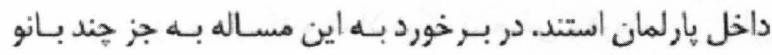

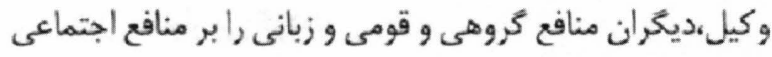

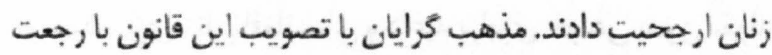
به بحث تشابه و تساوى در اسلام قسمتى از حقوق زنان ران ران اناديده كرفتند. اين در حاليست كه عدالت خواهى و حقوق مساويى كهاز از

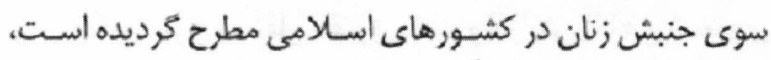

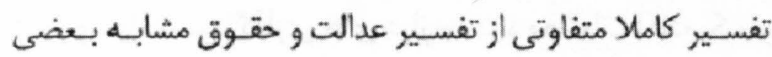
فقهاى افغانى دارد. تغيير و تعديل قــــانون مدنى، از اولويت هاى كارى إى تشكل هاى

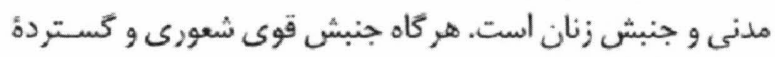

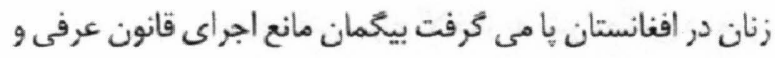

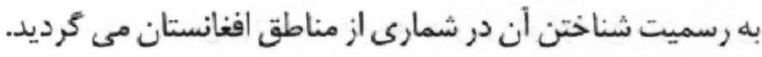

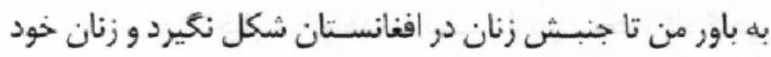

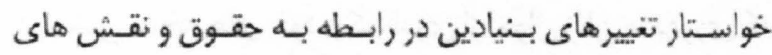

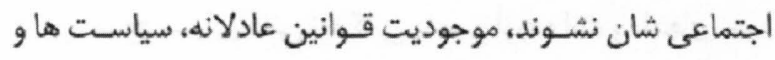

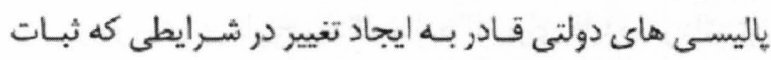

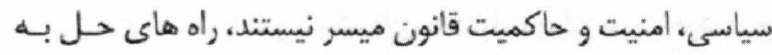
شمار نمى روند. تغييرات و ييشرفت هايى كه در اين راستا تا حسال

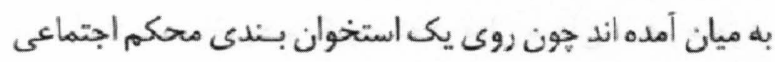

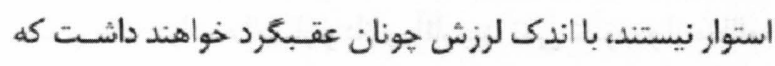

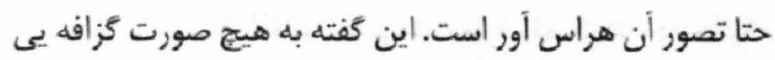

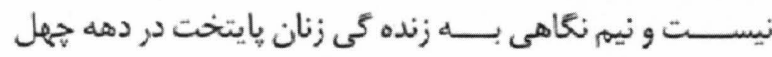

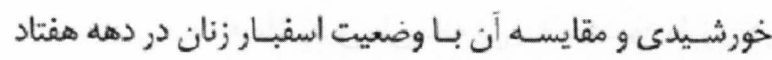
خورشيدى به خوبى بيانكا اين واقعيت تلخ است. زنان افغانسـتان در صد سال اخير شاهد جنين خرخش هائ دهشتئاى در سياست

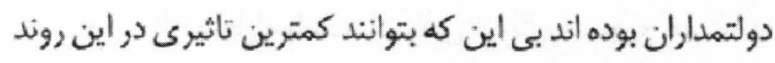

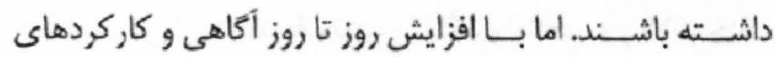

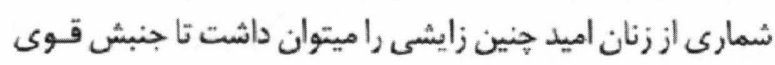

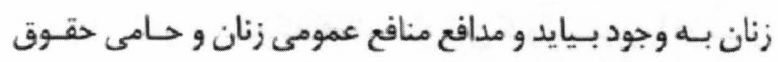
مساوى باشد. بحث بر ابرى جنسيتى بايست به كفتمان اجتماعى مبدل شود و از

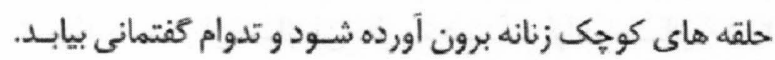

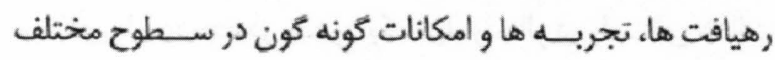

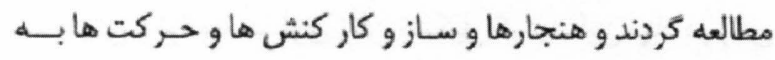
دقت بررسى كردند. بدون شك در مبـارزات جنسـيتى، مردان نيز

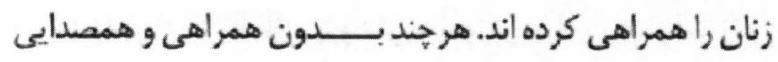

مشاركت دولتى و بستر سازى از سوى حركت هاى زنان، تصويب

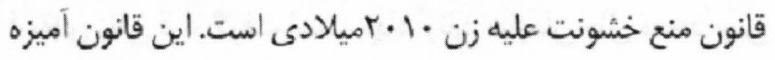

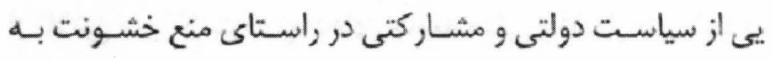

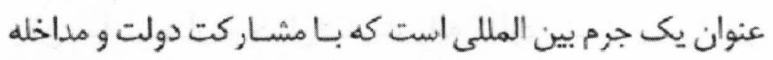

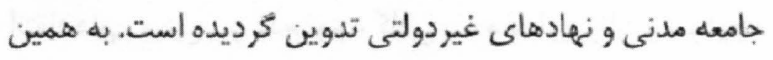

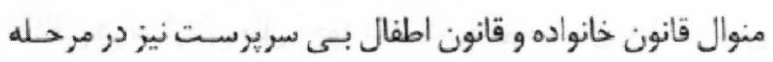

تصويب قرار دارند.

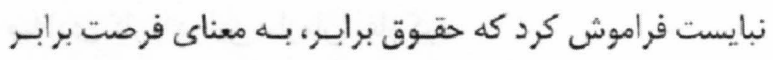

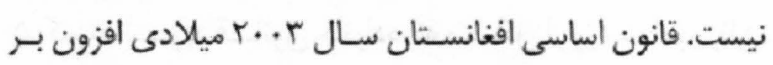

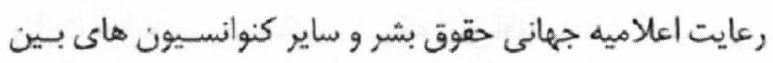

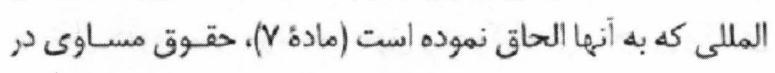
برابر قانون را براى همه شـهروندان افغانسـتان تضمين هى كند.

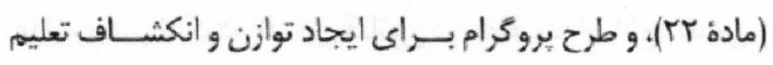

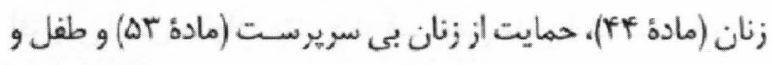

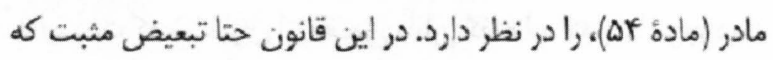

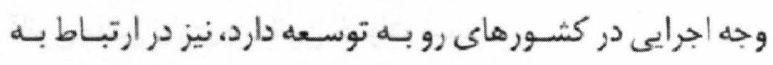

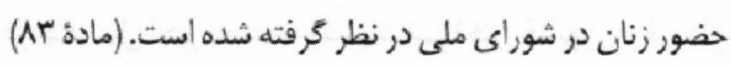

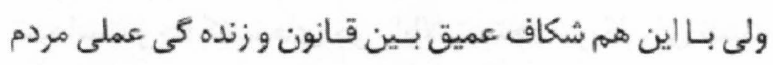

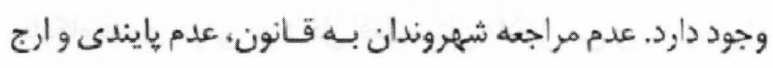

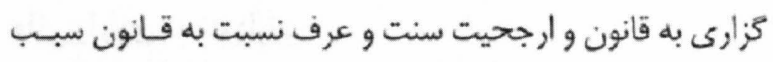

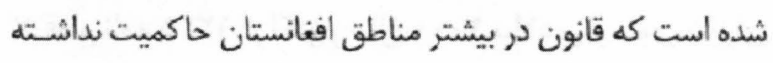

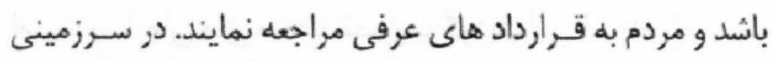

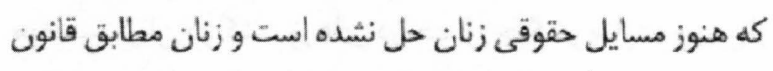

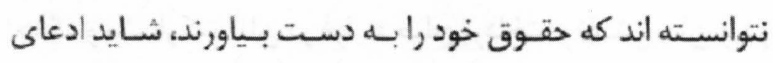

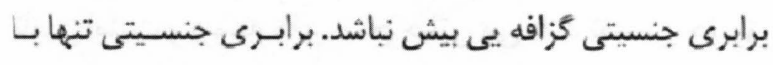

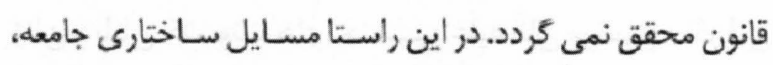

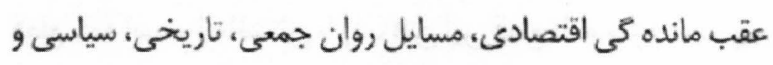

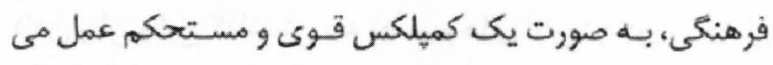

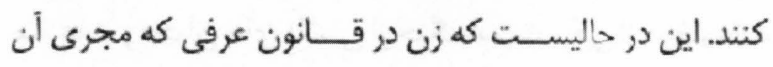

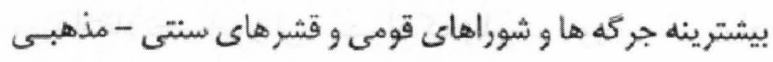

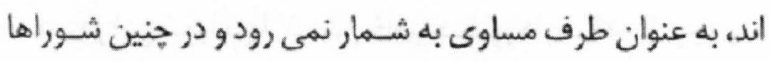

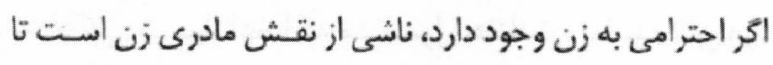

نقش اجتماعى او. (ه)

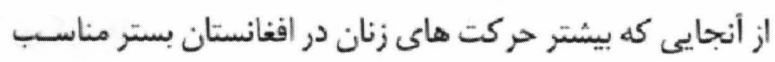

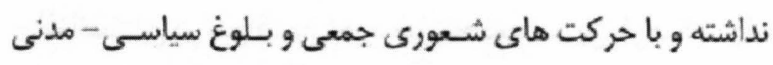

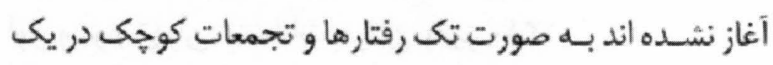

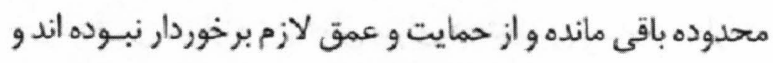

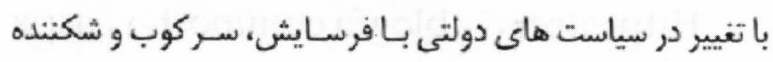
تى غيرقابل باورى رو به رو شده اند.

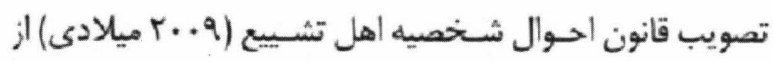


(داو)، دفتر مشورتى مسايل جنسيتى و ظرفيت سازى (اوسـيج) و

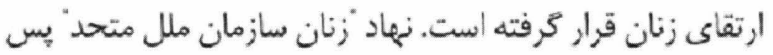

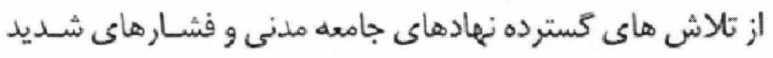

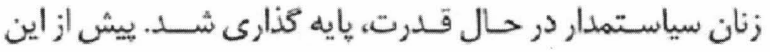

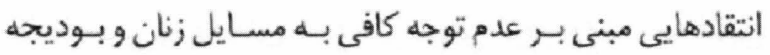

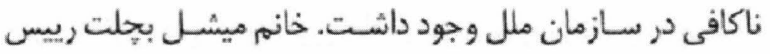

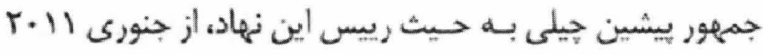
ميلادى كار رادر اين سازمان آغاز كرد.

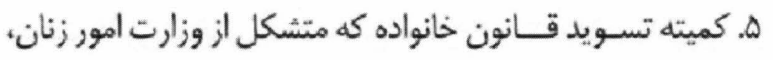

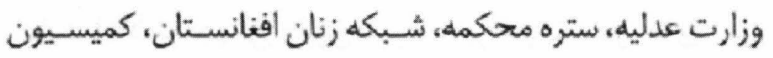

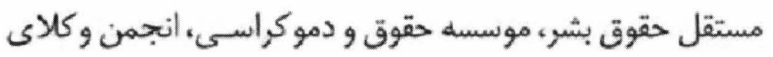

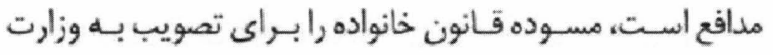

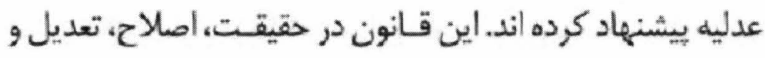

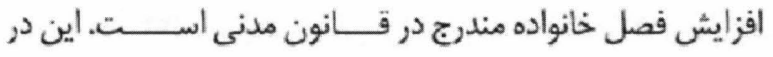

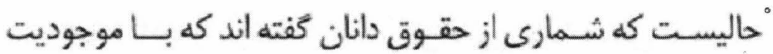

$$
\text { قانون مدنى نيازى به قانون خانواده نيست. }
$$

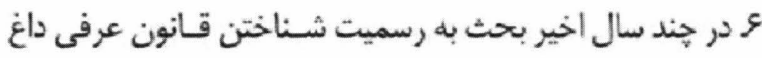

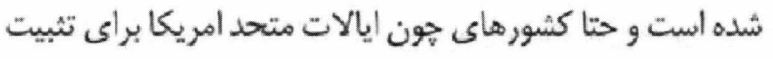

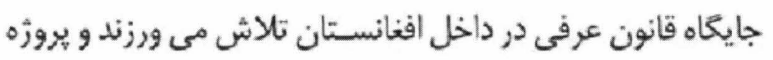
هايى را روى دست دارند.

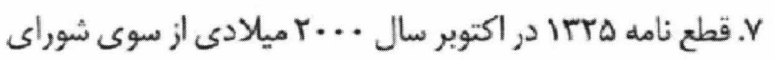

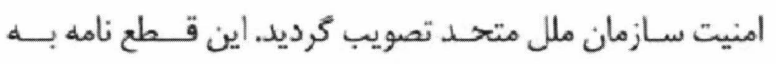

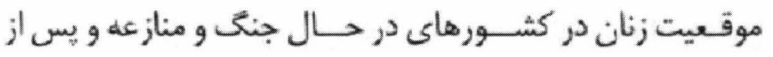

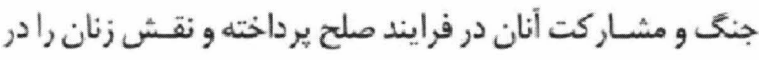

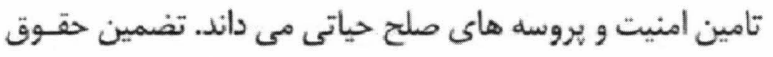

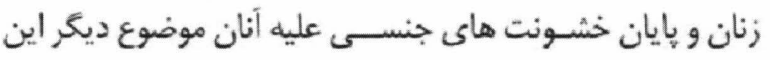

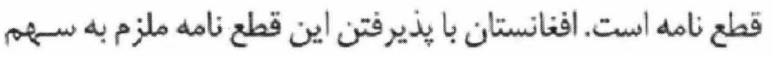

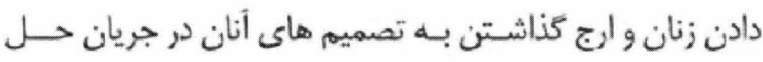

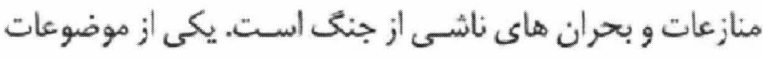

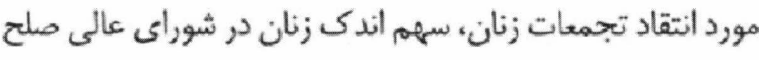

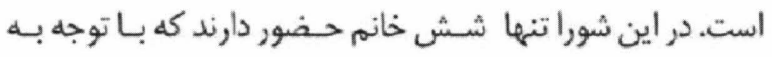

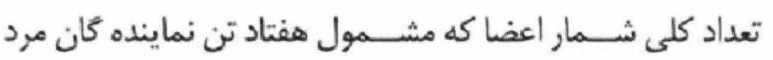

است، اين تركيب جنسى شورا غير منصفانه به نظر مى آيد. رويكرد ها:

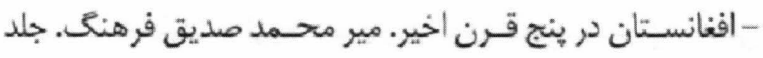

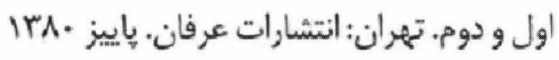

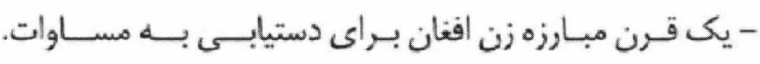

Http://arcr...blogfa.com/post-1 ..aspx

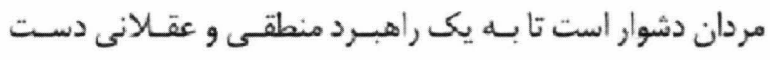

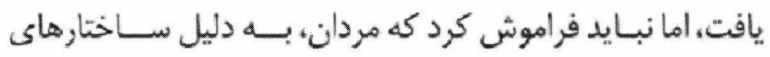

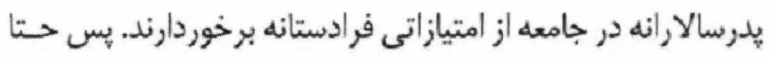

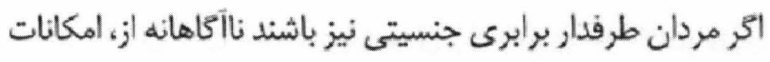

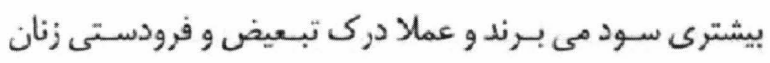
براى شان دشوار مى گرد دد. توانمند سازى زنان افغانستان و داعيه برابرى خواهى بذردون بذون مقوله

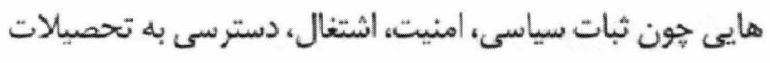

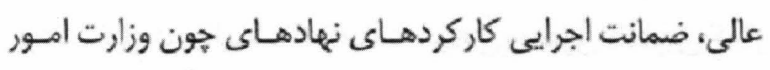

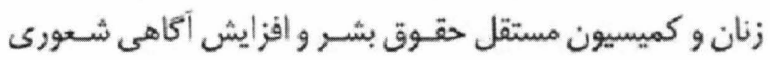

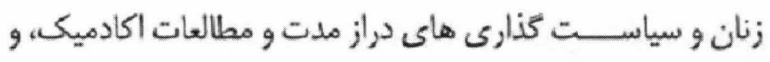

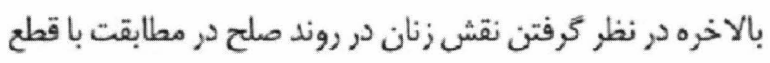

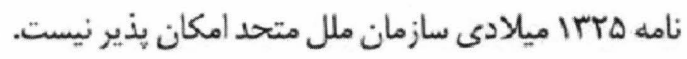
اشاره هـا: ا. اين ستون از شماره هفتم سراج الاخيار به نشر مطالبى در مورد

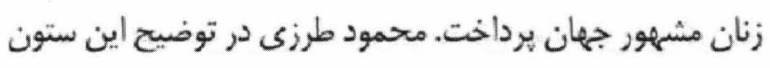

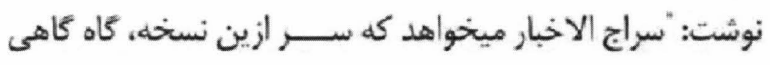

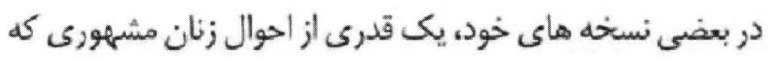

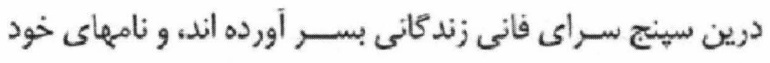

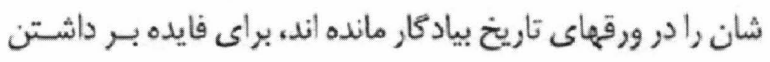
بى بى هاى مستورات و بـيخمهاى مخدرات وطن عزيز خود، درج

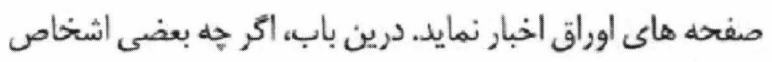

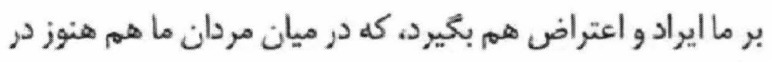

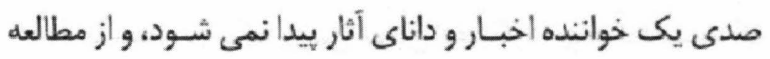

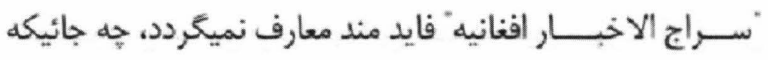

r. شـخصى بــه نام ملا رفيق طى نامه يـ بـهـ محسمود طرزى در

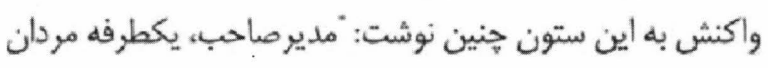

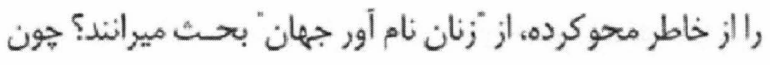

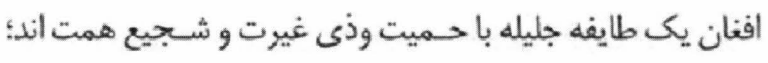

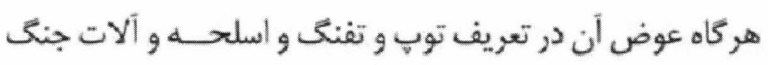

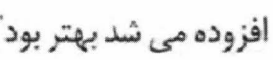

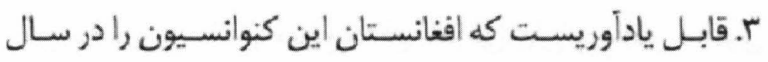

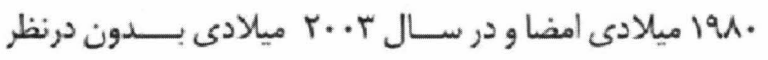
داشت هيج كونه تحفظى تصويب نموده است.

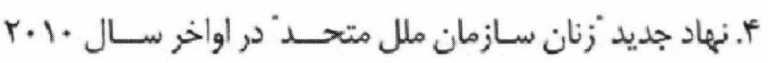

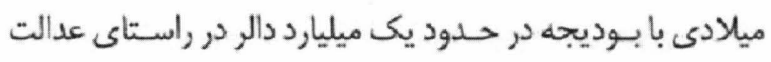

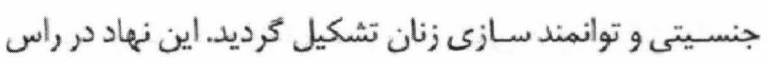

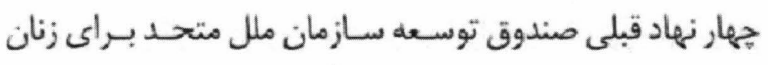

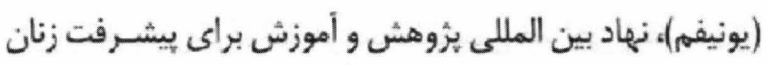


عرف 
كار بـندند. عنصر مادى عرف در صورتى كامل اسـت

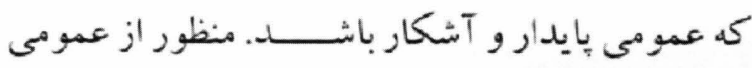
بـودن عادت اين نيسـت كه تمام مردم جامعه بـه آن خو

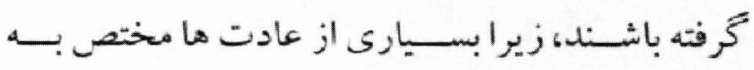

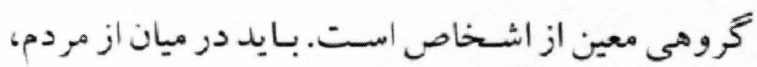

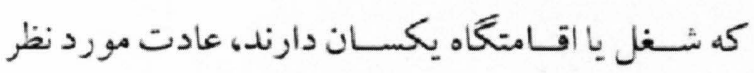
خصوصيت عمومى رابه خود كر فته باشد. و رعايت آن جنين شايع باشد كه بتوان كَفت، جز در موارد اسـتئنايى و نادر همه آن رامحترم ميشـهارند. و مقعصور از بايدار بودن هم اين اسـت كه عرف و عادتهاى زود گُخر نمى تواند وصف قاعدة عرفى رابه خود بخيرد. عنصر روانى عرف نيز داراى خصو صياتى خود اســت.

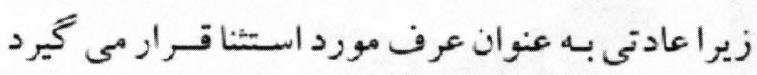
كه، بـه اعتقـاد كسـانى كه آن رارعايت مى كثند، الز ام آور باشد و جنين يندارد كه در زمرة قواعد حقوقى در

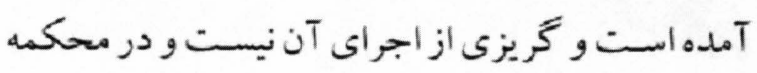
نيز استتاد مي شــود. بــــين ترتيب، غنصر روانى جواز ورود عادت اجتماع به جهان حقوق و لباسسى اسـت كه بـر آن مى يوشــانيد تا وصف الز امى بيابـــــو در رديف قـواعد حقوقى بـــ نظم موجود بييوندد. يعنى مردم در جامعه بـه اين عقـيده باشـــــ كه عرف مذكور مي تو اند عدالت را تطبيق و نظم رادر اجتماع بـه وجود ميا ورد. عرفى كه با جمع شدن دو عنصر مادى و روانى به وجود ميا يد در شمار قو اعد حقوقى مى آيد.

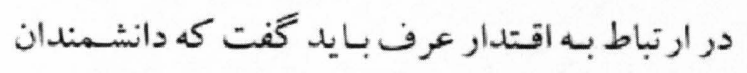
حقـوق و جامعه شناسـى در بـابـ مبــناى اقـتدار عرف كفتخ بسـيار كرده اند. اين بحسث ها ناشـى از اختلافى است كه در بارة مبناى حقـوق وجود دارد، بـراى نتيجه كيرى از آنها مى توان نظريات مختلف را جنين خلاصه Sرد ـدر حكو متهاى يـار لمانى، ملت حـــــ وضع قـــواعد
تو اند ار ادةٔ ملى را بـيان كند و اين ار اده حـاكم مطلق و

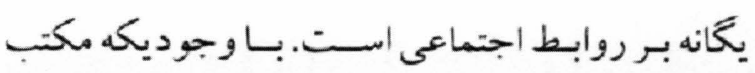
تاريخى با افر اط در قانون كُرايى به شدت مخالفت كرد و عرف را مهم ترين منبع حقوق شـمرد. آنجه امروز در مورد عرف وجود دارد نتيجهة بــر كرفته شــده از همين دونظر است. جون امروز در حقـوق افغانسـتان نيز ازعرف منحــيث يكى از منابع قوى حقوق استفاده بـه عمل ميايد، در اين

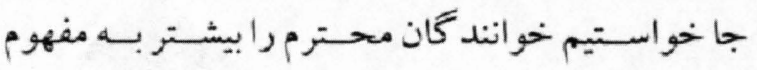
و معنى عرف آشنا ساخته و استفاده از اين منبـع حقـوق در افغانستان راتوسط مقنن در قوانين مختلف در يابيم.

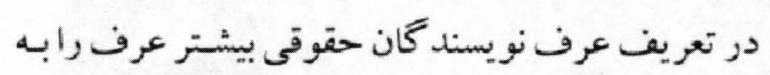
دومعنى تعريف نموده اند: 1 ـ هنغامى كه عرف در بر ابـر قـانون ميخذارند، در اين صورت تمام قـــواعدى راكه از رويداد هاى اجتماعى

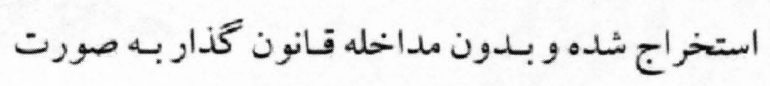
قاعدة حقوقى در آمده است، عرف كَته اند ا.

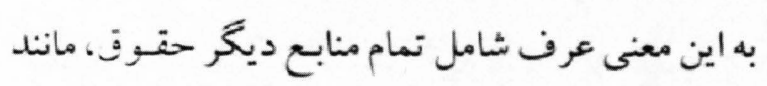

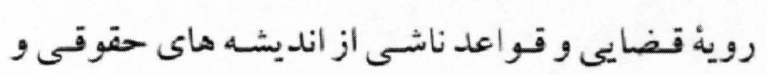
عادات و رسوم تجارتى، نيز مى شود.

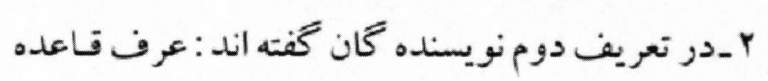
يى است كه بـه تدريج و خحود بـه خود ميان همة مردم يا

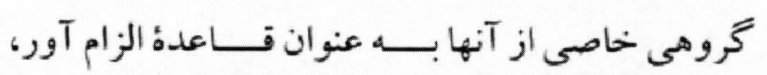

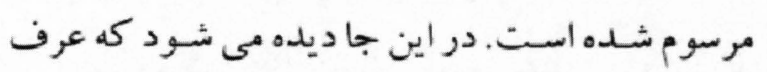

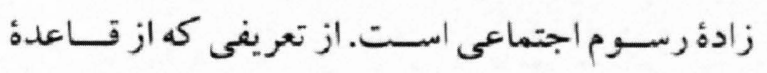

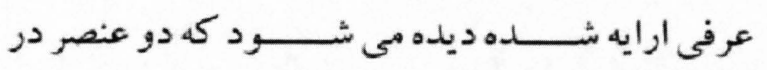
موجوديت عرف نقش بسيار اساسى رادارا اسـت يكى عنصر مادى و ديكُرى عنصر روانى. در ارتباط به عنصر مادى عرف بايد كفت كه كه عرف

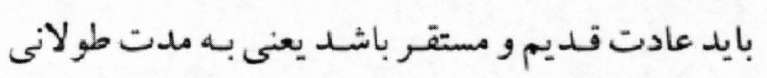

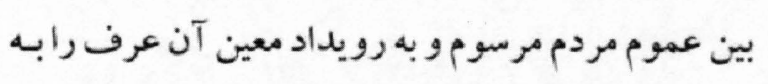


در مقابـل قـانون هستـند، و بـراى رفع اين احستياج، مى كي كوشند كه مقر رات ثابتى را بـين مردم مرسـوم سـازند.

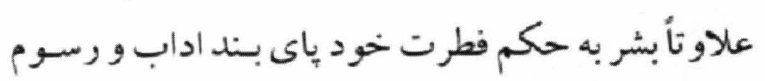
اند و از تجاوز از جنينى ســت ها مى بـرهيزتد ؛ بــه ويثره ف وقتى عادتى ضامن حفظ منافع عمومى باشد و خود بـه خود بـا خو اسـته هاى ان بـه وجود ايد، ثبـات و دوام بيشترى ميابد و به جاى مى رسد كه همه خحود را يا بند به آن مى دانند. اكر در ارتباط اهميت عرف در افغانستان صحبت كنيم در ميابـيـم كه حقـــوق تعاملى افغانســان داراى بيشــــه تاريخى طولانى اســـت زيرا در طول تاريخ حقــــوق تعاملى (عرف)مقدم بر ساير منابع حقـوق در افغانستـان شـناخته شــده اسـت كه ريشه هاى جندين هزار ســاله دارد. بـراى حقــوق تعاملى تعريف كلى عبـارت اســت از : عرف و تعاملاكت عبــار تند از قـــواعدى اســت كه از رويداد هاى اجتماعى استخر اج شـده و بــون دخالت قـانون كذذار بـه صورت قـاعدة حقــوق تعاملى در امده است. در افغانستان با وجودى انكه يك قسمت زياد از مسـايل حقوقى توسـط حقـوق تعاملى در عمل حـل و فصل مى شود، متأسفانه كه در قانون اساسـى افغانسـتان جاى اين منبع مهم عملى تعين نخر ديده اسـت ؛ اما اين نكته را نبايد فر اموش كرد كه در قانون مدنى افغانسـتان عرف و حقـوق تعاملى بـه گُونه اي بيش بـينى كر ديده كه در مخالفت با اساسـات عدالت واقع نشسود نصر النه ستانكزى، مبادى حقوق، ص 181. همجينان قانون مدنى افغانستان مواردى بيشـترى رجوع صريح و ضمنى رادر مواد مختلف خود از بـهـ عرف را دارد. در قانون تجارت افغانستان هم بـا اين گَّنه موارد بر مى خوريم.
حقوقى را بـه مجلس واگذار كرده، و اين مرجع نيز تنها از راه تصويب قو انين و با شـرايط خاص مى تواند حق تق خود رالعمال كند و ويخًر ملت نمى تو اند حقسى راكه يكبـــار واگذار كرده اســــت خود اعمال كند و از راه ايجاد عرف قاعدة حقوقى بسه وجود آورد ؛ يس عرف تنها در جاى معتبر اسـت كه كه قـانون اسـتناد بـه آن را جواز شمرده اسـتـ، و در اين مورد نيز عادت مورد نظر به عنوان قانون ضمنى اعتبار دارد و تمام اعتبـار خود را از تصويب قوه مقنته مى گيرد. در نظر ديخرى بيان شده كه قـانون و عرف فقط از نظر صورت خارجى با هم تفاوت دارد. اقتدار هر دو ناشسى از وجدان عمومى است، با اين تفاوت كه قانون به طور غير مستقيم از اين منبع الهام مى كَيرد و عرف محسعول مستقـيم وجدان عمومى اسـت. عرف و عادتى كه بين

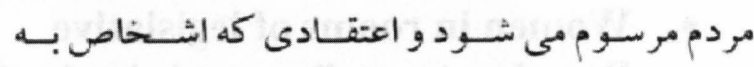
اجبارى بودن قو اعد ان ييدا مى كنند نشانه حقوق عرفى

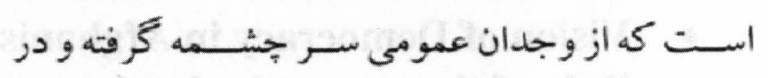
اجتماع وجود دارد. مقــدمه علم حقــوق، داكتر ناصر

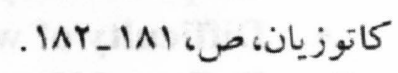
وقتى ملتى به شكل واحدى سياسى در آمد و صاحسب قانون اساسى كه حيثيت وثيقة ملى كشور رادار الست بايد قواى ملى رابه شيوه اي استعمال كند كه آن قانون معين كر ده است ؛ يس اكر قانون هم اين منبع متغيير را به رسميت بشناسـل، جِكَّونه مى توان ادعا كرد كه تمام قواعد موجود و ايندل آن به طور ضمنى مورد تصويب قانون كذار قر ار كر فته است و مقنن به امرى كه خود از ان بى اطلاع بوده رخايت داده است؟

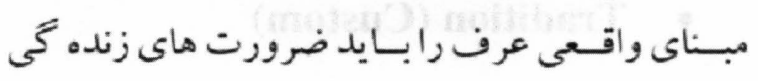
اجتماعى و خواسته هاى طبيعى انسـان دانسـت. مردم براى حسفظ منافع خود نياز مند امنيت و ثبـات و برابـرى 


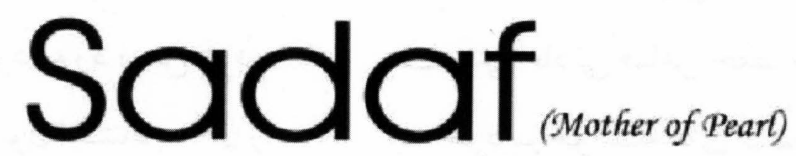

Quarterly Magazine for Women Published by

Cooperation Center for Afghanistan(CCA)

Vol. 21, Round Sixth, winter 2011

\section{Contents:}

- Mobilization of Women in Afghan Parliament

- Political Rights of Women

- the ways of practicing of laws

- Economical and Political freedom

- second parliament, challenges and hops for women

- Women in rooms of legislative

- Running to parliament is basic rights of women

- The best character of women is their kindness

- Vision of Democracy in Afghanistan

- Rule of the women in development

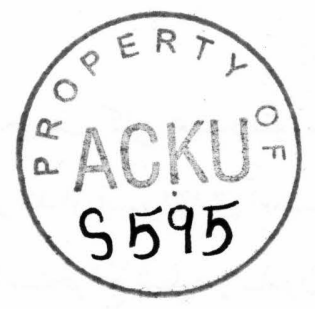

- Responsibility give power and energy to the person

- Difficulty of waiting

- Reflex of Human Rights and Dignity in "Seyasatnama"

- Women should have the rights of present about herself, her family and society

- the green space for dark eyes

- Children Situation during thirty years war

- This blank notebook ...

- Bad reputation, vice verse

- Drs. Soraya servant of the people ...

- The year of 1389 was full of success

- Women and Society

- Statement of Campaign of $\% 50$ for women rights

- The psychological situation of children

- Re identification of women rule in freedom fighting

- Tradition (Custom) 


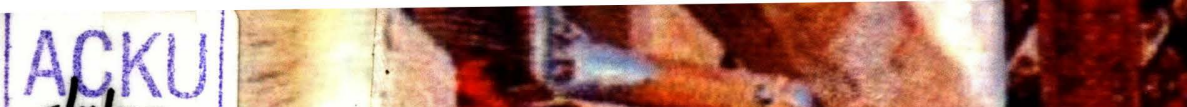

cintus $H Q$

1735.6

7400

V5/n21
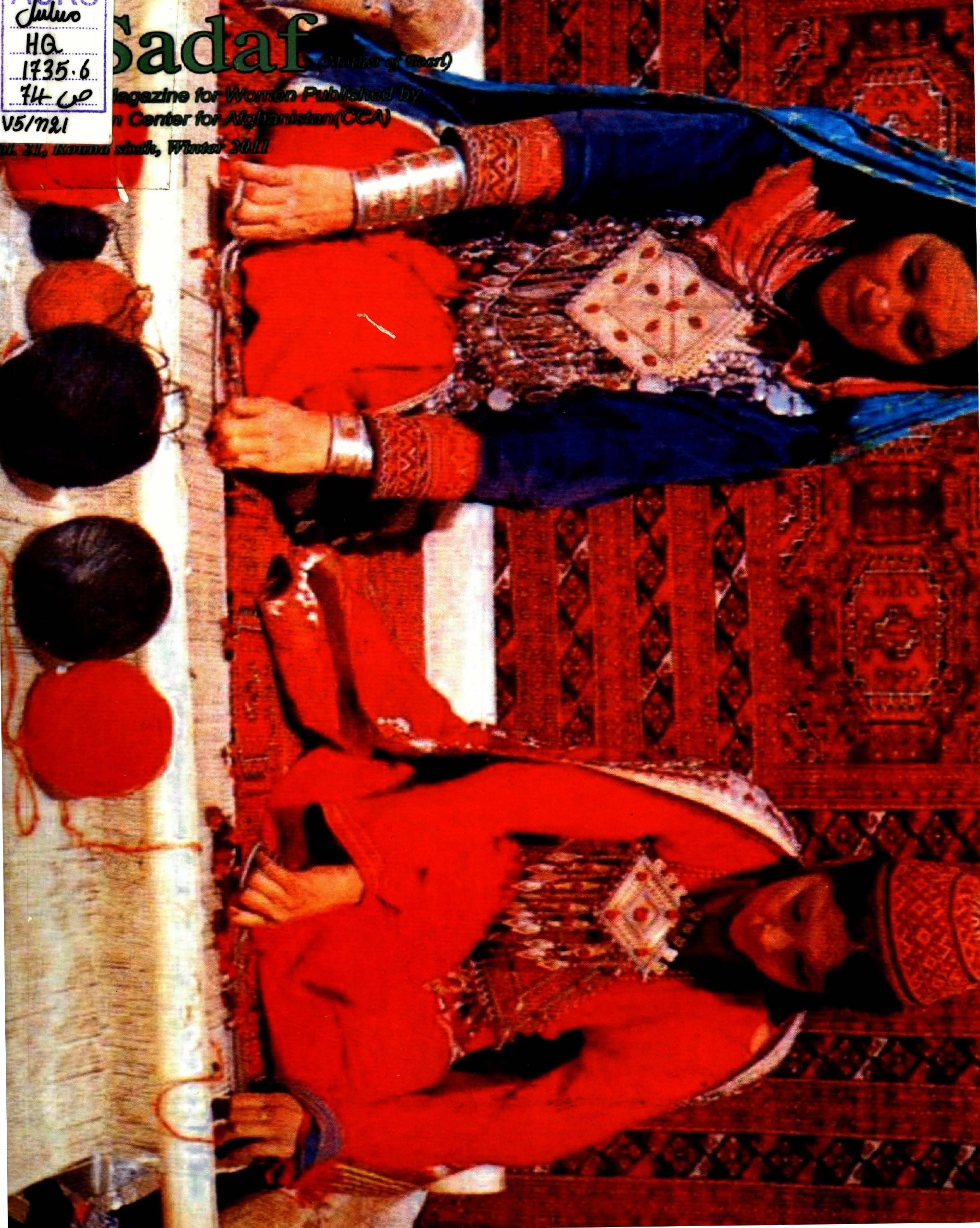